\title{
EVOLUÇÃO PETROGENÉTICA E METALOGENÉTICA DA MINA DE OURO DO PARI E ARREDORES, NE DO QUADRILÁTERO FERRÍFERO - MG
}

\section{GUSTAVO CORREAA DE ABREU}

Orientador: Prof. Dr. Johann Hans Daniel Schorscher

TESE DE DOUTORAMENTO

Nome

Presidente: Prof. Dr. Joahhn Hans Daniel Schorscher

Examinadores: Prof. Dr. Antenor Zanardo

Prof. Dr. Caetano Juliani

Dr. Claudio Luiz Goraieb

Prof. Dr. Jorge Silva Bettencourt

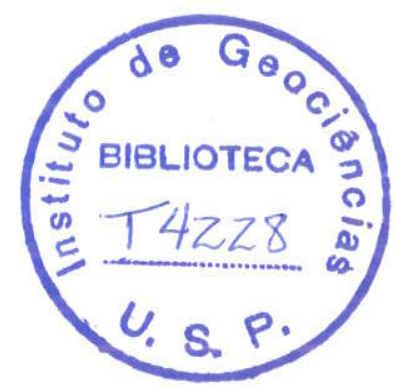

Assinatura
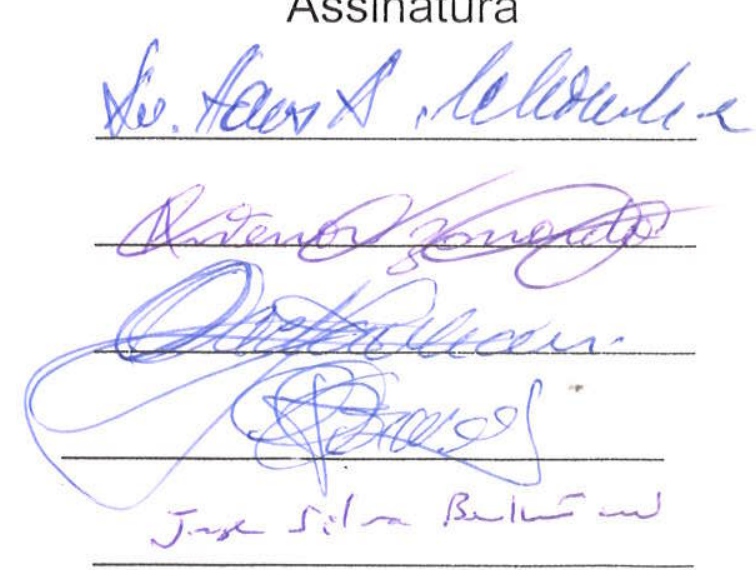

SÃO PAULO

2005 


\section{UNIVERSIDADE DE SÃO PAULO INSTITUTO DE GEOCIÊNCIAS}

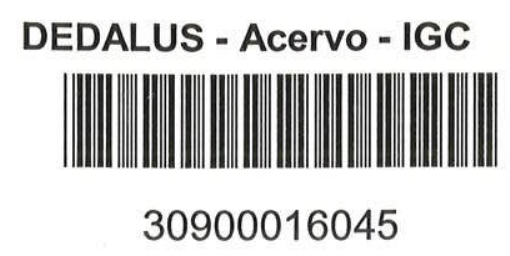

\section{EVOLUÇÃO PETROGENÉTICA E METALOGENÉTICA DA MINA DE OURO DO PARI E ARREDORES, NE DO QUADRILÁTERO FERRÍFERO-MG}

Gustavo CorrêA de Abreu

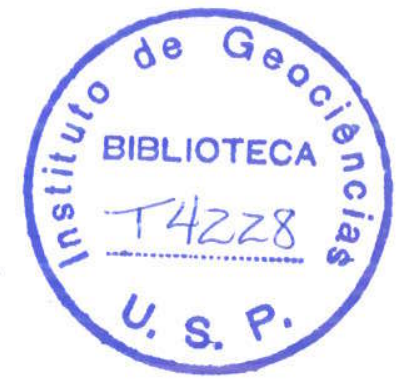

Orientador: Prof. Dr. Johann Hans Daniel Schorscher

TESE DE DOUTORADO

Programa de Pós-Graduação em Mineralogia e Petrologia

São Paulo 
Às irmãs

Marilia e Tamires 


\section{INDICE GERAL}

AGRADECIMENTOS. v

RESUMO vil

ABSTRACT viil

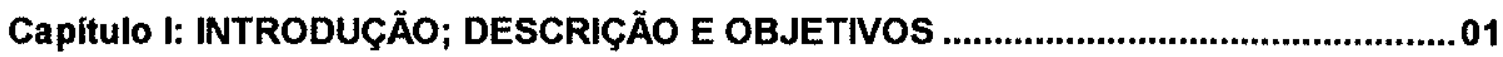

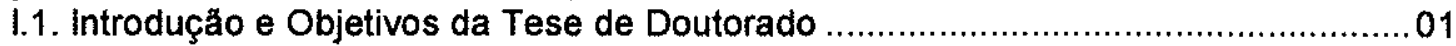

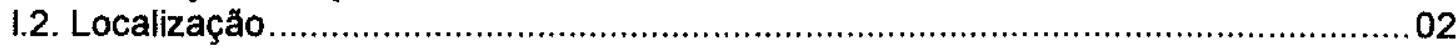

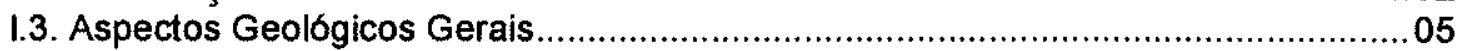

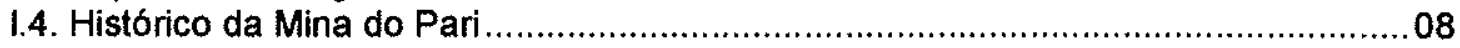

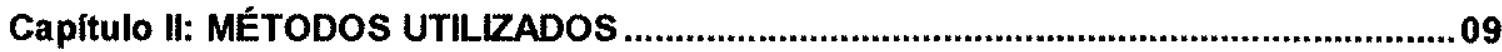

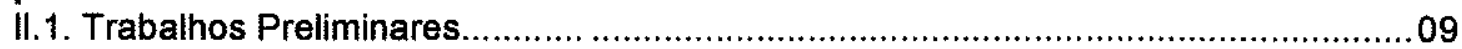

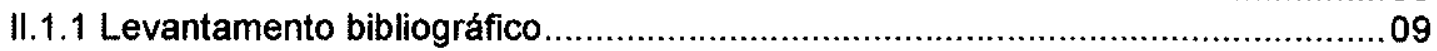

II.1.2 Revisão e estudo das coleções de amostras dos trabalhos anteriores ................09

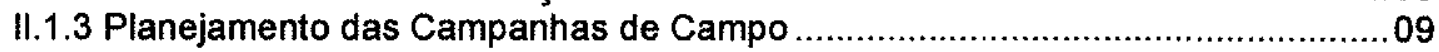

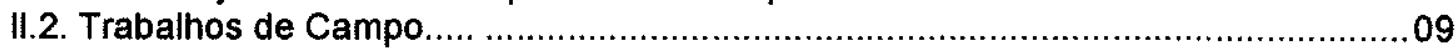

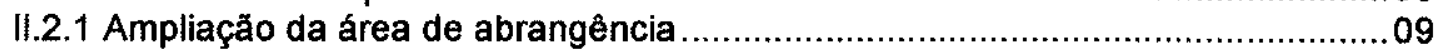

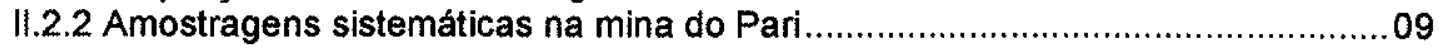

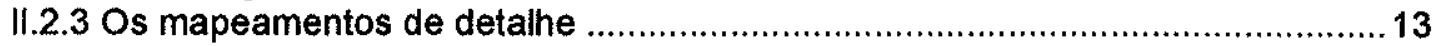

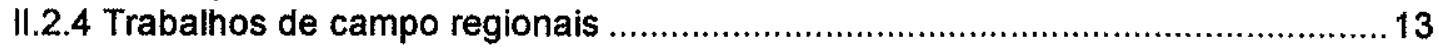

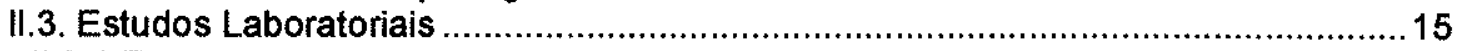

II.3.1 Foram realizados estudos mineralógico-petrográficos opticos ........................... 15

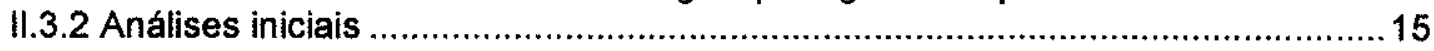

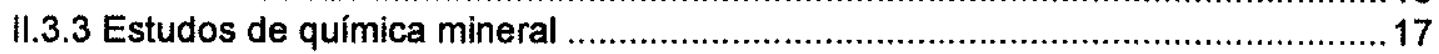

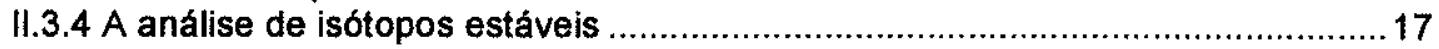

II.3.5 O tratamento informatizado dos dados químicos ...........................................20

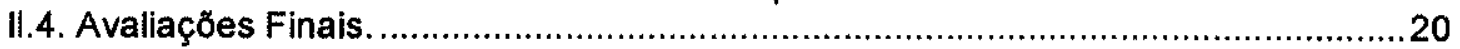

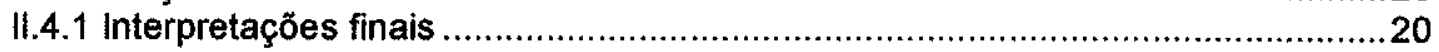

11.4.2 Redaçåo e defesa da Tese de Doutorado .....................................................20

Capitulo III: GEOLOGIA REGIONAL E TRABALHOS ANTERIORES .............................21

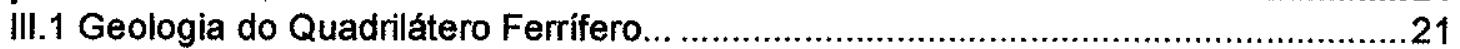

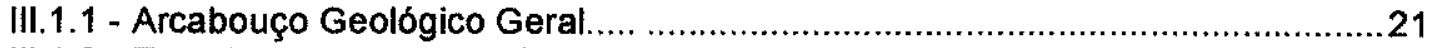

III.1.2 - Estratigrafia do Quadrilátero Ferrífero: Evolução dos Conceitos......................22

III.1.2.1 - Arqueano:Terrenos Granito-Gnáissicos e Sgr. Rio das Velhas....................24

III.1.2.2 - Paleoproterozóico: Supergrupos Minas e Espinhaço.................................27

III.1.3 - Evolução Tectono-Metamórfica do Quadrilátero Ferrífero..................................33

III.2 - Geologia da Porção NE do Quadrilátero Ferrífero....................................................37

III.2.1 Terrenos TTG (Tonalitos, Trondjemitos e Granodioritos) ...................................39

III.2.2 Seqüéncia Metavulcano-Sedimen. do Greenstone belt Rio das Velhas..............39

III.2.3 Metagranitóides Borrachudos(GB) e Metagranitóides Foliados c/ Fluorita

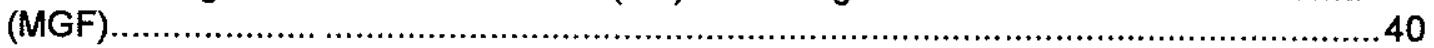

III.2.4 Os Supergrupo Minas e Espinhaço..............................................................41

III.2.5 Metamorfismo Regional e Evolução Estrutural............................................ 42

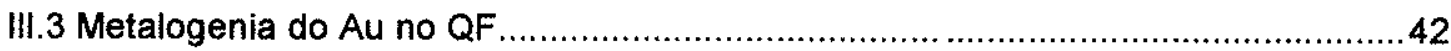

III.3.1 Revisão da Metalogenia da Mina do Pari e Arredores.....................................44

III.3.1.1 Geologia e Estruturas....................................................................44

III.3.1.2 Resumo da Petrografia da Mineralização e Ligas Naturais de Au...............55 


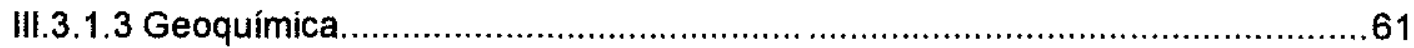

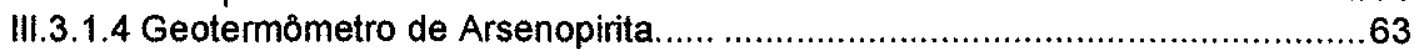

III.3.1.5 Conclusões Preliminares da Metalogênese da Mina do Pari.......................67

III.3.2 Metalogenia de Outras Minas de Au Arqueanas do Quadrilátero Ferrífero........68

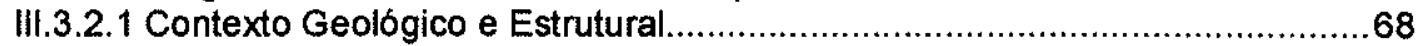

III.3.2.2 Paragêneses Silicáticas e de Sulfetos...................................................71

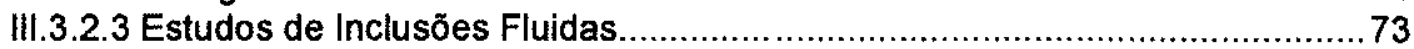

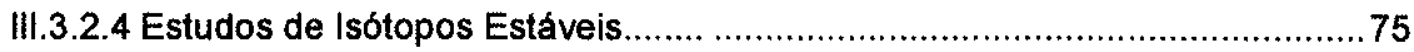

III.3.2.5 Estudos de Isótopos Radiogénicos e Geocronologia.....................................76

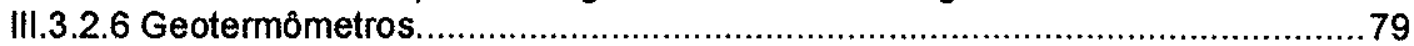

11I.3.3 Conclusס̋es Preliminares Sobre os Aspectos metalogenéticos Gerais...............80

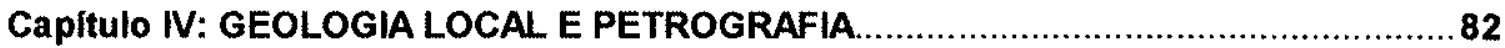

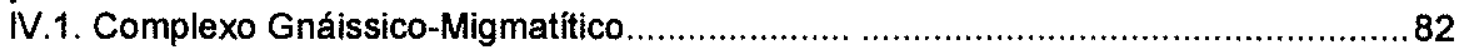

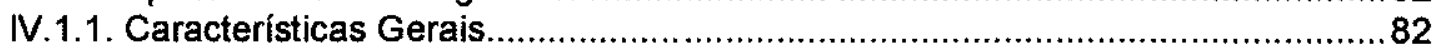

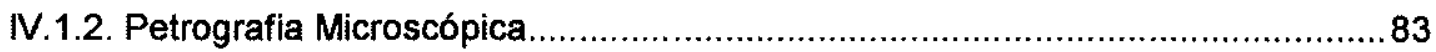

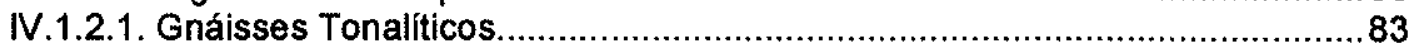

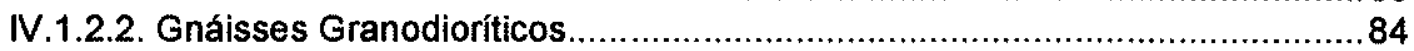

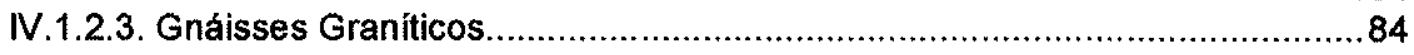

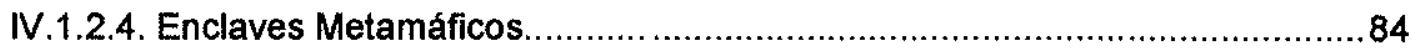

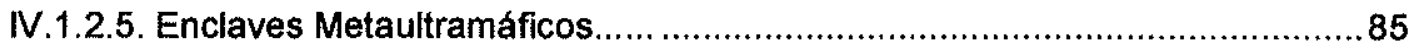

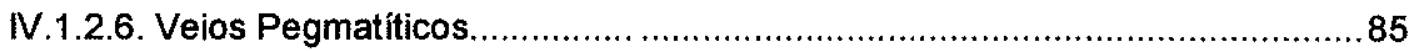

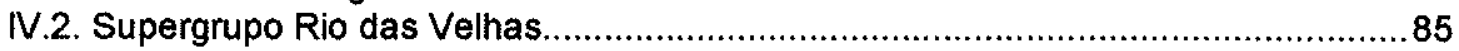

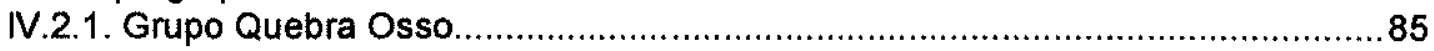

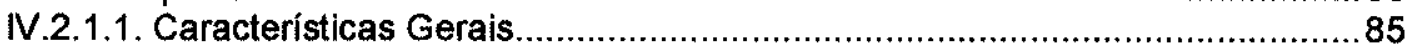

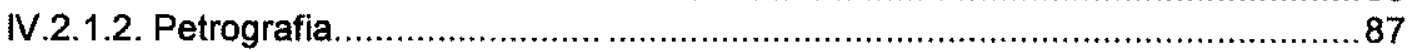

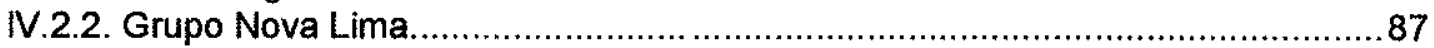

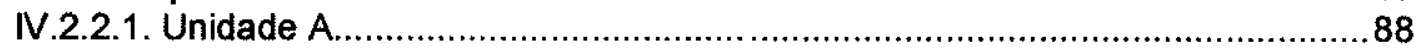

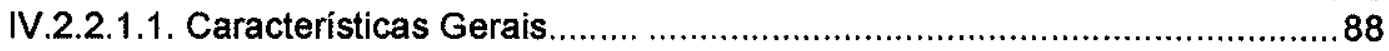

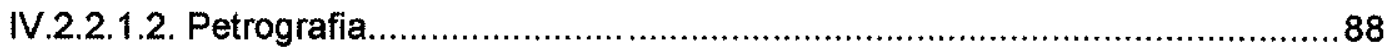

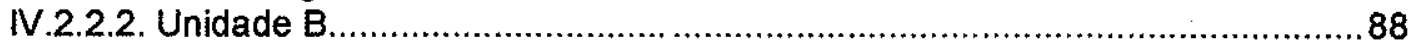

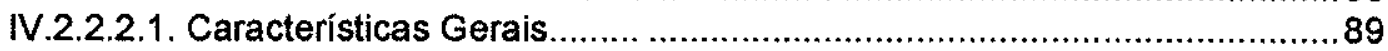

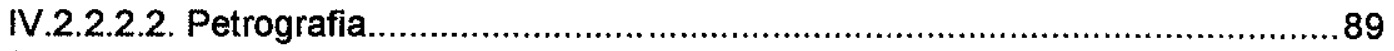

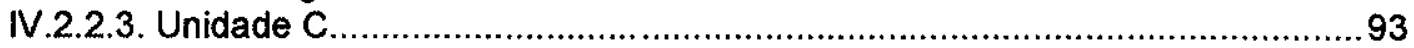

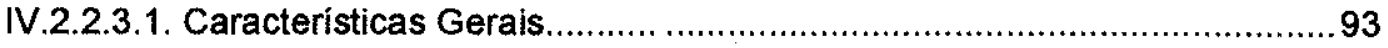

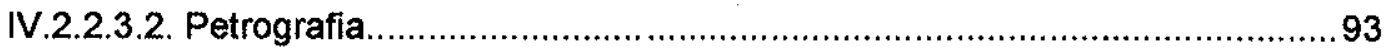

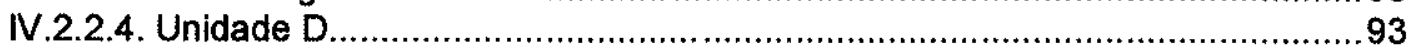

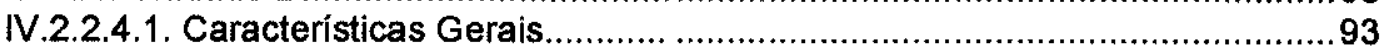

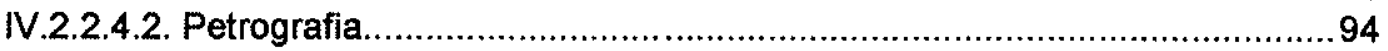

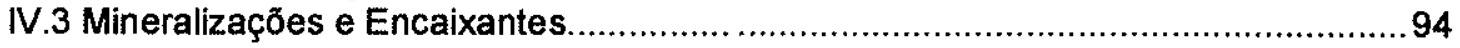

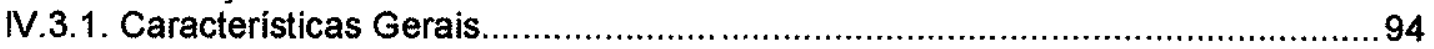

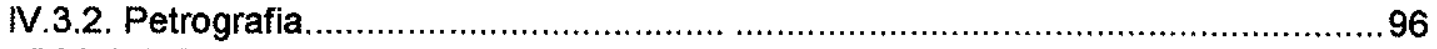

IV.3.2.1. Rochas Encaixantes da Lapa dMineralização........................................97

IV.3.2.1.1. Nivel de Entrada da Mina (N-00) do Pari...........................................97

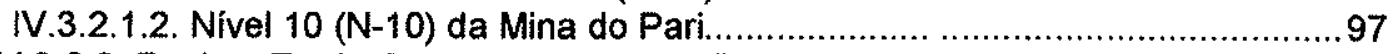

IV.3.2.2. Rochas En da Capa da Mineralização...................................................... 99

IV.3.2.2.1 Nivel de Entrada da Mina(N-00) do Pari............................................99

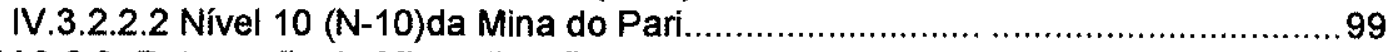

IV.3.2.3. Petrografia da Mineralização .............................................................. 100

IV.3.2.3.1. Nivel de Entrada (N-OO) da Mina do Pari........................................ 100

IV.3.2.3.2. Nivel 10 (N-10)da Mina do Pari....................................................... 100

IV.3.2.3.3. Petrografia de Minerais Opacos...................................................... 101

IV.3.2.3.4 Seqüência de Cristalização dos Minerais Opacos................................ 104 
IV.4 Ocorrências de Ouro nos Arredores de Pari, Quadrícula de Florália.................. 105

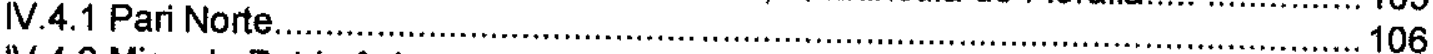

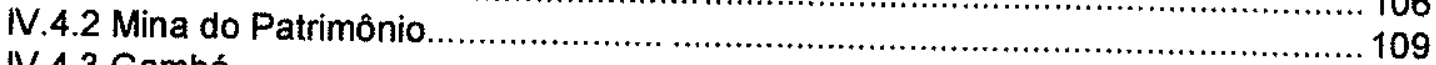

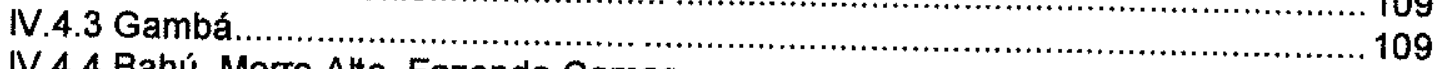

IV.4.4 Bahú, Morro Alto, Fazenda Camas.......................................................... 114

IV.4.5 Comparaçס̃es entre os Ambientes Arqueanos das Quadrículas Florália e Santa Bárbara.

IV.4.6 Avaliação Preliminar do Potencial Aurífero da Quadrícula............................ 114

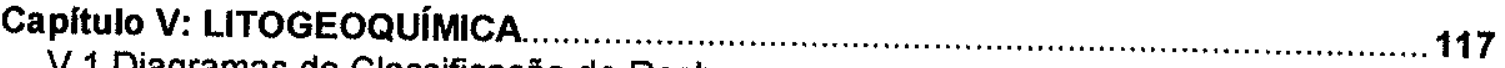

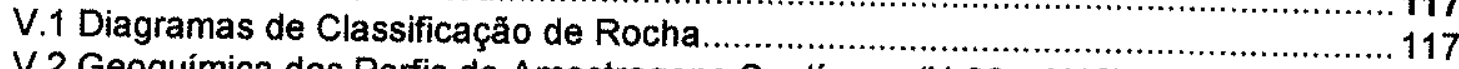

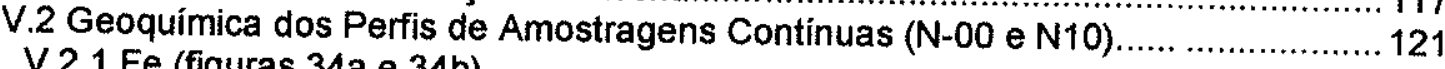

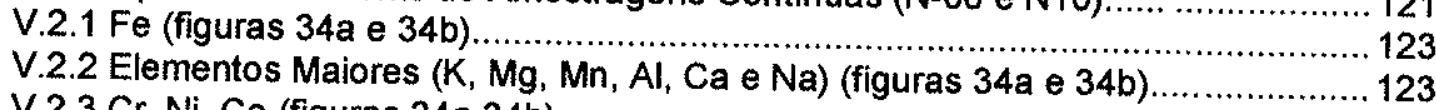

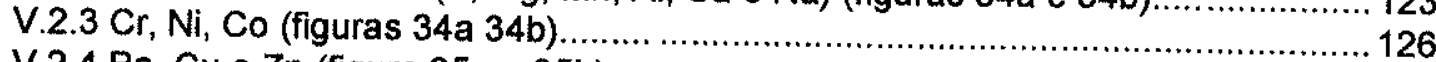

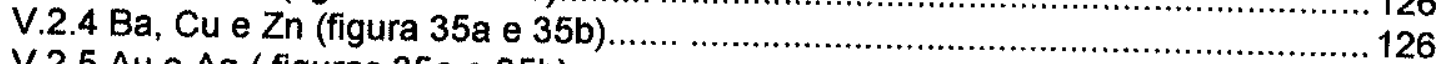

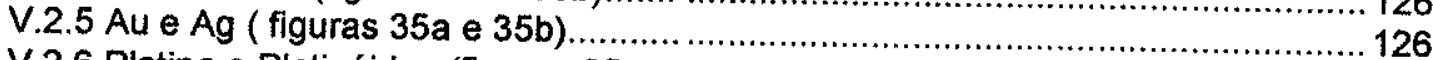

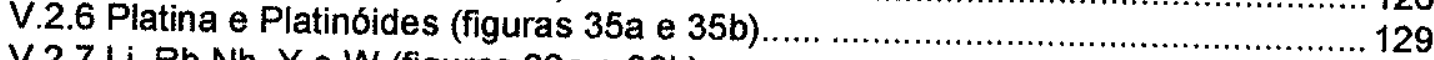

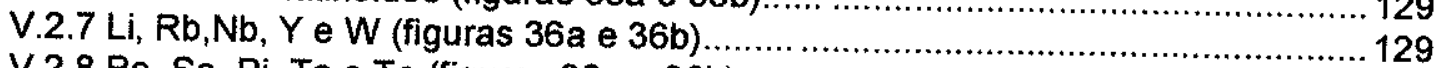

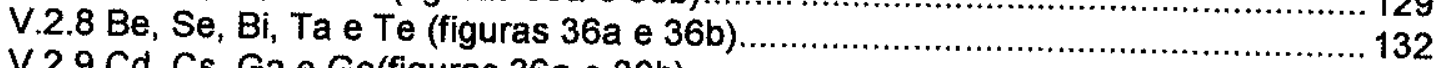

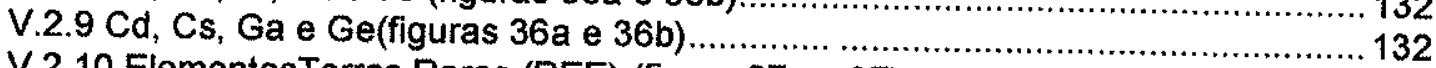

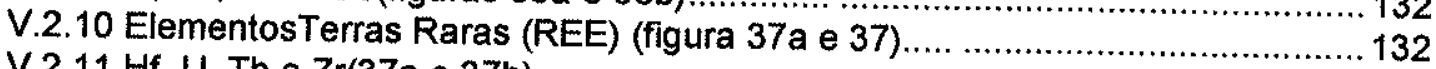

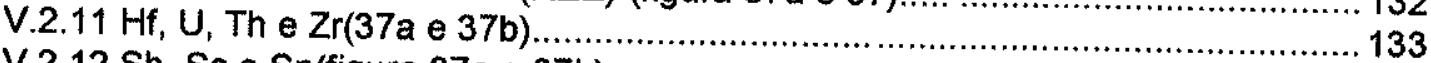

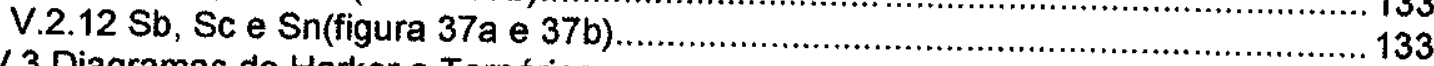

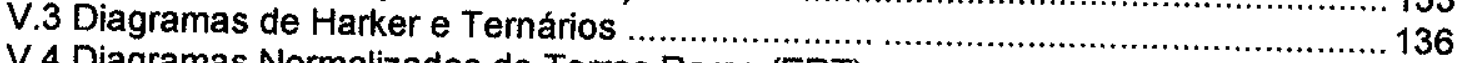

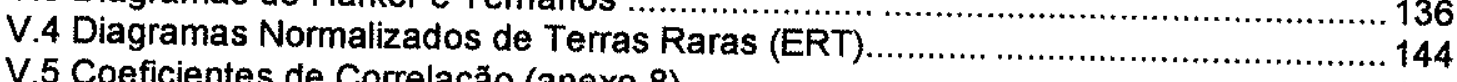

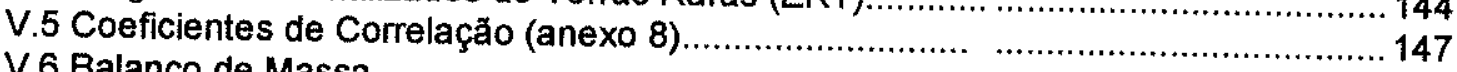

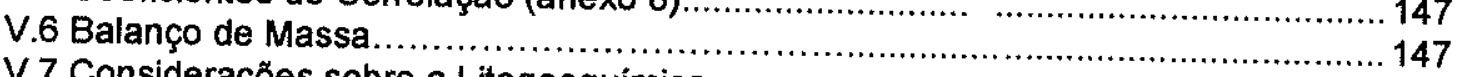

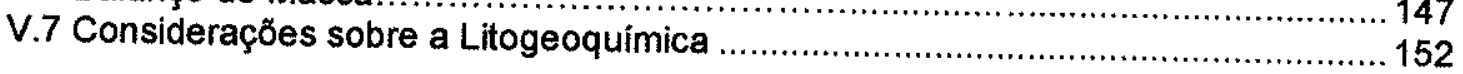

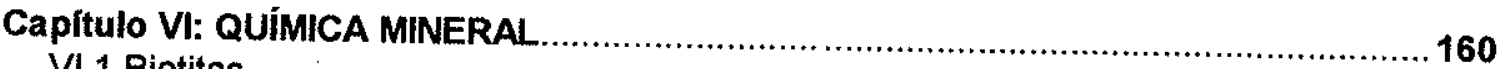

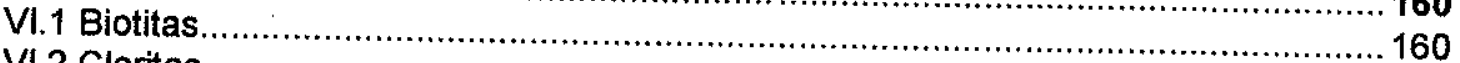

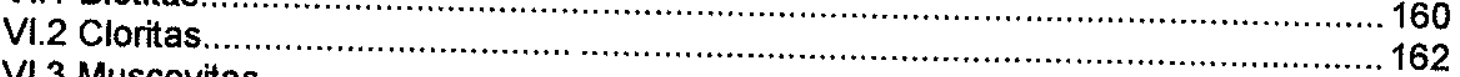

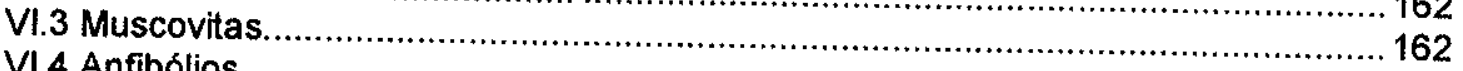

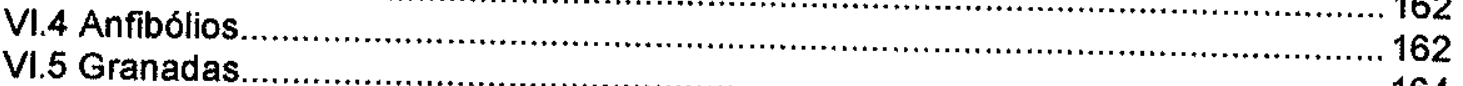

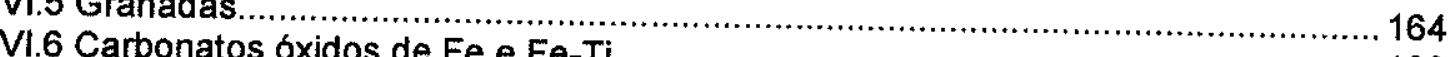

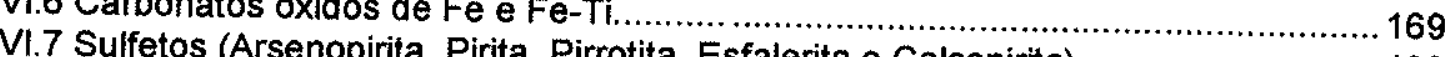

VI.8 Geotermômetros Grana

VI.9 Geotermómetro de Arsenopirita lio e Granada-Biotita (Grt-Amf e Grt-Biot) ..... .. 174

VI.10 Geotermômetro de Pirrotita

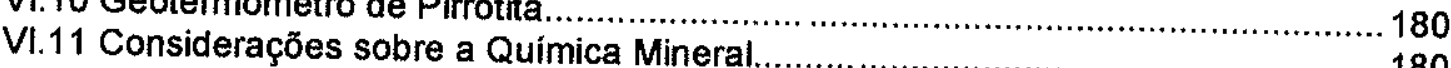

VI.11.1 Silicatos.

VI.11.2 Sulfetos.

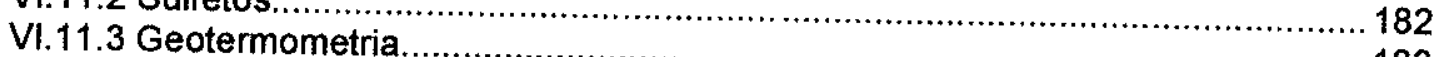

VII. ANALOGIA A OUTRAS MINAS E DISTRITOS AURIFEROS.............................. 185

VIII CONCLUSÕES E RECOMENDACÕES ..........................................................194

VIII.1 Consideraçס̃es Geológicas e Metalogenéticas Fundamentais …........................... 194

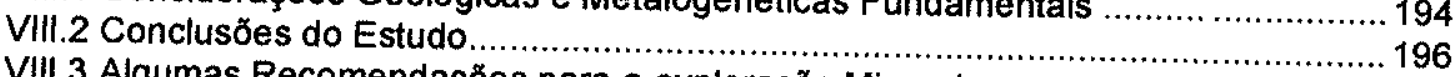

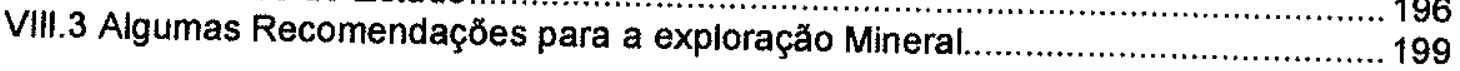




\section{AGRADECIMENTOS}

Agradeço ao meu orientador, o Prof. Dr. Johann Hans Daniel Schorscher, pela oportunidade, o estímulo constante, as discussões, os conselhos, todo um legado de conhecimentos aprofundados sobre o Quadrilátero Ferrífero. Agradeço muito pelo que aprendi nesses últimos anos.

À FAPESP pelo apoio financeiro, sem o qual, muitos dos dados não estariam aqui apresentados.

Ao Instituto de Geociências da USP, pelas portas sempre abertas aos ex-alunos, pela sua estrutura, sua biblioteca, seus laboratórios, seus funcionários e professores.

À Companhia Vale do Rio Doce, em especial às pessoas dos Srs. Paulo Amorim e Diógenes S. Vial, pelo apoio formal oferecido, pela autorização de estudar áreas da companhia, e pela amizade confiada.

Aos amigos Xisto Andrade, Xisto Andrade Jr. e Fernando Oliveira, da Mineração Itaitinga pelo apoio nos trabalhos de campo nas regióes de João Monlevade, Nova Era e Rio Piracicaba, MG.

À São Bento Mineração S.A., Grupo Eldorado, pela autorização de trabalho na área, pelas amostras e análises gentilmente fornecidas, e pelo apoio de seus geólogos Sérgio Martins, Fernando Valladares e Juliano.

À Yamana Desenvolvimento Mineral S.A., em especial aos Srs. Geólogos Evandro Cintra e Antenor Silva, que muito me apoiaram nos últimos dificeis meses dessa tese.

À Geoexplore Consultoria e Serviços, em especial a Mario Conrado Reinhardt e Vicente Pereira, seus diretores, que sempre acreditaram e respeitaram meu trabalho.

Aos colegas Alexandre Chiarini, Gustavo Gallo Vilela e Fernando Fernandes da BTX Serviços Geológicos, que vi ascender tão rápido, pela moradia, churrascos e festas, e muitas discussões salutares. 
Aos amigos do Programa de Pós-Graduação de Mineralogia e Petrologia: Peter, Yuri, Gaston, Valentino, Apum, Lucelene, Tatiana, Andréas, Fernando Valladares, Fernando Spinelli, Fernando Camargo, Iede e Klaus, pelo excelente convívio e colaboração.

Aos amigos de pós-graduação do IGc-USP, Werner Weber, Gelson Fambrini, Lucas Warren, Marcelo Bárbara, Mauro Geraldes, Marco Aurélio.

Aos sócios da Geonet Consultoria Geológica Ltda, Artur Deodato Alves (Metanol) e Carolina Correa (Carniceira), pelo apoio e confiança durante todo esse período.

Aos geólogos da Bahia, presentes nos trabalhos da Mina de Fazenda Brasileiro, que sempre prestaram seu apoio nas discussões comparativas: Lúcia Guarnieri, Emerson, Israel, Valter Teodoro Jr., Carlos Paraizo, Sérgio Brandão, Maurício Assis, Maurício Góis e Luís Navarro.

Aos prestadores de serviços, Restaurante Rei, do amigo Reinaldo Alves Monteiro e Globo Geologia e Serviços, do amigo José Claudivan, conhecidos nos rincões do Brasil, e que muito me apoiaram.

Não poderia deixar de mencionar Gilson Rosa de Jesus, Amaro Pedrosa, César Oliveira, Uili Silva, Otávio Gomes de Jesus, José Soares, Senhor Expedito e Dona Nede, pessoas estas que foram as grandes descobertas durante as campanhas de campo desta tese.

Ainda agradeço o apoio prestado pelos alunos de iniciação científica da AOS - Associação dos Orientados do Schorscher, Reginaldo, Gabriel e Ana Flávia, pela colaboração e companheirismo.

Aos professores João Batista Moreschi, Caetano Juliani, Gergely Szabó, e Antônio Romalino Fragoso Cesar, pelas discussర̃es e estímulos constantes.

Um agradecimento especial a Márcia Barbosa Vieira, que largou tudo para apoiar os meus passos nesses últimos dois anos. pela convivência, carinho e companheirismo.

E finalmente, agradeço aos meus pais, Gilberto e Graciema, que viram e sofreram comigo todos os reveses da vida durante esse período, mas que não deixaram em momento algum faltar o amor que alimenta as verdadeiras conquistas. 


\section{Resumo}

A mina do Pari é a principal de várias mineralizações e depósitos de ouro menores, que ocorrem na quadrícula Florália (1:25.000), na região NE do Quadrilátero Ferrífero, hospedadas em rochas metassedimentares, clásticas, químicas e vulcanoclásticas, metavulcânicas máficas e em veieiros de quartzo e quartzo-carbonáticos do Grupo Nova Lima, que é a unidade litoestratigráfica média vulcano-sedimentar máfica e química, do greenstone belt arqueano Rio das Velhas (definido como supergrupo homônimo). As mineralizações de ouro principais da mina do Pari e arredores, Pari Norte, Património, Gambá e Bahú, foram estudadas no campo, com mapeamento de semidetalhe (escalas 1:25.000 até 1:10.000) e perfilagens detalhadas, com levantamentos de subsolo e sondagens (apenas mina do Pari), incluindo ainda estudos comparativos da mina São Bento e arredores, e das áreas Quebra Osso, Tanque Preto, Serra do Seara, Cambotas e Gongo Soco. Os estudos laboratoriais mineralógico-petrográficos e calcográficos, litogeoquímicos multielementares (FRX, ICP-MS, fire assay-AAS) e de química mineral (microssonda eletrónica) visaram caracterizar as associações litológicas regionais e das mineralizações de ouro (minérios, rochas encaixantes imediatas e rochas hospedeiras) para elucidar os diferentes fatores petrometalogenéticos controladores das mineralizaçōes e sua variação no curso da evolução geológica regional policíclica por orogêneses superimpostas arqueanas até neoproteroź́icas/eopaleozoicas. Os resultados foram confrontados com a literatura de outras mineralizaçőes de ouro do Sgr. Rio das Velhas na região do Quadrilátero Ferrífero inclusive de inclusőes fluidas, isótopos estáveis e geocronológicos, e com modelos metalogenéticos de mineralizaçőes de ouro em greenstone belts arqueanos. Entre os resultados principais destacam-se: os minérios de ouro predominantes da mina do Pari e das mineralizaçóes maiores em sua continuação (Pari Norte, Património, Gambá), sendo BIF tipo Algoma vulcanogênicos, de fácies mista predominando sulfeto (arsenopirita, pirrotita); a origem singenética sedimentar-exalativa da mineralização, proximal em relação a centros submarinhos de vulcanismo básico toleiítico de zona de crescimento de fundo oceânico; as transformações polimetamórficas arqueanas até neoproterozóicas dos minérios, sob condições P-T máximas transicionais da fácies xisto verde superior para anfibolito durante o metamorfismo regional principal paleoproterozóico superior, final do Ciclo Minas/Espinhaço (Transamazónco); que este metamorfismo de grau médio não depauperou, pelo contrário, enobreceu os minérios de ouro, tanto texturalmente quanto aumentando os teores de Au (fineness) da liga natural do metal; que processos epigenéticos de zonas de cisalhamento e outros intrínsecos ao modelo "orogenic gold" năo contribuíram de forma notável à metalogênese da mina do Pari e das principais mineralizações associadas (exceto Bahú); e, por fim, que as reservas potencias de ouro destes depósitos, com base em cálculos estimativos conservadores, totalizam cerca de $44 \mathrm{t}$ de $\mathrm{Au}$. Os estudos comparativos e da literatura indicaram que outras mineralizações e jazidas de ouro no $\mathrm{Gr}$. Nova Lima, tambem podem ter tido origens sinsedimentares-exalativas, por exemplo, a mina São Bento, de ambiente sedimentar clástico fino (xistos grafitosos) e químico (BIF tipo Algoma de fácies sulfeto) distal de qualquer foco vulcánico, e as minas Morro Velho e Faria, entre outras. Também cabe destacar que o conceito de terrenos greenstone belt metamórficos de grau médio e alto arqueanos não terem potencialidade de ouro, precisa ser revisado, tanto a luz dos resultados de Pari, quanto de outras ocorrências mundiais, que hospedam inclusive jazidas de ouro de classe mundial. 


\section{Abstract}

Pari mine is the major one of several smaller gold mineralizations and deposits which occur in the Florália quadrangle (1:25.000), NE Quadrilátero Ferrifero, hosted in clastic, chemical and volcanoclastic metasediments and mafic metavolcanic rocks (amphibolites), as well as in quartz and quartz-carbonate veins of the Nova Lima Group - middle stratigraphical unit of mafic and chemical volcanosedimentary rocks of the Archaean Rio das Velhas greenstone belt (defined as the homonymous supergroup). The gold mineralizations of the Pari mine and surroundings, Pari Norte, Património, Gambá and Bahú, were studied with geological mapping (scales 1:25.000 to $1: 10.000$ ) and detailed profiling, with underground mining geology and diamond drilling (Pari mine only), including also comparative studies of São Bento mine and surroundings, as well as of the Quebra Osso, Tanque Preto, Serra do Seara, Cambotas and Gongo Soco areas. Mineralogical, petrographical, ore-microscopy, geochemical (FRX, ICP-MS, fire-assay-AAS) and mineral chemistry (microprobe) laboratory studies were carried out in order to characterize the regional lithological associations and those of the gold mineralizations (ores, immediate wall and host rocks) in order to elucidate the different petro-metallogenetical factors which controlled the mineralizations and their variation in the course of the polycyclic regional geological evolution through Archaean to Neoproterozoic/Eopaleozoic superimposed orogeneses. Results were confronted with literature on other gold mineralizations, mainly of the Rio das Velhas greenstone belt in the Quadrilatero Ferrífero region, including fluid inclusion, stable isotopes and geochronological studies, and with metallogenetical models of gold mineralizations in Archaean greenstone belts. Among the results, the following stand out: the main gold ores of the Pari mine and the other larger-sized mineralizations in the continuation of the Nova Lima Group (Pari Norte, Património, Gambá) proved to be volcanogenic Algoma type BIF of mixed facies, yet with sulphide predominance (arsenopyrite, pyrrhotite); the syngenetic sedimentary-exhalative origin of the Pari mineralization, proximal to a submarine spreading center of tholeitic volcanism; the Archaean to Neoproterozoic polymetamorphic transformations of the gold ores at maximum P.T conditions transitional from upper greenschist to amphibolite facies during the main regional metamorphism of Upper Paleoproterozoic age, at the end of the Minas/Espinhaço (Transamazonian) Cycle; that this medium-grade metamorphism did not impoverish the ore, quite on the contrary, it ennobled the ore, texturally as well as in augmenting the Au-content (fineness) of the natural Au-Ag gold alloy; that epigenetic shear-zone related processes and others, which are intrinsic to the "orogenic gold" concept, did not notably act in the metallogenesis of the Pari mine, nor of the other associated gold mineralizations (except Bahú); and, last not least, that the potential gold ressources of these deposits, based on conservative estimative calculations, total about $44 \mathrm{t}$ Au. The comparative studies and literature indicate that other gold deposits in the Nova Lima Group may also have had synsedimentary-exhalative origins, for instance, the Săo Bento mine mineralization, of a fine clastic (graphitic schists) and chemical (sulphide facies Algoma type BIF) sedimentary environment, distal to any active volcanic center, as well as the Morro Velho and Faria mines, among others. It must also be pointed out that the concept that medium and high grade metamorphic greenstone terrains do not own gold potential has to be reviewed in the light of the results of Pari, as well as of other Archean terrains worldwide which host even world class gold deposits. 


\section{Capítulo I: INTRODUÇÃO; DESCRIÇÃO E OBJETIVOS}

\section{I.1. Introdução e Objetivos da Tese de Doutorado}

O estado atual de conhecimentos da metalogênese do ouro ( $\mathrm{Au}$ ) no Quadrilátero Ferrífero (QF) é caracterizado muito mais pela polaridade e antagonismo a priori das opiniões científicas, muitas vezes conceituais e polêmicas, do que por contribuições fáticas novas ao conhecimento, considerando todos os aspectos marcantes e relevantes das mineralizações conhecidas, que, aliás, continuam as mesmas já descritas desde Calógeras (1904), Freyberg (1934) e Moraes e Barbosa (1939), entre outros, sem novas descobertas significativas.

Diante da discussão e controvérsia registrada na vasta literatura sobre a geologia da região do Quadrilátero Ferrifero e, em particular, no assunto da metalogenia do ouro arqueano, escolheu-se uma abordagem multidisciplinar-integrada, visto que foram poucos os autores mais recentes que realmente empregaram múltiplas ferramentas nos seus estudos (p.ex.: Ladeira, 1980; Luchesi, 1991; Abreu, 1995).

Entende-se ainda, que o estudo proposto permitirá elaborar, além de novos fundamentos metalogenéticos científicos, critérios de aplicação prospectiva, o que vem encontrando respaldo nos resultados de pesquisas internacionais (p.ex.: como conduzidas em Hemlo, no greenstone belt de Wawa, Canadá e muitas outras nos greenstone belts da Austrália ocidental) e na atuação e experiência acadêmica, científica e profissional do doutorando, sempre dedicada a pesquisa de mineralizações de ouro.

Esse estudo insere-se na principal linha de pesquisa do orientador que versa sobre a evolução crustal precambriana, petrogênese e metalogênese de partes SE do Cráton do São Francisco. Foi desenvolvido no prazo regular do curso de Doutorado do IGc-USP com a participação do orientador e sua equipe e contou também com o apoio de empresas mineradoras permitindo acesso e coleta de amostras em suas áreas de interesse, minas ativas e/ou abandonadas.

A Tese teve os seguintes objetivos principais e complementares:

a) Estudo das seqüências de rochas supracrustais do Supergrupo Rio das Velhas do Morro do Pari e arredores, incluindo a ampliação das áreas de abrangência e o aprimoramento dos mapas geológicos em escala 1:25.000, com os seguintes intuitos: 
a.1) Detalhamento litoestratigráfico e litoestrutural das seqüências (utilizando-se inclusive amostras e dados de sondagem).

a.2) Estudo da mineralização e suas rochas encaixantes, além dos diversos litotipos circunvizinhos pertencentes ao Supergrupo Rio das Velhas, com a conseqüente comparação entre as diversas mineralizações próximas (Bahú, Gambá, Patrimônio e São Bento), sobretudo quanto a forma, estratigrafia, estrutura, rochas encaixantes e ambientes.

b) Caracterização petro-metalogenética detalhada de todas as unidades litoestruturais mapeadas e descritas nos furos de sondagem, com enfoque nas rochas do Grupo Nova Lima, em particular aquelas mineralizadas em Au.

c) Estudo geoquímico da mineralização e de suas encaixantes, bem como o estudo da microgeoquímica das ligas naturais de $\mathrm{Au}-\mathrm{Ag}$, e das fases sulfetadas e silicáticas objetivando sua caracterização e modelamento metalogenético para o ouro.

d) Geotermometria em sulfetos e silicatos para avaliar as prováveis temperaturas dos processos metalogenéticos e metamórficos que originaram e transformaram a mineralização de Au da mina do Pari.

e) Geração e aprimoramento do modelo da geologia e metalogênese do ouro da mina do Pari através da interpretação e integração de todos os dados novos e antigos obtidos desde a dissertação de mestrado de Abreu (1995).

\section{I.2. Localização}

A mina do Pari (Fotografias 01 e 02) está localizada na quadricula de Florália, 1:25.000 (coordenadas: latitude $19^{\circ} 52^{\prime} 30^{\prime \prime} / 20^{\circ} 00^{\prime} 00^{\prime \prime} \mathrm{S}$ e longitude $43^{\circ} 15^{\prime} 00^{\prime \prime}$ $143^{\circ} 22^{\prime} 30^{\prime \prime} \mathrm{W}$ ) a qual foi a única não mapeada pela equipe DNPM-USGS (Figura 01).

A distância de Belo Horizonte a Santa Bárbara é de $100 \mathrm{~km}$, no sentido leste da capital mineira. $O$ acesso a partir de Belo Horizonte se dá pela BR-262 por $70 \mathrm{~km}$ até o entroncamento da MG-436, estando Santa Bárbara a $30 \mathrm{~km}$ deste ponto. 


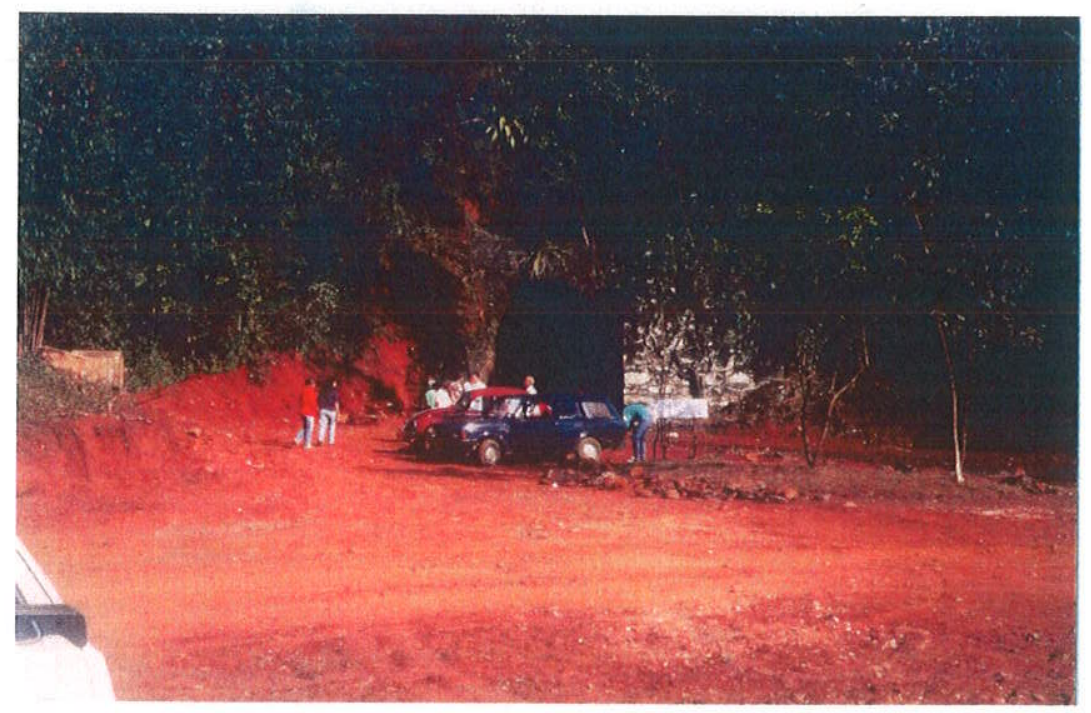

Fotografia 01: Entrada principal da mina do Pari, em 1988 quando do início dos trabalhos de re-avaliação da UNAMGEN Min. e Met. S.A.

Atravessando-se a cidade de Santa Bárbara, toma-se uma rodovia vicinal não pavimentada que leva a represa do Peti, caminhando-se nesta por $5 \mathrm{~km}$, toma-se então à direita, por outra estrada vicinal, até atingir a vila de Florália, com cerca de 1000 habitantes. A mina do Pari se encontra a $2 \mathrm{~km}$ a sul desta vila, às margens do rio Valéria, próximo à antiga estação ferroviária de Florália, na ferrovia Vitória Minas (CVRD).

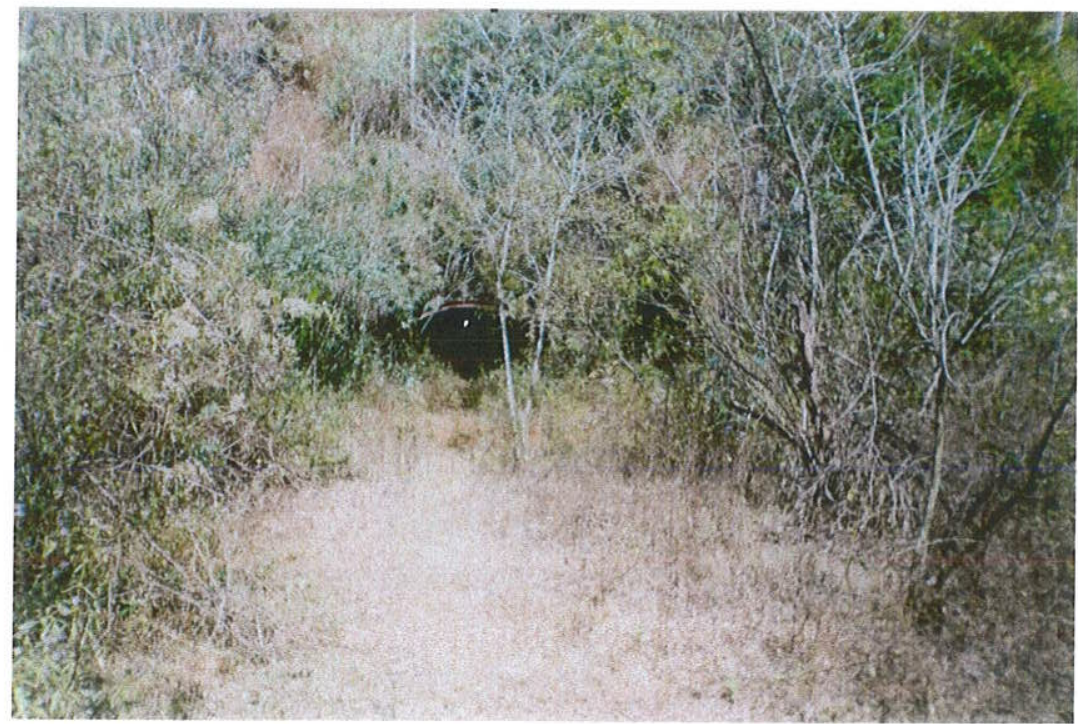

Fotografia 02: A mesma entrada da fotografia anterior nos dias de hoje, dominada pela vegetação. 


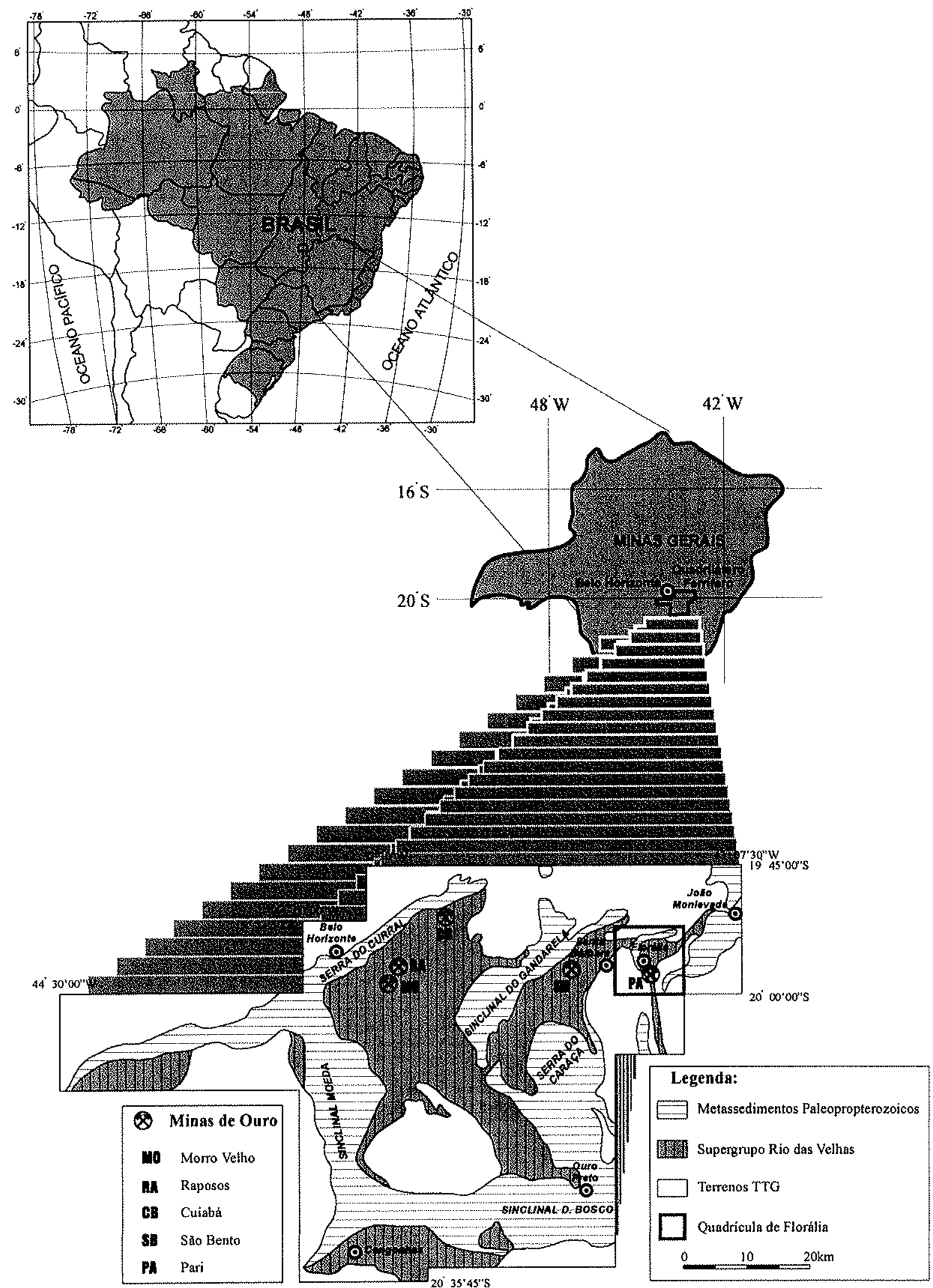

Figura 01

Mapa de Localização da Quadrícula de Florália 


\section{I.3. Aspectos Geológicos Gerais}

A geologia da porção NE do Quadrilátero Ferrífero, incluindo as quadrículas de São Gonçalo do Rio Abaixo (a norte), a de Florália (no centro) e Bateias (a sul), exposta em Dorr (1969) nos trabalhos da equipe do Convênio DNPM-USGS, foi apenas fotointerpretada e verificada em poucos perfis regionais para fins de integração no mapa regional em escala 1:150.000.

A área de estudo principal, a mina do Pari, caracteriza-se por ser uma extensão do "Greenstone belt Rio das Velhas" (Figura 02) e também de demais unidades litoestruturais do Quadrilátero Ferrífero (Schorscher, 1976a; 1978; 1979a; 1992; Inda et al., 1984; Schorscher et al., 1986; 1990). A região é um importante metalotecto, principalmente para $\mathrm{Au}$, e minério de ferro.

A importância metalogenética dessa mina de ouro (Fotografias 03, 04, 05 e 06), no âmbito do Quadrilátero Ferrífero, vem de suas características bastante distintas das demais mineralizações auríferas do Supergrupo Rio das Velhas. As condições metamórficas são de grau superior a da quase totalidade das minas de $\mathrm{Au}$ do Quadrilátero Ferrífero, isto é, a mina do Pari encontra-se na transição da fácies xisto verde alto para anfibolito.

Até então, somente o trabalho de Abreu (1995) fora de cunho acadêmico e sistemático de caracterização sumária do minério e suas encaixantes.

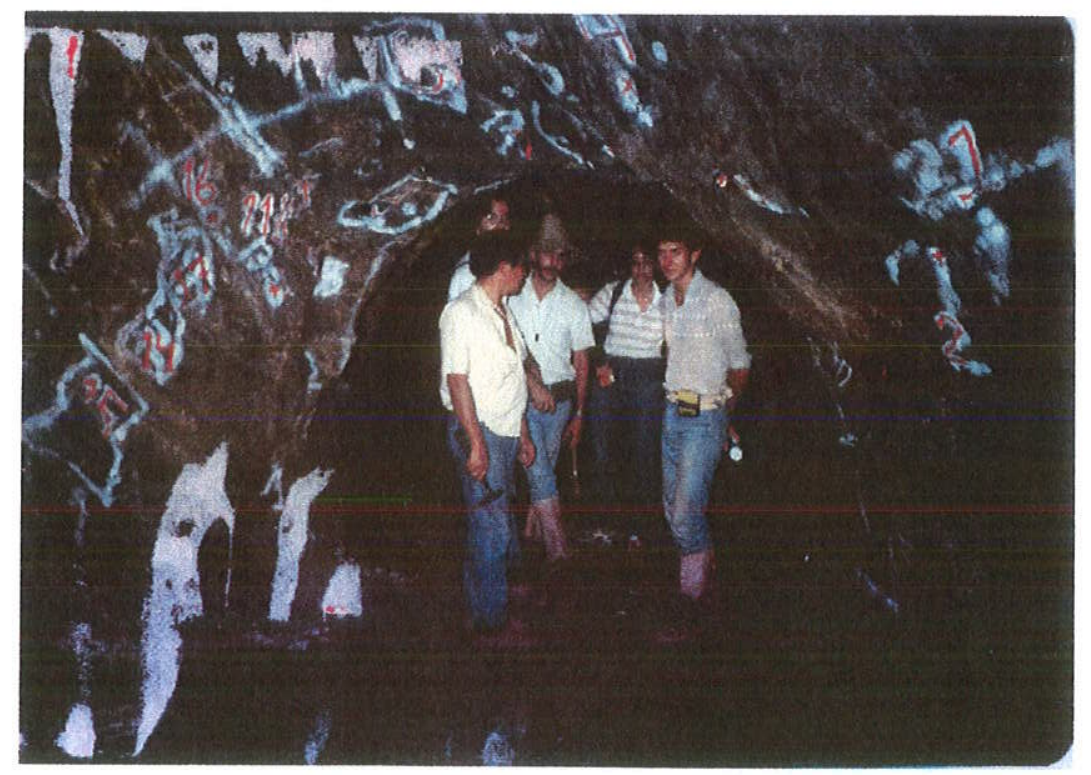

Fotografia 3: Local de amostragem no salão principal da mina do Pari (Nível-00), com as marcas da primeira amostragem de canal realizada em 1986. 


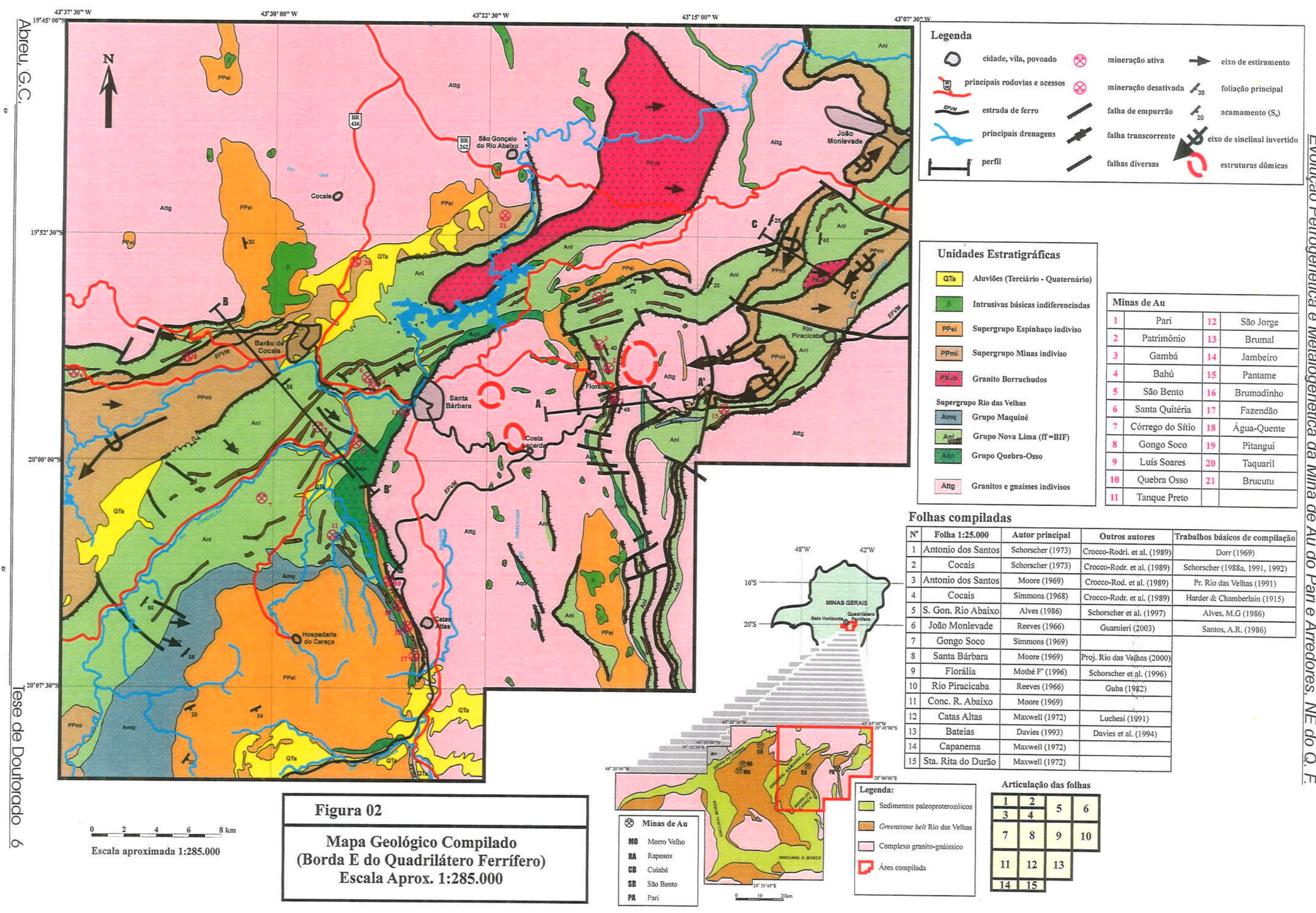




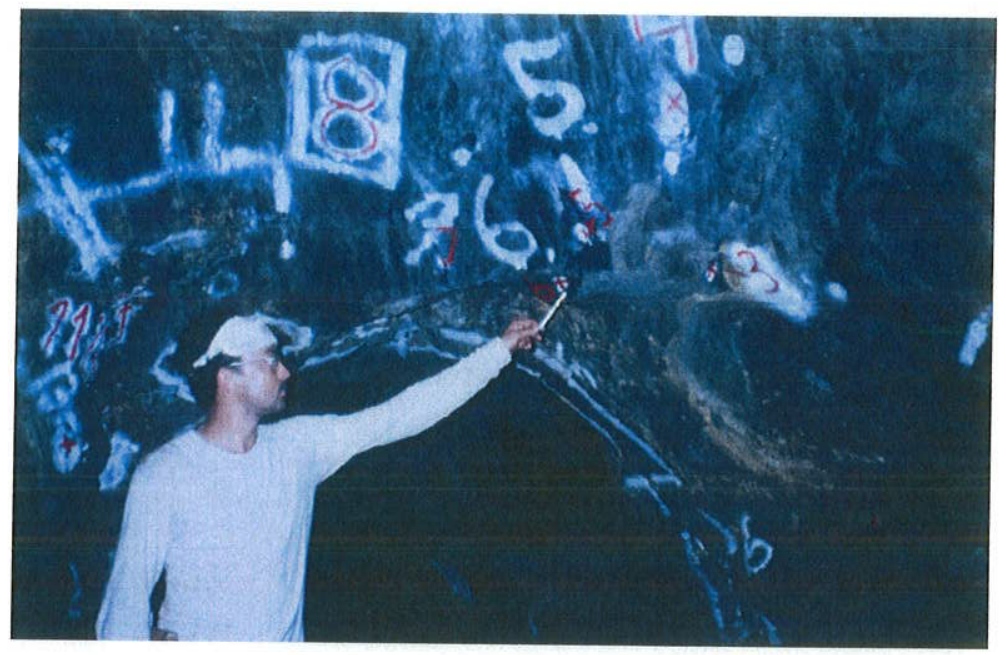

Fotografia 4: Detalhe da fotografia anterior mostrando os locais de amostragem. Salão principal (Nivel 00) da mina do Pari.

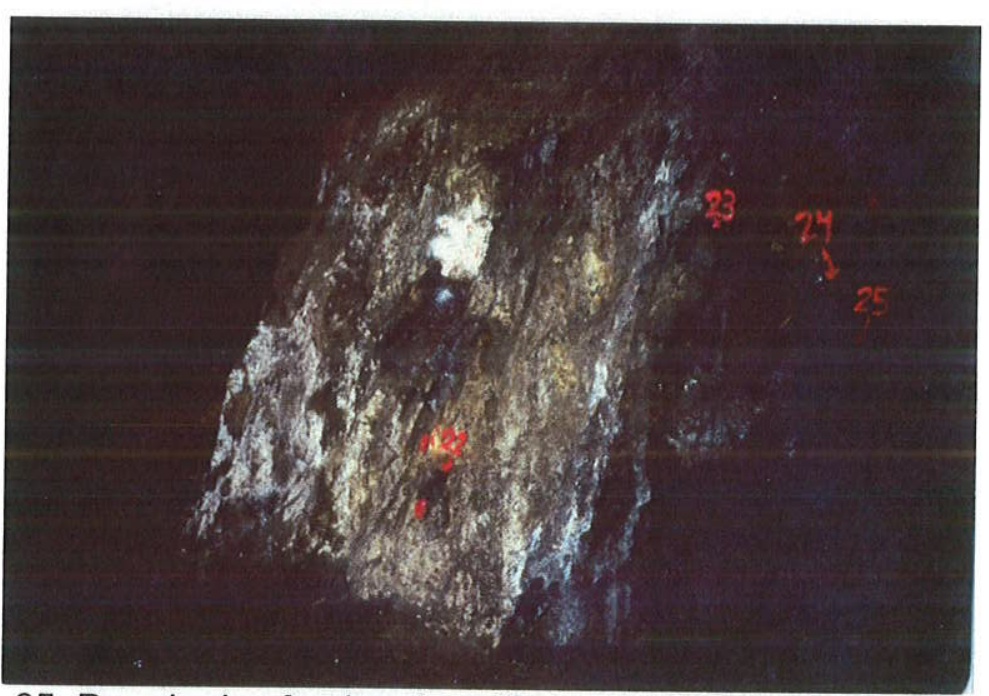

Fotografia 05: Parede dos fundos do salão principal da mina do Pari, com as marcas das amostras realizadas em vermelho.

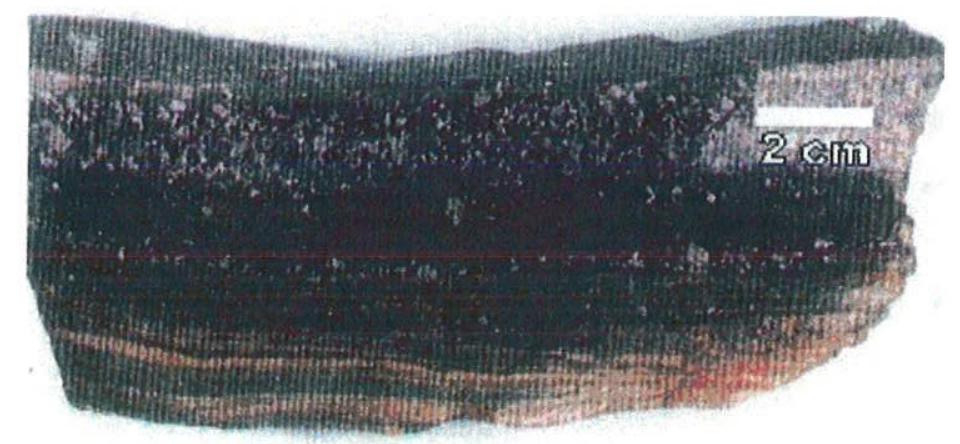

Fotografia 06: Amostra do minério aurífero típico da mina do Pari 
O presente estudo inclui geologia, mineralogia-petrografia, litogeoquímica, química mineral, microgeoquímica da liga natural $\mathrm{Au}-\mathrm{Ag}$ e de fases minerais usadas em geotermometria, e pretende contribuir aos conhecimentos da geologia e metalogenia do Au da região e, em geral, do Quadrilátero Ferrífero.

\subsection{Histórico da Mina do Pari}

As mais antigas informações a respeito das lavras de ouro na área vêm dos meados do século XIX, mencionando que o Coronel João José Carneiro de Miranda explorava aluviões e coluviões e rochas intensamente intemperizadas, não se sabendo com exatidão o local e não se tendo deste período nenhum registro escrito sobre a produção.

As operações em subsolo na Mina do Pari (Fotografias 1 a 5) iniciaram-se em 1882 pela Santa Bárbara Gold Mining Company Ltd. Esta empresa minerou até 1889, lavrando aproximadamente 270.000 t de minério, com um teor médio produzido de $10,5 \mathrm{~g} / \mathrm{t}$. Os proprietários desta empresa eram os ingleses William Turner Atherton e Percy Murly Gotto, também sócios de outras minas na região.

No final século XIX, entre 1885 e 1893, essa mina produziu cerca de 2,68 toneladas de $\mathrm{Au}$ com métodos bastante rudimentares de lavra e tratamento de minério. $\mathrm{A}$ recuperação do Au era feita por gravimetria e amalgamação. Quando da paralisação de suas atividades em 1937, a mina já operava numa profundidade vertical de cerca de $300 \mathrm{~m}$, lavrando rocha fresca, mostrando-se, já nessa época, que o minério sulfetado não possuia características refratárias de recuperação, diferentemente do que era constatado na Mina São Bento, entre outras da região, que permitiam extração do Au apenas em litologias intemperizadas, ou seja, em minério oxidado.

A partir de 1889, a Mina do Pari foi arrendada à Saint John Del Rey Mining Co. (atual Anglo Gold), que lavrou e desenvolveu a mina até a suas paralisação em 1937.

Após o abandono, a mina encheu-se de água até o nível principal de acesso e assim permaneceu até junho de 1988, quando a Unamgen Mineração e Metalurgia S.A. iniciou os trabalhos para reavaliação das reservas, vindo então a concluí-los no início de 1991.

O autor trabalhou na UNAMGEN Min. e Met. S.A. por periodo de 3 anos, participando integralmente da reavaliação do depósito. 


\section{Capítulo II: MÉTODOS UTILIZADOS}

Nesta tese utilizou-se um acervo metodológico diversificado, entretanto, bastante simples. Basicamente, utilizaram-se das ferramentas da geologia fundamental, incluindo revisões da literatura, trabalhos de campo (mapeamento regional, de semidetalhe e detalhe) e estudos laboratoriais de caracterização petrográfica, litogeoquímica e de química mineral.

Em resumo, procurou-se caracterizar e descrever detalhadamente a problemática, buscando então o seu entendimento. A seguir são listadas as principais etapas conceituais do trabalho.

\section{II.1. Trabalhos Preliminares}

II.1.1 Levantamento bibliográfico segundo enfoques temáticos, regionais e locais. Inclui-se ainda, a compilação de um mapa regional preliminar da borda NE do Quadrilátero Ferrífero (QF), 1:100.000 (Anexo 01), o qual posteriormente foi corrigido e complementado com as novas informações obtidas de campo e petrografia.

II.1.2 Revisão e estudo das coleções de amostras dos trabalhos anteriores de Schorscher et al. (1986 e 1990) e das da dissertação de mestrado de Abreu (1995), disponíveis no IG-USP, incluindo litologias regionais da área e rochas e minérios da Mina do Pari, Mina São Bento além de outras.

\section{II.1.3 Planejamento das Campanhas de Campo}

\section{II.2. Trabalhos de Campo}

11.2.1 Ampliação da área de abrangência e melhoria do mapeamento litoestrutural em escala 1:15.000, do morro do Pari e arredores (Figura 03).

II.2.2 Amostragens sistemáticas na mina do Pari foram realizadas tanto no nivel de entrada $(\mathrm{N}-00)$, quanto no nivel $10(\mathrm{~N}-10)$ (Figuras 04 e 05), em amostras de mão, 


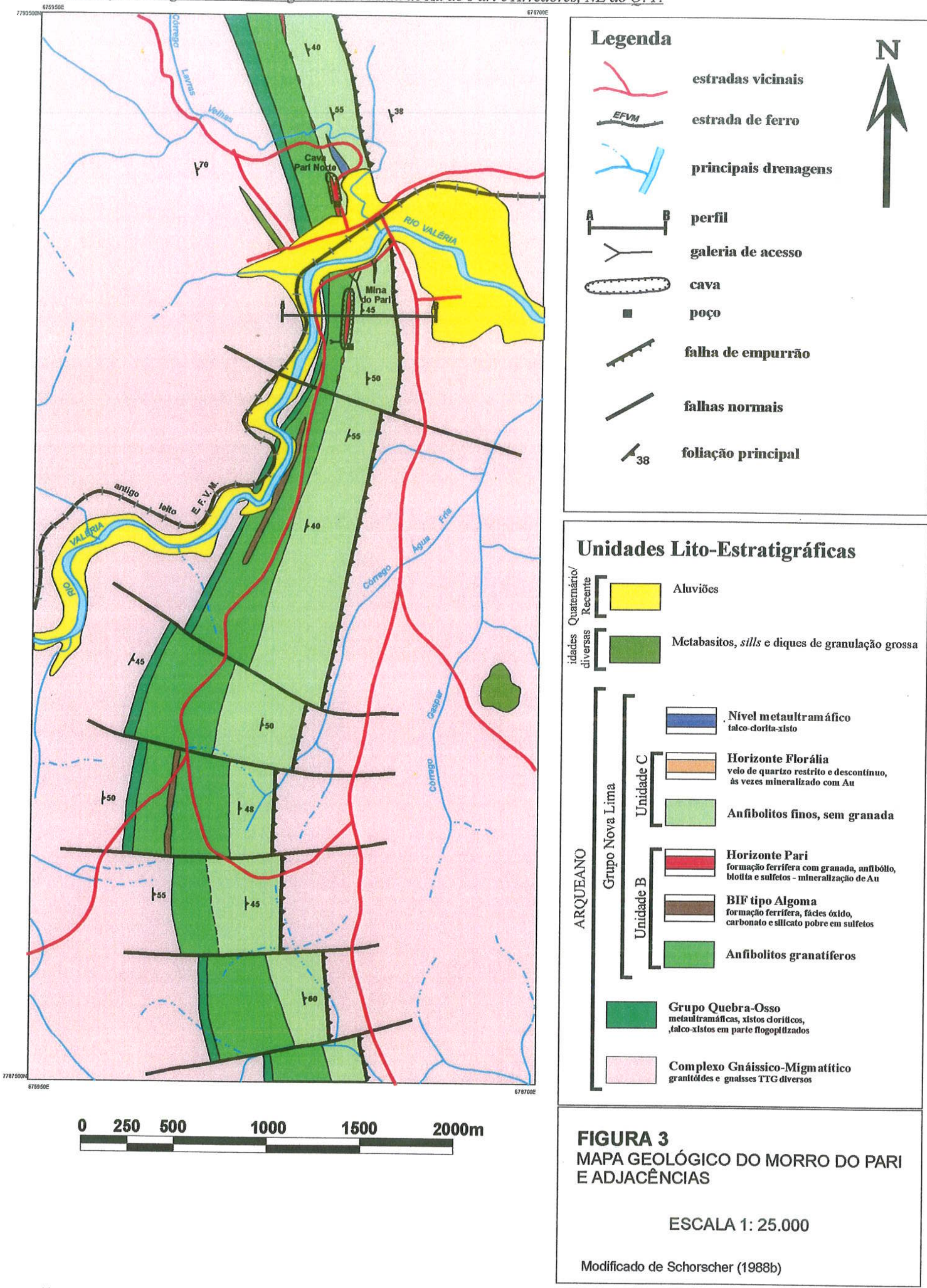



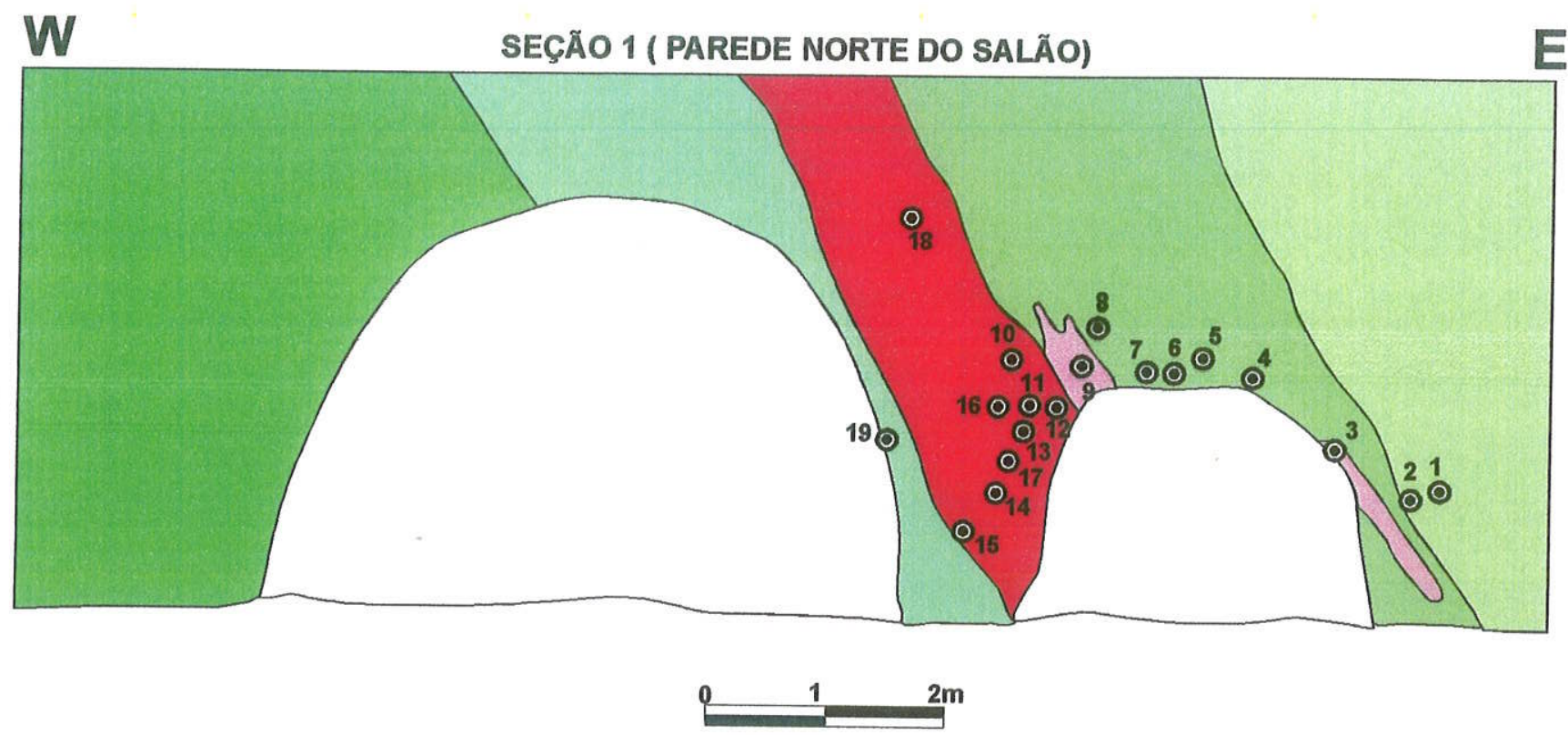

E

\section{SEÇÃO 2 ( PAREDE NORTE DO SALÃO)}
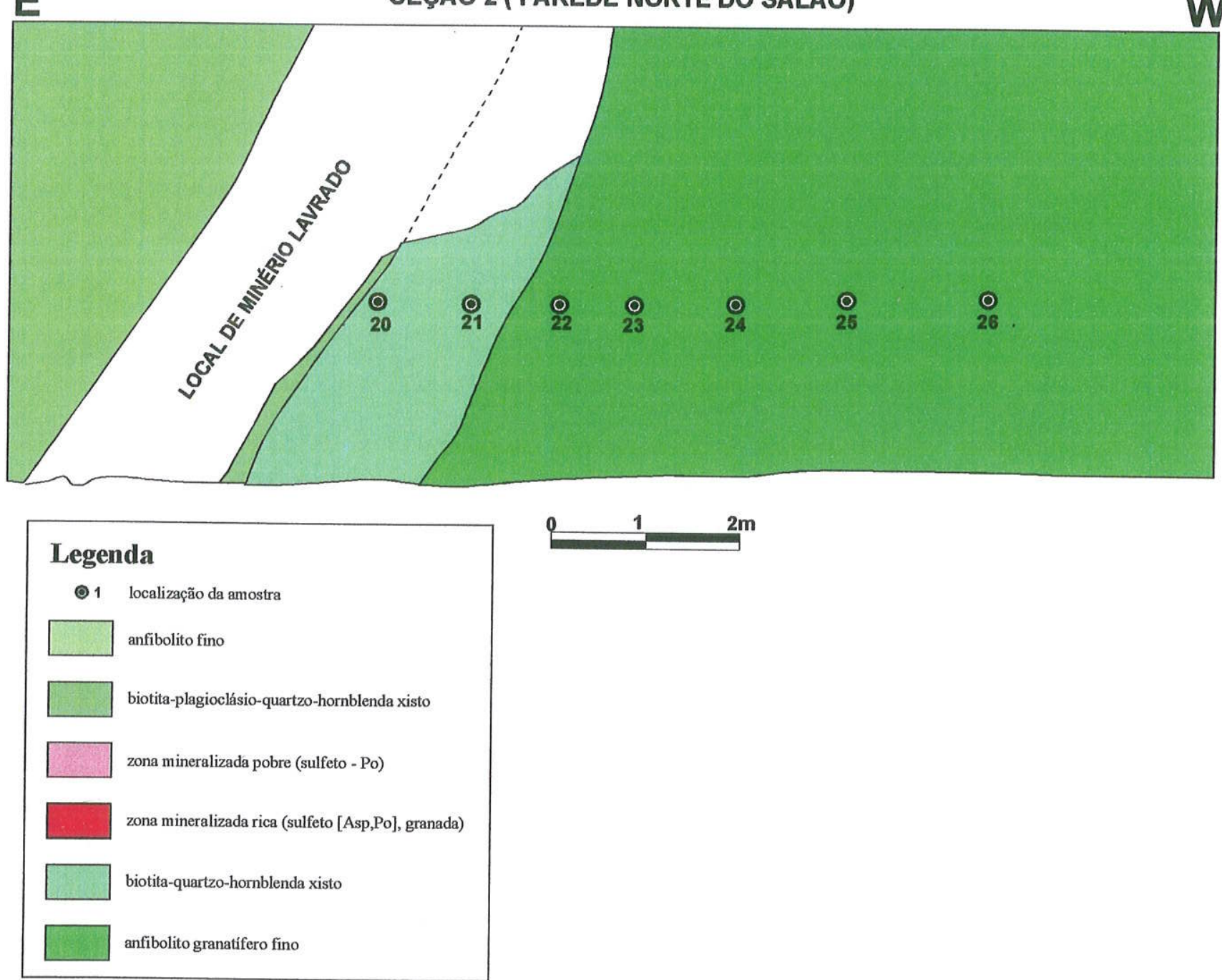

Figura 04:

Seções de amostragem do salão principal da Mina do Pari, nível de entrada (N-00) 

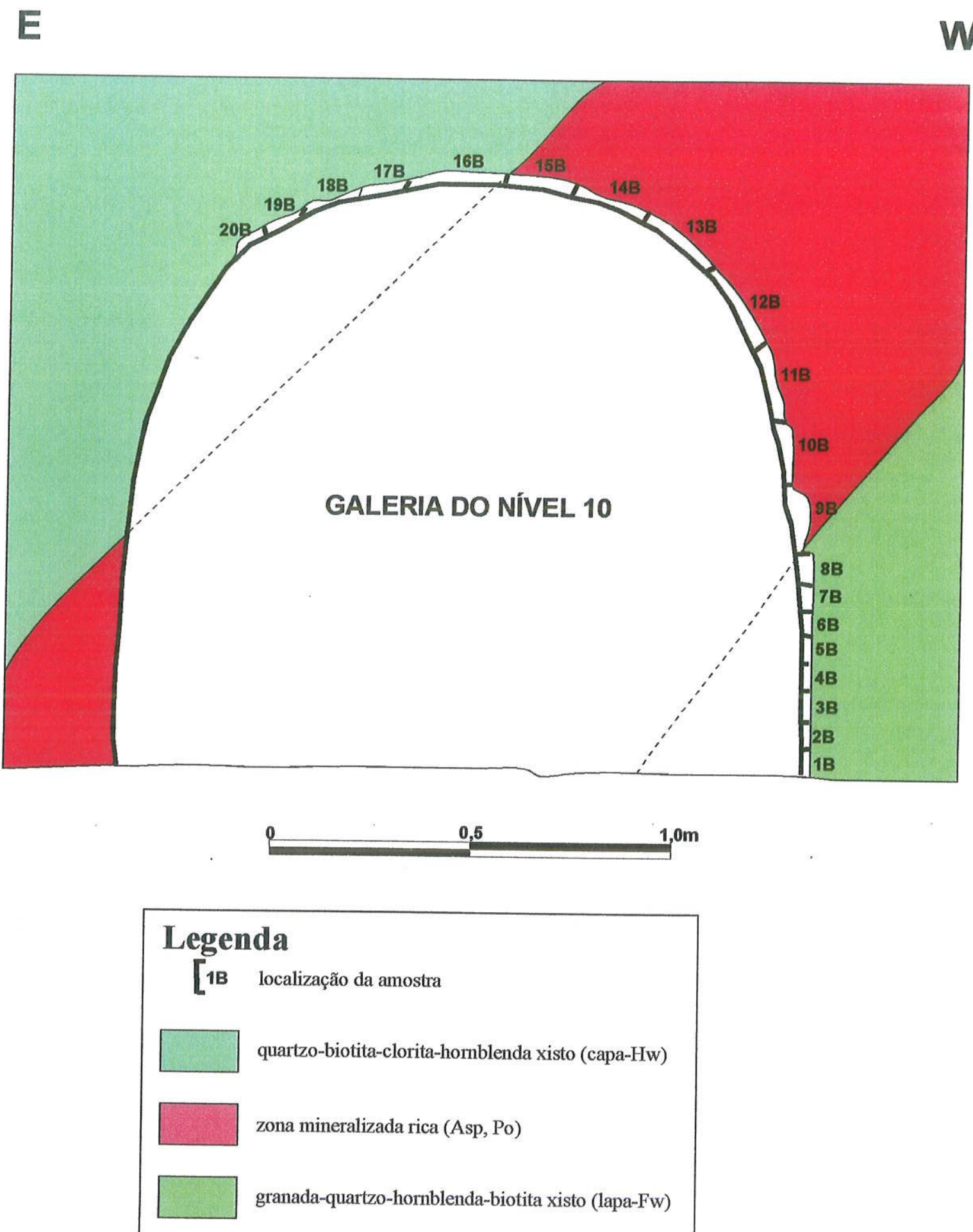

Figura 05:

Seção de amostragem na galeria do nível 10 ( $\mathrm{N}-10)$ 
ainda nos trabalhos de dissertação de mestrado (Abreu, 1995), e completados com testemunhos de sondagem rotativa a diamante cedidos pela UNAMGEN Mineração e Metalurgia S.A. (onde o autor trabalhou entre 1988 e 1991).

Para a tese de doutorado foram feitas novas amostragens de superficie e de testemunhos de sondagem, para ampliar as coleções já existentes da zona mineralizada e litotipos encaixantes. Nesta etapa contou-se com o apoio da São Bento Mineração S.A., Grupo Eldorado, detentora dos testemunhos da mina do Pari, que também autorizou descrever e amostrar ainda mais litotipos provenientes dessas sondagens da região do prospecto Brumal e da mina São Bento.

II.2.3 Os mapeamentos de detalhe, em galerias e rampas da mina do Pari foram concluídos ainda nos trabalhos de Abreu (1995) (Figura 06). Cabe salientar, que neste caso, a mina do Pari permaneceu, desde sua paralisação em 1937, com todas as galerias e rampas, abaixo do nivel de entrada ( $\mathrm{N}-00)$, cheias d'água. O Ribeirão Valéria, à frente da entrada principal da mina, sofre de enchentes periódicas, atingindo cotas superiores ao piso dessa galeria, e assim causando o total afogamento das galerias da mina. No período de 1988 a 1989, a UNAMGEN Mineração e Metalurgia S/A, durante a reavaliação da mina do Pari, efetuou trabalhos de bombeamento das galerias, o que levou quase um ano e meio de trabalho. Isso permitiu o acesso aos niveis inferiores (10 e 11), através dos $450 \mathrm{~m}$ de rampa inclinada a 45 graus.

Os horizontes mineralizados foram então facilmente identificados e mapeados devido às crostas oxidadas dos sulfetos do minério, em contraste aos xistos encaixantes. Naquela época, os canais de amostragem a cada $1,5 \mathrm{~m}$, realizados com serra diamantada a ar comprimido, permitiram a visualização dos sulfetos. Porém, a observação de estruturas em escala métrica de afloramento nas galerias ficou um pouco prejudicada, de forma que a análise estrutural teve de contar ainda com levantamentos de outros afloramentos em galerias fora da mineralização, e nos arredores do Morro do Pari e da região da Quadrícula de Florália.

II.2.4 Trabalhos de campo regionais com intuito de integração de dados compreenderam perfis clássicos, tais como: Mina do Pari-Rio Piracicaba (Figura 07), Serra do Seara (Figura 08) e Serra das Cambotas-Sinclinal Gandarela-Mina São Bento (Figura 09). Para a conclusão desta etapa ainda foi estudado um perfil na borda norte da Serra do Caraça, cortando rochas do Supergrupo Rio das Velhas (Grupos Quebra Osso, Nova Lima e Maquiné ), até atingir o contato com as 


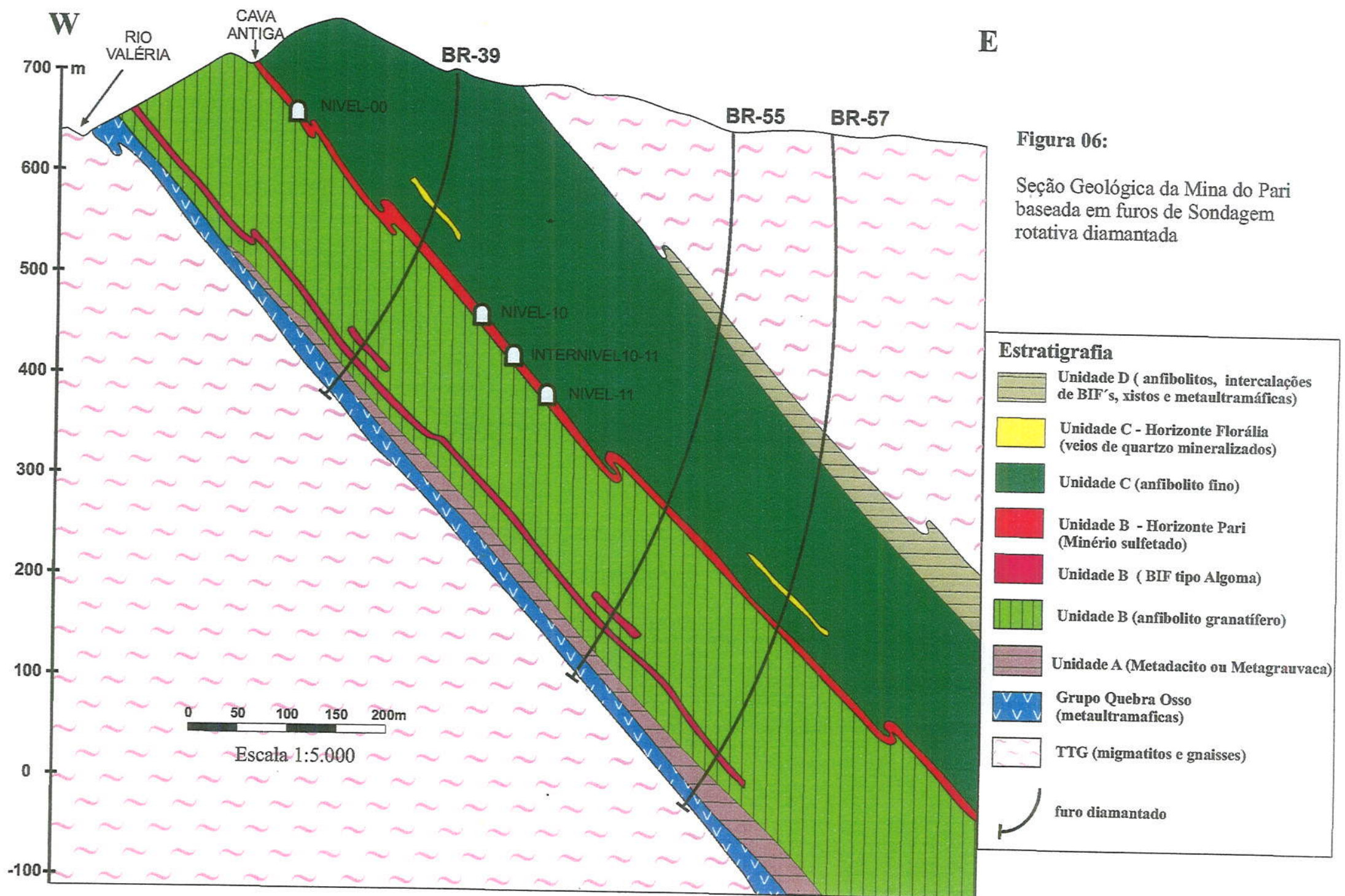


seqüências paleoproterozóicas do Supergrupo Espinhaço, subindo o vale do córrego Tanque Preto.

A relação dos afloramentos estudados encontram-se no Anexo 2.

\section{II.3. Estudos Laboratoriais}

II.3.1 Foram realizados estudos mineralógico-petrográficos ópticos convencionais de lâminas delgadas e seções polidas para a caracterização dos diversos litotipos encontrados na área de estudo. Para tanto foi utilizado o microscópio petrográfico de polarização, marca Zeiss $\mathrm{BX}-50$, tanto para luz transmitida quanto para luz refletida. Durante os trabalhos desta pesquisa pode-se fazer um levantamento petrográfico de toda a litoteca existente que foi coletada por Abreu (1995). Deste trabalho, juntaramse 236 amostras de rocha (de mão, canal e testemunhos de sondagem), das quais se confeccionaram 220 lâminas petrográficas, 143 seções polidas e 10 seções delgadas e polidas para análise via microssonda eletrônica (Anexo 3). A partir disso, nessa pesquisa de doutorado, foram elaborados os aspectos mais relevantes da petrografia da mineralização aurífera da mina do Pari.

\begin{tabular}{|c|c|}
\hline TABELA 01 - LIMITES DE DETECÇÃO EM ANÁLISES QUÍMICAS & Lim. \\
\hline Au (ppb): Fire assay (Fusăo e copelacăo)/ Absorcăo Atómica & $0.30 \mathrm{ppm}$ \\
\hline As (ppm): Aqua Régial Absorcăo Atómica & $0.01 \mathrm{ppm}$ \\
\hline Ag (ppm): Áqua Réqia/ Absorcăo Atómica & $0,01 \mathrm{ppm}$ \\
\hline S (\%): Áqua Régia/ Absorçăo Atómica & $0.003 \%$ \\
\hline Ni (pom): Aqua Régial Absorcăo Atômica & $0.01 \mathrm{ppm}$ \\
\hline Cu (ppm): Aqua Regial Absorcăo Atómica & $0.01 \mathrm{ppm}$ \\
\hline $\mathrm{Pb}$ (ppm): Aqua Régia/ Absorcăo Atómica & $0,01 \mathrm{npm}$ \\
\hline Zn (ppm): Aqua Régial Absorcăo Atómica & $0.01 \mathrm{ppm}$ \\
\hline Elementos maiores - Fluorescéncia de raios $X(X R F)$ & $0.01 \%$ \\
\hline Elementos traco comuns - Fluorescéncia de raios $X(X R F)$ & 1-5. pom \\
\hline Th $\mathrm{U}$ La ce e Nd - Fluorescéncia de raios X $(X R F)$ & $10-25 \mathrm{pr}$ \\
\hline
\end{tabular}

II.3.2 Análises iniciais, em 50 amostras, para elementos maiores e menores via fluorescência de raios $X$ (FRX) seqüencial automática foram efetuadas com equipamento Phillips no Instituto de Geociências de Hamburgo, Alemanha, pelo orientador, em 1990, e constam em Abreu (1995). Os limites de detecção deste método são apresentados na Tabela 01. 


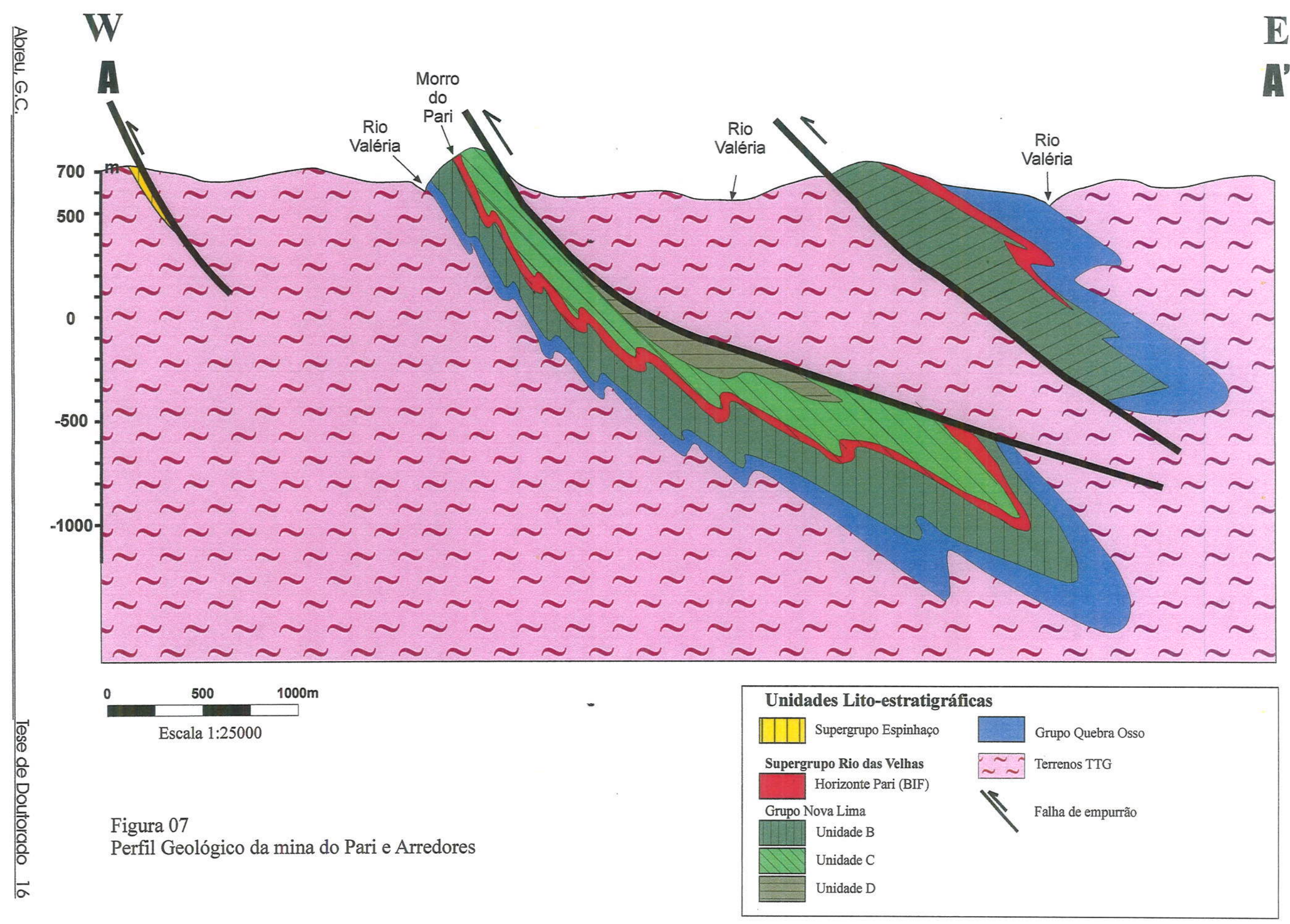


- Preparação e análise via ICP-MS de novas alíquotas das mesmas 50 amostras foram feitas nos laboratórios de Tratamento de Amostras (LTA) do IGc-USP e de ICP-MS do Departamento de Química, pelo grupo de pesquisa EANA (Espectrometria Atômica e Nuclear Aplicada), da PUC-RJ orientado pelos professores doutores Norbert F. Miekeley e Carmem L. Porto da Silveira (Tabela 01). - As análises de $A u \mathrm{~g} / \mathrm{t}=\mathrm{ppm}$ ) via fusão e copelação com dosagem por Absorção Atômica com extração Água Régia, e análise por Absorção Atômica, para As, Ag, $\mathrm{S}$, $\mathrm{Ni}, \mathrm{Cu}, \mathrm{Pb}, \mathrm{Zn}$, foram realizados numa $3^{\mathrm{a}}$ série de alíquotas das mesmas 50 amostras acima citadas, nos laboratórios de análises da São Bento Mineração S.A.

Os dados analíticos integrais são apresentados no Anexo 4.

II.3.3 Estudos de química mineral via microssonda eletrônica das ligas naturais do $\mathrm{Au}$, sulfetos e silicatos diversos para caracterização destes e uso em geotermometria; também foram realizados em diferentes etapas.

- Dados iniciais de sulfetos e de ligas naturais de Au obtidos pelo orientador já foram comentados por Schorscher et al. (1991) e Abreu (1995), e também foram contemplados neste trabalho. Estes dados foram produzidos com equipamento CAMECA-CAMEBAX e padrões internacionais de sulfetos e elementos puros, pelo orientador em convênio internacional no Instituto de Geociências da Universidade de Mainz, Alemanha.

- A microssonda eletrônica Jeol - Superprobe JXA-8600, automação NORAN, com 05 espectrômetros de cristais e um detector de estado sólido (EDS), dos laboratórios do departamento GMG-IGc-USP foi utilizada pelo signatário, numa primeira etapa, em 2003, para análises dos minerais silicáticos: granada, biotita, anfibólio, clorita, muscovita, carbonato; e óxidos, tanto para sua caracterização quanto para uso em geotermometria. Uma segunda etapa analítica do signatário, também em 2003, foi dedicada a análises de sulfetos. Nas análises de silicatos e carbonatos utilizou-se feixe analítico de diâmetro $\phi=10 \mu \mathrm{m}$ e de $\phi=5 \mu \mathrm{m}$ para óxidos.

Os dados de química mineral encontram-se no Anexo 5.

II.3.4 $\mathrm{A}$ análise de isótopos estáveis $(\mathrm{O}, \mathrm{C}, \mathrm{S})$ e instáveis e radiogênicos $(\mathrm{Pb}, \mathrm{Sr})$ de fases minerais específicas existentes no minério e suas encaixantes, nos laboratórios do CEPEGEO, no IG-USP, foi descartada devido aos métodos aí utilizados. Até o momento, o laboratório de isótopos estáveis somente utiliza 


\section{Figura 08}

Perfil Geológico-Estrutural

da Serra do Seara (C - C')

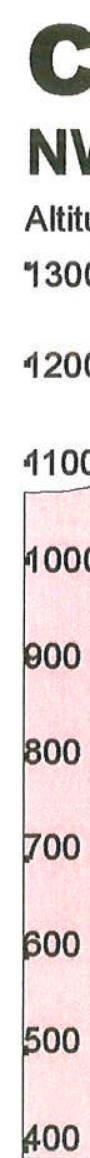

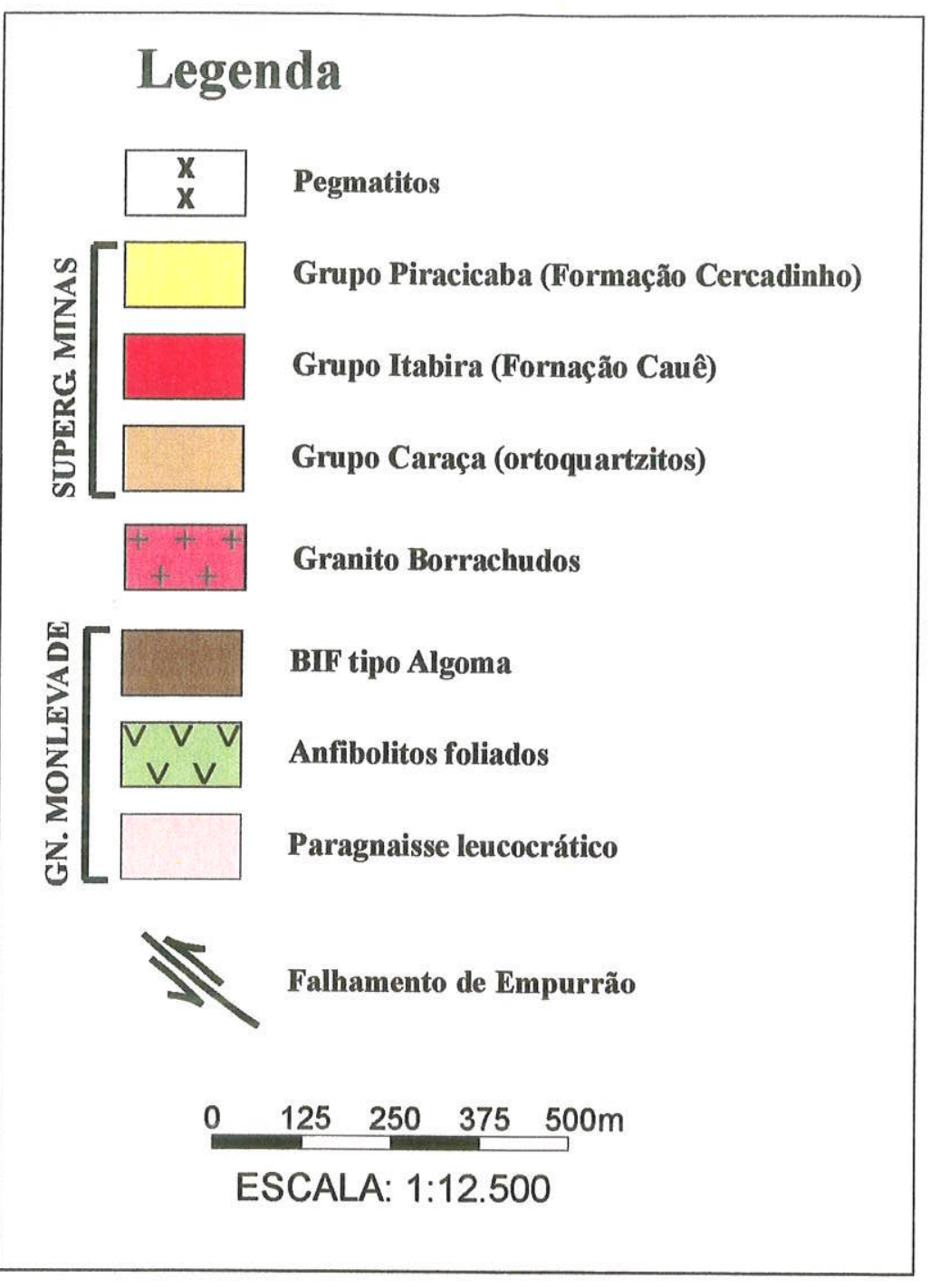

Mina de Ferro

do Batatinha

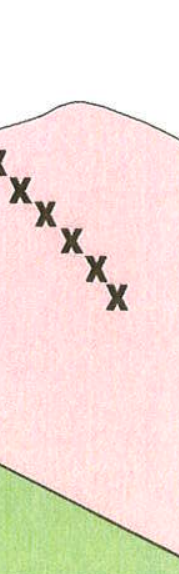

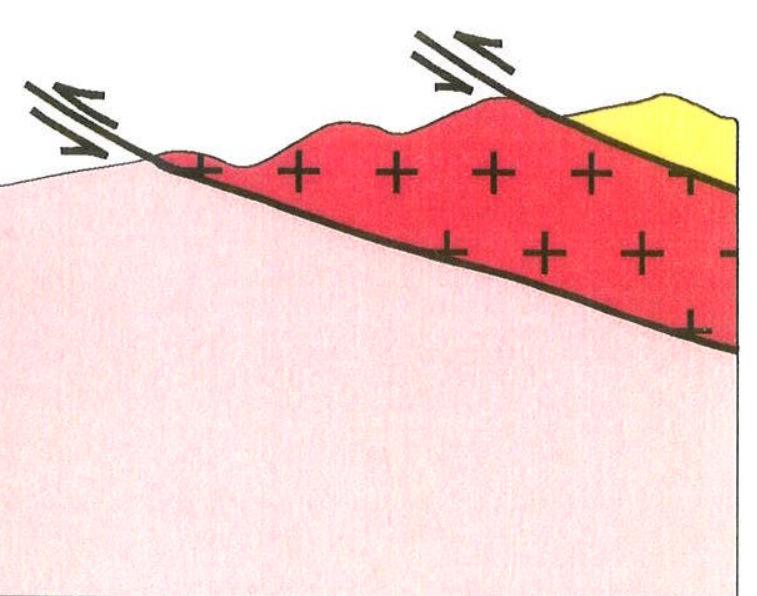




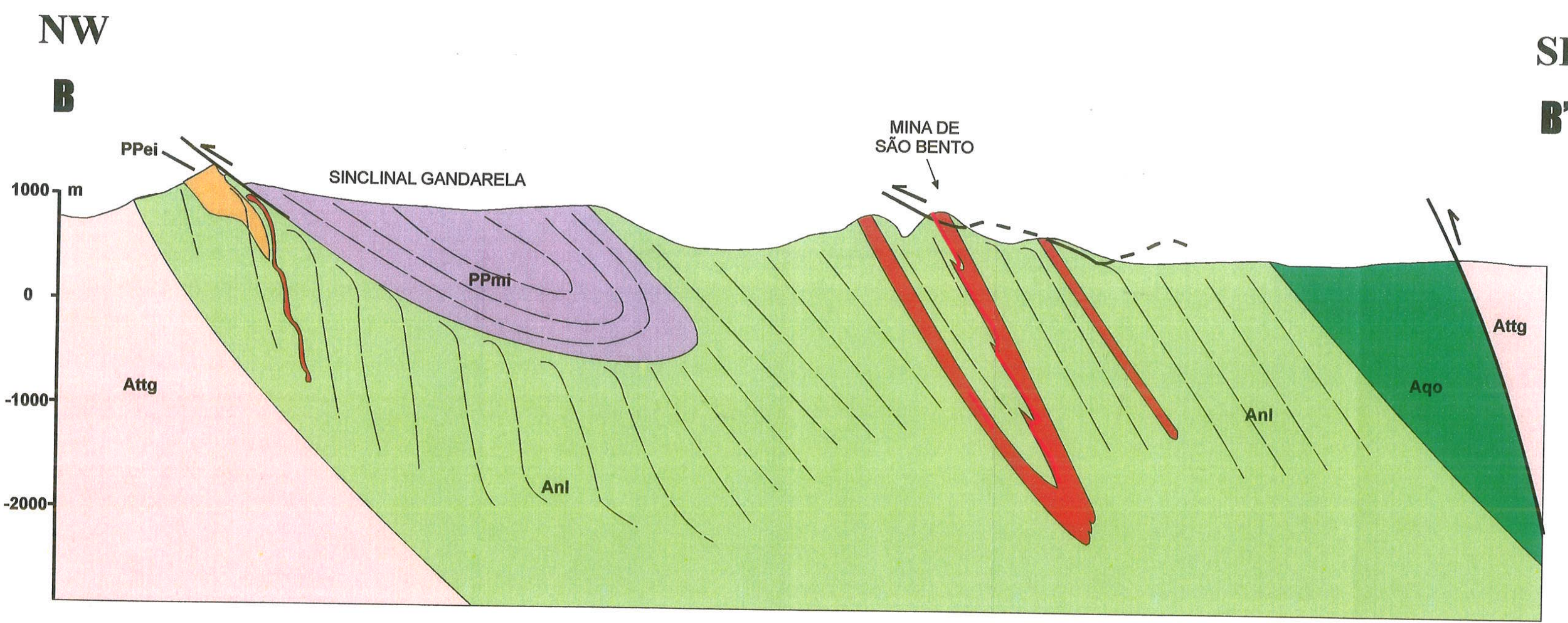

\section{Figura 09:}

Perfil Geológico do Q.Osso ao Sinclinal Gandarela (B - B')

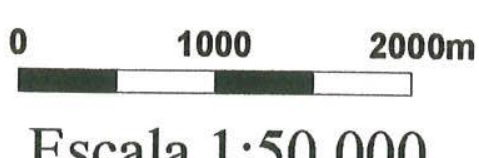

\begin{tabular}{|c|c|c|c|c|c|}
\hline \multirow{2}{*}{\multicolumn{2}{|c|}{ Legenda }} & \multicolumn{4}{|c|}{ Supergrupo Rio das Velhas } \\
\hline & & & \multicolumn{2}{|c|}{$\begin{array}{l}\text { Formação ferrífera São Bento } \\
\text { (fácies sulfetada) }\end{array}$} & \multirow[b]{2}{*}{ Granitos e gnaisses indivisos } \\
\hline PPei & Supergrupo Espinhaço indiviso & & Formação ferrífera & Attg & \\
\hline \multirow[t]{2}{*}{ PPmi } & Supergrupo Minas indiviso & Anl & Grupo Nova Lima & 7 & Falha de empurrão \\
\hline & & Aqo & Grupo Quebra Osso & & \\
\hline
\end{tabular}


- método por dissolução química global de carbonatos. Nesse sentido, as caracterizações petrográficas têm mostrado que ocorrem cristais de carbonatos de diferentes gerações genéticas, e que sobretudo aqueles associados intimamente à mineralização aurifera são partículas diminutas e ricas em inclusões de difícil separação das fases necessárias. Assim, o método atual poderia comprometer a confiabilidade dos resultados. O mesmo problema metodológico, de forma similar, apresenta-se na análise de isótopos instáveis e radiogênicos. A proposta inicial dos trabalhos, de tentar avaliar as fases minerais especificas e correlacionado aos resultados diversos processos sofridos pela mineralização, ficaria por completo comprometida utilizando-se os métodos de rocha total.

2.3.6 O tratamento informatizado dos dados químicos na confecção de tabelas, planithas, diagramas e gráficos diversos, incluiu também a digitalização de mapas, perfis e seções geológicas da mina do Pari e região. Para tanto tem-se utilizado diversos programas de computação especializados em cada caso (Tabela 02).

\begin{tabular}{|l|l|}
\hline \multicolumn{2}{|c|}{ Tabela 02: Programas de Computação Utilizados } \\
\hline \multicolumn{1}{|c|}{ Tratamento Utilizado } & Programa \\
\hline \multicolumn{1}{|c|}{} & MinPet, Excel \\
\hline Química de Rocha, Classificação e Análise & MinPet \\
\hline Quimica Mineral & Excel (Office-97) \\
\hline Planilhas e Gráficos em Geral & CorelDraw, Autocad R14 \\
\hline Desenhos e Mapas & Word (Office97) \\
\hline Textos e Edição & GPt, PTMafic, Rettiger (1999) \\
\hline Geotermobarometria & \\
\hline
\end{tabular}

\subsection{Avaliações Finais}

11.4.1 Interpretações finais com base na análise e integração dos dados obtidos no campo, na mina, laboratoriais: mineralógico-petrográficos, geoquímicos, microgeoquímicos, e da literatura (de inclusões fluidas e isotópicos).

11.4.2 Redação e defesa da Tese de Doutorado. 


\section{Capítulo III: GEOLOGIA REGIONAL E TRABALHOS ANTERIORES}

\section{III.1. Geologia do Quadrilátero Ferrífero}

A literatura geológica muito vasta e diversificada do Quadrilátero Ferrífero (QF) foi produzida em trabalhos acumulados, com tendência sempre crescente, nos últimos 300 anos. Portanto, a revisão que se segue, enfatiza o estado atual do conhecimento geológico, analisando a evolução das principais linhas de pensamento em seus aspectos mais importantes para a formação e transformação das rochas e das mineralizações auriferas, da evolução arqueana e paleo a neoproterozóica. Sempre quando foi considerado necessário, buscaram, em trabalhos clássicos, muitas vezes antigos e de difícil acesso, as bases especificas de definições geológicas originais, como locais típicos, afloramentos e regiões-chave, descrições petrográficas meso e microscópicas, assim como os fundamentos geotectônicos válidos naquelas épocas e sua possivel transposição para os conceitos atuais mais adequados.

\section{III.1.1. Arcabouço Geológico Geral}

O Quadrilátero Ferrifero (QF) situamse na porção SE do Cráton do São Francisco (CSF), na zona de transição entre as partes estáveis do cráton a W, de constituição arqueana, e o Cinturão Móvel Atlântico, proterozóico, policíclico e poligenético a $\mathrm{E}$. Este cinturão é subdividido, entretanto sem delimitações e definições exatas, e nas faixas Ribeira e Araçuai, em suas partes $S$ e $N$, respectivamente. Essa grande região inclui rochas arqueanas e proterozóicas retrabalhadas, também rochas neoformadas por eventos tectono-metamórficos superimpostos arqueanos $e$ as orogêneses dos ciclos Minas/Espinhaço e Brasiliano, respectivamente, paleo e neoproterozóicos.

$O$ QF é ainda a principal e mais tradicional província metalogenética do Brasil, em produção contínua há cerca de 300 anos, sendo os principais bens minerais o ouro, minérios de ferro, mármores, rochas magnesianas, minérios de manganês e minerais gema. Sob aspectos acadêmico-científicos vale destacar que foi nesta região que a Geologia Cientifica foi introduzida no Brasil, inicialmente como disciplina auxiliar à mineração e, posteriormente, como ciência independente. 
O QF e suas circunvizinhanças são, portanto, terrenos clássicos, por excelência, da geologia précambriana do Brasil e mundial. Já em seus trabalhos pioneiros do período de 1810 a 1821, o barão W.L. von Eschwege, capitão-mor das minas em além-mar da Coroa Portuguesa, estabeleceu os fundamentos geológicos para toda a região, de certo modo, válidos até hoje, incluindo a subdivisão litoestratigráfica, compartimentação geotectônica e, também, os princípios metalogenéticos (cf.: Schorscher 1988 e 1992). Em "O Pluto Brasiliensis", sua principal obra sobre a geologia e recursos minerais do Brasil, Eschwege $(1825,1833)$ explicita tais fundamentos e ainda fornece um importante cadastro, daquela época, sobre a produção mineral do pais.

Aqui serão relatados apenas os aspectos regionais mais significativos para a presente pesquisa:

- do Arqueano, em particular da seqüência metavulcano-sedimentar Rio das Velhas de tipo greenstone belt, reconhecida e estabelecida como tal, e conseqüentemente redefinida como Supergrupo Rio das Velhas por Schorscher (1976a, 1978, 1979a,b, 1980a);

- do Paleoproterozóico, na forma dos restos metassedimentares dos Supergrupos Minas e Espinhaço;

- da evolução tectono-metamórfica policíclica arqueana e proterozóica.

Diversos autores mais atuais, como por exemplo: Dorr 1969; Inda et al. 1984; Schorscher 1988 e 1992; Ladeira, 1988, Machado, N. et al. 1989 e 1996; Teixeira et al., 1996a; COMIG 1994a, b, Padilha et al. 2000; entre muitos outros, têm contribuído de maneira substancial com novos dados, nos mais diversos aspectos e com novas interpretações a respeito da evolução geológica regional.

\section{III.1.2. Estratigrafia do Quadrilátero Ferrífero: Evolução dos Conceitos}

As primeiras divisões estratigráficas para a região do Quadrilátero Ferrifero devemse a Eschwege (1833) e Pissis (1842), que já separaram as rochas xistosas auriferas arqueanas, hoje atribuidas ao Supergrupo Rio das Velhas, das coberturas metassedimentares quartzito-itabiríticas e quartzíticas proterozóicas, incluídas hoje, respectivamente, nos Supergrupos Minas e Espinhaço. Esses autores propuseram ainda, para estas coberturas, subdivisões e correlações litoestratigráficas muito pertinentes (cf. Schorscher, 1975; 1988). Derby (1906) introduziu o termo Minas Series - Série de Minas para uma associação de mica-xistos, quartzitos, itabiritos e calcários sobrepondo-se aos gnaisses embasamentais, intrudidos por um corpo 
granítico de dimensões quilométricas na região de Gouveia - no anticlinal central da Serra do Espinhaço Meridional. Separou a Série de Minas, ainda no topo, das seqüências quartzíticas conglomeráticas e mica-quartzíticas de cobertura, e correlacionou esses dois conjuntos, respectivamente, com as associações litológicas similares das principais estruturas itabiríticas e quartzíticas (Pico do Itacolomi) do QF, designando e definindo as últimas, posteriormente, como Série Itacolomi. E de certo interesse notar que, enquanto as principais unidades itabiríticas do QF continuam até hoje válidas, no sentido de Derby, compreendidas no Supergrupo Minas paleoproterozóico, a associação original das rochas xistosas e itabiríticas da região de Gouveia que provou pertencer a uma seqüência metavulcano-sedimentar arqueana de tipo greenstone belt (Fogaça et al., 1984; Inda et al. 1984; Machado, N. et al., 1989).

A subdivisão litoestratigráfica das rochas metassupracrustais do Quadrilátero Ferrifero, em sua essência até hoje usada, foi elaborada por Harder e Chamberlin (1915). Estes separaram a Série Minas, considerada na época algonquiana, dos xistos máficos, metavulcanitos e gnaisses da base que consideraram provavelmente arqueanos e subdividiram em 5 formações denominadas da base para o topo: Quartzito Caraça, Xisto Batatal, Formação Ferrífera Itabira, Formação Piracicaba e Quartzito Itacolomi. Adicionalmente, mencionaram ainda, entre outras observações, a ocorrência na borda $E$ do QF de um "...thrust sheet of mafic lavas..." (lavas máficas formando um corpo tabular de arraste) de significado regional. Posteriormente, Barbosa, O. (1954) propôs incluir os xistos arqueanos do Quadrilátero Ferrifero, de Harder e Chamberlin, (1915) na sua Série Barbacena, mais antiga que a Série Minas e de maior extensão regional - que incluiria, na região de Barbacena, rochas altamente cristalinas como gnaisses, granulitos e kinzingitos. Oliveira (1956) questiona os trabalhos de Barbosa, O. (1954), propondo para a área do QF uma Série Pré-Minas de rochas metassedimentares que estariam sotopostas aos quartzitos da Série Minas e sobrepostas aos gnaisses e granitos do embasamento.

\section{III.1.2.1. Arqueano: Terrenos Granito-Gnáissicos e Sgr. Rio das Velhas}

Nos mapeamentos de escala 1:25.000, do Quadrilátero Ferrifero, efetuados no convênio USGS-DNPM, Rynearson et al. (1954) e Matheson (1956) descreveram contatos discordantes entre a Série Pré-Minas e a Série Minas. Assim, Dorr et al. (1957) redefinem a Série Pré-Minas e a denominam de Série Rio das Velhas, dividindo-a no Grupo Nova Lima, inferior, constituido por xistos, filitos, rochas 
metavulcânicas, metagrauvacas e formações ferríferas tipo Algoma e Grupo Maquiné, superior, constituido principalmente de quartzitos e metaconglomerados. Dorr (1969) considera a Série Rio das Velhas representativa de um ambiente eugeossinclinal, com evolução de depósitos de tipo flysch, do Grupo Nova Lima, para depósitos de tipo molasse, do Grupo Maquiné.

Almeida (1976) e Schorscher (1976a) consideraram e reinterpretaram a Série Rio das Velhas, eugeossinclinal segundo Dorr (1969), como um greenstone belt arqueano, utilizando-se dos dados anteriores da literatura e de novas observações e revisões de campo. Schorscher $(1978,1979 a, 1979 b, 1980 a)$ confirmou definitivamente a nova interpretação, com a descoberta de metakomatiitos (ultramáficos e ultrabásicos efusivos), incluindo tipos spinifex, de pillow lava, block lava, derrames maciços e piroclásticos, num corpo regional extenso na borda $E$ do Quadrilátero Ferrífero, aflorante às margens córrego do Quebra Osso. O Grupo Quebra Osso, então definido, estaria na base do Supergrupo Rio das Velhas, possuindo um contato gradativo com o Grupo Nova Lima, ainda que, na seção tipo, em posição invertida. Cabe ainda mencionar que este corpo metaultramáfico já foi mapeado e interpretado nos estudos do projeto DNPM-USGS, por Simmons (1968), Dorr (1969) e Maxwell (1972), como de rochas verdes intrusivas, respectivamente, nas séries Rio das Velhas e Minas, e que é muito provavelmente o mesmo já mencionado por Harder e Chamberlin (1915), como de lavas máficas em corpo de arraste da borda $E$ do Quadrilátero Ferrífero, sem maiores especificações do local. Drake e Morgan (1980), sem nenhuma refer6encia aos trabalhos acima comentados, compararam a Série Rio das Velhas como uma seqüência ofiolitica, ainda considerando as ultramáficas como intrusivas serpentinizadas.

Schorscher (1978, 1979a, b, 1980a), compreendendo o Grupo Quebra Osso junto com os grupos Nova Lima e Maquiné de Dorr e colaboradores, definiu 0 greenstone belt Rio das Velhas, elevando-o a categoria de Supergrupo, com subdivisão formal em 3 grupos, da base ao topo:

- Grupo Quebra Osso: seqüência metaultramáfica vulcânica (metakomatiitos), com intercalações de metassedimentos químicos (BIF, metacherts) subordinados;

- Grupo Nova Lima: seqüência de xistos predominantemente máficos, metabasitos/anfibolitos, formações ferriferas tipo Algoma, de fácies diversas, metagrauvacas e raros metassedimentos mais maduros (quartzitos, entre outros);

- Grupo Maquiné: quartzitos e metaconglomerados com piritas detríticas. 
Ladeira (1980 e 1988) com trabalhos metalogenéticos na Mina de Morro Velho, no distrito de Nova Lima, propôs uma seqüência estratigráfica para o Supergrupo Rio das Velhas, quase que de forma semelhante a Schorscher (1978, 1980c e1992). Embora não tenha admitido o Grupo Quebra Osso separadamente do Grupo Nova Lima de Dorr (1969), considerou como unidade basal deste, a denominada Unidade Metavulcânica, onde incluiu, além das lavas metultramáficas, metabasaltos e metatufos. Desta forma, como se observa nos mapas mais detalhados da região de Nova Lima, no centro do Quadrilátero Ferrifero, ocorrem corpos de metaultramáficas intercaladas às diversas outras rochas do Grupo Nova Lima. Apenas na porção leste e nordeste do Quadrilátero Ferrifero é que as metaultramáficas efusivas, verdadeiros komatiitos peridotíticos, com textura spinifex, entre outras, são encontradas e que já foram mapeadas em detalhe por Sichel (1983), Queiroga et al. (1988), e Luchesi (1991), e estão em contato com rochas TTG, hoje em posição invertida, e em contato gradacional sobre litotipos metapelíticos e químicos do Grupo Nova Lima, ou seja, definindo a base do Sgr. Rio das Velhas.

Outras ocorrências de rochas metaultramáficas foram mapeadas em outras porções do Quadrilátero Ferrífero, a exemplo de Florália (Alves, 1986; Davies, 1993; Abreu, 1995 e 1996; Mothé Fo, 1996), Nova Era e Itabira (Schorscher, 1978; Machado, 1994 e 1998), e estas têm sido correlacionadas às extensões do Grupo Quebra Osso.

Mais recentemente, trabalhos do Convênio DNPM-CPRM (1996), do assim chamado de Projeto Rio das Velhas, baseando-se na aquisição de novos dados aerogeofísicos e da integração de dados preexistentes, iniciaram uma subdivisão maior no Grupo Nova Lima, mantendo as rochas komatíticas do Quebra Osso como sendo uma subunidade da base da associação máfica-ultramáfica. Entretanto, as 5 associações de ambientes criadas para o Grupo Nova Lima (da base ao topo: metavulcânica plutônica máfica-ultramáfica: Quebra Osso, Córrego. dos Boiadeiros e Ouro Fino; metavulcanossedimentar química: Morro Vermelho; metavulcanossedimentar químico-pelítica: Santa Quitéria; metavulcanossedimentar clástica: Ribeirão Vermelho e Mestre Caetano; metassedimentar clástica marinha: Mindá, Córrego do Sítio, Córrego da Paina, Fazenda Velha, Pau d'Óleo e Catarina Mendes) não possuem seções colunares estratigráficas, nem mesmo perfis-tipo levantados em detalhe, que comprovem esta estratigrafia, bem como nada se descreve sobre a natureza dos contatos entre tais unidades. De fato, trata-se de litofácies mapeadas em regiões distintas do Quadrilátero Ferrifero e integradas de maneira bastante empírica. Observa-se também, a falta de um bom levantamento 
bibliográfico, desconsiderando-se inúmeros trabalhos preexistentes, que possuem mapas e dados de campo, tais como Alves (1986), Luchesi (1991), Queiroga et al. (1998), Abreu (1995 e 1996), Schorscher (1978, 1979a,b, 1980a,b,c, 1988a, 1991 e 1992), Schorscher e Mothé Fo (1983) e Schorscher et al. (1982, 1990 e 1997).

De maneira semelhante, porém com uma lógica estratigráfica mais adequada, os trabalhos da CPRM na folha Itabira 1:100.000 (Padilha et al., 2000), colocam novamente o Grupo Quebra Osso na base do Supergrupo Rio das Velhas e mantém 4 subdivisões para o Grupo Nova Lima (Ouro Fino, Santa Quitéria, Mindá e Córrego do Sítio). Entretanto, Padilha et al. (2000) fornecem citações erradas no texto (p.ex. Schorscher, 1973, para a definição do Gr. Quebra Osso), dentre muitas outras imprecisões que suscitam descrédito ao trabalho.

As idades radiométricas das rochas do Greenstone Belt Rio das Velhas apenas recentemente foram definidas com maior precisão. Os trabalhos de Herz (1970) foram pioneiros desse gênero no Quadrilátero Ferrífero, e mostraram idades Arqueanas, Paleoproterozóicas a Brasilianas, respectivamente com os métodos $\mathrm{Rb}-\mathrm{Sr}$ e K-Ar em minerais e rochas. Thorpe et al. (1984) determinaram idades modelo $\mathrm{Pb}-\mathrm{Pb}$ de cerca de $3,0 \mathrm{Ga}$ em galenas das mineralizações auríferas do distrito de Nova Lima, MG.

Nos trabalhos de Machado, N. e Carneiro (1992), Machado, N. e Noce (1993) Machado, N. et al. $(1989,1996)$, Carneiro e Teixeira (1992), Carneiro et al. (1993), foram reportadas idades superiores a $3,4 \mathrm{Ga}$ em zircões de rochas graníticas e em zircões detríticos derivados das rochas graníticas regionais, que por Dorr e Barbosa (1963) e Dorr (1969) foram consideradas muito mais jovens, com base nas datações radiométricas iniciais daquela época (Herz et al., 1961). Assim, caracteriza-se para a região do QF, uma evolução policiclica, que causou rejuvenescimentos isotópicos sucessivos dos sistemas $\mathrm{Rb}-\mathrm{Sr}$ e K-Ar de minerais e rochas.

Outros trabalhos geocronológicos com tentativa de avaliar idades metalogenéticas no Supergrupo Rio das Velhas são apresentados por de Wit et al. (1994 e 2004) e Schrank e Machado, N. (1996a,b). O primeiro utilizou o método $\mathrm{Pb}-\mathrm{Pb}$ em sulfetos obtendo 2,72 Ga para a mineralização São Bento e 2.1 Ga para o metamorfismo em BIF (rocha total). No entanto, há de se entender que a idade mais antiga já poderia ser uma idade metamórfica preservada nos sulfetos. Schrank e Machado, N. $(1996 a, b)$ analisaram diversas rochas e minerais pelo método U-Pb em zircão e monazitas. Foram assim obtidas idades desde 3,5 a 0,462 $\mathrm{Ga}$. Em zircões, as idades quase sempre eram superiores a 2,2 G.a., com grande predominância de idades arqueanas. Assim, interpretaram vários periodos de idades metamórficas 
principais de 2,900 a 2,850 $\mathrm{Ga}, 2,020$ a 1,806 Ga e 0,625 a 0,462 Ga que, entre outros, Inda et al. (1984) e Schorscher (1992), já correlacionavam aos principais eventos tectono-deformacionais do QF, respectivamente Rio das Velhas, MinasEspinhaço e Brasiliano.

De fato, trabalhos de cunho sistemático aplicados à geologia e metalogenia do Au arqueano no Quadrilátero Ferrifero, com detalhados estudos da tipologia dos zircões, que levem em consideração a existência de vários tipos de zircões, desde ígneos a metamórficos, e que avaliem e separem seus sobrecrescimentos, entretanto, ainda não foram feitos. Embora fossem pré-requisitos imprescindíveis, por exemplo, para o uso qualificado de técnicas mais refinadas de análises isotópico-geocronológicas como a SHRIMP.

O caráter policiclico da evolução dos terrenos arqueanos do QF, já demasiadamente demonstrado e argumentado, com certeza, também causou reflexos nas características isotópicas e geocronológicas dos seus depósitos auriferos.

\section{III.1.2.2. Paleoproterozóico: Supergrupos Minas e Espinhaço}

Dorr et al. (1957) e Dorr (1966 e 1969) revisaram e definiram a estratigrafia da Série Minas no Quadrilátero Ferrífero, que foi oficialmente adotada pelo projeto DNPM-USGS e, por longo tempo, mantida como subdivisão tipo desta Série na Geologia do Brasil, compreendendo, da base para o topo, as seguintes unidades:

- Grupo Tamanduá: subdividido no Quartzito Cambotas, como formação basal de depósitos arenosos costeiros, em corpos parálico-prismáticos lenticulares e descontínuos, formando, como local tipo, a serra homônima (Serra das Cambotas) (fotos 07, 08, 09), e várias outras estruturas análogas de direção N-S predominante, principalmente na região $\mathrm{E}$ do Quadrilátero Ferrifero - por exemplo, a Serra do Caraça (foto 10); e numa formação superior, sem nome formal, de micaquartzitos, filitos, formações ferriferas restritas, e xistos diversos, de depósitos plataformais sem maior continuidade lateral;

- Grupo Caraça: com duas formações, Moeda, de quartzitos e metaconglomerados (com seixos de quartzo, ouro, pirita detrítica, fracamente uraníferos) e Batatal, de filitos grafitosos e BIF restritos;

- Grupo Itabira: com os itabiritos (BIF tipo Lago Superior) da Formação Cauê (hematíticos) e carbonatos/mármores e metamargas dolomíticos da Formação 
Gandarela, além de BIF hematita-magnetíticos, quartzo-dolomíticos, de fácies transicionais entre as duas formações (Fotos 11, 12, 13, 14 e 15);

- Grupo Piracicaba: com as formações Cercadinho (quartzitos, em geral finos, por vezes ferruginosos e micáceos, e filitos diversos, com destaque para os típicos filitos prateados), Fecho do Funil (filitos, folhelhos e filitos carbonáticos), Taboões (quartzitos finos), Barreiro (filitos grafitosos) e Sabará (com depósitos vulcanoclásticos, clásticos, e vulcanitos de uma seqüência vulcano-sedimentar básica a ácida bastante completa).

Kneidl e Schorscher (1972), Schorscher (1973, 1975, 1976a,b, 1980a,c), Pflug e Renger (1973) e Amaral et al. (1976), entre outros, correlacionaram os quartzitos das serras do Caraça, das Cambotas e algumas outras estruturas e litologias análogas do Quadrilátero Ferrífero, como pertencentes ao Supergrupo Espinhaço. Schorscher e colaboradores (Alves, 1986; Santos, 1986; Barbosa, 1988; Schorscher et al. 1990, 1997; Luchesi, 1991; Schorscher, 1992; Guimarães, 1992; Davies, 1993; Mothé Fo., 1996) detaharam ainda o Supergrupo Espinhaço no Quadrilátero Ferrífero e arredores, reconhecendo, inequivocamente, as formações Sopa Brumadinho e Galho do Miguel. Como exemplo, nas serras das Cambotas, do Caraça, do Pinho e na quadricula de Florália, entre outras, e reafirmaram a pene-contemporaneidade dos Supergrupos Minas e Espinhaço, que representariam depósitos, respectivamente, distais e proximais da evolução sedimentar da margem continental paleoproterozóica do Cráton do São Francisco no Ciclo Minas/Espinhaço.

Daí resultaram também algumas reordenações estratigráficas, entre elas:

- a exclusão do Grupo Tamanduá do Supergrupo Minas: sua formação basal, o Quartzito Cambotas, foi incluído no Supergrupo Espinhaço e a formação superior, sem nome formal, no Grupo Nova Lima;

- a inclusão, na região da Serra do Cipó, de uma unidade adicional denominada Seqüência de Xistos Verdes, na base do Supergrupo Espinhaço;

- na região de Itabira, a inclusão de duas unidades adicionais denominadas Seqüência de Paragnaisses e Seqüência de Xistos Verdes, na base do Supergrupo Minas e,

- a sugestão de excluir a Formação Sabará do Grupo Piracicaba, face às suas características vulcano-sedimentares, drasticamente diferentes das demais formações deste Grupo, constituídas de depósitos de plataforma estável (Inda et al., 1984; Schorscher, 1992). 
Colunas estratigráficas do Supergrupo Espinhaço nas extremidades meridionais da Serra do Cipó e Quadrilátero Ferrífero, e do Supergrupo Minas, estão representadas nas Tabelas 03 e 04 , respectivamente.

(A)

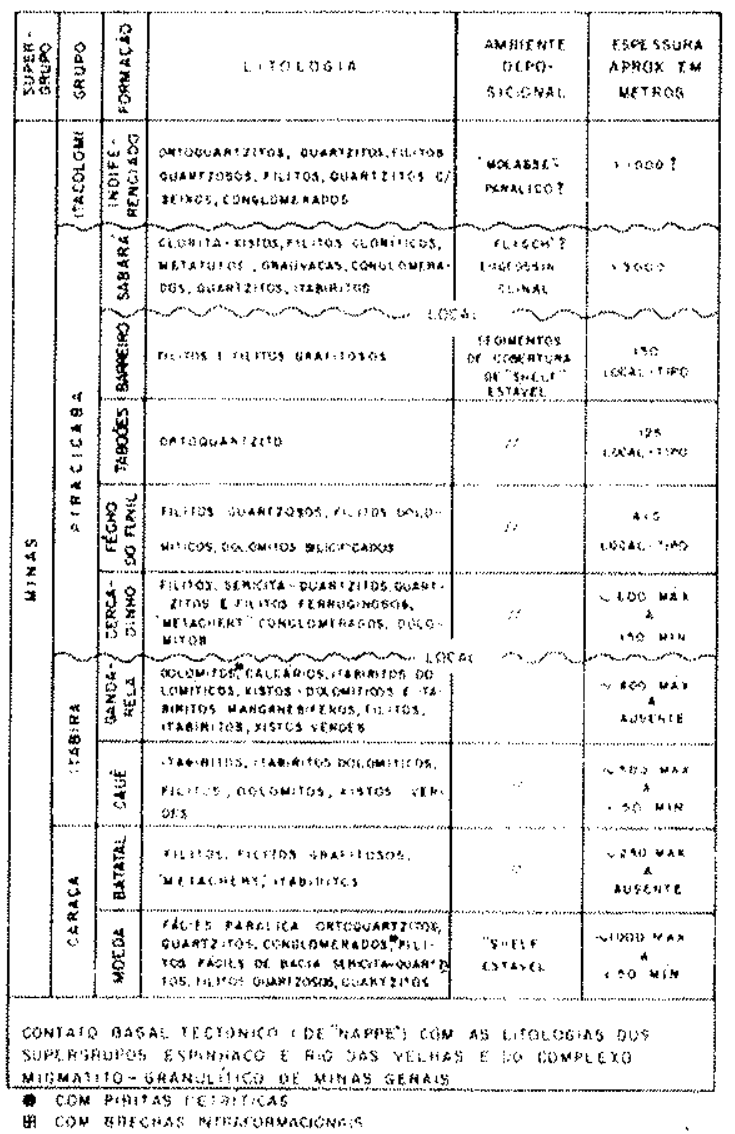

(B)

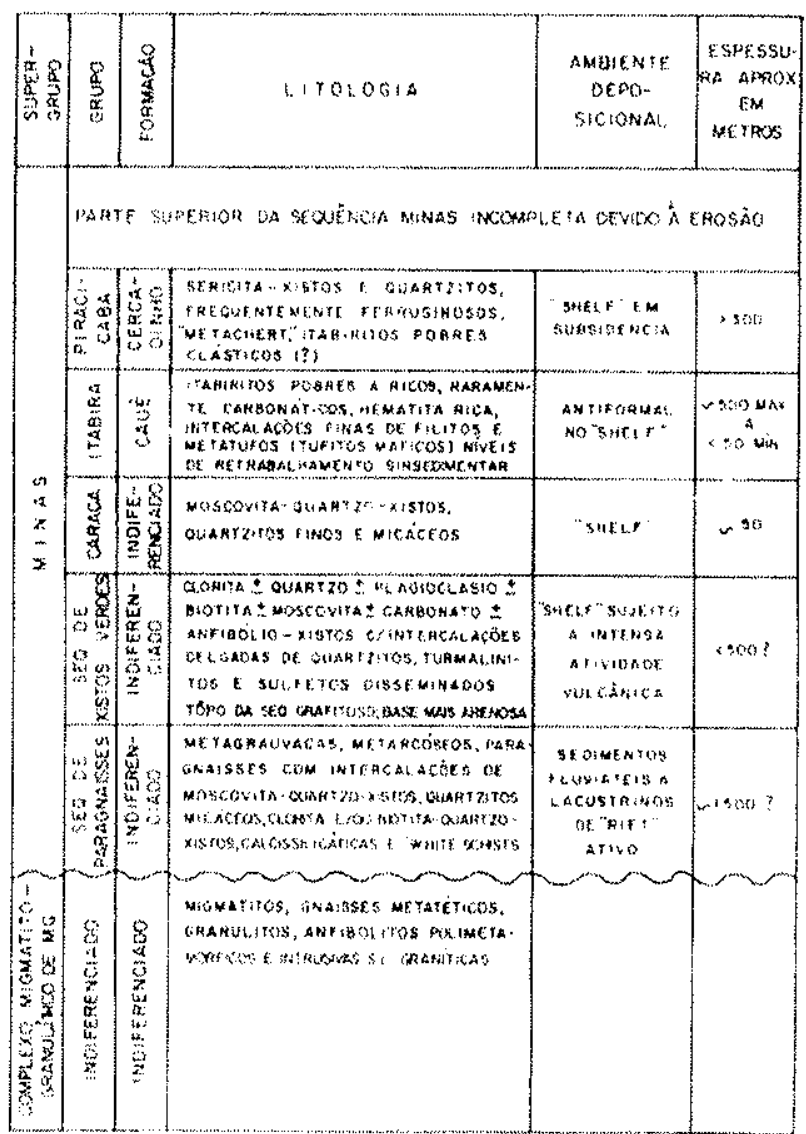

Tabela 03: Colunas estratigráficas do Supergrupo Minas: A - No QF, seg. Dorr (1969), com modificações; B - na região de ltabira, MG, seg. Schorscher (1975) e Schorscher e Guimarães (1976).

Segundo Schorscher $(1975,1988,1992)$, e reafirmado em Castro (1998), o Ciclo Minas/Espinhaço iniciaria no Paleoproterozóico Inferior, com a formação de um sistema de rifte intracontinental com magmatismo diamantifero (documentado pelos diamantes da formação Sopa Brumadinho, Supergrupo Espinhaço), na crosta siálica preexistente de terrenos TTG e granito-greenstone belt, formados nos estágios arqueanos precedentes na evolução crustal. A isso se seguiria um período sedimentar principal, em acompanhamento da evolução distensiva do sistema rifte para uma margem passiva, com deposição proximal ao continente, dos sedimentos do Supergrupo Espinhaço, em parte praiais eólicos (uma parte da formação Galho do Miguel) e em área mais distal, do Supergrupo Minas (com apenas fraco magmatismo/vulcanismo básico a ácido). 


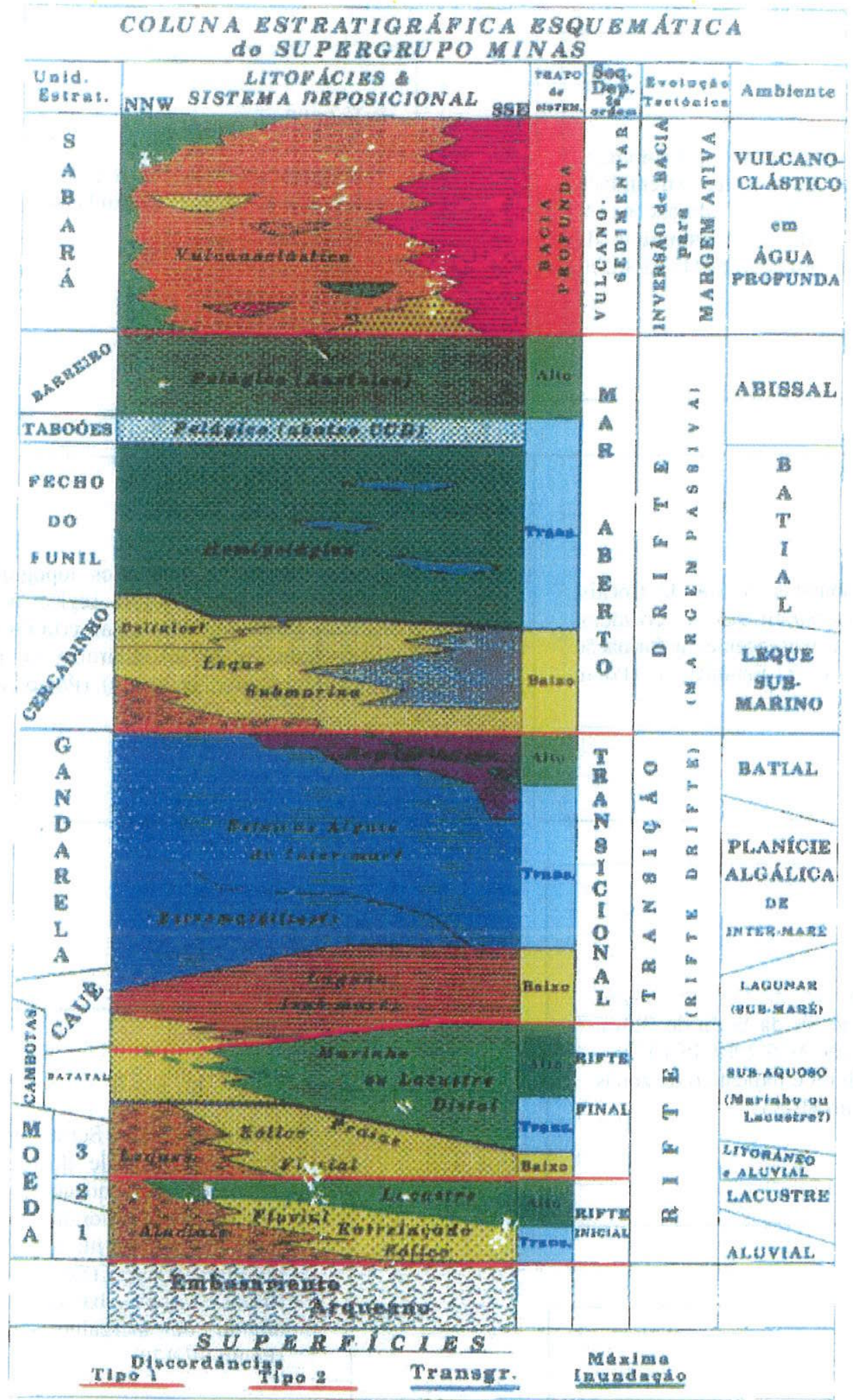

Tabela 04: Coluna estratigráfica do Supergrupo Minas, baseada em Dorr (1969) e Schorscher (1975) modificada por Castro (1998). Nota-se o posicionamento do quartzito Cambotas como o equivalente praial cronocorrelato das formações Cauê e Batatal, indicando a penecontemporaneidade dos supergrupos Minas e Espinhaço. 


\section{Foto 07:}

Quartzitos do Supergrupo Espinhaço, formação Galho do Miguel, na extremidade W da Serra das Cambotas, alinhados em direção E-W por arraste, as estruturas de acamamento mostram-se N45E/35-45SE. (Ponto GS-101)
Foto 08:

Vista panorâmica, de W para E, escarpa da Serra das Cambotas, alinhada N-S. (Ponto GS-110)

Foto 10:

Vista para Sul, dos altos topográficos do Sinclinal Gandarela, na região de Gongo Soco, no plano de fundo a Serra do Caraça e no primeiro plano itabiritos da formação ferrífera Cauê (Sgr. Minas). (Ponto GS-35)

\section{Foto 11:}

Dobras em padrão "m" ou "w", nos itabiritos da porção SE da Serra do Seara. Os eixos tem direção N15-20E/ $05-10^{\circ} \mathrm{NE}$. Este padrão estrutural é indicativo de zonas de charneira. (Ponto SE-85)

Foto 13:

Corte da BR-436, próximo a Cocais, mostrando o contato do Sinclinal Gandarela, de itabiritos da formação Cauê(Sgr. Minas), com as rochas das unidades do embasamento granito-gnáissico, intensamente milonitizado. (Ponto GS-156)

Foto 12:

Na borda ESE da Serra do Seara, no vale de erosão de um pequeno córrego, afloram itabiritos hematíticos da fm. Cauê (Sgr. Minas) com baixo ângulo de mergulho. (Ponto SE-120) 


\section{- Prancha 01}
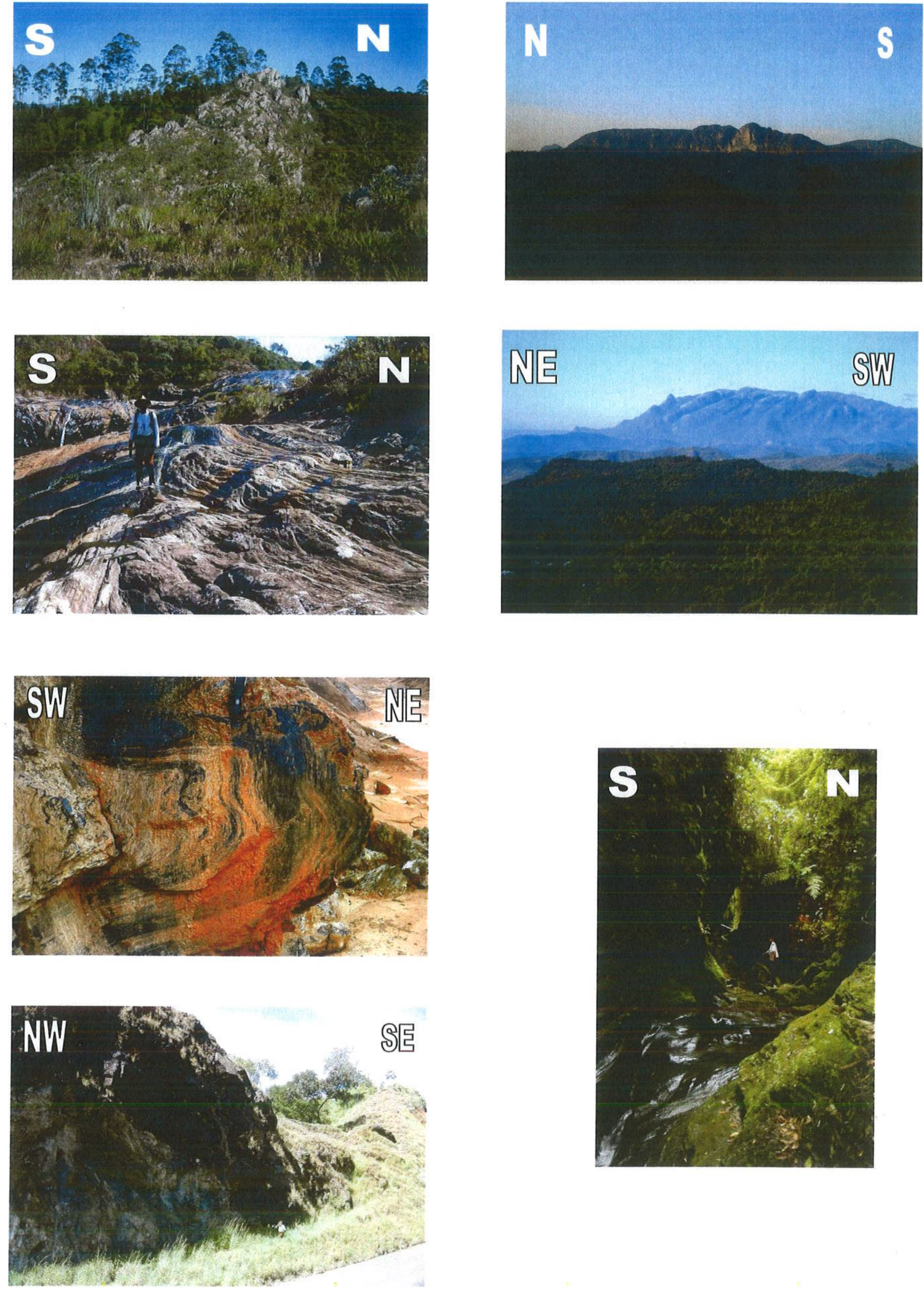
A evolução terminaria pela inversão da margem continental passiva para ativa, indicada pela sedimentação distal vulcano-sedimentar sinorogênica do Grupo Sabará (unidade superior do Supergrupo Minas), numa orogênese colisional predominantemente ensiálica, de tipo alpino, designada de orogênese do Ciclo Minas/Espinhaço. Esta causou obducção/duplicação crustal, tectônica de nappes de cobertura e metamorfismo regional progressivo, de $W$ para $E$, da fácies xisto verde (nas partes centrais e W do Quadrilátero Ferrífero) a anfibolito superior e granulito, na faixa Rio Piracicaba, Nova Era, Piçarrão e Santa Maria de Itabira, com continuações para N, até Sabinópolis e Guanhães e para S, até Acaiaca e Ponte Nova.

O metamorfismo apresentou evolução plurifacial como efeito típico de gradientes $\mathrm{P} / \mathrm{T}$ variáveis, indicado por paragêneses pré a sintectônicas, de mais alta $P$, e póstectônicas, de T mais elevadas.

A idade de deposição do Supergrupo Minas é tipicamente paleoproterozóica, dada pela natureza de seus sedimentos, que, como no caso dos metaconglomerados auríferos piritosos e fracamente uraníferos, com seixos de quartzo, da Formação Moeda (quartz-pebble metaconglomerates, de tipo Witwatersrand) e dos itabiritos da Formação Cauê (formações ferriferas do tipo Lago Superior), são depósitos típicos, constituindo-se em marcos universais de litofácies e cronológicos da evolução terrestre, que foram formados, globalmente, entre 2,6 a 2,3 $\mathrm{Ga}$ aproximadamente. Idades geocronológicas da formação Gandarela, sendo $2,4 \mathrm{Ga}$ para a deposição/diagênese e 2,1G. para o metamorfismo, foram obtidas por Babinski et al. (1991 e 1995).

Assim, Schorscher (1992) admitiu um intervalo, de sedimentação até a inversão, para o Supergrupo Minas, de 2,6 até 2,1 $\mathrm{Ga}$, estendido por correlações litoestratigráficas e tectono-metamórficas, inclusive ao Supergrupo Espinhaço, o que é aqui reafirmado.

A idade da orogênese do Ciclo Minas/Espinhaço foi considerada por Schorscher (1992), com base nos dados geocronológicos disponiveis na literatura, desde Herz (1970) até o presente (por ex. Teixeira et al., 1996; Machado, N. et al., 1996; Dussin et al., 1995; Rettinger, 1998) como paleoproterozóica final, compreendida no intervalo de 2,1-1,8 Ga, tipicamente do evento Transamazônico.

Mais recentemente, foram também obtidos resultados geocronológicos correspondentes em rochas do Quadrilátero Ferrífero e da Serra do Espinhaço Meridional (Machado, N. et al., 1989a, b; 1996, Endo, 1997; Cordani et al., 2000; Teixeira et al., 2000, Endo e Machado, R., 2002). Estes autores, baseando-se em datações U/Pb em zircões detríticos (Machado et al., 1996), consideraram os 
quartzitos do alto da Serra do Caraça como pertencentes ao Supergrupo Minas (indiviso) pelo simples fato das idades daqueles zircões detríticos serem todas arqueanas, e desconsideraram por completo a natureza litofaciológica daquelas rochas.

De fato, os quartzitos paleoproterozóicos que constituem os altos topográficos da Serra do Caraça diferenciam-se, em muito, dos quartzitos típicos do Supergrupo Minas, da formação Moeda (Grupo Caraça), com piritas detríticas, conglomerados polimíticos e estratificações cruzadas de pequeno a médio porte, e do Gr. Piracicaba das formações Cercadinho e Taboões.

Conforme as descrições de Simmons e Maxwell (1961) e Dorr (1969), dentre outros trabalhos da equipe DNPM-USGS, as rochas constituintes do assim denominado Grupo Tamanduá seriam quartzitos relativamente puros, sem piritas detríticas, e normalmente tendo zircões como principal mineral pesado. Foram incluídas estratigraficamente no topo da Série Rio das Velhas (Simmons e Maxwell, 1961), na base da Série Minas (Dorr, 1969) e como continuações dos quartzitos da Serra do Espinhaço nas quadriculas de Antônio dos Santos e Cocais (Moore, 1969). Naquela época não se admitiu a aloctonia (nappes) do Supergrupo Minas sobre as demais unidades arqueanas e paleoproterozóicas do QF, conforme sugerido e demonstrado por Barbosa, A.L.M. (in Dorr, 1969), Fleischer (1971), Schorscher (1975, 1976, 1979, 1980 e 1992) e Guba (1982), e também afirmado por Quémeneur (1984), entretanto, sem citar nenhum dos trabalhos anteriores.

\section{III.1.3. Evolução Tectono-Metamórfica do Quadrilátero Ferrifero}

Quanto à evolução tectono-metamórfica, o QF já foi e ainda continua alvo de pesquisas e assunto de discussões, controvérsias maiores e demasiadamente polêmicas; no entanto, dois eventos orogenéticos foram os mais marcantes: a orogênese Rio das Velhas, no final do Arqueano, e a orogênese do ciclo MinasEspinhaço, de idade Paleoproterozóica, inserindo-se nesta idade também o assim denominado de "Cinturão Mineiro" (Teixeira et al..1993, 1994 e 1996) verificado apenas com geocronologia em rochas TTG arqueanas embasamentais.

A orogênese Rio das Velhas encerrou o estágio granito-greenstone belt de evolução crustal arqueana na região E-SE do Cráton do São Francisco por volta de 2,9 - 2,7 G.a.. Esta deixou seu registro principal na associação das seqüências 


\section{Prancha 02}

\section{Foto 14:}

No mesmo local da foto 14, o Itabirito Cauê (Sgr. Minas) mostra-se intensamente dobrado em dobras assimétricas de arraste, com eixo subhorizontal e vergência para W. (Ponto GS156)
Foto 15:

Detalhe da foto 14 , mostrando-se o aspecto assimétrico, com rompimento do flanco invertido, das dobras de arraste no itabirito Cauê (Sgr. Minas). (Ponto GS-156)
Foto 16:

Graníto Borrachudos (GB) encontrado à leste da Serra do Seara. O GB apresenta-se cortado por três diques de aplitos deciméricos e subconcordantes à foliação principal. (Ponto SE-53)

Foto 18:

Na porção N da Serra do Seara, um corpo pegmatítico rico em feldspato alcalino e biotitas de tamanho decimétrico, corta verticalmente as estruturas Sn do Gnaisse Monlevade. (Ponto SE-133)

\section{Foto 19:}

Na borda E da Serra do Seara, um corpos pegmatóide, dispondose de forma subconcordante à foliação regional, principal Sn, do Gnaisse Monlevade. (Ponto SE-133)
Foto 17:

$\mathrm{Na}$ borda WNW da Serra do Seara, aflora - Gnaisse Monlevade (de rochas do Supergrupo Rio das Velhas na fácies anfibolito médio), exibindo baixo ângulo de caimento de sua foliação principal. (Ponto SE-130)

Foto 20:

Na borda E da Serra do Seara, galeria de garimpeiros de pedras preciosas (água marinha, alexandrita), mostra o Gnáisse Monlevade intemperizado. (Ponto SE-134)

Foto 21:

Paragnaisse metapelítico heterogêneo da borda do minério sulfetado da mina do Pari, rico em granada, intercalado a niveis de, anfibólio e biotita. (Ponto PA-05) 


\section{Prancha 02}
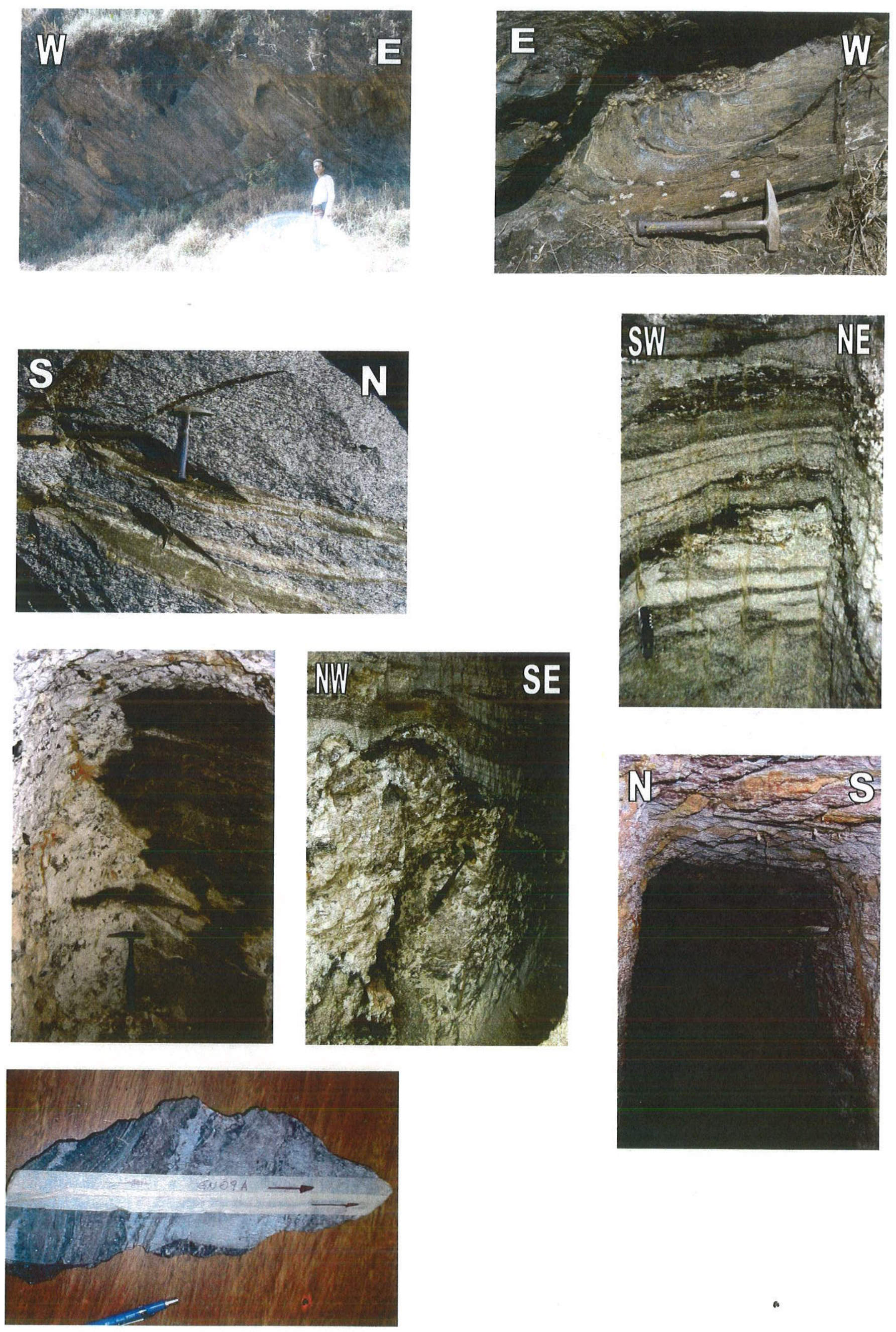
supracrustais do greenstone belt Rio das Velhas, com metagranitóides TTG, em domos, e os metagranitóides Borrachudos. O metamorfismo regional, deste evento, foi de fácies xisto verde inferior a médio, nas regiões central e leste do Quadrilátero Ferrífero e em grande parte dos terrenos TTG, indicado por paragêneses retrometamórficas, atingindo localmente a fácies xisto verde superior e anfibolito inferior nas regiões $\mathrm{W}$ e $\mathrm{NW}$ do $\mathrm{QF}$.

A orogênese final do Ciclo Minas-Espinhaço, paleoproterozóico, foi considerada por vários autores como Dorr (1969), Herz (1970) e Schorscher (1975, 1980a; 1992), entre outros, como o principal evento orogênico da evolução crustal regional no Proterozóico, o que, quanto ao metamorfismo regional progressivo, foi recentemente confirmado por estudos geotermobarométricos e geocronológicos integrados (Rettinger et al., 1996; Machado, G. 1998; Rettinger 1998).

Quanto a evolução estrutural existem opiniões divergentes advogando processos autóctones (Dorr, 1969; Ladeira e Viveiros, 1984; Alkmin et al., 1994; entre outros) e alóctones (Fleischer, 1971; Schorscher, 1975, 1976b, 1980 $, 1988^{\mathrm{a}}, 1992$ ), entre outros, sendo aqui reafirmado o conceito de tectônica alóctone para as unidades do Supergrupo Minas do QF, com base nas verificações feitas nos trabalhos de campo desta pesquisa, em estruturas da borda leste e norte do QF, na sobreposição do Sinclinal Gandarela à Serra das Cambotas.

A existência de uma orogênese uruaçuana, mesoproterozóica, é controvertida e admitida, por apenas poucos autores, para explicar a evolução do Supergrupo Espinhaço a N do Quadrilátero Ferrifero (p.ex. Almeida Abreu e Pflug, 1994).

A orogênese Brasiliana, de idade neoproterozóica à eopaleozóica, como principal e/ou o mais marcante diastrofismo proterozóico é afirmada por autores como Brito Neves et al. (1979), Teixeira (1982), Belo de Oliveira (1986), Endo (1997) e outros que se baseiam em dados essencialmente estruturais e geocronológicos, seqüenciando as deformações e correlacionando-as com dados K-Ar, Ar-Ar e Rb-Sr, provenientes, em sua maioria absoluta, de rochas e minerais de unidades mais antigas, policiclicas.

Nos trabalhos da equipe DNPM-USGS, Gair $(1958,1962)$ e Herz $(1970,1978)$ já mostraram evidências de efeitos termais locais, à NW de Nova Lima, nos domos de Santa Luzia e Caeté; na porção WNW do domo de Bação e associavam-nas a intrusões graniticas, consideradas mais jovens que a Orogênese Minas, que muitas vezes apresentam metamorfismo de contato, atingindo fácies anfibolito (granada estaurolita - sillimanita). No mesmo contexto inserem-se os efeitos de coronitização em metadiabásios que cortam as seqüências do QF e Espinhaço Meridional 
observados por Schorscher $(1975,1991)$ e Guimarães (1992), relacionando-os ao evento de termal Brasiliano.

Santos (1986), Veneziani (1987) e Schorscher (1976a,b, 1980a, 1992) também consideraram os efeitos essencialmente térmicos locais como pósMinas/Espinhaço, a expressão mais provável do evento Brasiliano, sobretudo nas porções leste e nordeste do Quadrilátero Ferrífero, onde se registraram as idades KAr caracteristicas desse evento. Processos tectônicos compressivos seriam subordinados, de baixa intensidade e restritos às poucas regiōes, onde, efetivamente, possam ser observados. Por exemplo, a NNE de Belo Horizonte, nos arredores a E de Lagoa Santa e Cardeal Mota, ocorrendo rochas do Supergrupo Espinhaço, da borda W da Serra do Cipó empurradas por falhas inversas, de médioalto ângulo, contra e sobre as rochas do Grupo Bambuí.

Para a evolução tectono-metamórfica regional policiclica arqueana à neoproterozóica, da borda SE do Cráton do São Francisco, são de particular interesse alguns dados recentes de datação e geotermobarometria de paragêneses metamórficas. Rettinger (1998) verificou nos gnaisses metapelíticos, gnaisse Monlevade, segundo Reeves (1966), de protolitos arqueanos (Grupo Nova Lima), da região compreendida entre Nova Era, Piçarrão e Itabira, de fácies anfibolito inferior a granulito, em granadas metamórficas, a ocorrência de:

- inclusões de monazitas com idades arqueanas algo variáveis, nos núcleos das granadas formadas no estágio metamórfico inicial de fácies xisto verde, indicativas da história termal anterior das monazitas detríticas dos protolitos no Arqueano;

- inclusões de monazita de idade paleoproterozóica superior, de 2,2-1,8 Ga, nas zonas de borda das granadas, com composições indicativas do pico termal do principal metamorfismo regional e,

- monazitas livres na textura de fundo das mesmas rochas, com idades variáveis mesoproterozóicas superiores a neoproterozóicas, na faixa de 1,4-0,5 Ga, representando monazitas reequilibradas parcial à totalmente, dependendo da intensidade local de um ou dois eventos metamórficos posteriores, dos ciclos brasiliano, e eventualmente, uruaçuano.

Estes resultados indicam, claramente, a orogênese final do ciclo Minas/Espinhaço, paleoproterozóico, como principal evento tectono-metamórfico regional, que imprimiu e conservou sua idade por reequilibração das monazitas, incluídas durante o crescimento das granadas em suas zonas externas e bordas, formadas durante 0 pico termal do metamorfismo regional. Este evento segue-se a uma história metamórfica anterior, seja da constituição dos terrenos TTG e graniticos arqueanos (como mais prováveis formadores e fornecedores das monazitas detríticas), seja de 
reequilibração variável, já como monazitas detríticas, nos protolitos metassedimentares dos gnaisses metapeliticos, durante a orogênese Rio das Velhas, retratada pelas idades das monazitas incluidas nos núcleos das granadas de baixo grau metamórfico. E, por final, seguiram-se ao metamorfismo principal, um ou dois eventos metamórficos, em geral mais fracos, entretanto variáveis, causando as reequilibrações observadas nas monazitas livres na matriz da rocha, no ciclo brasiliano e/ou, eventualmente, ainda no ciclo uruaçuano.

\section{III.2. Geologia da Porção NE do Quadrilátero Ferrífero}

A porção NE do Quadrilátero Ferrífero, a despeito de sua rica e diversificada produçăo mineral, incluindo ouro, ferro, manganês, rochas magnesianas, mármores, minerais gema e outros minerais e rochas, ainda carece de estudos geológicos básicos. Os mapeamentos existentes são em geral de escalas regionais $(1: 100.000$, ou de menor detalhe ainda) e os mapeamentos de semi-detalhe (1:25.000, Convênio DNPM-USGS) escassos e descontínuos; muitas vezes desobedecem ainda as regras de nomenclatura geológica e de nomes prioritários, falta mesmo uma nomenclatura sistemática e unificada para a denominação inclusive das unidades lito-estratigráfico-estruturais principais. Tal fato fica até certo ponto compreensível, em função do grau metamórfico maior nesta região, que desconfigurou as aparências típicas de unidades litológicas bem conhecidas e estratigraficamente definidas em regiões de fraco metamorfismo. Xistos, filitos e arenitos líticos da fácies dos xistos verdes são transformados na fácies anfibolito em gnaisses diversos; metabasitos e metaultramáficas em ortoanfibolitos; metassedimentos carbonáticos impuros inclusive BIF de fácies carbonato e silicato em gnaisses cálciossilicáticos e paraanfibolitos, e as rochas senso lato graníticas preexistentes como migmatitos, gnaisses graníticos e granitóides ígneos intrusivos a subvulcânicos, sofrem anatexia e migmatização e/ou remigmatização variável, e assim por diante. Consequentemente ocorre com bastante freqüência, que uma mesma unidade geológica da região $E$ e NE do Quadrilátero Ferrífero seja referida sob nomes diferentes, ou, ainda, que unidades distintas sejam confundidas e designadas com o mesmo nome.

Entretanto, ocorre também, que nomes específicos e reservados de litotipos definidos com local típico, sejam desvirtuados para usos diferentes da definição original. Este é o caso do Granito Borrachudos (Foto 16). 
As áreas mais bem estudadas da região $E$ e $N E$ do Quadrilátero Ferrífero compreendem o Distrito Ferrífero de Itabira, mapeado em escala 1:25.000 por Dorr e Barbosa (1963), a região maior deste distrito compreendendo 4 quadrículas 1:20.000 mapeadas por Schorscher $(1973,1975)$ e as quadrículas $1: 25.000$ de João Monlevade e Rio Piracicaba mapeadas por Reeves (1966), de Florália por Alves (1986), Schorscher et al. (1990, 1997), Abreu (1995) e Mothé Fo. (1996), de São Gonçalo do Rio Abaixo por Alves (1986) e Schorscher et al. (1997), e de Bateias por Alves (1986), e Davies et al. (1997).

Segundo Schorscher e colaboradores, que atualmente mais se dedicaram ao estudo básico sistemático, regional e de detalhe com enfoques petro-metalogenéticos das partes $E$ e NE do QF, estas quadrículas compreendem e são constituídas das continuações das principais unidades precambrianas antigas, arqueanas e paleoproterozóicas, das partes do QF adjacentes a $W$ (onde ocorrem fracamente metamórficas e/ou retrometamórficas). Apenas foram afetadas e transformadas mais forte e progressivamente pelo principal metamorfismo regional final do ciclo Minas/Espinhaço (paleoproterozóico), sob condições variáveis de fácies xistos verdes superior até anfibolito superior e localmente hidrogranulito/ granulito. São estas:

- Terrenos TTG de rochas sensu lato graníticas poligenéticas polimetamórficas de alto grau (migmatitos e gnaisses) e metaigneas, sendo as rochas arqueanas mais antigas da região, transformadas por processos de feldspatização, anatexia/remigmatização e granulitização;

- Seqüências metavulcano-sedimentares do Greenstone Belt Rio das Velhas arqueano, transformadas em xistos, gnaisses e anfibolitos diversos, meso a catazonais, em partes da área denominadas segundo Reeves (1966) de Gnaisse Monlevade;

- Metagranitóides Borrachudos tardi-arqueanos e seus equivalentes e produtos de transformação por rehomogeneização anatética pelo principal metamorfismo regional progressivo do Ciclo Minas/Espinhaço, os Metagranitóides Foliados com Fluorita paleoproterozóicos;

- Metassedimentos paleoproterozóicos dos Supergrupos Minas e Espinhaço, transformados segundo sua composição e o grau metamórfico local, em xistos e gnaisses diversos, meso a catazonais. 


\section{III.2.1. Terrenos TTG (Tonalitos, Trondhjemitos e Granodioritos)}

As rochas típicas destes terrenos são migmatitos, gnaisses metatéticos e metagranitóides intrusivos retrometamórficos na fácies xisto verde baixo a médio, com composições variando de leucotonalitos e trondhjemitos a granodioritos, predominando as duas primeiras. Nos processos de transformação progressivos de feldspatização e anatexia da região E-NE do Quadrilátero Ferrífero, estas rochas tornam-se mais graníticas, por enriquecimento de feldspato alcalino potássico. Souza (1988) e Machado, G. (1998) efetuaram estudos petrográficos e geoquímicos de mais detalhe em ocorrências de metagranitóides TTG da região das mineralizações de esmeraldas de Capoeirana e Belmont, à $\mathrm{N}$ de Nova Era.

O estudo até hoje mais abrangente dos metagranitóides, gnaisses e migmatitos TTG da região E-NE do Quadrilátero Ferrífero foi realizado por Schorscher (1992). Dados complementares encontram-se em Machado G. (1994, 1998) e Guarnieri (2003).

\section{III.2.2. Seqüência Metavulcano-Sedimentares do Greenstone Belt Rio das Velhas}

Entre as rochas do Supergrupo Rio das Velhas que foram até o presente reconhecidas na região E-NE do Quadrilátero Ferrifero constam, as metaultramáficas do Grupo Quebra Osso, transformadas em anfibolitos ou talcoanfibolio xistos e contendo, por vezes, níveis finos de cromititos disseminados pobres. Quando em contato tectono-metamórfico-metassomático com metagranitóides Borrachudos (Foto 16) e/ou metagranitóides foliados com fluorita apresentam-se transformados em biotititos/flogopititos e, eventualmente, estão mineralizados com esmeraldas (por exemplo, nas regiões das mineralizações de Belmont, Capoeirana, Quilombo, Canta Galo, Graças a Deus, e outras, nos arredores de Nova Era).

As rochas do Grupo Nova Lima, de composiçöes mais variáveis e heterogêneas, encontram-se transformadas em seqüências de gnaisses bandados, incluindo fácies/bandas máficas anfibolíticas, metapelíticas (com biotita, granada, estaurolita, . cordierita, sillimanita, quartzo, entre outros), cálciossilicáticas e de BIF tipo Algoma diversos, félsicas-graníticas e de metassedimentos mais maduros como quartzitos, mica quartzitos e quartzo-mica xistos, entre outros, e foram referidos sob diversos nomes na literatura. Reeves (1966) designou-as com o nome local de Gnaisse Monlevade (Fotos 17, 18, 19 e 20), apenas sugerindo serem possivelmente equivalentes mais metamórficos do Grupo Nova Lima. Schorscher $(1973,1975)$ usou o termo petrográfico descritivo de gnaisses bandados anfibolito-graníticos 
considerando-os como um membro basal de paragnaisses do Supergrupo Minas; nos estudos posteriores reconheceu serem as continuidades físicas do Grupo Nova Lima mais metamórfico (Schorscher, 1988 e 1992; Schorscher et al., 1990 e 1997). Já Souza (1988) e Machado, G. (1994 e 1998) em seus estudos de detalhe na região das jazidas de esmeraldas de Belmont e Capoeirana designaram-nas com o termo genético de seqüência metavulcano-sedimentar arqueana.

Rochas típicas do Grupo Maquiné até o presente não foram reconhecidas na região.

III.2.3. Metagranitóides Borrachudos (GB) e Metagranitóides Foliados com Fluorita (MGF)

O termo Metagranitóides Borrachudos (segundo Schorscher, 1992) será aqui utilizado para designar um tipo específico e característico de metagranitóides deformados da região a NW da cidade de Itabira, MG, que Dorr e Barbosa (1963) encontraram, minuciosamente caracterizaram (com métodos integrados geológicos, mineralógico-petrográficos e geoquímicos), e com base num local-típico definiram e denominaram de Granito Borrachudos. Ainda, consideraram-no como um granito ígneo intrusivo potássico tardio e não-metamórfico; de fato, como a rocha precambriana mais jovem da região de Itabira. Trata-se de um álcali-feldspato granito com fluorita, hololeucocrático, cinza-claro, grosso, maciço a levemente foliado, tipicamente marcado por uma forte lineação mineral de agregados de biotita de orientação regionalmente constante $E-W\left(N 90 \pm 10^{\circ} \mathrm{E}\right)$ e de baixos ângulos de caimento para $E\left(\sim 15-30^{\circ}\right)$. Sua composição modal varia algo, de álcali-feldspato granito predominante, até granito e quartzo-monzonito, ricos em quartzo. O feldspato principal e típico é mesopertita; ocorre ainda plagioclásio saussuritizado em quantidades diminutas. A biotita, principal mineral máfico, é verde escura, rica em Fe. Fluorita ocorre como constituinte menor típico em quantidade de até $3 \%$ modais. Outros constituintes regulares menores (acessórios e secundários) são muscovita, epidoto, leucoxênio/titanita, zircão, allanita, apatita e magnetita. Como constituintes menores eventuais ocorrem ainda granada, clorita e riebeckita. Geoquimicamente são álcali-feldspato granitos ricos em elementos incompatíveis (Dorr e Barbosa, 1963; Herz, 1970; Schorscher, 1975, 1992).

Posteriormente outros corpos destes metagranitóides foram encontrados e assim caracterizados nas regiões da represa do Petí a São Gonçalo do Rio Abaixo (Herz, 1970; Schorscher, 1975, 1992) e de Belmont a Capoeirana a SE de Itabira (Schorscher, 1975, 1992; Machado G. 1994, 1998), sendo que Reeves (1966) ainda 
mencionou a ocorrência de rochas similares da região das quadrículas Monlevade e Rio Piracicaba por ele mapeadas. Entretanto, sem fornecer caracterizações suficientes e/ou a localização e delimitações dos corpos, essas ocorrências continuaram incertas e à confirmar. Tal confirmação foi possivel nos trabalhos de campo desta pesquisa que levaram a definição de mais de um corpo destes metagranitóides, típicos (Foto 16) na quadricula Rio Piracicaba.

Mais recentemente, Grossi Sad et al. (1990) compreenderam uma série de corpos de rochas graniticas com características geológicas e mineralógico-petrográficas, entre si diferentes, com base essencialmente em suas propriedades geoquímicas similares, num contexto geológico, genético e metalogenético conjunto designandoos de "Suíte Borrachudos" de idade arqueana, porém sem verificar sua similaridade ou não com o litotipo da definição e da localidade-tipo original. Dussin (1994) e Dussin et al. (1997) incluiram ainda as rochas que denominaram de "Riolitos Borrachudos" e consideraram de idade mesoproterozóica na "Suíte Borrachudos" arqueana de Grossi Sad et al. (1990) e também Fernandes et al. (1995a,b) incluíram mais outras rochas sem quaisquer verificações nesse contexto. Usando o nome Granitos Borrachudos para rochas nitidamente diferentes daquelas da definição original de Dorr e Barbosa (1963); todos esses autores divergem ainda quanto às rochas, sua geologia, mineralogia e petrografia, idade e gênese tanto de Dorr e Barbosa (1963) quanto de Grossi Sad et al. (1990) e também entre si.

Em função do exposto, nesta Tese, o termo e conceito de "Suíte Borrachudos" será abolido; as rochas originais de Dorr e Barbosa (1963) serão aqui designadas segundo Schorscher (1992) de Metagranitóides Borrachudos (que mais corretamente retrata a natureza do litotipo), e este termo será utilizado exclusivamente para corpos de rochas que de fato se conformam aos critérios geológicos (relações de idade e geotectônicas), mineralógico-petrográficos e geoquímicos das rochas da definição original, obedecendo as regras fundamentais de definição de corpos graniticos.

\section{III.2.4. Supergrupos Minas e Espinhaço}

O Supergrupo Minas está presente na região NE do Quadrilátero Ferrífero, sobretudo nos distritos de Itabira e João Monlevade, além de continuidades e/ou lentes dobradas e disruptas nos municípios de Nova Era, Rio Piracicaba, Piçarrão, Hematita, Santa Maria de Itabira, Esmeraldas de Ferros e Ferros. Basicamente são reconhecidos os grupos Caraça, Itabira e Piracicaba, muitas vezes apenas de forma indivisa e via de regra incompletos. 
Restos de erosão do Supergrupo Espinhaço e partes de fácies transicionais com o Supergrupo Minas foram reconhecidos nas quadriculas Florália, Bateias e Catas Altas.

\section{I.2.5. Metamorfismo Regional e Evolução Estrutural}

O metamorfismo regional principal do Ciclo Minas/Espinhaço, na borda E-SE do Cráton do São Francisco se intensifica de W para $E$.

Nas áreas clássicas do Quadrilátero Ferrífero predomina a fácies dos xistos verdes, enquanto que na borda $E$ e NE, fácies superiores foram atingidos, o que provavelmente veio a dificultar o reconhecimento de muitos dos litotipos que foram definidos em outras regiões de grau metamórfico menor. Na região de ltabira, João Monlevade e Nova Era, o metamorfismo atinge fácies anfibolito, com locais já mais a leste, em transição à fácies hidrogranulito. Isso foi reconhecido por paragêneses minerais em xistos e gnaisses e mapeado por Schorscher (1975) e seus orientados, e confirmado com geotermobarometria metamórfica por Rettinger et al. (1996), Machado G. (1998), Rettinger (1998) e Guarnieri (2003).

Estruturalmente, observa-se a partir da borda $E$ do Quadrilátero Ferrífero o achatamento sistemático dos ângulos de caimentos das foliações metamórficas principais, predominantemente nas regiões a $E$ de Nova Era.

\section{III.3. Metalogenia do Au no Quadrilátero Ferrifero}

O resumo da metalogenia do Ouro no Quadrilátero Ferrifero a seguir apresentado foi elaborado enfatizando as unidades e os eventos geológicos principais, dos quais se conhecem mineralizações auríferas, baseado em Ladeira (1988), Vial (1988), Schorscher et al. (1991), Schorscher (1992), Lobato et al. (1998 a, b), entre outros.

\section{a) Terrenos TTG}

Sem ocorrências primárias até hoje identificadas na região do Quadrilátero Ferrífero e adjacências, são considerados terrenos estéreis para Au (Ladeira, 1988; Schorscher, 1992). 


\section{b) Greenstone Belt Rio das Velhas}

São encontradas mineralizações auriferas em todas as suas unidades: no Grupo Quebra Osso, em BIF intercalados aos derrames ultramáficos e em veios remobilizados de magnesita nas rochas metaultramáficas cisalhadas (Schorscher et al., 1991a; Abreu, 1995); no Grupo Nova Lima, em BIF de fácies sulfeto, em formações de "Lapa Seca" e em veios de quartzo (Dorr, 1969; Ladeira, 1980, 1988; Schorscher, 1992, entre outros) e no Grupo Maquiné, como Au detrítico em metaconglomerados e remobilizado em veios de quartzo (Ladeira, 1988; Schorscher, 1992; Menezes, 1996, 1999; e Menezes e Leonardos,1992).

\section{c) Supergrupos Minas e Espinhaço}

Ocorrem mineralizações de Au e U detríticos em palaeoplacers e palaeoplacers modificados nos metaconglomerados da Formação Moeda; Au detrítico nos metaconglomerados da Fm. Sopa-Brumadinho; Au em veios de quartzo remobilizado em fraturas; Au e turmalina em zona de contato tectônico do Supergrupo Rio das Velhas e Supergrupo Minas (Passagem de Mariana); Au e Pd em "jacutingas" auríferas da formação Cauê, sendo as "jacutingas" porções do itabirito cortadas por veieiros de carbonatos de Fe-Mn-Ca, especularita, quartzo grosso de veio e caulim (Vial, 1980a,b e 1988, Ladeira, 1988; Schorscher et al., 1991, Chauvet et al. 2001).

Muitos autores, como Lobato et al. (1998a,b), Martins-Pereira (1995), RibeiroRodrigues et al. (1996); Godoy (1994), Toledo et al. (1998) e Vieira (1988 e 1991), entre outros, baseando-se em dados estruturais e geotermobarométricos e químicos de inclusões fluidas de veios de quartzo, advogam processos quase que exclusivamente epigenéticos, hidrotermais e metamórficos para a formação dos depósitos auríferos associados às formações ferríferas tipo algoma (BIF-hosted), correlacionando-os, via de regra a eventos tectono-termais regionais, sejam do final do arqueano, da orogênese Minas-Espinhaço ou mesmo do Ciclo Brasiliano. Esta linha de interpretações reproduz enfoques da literatura internacional, como por exemplo, de Phillips e Groves (1983); Hodgson (1989), e Goldfarb et al. (2001), entre muitos outros, que enfatizam o modelo de Au orogenético.

Seguindo uma outra linha de evidências e pensamentos metalogenéticos, Moreschi (1972), Ladeira (1980, 1988), Vial (1980a, b), Schorscher et al. (1986 e 1991), Abreu (1995), Valladares $(2000,2004)$ e De Wit et al. $(1994,2004)$ destacam as características originais sinsedimentares desses minérios e/ou protominérios de Au, para daí avaliar suas modificações, parciais ou mesmo totais, por processos 
posteriores, sejam hidrotermais pós-magmáticos ou metamórficos e hidrotermais. Trata-se de processos que embasam o conceito vulcano-exalativo, que causam a deposição de sedimentos químicos com sulfetos e Au em fundos oceânicos relacionados a centros magmáticos ativos, de origem singenética e posteriormente singenética-modificada por processos superimpostos diversos, diagenéticos, tectono-metamórfico-hidrotermais, magmáticos e pós-magmáticos. Este modelo foi desenvolvido por Oftedal (1958), Stanton (1959 e 1960), Routhier (1963), Ramdohr (1969), Sangster (1972), Amstutz (1974), Hutchinson (1973, 1993), Fripp (1976a, b) e Fyfe e Londsdale (1982), entre muitos outros.

A metalogênese do $\mathrm{Au}$ arqueano há muito é matéria polêmica, o que é compreensivel, dado o fato de que rochas e depósitos minerais tão antigos sempre sofreram mais de um processo genético e de transformação. Assim, dependendo da base de dados que os autores considerem mais relevantes e utilizem, poderão chegar a conclusões opostas sobre o mesmo depósito. A proposta aqui é evidenciar que mais de um processo atuou na gênese e evolução dessas mineralizações, que sempre, inserem-se em terrenos policíclicos. A grande questão é reconhecer corretamente e evidenciar as características genéticas iniciais desses depósitos arqueanos. De fato, já Schorscher et al. (1986 e 1991), Abreu (1995) e, mais recentemente, Valladares $(2000,2004)$ evidenciaram claramente algumas características multi-estágio na formação dos minérios da mina do Pari e da mina São Bento, como será visto a seguir.

Nesta tese enfocam-se as mineralizações arqueanas do Grupo Nova Lima, especificamente aquelas que ocorrem associadas ou intimamente relacionadas às formações ferriferas tipo Algoma e/ou em formações de "Lapa Seca".

Apenas alguns comentários serão feitos e citados relatos a respeito da mineralização de Au da mina de Passagem de Mariana, das ocorrências de Au no Grupo Quebra Osso, e em veios de quartzo auriferos.

\section{III.3.1. Revisão da Metalogenia do Au da Mina do Pari e Arredores}

Baseado nos trabalhos de Abreu (1995) e de Schorscher et al. (1986 e 1991), revisaram-se os pontos fundamentais da metalogênese da mina do Pari, mediante os dados já disponíveis.

\section{III.3.1.1. Geologia e Estruturas}


A mina do Pari (figuras 03, 06 e 07) é inserida na continuação do Greenstone Belt Rio das Velhas, à E de Santa Bárbara, na quadrícula de Florália, que se constitui da base para o topo, de:

- Grupo Quebra Osso (espessura de $<10-20 \mathrm{~m}$ ), metaultramáfico, de anfibolitos e talco - anfibólios - Mg-clorita xistos, com raros sulfetos magmáticos, flogopitizado no contato inferior tectônico com as rochas TTG do Domo de Sta. Bárbara a W; e

- Grupo Nova Lima (espessura mínima 300m), na região da mina do Pari predominantemente metavulcânico máfico, de ortoanfibolitos diversos com intercalações metassedimentares químicas de BIF tipo algoma e metapelíticas (biotita - granada - quartzo xistos e paragnaisses).

$\mathrm{Na}$ área do morro do Pari, através de mapeamento geológico de superfície e galerias, descrição de testemunhos de sondagem, petrografia e litogeoquímica (Abreu, 1995), o Grupo Nova Lima foi subdividido, da base para o topo (Figura $10 \mathrm{e}$ 11), em:

a) Anfibolitos granatíferos da lapa (AnfG FW - 150m), com intercalações métricas a decamétricas de BIF de fácies óxido, silicato, carbonato e mistos (unidade B), sendo o contato basal, com o Grupo Quebra Osso, concordante - transicional. Eventualmente ocorre ainda um corpo fino e descontínuo de metagrauvacas ou metavulcânica félsica, possivelmente um metadacito (unidade A) no contato entre o Gr. Quebra Osso e os anfibolitos granatíferos da unidade B. No topo do anfibolito granatífero ocorre a mineralização aurífera principal de xistos granatíferos e anfibolíticos, com intercalações de BIF ricas em arsenopirita e pirrotita, denominada de Horizonte Pari (Figuras 04, 05 e 06).

b) Anfibolitos finos da capa (Anf HW - $150 \mathrm{~m}$ ) bastante homogêneos (sem granada) (unidade C) são típicos ortoanfibolitos de origens metavulcânicas. Dentro desses anfibolitos finos ocorre, de forma descontínua, um veio de quartzo com pintas de Au livre, visiveis a olho nu, denominado "Horizonte Florália", sendo disposto cerca de $60 \mathrm{~m}$ (distância real) acima do horizonte mineralizado principal da mina do Pari (Horizonte Pari).

c) Anfibolitos finos com intercalações centimétricas a métricas de niveis de anfibolitos granatiferos, granada-biotita xistos, BIF e níveis carbonáticos (unidade D) encontram-se sobrepostos com contato tectônico por falha de empurrão de $E$ para $W$, por gnaisses extremamente deformados e cisalhados e/ou milonitizados e também K-feldspatizados, indicando intensos processos tectono-metamórficos e 
Evolucao P'etrogenetica e Metalogenetica da Mina de AU do Parl e Arredores. NE do U. F.

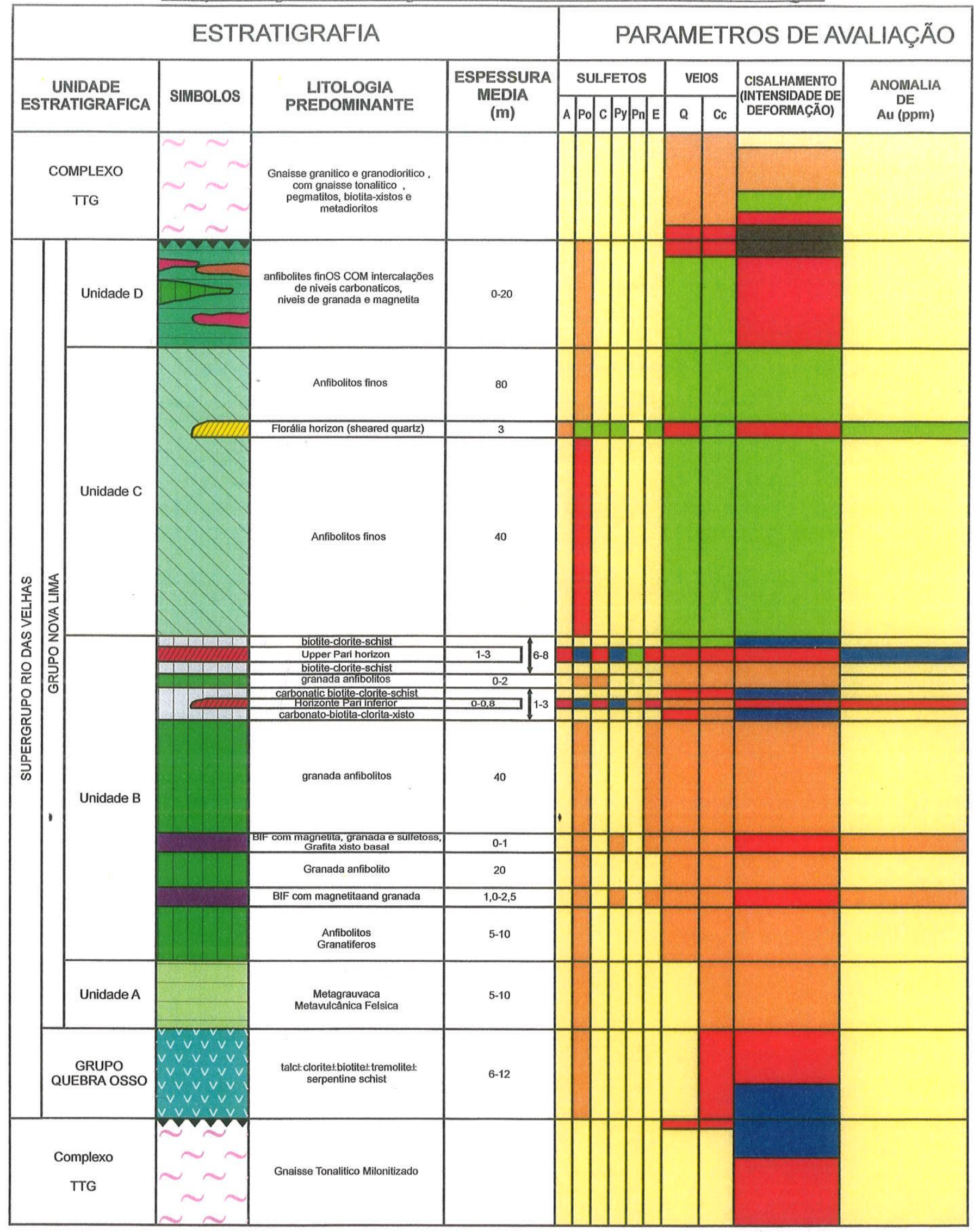

\section{EXPRESSIVIDADE}

\begin{tabular}{|lllll}
\hline Muito Fraca & A & Arsenopirita & Pn & Pentlandita \\
\hline$\square$ Fraca & Po & Pirrotita & E & Esfalerita \\
Moderado & C & Calcopirite & Q & Quartzo \\
\hline Forte & Py & Pirita & Cc & Carbonato \\
\hline Muito Forte & a
\end{tabular}

Figura 10:

Coluna estratigrafica simplificada da Mina do pari e alguns parâmetros de avaliação.

Abreu, G.C. 
Figura 11:

Seções geológicas dos furos rotativos diamantados da Unamgen Min. e Met. S.A., BR-039, BR-055 e BR-057

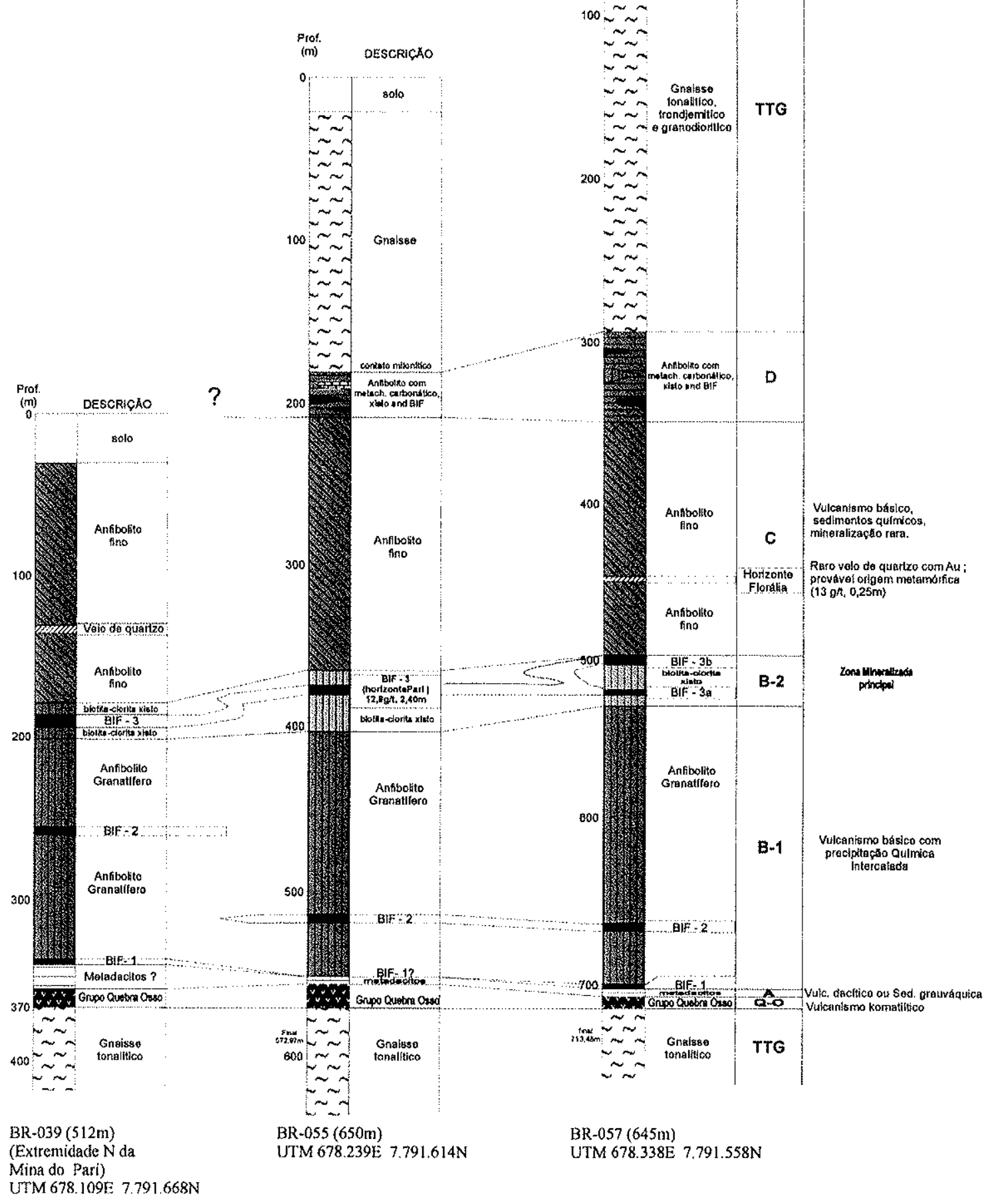


metassomáticos. Nas continuações regionais encontram-se na unidade $D$ ainda pequenos corpos metaultramáficos xistosos e/ou milonitizados tectonicamente disruptos.

A mineralização de Au principal da mina do Pari, o Horizonte Pari é de pouca espessura, variando de centímetros a poucos metros, porém, continuo ao longo do mergulho. Porém, ao longo de sua extensão é cortado por diversas falhas de um sistema de direção aproximada N05ㅌ (Figuras 12, 13, 14 e 15).

O corpo mineralizado compöe-se de quartzo, hornblenda, carbonato, granada, grunerita, Fe-clorita e sulfetos (arsenopirita e pirrotita, principalmente), caracterizando-se como uma típica formação ferrifera, do tipo Algoma, metamorfizada em fácies xisto verde alto/anfibolito inferior.

As encaixantes da capa e lapa da mineralização possuem espessuras variando de 2 a 10 metros, e consistem de hornblenda-clorita-biotita xistos, por vezes com niveis carbonáticos, sendo cortadas por veios de quartzo estéreis, tanto pseudoconcordantes quanto discordantes. Macroscopicamente não se notam diferenças petrográficas entre os litotipos de capa e lapa.

Estruturalmente a seqüência litoestratigráfica da mina do Pari está em posição normal (figuras 06 e 07), de acordo com a estratigrafia regional e local proposta por Schorscher (1980a, 1988a,b, 1992, Schobbenhaus et al. 1981/1995, Inda et al. 1984), reafirmando-se ainda a estrutura homoclinal com caimento para $E$ (Schorscher, 1988b; Abreu, 1995).

Nas figuras 16 e 17, os estereogramas e um bloco diagrama esquemático resumem as estruturas da área estudada (da mina e do morro do Pari).

A mineralização de Au da mina do Pari foi afetada por todas as fases de deformação reconhecidas (figuras 03,06 e 07), inclusive a mais antiga, definida como $S_{n-1}$, considerada de idade arqueana, haja vista, que é nitidamente anterior à $S_{n}$ do principal evento metamórfico regional da orogênese Minas/Espinhaço paleoproterozóico.

Em outras regiões e mineralizações de Au do Quadrilátero Ferrífero diversos autores como Ladeira (1980 e 1988), Martins Pereira (1995), Endo (1997), Lobato et al. $(1998 a, b)$, entre outros, também já notaram essa deformação e considerarammna de idade arqueana.

A feição típica da mineralização é vista na foto 21 (Prancha 2), onde bandas de sulfetos recristalizados por metamorfismo aparecem intercaladas com bandas silicáticas e carbonáticas, o que caracteriza o típico bandamento das formações ferriferas do tipo Algoma policíclicas. 


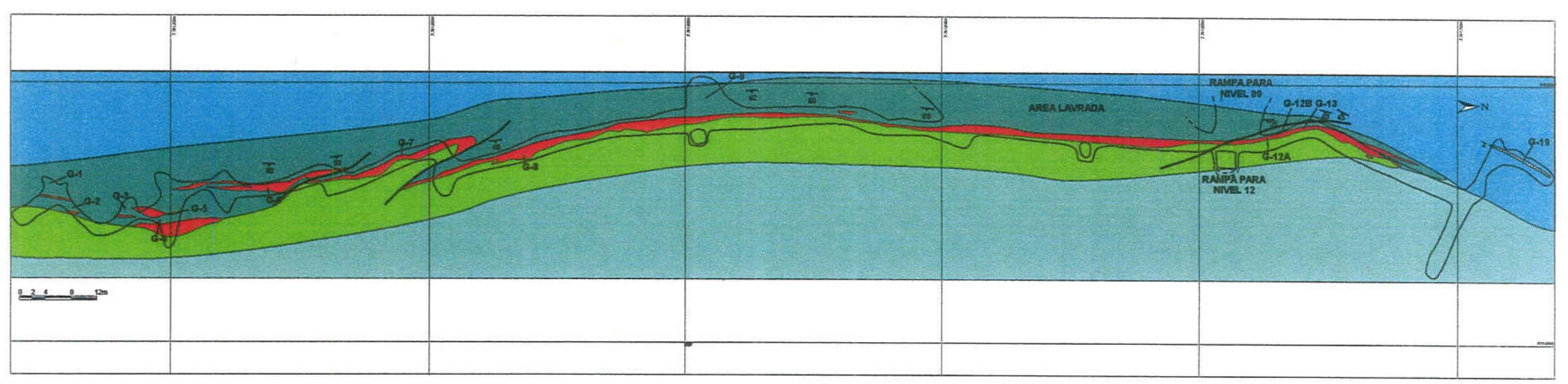

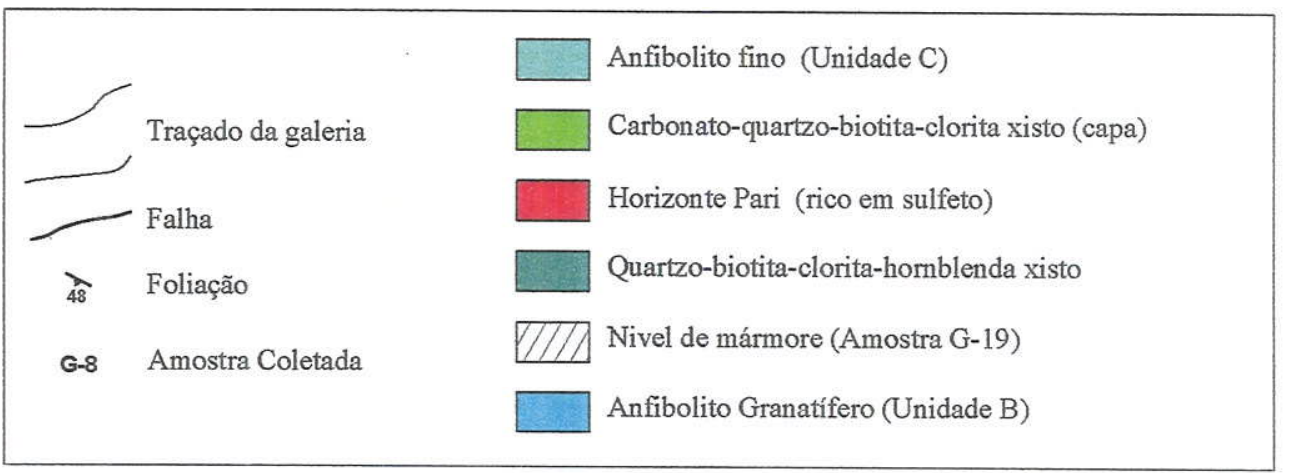




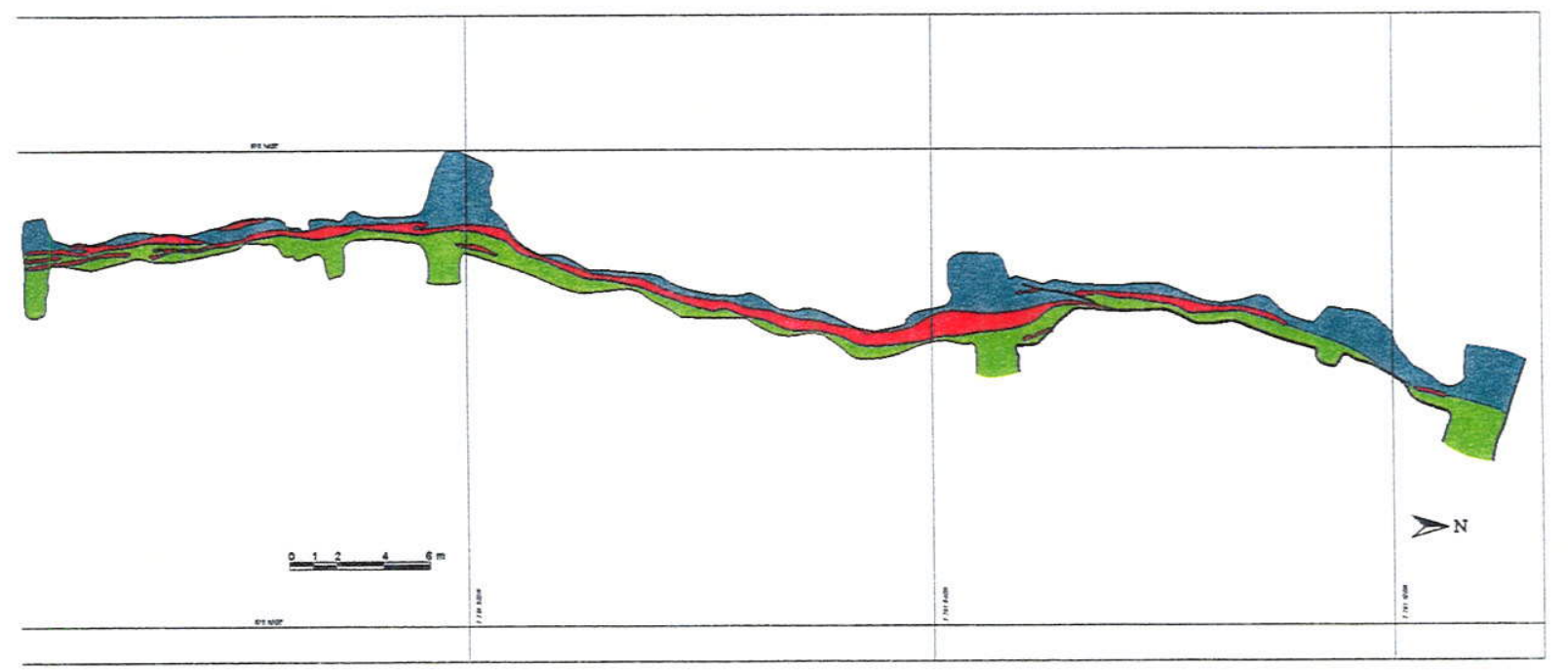

Figura 13:

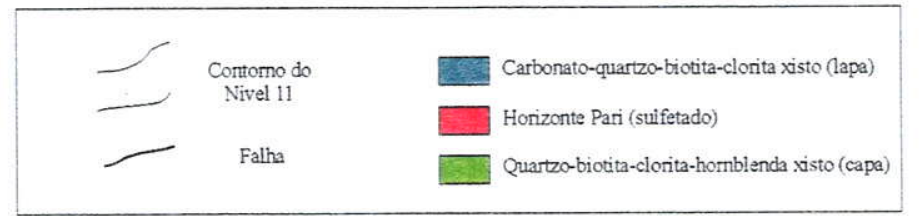

Mapa geológico do nivel 1 da mina do Pari. 


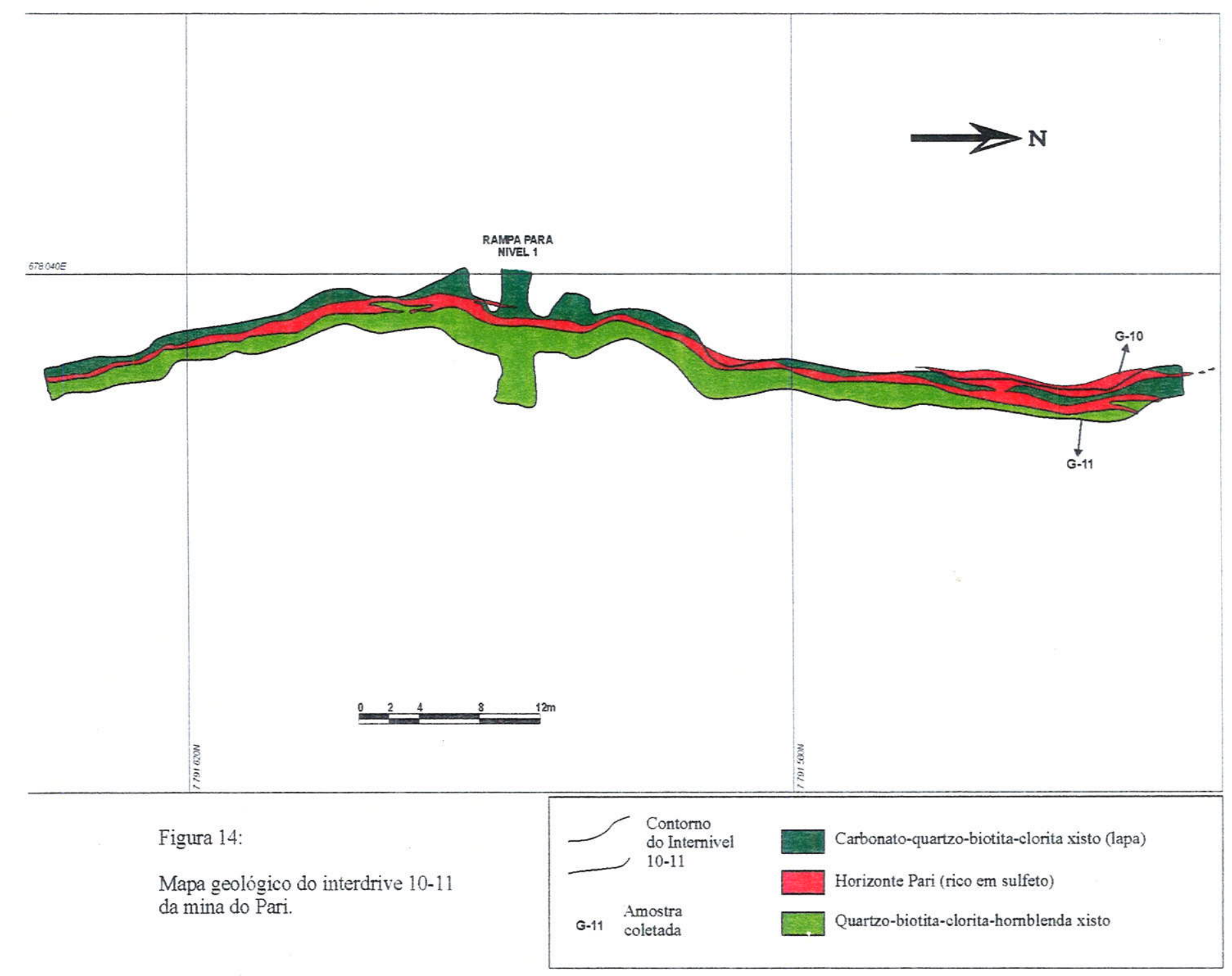


Evolução Petrogenética e Metalogenética da Mina de Au do Pari e Arredores, NE do Q. F.
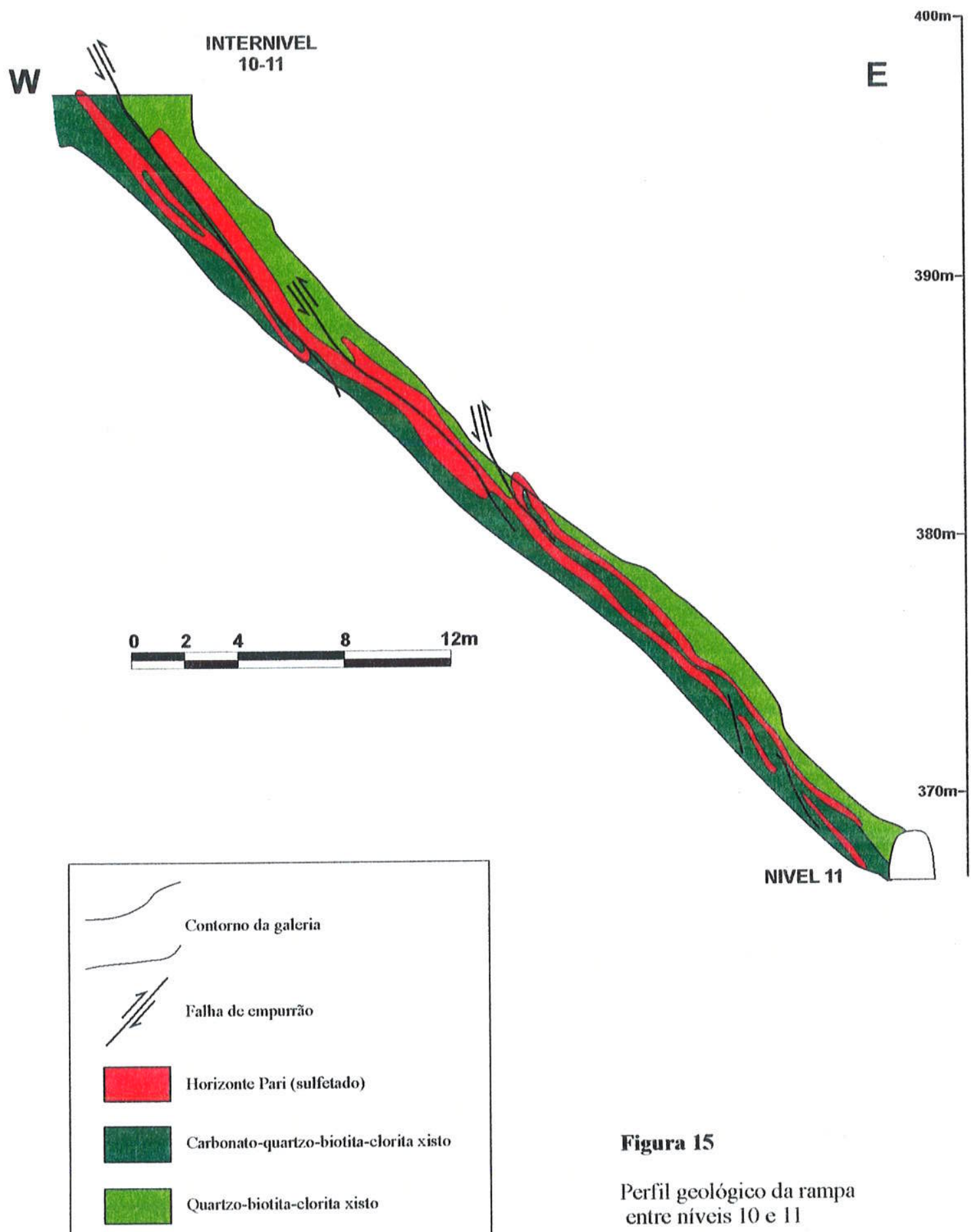

Figura 15

Perfil geológico da rampa entre niveis 10 e 11 

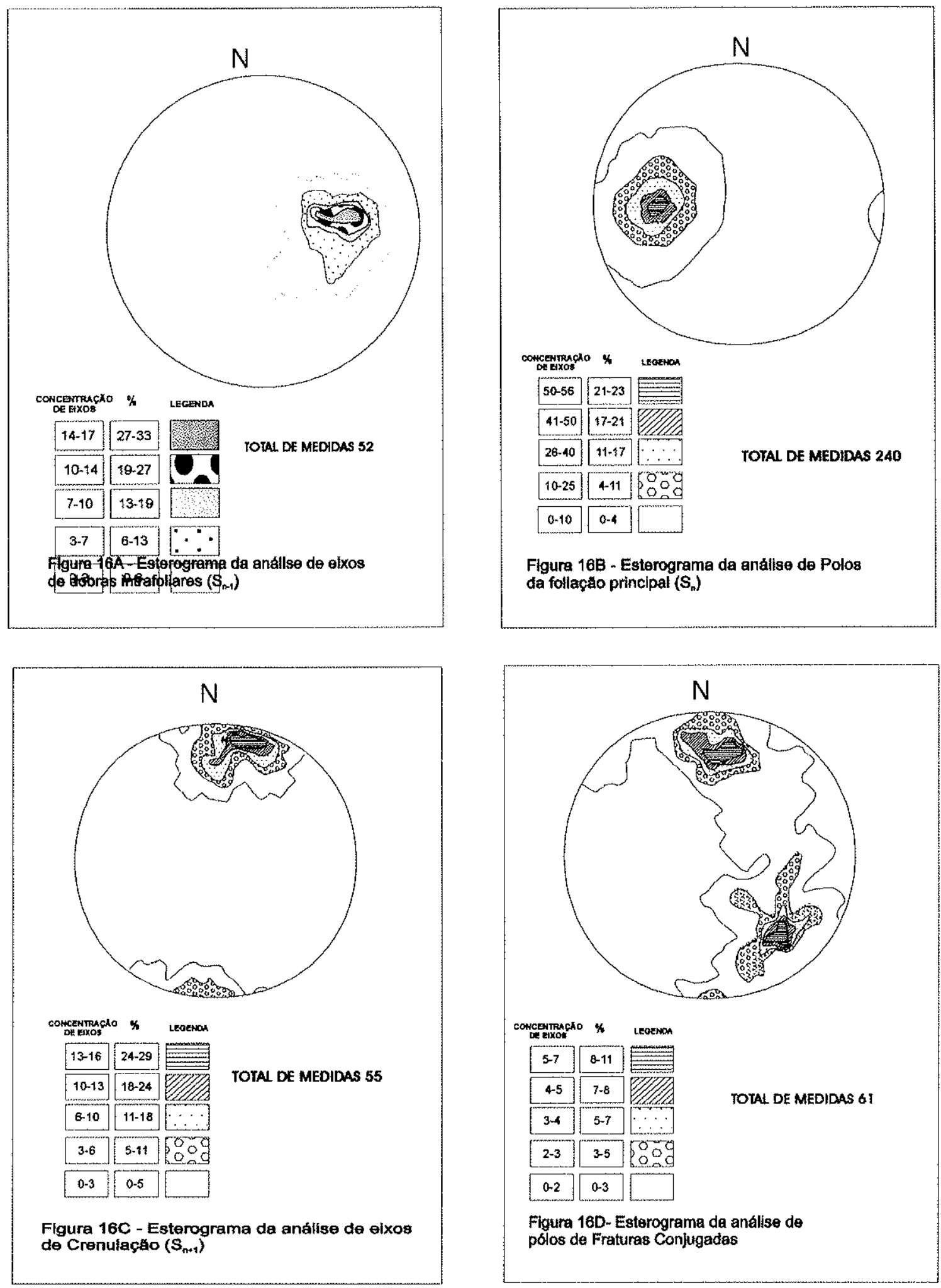

FIGURA 16: Estereogramas dos elementos estruturais observados na mina do Parí e arredores, Quadrícula de Florália. A - Dobras intrafoliares; B Foliação Principal; C-Eixos de Crenulação e D Fraturamentos. 


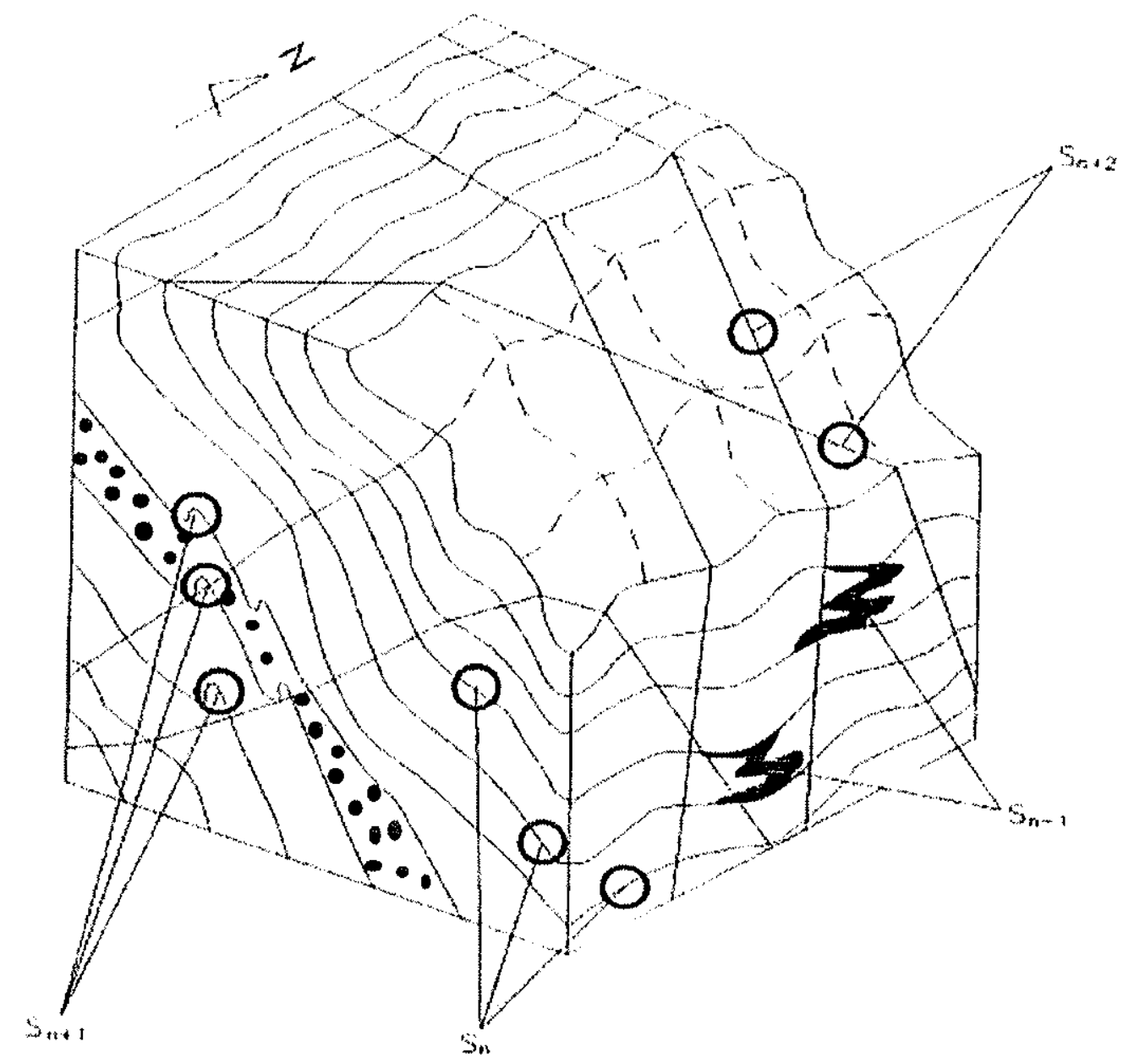

Figura 17: Bloco diagrama das estruturas da Mina do Pari. O estrato bachurado com bolinhas representa o corpo mineralizado, concordante, afetado por todas as deformaçōes. Sn a foliaçăo principal, de direçăo regional N 0-10 E/ 40-60 SE, e está dobrada pela $S n+1$ (de eixos subhorizontais $N$-S) que por sua vez está ondulada pela $\mathrm{Sn}+2$. As dobras antigas, palimpsésticas pertencem a foliaçăo $\mathrm{Sn}-1$, com eixos caindo para $E$, paralelos ao mergutho da $S n$, indicando compressão e movimenação $\mathrm{N}-\mathrm{S}$ pretérita a $\mathrm{S} n$. Os sulfetos da mineralizaçã̃o aurifera da mina do Pari são afetados por todas estas deformaçóes (Abreu, 1995). 
A mineralização de Au principal da mina do Pari, do Horizonte Pari, obedece perfeitamente aos critérios do tipo stratabound e estratiforme proposto por Kerswill (1993), sendo concordante às estruturas $S_{\circ}$ deposicionais e afetada pelas estruturas deformacionais da área estudada em conjunto e homogeneamente com as rochas encaixantes da seqüência metavulcano-sedimentar arqueana. Em analogia, também as minas de Morro Velho (Ladeira 1980, 1986 e 1991), Cuiabá (Vial, 1988), e São Bento (Valladares, 2000, 2004; de Wit, 2004), entre outras, já foram e/ou vem sendo interpretadas como de origens singenéticas vulcano-exalativas, seja de seus minérios ou protominérios.

\section{III.3.1.2. Resumo da Petrografia da Mineralização e Ligas Naturais de Au}

Na mineralização da mina do Pari, Abreu (1995) mostrou aspectos diferenciados em relação a mina São Bento (Abreu et al., 1988; Martins Pereira, 1995), que serão comentados adiante.

A petrografia macroscópica da mina São Bento e seus litotipos principais estão apresentados nas fotografias de 25 a 31 (Pranchas 03 e 04). As fotomicrografias de 06 a 08 (Prancha 08) mostram os aspectos mineralógicos e texturais principais. Maiores detalhes poderão ser observados nas pranchas 16,17 e 18, no anexo 6 .

$\mathrm{Na}$ mina do Pari, a seqüencia das rochas da mineralização aurifera, quando observado no sentido das encaixantes para a zona mineralizada, mostra certas variações típicas, como o decréscimo percentual de hornblenda, com o acréscimo de opacos (arsenopirita e pirrotita), granada, clorita rica em $\mathrm{Fe} e$ grunerita/fluotaramita. Nas encaixantes são notáveis a presença e enriquecimentos em Mg-clorita, carbonatos e plagioclásio. O quartzo tem comportamento aleatório, tanto na mineralização (níveis ricos em bandas de chert) quanto nas encaixantes (veios remobilizados). Estes veios, citados por último, são comuns em toda a seqüência estratigráfica das unidades do Supergrupo Rio das Velhas, e representam remobilizados tardios em fraturas tanto concordantes quanto discordantes. A biotita, também tem comportamento aleatório em sua distribuição, tanto nas encaixantes, quanto no minério. Porém é muito mais comum nas encaixantes da capa e lapa, ou sugerindo zonas de alteração potássica que envolvem a mineralização. Dentro das rochas anfibolíticas, já mais distantes da zona mineralizada, a biotita passa a ser mineral acessório. 
Foto 22:

Amostra de testemunho de sondagem rotativa a diamante, cedido pela UNAMGEM, que consiste em tonalito milonítico do Complexo Gnáissico-Migmatítico.

\section{Foto 24:}

Amostra de testemunho de sondagem rotativa a diamante, cedido pela UNAMGEM, que consiste em porção pegmatóide, de grã grossa, rica em $\mathrm{K}$-feldspato e exsoluções de albita visíveis a olho nú.

\section{Foto 26:}

Minério da mina São Bento, proveniente do nivel 23, onde observa-se intenso cisalhamento de suas bandas e intensa carbonatação (branco-amarelado). A amostra foi coletada em zona de falha que corta o minério.

\section{Foto 28:}

Minério da mina São Bento contendo fácies mista de formação ferrífera bandada, tipo Algoma (Carbonato, óxido e sulfeto)

\section{Foto 23:}

Amostra de testemunho de sondagem rotativa a diamante, cedido pela UNAMGEM, que consiste em granodiorito milonítico do Complexo Gnáissico-Migmatítico.

Foto 25:

Minério da mina São Bento, proveniente do nivel 15 , onde observa-se vênulas de quartzo e sulfetos remobilizados. A amostra foi coletada em zona de charneira de dobras de eixo sub-horizontal.

\section{Foto 27:}

Formaçao ferrífera Algoma, Membro ferrífero do topo, da mina são Bento. Observa-se níveis de magnetita (nódulos pretos) e carbonato (branco).

\section{Foto 29:}

Minério da mina São Bento, semelhante a foto 06 , porém mais inensamente sulfetado. Notar a intensa remobilização nos nódulos de quartzo e mesmo da forma nodular das massas sulfetada. 


\section{Prancha 03}
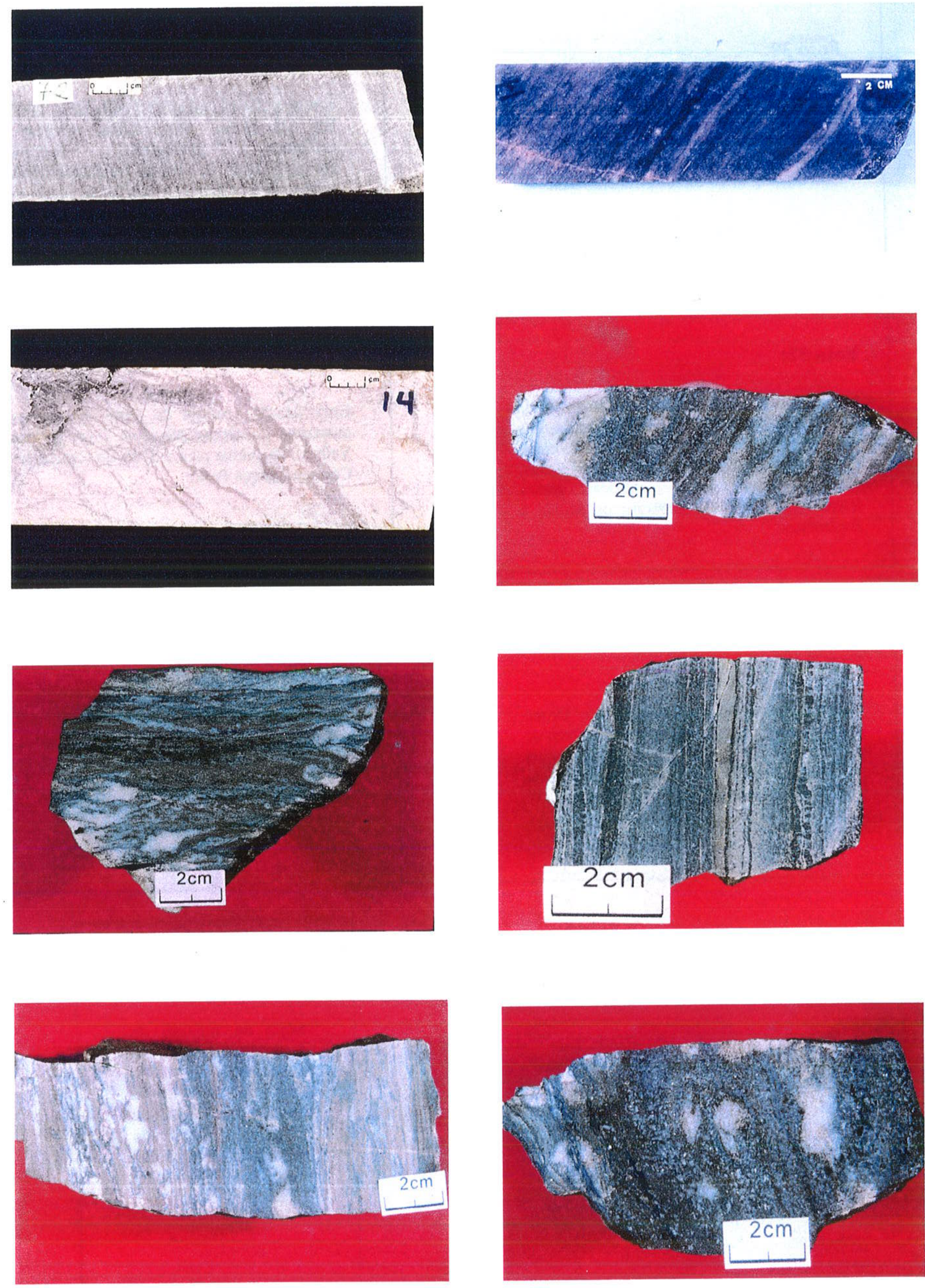


\section{Foto 30:}

Amostra SB-02, nivel 15 (Valladares, 2004), xisto metapelítico gratĭtoso, da mina São Bento, denominado de Xisto Grafïtoso Basal, que também neste trabalho é considerado do topo estratigtafico da zona mineralizada.

\section{Foto 32:}

Metaconglomerado oligomítico da Serra da Boa Vista, logo à E da Serra do Caraça, que por Dorr (1969) foi considerado como Formação. Moeda (Sgr Minas) e por Luchesi (1991) como fácies clástica grossa transicional entre os Supergrupos Minas e Espinhaço.

\section{Toto 34:}

Metaconglomerados polimíticos do Grupo Maquine (Sgr. R. das Velhas), com seixos de metacherte, BIF e xistos exclusivamente provenientes do Grupo Nova Lima, no vale do Corrego Tanq̧ue Preto.
Sroto 31:

Amostra SB-16, nivel 15 (Valladares, 2004), BIF de fắcies óxido (cinza escuro) e carbonato (amarelo) mostrando enriquecimento de sulfetos em remobilizados (cinza claro brilhante) discordantes junto com nódulos quartzo (branco).

\section{Foto 33:}

Estratificação cruzada de porte médio nos quartzitos do Grupo Maquiné (Sgr. R. das Velhas), na subida para a Serra do Caraça, no Córrego Tanque Preto.

\section{Foto 35:}

Quartzitos do Grupo Maquiné (Sgr. R. das Velhas) com pequenas estratificações cruzadas e piritas detríticas.

\section{Foto 36:}

Flanco normal do Sinclinal Gandarela, com caimento médio entre 25 e $35^{\circ}$ para SE. Vista para E da área do Gongo Soco.

\section{Foto 37:}

Mina de minério de ferro do Batatinha, no município de Rio Piracicaba, onde observa-se o Gnáisse Monlevade empurrado sobre os itabiritos hema títicos da formação. Cauê (Sgr. Minas). 


\section{Prancha 04}
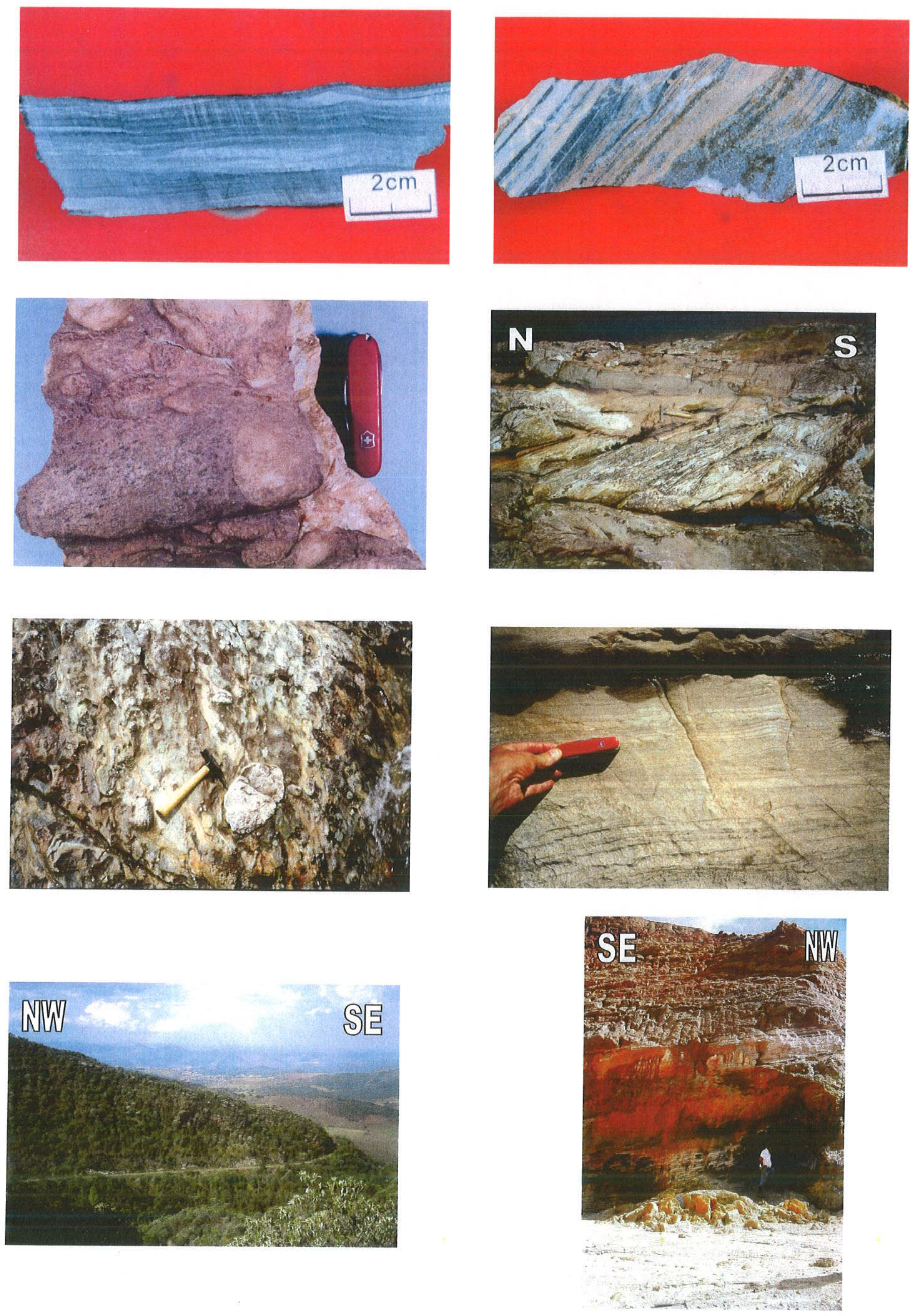
Os anfibolitos encaixantes da mina do Pari, denominados no anexo 3 de Anf-HW (anfibolitos da capa) e AnfG-FW (anfibolitos granatíferos da lapa), são constitúldos principalmente por hornblenda (50-84\%) e quartzo (10-25\%), podendo possuir, ainda, plagioclásio (1-10\%) e carbonato (0-15\%).

Clorita e biotita são minerais mais raros nesses anfibolitos, e costumam aparecer com relativa freqüência na medida em que se aproxima das encaixantes da lapa e/ou capa do minério. A granada somente aparece em abundância nos anfibolitos da lapa (AnfG-FW). Carbonato e plagioclásio (0-15\%) são mais abundantes nos AnfHW (da capa) que nos anfibolitos granatiferos da lapa (AnfG-FW).

A capa e a lapa da mineralização constituem-se de clorita-biotita-quartzo-hornblenda xistos bastante deformados, e com intensa recristalização dessas fases minerais principais.

A capa da mineralização, apesar de algumas diferenças entre o nivel de entrada ( $\mathrm{N}$ $00)$ e o nível $10(\mathrm{~N}-10)$, apresenta a seguinte constituição petrográfica: hornblenda (60-78\%), Mg-clorita (0-20\%), biotita (1-20\%), quartzo (5-20\%), plagioclásio (2-10\%), carbonato (0-10\%) e opacos (0-3\%). Dentre as diferenças entre a capa do $\mathrm{N}-00$ e do $\mathrm{N}-10$, nota-se que, na capa há maior abundância em biotita, plagioclásio, carbonato e granada.

A lapa da mineralização que macroscopicamente assemelha-se a capa, mostra-se microscopicamente com a seguinte constituição: hornblenda (25-85\%), Mg-clorita (0$20 \%$ ), biotita (2-35\%), quartzo (5-35\%), plagioclásio (1-15\%), carbonato $(0-15 \%)$ e opacos (0-10\%). Entre as diferenças na lapa do $\mathrm{N}-00$ e do $\mathrm{N}-10$, nota-se a maior abundância de Mg-clorita, hornblenda, opacos e granada.

As diferenças entre a capa e a lapa do minério são bem mais acentuadas na seção do nível 10 , onde a lapa diferencia-se pela presença de plagioclásio e carbonato (ausentes na capa) e também pela maior freqüência de biotita e quartzo (Figuras 18 e 19). Por essas diferenças, e pelo mapeamento das galerias, considera-se que a seção do nível de entrada, poderia estar afetada por cisalhamentos na extremidade do corpo, causando possiveis inversões.

A petrografia do minério mostrou a seguinte constituição modal (em \%-vol.):

a) no nivel $10(\mathrm{~N}-10)$ : hornblenda $(0,5-29)$ Fe-clorita (0-3), biotita $(4,5-30)$, quartzo (15-55), plagioclásio (10-20), carbonato (0-15), grunerita/fluotaramita (0-30) e opacos $(12,5-32,5)$;

b) no nivel de entrada ( $N-00)$ : hornblenda (1-33) Fe-clorita $(0-20)$, biotita (15-40), quartzo (20-65), plagioclásio (10-15\%), carbonato (0-1\%), grunerita/fluotaramita $(0-5)$ e opacos (1-15). Outros minerais em traços $(<0,5)$ tais como apatita, zircão e 
N10 Distribuiçăo Modal

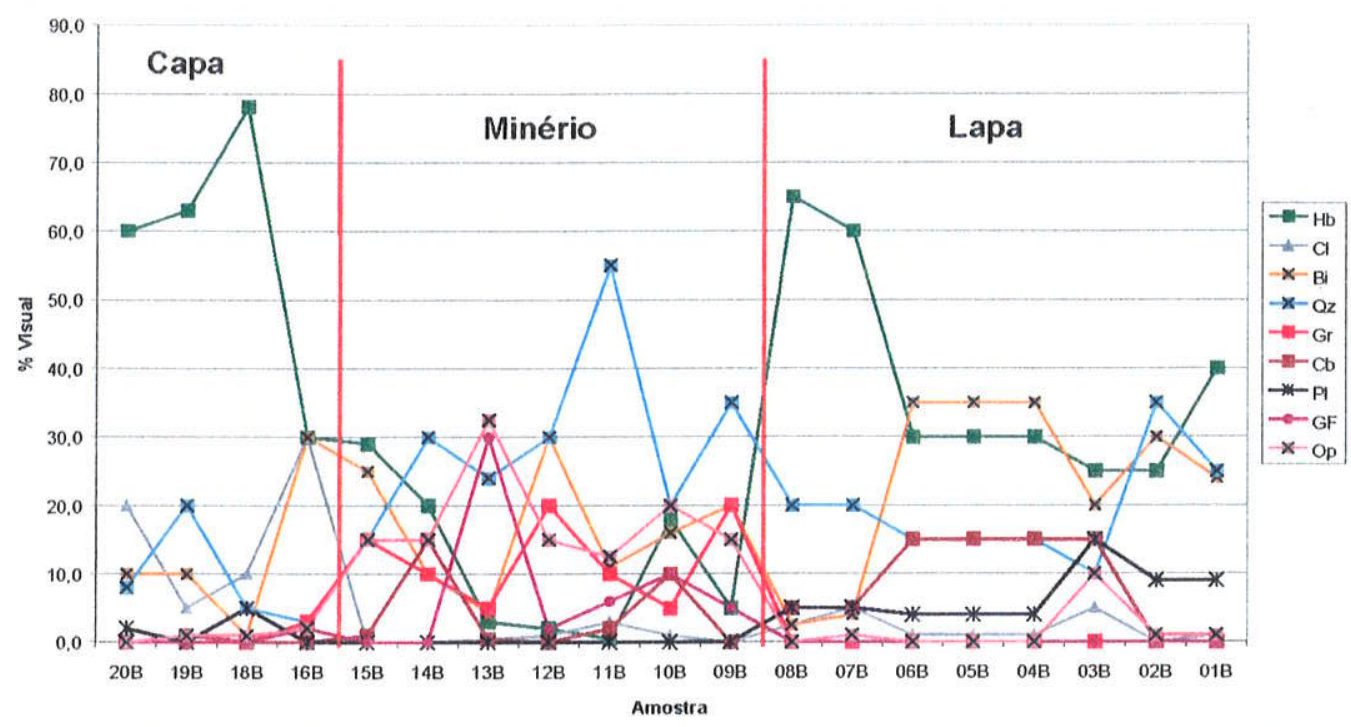

Figura 18: Distribuição modal das fases minerais principais, por estimativa visual, nas amostras do perfil litoestrutural do nivel 10 (N-10) da mina do Pari. (Hb-hornblenda; Cl-clorita; Bi-biotita, Qz-quartzo; Gr-granada; Cb-carbonato; PIplagioclásio; GF-anfibólios tipo cummingtonita-grunerita e/ou fluotaramita; Op-opacos).

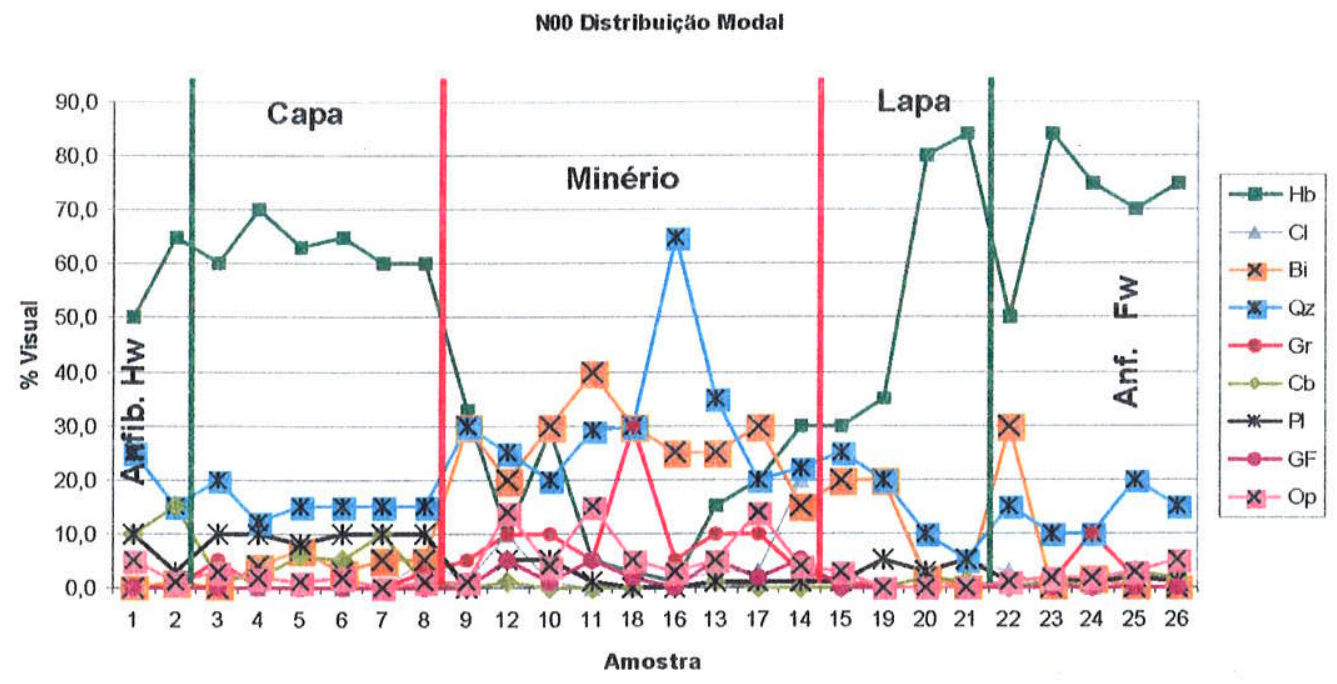

Figura 19: Distribuição modal das fases minerais principais, por estimativa visual, nas amostras do perfil do nivel de entrada $(\mathrm{N}-\mathrm{OO})$ da mina do Pari (Hb-homblenda; $\mathrm{Cl}$-clorita; Bi-biotita, Qz-quartzo; Gr-granada; $\mathrm{Cb}$-carbonato; Plplagioclásio; GF-anfibólios tipo cummingtonita-grunerita e/ou fluotaramita; Op-opacos). "Anf Hw" são os anfibolitos dispostos na capa, e os "Anf Fw" são os da lapa. 
epidoto, também foram observados, existindo tanto nos anfibolitos, quanto nas rochas da capa e da lapa, e na própria mineralização.

Observa-se que, o local de amostragem do $\mathrm{N}-10$ constitui-se em porção rica da mineralização, contrariamente das amostras do $\mathrm{N}-00$ (extremidade Norte do minério), em zona de fechamento por provável zona de cisalhamento posterior à mineralização aurífera.

Das fases de minerais opacos, no minério destacam-se a pirrotita e arsenopirita, os quais constituem entre 70 e $85 \%$ dos minerais opacos do minério. Também se observaram, com menor freqüência calcopirita $(0-1 \%)$, esfalerita $(<1 \%)$, pentlandita $(<0,01 \%)$, ilmenita $(0-1 \%)$ e magnetita $(0-2 \%)$. Pirita só foi observada fora da zona mineralizada, frequentemente associada às fraturas tardias, discordantes às principais estruturas.

As fases minerais opacas foram representadas na ordem de sua formação, na figura 20 , conforme sua disposição estrutural e textural na rocha.

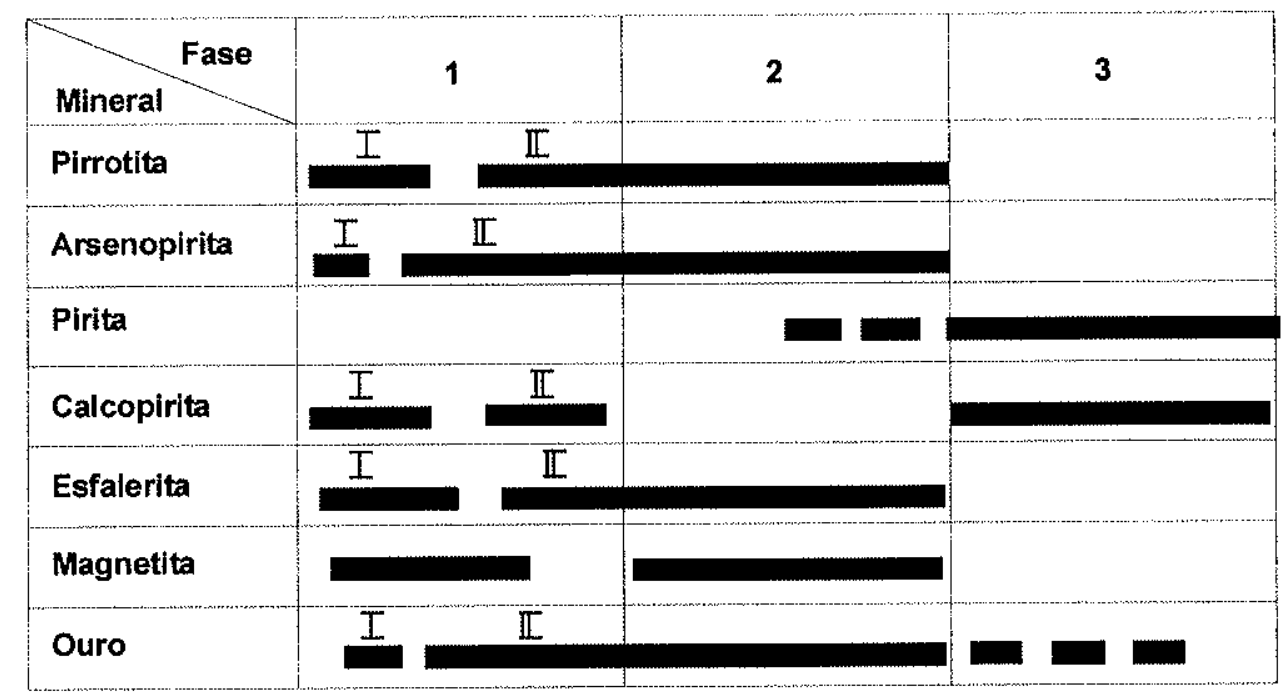

Fase 1 - Deposiçăo e Diagênese

Fase 2 - Transformações Metamórficas

Fase 3 - Remobilizaçóes Tardias e Finais

Figura 20: Seqüência de cristalização dos minerais opacos principais no minério de ouro da mina do Pari.

O Au da mina do Pari aparece em duas gerações granulométricas e texturais distintas e suas composições analisadas por microssonda eletrônica (Schorscher et al., 1991, Abreu, 1995, 1996 e 2001) também são diferentes nos teores de Ag. A geração de Au mais antiga, aparece em grãos de granulometria bastante reduzida 
$(5-15 \mu \mathrm{m})$ inclusos nas arsenopiritas de $1^{\mathrm{a}}$ geração (Fotomicrografia 01). Outra geração, granulometricamente superior $(0,01$ a $0,5 \mathrm{~mm})$, aparece inclusa em minerais metamórficos, em granadas (fotomicrografia 05) e/ou magnetitas poiquiloblásticas (fotomicrografia 03), ou ainda, livre na matriz (fotomicrografia 04).

Estes aspectos texturais e composicionais dos grãos de Au evidenciam que ocorreu uma recristalização metamórfica sobre uma mineralização preexistente, o que é corroborado pela maior pureza da liga natural do grão de Au da segunda geração, que foi remobilizada e recristalizada, com remoção de Ag em solução.

Gráficos mostrando a distribuição modal dos minerais nas amostras de canais das galerias dos niveis de entrada $(\mathrm{N}-00)$ e $10(\mathrm{~N}-10)$ (figuras 04 e 05) são apresentados nas figuras 18 e 19 . Nota-se também uma pequena tendência de assimetria da distribuição modal de alguns minerais (p.ex. granada, carbonato, plagioclásio, entre outros) nas rochas da capa e da lapa dos dois níveis amostrados.

\section{III.3.1.3. Geoquímica}

Nos trabalhos de dissertação de Mestrado de Abreu (1995) obtiveram-se 78 análises de rochas e minérios via fluorescência de raios $X$ (elementos maiores e 20 elementos traço) além de análises de Au por fire assay e absorção atômica. Agora, esses dados foram completados com análises por ICP-MS.

No ítem V.2 do capítulo $V$ são discutidos os perfis geoquímicos da distribuição dos elementos analisados, nas amostras dos níveis 00 e 10 da mina do Pari, representativos das seções de amostragens contínuas da lapa a capa (conforme as figuras 04 e 05). Observa-se claramente a assimetria no comportamento geoquímico de alguns elementos nas encaixantes do minério, notadamente, de $\mathrm{Mg}, \mathrm{Na}, \mathrm{Cr}$ e $\mathrm{Ni}$. Um fato que também chamou a atenção foi o enriquecimento de $\mathrm{Na}$ nas encaixantes de lapa do N-10, o que foi interpretado por Abreu (1995) como efeito de espilitização em seqüências vulcânicas básicas associadas às formações ferriferas ou mesmo corpos de exalitos de fundo oceânico. O enriquecimento de $\mathrm{Mg}, \mathrm{Cr}$ e Ni na capa da mineralização é sugestivo de indicar a base de novos derrames (pós mineralização) com concentração de minerais ferro-magnesianos, tais como olivinas ou piroxênios, hoje transformados em anfibólios. Trata-se, portanto, de uma assinatura geoquímica de derrames basálticos de fundo oceânico, que na base da mineralização estão espilitizados e no topo isentos dessa alteração, indicando processos cumuláticos. De forma alguma, porém, as distribuições geoquimicas observadas aproximam-se do formato simétrico comum nos padrões de mineralizações epigenéticas, ou de origem 
pós-pico de metamorfismo, descrito nos modelos de Phillips e Groves (1983), Phillips (1985), Hodgson (1989 e 1993) e Goldfarb et al. (2001).

Diferentemente também dos relatos de Lobato et al. (1998a,b) de algumas mineralizações de Au do Quadrilátero Ferrífero, ou ainda de MacGeehan e Hodgson (1980) na minas de Campbell e Dikenson, no distrito de Red Lake (Canadá). Nas minas do Pari e São Bento não foram observados os efeitos de lixiviação, nas encaixantes, atribuídas às soluções hidrotermais, que removem $\mathrm{MgO}, \mathrm{Na}_{2} \mathrm{O}$ (mais móveis), com o relativo enriquecimento de $\mathrm{FeO}, \mathrm{CaO}$ e $\mathrm{MnO}$.

De modo geral, o comportamento geoquímico dos elementos maiores analisados na mina do Pari se mostra oposto ao descrito nas zonas de cisalhamento por Yonkee et al. (2003).

A presença de $\mathrm{Au} / \mathrm{Ag}$ se limita à zona sulfetada, ou seja, ao minério em si aqui descrito. Há forte correlação positiva entre o Au-Ag com os teores de As e Zn. Também observam-se correlações positivas moderadas com $\mathrm{Cu}$ e $\mathrm{Ba}$.

As venulações e veios de quartzo concordantes e discordantes existentes na mineralização, de fato, não têm expressão típica quanto às características metalogenéticas da mineralização.

As análises químicas via fire assay (Au-ppm) em uma seção completa do furo BR-39 (Abreu, 1995), mostraram que nenhum desses veios de quartzo remobilizado, à exceção do Horizonte Florália apresenta-se mineralizado.

O comportamento dos elementos terras raras (REE) (anexo 7) mostra leves assimetrias de distribuição entre a capa (HW-hangwall) e lapa (FW-footwall), e junto à zona mineralizada, têm-se as maiores concentrações de terras raras, sobretudo quanto aos valores de $\mathrm{Ce}, \mathrm{Nd}$ e $\mathrm{La}$.

No nível 10, a capa mostra concentrações crescentes de REE de forma em direção à mineralização, enquanto no nível 00 este fato é característico da lapa.

Nos padrões de REE normalizados (Anexo 7), também se observam os diferentes comportamentos geoquímicos das encaixantes de capa e lapa, e da zona do minério.

Independentemente da normalização utilizada, observam-se enriquecimentos variáveis em terras raras leves (LREE) entre capa e lapa, bem como diferentes dispersões entre amostras próximas, desses litotipos encaixantes.

As anomalias negativas de Eu nos diagramas do anexo 7, devem-se as concentrações de Eu nos vents atuais do East Pacific Rise, muito mais altas em relação às concentrações das amostras da mina do Pari. 


\section{III.3.1.4. Geotermômetro de Arsenopirita}

A despeito da discussão na literatura sobre o uso do geotermômetro de arsenopirita, proposto por Clark (1960), re-examinado por Kretschmar e Scott (1976) e Barton e Skinnner (1979), este pode ser utilizado com certas restrições, conforme alertaram Sharp et al. (1985), que consideram o uso desse geotermômetro válido para depósitos metamorfizados em fácies xisto verde a anfibolito baixo. Para depósitos em fácies granulito o geotermômetro oferece temperaturas significativamente mais baixas e para os depósitos hidrotermais de baixas temperaturas (epitermais) temperaturas inconsistentes.

A mina do Pari, encontra-se dentro da faixa metamórfica considerada ótima para o uso deste método, sendo esse caso também para a grande maioria dos demais depósitos de Au conhecidos do Supergrupo Rio das Velhas.

$\mathrm{Na}$ tabela 05 e anexo 5 encontram-se os dados composicionais das arsenopiritas da mina do Pari (Schorscher et al., 1991, in: Abreu, 1995), bem como de outras mineralizações do Quadrilátero Ferrífero e do Zimbabwe (Godoy, 1994; Oberthür et al., 1990).

No gráfico da figura 21, foram representados os dados da tabela 05 obtendo-se como resultados as temperaturas prováveis para os minérios desses depósitos.

No minério da mina do Pari, os núcleos de arsenopiritas mostraram temperaturas entre 485 a $520^{\circ} \mathrm{C}$. Aquelas arsenopiritas, portadoras de Au incluso de granulometria muito fina (arsenopirita de $1^{a}$ geração), indicaram temperaturas mais baixas de seus núcleos, entre 485 a $491^{\circ} \mathrm{C}$, e àquelas da segunda geração de 500 a $520^{\circ} \mathrm{C}$.

Ao se observar as paragêneses metamórficas da mina do Pari (hornblenda + granada + grunerita + plagioclásio $A n>30$ ) estas indicam temperaturas maiores que 400 e até $520^{\circ} \mathrm{C}$, ou seja, condições de xisto verde alto a anfibolito inferior, para um metamorfismo do tipo Barrowiano (de pressões médias), segundo de Winkler (1977); Schorscher (1992) e Herz (1978). Segundo Clark (1960), a coexistência em equilíbrio das fases arsenopirita e pirrotita, inexistindo conjuntamente a pirita indica temperaturas superiores a $491^{\circ} \mathrm{C}$, que de fato, é o caso das paragêneses do campo metamórfico no qual a mina do Pari se insere (figura 22).

Assim, com base nos dados geotermométricos das duas gerações principais de arsenopiritas e das paragêneses de silicatos e sulfetos metamórficas, resume-se o seguinte quadro metalogenético: 


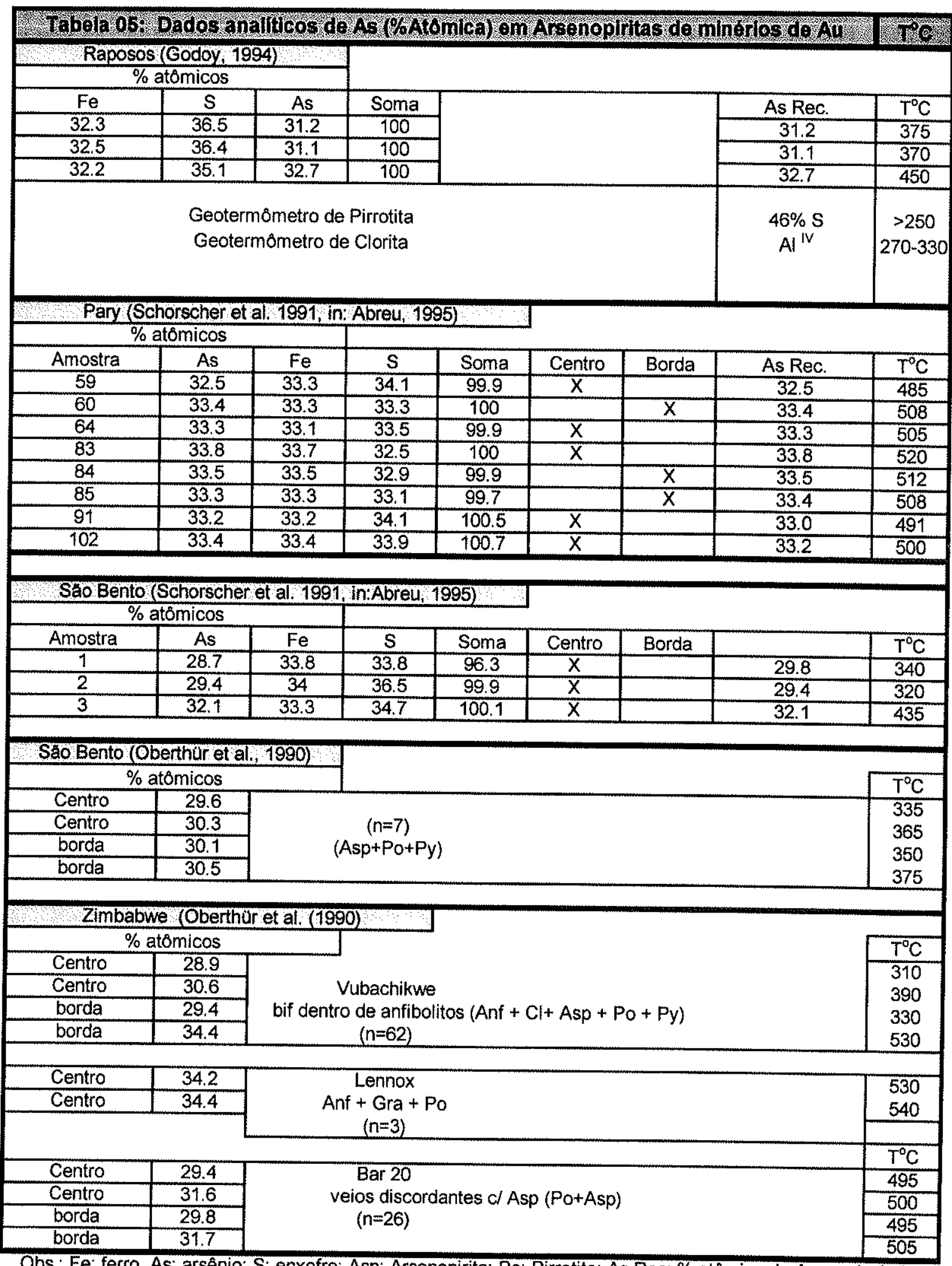

Obs.: Fe: ferro, As; arsênio; S; enxofre; Asp: Arsenopirita; Po; Pirrotita; As Rec: \% atómica de As recalculada. $\mathrm{T}^{\circ} \mathrm{C}$ : Tmperatura em graus Celcius. Gra; granada; Anf: anfibo'lio; $\mathrm{Cl}$ : clorita 


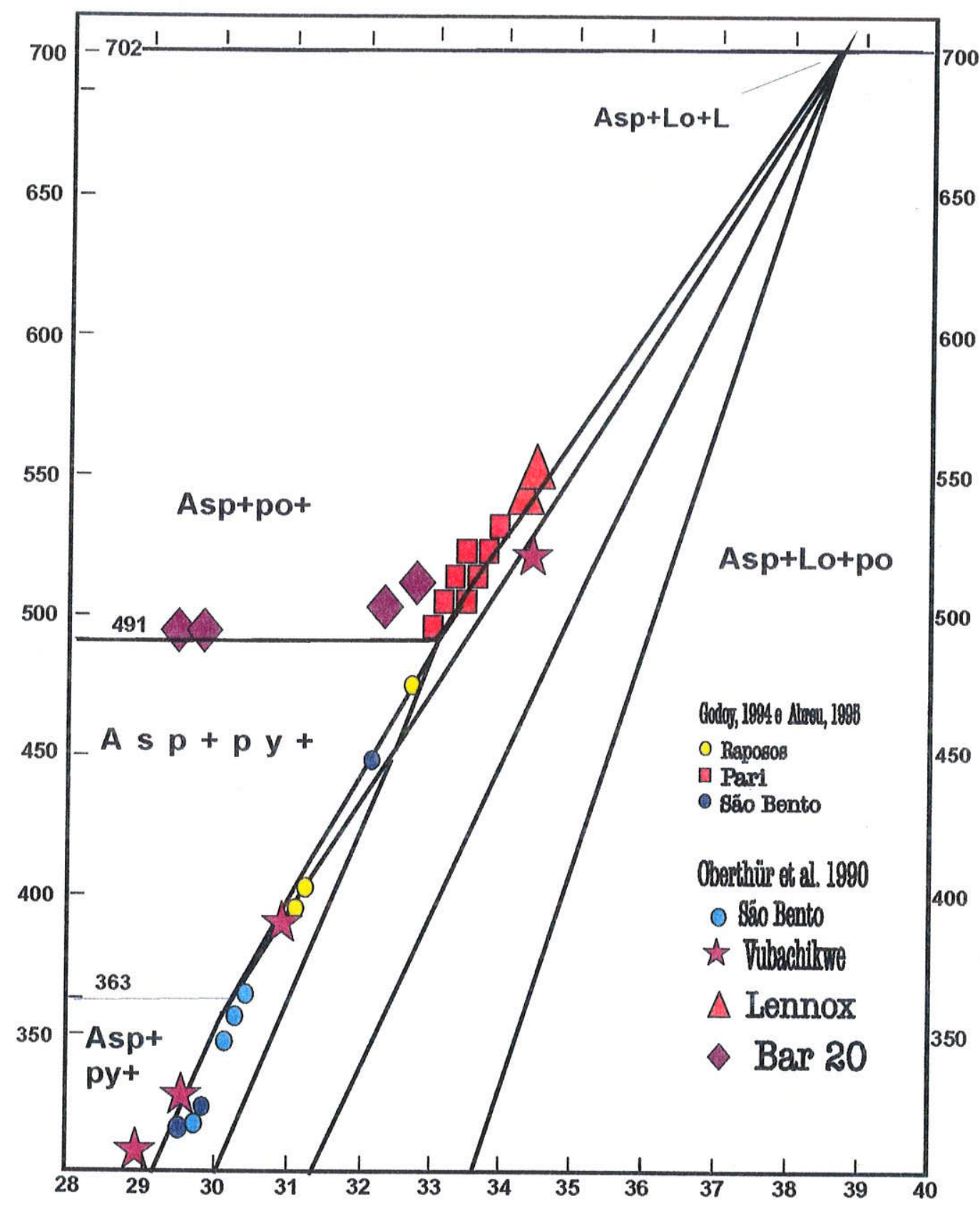

Figura 21: Geotermômetro de "As em Arsenopirita", segundo Sharp et al.(1985), mostrando dados das minas de Au arqueanas do Pari e São Bento (Schorscher et al., 1991, in: Abreu, 1995); Raposos (Godoy, 1994) do Quadrilátero Ferrifero; e Vulbachikwe, Lennox e Bar20 (Oberthür et al., 1990) do Zimbabwe. asp: arsenopirita; po: pirrotita; lo: loellingita; py: pirita; L: liquido. 

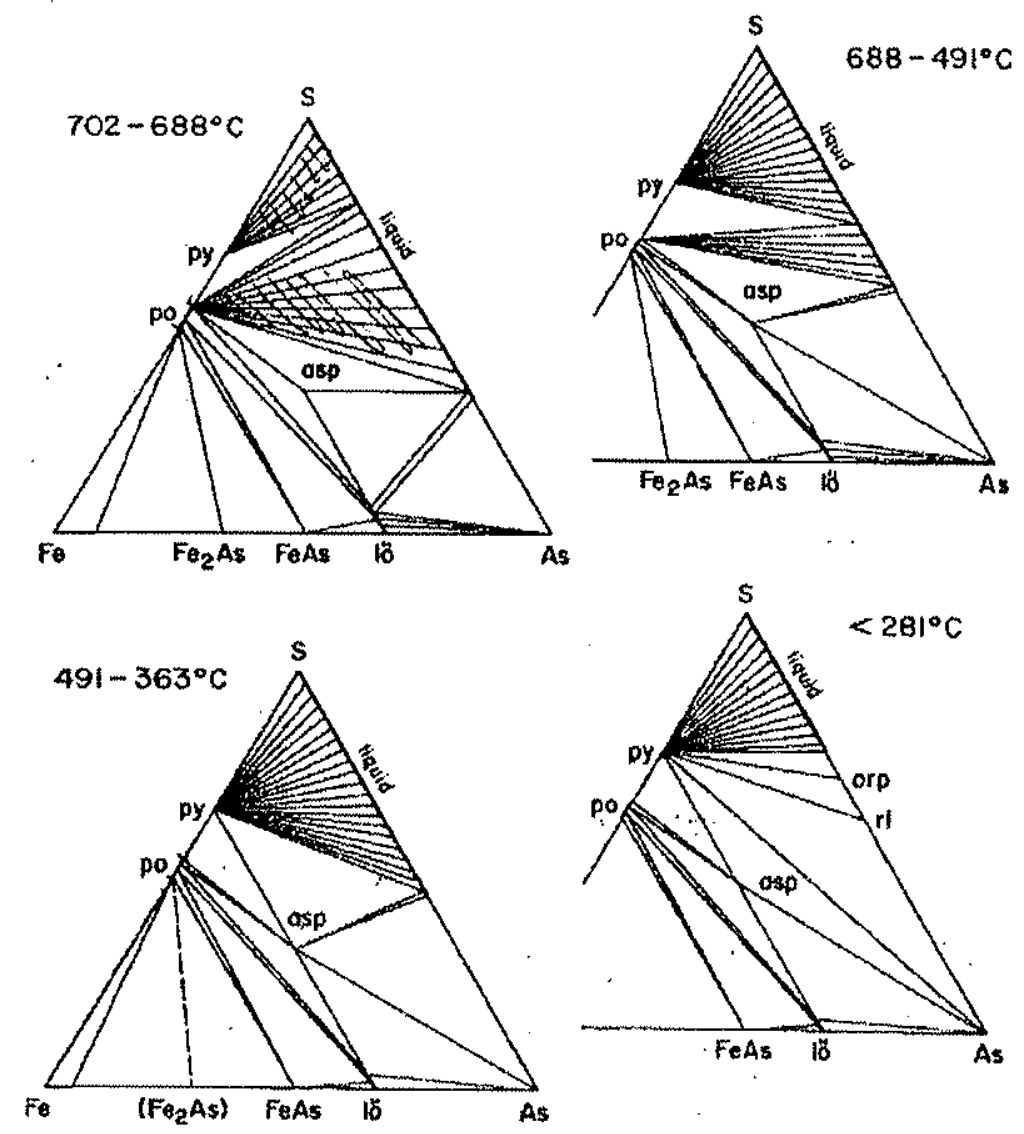

Figura 22: Diagramas Fe-As-S (Clark 1960, Barton, 1969), mostrando a variaçăo de paragêneses em funçăa da composição do sistema original e das condiçбes de temperatura. A partir de $491^{\circ} \mathrm{C}$ os sulfetos Arsenopirita (asp), Pirita (py) e Pirrotita (po) não mais coexistem em equilíbrio termodinåmico, sendo possiveis os pares Arsenopirita-Pirita, Arsenopirita-Pirrotita ou Pirita-Pirrotita, ou ainda combinaçóes com a presença de löllingita (lo) ou As nativo. 
- Arsenopiritas de $1^{a}$ Geração: temperaturas entre 485 e $491^{\circ} \mathrm{C}$, sendo sulfetos poiquiloblásticos parcialmente reequilibrados pelas condições metamórficas, de fácies xisto verde alto (indicado pelas paragêneses silicáticas, porém sem recristalização total e perda das inclusões de $A u$ );

- Arsenopiritas de $2^{a}$ Geração: temperaturas entre 500 e $520^{\circ} \mathrm{C}$, sendo os sulfetos idioblásticos, totalmente reequilibrados, constituindo-se em recristalizados metamórficos, que representam as condições de temperatura do pico do metamorfismo regional na área da mina do Pari.

Assim, as temperaturas encontradas, não necessariamente retratam a formação original do minério aurífero, sendo mais provavelmente o produto do metamorfismo regional principal, atuante sobre uma mineralização preexistente.

Comparando-se, os dados da mina do Pari com os demais apresentados na figura 21, observa-se a compatibilidade das condições metamórficas regionais de fácies xisto verde superior nas minas de Lennox e Bar 20, do Zimbabwe (Oberthür et al. (1990), mas que infelizmente, não se tem as informações dos aspectos texturais das arsenopiritas avaliadas.

\section{III.3.1.5. Conclusões Preliminares da Metalogênese da Mina do Pari}

Todos os dados existentes, de trabalhos de Schorscher et al. $(1986,1991)$ e Abreu (1995), mostraram evidências de alterações de fundo oceânico nas encaixantes da mineralização. Há duas gerações de $A u$, texturais e composicionais distintas, bem como 2 gerações de arsenopiritas correlacionáveis às de Au.

As interpretações metalogenéticas de Schorscher et al. (1991) e Abreu (1995 e 1996) são suportadas por trabalhos detalhados, petrográficos e geoquímicos, e apontam para 2 fases metalogenéticas:

a) Fase 1: vulcanogênica sedimentar-exalativa de fundo oceânico, causando a deposição dos BIF sulfetados auríferos e a espilitização dos protolitos dos anfibolitos granatiferos da lapa da mineralização;

b) Fase 2: de metamorfismo regional progressivo, causando a recristalização das paragêneses de silicatos e sulfetos dos BIF auríferos e das rochas encaixantes, incluindo a purificação da liga natural de Au livre, além do aumento de sua 
granulometria. Por fim, ocorreram ainda remobilizações locais muito discretas, formando os veios de quartzo tardios, por vezes com algum Au.

Preliminarmente, pode-se admitir que também as demais mineralizações auríferas arqueanas do QF poderão ser reinterpretadas como condicionadas por processos polifásicos ou de multi-estágios, incluindo desde processos vulcano-exalativos iniciais até processos hidrotermais-metamórficos posteriores.

A seguir serão resumidos os dados de diversas outras minas e mineralizações de Au arqueanas do Supergrupo Rio das Velhas, com o intuito de embasar comparações e conclusões a respeito de sua evolução metalogenética.

III.3.2. Metalogenia de Outras Mineralizações de Au Arqueanas do Quadrilátero Ferrifero

Através de pesquisa bibliográfica foram coletados dados das minas de São Bento (Figura 23), Morro Velho, Raposos, Cuiabá, Faria, Juca Vieira, Bahú e Passagem de Mariana.

A mina de Passagem de Mariana, no entanto, é caracterizada por estar em situação de contato litológico tectono-metamórfico entre as unidades arqueanas do Sgr. Rio das Velhas e paleoproterozóicas do Sgr. Minas, possuindo um corpo mineralizado rico em turmalina (Fleischer, 1971; Fleischer e Routhier, 1973; Vial, 1988a; Chavet et al., 2001), diferentemente das demais mineralizações tipicamente arqueanas, sendo considerada muito mais jovem.

As mineralizações maiores, tipicamente arqueanas, estão claramente hospedadas nos litotipos do Greenstone Belt Rio das Velhas, e intimamente associadas aos metassedimentos químicos, seja formação ferrífera ou metacherts ou em formações "Lapa Seca" (Ladeira, 1980). Diferentemente disso, têm-se ainda os pequenos e descontínuos veios de quartzo mineralizados, com pouco sulfeto $( \pm 1 \%)$, a exemplo de Juca Vieira, do Horizonte Florália na mina do Pari, a mina do Bahú e os veios de quartzo auríferos irregulares na Formação Carrapato, na área da mina São Bento, dentre muitos outros tratados na literatura.

\section{III.3.2.1. Contexto Geológico e Estrutural}

Os maiores corpos mineralizados do Supergrupo Rio das Velhas, e até o presente 


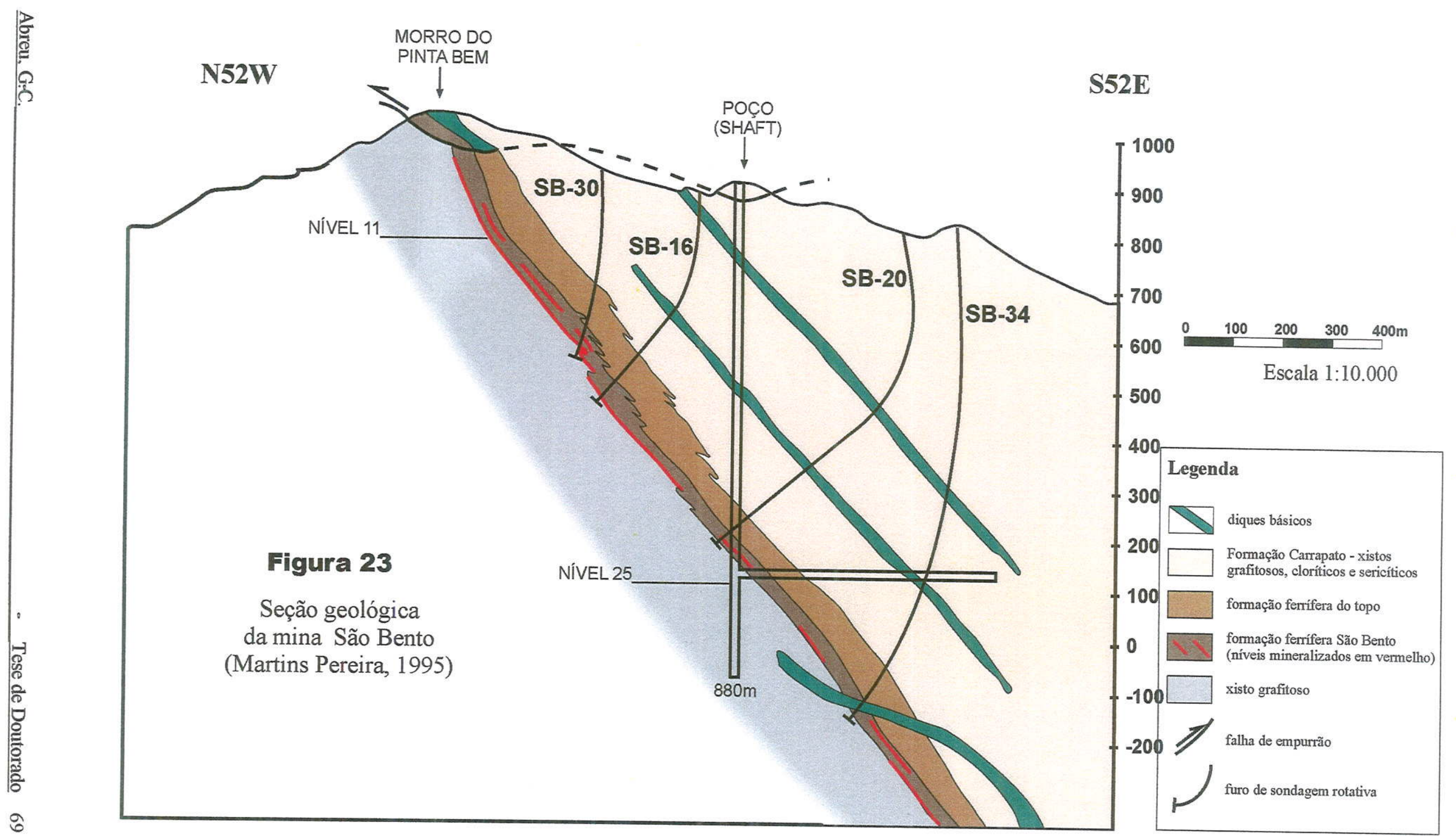


conhecidos e estudados pertencem às minas Morro Velho, Cuiabá, São Bento, Raposos e Faria.

Todas essas mineralizações hospedam-se em metassedimentos químicos (BIF) arqueanos, e associam-se intimamente às paragêneses minerais sulfetadas, principalmente arsenopirita, pirita e pirrotita, e secundariamente com calcopirita, esfalerita, tetraedrita, cubanita e pentlandita.

Todas as mineralizações auríferas foram afetadas por eventos tectono-termais metamórficos, e a depender da situação local, foram fraco a fortemente dobradas e redobradas. No distrito de Nova Lima (minas de Morro Velho, Raposos e Faria) as mineralizações mostram intenso redobramento, exibindo padrões de dobras isoclinais (Moreschi, 1972; Ladeira, 1980 e 1988; Toledo, 1987; Godoy, 1994, Ribeiro-Rodrigues, 1998). Também na mina São Bento são descritas e mapeadas dobras isoclinais rompidas, de eixo subhorizontal, efeito de empurrão SE para NW (Martins Pereira, 1995), exibindo padrões de dobras em bainha. Entretanto, analisado as estruturas sedimentares $\left(S_{0}\right)$ em relação às deformações pode-se concluir, que em todas essas mineralizações, os minérios se dispõem de maneira essencialmente concordantes. Exceções são dadas, por remobilzações em zonas de charneiras dessas dobras ou ainda, em veios preenchendo fraturas tipo $\mathrm{T}$ (tension gashes), dentro do corpo da mineralização, jamais estendendo-se além disso.

Os conjuntos litológicos encaixantes dessas mineralizações auríferas variam de formaçōes ferríferas do tipo algoma, metassedimentos pelíticos, até metavulcânicas diversas, diferenciando-se das demais os contextos da mina do Pari e de Cuiabá, cujas mineralizações auriferas, hospedam-se exclusivamente em formações ferríferas, intercaladas em seqüências de metavulcânicas máficas (anfibolitos). Porém, na mina de Cuiabá, existem ainda rochas vulcânicas félsicas associadas, diferentemente da mina do Pari e arredores, onde tais rochas não foram verificadas em associação próxima à mineralização.

Muitas das mineralizações auríferas são cortadas por diques de metabásicas posteriores, como por exemplo, nas minas de São Bento e Raposos. Estes, entretanto, não se associam à metalogênese desses depósitos (Martins Pereira, 1995; Godoy, 1994) e apenas os cortam, podendo gerar pequenas remobilizações locais, sejam enriquecimentos ou depauperações.

Nas tabela 06a e 06b forma resumidas comparativamente as caracteristicas gerais das mineralizações aqui comentadas. As mineralizações possuem nítidos controles litoestratigráficos e estruturais, estando sempre hospedadas em metassedimentos químicos, e deformadas, com controle linear marcante; $570^{\circ} \mathrm{E}$ no distrito de Nova Lima, $S 50^{\circ} \mathrm{E}$ em São Bento, Santa Quitéria e Córrego do Sítio; e S80-85 E nas mina 
do Pari, Bahú, Gambá e Patrimônio no distrito de Florália (Figura 02 e anexo 01). A idade dessas deformações ainda é discutivel. Pelo que se observa na mina São Bento, as estruturas principais, $\mathrm{N} 45-50^{\circ} \mathrm{E}$ são relacionadas ao evento arqueano Rio das Velhas (Martins Pereira, 1995), sendo 0 evento Minas-Espinhaço (Transamazônico), representado por falhamentos diversos, de direção N-S até NNW-SSE, com caimentos de 50-70 (a estes se associam os metadiabásios) e arrastes de baixo ângulo (subhorizontais), próximos à superfície (Figura 09 e 23), e ambos cortando a mineralização da mina São Bento.

\section{III.3.2.2. Paragêneses Silicáticas e de Sulfetos}

$\mathrm{Na}$ tabela $06 \mathrm{~b}$ foram compilados os dados médios da relação Au/Ag (fineness), e de outros elementos associados a liga natural de $\mathrm{Au}$, com dados sobre o grau metamórfico, bem como as paragêneses dos minérios, incluindo sulfetos e silicatos. As paragêneses silicáticas das mineralizações de Au arqueanas podem ser resumidas em quatro tipos principais:

a) quartzo + siderita + clorita + carbonato \pm estipnomelano \pm sericita: típica para os depósitos auríferos associados a formações ferríferas tipo algoma, porém em fácies xisto verde inferior, com temperaturas máximas de até $\sim 300^{\circ} \mathrm{C}$.

b) quartzo + ankerita \pm Fe-dolomita: típica para os depósitos associados a formações de "Lapa Seca" (i.e., BIF de fácies carbonato), como da Mina de Morro Velho (Ladeira, 1980), também em fácies xisto verde.

c) quartzo + carbonato + hornblenda + granada: típica para os depósitos auríferos da quadrícula de Florália, ente eles: Pari, Patrimônio, Gambá e Bahú, todos em fácies xisto verde superior transicional para fácies anfibolito, com temperaturas atingindo até $520^{\circ} \mathrm{C}$.

d) quartzo \pm carbonato \pm sulfetos: típica para depósitos de veios de quartzo, tais como o Horizonte Florália da mina do Pari; veios de quartzo auríferos na Formação Carrapato (Mina São Bento), e os veios de quartzo das minas do Bahú e Juca Vieira. Nestes, o grau metamórfico regional pouco influenciou, indicando tratar-se de típicos veios tardios de remobilizações, pós-pico do metamorfismo regional principal da área. 
Tabela 6a: Resumo das Principais minas estudadas em detalhe do Q.F. - Localização e características gerais

\begin{tabular}{|c|c|c|c|c|c|c|c|c|}
\hline & \multirow{2}{*}{ Autor } & \multirow{2}{*}{ Mina } & \multicolumn{2}{|c|}{ Localizaçāo } & \multirow{2}{*}{ Contexto Lítoestrutural } & \multicolumn{3}{|c|}{ Encaixantes e Hospedeiras } \\
\hline & & & Porção do QF & Municipio & & Hospedeira & lapa & capa \\
\hline 1 & Ladeira(1980) & Mina Grande & Centro-Oeste & Nova Lima & NL/VS/Bif hosted & Lapa Seca & máficas & xistos \\
\hline 2 & Vieira $(1988,1991)$ & Juca Viera & Centro-Norte & Caeté & NLNS/Bif hosted & Veio de quartzo & Máfica & Máfica \\
\hline 3 & Godoy (1994) & Raposos & Centro-Oeste & Nova Lima & NLNS/Bif hosted & $\mathrm{BIF}$ & máficas/ultram. & metatufos/metapelitos \\
\hline 4 & Toledo (1987) & Cuiabá & Centro-Norte & Caeté & NLMáfico/Bif hosted & $\mathrm{BiF}$ & máficas & máficas \\
\hline 5 & Moreschi (1972) & Faria & Centro-Norte & Caeté & NLIMáfico/Bif hosted & BIF & grafita-xisto & máficas/sedimentos \\
\hline 6 & Alves (1995) & Såo Bento & $\mathrm{NE}$ & Santa Bárbara & NL/S/Bif hosted & BIF & grafita-xisto & BIF \\
\hline 7 & Abreu (1995) & Pari & $\mathrm{NE}$ & Santa Bárbara & NLAMáfico/Bif hosted & BIF impuro & anf-clorita-biotita xisto o/ gran. & anf-clorita-biotita xisto cl gra \\
\hline 8 & Abreu (1995) & Bahu & $\mathrm{NE}$ & Santa Bárbara & NLNS/Bif hosted & Veio de quartzo & anf-clorita-biotita xisto c/ gran. & anf-clorita-biotita xisto c/gran. \\
\hline 9 & Vial (1988) & Passagem & $\mathrm{SE}$ & Mariana & Contato Minas/NL & veio qzofturmalinito. & itabirito dolomítico & qzo-carb-sericita-biot xisto \\
\hline & & & & & & & & \\
\hline
\end{tabular}

NLVS/Bif hosted: Grupo Nova Lima- Domínio vulcano-sedimentar, hospedada em formação ferrifera (BIF),

NL/Máfico/Bif hosted: Grupo Nova Lima- Domínio vulcânico básico, hospedada em formação ferrifera(BIF),

NL/S/Bif hosted: Grupo Nova Lima- Dominio sedimentar químico, hospedada em formação ferrifera (BIF).

Contato Minas/NL: Hospedada no contato tectonico entre o Supergrupo Minas e Supergrupo Rio das Velhas

Tabela 6b: Resumo das Principais minas estudadas em detalhe do Q.F. - Características Metalogenéticas Gerais

\begin{tabular}{|c|c|c|c|c|c|c|c|c|}
\hline & Autor & Mina & Teor Médio & $\mathrm{Au} / \mathrm{Ag}$ & Outros elementos & Grau Metamófico & \multicolumn{2}{|c|}{ Paragéneses do Minério } \\
\hline & & & $(A \cup g / t)$ & & (na liga natural de $\mathrm{Au}$ ) & & Sulfetos & Silicatos e Carbonatos \\
\hline 1 & Ladeira(1980) & Mina Grande & 11.0 & $4-4,1 ; 5,7-6.46$ & $\mathrm{Pt}_{1}, \mathrm{Pd}$ traços $(0,09$ a $0,15 \mathrm{ppm})$ & Xisto verde & Py-Po (Asp) (Ccp-Cu) & qzo-ank \\
\hline 2 & Vieira $(1988,1991)$ & Juca Viera & 5.6 & 13.61 & - & Xisto verde & Py-Po-Ccp (Asp) $<1 \%$ & $q z 0$ (cl-cab-se-ab) \\
\hline 3 & Godoy (1994) & Raposos & 6.0 & 4,75 (Ladeira, 1980) & $\mathrm{Pt}, \mathrm{Pd}, \mathrm{Ni}, \mathrm{Co}, \mathrm{Cu}$ tracos & Xisto verde & $P_{0}(P y-A s p)$ e Py-Asp & quo-sid \\
\hline 4 & Toledo (1987) & Cuiabáá & $8 \mathrm{a} 11$ & 6 & $\because$ & Xisto verde & Py (Po-Asp-Ccp-Sp-Gn) & qzo-sid-cl \\
\hline 5 & Moreschi (1972) & Faria & 8.6 & 5 & - & Xisto verde & Py-Po-Asp (Sp-Ccp-Gn-Tt) & gzo-sid-cl \\
\hline 6 & Alves (1995) & São Bento & 11.0 & $2,07-2,1,4,85-7,1$ & $\mathrm{Cu}$ & Xisto verde & Asp-Po-Py(Sp-Gn-Ccp) & qzo-sid-cl-stp \\
\hline 7 & Schorscher et al, in Abreu(1995) & Pari & 10.0 & $4,35-5,13 ; 4,8-6,18$ & - & Xisto verde alto & Asp-Po-(Ccp-Sp-Pn) & gzo-cab-gra-hom \\
\hline 8 & Schorscher et al, in Abreu(1995) & Bahu & & $5,62-6,09$ & - & Xisto verde alto & Py & qzo-cab \\
\hline 9 & Vial (1988) & Passagem & $6-14$ & & - & Xisto verde? & Asp-Py/Po & qzo-turm-anf \\
\hline & & & & & - & & & \\
\hline
\end{tabular}

Py-pirita Po-pirrotita, Asp-arsenopirita, Sp-esfalerita, Ccp-calcopinta Gn-galena Tt-tetraedrita Cu-cubanita Pn-pentlandita, ank-ankerita

qzo-quarzo, ci-clorita,cab-carbonato, se-sericita, ab-albita, sid-siderita, stp-stilpnomelano, gra-granada, horn-hornblenda, turm-turmalina, anf-anfibólio. 
A proporção de sulfetos nas mineralizações de Au do Supergrupo Rio das Velhas é bastante variável. No entanto existe sempre uma forte correlação do Au com os sulfetos presentes em cada caso. Nas minas do Pari e São Bento há forte correlação positiva entre a arsenopirita e o Au (Martins Pereira, 1995; Abreu, 1995, Valladares, 2004).

As paragêneses sulfetadas principais mostram quase constância de:

- Arsenopirita (Asp) + Pirrotita (Po) + Pirita (Py), na mina São Bento, e - Arsenopirita (Asp) + Pirrotita (Po), na mina do Pari.

Como fases subordinadas aparecem esfalerita $(\mathrm{Sp})$, calcopirita $(\mathrm{C} c p)$, cubanita $(\mathrm{Cu})$, tetraedrita $(\mathrm{Tt})$ e pentlandita $(\mathrm{Pn})$. A galena $(\mathrm{Gn})$ aparece raramente, em veios tardios, nas minas de Morro Velho e São Bento, bem como em traços nos veios da mina do Bahú e no Horizonte Florália da mina do Pari.

Novamente, comparando-se as paragêneses de sulfetos principais, de arsenopirita, pirrotita e pirita, com o grau metamórfico regional de cada uma das mineralizações, observamse, segundo Clark (1960) (figura 22), que apenas a mina do Pari, indica condições metamórficas mais elevadas, pela co-existência paragenética de Arsenopirita + Pirrotita (na ausência de pirita), indicando $\mathrm{T}>491^{\circ} \mathrm{C}$.

\section{III.3.2.3. Estudos de Inclusões Fluidas}

Estudos de inclusões fluidas estão disponiveis das minas Raposos (Godoy, 1994), São Bento (Alves, 1995) e Cuiabá (Toledo et al., 1998). Os principais resultados são apresentados na tabela 07.

$\mathrm{Na}$ mina Raposos foram identificadas 5 tipos ou classes de inclusões fluidas em veios de quartzo associados à mineralização. Dos veios, entretanto, não foram dadas as descrições exatas de sua localização, posicionamento estratigráfico e estrutural, nem as características petrográficas (deformação e recristalização do quartzo) e eventuais outros constituintes minerais.

As inclusões encontradas são classificadas em: do tipo I $\left\{\mathrm{H}_{2} \mathrm{O}, \mathrm{CH}_{4},\left(\mathrm{~N}_{2}\right), \mathrm{NaCl}\right.$ e $\left.\mathrm{CO}_{2}\right\}$, subdivididas em: la $\left\{\mathrm{H}_{2} \mathrm{O}, \mathrm{CH}_{4},\left(\mathrm{~N}_{2}\right), \mathrm{NaCl}\right.$ e $\left.\mathrm{CO}_{2}\right\}$ e lb $\left\{\mathrm{CH}_{4}\right.$ e $\left.\mathrm{N}_{2}\right\}$ com salinidade de $14,3 \%$ equivalentes de $\mathrm{NaCl}$; as do tipo II $\left\{\mathrm{H}_{2} \mathrm{O}, \mathrm{CO}_{2}, \mathrm{NaCl}\right.$ e $\left.\mathrm{CH}_{4}\right\}$ com $8.49 \%$ equivalentes de $\mathrm{NaCl}$ e as do tipo III $\left\{\mathrm{H}_{2} \mathrm{O}, \mathrm{NaCl}\right.$ ou $\left.\mathrm{KCl}\right\}$, de alta 
Tabela 7: Dados de Inclusőes Fluidas, Isótopos Estáveis, Paragênese, Geoermômetro de Arsenopirita e Temperaturas de Metamorfismo

\begin{tabular}{|c|c|c|c|c|c|c|c|c|c|}
\hline & & & \multicolumn{2}{|c|}{$\mathrm{PeT}$} & \multicolumn{3}{|c|}{ Inclusōes Fluidas } & \multicolumn{2}{|c|}{ Isótopos Estáveis } \\
\hline & Autor & Mina & $T(\mathrm{C}) \mathrm{F}$ & (kbar) & Tipos & Fluidos & $\mathrm{NaCl}$ (\%eq.) & $\mathrm{C}^{12}(\% / \infty)(\mathrm{PDB})$ & $\mathrm{O}^{10}\left(\mathrm{~T}_{\infty}\right)(\mathrm{SMOW})$ \\
\hline 1 & Ladeira(1980) & Mina Grande & $380-500^{1}$ & $2-4$ & & & & & $15,82-17,36$ (qzo) e $12,81-13,66(\mathrm{r})$ \\
\hline 2 & Vieira $(1988,1991)$ & Juca Viera & & & & & & & \\
\hline 3 & Godoy, 1994 & Raposos & & & $\mathrm{I}$ & $\mathrm{H}_{2} \mathrm{O}, \mathrm{CH}_{4}\left(\mathrm{~N}_{2}\right), \mathrm{NaCl}$ e $\mathrm{CO}_{2}$ & 14.3 & -4 a -6 (minério, bif e remobiliz.) & \\
\hline & Godoy, 1994 & Raposos & & & la & $\mathrm{H}_{2} \mathrm{O}, \mathrm{CH}_{4}\left(\mathrm{~N}_{2}\right), \mathrm{NaCle} \mathrm{CO}$ & 14.3 & $\sim 0$ (máficas) & \\
\hline & Godoy, 1994 & Raposos & & & 16 & $\mathrm{CH}_{4} \mathrm{eN}$ & 14.3 & $-18,2$ & \\
\hline & Godoy, 1994 & Raposos & & & II & $\mathrm{H}_{2} \mathrm{O}, \mathrm{CO}_{2}, \mathrm{NaCl}$ e $\mathrm{CH}_{4}$ & 8.49 & & \\
\hline & Godoy, 1994 & Raposos & & & III & $\mathrm{H}_{2} \mathrm{O}, \mathrm{NaCl} \mathrm{ou} \mathrm{KCl}$ & aita & & \\
\hline 4[ & Toledo et al.(1998) & Cuiabá & $250-520^{*}$ & & & $\mathrm{CH}_{4} \mathrm{eCO}{ }_{2}\left(\mathrm{~N}_{2} \mathrm{eH} \mathrm{H}_{2} \mathrm{SeHS}\right)$ & $5,9 a 8$ & & \\
\hline 5 & Moreschi (1972) & Faria & $300-400$ & & & & & & \\
\hline 6 & Alves (1995) & Sẫo Bento & 300 & 3.2 & $1 \mathbf{a}$ & $\mathrm{CO}_{2}, \mathrm{CH}_{4} \mathrm{e} \mathrm{N}$ & $3,4 a 5$ & & \\
\hline & Alves (1995) & Sáo Bento & & & $1 \mathrm{~b}$ & $\mathrm{CO}_{2}, \mathrm{CH}_{4} \mathrm{e}\left(\mathrm{N}_{2}\right)$ & $3,4 a 5$ & & \\
\hline & Alves (1995) & São Bento & 200 & 1 & 10 & $\mathrm{~N}_{2}, \mathrm{CH}_{4} \& \mathrm{CO}_{2}$ & 3,4 a 5 & & \\
\hline & Alves (1995) & Săo Bento & & & 2 & $\mathrm{~N}_{2} \mathrm{e} \mathrm{CO}$ & & & \\
\hline & Alves (1995) & Săo Bento & & & 3 & $\mathrm{H}_{2} \mathrm{O}$ & & & \\
\hline & Schorscher et al. 1991, in Abreu(1995) & Pari & $320-515^{*}$ & & & & & & \\
\hline & Schorscher et al. 1991, in Abreu(1995) & Bahu & $320-515^{*}$ & & & & & & \\
\hline
\end{tabular}

"Temperaturas de metamorfismo baseadas em paragêneses metamórficas ou geotermômetro de Arsenopinta.(rt: rocha total, qzo: quartzo)

Nas minas asterisco a Temperatura foi indicada por paragêneses metamóricas.

Nas minas do Pari e Bahú foram utuilizados ambos os métodos: gecermômetro de arsenopirita e paragêneses metamórficas. 
salinidade. Segundo Godoy (1994), estes fluidos seriam de origem metamórfica e relacionados à gênese da mineralização. Porém, há de se considerar que inclusões aquo-carbônicas de relativamente alta salinidade já foram interpretadas por Fyfe e Kerrich (1984), estudando minas de Au e metais base da região do Abitibi (Canadá), como de origens vulcano-exalativas ou magmático-hidrotermais.

Na mina São Bento, Alves (1995) também identificou 5 tipos de inclusões fluidas que aparecem tanto em veios de quartzo associados à mineralização quanto em veios que cortam unidades estéreis. No caso, têm-se as seguintes inclusões: tipo 1a $\left\{\mathrm{CO}_{2}, \mathrm{CH}_{4}\right.$ e $\left.\mathrm{N}_{2}\right\}$ indicando $\mathrm{T}=300^{\circ} \mathrm{C}$ e $\mathrm{P}=3,2 \mathrm{~kb}$, tipo $1 \mathrm{~b}\left\{\mathrm{CO}_{2}, \mathrm{CH}_{4}\right.$ e $\left.\left(\mathrm{N}_{2}\right)\right\}$ e tipo 1c $\left\{\mathrm{N}_{2}, \mathrm{CH}_{4}\right.$ e $\left.\mathrm{CO}_{2}\right\}$ indicando $\mathrm{T}=200^{\circ} \mathrm{C}$ e $\mathrm{P}=1 \mathrm{~kb}$, com salinidades entre 3,4 e $5 \%$ equivalentes de $\mathrm{NaCl}$; as do tipo $2\left\{\mathrm{~N}_{2}, \mathrm{CO}_{2}\right\}$ de baixa salinidade e tipo $3\left\{\mathrm{H}_{2} \mathrm{O}\right\}$ hipersalinas. Nas inclusões fluidas da mina São Bento, a componente carbônica, mais expressiva, indicaria uma provável origem metamórfica, interpretada segundo os estudos de Fyfe e Kerrich (1984).

Na mina de Cuiabá Toledo et al. (1998) caracterizaram apenas um tipo de inclusões fluidas de $\left\{\mathrm{CH}_{4}, \mathrm{CO}_{2},\left(\mathrm{~N}_{2}\right), \mathrm{H}_{2} \mathrm{~S}\right.$ e HS $\}$ com salinidades entre 5,9 e $8 \%$ equivalentes $\mathrm{NaCl}$.

Desses estudos de inclusões fluidas, depreende-se uma considerável variação composicional entre as diversas minas e que, de fato, também possuem características litoestruturais, petrográficas e geoquímicas, de minérios e rochas encaixantes e hospedeiras, bastante distintas.

Comparando as minas Raposos e São Bento, observa-se que existem os mesmo tipos morfológicos e seqüências temporais de inclusões fluidas, mas que apresentam composições distintas.

O significado das inclusões fluidas em mineralizações que sofreram diversos processos (multimestágio) ainda é pouco discutido na literatura. Alguns autores, como Lobato et al. (1998), Vieira $(1988,1991)$, Toledo et al. (1998), interpretam as características dessas inclusões, e as condições de pressões e temperaturas, assim deduzidas, como sendo às mesmas da formação principal do depósito. Pela literatura internacional, as composições das inclusões fluidas mais antigas, indicariam fluidos de origem magmática (Fyfe e Kerrich, 1984; Hutchinson e Burlington, 1984; Mason, 1992, 1995; Yao et al., 1999; entre muitos outros).

III.3.2.4. Estudos de Isótopos Estáveis 
Nas mineralizações auríferas arqueanas do Supergrupo Rio das Velhas ainda são bastante escassos os estudos de isótopos estáveis (tabela 7).

Da mina Morro Velho, Ladeira (1980 e 1988) apresentou dados de $\delta 0^{18}$ (SMOW) para veios de quartzo na formação Lapa Seca $(+17,0 \%$ ) e nos metabasaltos $(+17 \% 0)$, de veios de quartzo tardios $(+16,0 \%$ ) e de rocha total (metabasaltos) $(+12,75$ a $+13,07 \%$ ), interpretando a origem da mineralização como singenéticaexalativa de um sistema hidrotermal convectivo de fundo oceânico, e origens metamórficas para os fluidos dos veios de quartzo tardios.

De maneira análoga, com estudo de $\delta \mathrm{O}^{18}$ (SMOW) em rocha total de metabasitos alterados ou não por processos hidrotermais de fundo oceânico e posteriormente metamorfizados, do Grupo Serra do Itaberaba (Estado de São Paulo), Perez-Aguilar (2001), obteve, para metabasitos sem alterações hidrotermais valores entre +5 e +9 $\%$ (protolitos) e para metabasitos com alteração hidrotermal progressiva, valores crescentes entre $+8,6$ e $+16,9 \%$.

Estes resultados, indiretamente, corroboram as interpretações de Ladeira (1980) para os metabasaltos do Grupo Nova Lima, anteriores ao metamorfismo regional no Quadrilátero Ferrífero que também devem ter sofrido alterações hidrotermais de fundo oceânico.

$\mathrm{Na}$ mina de Raposos, Godoy (1994) obteve dados isotópicos de $\delta C^{13}$ (PDB) do minério, da formação ferrífera e dos carbonatos remobilizados (-4 a $-6 \%$ \%), nos carbonatos dos metabasaltos $(\sim 0 \%)$, e de grafita $(-18,2 \% \circ)$. Sua interpretação quanto à gênese da mineralização, no entanto, salienta apenas os aspectos de natureza tectônica e metamórfica, não discutindo os resultados isotópicos em detalhes maiores. Porém, com base nos estudos de Craig (1953), Rankama (1963), bem como de Santos et al. (2000), os dados de $\delta C^{13}$ (PDB), acima obtidos, poderiam ser interpretados ainda de outra forma: para as formações ferriferas e metabasaltos os valores seriam compativeis com carbonatos marinhos; enquanto as grafitas mostrariam uma possivel origem biogênica. Isto indicaria uma possivel relação de singênese da mineralização de $\mathrm{Au}$ e das formações ferriferas e posterior metamorfismo de fácies xisto verde. Silva e Xavier (1997) descreveram um fato semelhante em materiais carbonosos do greenstone belt do rio Itapicuru, na Bahia.

\section{III.3.2.5. Estudos de Isótopos Radiogênicos e Geocronologia}

Vários estudos geocronológicos já foram realizados em diversas das mineralizações auríferas arqueanas e outros litotipos do Supergrupo Rio das Velhas (tabela 08). 
Tabela 08: Geocronologia das Mineralizações Auriferas do Q.F.

\begin{tabular}{|c|c|c|c|c|c|c|}
\hline Local & & & & ocronologia & & \\
\hline Mina ou Distrito & Grăo ou Rocha & método & Rocha & Interp Orig. & idade (G.a) & Autor \\
\hline Morro Velho & Galena & $\mathrm{Pb}-\mathrm{Pb}(\mathrm{G})$ & veio discordante & Metalogênese & $3,0-2,7$ & Thorpe et al (1984) \\
\hline Morro Velho & Galena & $\mathrm{Pb}-\mathrm{Pb}(\mathrm{Gn})$ & veio discordante & remob.l & $2,45-2,41$ & Thorpe et al (1984) \\
\hline Morro Velho & Galena & $\mathrm{Pb}-\mathrm{Pb}\left(\mathrm{G}_{n}\right)$ & veio discordante & remob.ll & $2,175-2,1$ & Thorpe et al (1984) \\
\hline Morro Velho & Galena & $\mathrm{Pb}-\mathrm{Pb}(\mathrm{Gn})$ & veio discordante & remob.lll & 0.6 & Thorpe et al (1984) \\
\hline Morro Velho & Sulfetos (Asp, Pye Po) & $\mathrm{Pb}-\mathrm{Pb}$ (Sulf.) & minério sulfetado & Deposiçāo & 2.82 & Dewitt et al. (1994) \\
\hline Morro Velho & Rocha Total (Bif c/ Siderita) & $\mathrm{Pb}-\mathrm{Pb}(\mathrm{t})$ & Lapa Sêca cinza estéril & Deposiçăo & 2.8 & DeWitt et al. (1994) \\
\hline Morro Velho & Zircão peq. Redondo & U-Pb Zircão & "tufito félsico" & Detritico & 3.126 & Schrank \& Machado $(1996 a, b)$ \\
\hline Morro Velho & Zirca com arestas & U-Pb Zircăo & "tufito félsico" & Detrítico & $2,777 a 2,776$ & Schrank \& Machado (1996a, b) \\
\hline Morro Velho & Zircảo detrítico? & U-Pb Zircão & "fuffito félsico" & Detrítico & 2.278 & Schrank \& Machado (1996a, b) \\
\hline Morro Velho & Monazita redonda & U-Pb Monaz. & "tufito félsico" & Detritico & 2.068 & Schrank \& Machado (1996a, b) \\
\hline Morro Velho & Monazita euhédrica & U-Pb Monaz. & "tufito félsico" & Detritico & 1.875 & Schrank \& Machado $(1996 a, b)$ \\
\hline Morro Velho & Zircăo detrítico? & U-Pb Zircäo & Lapa Sêca cinza & Detrítico & 2,771 a 2,748 & Schrank \& Machado $(1996 a, b)$ \\
\hline Morro Velho & Monazita detrifica? & U-Pb Monaz. & Lapa Seca cinza & Detritico & $2,705+-1$ & Schrank \& Machado $(1996 a, b)$ \\
\hline Passagem de Mariana & Monaz. Euh.,inclusóes de sulf. & U-PbMonaz. & veio discordante & metamorismo & 2.093 & Schrank \& Machado (1996a, b) \\
\hline Passagem de Mariana & Monaz. Euh.,inclusdes de sulf. & U-Pb Monaz. & veio discordante & metamorfismo & $1,843 \mathrm{a} 0,462$ & Schrank \& Machado $(1996 a, b)$ \\
\hline Carrapato & 23 Zircoses detríticos & U-Pb Zircazo & metagrauvaca Carrapato & Sedimentaçá & $3,539+-34$ a $2,996+-38$ & Schrank \& Machado $(1996 a, b)$ \\
\hline Carrapato & 4 Zircöes euédricos & U-Pb Zircão & metagrauvaca Carrapato & sed. e metam. & 2,900 e 3,232 (disc) e 3,198 (ca) & Schrank \& Machado (1996a, b) \\
\hline Carrapato & 3 Monazitas & U-Pb Monaz. & metagrauvaca Carrapato & metamorfismo & $2,850-2,879$ (dis) e 2,921 (ca.) & Schrank \& Machado $(1996 a, b)$ \\
\hline Cujabá & 2 Monazites & U-Pb Monaz. & metagrauvaca Cuiabá & metamorfismo & $2,854-2,857$ & Schrank \& Machado (1996a, b) \\
\hline Maquiné & 5 Zircóes & U-Pb Zircảo & Quartzito-Maquiné & Detritico & $3,261-2,877(\mathrm{ca})$ e $3,006-2,913(\mathrm{ds})$ & Schrank \& Machado (1996a, b) \\
\hline Maquiné & Monazita & U-Pb Monaz. & Quartzito-Maquiné & metamorismo & $2,020-1,989$ & Schrank \& Machado $(1996 a, b)$ \\
\hline Nova Lima & Zirctólímpido prismático & U-Pb Zircấo & metassed. Intrabasaltos & metamorfismo & 1,806 e sobrecresc. 0,625 & Schrank \& Machado (1996a, b) \\
\hline Săo Bento & Sulfetos (Asp, Py) & $\mathrm{Pb}-\mathrm{Pb}$ (Sulf.) & minério sulfetado & Deposiça & 2.72 & DeWit et al. (1994 e 2004) \\
\hline Sảo Bento & BIF(qzo+magnet.+siderita) & $\mathrm{Pb}-\mathrm{Pb}(\mathrm{rt})$ & BIF (qzo+magnet.+siderita) & metamorismo & 2.1 & DeWit et al. (1994 e 2004$)$ \\
\hline
\end{tabular}

Abreu, G.C. 
Dois métodos principais foram utilizados nas tentativas mais recentes de obter as idades de formação das mineralizações auríferas: $\mathrm{Pb}-\mathrm{Pb}$ e U-Pb.

Na mina Morro Velho Thorpe et al. (1984) datando galenas de veios discordantes e/ou remobilizados da mineralização pelo método $\mathrm{Pb}-\mathrm{Pb}$, identificaram até 4 faixas de idades precambrianas bastante distintas, de $3,0-2,7 ; 2,45-2,41 ; 2,175-2,100$ e 0,6 Ga, que interpretaram como da época metalogenética e de 3 eventos de remobilizações posteriores.

De Wit et al. $(1994,2004)$, também com o método $\mathrm{Pb}-\mathrm{Pb}$, porém em rocha total (minérios de ouro), obtiveram idades de 2,82 e 2,8 Ga na mina Morro Velho e 2,72 e 2,1 na mina São Bento, interpretado-as, respectivamente, como idades da metalogênese (para Morro Velho) e da metalogênese e de um evento posterior de metamorfismo (para São Bento). Estes autores salientaram ainda a possibilidade de mineralização singenética para a mina São Bento, com a deposição dos sulfetos penecontemporânea às formações ferriferas hospedeiras do tipo algoma; já no caso da mina Morro Velho, atribuiram à mineralização aurífera uma origem epigenética.

Schrank e Machado (1996a,b) dataram um elevado número de cristais individuais de zircões e monazitas pelo método $\mathrm{U}-\mathrm{Pb}$, e identificaram diversas faixas de idades compreendidas no intervalo geral de 3,54 a 0,62 Ga, com máximos no Arqueano (de 3,2 a $2,8 \mathrm{Ga}$ ) e no Paleoproterozóico médio a superior (de 2,3 a 1,8 Ga), além de uma idade neoproterózoica $(0,625 \mathrm{Ga})$. O mérito geocronológico dos trabalhos de Schrank e Machado (1996a,b), porém, é limitado por várias incertezas e imprecisões geológicas, mineralógicas e petrográficas. Estes autores reinterpretaram as rochas metassedimenares químicas e metavulcanoclásticas arqueanas do Gr. Nova Lima no distrito do local-tipo (de Nova Lima) como do Grupo Sabará (Supergrupo Minas) paleoproterozóicas, apenas com base nos resultados de suas datações. Também mencionaram a datação de "metagrauvacas Carrapato" da mina São Bento sem qualquer descrição petrográfica mais pormenorizada, sendo, de fato, as rochas amplamente predominantes da assim informalmente denominada "formação Carrapato" na região da mina, rochas finas, quartzo-albita-sericita-clorita xistos grafitosos. Por fim, também não forneceram dados tipológicos mais completos dos zircões e monazitas datados, que seriam imprescindiveis para sustentar as interpretações dadas às respectivas idades.

Independentemente das divergências interpretativas entre os diferentes autores, é notável, como mesmo os resultados geocronológicos mais recentes, na realidade, apenas refletem e consubstanciam os principais eventos tectono-termais regionais que afetaram total ou parcialmente todos os litotipos do Supergrupo Rio das Velhas, e suas mineralizações de Au e que, de fato, pouco avançaram em relação às 
datações clássicas e respectivas interpretações. Já Herz (1970), completando e integrando os dados geocronológicos pioneiros $\mathrm{K}$-Ar e $\mathrm{Rb}-\mathrm{Sr}$ em minerais e rochas totais, claramente definiu as idades da orogênese arqueana da Série Rio das Velhas na faixa de 2,9-2,7 Ga, da orogênese da Serie Minas de 2,2-1,8 Ga e do evento tectono-termal Brasiliano de 0,6 0,45 Ga.

Assim, a despeito da aparente coerência interpretativa dos trabalhos de De Wit et al. $(1994,2004)$, reitera-se aqui a possibilidade das mineralizações de ouro das minas Morro Velho e São Bento serem ainda mais antigas que as idades obtidas de respectivamente 2,82 e $2,72 \mathrm{Ga}$. O ponto principal é que estas idades $\mathrm{Pb}-\mathrm{Pb}$, coincidem perfeitamente com o evento tectono-termal da orogênese Rio das Velhas; e que este evento, certamente, também afetou e reequilibrou isotopicamente, parcial a totalmente, quaisquer eventuais mineralizações de Au preexistentes, sejam singenéticas sedimentares-exalativas ou epigenéticas.

Para a evolução via de regra policíclica e poligenética das mineralizações de ouro de greenstone belts arqueanos, abordagens como de Rettinger (1998, Cap. III, ff.) no estudo de rochas metamórficas do Supergrupo Rio das Velhas poderão ser futuramente de grande interesse. As datações químicas ( $\mathrm{U}-\mathrm{Th}-\mathrm{Pb}$ ) via microssonda eletrônica, de diferentes gerações de monazitas no contexto paragenético e textural metamórfico de minérios de ouro e suas rochas hospedeiras e encaixantes, aliadas à caracterização micro-química quantitativa (completa) das monazitas datadas (para fins de análises de procedência) e aliadas, ainda, com estudos geotermobarométricos das paragêneses metamórficas associadas (de silicatos, carbonatos e sulfetos) permitem reconstruir as trajetórias P-T-t de um determinado depósito, fornecendo ainda meios para verificação e controle do significado de eventuais datações baseadas em sistemática isotópica.

\section{III.3.2.6. Geotermômetros}

$\mathrm{Na}$ tabelas 05-07 são mostrados os métodos e resultados dos diversos estudos geotermométricos já efetuados nas mineralizações de Au do Supergrupo Rio das Velhas, que sempre evidenciam temperaturas semelhantes àquelas do metamorfismo regional principal atuante nessas mineralizações.

Autores como Lobato et al. (1998a,b), Vieira (1988, 1991), Godoy (1994), Martins Pereira (1995) e Toledo et al. (1998), entre muitos outros, interpretaram essas temperaturas como aquelas da formação das mineralizações, que consideraram epigenéticas, pós-pico metamórfico, reforçando suas hipóteses com dados estruturais. 
No entanto, outros autores, como Ladeira $(1980,1988)$, Schorscher et al. (1986, 1991), Abreu (1995), De Wit et al. (1994, 2004) e Valladares (2004), afirmaram reafirmam em seus trabalhos, as assinaturas singenéticas, vulcano-exalativas, dessas mineralizações, considerando as feições epigenéticas como de recristalizações metamórficas e remobilizações locais, claramente posteriores a formação dos depósitos auríferos. Assim, consideram as temperaturas obtidas nos diversos estudos geotermométricos como de reequilibrações metamórficas locais e regionais, de eventos posteriores a formação das mineralizações. Na figura 21 , pode-se observar o geotermômetro de Arsenopirita aplicado a mina do Pari e a outras minas de Au do Quadrilátero Ferrífero, em comparação com alguns exemplos mundiais de mineralizações auríferas arqueanas em greenstone belts.

\section{III.2.3. Conclusões Preliminares Sobre os Aspectos Metalogenéticos Gerais}

Fato relevante, verificado em grande parte dos trabalhos consultados, é a falta de localização precisa das amostras dos veios e dos minérios dos quais foram obtidos dados de inclusões fluidas, isótopos, geotermômetros e outros. Afinal, o que se pretende é avaliar as possiveis e variadas fases que possam ter remobilizado ou transformado a mineralização aurifera. Nisso, a caracterização precisa dos locais, tipos de estruturas, as gerações de veios, seus teores metálicos, tornam-se informações vitais, para que se possam entender os processos da evolução petrogenética e metalogenética da mineralização e suas encaixantes. Assim, listaram-se as principais considerações já conclusivas, extraídas da literatura e confirmadas nessa pesquisa, sobre a metalogenia de Au do QF.

- As mineralizações auríferas do Supergrupo Rio das Velhas dividem-se em dois tipos principais, segundo a rocha hospedeira: a) hospedadas em metassedimentos químicos, e b) em veios de quartzo.

- Existem 2 gerações principais, texturais e composicionais de ligas naturais de AuAg distintas, coexistindo nas principais mineralizações de $\mathrm{Au}$ em metassedimentos químicos, sendo de Au incluso em sulfetos e de Au livre, intercrescido com os minerais do minério e da ganga. Nos minérios da mina do Pari, Schorscher et al. (1991) e Abreu (1995) consideraram o Au da primeira geração como sinsedimentar e a parte principal do Au da segunda geração, como remobilizado metamórfico. 
- Geotermômetros sempre apresentam temperaturas compatíveis àquelas da fácies mais alta do principal ou do ultimo evento de metamorfismo da região.

- Inclusões fluidas também refletem, em sua maioria absoluta, muito mais às condições metamórficas das rochas locais, do que retratarem fielmente o fluido original mineralizante. A suposição neste trabalho de pesquisa é que as assinaturas geoquímicas das inclusões fluidas são o resultado de misturas de fluidos por processos superimpostos, originais sedimentares, seguidos por diagenéticos, e finalmente, modificados por um ou mais eventos tectono-metamórficos, estes últimos remobilizantes locais e posteriores à mineralização.

- Os dados de isótopos estáveis são ainda poucos e apenas parcialmente significativos e/ou compreendidos, o que torna sua discussão difícil. Também ainda, pouco ou nada se sabe sobre o comportamento exato desses isótopos em mineralizações arqueanas de $\mathrm{Au}$, quando em áreas afetadas por múltiplos processos superimpostos, desde sedimentares a diagenéticos, magmáticos e pósmagmáticos, metamórficos e deformacionais.

- A geocronologia apresenta dados claramente referentes aos principais eventos tectono-metamórficos regionais, arqueanos até neoproterozóicos/eopaleozóicos, que atuaram no Quadrilátero Ferrífero e que assim se registraram em seus litotipos.

- A localização exata e a descrição pormenorizada das amostras coletadas para estudos com métodos mais refinados, a sua caracterização petrográfica e geoquímica detalhada, dentro de seu contexto estratigráfico e litoestrutural na mineralização ou nas encaixantes, tornam-se fundamentais no entendimento da metalogênese. Muitas vezes, em exemplos da literatura disponivel, não se tem os detalhes da mineralogia, petrografia e/ou geoquímica global das amostras. Não se sabe exatamente quais veios, minérios e/ou encaixantes foram investigados com métodos citados, principalmente, nos estudos de inclusões fluidas e isotópicos. 


\section{Capitulo IV: GEOLOGIA LOCAL E PETROGRAFIA}

A geologia local já foi descrita e comentada no Capítulo III desta tese. Portanto, neste capítulo enfocaram-se apenas aspectos complementares e principalmente petrográficos das unidades descritas e mapeadas na região da mina do Pari. Muitas das amostras aqui apresentadas foram coletadas em subsolo ou de testemunhos de sondagens cedidos pela UNAMGEN Min. e Met. S.A., hoje Eldorado Gold Co., proprietária da mina São Bento e que mantém diversos alvarás de pesquisa na região de Santa Bárbara e Barão de Cocais, MG.

\section{IV.1. Complexo Gnáissico-Migmatítico}

\section{IV.1.1. Caracteristicas Gerais}

As rochas do Complexo Gnáissico-Migmatítico ou Complexo TTG (Tonalito, Trondhjemito, Granodiorítico) ocupam as áreas a leste e a oeste das rochas supracrustais do Supergrupo Rio das Velhas, representando cerca de $65 \%$ da superfície da área mapeada (Figuras 1, 2, 3). Em seção transversal W-E a estruturação geológica, confirmada por sondagens, mostra que tais rochas ocorrem com contatos tectônicos tanto sobrepostas quanto sotopostas à seqüência supracrustal arqueana.

Em superfície são escassos os afloramentos de rochas frescas, entretanto, ocorrem em exposição quase contínua nos cortes da estrada de ferro Vitória-Minas e nas ribanceiras e leito do rio Valéria. Nas áreas do complexo TTG predomina um relevo mais arrasado de morros e vales suaves. O solo caracteriza-se por ser de coloração esbranquiçada, bastante arenoso, e os saprólitos preservam as estruturas originais com feldspatos caolinizados. É comum a presença de venulações de quartzo hialino, branco-Jeitoso e/ou fumê, assim como de mobilizados pegmatóides caracterizados por placas centimétricas de muscovita associada a quartzo e feldspato (caolinizado) grossos (centimétricos).

As rochas frescas desta unidade foram obtidas principalmente de furos de sondagem da porção leste do Complexo Gnáissico-Migmatítico, que cortaram estas litologias antes de atravessar as supracrustais do Supergrupo Rio das Velhas (Figura 06).

Macroscopicamente, as rochas TTG são cinza-claras equi a subequigranulares médias a finas, mais raramente porfiriticas, distinguindo-se os seguintes litotipos principais: gnaisses tonalíticos (Fotografia 22), gnaisses granodioríticos (Fotografia 23), gnaisses graníticos, veios pegmatíticos (Fotografia 24) e venulações quartzosas 
com espessuras até métricas. Ocorrem ainda anfibolitos metabásicos e rochas metaultramáficas (anfibolitos e esteatitos), na forma de intercalações métricas a submétricas, que por suas características petrográficas polimetamórficas não se correlacionam às seqüências supracrustais do Supergrupo Rio das Velhas.

Os gnaisses graníticos são raros e referem-se a porções mais ricas em microclínio dos gnaisses granodioriticos, sobretudo em locais onde se observa intensa catáclase e/ou milonitização. Admite-se que estes litotipos tenham sofrido metassomatismo potássico durante eventos tectono-metamórficos proterozóicos (Mothé $F^{\circ}, 1996$ ).

Em todos os furos de sondagem observou-se que a foliação milonítica se intensifica em direção aos contatos com as supracrustais, assim, como também aumenta a incidência dos litotipos mais ricos em microclínio e de veios de quartzo. A foliação milonitica, de fato, constitui-se numa das principais caracteristicas regionais dos contatos do Complexo TTG gnáissico-migmatítico com o Supergrupo Rio das Velhas, dado o soerguimento arqueano deste complexo em domos, que ainda sofreram reestruturações posteriores por um ou mais eventos tectônicos (e metamórficos) regionais de vergências para oeste.

\section{IV.1.2. Petrografia Microscópica}

\section{IV.1.2.1. Gnaisses Tonalíticos}

Apresentam-se com texturas granoblásticas equi a subequigranulares; sua granulometria média varia de 0,3 a $5 \mathrm{~mm}$, sendo mais raros os tipos e/ou porções porfiroblásticas (Fotografia 22). A mineralogia modal básica compreende plagioclásio (An: $24-28$ = oligoclásio) entre 35 e $45 \%$, quartzo entre 30 e 40\%, microclínio entre 5 e $15 \%$, biotita entre 2 e $5 \%$, muscovita entre 0,5 e $3 \%$, sericita entre 1 e $5 \%$, e minerais opacos entre 0,5 e 1,5\%. Como minerais em traços acessórios e secundários são comuns apatita, epidoto, carbonatos, clorita, e zircão.

Os plagioclásios mostram-se moderadamente zonados, por vezes deformados e/ou fraturados, sendo notável a presença e feição textural do microclínio, que muitas vezes, aparece nas bordas ou em fraturas no interior dos grãos de plagioclásio mostrando relações de substituição entre os feldspatos, indicativas de um evento metassomático potássico, ainda que incipiente que afetou os tonalitos. Sericita e carbonatos também aparecem às vezes em fraturas ou núcleos dos grãos de plagioclásio, porém não são comuns. O quartzo mostra extinção ondulante e normalmente é de granulometria fina (de 0,3 a $0,5 \mathrm{~mm}$ ). As biotitas possuem um 
pleocroísmo verde claro a verde oliva, e raramente são transformadas e/ou associadas com cloritas.

\section{IV.1.2.2. Gnaisses Granodioríticos}

Sua estrutura (Fotografia 23) é semelhante à dos gnaisses tonalíticos, porém ocorrem dois tipos texturais principais, um granoblástico subequigranular com marcante orientação dos minerais, por vezes até bandado; e outro porfiroblástico com apenas leve orientação de seus minerais.

Para ambos a composição modal estimada mostra plagioclásio (An 22-27 = oligoclásio) entre 10 e $30 \%$, microclínio entre 15 e $25 \%$, quartzo entre $20-30 \%$, biotita entre 5 e $10 \%$, epídoto entre 0,5 e $2 \%$, sendo os opacos raros. Entre os minerais em traços ocorrem titanita, apatita, carbonato e sericita.

Os cristais de plagioclásio estão mais intensamente substituídos por microclínio que nos gnaisses tonalíticos; assim muitos, senão todos os porfiroblastos de microclínio possuem pequenos restos de plagioclásio como inclusões.

\section{IV.1.2.3. Gnaisses Graníticos}

Possuem estrutura bandada fortemente orientada, com texturas miloníticas marcantes, e quase sempre, contém intercalações de veios e niveis pegmatíticos de granulometria grossa, ricos em microclínio, quartzo e muscovita.

Nos gnaisses graníticos predomina o microclínio (30 a 35\%) sobre o plagioclásio (5 a $15 \%$ ), quartzo recristalizado (30 a $45 \%$ ), e biotita de cor verde a verde oliva (2 a $5 \%)$ que é o principal mineral máfico. Minerais em traços acessórios e secundários são carbonatos, epídoto, zircão, titanita, apatita e allanita.

\section{IV.1.2.4. Enclaves Metamáficos}

São rochas foliadas, grano-lepidobláticas, e cuja composição mineralógica apresenta biotita de cor castanha avermelhada (20-40\%), quartzo (10-20\%), plagioclásio albítico (5-15\%), hornblenda (2-5\%), carbonatos $(5-15 \%)$ e epídoto $(5-$ $15 \%)$. Mostram ainda como minerais traços titanita, apatita, opacos e allanita.

A classificação dos protolitos é bastante insegura visto as intensas transformações mineralógico-texturais metamórficas. Provavelmente tratava-se de protolitos de rochas metabásicas alterados em processos metassomáticos com fluidos metamórfico-hidrotermais. 


\section{IV.1.2.5. Enclaves Metaultramáficos}

São rochas heterogêneas, com porções máfico-ultramáficas, de cores verdes escuras foliadas, principalmente nas porções mais ricas em biotita (e epídoto) e mobilizados félsicos em veios de cores claras. A textura mostra-se granolepidoblástica e equigranular nos níveis máfico-ultramáficos e inequigranular porfiroblástica nas porções félsicas ricas em quartzo e microclínio.

A mineralogia essencial das porções máfico-ultramáficas é constituída por talco, Mgclorita, epídoto, biotita, plagioclásio; ocorrem ainda microvenulações de quartzo e também porções com porfiroblastos de microclínio.

\section{IV.1.2.6. Veios Pegmatíticos}

Apresentam textura muito grossa (Fotografia 24), sendo que o microclínio (60-70\%) chega a atingir mais de $5 \mathrm{~cm}$ de dimensão maior. Em cortes polidos observam-se pertitas com lamelas de exsolução de albita perfazendo de 2 a $5 \%$ da pertita, com até $1 \mathrm{~mm}$ de espessura. Mostram também quartzo (10-20\%), muscovita $(2-5 \%)$, e uma segunda geração textural de exsoluções micropertíticas nos microclínios. Os minerais opacos são raros.

\section{IV.2. Supergrupo Rio das Velhas}

$\mathrm{Na}$ área o Supergrupo Rio das Velhas é representado por restos do Grupo Quebra Osso e uma porção predominantemente metamáfica do Grupo Nova Lima (Figuras 1 e 2).

\section{IV.2.1. Grupo Quebra Osso}

\section{IV.2.1.1. Características Gerais}

O Grupo Quebra Osso é a unidade basal da seqüência greenstone belt na área, estendendo-se em continuidade física até o perfil da seção tipo do córrego Quebra Osso. Está em contato direto, tectônico, sobreposto aos gnaisses do Complexo Gnáissico-Migmatítico e, em contato estratigráfico normal, gradacional em 


\section{Foto 38:}

Amostra de rocha metaultramáfica do Grupo Quebra Osso com típica estrutura de "pillow lavas" pequenas, exibindo bordas com zonas de palagonitização milimétricas a centimétricas, além de material piroclástico "inter-pillow".

\section{Foto 39:}

Amostra T-39, anfibolito fino com bandas quartzo-carbonáticas cisalhadas.

\section{Foto 41:}

Amostra T-42, de anfibolito fino com bandas quartzo-carbonáticas cisalhadas.

\section{Foto 43:}

Amostra T-60, de anfibolito biotítico fino (Unidade B) com bandas de hornblenda, crenulado.
Amostra $\mathrm{T}-58$, anfibolito fino com bandas quartzo-carbonáticas cisalhadas.

\section{Foto 44:}

Amostra T-66, de anfibolito grosso.

\section{Foto 45:}

Amostra G-01, de mão, do nível 10 da mina do Pari, de anfibolito grosso com porfiroblástos milimétricos de granada. 


\section{Prancha 05}
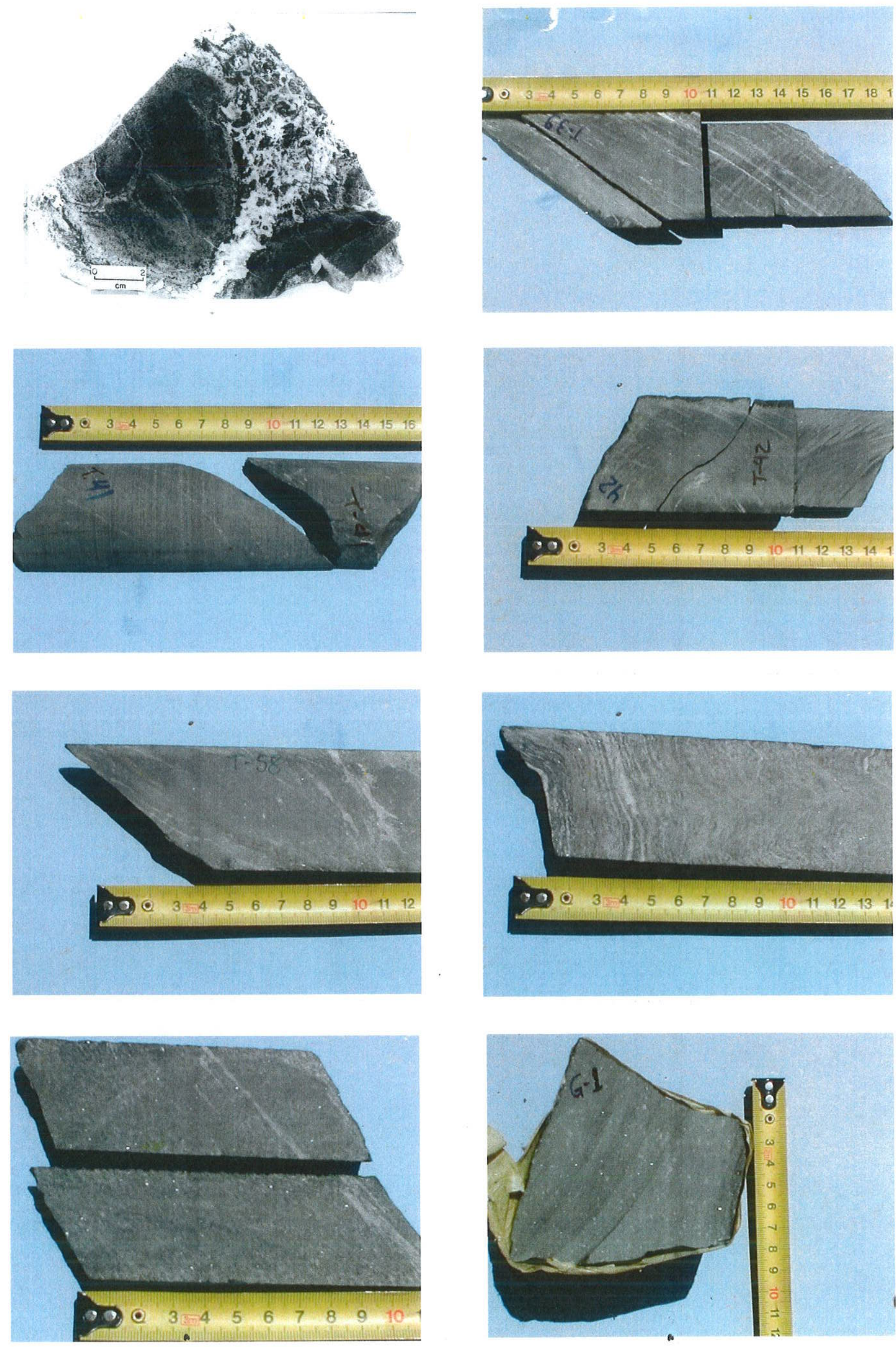
pequeno intervalo, com o Grupo Nova Lima no topo, mostrando o Supergrupo Rio das Velhas no local, em posição normal, diferentemente do que foi descrito da Quadrícula Santa Bárbara (1:25.000), a oeste (Schorscher, 1988, 1992; Luchesi, 1991).

A espessura do Grupo Quebra Osso, na área do morro do Pari, verificada através de sondagens varia entre 6 e $12 \mathrm{~m}$.

As rochas metaultramáficas são representadas por anfibólio-clorita xistos (Fotografias 54,56,57), por vezes com niveis de talco-clorita xistos, intensamente deformados (cisalhados). Niveis extremamente ricos em biotita (flogopita porfiroblástica) grossa são comuns principalmente próximos aos contatos tectônicos com o Complexo Gnáissico-Migmatítico e evidenciam um processo sinmetamórfico de metassomatismo potássico de biotitização/flogopitização das rochas metaultramáficas.

Uma das sondagens interceptou um horizonte centimétrico de sulfetos maciços rico em pirrotita e calcopirita, apresentando teores anômalos de $\mathrm{Ni}$ e $\mathrm{Au}$, respectivamente de 2510 e $0,10 \mathrm{ppm}$, atestando assim o potencial metalogenético deste grupo de rochas, para mineralizações de sulfetos magmáticos (Fotografia 54).

\section{IV.2.1.2. Petrografia}

A composição petrográfica principal é de anfibólio-clorita xistos, bandados com niveis ricos em clorita e outros ricos em anfibólio. As cloritas são magnesianas e se dispõem em bandas centimétricas a milimétricas. Os anfibólios (hornblenda e cummingtonita) dispõem-se também em bandas centimétricas, ora com textura nematoblástica, ora discordantes a foliação principal como porfiroblastos tardi a póscinemáticos.

Não foram observados restos de estruturas ígneas primárias preservadas. Porém é marcante o crescimento de porfiroblastos, discordantes da foliação principal, de biotitas, de cor verde oliva, sobretudo na zona de contato das metaultramáficas com os gnaisses, bem como na porção do topo do contato estratigráfico transicional com - Grupo Nova Lima. Junto às porções mais biotitizadas da rocha, ou seja, principalmente nas proximidades do contato inferior são freqüentes venulações centimétricas de quartzo. A biotitização e a venulitização de quartzo indicam a composição dos fluidos tectono-metamórficos hidrotermais metassomatizantes como alcalinos-potássicos, portadores de $\mathrm{SiO}_{2}$ e também de $\mathrm{Al}_{2} \mathrm{O}_{3}$.

\section{IV.2.2. Grupo Nova Lima}


No morro do Pari, através dos testemunhos de sondagem, o Grupo Nova Lima foi subdividido em 4 unidades litoestratigráficas informais, designadas, da base para 0 topo, de A, B, C e D (figuras 10 e 11):

\section{IV.2.2.1. Unidade A}

\section{IV.2.2.1.1. Características Gerais}

A unidade $A$ encontra-se na base da seqüência do Grupo Nova Lima, no morro do Pari, sobreposta ao Grupo Quebra Osso com contato estratigráfico normal, eventualmente tectonizado e milonítico em pequeno intervalo. $O$ contato $\mathrm{com}$ a unidade $B$, no topo, também é normal. A unidade $A$ è descontínua, podendo faltar localmente; nesses casos a unidade B jaz diretamente sobre o Gr. Quebra Osso, com contatos estratigráficos normais.

$\mathrm{Na}$ unidade A predominam rochas foliadas, de granulação fina (Fotografia 55, Prancha 07), cores cinza médias, sem aparente variação composicional sugestiva de acamamento, porém contendo finas intercalações de clorita xistos ( 0 a $5 \mathrm{~m})$.

A espessura dessa unidade varia entre 0 e $10 \mathrm{~m}$.

\section{IV.2.2.1.2. Petrografia}

Ao microscópio o litotipo principal da unidade A do Grupo Nova Lima é representado por quartzo-hornblenda-biotita-plagioclásio xistos de estrutura foliada e textura grano-lepidoblástica fina, com granulometria média sempre inferior a $1 \mathrm{~mm}$. Os grãos de quartzo são recristalizados poligonais e os plagioclásios em grãos ovalados a arredondados, quase sempre, envoltos de massas foliadas de biotitas, conferem aos xistos aspecto de rochas metassedimentares, no caso de metasubgrauvacas. Por outro lado, há porções mais preservadas em que texturas palimpsésticas sugerem origens de protolitos igneos vulcânicos intermediários, prováveis metadacítos, cortadas e transformadas por cisalhamento. Assim, observa-se que onde o cisalhamento milonítico é mais intenso, aparecem mais as características estruturais e texturais de uma metagrauvaca, enquanto que as porções mais preservadas tendem a caracterizar o protolito ígneo mais provável como uma rocha vulcânica intermediara.

Também ocorrem na unidade A clorita xistos, em finos niveis foliados, intercalados aos quartzo-hornblenda-biotita-plagioclásio xistos. Os clorita xistos possuem textura 
pórfiro-lepidoblástica, sendo os porfiroblastos de clorita magnesiana, hornblenda e mais raramente de biotita. Esses xistos são descontínuos e não aparecem em todos os furos; foram classificados como metatufos e/ou metatufitos máficos.

\section{IV.2.2.2. Unidade B}

\section{IV.2.2.2.1. Características Gerais}

A unidade B (informalmente chamada ainda de formação Pari) constitui-se basicamente de anfibolitos granatiferos com intercalações métricas de BIF tipo Algoma de fácies mistas, com quartzo, magnetita, grunerita, raros sulfetos, carbonatos, em proporções variáveis, às quais se associam finas lentes de xistos grafitosos. Como topo da unidade $B$ aparece o horizonte sulfetado com arsenopirita e pirrotita, portador da mineralização de Au, também denominado de horizonte Pari ou subunidade B1. Este é balizado, na capa e na lapa, por clorita-hornblenda-biotita xistos com venulações quartzosas centimétricas a milimétricas. A espessura da unidade B varia de 150 a 180m (Figuras 10, 11).

\section{IV.2.2.2.2. Petrografia}

Basicamente, encontram-se 5 tipos petrográficos distintos: a) anfibolitos granatíferos; b) formações ferriferas tipo Algoma; c) grafita xistos; d) rochas encaixantes da mineralização, e) minérios do horizonte mineralizado (Horizonte Pari, subunidade B1). Os minérios de ouro e as rochas encaixantes da mineralização serão detalhados em capítulo próprio (cap. IV.3).

\section{a) Anfibolitos Granatíferos}

São rochas de cores verdes escuras a pretas, de estrutura foliada, e textura granonematoblástica. Por vezes, observam-se porções inequigranulares, as hornblendas formando porfiroblastos poiquiloblásticos, de granulometria grossa.

A composição modal geral compreende hornblenda verde e anfibólio incolor (cummingtonita), que somam entre $50-60 \%$, com cristais de 2 a $3 \mathrm{~mm}$ de comprimento. Ainda tem-se quartzo (10-15\%); plagioclásio (10-15\%); granada almandina (3-5\%) euhédrica; biotita castanha avermelhada (2-5\%); e opacos $(2-3 \%)$. As granadas foram identificadas por difração de raios $X$, após separação de 


\section{Foto 46:}

Amostra GN-01, de biotita-hornblenda xisto fino do Grupo Nova Lima, encaixante da capa (hangwall) do minério no nivel de entrada (N00 ), da mina do Pari.

\section{Foto 48:}

Amostra GN-19, de homblenda-biotita xisto fino do Grupo Nova Lima, encaixante da lapa (footwall) do minério no nivel de entrada (N00) , da mina do Pari.

\section{Foto 50:}

Amostra GN-23, de hornblenda-biotita xisto fino do Grupo Nova Lima, encaixante da lapa (footwall) do minério no nivel de entrada $(\mathrm{N}$ 00) da mina do Pari.

\section{Foto 52 :}

Amostra 07B, hornblenda-biotita xisto, grosso, bastante foliado, do Grupo Nova Lima, da encaixante da lapa (footwall) do minério no nivel $10(\mathrm{~N} 10)$, da mina do Pari.

\section{Foto 47:}

Amostra GN-08, de hornblenda-biotita xisto fino do Grupo Nova Lima, encaixante da lapa (footwall) do minério no nível de entrada (N00 ), da mina do Pari.

\section{Foto 49:}

Amostra GN-22, de hornblenda-biotita xisto fino do Grupo Nova Lima, encaixante da lapa (footwall) do minério no nivel de entrada (N00), da mina do Pari.

\section{Foto 51:}

Amostra GN-26, anfibolito grosso, pouco foliado, do Grupo Nova Lima, já pouco distante da encaixante da lapa (footwall) do minério no nivel de entrada $(\mathrm{N}-00)$, da mina do Pari.

\section{Foto 53}

Amostra 14B, granada-hornblenda-biotita xisto, grosso, bastante foliado, do Grupo Nova Lima, da encaixante da capa (hangwall) do minério no nivel 10 (N10), da mina do Pari. 


\section{Prancha 06}
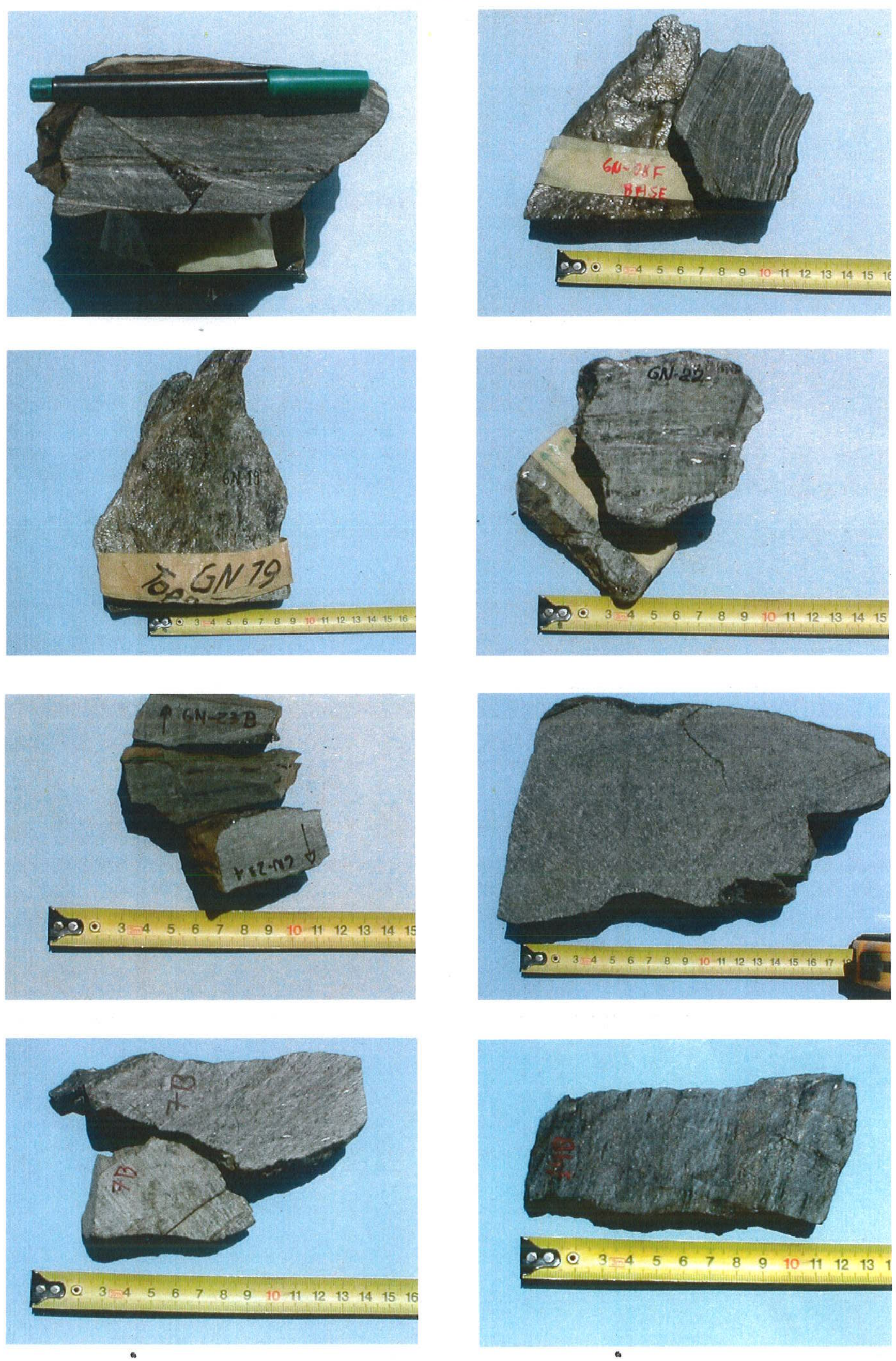
minerais em grãos sob lupa binocular, bem como analisadas por microssonda eletrônica. Os minerais em traços, acessórios e secundários, são apatita, epídoto e carbonatos.

\section{b) Formacões Ferriferas Bandadas (BIF) tipo Algoma}

São rochas de estrutura bandada, com bandas milimétricas $a_{1}$ mais raramente, centimétricas (Fotografia 60), alternando-se bandas de textura nematoblástica, essencialmente de grunerita e fluotaramita e bandas granoblásticas compostas de granada almandina, magnetita, pirita, pirrotita, quartzo e carbonatos. Trata-se, portanto de BIF mistas incluindo fácies silicato, óxido com magnetita, sulfeto e carbonato. A composição mineralógica modal estimada (em \% de volume) é de: grunerita (50-70\%), fluotaramita (8-12\%), quartzo (2-5\%), opacos (magnetita, pirita e pirrotita) $(2-5 \%)$, granada (1-3\%), carbonato (1-3\%) e biotita (traços).

Os anfibólios foram identificados opticamente. A fluotaramita tem pleocroísmo verde azulado a verde amarelado, $2 \mathrm{~V} \sim 20^{\circ}$, biaxial $(\mathcal{*})$, ângulo de extinção $\left(Z^{\wedge} \mathrm{C}\right)$ entre $10 \mathrm{e}$ $14^{\circ}$ e birrefringência máxima observada de 0,012 . A grunerita tem pleocroísmo fraco, incolor a amarelo, $2 \mathrm{~V}$ alto $\left(>60^{\circ}\right)$, ângulo de extinção $\left(Z^{\wedge} \mathrm{C}\right)$ entre 10 e $15^{\circ}$, birrefringência entre 0,040 e 0,045 e apresenta-se tipicamente com geminação polissintética.

\section{c) Grafita Xistos}

Apresentam cores cinza claras a escuras, estrutura bandada e finamente foliada, por vezes dobrada, textura granoblástica a grano-porfiroblástica, com porções pórfirom lepidoblásticas.

Microscopicamente apresentam a composição modal média estimada (em \% de volume): quartzo $(45 \%)$, granada $(25 \%)$, biotita + grafita + clorita $(25 \%)$, minerais opacos $(5 \%)$. Como traços aparecem apatita e carbonatos.

As bandas ricas em quartzo se intercalam com niveis micáceos com porfiroblastos de granada almandina. Nas massas micáceas se misturam biotita e Mg-clorita, além da grafita fina dispersa.

As granadas são milimétricas, poiquiloblásticas com inclusões de quartzo, biotita, grafita e sulfetos. Suas formas externas pós-tectônicas são euhédricas, e as porções internas poiquiliticas, por vezes helicíticas reliquiares de estágios metamórficos pretéritos, inclusive sintectônicos. 


\section{Prancha 07}

\section{Foto 54:}

Amostra GP-01, com núvel centimétrico de sulfeto maciço (pirrotita e calcopirita) intercalado nas rochas metaultramáficas do Grupo Quebra Osso, na área da mina do Pari.

\section{Foto 56:}

Amostra GP-07, metaultramáfica com níveis centimétricos (cor escura) de flogopita, Grupo Quebra Osso, na área da mina do Pari.

\section{Foto 58:}

Amostra GP-10, anfibolito grosso, pouco foliado, recortado por vênulas quartzo carbonáticas intensa e irregular, na posição da encaixante da capa (HW), Grupo Nova Lima, (Furo BR-57).

\section{Foto 55:}

Amostra GP-03, quartzo-hornblenda-biotitaplagioclásio xistos fino, da base do do Grupo Nova Lima (Unidade A), Supergrupo Rio das Velhas na área da mina do Pari.

\section{Foto 57:}

Amostra GP-08, nível rico em flogopita, nas metaultramáficas do Grupo Quebra Osso, área da mina do Pari.

\section{Foto 59:}

Amostra GP-11, anfibolito foliado grosso, com vênulas de quartzo e carbonato estiradas segundo $\mathrm{Sn}$, da encaixante de capa (HW) do minério no nível de entrada, Grupo Nova Lima, (Furo BR-57).

\section{Foto 60:}

Amostra GP-15, BIF tipo algoma, bastante foliado, Unidade B, do Grupo Nova Lima, (Furo BR-57). Evidencia dobras da foliação $\mathrm{Sn}+1$. 


\section{Prancha 07}
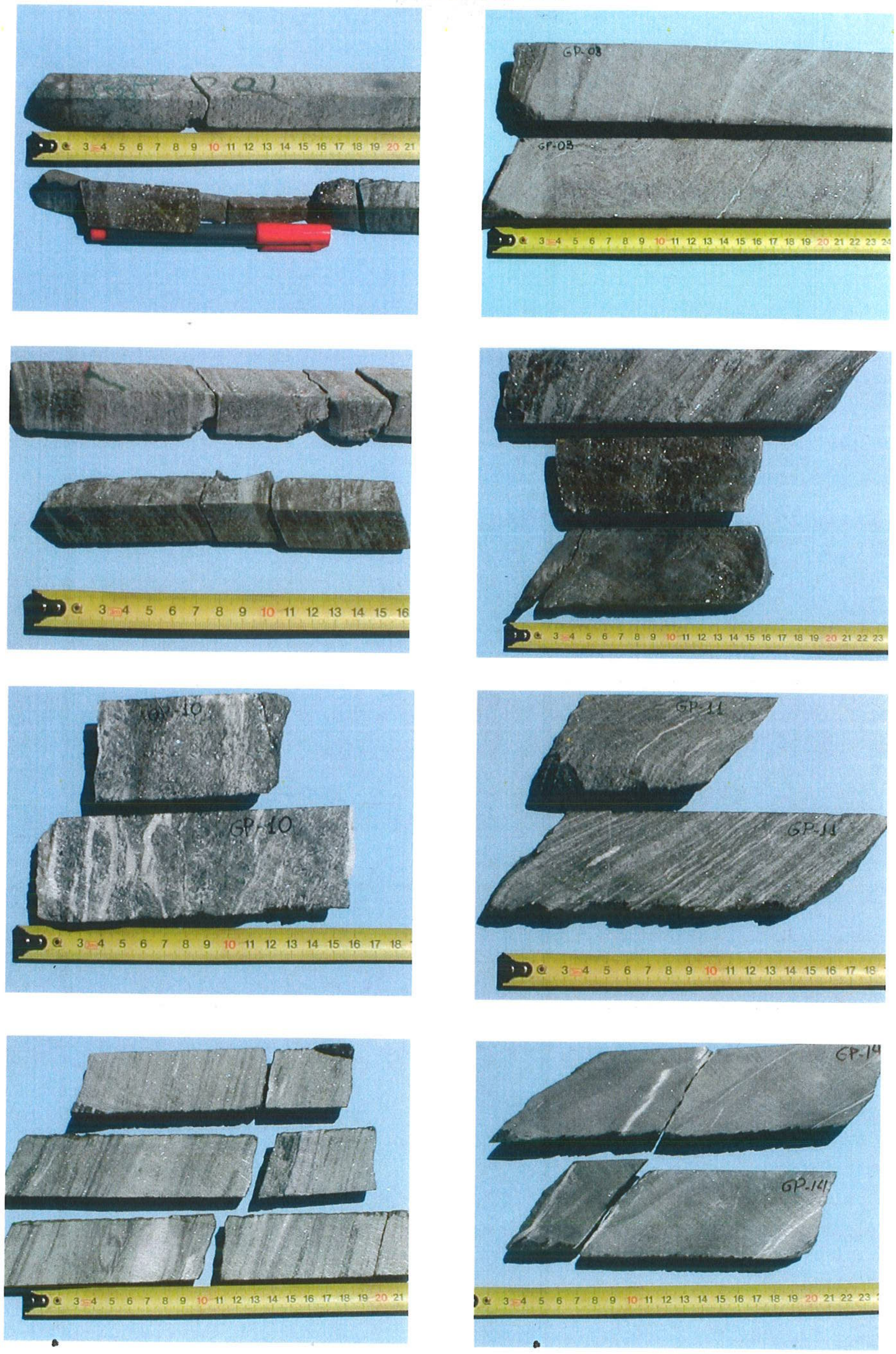


\section{IV.2.2.3. Unidade C}

\section{IV.2.2.3.1. Características Gerais}

A unidade $\mathrm{C}$ é constituída predominantemente por anfibolitos finos, sem granadas $\mathrm{e}$ isentos de intercalações de formações ferriferas bandadas (BIF). A espessura total da unidade $C$ é de no mínimo $150 \mathrm{~m}$.

Em meio a esta unidade ocorre um veio de quartzo, deformado e metamórfico/ recristalizado, mineralizado com Au. Este, porém, apresenta-se descontínuo, irregular e com dimensões reduzidas (de espessura decimétrica e extensão métrica), também denominado informalmente de Horizonte Florália.

\section{IV.2.2.3.2. Petrografia}

Os anfibolitos finos são rochas de cores verdes escuras a pretas, tem estrutura finamente foliada com raros niveis bandados e textura grano-nematoblástica; raramente ocorrem tipos porfiroblásticos com hornblendas de até $1 \mathrm{~mm}$.
A composição mineralógica mostra hornblenda (60-80\%), quartzo (05-10\%), plagioclásio $(05-15 \%)$ e minerais menores como opacos, biotita, titanita, epídoto e carbonatos.
Próximo ao veio de quartzo mineralizado aumenta a quantidade de biotita e carbonatos, que juntos atingem até $10 \%$ modais.

\section{IV.2.2.4. Unidade D}

\section{IV.2.2.4.1. Características Gerais}

A unidade $D$ forma o topo da seqüência do Grupo Nova Lima na área, e mostra-se bastante heterogênea, irregular e descontinua por motivos tectônicos.

Constitui-se de anfibolitos finos, xistos máficos e metapelíticos miloníticos, sendo comuns intercalações de lentes carbonáticas, niveis de anfibolitos granatíferos, e de lentes decimétricas a métricas de formações ferríferas tipo Algoma. A espessura máxima encontrada da unidade $D$ é de $20 \mathrm{~m}$. 
Admite-se que a unidade $D$ esteja truncada por falha de empurrão de $E$ para $W$, pela colocação do Complexo Gnáissico-Migmatítico sobre o Supergrupo Rio das Velhas (Figura 07).

\section{IV.2.2.4.2. Petrografia}

Os anfibolitos finos da unidade $D$ se assemelham integralmente, aos seus pares da unidade $C$, e os anfibolitos granatíferos $e$ as formações ferriferas tipo Algoma aos litotipos análogos da unidade B. Portanto, refere-se 0 leitor as descrições petrográficas dos respectivos itens (IV.2.2.2.2 e IV.2.2.3.2).

As lentes carbonáticas apresentam estrutura foliada dobrada e textura granoblástica. Constituem-se de quartzo e carbonatos de granulometria fina $(0,2$ a $0,5 \mathrm{~mm})$, em proporções aproximadas de 1:1. Como minerais em traços ocorrem biotita e opacos. Trata-se de lentes de metacherts carbonáticos.

\section{IV.3. MINERALIZAÇÃO E ENCAIXANTES}

\section{IV.3.1. Características Gerais}

Para a caracterização da mineralização aurifera e suas rochas encaixantes foram realizados estudos em duas seções de amostragem contínuas, representando perfis da mineralização, incluindo tanto os minérios como as rochas encaixantes imediatas de lapa e capa, assim como anfibolitos associados da seqüência metavulcanosedimentar. Uma dessas amostragens foi realizada no nível 10 da mina, na porção central, rica do corpo de minério (Figura 05). A outra, no nível de entrada da mina, na extremidade norte do corpo (Figura 04; Fotografias 3-5).

A mineralização da mina do Pari (horizonte Pari) compreende dois horizontes mineralizados. O primeiro, na base, é descontínuo, de ocorrência restrita, espessura submétrica e foi informalmente denominado de horizonte Pari Inferior. O segundo informalmente denominado horizonte Pari Superior, é o nível econômico que foi lavrado nos períodos de atividade da mina, possuindo espessura variável, de 0,50 a 2,5 metros (Figuras 12-14).

A mineralização foi estudada por mapeamento das lavras antigas e sondagens profundas apresentando comportamento de controle litoestratigráfico (stratabound), sendo contínua numa extensão longitudinal-lateral (no strike) de 150 até $200 \mathrm{~m}$ e, no plano do mergulho, por mais de 500 metros. 


\section{Fotomicrografia 01:}

Amostra 12B: Au de granulometria fina $(\phi \sim 10 \mu \mathrm{m})$, la geração, incluso em arsenopirita rica em inclusðes de silicatos. Seção polida do minério da Mina do Pari (microscopia de luz refletida).

\section{Fotomicrografia 02:}

Amostra 13B: Magnetitas poiquiloblásticas $(\phi \sim 2 \mathrm{~mm})$ englobando sulfetos do minério (arsenopirita e pirrotita). Seção polida do minério da Mina do Pari, de BIF da fácies de transição óxido e sulfeto (microscopia de luz refletida).

\section{Fotomicrografia 03:}

Amostra 13B: Magnetita poiquiloblástica com inclusões de $\mathrm{Au}$, grãos amarelos $(\phi \sim 30 \mu \mathrm{m})$ e esfalerita (Cinza escuro). Seçáo polida do minério da Mina do Pari, de BIF fácies mista oxido e sulfeto(microscopia de luz refletida).

\section{Fotomicrografia 05:}

Amostra GN-17: Grãos de Au (amarelo) $(\phi \sim 0,3 \mathrm{~mm})$ e pirrotita (cinza claro), como inclusões em granada (cinza escuro). Observa-se claramente a compressão dos grãos de $\mathrm{Au}$ pelos contomos lobulares do interior da granada. Seção polida do minério da Mina do Pari (microscopia de luz refletida).

\section{Fotomicrografia 04:}

\section{Amostra GN-10: Grão grosso de Au}

livre ( $\phi \sim 0,5 \mathrm{~mm})$, em matriz silicática, com um. grão de arsenopirita associada, no canto superior esquerdo da foto. Seção polida do minério da Mina do Pari (microscopia de luz refletida).

\section{Fotomicrografia 06:}

Amostra SB-B: Grão de Au fino $(\phi \sim 20 \mu \mathrm{m})$, na borda da arsenopirita. Típica feição textural do minério sulfetado da Mina São Bento (Horizonte São Bento). Seção polida do minério da Mina São Bento (foto por microscopia de luz refletida).

\section{Fotomicrografia 08:}

Amostra SB-A: Grão de Au grosso ( $\phi \sim 0,2 \mathrm{~mm}$ ), incluso em pirrotita. Seça polida do minério da Mina São Bento (microscopia de luz refletida).

Amostra SB-B:Dois grãos de Au inclusos em pirita poiquiloblástica. A Pirita (levemente amarela) mostra-se rica em inclusões de silicatos (pretos), pirrotita(cinza-amarelada). Seção polida do minério da Mina São Bento (microscopia de luz refletida). 


\section{Prancha 8}
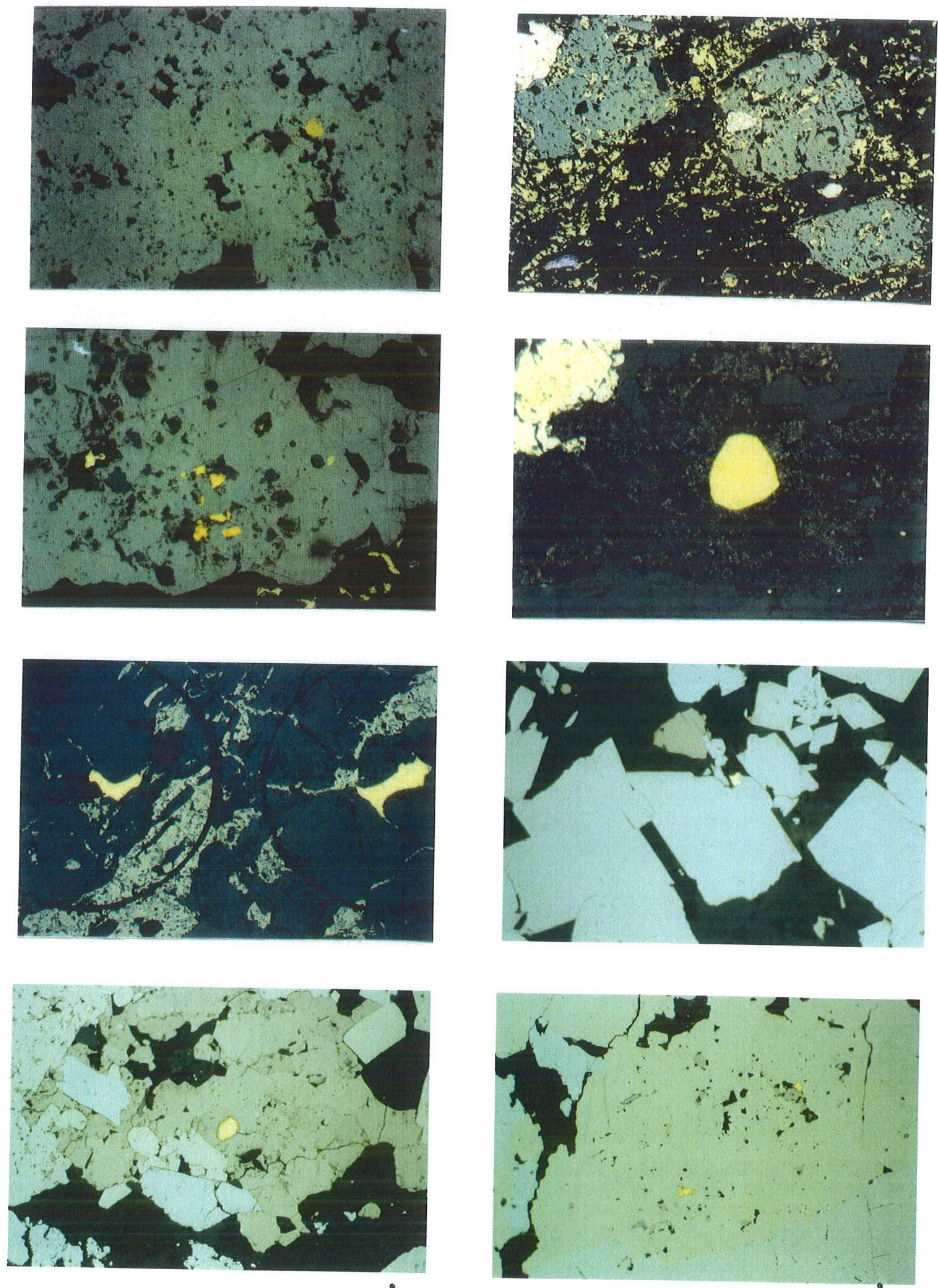
Os dois horizontes mineralizados são petrográfica, mineralógica e geoquimicamente semelhantes, e quando ambos aparecem, estão bastante próximos um do outro (Figuras 10-15). Este trabalho estuda em detalhe o horizonte Pari Superior, devido à inexistência do horizonte Pari Inferior nos locais das amostragens seriadas em perfis contínuos (Figuras 4, 5). Assim, em função das similaridades registradas em locais de observação e amostragens complementares com estudos petrográficos, consideram-se válidas para o horizonte Pari Inferior a grande parte das considerações feitas sobre o horizonte estudado.

As espessuras das rochas encaixantes imediatas da capa e da lapa da mineralização variam de 1 a 8 metros, e também diferem em alguns aspectos mineralógico-petrográficos e, principalmente, geoquímicos (apresentados e discutidos a seguir); no entanto, nos aspectos estruturais há muita semelhança. Trata-se de xistos metamáficos e metapelíticos intensamente deformados, apresentando as foliações $S_{n}$ e $S_{n+1}$ bem desenvolvidas, e muitas vezes estruturas tipo $S$ e $C_{1}$ indicando cisalhamento gerado por esforços diferenciais no sentido direcional geral de $E$ para $W$, do evento deformativo principal.

Ressaltam as grandes diferenças na resposta à deformação cisalhante das rochas xistosas encaixantes imediatas em relação à mineralização, assim como aos anfibolitos hospedeiros, associados à base e ao topo das encaixantes. Isso ocorre em função das diferenças composicionais mineralógico-petrográficas $e$, conseqüentemente, de competência, sendo as rochas encaixantes da capa e lapa da mineralização ricas em minerais micáceos. Os minérios são rochas metassedimentares químicas, BIF tipo Algoma maciços, ricos em sulfetos $e$ silicosos, altamente litificados desde a diagênese e de muito maior competência. Os anfibolitos associados também são bem mais competentes que os xistos encaixantes de lapa e capa. O corpo de minério, as encaixantes imediatas predominantemente xistosas da lapa e da capa e os anfibolitos hospedeiros associados à base e no topo, apresentam as mesmas foliações; apenas a $S_{n-1}$ só aparece nos níveis sílico-carbonático-sulfetados de espessura decimétrica internos à mineralização (Fotomicrografias 13,14; Prancha 09), assim como nos demais niveis de BIF intercalados do Gr. Nova Lima.

\section{IV.3.2. Petrografia}

Neste item serão apresentadas, separadamente, as descrições petrográficas das rochas encaixantes da lapa e da capa da mineralização, assim como dos minérios 
de ouro, ressaltando que estudos dos minerais opacos só foram efetuados para o corpo mineralizado.

\section{IV.3.2.1. Rochas Encaixantes da Lapa da Mineralização}

\section{IV.3.2.1.1. Nível de Entrada (N-00) da Mina do Pari}

Neste nivel ocorrem como rochas principais clorita-biotita-plagiclásio-quartzohornblenda xistos, de textura porfiroblástica com matriz grano-nematoblástica, às vezes contendo ainda raros níveis lepidoblásticos.

A clorita magnesiana, fina, ocorre equitativamente distribuida na matriz finamente foliada, em proporções variáveis, perfazendo de 0 a $20 \%$ modais das rochas, apresentando teores crescentes em direção à zona mineralizada.

A biotita (0-15\%vol.) mostra pleocroísmo castanho avermelhado a castanho esverdeado. Aparece na matriz da rocha, em bandas finas, associada com clorita. A quantidade de biotita também aumenta em direção a zona mineralizada.

O plagioclásio ( $2-5 \%$ vol.), da matriz, de granulometria fina (de $0,1-0,2 \mathrm{~mm}$ ) tende a diminuir em direção à mineralização.

O quartzo (5-25\%vol.) mostra, em geral, recristalização poligonal, por vezes extinção ondulante, sendo o mineral granular mais importante da matriz. Sua ocorrência é ainda comum em microvenulações, algumas vezes, associado com carbonatos. $A$ quantidade total de quartzo também aumenta em direção à zona mineralizada.

A hornblenda (35-85\%vol.) é o mineral predominante; sua abundância diminui em direção ao corpo mineralizado. Comumente, forma porfiroblastos de até $5 \mathrm{~mm}$ de dimensão maior, cristalizados preferencialmente nos planos axiais das crenulações, na foliação $S_{n+1}$. Também aparece na matriz da rocha em cristais prismáticoaciculares finos, nesses casos, orientada, preferencialmente, na foliação principal $S_{n}$. São hornblendas de pleocroismo moderado a forte, com cores verde-claras a verdeoliva, biaxiais negativas, com ângulos $2 \mathrm{~V}$ altos $\left(>65^{\circ}\right)$, e baixos ângulos de extinção $\left(z^{\wedge} \mathrm{C}\right.$ variando de $\left.10-15^{\circ}\right)$

\section{IV.3.2.1.2. Nivel $10(\mathrm{~N}-10)$ da Mina do Pari}

No nivel 10, as rochas predominantes são carbonato-plagioclásio-quartzo-cloritabiotita-hornblenda xistos, com texturas porfiroblásticas em matrizes grano- 


\section{Fotomicroorafia 09:}

Amostra GN-10: Quartzo-clorita-granadabiotita xisto com opacos da mineralização aurifera do $\mathrm{N}-00$ da mina do Pari. (borda vertical $2 \mathrm{~mm}$, polarizadores cruzados).

\section{Fotomicrografia 11:}

Amostra 12B: Granada-biotita-quartzohornblenda xisto com opacos da mineralização aurffera do $\mathrm{N}-10$ da mina do Pari. Nota-se o aspecto tardi a pós cinemático da granada poiquiloblástica. (borda vertical $3 \mathrm{~mm}$, polarizadores cruzados).

\section{Fotomicroqrafia 13:}

Amostra 13B: Biotita-quartzo xisto com opacos da mineralização aurifera do $\mathrm{N}-10$ da mina do Pari. Notam-se microdobras reliquiares em um nivel de sulfetos muito finos. (borda vertical $3 \mathrm{~mm}$, polarizadores cruzados).

\section{Fotomicrografia 15:}

Amostra T-42: Anfibolito fino crenulado. (borda vertical $5 \mathrm{~mm}$, polarizadores crizados).

\section{Fotomicrografia 10:}

Amostra GN-10: Quartzo-clorita-granadabiotita xisto com opacos da mineralização aurífera do N-00 da mina do Pari. (borda vertical $2 \mathrm{~mm}$, polarizadores paralelos).

\section{Fotomicrografia 12:}

Amostra 12B: Granada-biotita-quartzohornblenda xisto com opacos da mineralizaçáo aurifera do N-10 da mina do Pari. Nota-se o aspecto tardi a pós cinemático da granada poiquiloblástica. (borda vertical $3 \mathrm{~mm}$, polarizadores paralelos).

\section{Fotomicrografia 14:}

Amostra 13B: Biotita-quartzo xisto com opacos da mineralização aurfera do $\mathrm{N}-10$ da mina do Pari. Notam-se microdobras reliquiares em um nivel de sulfetos muito finos (borda vertical $3 \mathrm{~mm}$, polarizadores paralelos).

\section{Fotomicrografia 16:}

Amostra GN-15B: Nivel de clorita-biotita xisto de granulometria média a grossa. As cloritas sao magnesianas e aparecem como porfiroblastos discordantes a foliaçáo principal. (borda vertical com $5 \mathrm{~mm}$, polarizadores cruzados)

\section{Fotomicrografia 18:}

Amostra GN-09: Detalhe de quartzo-bitotitahornblenda xisto sulfetado do minério do $\mathrm{N}-\mathrm{OO}$ da mina do Pari. (borda vertical: $3 \mathrm{~mm}$, polarizadores paralelos).
Amostra T-58: Detalhe de quartzo-bitotitalapa do minério da mina do Pari. (borda vertical: $3 \mathrm{~mm}$, polarizadores cruzados). 


\section{Prancha 09}
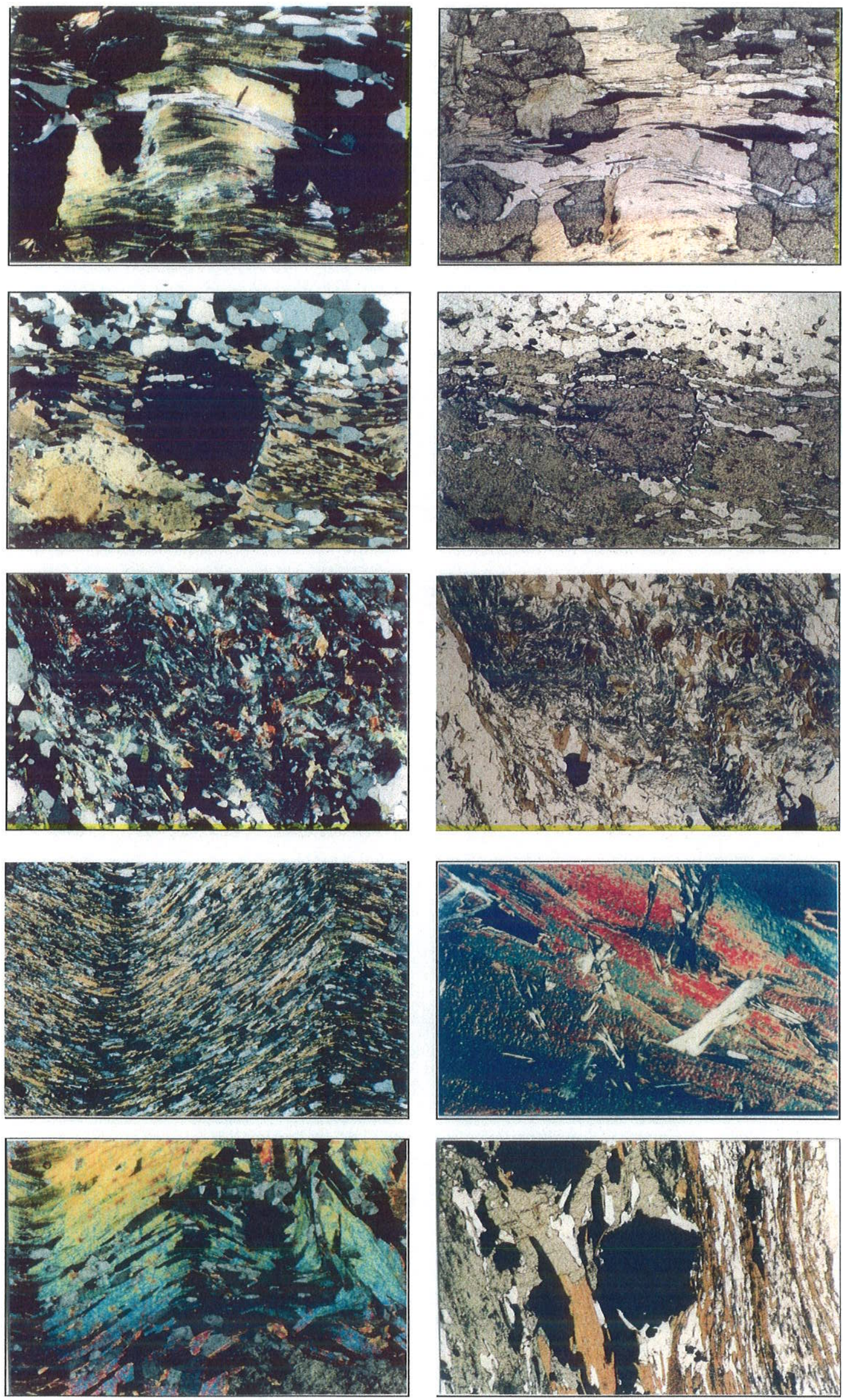
nematoblásticas, às vezes, com niveis lepidoblásticos (Fotomicrografia 19, Prancha 10).

Carbonatos (0-10\%vol.) aparecem, eventualmente, em grãos recristalizados poligonais ou intersticiais nos niveis quartzosos da matriz, e também remobilizados, preenchendo fraturas. O plagioclásio (5-10\%vol.) ocorre de forma semelhante ao nivel de entrada da mina, sendo, porém, mais freqüente. Tende a diminuir em direção a zona mineralizada. Quartzo (10-25\%vol.) apresenta-se texturalmente análogo como nas amostras do nível de entrada, entretanto, tende a diminuir em direção ao corpo de minério. A biotita (20-45\%vol.), ainda que mais freqüente, ocorre de forma semelhante às amostras do nivel de entrada, inclusive quanto à tendência de aumentar de quantidade em direção ao corpo de minério. A hornblenda (20$65 \%$ vol.) e a clorita magnesiana (0-15\%vol.) também têm características semelhantes às amostras equivalentes do nivel de entrada. Os minerais em traços (constituintes que perfazem $<1 \%$ modal) comuns em ambos os niveis são rutilo, titanita, apatita, zircão e opacos.

\section{IV.3.2.2. Rochas Encaixantes da Capa da Mineralização}

IV.3.2.2.1. Nivel de Entrada $(\mathrm{N}-00)$ da Mina do Pari

As litologias predominantes são biotita-carbonato-plagioclásio-quartzo-hornblenda xistos, com pirita como mineral opaco principal. A textura é grano-nematoblástica com porções porfiroblásticas à hornblenda.

As composições modais variam (em \%vol.): biotita (0-5), carbonatos (1-10), plagioclásio (10-15), quartzo (15-25) e hornblenda (45-60).

Biotita, carbonatos e plagioclásio diminuem em quantidade em direção ao corpo de minério, ao passo que quartzo e hornblenda aumentam. As demais propriedades microscópicas intrínsecas de cada fase mineral são análogas às descritas das encaixantes da lapa da mineralização.

IV.3.2.2.2. Nivel $10(\mathrm{~N}-10)$ da Mina do Pari

Predominam quartzo-plagioclásio-clorita-biotita-hornblenda xistos grano-lepidoblásticos com porções porfiroblásticas à hornblenda e biotita. As composições modais são (em \%vol.): quartzo (5-10\%), plagioclásio (0-10\%), clorita (5-20\%), biotita (0$20 \%)$ e hornblenda (35-80\%). 
Quartzo e hornblenda aumentam em quantidade na direção do nível mineralizado; a biotita diminui. Das demais fases, plagioclásio e clorita, principalmente, não alteram suas proporções com a aproximação à mineralização.

\section{IV.3.2.3. Petrografia da Mineralização Aurífera}

\section{IV.3.2.3.1. Nível de Entrada (N-00) da Mina do Pari}

As amostras seriadas do nível de entrada interceptaram uma porção mais pobre da mineralização, com espessura total e teores de ouro menores em relação à composição média encontrada na extremidade norte do corpo.

O minério de ouro constitui-se em xistos nemato a lepidoblásticos e porfiroblásticos, bandados e foliados, da seguinte composição modal (em \%vol.): hornblenda (5-65), quartzo (10-65), biotita (2-45), granada almandina (1-20) e plagioclásio $(<1-5)$. Os minerais opacos constituem de $1-15 \%$ modais, sendo ainda observadas Fe-cloritas, Mg-cloritas e carbonatos na matriz.

As hornblendas ocorrem em duas gerações texturais distintas, finamente orientadas na matriz e também como porfiroblastos discordantes à foliação principal, por vezes, poiquiloblásticos.

A biotita é castanha avermelhada; normalmente, aparece dispersa na matriz e, eventualmente, com concentração variável em bandas milimétricas a centimétricas. Raramente forma porfiroblastos (Fotomicrografia 22, Prancha 10).

As granadas porfiroblásticas e poiquiloblásticas se desenvolvem, sobretudo, nos níveis ricos em biotita (Fotomicrografias 9-12, Prancha 09; Fotomicrografias 20, 23, 27, Prancha 10). São euhédricas externamente e, internamente, mostram texturas poiquilíticas em planos subparalelos ou helicíticas. São particularmente comuns as inclusões de minerais opacos componentes do minério sulfetado, sobretudo, pirrotita e, bastante freqüentes ainda, inclusões até macroscopicamente visiveis de ouro. O quartzo e o plagioclásio ocorrem, preferencialmente, nas bandas granoblásticas, quase sempre associados com quantidades pequenas de carbonatos, formando arranjos granoblásticos poligonais em sua trama textural. O quartzo ocorre, ainda, em veios remobilizados tardios e discordantes.

IV.3.2.3.2. Nível $10(\mathrm{~N}-10)$ da Mina do Pari

Abreu, G.C. 
No nivel 10, a mineralização compõe-se de xistos bandados e foliados, por vezes, crenulados e com dobras intrafoliares, cuja mineralogia modal compreende (em $\%$ vol.): hornblenda (0-30), quartzo (15-80), biotita (1-40), porfiroblastos de granada almandina (1-45) e plagioclásio (<1). Os minerais opacos constituem de $5-35 \%$ modais. Foram ainda observadas na matriz Fe-cloritas, Mg-cloritas, grunerita e fluotaramita.

Comparativamente aos minérios do nível de entrada, os do nivel 10 mostram diferenças significantes. São mais ricos em sulfetos $e$, conseqüentemente, mais ricos também em ouro. Não ocorre plagioclásio nas partes centrais do corpo mineralizado, apenas nas bordas e, mesmo assim, em diminutas quantidades. Os conteúdos de quartzo e de granada, em média, são mais elevados e, comumente, ocorrem ainda dois tipos adicionais de anfibólios, grunerita e fluotaramita, além da hornblenda.

A grunerita e fluotaramita (com propriedades microscópicas semelhantes aos anfibólios equivalentes já descritos dos BIF tipo Algoma da unidade B do Gr. Nova Lima) ocorrem freqüentemente associadas com magnetita, constituindo bandas de BIF do tipo Algoma de fácies mista, óxido a magnetita-silicatos, granonematoblásticas, intercaladas no interior da mineralização.

Estruturalmente, os minérios mostram-se afetados tanto pelas micro-dobras intrafoliares $\left(S_{n-1}\right)$ palimpsésticas preservadas (Fotomicrografia 13, Prancha 09; Fotomicrografias 20,28, Prancha 10), quanto pelas deformações subseqüentes $\left(S_{n_{1}}\right.$ $S_{n+1}$ e $\left.S_{n+2}\right)$.

\section{IV.3.2.3.3. Petrografia de Minerais Opacos}

Neste item, serão descritos conjuntamente os minérios das duas interseções de amostragens seriadas (Figuras 04, 05), assim como algumas observações metalogenéticas relativas às rochas encaixantes.

No nivel de entrada da mina do Pari, na capa da mineralização, ocorre pirita xenomórfica (1-2\%vol.) intersticial à matriz das rochas e também, remobilizada em fraturas. O mesmo acontece no nível 10, porém, nas amostras da lapa da mineralização.

Nos dois níveis do minério, os minerais opacos principais são (em \% de volume relativos aos minerais opacos totais): pirrotita (50-70\%) e arsenopirita (25-45\%); os demais minerais, calcopirita, esfalerita, pentlandita e ouro, totalizam até $5 \%$. Pirita e/ou marcassita criptocristalinas ocorrem como produtos de alteração secundária 
(retrometamórfico-hidrotermal ou intempérica incipiente) das pirrotitas em estruturas tipo birds eyes ("olho de pássaro") e não serão tratadas em maiores detalhes. Um aspecto mineralógico-textural geral do minério sulfetado de ouro da mina do Pari é mostrado na fotomicrografia 01 (Prancha 08).

A pirrotita está presente em duas gerações texturais. A geração principal é de cristais anedrais, de tamanho maior, alongados na foliação, evidenciando a elevada maleabilidade/plasticidade do mineral sob efeitos tectono-metamórficos. Em função dessa propriedade, é quase sempre pobre em inclusões de calcopirita, esfalerita e/ou arsenopirita, ocorrendo, entretanto, pequenas inclusões (exsoluções ou segregações) de pentlandita, formando texturas flaming ("em chamas"). Essas pirrotitas metamórficas mostram alterações secundárias para pirita/ marcassita em birds eyes. Uma outra geração de pirrotitas, anterior às pirrotitas metamórficas acima descritas, é representada por diminutas inclusões do mineral em arsenopiritas e, mais raramente, em calcopiritas.

Arsenopirita ocorre em duas gerações texturais bem definidas. As arsenopiritas da primeira geração formam cristais anedrais a subedrais, sempre ricos em inclusões de outros sulfetos (pirrotita, esfalerita e calcopirita), silicatos, e de ouro refratário de granulometria fina $(<10 \mu \mathrm{m})$ (Fotomicrografia 01, Prancha 08). Comumente, apresentam bordas externas idioblásticas (euhedrais) indicativas de supercrescimento e transformação metamórfica progressiva em arsenopiritas da segunda geração. A segunda geração de arsenopiritas é representada por cristais idioblástico-idiomórficos, virtualmente isentos de inclusões neoformados ou, originados por transformação/ substituição e recristalização parcial a total, metamórfica progressiva das arsenopiritas (anedrais) da primeira geração. Estágios intermediários de transformação/substituição são caracterizados por arsenopiritas idioblásticas que apresentam decrescência de inclusōes (em tamanho e número), dos centros para as bordas dos cristais. Assim, indicando, ainda, um processo eficiente de eliminação de todas as inclusões, inclusive as de ouro, durante a transformação por recristalização idioblástica metamórfica progressiva das arsenopiritas I para arsenopiritas II.

A calcopirita também aparece em duas gerações texturais: a primeira, comumente, como pequenas inclusões nas arsenopiritas da primeira geração (arsenopirita I) $e_{\text {, }}$ mais raramente, nas pirrotitas principais, e a segunda, como calcopirita livre, de granulação mais grossa, entretanto, ainda assim, mais fina que os demais sulfetos livres. A calcopirita livre pode apresentar inclusões de pirrotita, esfalerita e arsenopirita. 


\section{Fotomicrografia 19:}

Amostra 5B: Quartzo-biotita-cloritahorneblenda xisto com vênula de cartonato preenchendo fratura. Encaixante de lapa (FW) do N-10 da mina do Pari. (borda vertical: $5 \mathrm{~mm}$, polarizadores cruzados).

\section{Fotomicrografia 21:}

Amostra 18B: Clorita-biotita-hornblenda xisto encaixante da capa (HW) do N-10 da mina do Pari. Nota-se aspecto tardi a pós cinemático do porfiroblasto de homeblenda (borda vertical: $3 \mathrm{~mm}$, polarizadores cruzados).

\section{Fotomicroprafia 23:}

Amostra 11B: Granada-quartzo-biotita xisto com opacos da mineralizaçao aurifera do $\mathrm{N}$ 10 da mina do Pari. Nota-se microdobra reliquiar marcada por sulfetos muito finos, inclusos em granada. (borda vertical: $3 \mathrm{~mm}$, polarizadores paralelos).

\section{Fotomicrografia 25:}

Amostra 18B: Detalhe de porfiroblasto poiquilitico de homblenda crescendo sobre a matriz de clorita-quartzo-biotita xisto (HW do $\mathrm{N}-10$ ). (borda vertical: $4 \mathrm{~mm}$, polarizadores cruzados).

\section{Fotomicrografia 27:}

Amostra 13B: Detalhe de porfiroblasto de granada ligeiramente rotacionado indicando final de crescimento tardi a pós cinemático. Minério do N-10 (borda vertical: $3 \mathrm{~mm}$, polarizadores paralelos).

\section{Fotomicroarafia 20:}

Amostra 12B: Granada-quartzo-biotita xisto com opacos da mineralizaçáo aurffera do $\mathrm{N}-10$ da mina do Pari (borda vertical: $5 \mathrm{~mm}$, polarizadores paralelos).

\section{Fotomicroorafia 22:}

Amostra 20B: Biotita-hornblenda-clorita xisto do HW do N-10 da mina do Pari, com porfiroblastos de biotita e hornblenda tardi a pós cinemático dos discordantes da foliaçáo da matriz clorítica Sn. (borda vertical: $3 \mathrm{~mm}$, polarizadores cruzados).

\section{Fotomicroerafia 24:}

Amostra 19B: Clorita-homblenda-biotita xisto encaixante do HW do N-10 da mina do Pari. (borda vertical: $3 \mathrm{~mm}$, polarizadores paralelos).

\section{Fotomicrografia 26:}

Amostra GN-03: Plagioclásio-quartzohornblenda xisto em textura nematoblástica. Encaixante de capa do $\mathrm{N}-00(\mathrm{HW})$ (borda vertical: $2 \mathrm{~mm}$, polarizadores cruzados).

\section{Fotomicrografia 28:}

GN-14: Detalhe de quartzo-hornblenda-biotita xisto pouco sulfetado mostrando microdobra reliquiar. Amostra (borda vertical: $3 \mathrm{~mm}$, polarizadores paralelos). 


\section{Prancha 10}
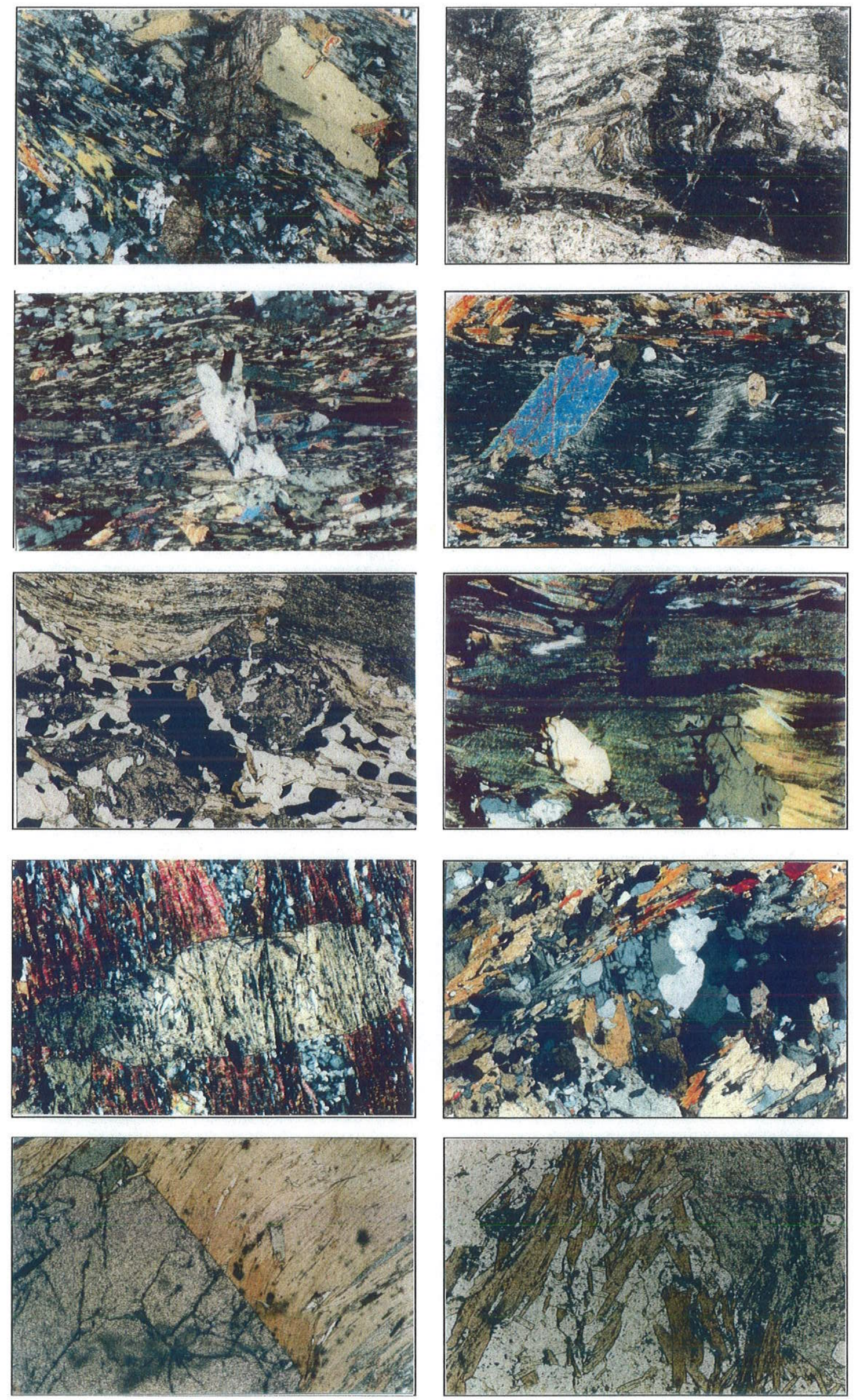
A esfalerita é mais comum que a calcopirita e aparece tanto livre na matriz, com formas intersticiais irregulares e raras inclusões, quanto como inclusões na arsenopirita l, calcopirita e, eventualmente, na pirrotita, em grãos de cortes ovalados a circulares diminutos.

A magnetita só aparece em niveis de BIF tipo Algoma de fácies óxido à magnetita, ou de fácies mistas óxido-silicato-carbonato, que localmente se intercalam como partes da mineralização. É subédrica a euhédrica e poiquiloblástica, com inclusões de todos os sulfetos conhecidos no local inclusive com inclusões de ouro (Fotomicrografias 02, 03, Prancha 08). Entretanto, não foram observados sulfetos englobando magnetita.

Ouro ocorre em três gerações texturais distintas, sendo mais abundante nos níveis mais ricos em sulfetos totais e, principalmente, em arsenopiritas. A geração mais antiga - ouro primário - ocorre com granulação muito fina (grã média < 10 $\mu \mathrm{m}$ ) como inclusões na arsenopirita I (Fotomicrografia 01, Prancha 08). Pode ocorrer também na forma de inclusões similares na magnetita (Fotomicrografia 03, Prancha 08). Este ouro primário, refratário, perfaz em média $<15 \%$ do ouro total. A principal parte do ouro ( $>85 \%$ do total), entretanto, é ouro livre, de granulometria média bem mais grossa, variando de poucos décimos a meio milímetro (Fotomicrografias 03, 04, 05, Prancha 08). Tem sua formação relacionada aos processos metamórficos regionais, ou seja, a reprecipitação do ouro I liberado nas transformações metamórficas das arsenopiritas e crescimento dos grãos de Au II livre, por cristalização acretiva. Por último, ocorre ainda ouro livre de grã grossa em veios de quartzo remobilizados metamórficos e deformados (p.ex.: "horizonte Florália" na unidade C do Gr. Nova Lima) com ou sem sulfetos associados e sem importância econômica, na área do morro do Pari.

\section{IV.3.2.3.4 Seqüência de Cristalização dos Minerais Opacos}

O modelo elaborado para a seqüência de cristalização dos minerais de minérios na mineralização de ouro da mina do Pari é mostrado na figura 20 (e já foi inicialmente comentado no Capítulo III). Na seqüência de cristalização reconstituida a partir das propriedades texturais dos minerais metálicos, sulfetos, magnetita e ouro, distinguiram-se três fases principais. A primeira representa a deposição e cristalização inicial desses minerais. A segunda fase compreende suas transformações metamórficas. Por último, a terceira fase refere-se as remobilizações finais. 
A Fase 1 caracteriza-se como da deposição primária e inicial dos sulfetos, do ouro e da magnetita e de suas transformações subseqüentes imediatas (diagenéticas) nos protominérios, tratando-se, indubitavelmente, da fase mais difícil de estudos e compreensão, por ter sofrido todos os eventos e transformações posteriores. No entanto pelo arranjo textural dos grãos e sua distribuição na matriz, foi possível separar duas gerações (I e II) de pirrotita, calcopirita e esfalerita e uma geração única de arsenopirita, magnetita e ouro. O ouro desta geração é caracterizado como inclusões em arsenopirita e magnetita (ouro refratário) e possui granulometria muito fina $(\varnothing<10 \mu \mathrm{m})$. O ouro livre desta geração, que eventualmente existiu, ou não foi preservado, ou não foi reconhecido como tal, em função de sobrecrescimentos posteriores.

A Fase 2 compreende as transformações metamórficas da mineralização, originando arsenopirita e magnetita idioblásticas, pirrotita deformada e ouro em grãos grossos livre. Nesta fase ocorreu o crescimento metamórfico diferenciado desses minerais, eventualmente englobando fases menores como novas inclusões, ou expulsando as inclusões pretéritas. Nos locais onde a magnetita predominou esta englobou, durante seu crescimento, todas as outras fases minerais presentes (sulfetos, silicatos e ouro). Já a arsenopirita I, nesta fase, durante a sua recristalização metamórfica para arsenopirita II idioblástica, expulsou todas as inclusões, inclusive de ouro de seu interior. O ouro assim mobilizado originou, por reprecipitação e crescimento por cristalização acretiva, uma segunda geração de ouro grosso livre na matriz da rocha, que perfaz $\sim 85 \%$ do ouro total contido no minério da mina do Pari.

A Fase 3 caracteriza-se por remobilizações e reprecipitações tardias e finais de pirita e calcopirita em zonas de cisalhamento e de fraturas. Ouro, em pequenas quantidades, pode ocorrer associado a esses sulfetos e, também, em veios de quartzo e quartzo-carbonáticos, com ou sem sulfetos associados.

IV.4. Ocorrências de Ouro nos Arredores de Pari, Quadricula de Florália

$\mathrm{Na}$ quadrícula de Florália existem 08 minas antigas e ocorrências de Au que foram lavradas até início do século XX. A principal e mais conhecida foi a mina do Pari com recursos totais (produzidos+estimados) de 13,3t de $\mathrm{Au}$, seguida pelas outras: Pari Norte, Patrimônio, Gambá, Fazenda Camas ou Adiles, Morro Alto, Bahú e Cururu. Todas essas mineralizações, exceto Cururu (que é uma ocorrência aluvionar), inserem-se nas continuidades do greenstone belt Rio das Velhas na parte NE do QF 
e hospedam-se em diversas unidades litoestratigráficas do Gr. Nova Lima metamórfico na zona de transição da fácies xisto verde superior a $W$, para anfibolito na parte $E$ da quadrícula. A cerca de $15 \mathrm{~km}$ a $W$ da mina do Pari ocorrem ainda as minas São Bento, atualmente com produção de 3,2 t de Au/ano, e Córrego do Sítio em fase de expansão para o subsolo, ambas porém hospedadas em conjuntos litológicos do Gr. Nova Lima de ambientes essencialmente metassedimentares.

Para a mina do Pari, foi possivel estabelecer um quadro litoestratigráfico e faciológico, preciso, com a mineralização de ouro ocorrendo em BIF de tipo Algoma intercalado em anfibolitos de derrames metabásicos, ou seja, num ambiente vulcânico básico proximal.

Com o conhecimento dos litotipos e dos ambientes das minas do Pari (Abreu, 1995) e São Bento, sedimentar pelítico e exalativo químico distal (Abreu, A. et al., 1988; Abreu, 1995; Valladares, 2000, 2004), foram estudados e feitas inferências litoestratigráficas, faciológicas, estruturais e do potencial aurífero de algumas das outras ocorrências da quadrícula de Florália, acima citadas.

\section{IV.4.1. Pari Norte}

Essa ocorrência aurifera localiza-se a cerca de $500 \mathrm{~m}$ a norte da entrada da mina do Pari, tratando-se, possivelmente de sua extensão. A estruturação principal no local é N05- $10 \mathrm{~W} / 45^{\circ} \mathrm{NE}$, havendo uma continuidade da estruturação do Sgr. Rio das Velhas, quase perfeita, da mina do Pari, incluindo Pari Norte, até pouco a $\mathrm{N}$ da mina do Patrimônio.

As figuras 24 e 25 mostram respectivamente o mapa e a seção geológica do prospecto Pari Norte. Desta ocorrência, não existem estudos no subsolo e também não foram realizadas sondagens, de forma que todo o conhecimento provém de mapeamento e amostragens de superfície. A cava de Pari Norte, em grande parte, já está entulhada, restando apenas numa intersecção a boca de um pequeno poço cheio de água e uma pequena galeria na extremidade $\mathrm{N}$ da cava. $\mathrm{Na}$ boca do poço, foi realizada uma amostragem de canal que resultou em até $8,5 \mathrm{~g} / \mathrm{t}$ de $\mathrm{Au}$ num intervalo de $2 \mathrm{~m}$. O mapeamento geológico também mostrou que as mesmas unidades litoestratigráficas encontradas em Pari continuam até Pari Norte, confirmando os grupos Quebra Osso e Nova Lima, com suas subdivisões nas unidades B, C e D. Uma diferença apenas é que na porção basal da unidade C ocorre ainda, um fino corpo de rocha metaultramáfica, de 3 a $5 \mathrm{~m}$ de espessura aparente, estendendo-se por cerca de $250 \mathrm{~m}$, intercalado aos anfibolitos. A cava de 

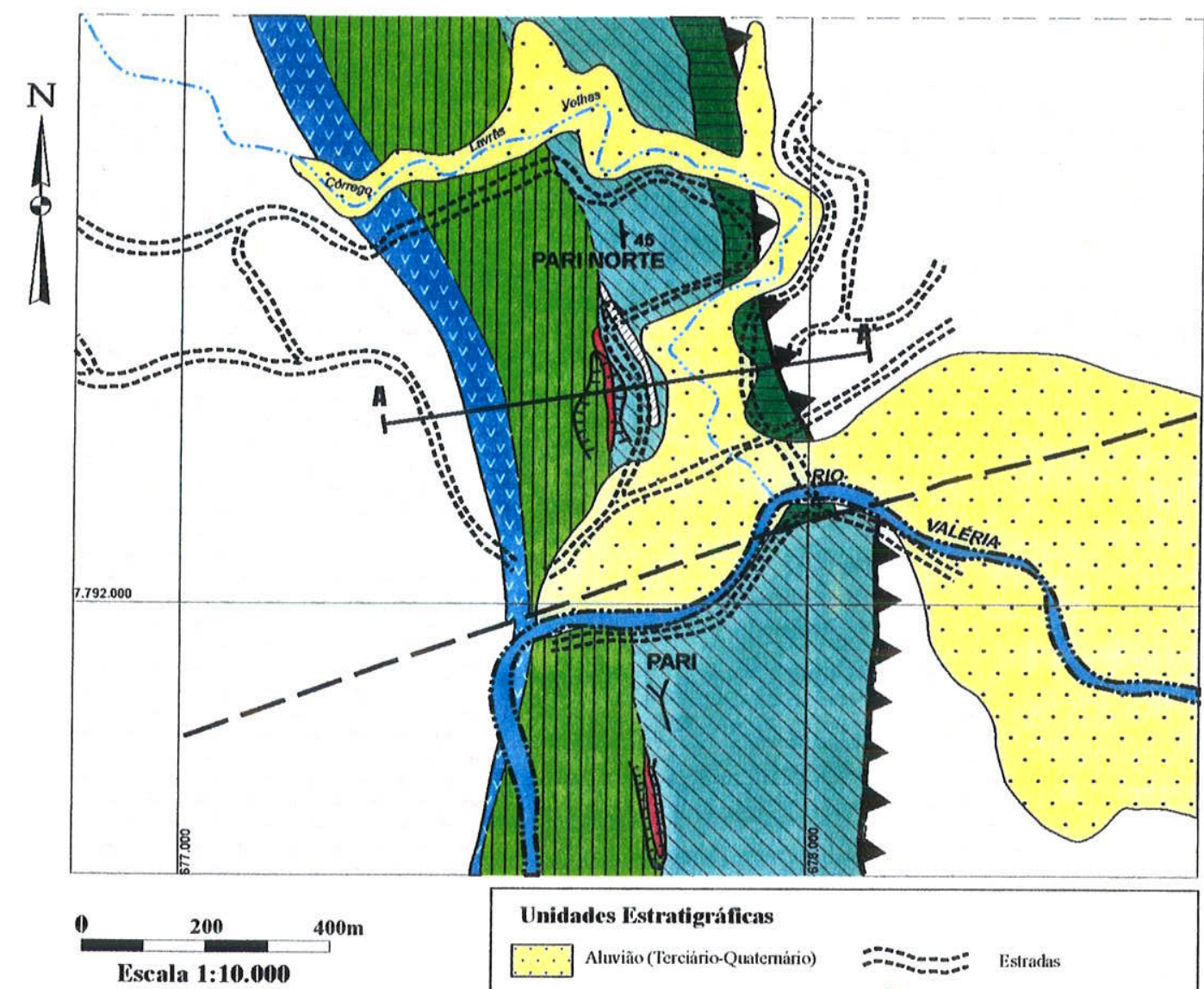

Figura 24:

Mapa geológico da área de Pari Norte, Unidades Istratigráficas

$\therefore \quad$ Aluvião (Tercéário-Quatemário)

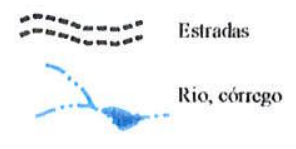

Grupo Nova Lima

IDI Unidade B (granacha anfibolitos

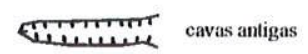

Unidade $\mathrm{C}$ (anfibolito fino, terme cavas antigas

com nivel de metraultranáfica) $>\quad$ Mina Alxandonada

Unidade D A

PVY Grupo Quebra Osso

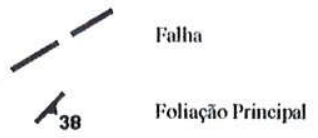
incluindo ao sul a área da mina do Pari.

TTG 
Evolução Petrogenética e Metalogenética da Mina de Au do Pari e Arredores, NE do Q. F.
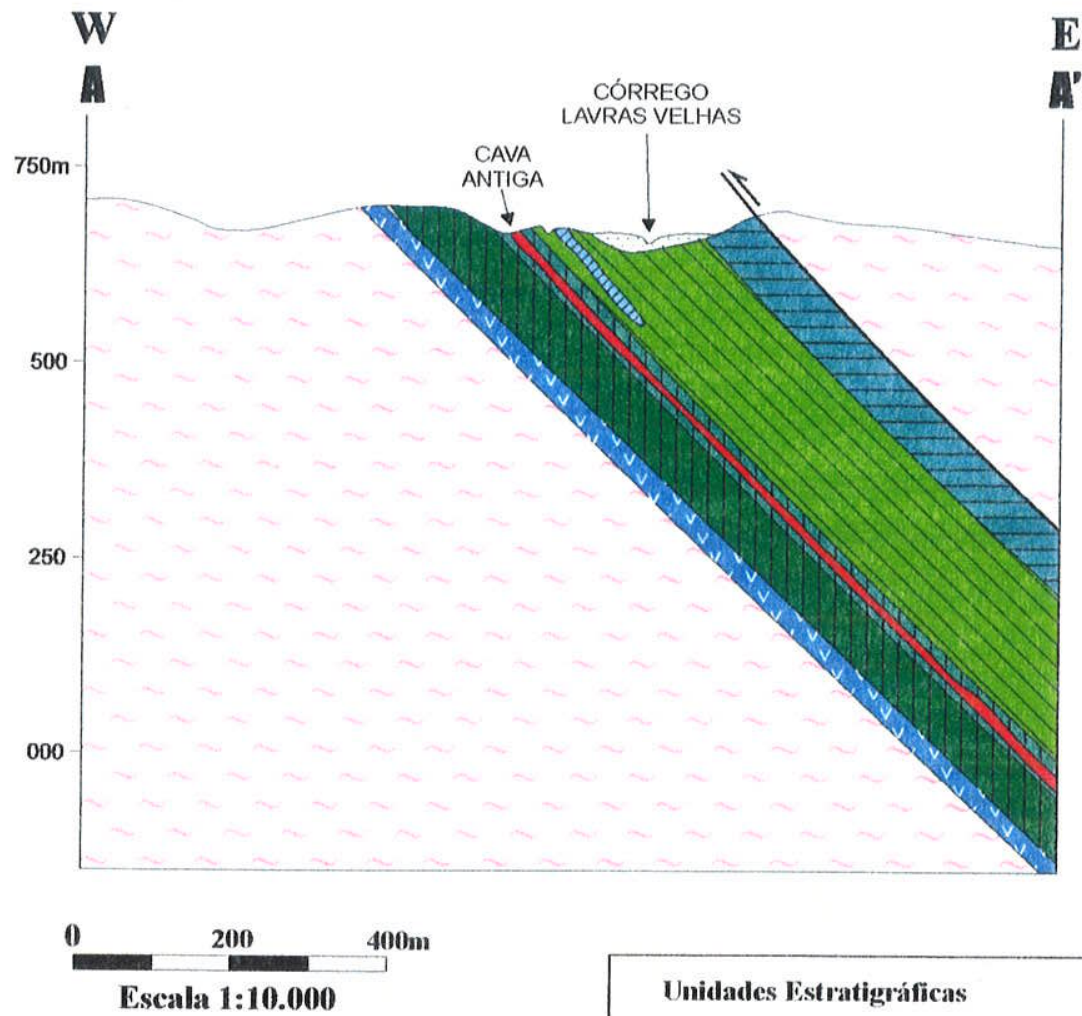

\section{Figura 25:}

Seção geológica da área de Pari Norte.

Unidades Estratigráficas

$\because \therefore$ Aluvião (Terciário-Quatentánio)

Grupo Nova Lima

Wnidade D

Unidade C (anfibolito fino com talco xisto)

B. B unit (granada anfibolito e BIF)

VV V Grupo Quebra Osso

$\square$ TTG

Falha de empurtão
E

I 
Pari Norte possui em superficie dimensões comparáveis a cava de Pari, entretanto, desconhecem-se dados históricos geológicos e/ou de produção, bem como quaisquer caracteristicas sobre a continuação da mineralização em profundidade. No local da cava também não foram encontrados litotipos frescos para a realização de estudos mineralógico-petrográficos, geoquímicos e microgeoquímicos comparativos à mina do Pari.

\section{IV.4.2. Mina do Patrimônio}

A mina do Patrimônio localizamse bem de fronte ao vilarejo de Florália, ou seja, na direção $E$, cerca de $1,5 \mathrm{~km}$ a N de Pari Norte (Figura 26). Chegou a ser operada no século XIX pela Congregação local da Igreja Católica. Dados históricos do DNPM citados por Padilha et al. (2000), relatam teores de Au entre 15 e $20 \mathrm{~g}$ de Au/t. O acesso principal da mina está obstruído, restando apenas as pilhas de rejeito na entrada da galeria principal, hoje arriada.

O mapeamento geológico em superfície, auxiliado por pequenas galerias antigas no morro do Patrimônio confirmou as mesmas unidades e subunidades do Sgr. Rio das Velhas, também mapeadas tanto em Pari quanto em Pari Norte, bem como a continuidade da estruturação geral desde Pari Norte (Figuras 26, 27). A mineralização foi identificada em amostras do rejeito da mina, como semelhante à mina do Pari. Com base nos estudos feitos estimamse uma extensão de cerca de 120 $m$ com espessuras semelhantes à mineralização da mina do Pari.

\section{IV.4.3. Gambá}

Essa mineralização (Figura 28, 29) encontra-se a cerca de $2 \mathrm{~km}$ a N, em linha reta, da mina do Patrimônio, na continuação do mesmo contexto litoestratigráfico e estrutural, das demais minas mineralizações aqui já descritas. Foi estudada com mapeamento geológico de superfície e trabalhos de prospecção e pesquisa pela Unamgen Min. e Met. S.A., porém não foi sondada nem investigada no subsolo. A foliação principal no local inflete para N15-25W/20-40 NE, sendo que essa inflexão se origina logo a norte do falhamento normal, de direção aproximada WSW-ENE, que corta a estruturação do Sgr. Rio das Velhas pouco a $\mathrm{N}$ da mina do Patrimônio (Figura 26).

Também foi lavrada no século $X \mid X$, após descerem um poço em subsolo inclusive. $A$ subunidade B-2 do Gr. Nova Lima é aqui mais espessa que nas demais localidades, entretanto, o ângulo de mergulho da foliação principal é bem mais baixo. 


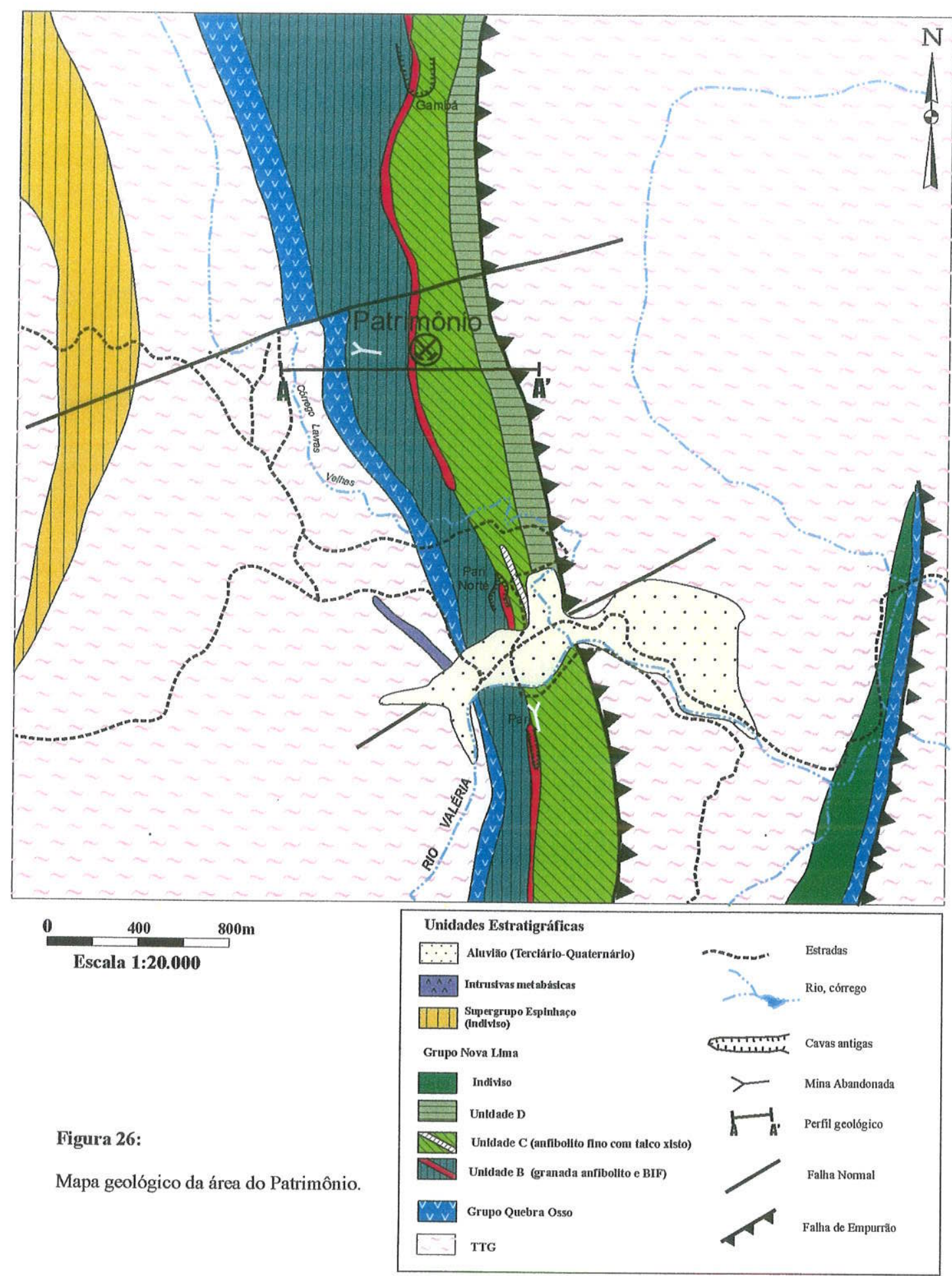




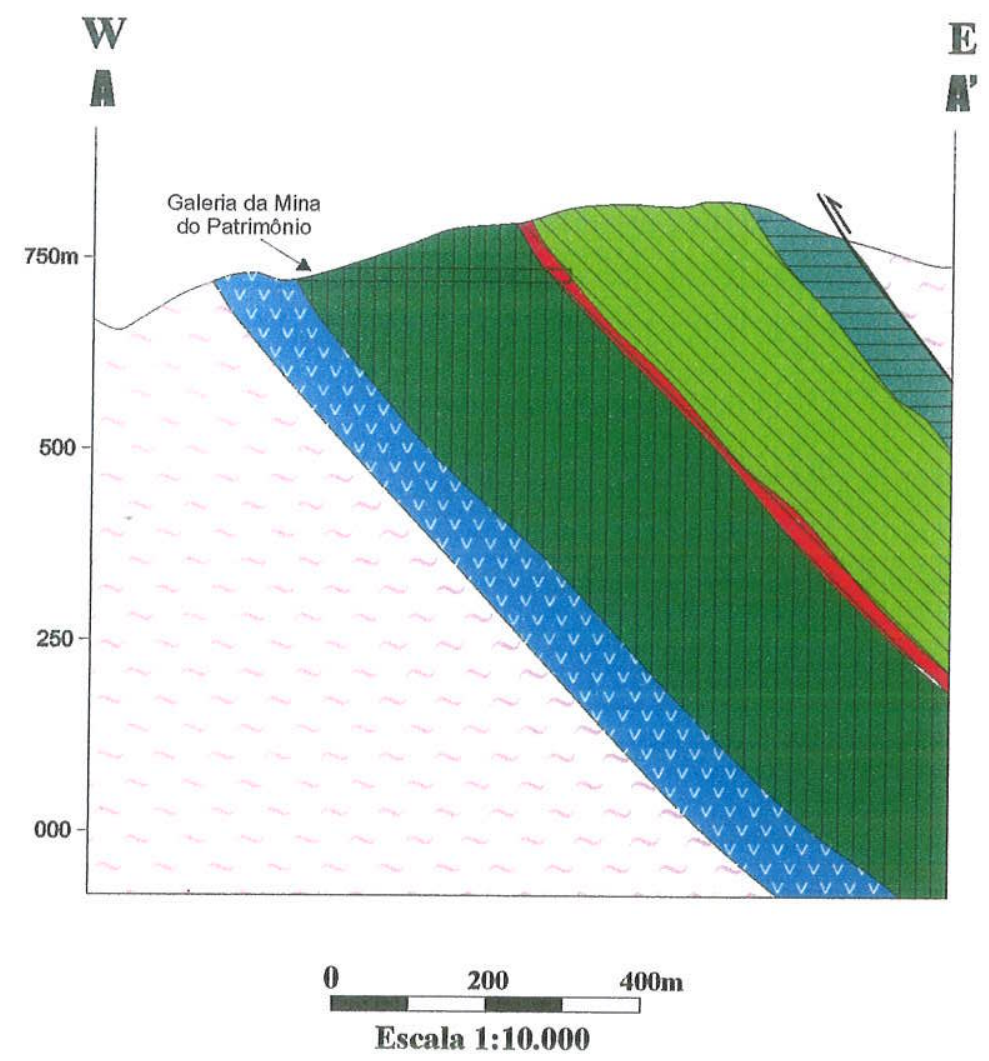

$\mathbb{E}$

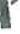

Escala 1:10.000

Figura 27:

Seção geológica da área do Patrimônio.

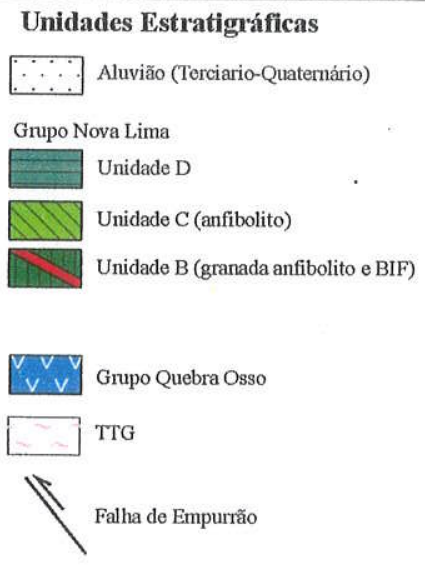




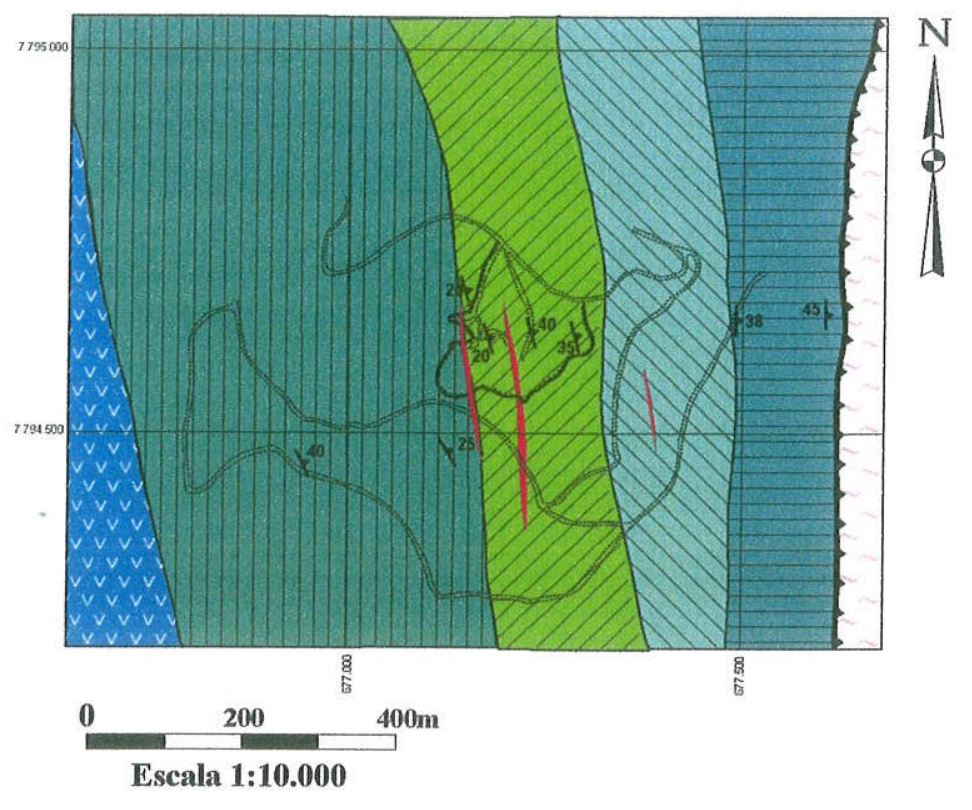

Figura 28:

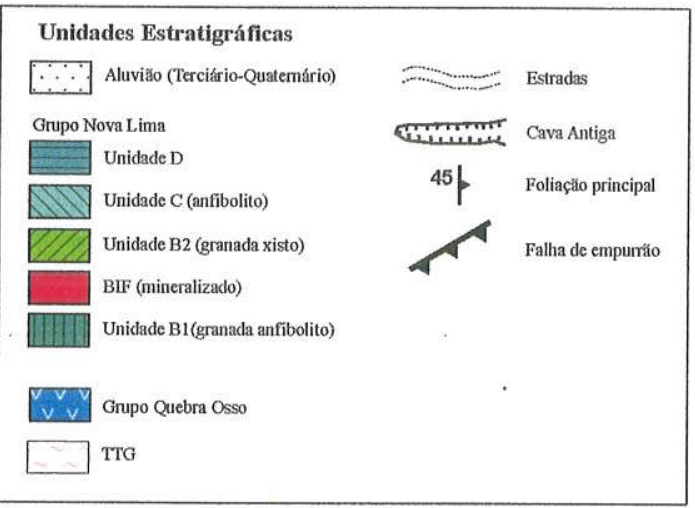

Mapa geológico da área do Gambá. 

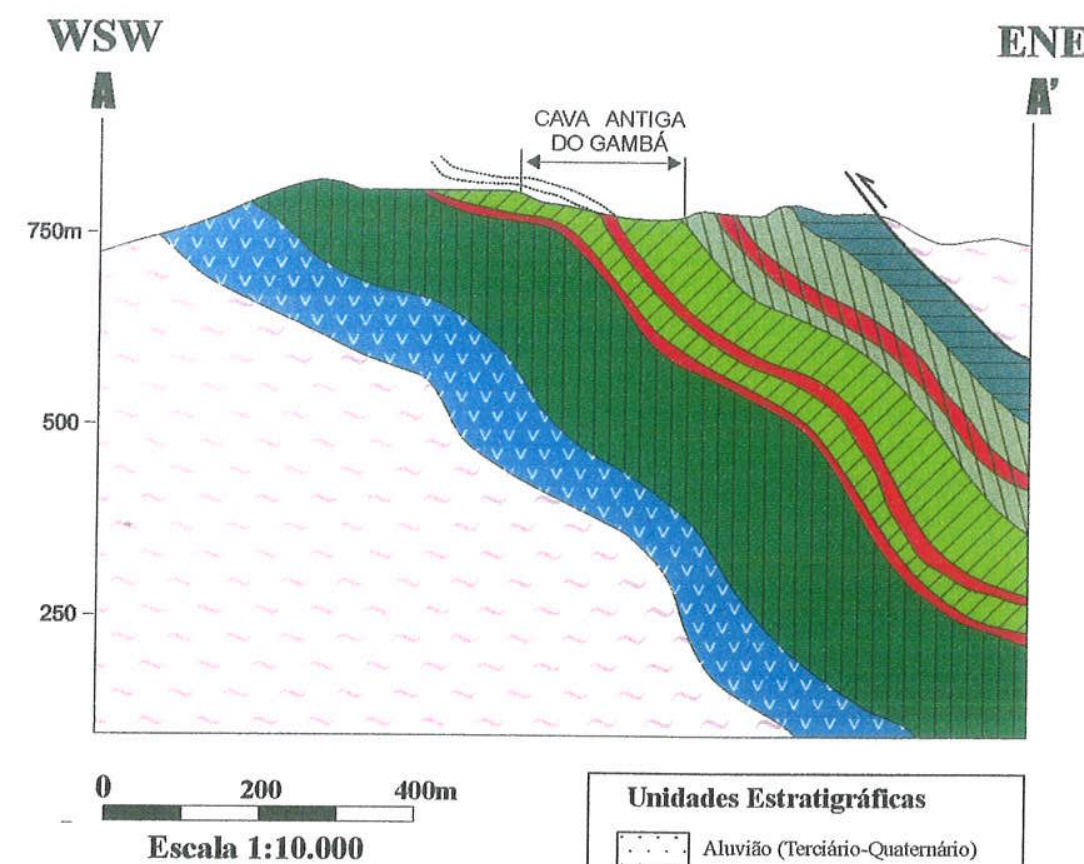

Figura 29:

Seção geológico da área do Gambá.

\begin{tabular}{|c|c|}
\hline \multirow{2}{*}{\multicolumn{2}{|c|}{$\begin{array}{l}\text { Unidades Estratigráficas } \\
\qquad \because \because \text { Aluvião (Terciário-Quaternário) }\end{array}$}} \\
\hline & \\
\hline \multicolumn{2}{|c|}{ Grupo Nova Lima } \\
\hline & Unidade D \\
\hline & Unidade C (anfibolito) \\
\hline & Unidade B2 (granada xisto) \\
\hline & BIF (mineralizado) \\
\hline & Unidade B1 (granada xisto) \\
\hline & Grupo Quebra Osso \\
\hline & TTG \\
\hline & Falha de Empurrão \\
\hline
\end{tabular}


O mapa e a seção geológica da mineralização do Gambá são apresentados nas figuras 28 e 29. Até a área desta mineralização continuam as mesmas unidades litoestratigráficas da mina do Pari, totalizando cerca de $4 \mathrm{~km}$ de extensão de direção constante aproximada N-S. Porém, para as mineralizações não se observa a mesma continuidade; parecem ser corpos lenticulares descontínuos. Em direção de sul para norte, é nítido o aumento da espessura da subunidade B-2, bem como da unidade D, do Gr. Nova Lima, devido aos efeitos diferenciais dos falhamentos de empurrão de $E$ para W.

\section{IV.4.4. Bahú, Morro Alto, Fazenda Camas}

Essas pequenas ocorrências de ouro aparecem na porção norte do Grupo Nova Lima na Quadrícula de Florália, onde as direções das principais estruturas são E-W, com caimentos de alto ângulo para sul (Figura 2 e Anexo 1). A estruturação principal da porção centro-norte da área é N75-85E/70-75 $\mathrm{SE}$. Há um falhamento com expressiva componente transcorrente e de empurrão, em rampa oblíqua, a cerca de $1 \mathrm{~km}$ a norte da mineralização do Gambá, que trunca a estruturação aproximadamente N-S do Sgr. Rio das Velhas contínua desde a mina do Pari.

Em poucas amostras pontuais, apenas de rejeitos da antiga mina do Bahú, hoje toda aterrada e de afloramentos da mineralização Morro Alto, foram encontrados teores de $\mathrm{Au}$ de até $1,26 \mathrm{~g} / \mathrm{t}$ em intervalo de $1 \mathrm{~m}$, em anfibolito granatífero ferruginoso intemperizado. Nas proximidades da mina do Bahú ocorrem pequenas pilhas de quartzo de veios com pintas de Au. Cabe ainda salientar que, com todas essas mineralizações de $\mathrm{Au}$ são também encontrados niveis de BIF e/ou anfibolitos granatíferos associados.

\section{IV.4.5. Os Ambientes Arqueanos das Quadriculas Florália e Santa Bárbara}

$\mathrm{Na}$ Quadrícula Florália as principais mineralizações de ouro ocorrem em niveis de BIF hospedadas em associações litológicas do $\mathrm{Gr}$. Nova Lima onde predominam as rochas metavulcânicas básicas, estando essas associações em disposição estratigráfica e estrutural normal. Já na Quadrícula Santa Bárbara predominam, no mesmo contexto litoestratigráfico e metalogenético, rochas metassedimentares pelíticas e químicas exalativas. As mineralizações auríferas das minas São Bento, Santa Quitéria e Córrego do Sítio, também intimamente associadas à BIF sulfetados 
e/ou xistos grafitosos venulados (vênulas de quartzo), encaixam-se em espessas seqüências de xistos metapelíticos grafitosos. Inexistem, a exceção de diques proterozóicos, metavulcânicas básicas nas seqüências das minas de Au dessa área. Assim, as mineralizações de ouro das minas São Bento, Santa Quitéria e Córrego do Sítio, sejam sedimentares-exalativas ou de veieiros hidrotermais, claramente se caracterizam como formadas e hospedadas em ambientes distais de qualquer foco de vulcanismo básico arqueano.

Na região de Santa Bárbara, partindo-se de SE (vale do córrego Quebra Osso) para NW (sinclinal Gandarela) observam-se todas as litologias arqueanas em posição invertida (figura 09). Assim, o Grupo Quebra Osso está truncado a $E$ por falha de alto ângulo e jaz sobre o Grupo Nova Lima, também invertido, a W. Na Mina São Bento aparecem no Gr. Nova Lima dobras de tipo "s" com eixo subhorizontal, neste caso, também evidenciando sua estrutura em posição invertida. Possivelmente, o conjunto das formações ferríferas na região da mina São Bento, representam os flancos de um sinformal especial invertido vergente para $W$. Neste caso, a mina São Bento estaria no flanco inverso.

\section{IV.4.6 Avaliação Preliminar do Potencial Aurífero da Quadrícula}

A mina do Pari possui uma confiável estimativa de recursos, baseada na reavaliação feita pela Unamgen Min. e Met. S/A., que já foram divulgados em Padilha et al. (2000), em conjunto com demais estimativas para outras ocorrências de Au da quadrícula Florália.

Com base nas observações de mapeamento, descrições petrográficas e teores de $\mathrm{Au}$ (quando disponíveis) dos minérios, assim como nas espessuras médias das zonas mineralizadas e suas extensões, muitas vezes estimadas pela expressão em superfície de suas antigas cavas a céu aberto, foi realizado um cálculo na tentativa de avaliar os recursos potenciais de Au estimados, para as minas do Pari, Pari Norte, Patrimônio, Gambá e Bahú. As quatro primeiras caracterizam-se pelo mesmo contexto litológico, estrutural e metalogenético, definido na mina do Pari, permitindo assim a extrapolação desse modelo até a mina do Gambá. Apenas para a mina do Bahú, da qual há poucas informações, tinham que ser feitas estimativas mais vagas e cautelosas, já que a única informação de valor econômico, foi encontrada em amontoados de quartzo de veios com pintas de Au visiveis, o que foi inferido como o possivel minério de Bahú. 
O cálculo estimativo do potencial de recursos auríferos da quadrícula de Florália é apresentado na Tabela 09 e 10.

\begin{tabular}{|c|c|c|c|c|c|c|c|}
\hline Epoca & Atlividade & Volume & Teor & ton. & onças (milhöes) & Prof. & Obs. \\
\hline & & $t$ & $g / t$ & $\mathrm{Au}(\mathbf{t})$ & Au(Moz) & (m) & \\
\hline$?-1882$ & céu aberto & 50.000 & 12,00 & 0,600 & 0,019 & 35 & Céu aberto - garimpo? \\
\hline $1882-1889$ & Subsolo & 270.000 & 10,50 & 2,835 & 0,091 & $35-200$ & Sta Barbara Gold Mining Co \\
\hline $1889-1937$ & Subsolo & 120.000 & 12,50 & 1,500 & 0,048 & $200-300$ & St John del Rey Mining Co \\
\hline $1988-1990$ & recorsos cubados & 552.300 & 15,17 & 8,378 & 0,269 & $300-800$ & Unamgen Min. Met \\
\hline & & & & & & & ontim \\
\hline Total & Recursos + Produçắo & 992.300 & 13,42 & 13,313 & 0,428 & & estimado \\
\hline \multirow[t]{2}{*}{ Mineralizaçá } & \multirow{2}{*}{$\begin{array}{c}\text { Extençáo } \\
\text { Comprimento (m) }\end{array}$} & $t$ & $g / t$ & Au(t) & $\mathrm{Au}(\mathrm{Moz})$ & (m) & Obs \\
\hline & & & & & & & \\
\hline $\begin{array}{l}\text { Pari Norto } \\
\text { Património } \\
\text { Gambá } \\
\text { Bahú } \\
\end{array}$ & $\begin{array}{c}250-2 \\
200-2 \\
100-3,5 \\
?\end{array}$ & $\begin{array}{r}900.000 \\
900.000 \\
1.500 .000 \\
300.000 \\
\end{array}$ & $\begin{array}{l}8,5 \\
8,0^{*} \\
3,2^{*} \\
10^{*} \\
\end{array}$ & $\begin{array}{l}7,65 \\
7,20 \\
4,80 \\
3,00 \\
\end{array}$ & $\begin{array}{l}0,246 \\
0,231 \\
0,154 \\
0,096 \\
\end{array}$ & $\begin{array}{l}800 \\
800 \\
500 \\
800 \\
\end{array}$ & $\begin{array}{l}\text { toor médio estimado } \\
\text { teor métio estimado } \\
\text { teor médio estimado }\end{array}$ \\
\hline Total & & 3.600 .000 & 8,5 & 30,6 & 0,728 & & \\
\hline Total & Parl + Outras minas & $4,592,300$ & 9,6 & 43,913 & 1,156 & & \\
\hline
\end{tabular}

Tabela 10: Dados informativos das ocorréncias aurfferas da Q. Florália

\begin{tabular}{|c|c|c|c|}
\hline Número & Nome & Contexto & teor Au(g/t) \\
\hline A-117 & Baú & BIF & $?$ \\
\hline A-118 & Faz.Camas-Adiles & anfibólio-xisto granatifero & $?$ \\
\hline A-119 & Gambá & BIF & $?$ \\
\hline A-120 & Morro Alto & anfibólio-xisto granatífero & 1,24 \\
\hline A-121 & Córrego Bonito & anfibólio-xisto granatifero & 0,26 \\
\hline A-122 & Património & BIF & 17,5 \\
\hline A-123 & Pari & BIF & 15,17 \\
\hline A-124 & Cururu & Aluviǻo & $0,12^{\star}$ \\
\hline
\end{tabular}

$\left({ }^{*} \mathrm{~g} / \mathrm{m} 3\right)$

Obs: Dados Extraídos de Padilha et al.(2.000)

Considerando uma profundidade estimada das mineralizações individuais, ao longo do mergulho de $1000 \mathrm{~m}$, o valor potencial estimado para a área é de 1,15 Moz (milhões de onças), ou seja, de cerca de 44 toneladas de Au. 


\section{Capítulo V: LITOGEOQUIMICA}

A geoquímica das rochas da mina do Pari já foi tratada, de maneira geral, em Abreu (1995), caracterizando as diferentes unidades que ocorrem na região do morro do Pari, incluindo os gnaisses, migmatitos e metagranitóides do Complexo TTG, as metaultramáficas do Gr. Quebra Osso e os anfibolitos e xistos diversos do Gr. Nova Lima. Neste estudo foram enfocados especificamente os litotipos mais próximos e intimamente associados à mineralização aurífera. Partiu-se das amostragens detalhadas seriadas continuas dos niveis de entrada $(\mathrm{N}-00)$ e $10(\mathrm{~N}-10)$ e incluíramse ainda amostras provenientes de testemunhos de sondagem e das galerias mapeadas em subsolo da mina do Pari (Figuras 4, 5, 12-14).

Para tanto foram analisados os diversos litotipos coletados por grupos litológicos: anfibolitos finos, também designados anfibolitos da capa ou hangwall (HW), provenientes sobretudo da unidade $\mathrm{C}$; anfibolitos granatiferos, ou anfibolitos da lapa ou footwall ( $F W$ ) provenientes da unidade $B$; xistos encaixantes da capa, ou xistos do hangwall (HW) e os xistos de lapa, ou xistos do footwall (FW) da mineralização aurifera. Também foram analisadas e estudadas as amostras da mineralização aurifera, tanto do $\mathrm{N}-00$, na extremidade norte do corpo mineralizado, quanto do $\mathrm{N}$ 10 , em porção central, mais rica em sulfetos e ouro.

Foram realizadas análises de elementos maiores (\% peso por óxidos) e de elementos traço por fluorescência de raios $X$, que foram utilizados para a caracterização do magmatismo, classificação dos protolitos igneos e suas eventuais alterações, como espilitização, palagonitização, hidrotermalismo de fundo oceânico e transformações metamórfico-metassomáticas posteriores. Com análises por ICP. MS foi completado o acervo de dados de elementos traço, para a reconstrução e análise da evolução geoquímica petro-metalogenética nos perfis de amostragens seriadas e de anfibolitos hospedeiros proximamente associados à mineralização. Esses dados também serviram para a análise dos elementos terras raras (ETR) em diagramas normalizados, e para o melhor entendimento da derivação e gênese dos xistos encaixantes (da lapa e da capa), bem como de suas relações com a mineralização. Adicionalmente, foram feitas ainda análises de maior precisão para os metais nobres $\mathrm{Au}$ e $\mathrm{Ag}$, e de As, por fusão e copelação (fire assay) e com extração por água régia e dosagem via absorção atômica.

\section{V.1. Diagramas de Classificação de Rocha}


O uso de diagramas de classificação química convencionais, tais como de Winchester e Floyd (1977) e Le Maitre (1989) mostrou-se inadequado para a classificação dos litotipos da mina do Pari, sobretudo quanto as encaixantes imediatas da mineralização aurifera, os xistos da capa (HW) e da lapa (FW). Assim, observa-se no diagrama TAS de Le Maitre (1989) (figura 30), que principalmente os anfibolitos finos e os anfibolitos granatíferos caem no campo dos basaltos. No entanto, os litotipos xistosos, encaixantes imediatos da mineralização, se distribuem mostrando grandes variações de álcalis e $\mathrm{SiO}_{2}$ entre todos os campos das rochas basálticas e andesíticas. Essas encaixantes, embora indiquem certa filiação com as respectivas rochas vulcânicas são, de fato, derivadas de litotipos diferentes das rochas magmáticas puras indicadas nos campos do diagrama, seja por razões originais de processos genéticos diferentes, ou por alterações posteriores que sofreram antes, durante ou após a formação da mineralização aurífera.

A figura 30 a caracteriza o magmatismo dos protolitos dos anfibolitos como toleíitico. O diagrama AFM ainda apresenta duas linhas de tendências distintas. A linha 1 , traçada pelas rochas menos alteradas, caracterizada principalmente pelos anfibolitos, denota a típica tendência toleiítica, muito comum nos basaltos de fundo oceânico. A linha 2, separa o campo das rochas cálcio-alcalinas onde são representados principalmente os xistos encaixantes imediatos da mineralização aurifera, indicando que, de fato, trata-se dos efeitos das alterações hidrotermais $e$ metassomáticas ocorridas, com maior efetividade, nas encaixantes da lapa da mineralização (FW), sobretudo nas amostras do $\mathrm{N}-10$.

$\mathrm{Na}$ figura 31, no diagrama $\mathrm{K}_{2} \mathrm{O} \times \mathrm{SiO}_{2}$ (Le Maitre, 1989), observam-se enriquecimentos fortes variáveis de $\mathrm{K}_{2} \mathrm{O}$ com pouca variação da sílica, para os xistos encaixantes imediatos da mineralização, sobretudo os da lapa (FW), destacando essas rochas como litotipos completamente distintos dos anfibolitos diversos, finos e granatiferos. Estes últimos, porém, continuam representados preferencialmente no campo dos basaltos de baixo-K (até médio-K), com pequenas variações referentes a possiveis processos de diferenciação magmática, para os campos dos cumulados basálticos e dos andesitos basálticos.

$\mathrm{Na}$ figura 32, no diagrama $\mathrm{SiO}_{2} \times \mathrm{Zr} / \mathrm{TiO}_{2}$ (Winchester e Floyd, 1977), a grande maioria das rochas se concentram no campo dos basaltos subalcalinos (toleititicos) a subalcalinos e dos andesitos. Desse diagrama merece desta, que todas as rochas estudadas, mesmo os xistos encaixantes imediatos da mineralização do HW do N10 mais ricos em sílica, mostram razões dos elementos imóveis $\mathrm{Zr} / \mathrm{Ti}$, que sustentam sua filiação, mais ou menos direta do magmatismo toleiitico predominante. 


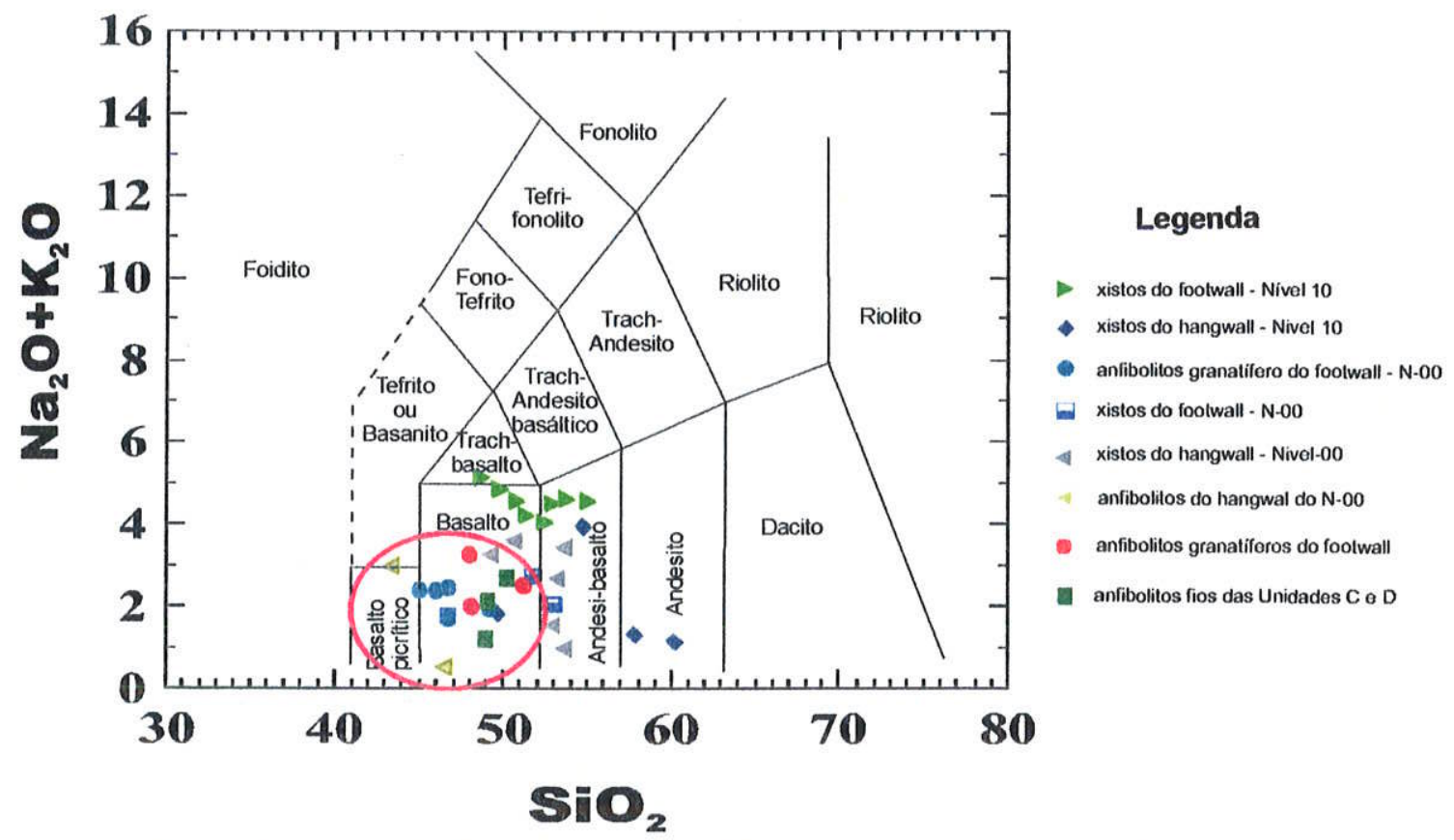

Figura 30: Diagrama TAS de Le Maitre (1989), mostrando os xistos e anfibolitos da mina do Pari, concentrando-se no campo dos basaltos e andesitos-basálticos. Os litotipos, mais pobres em álcalis, que plotam na porção mais baixa do diagrama possivelmente sofreram alguma diferenciação e representam rochas cumuláticas de bases de derrames. Os outros mais ricos em álcalis são xistos encaixantes da lapa da mineralização( $\mathrm{N}-10)$.

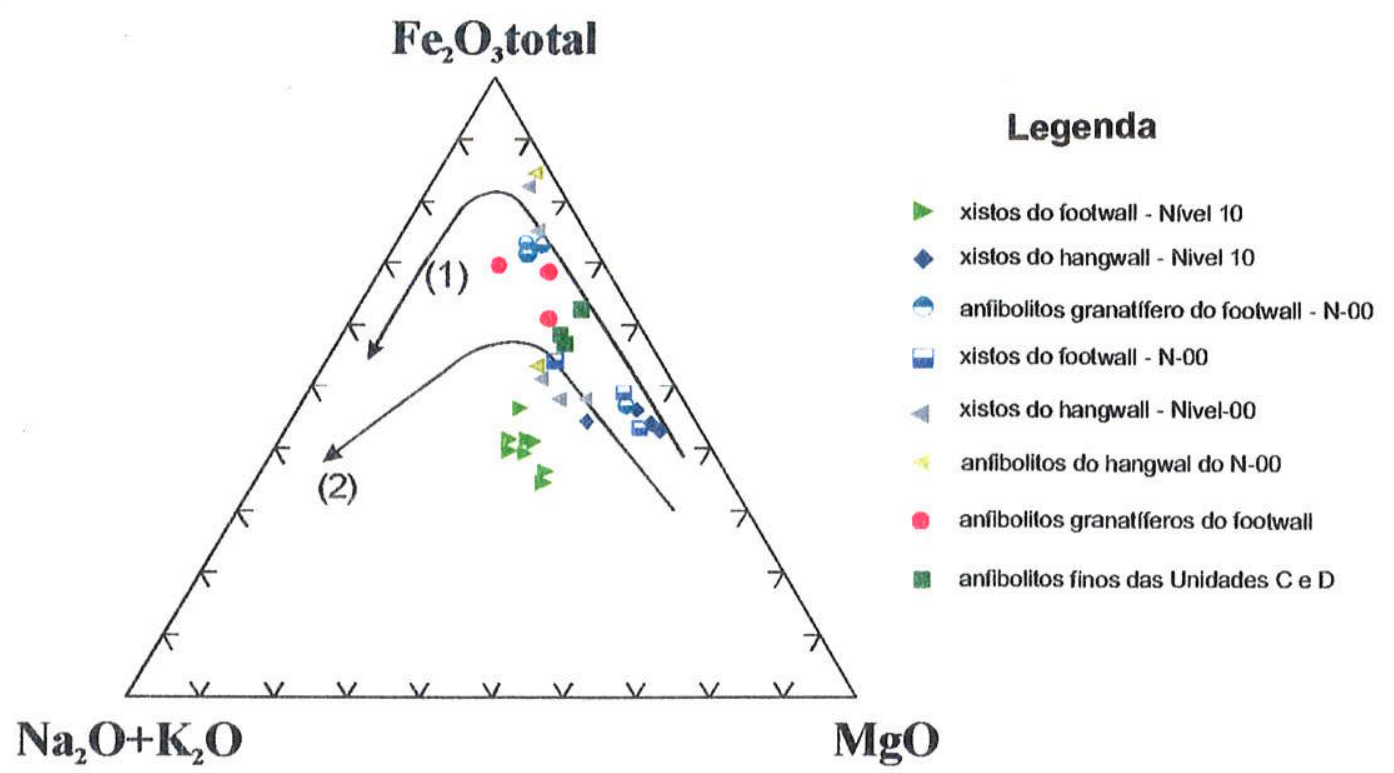

Figura 30a: Diagrama AFM dos xistos encaixantes (capa e lapa) e anfibolitos próximos da mineralização da mina do Pari. A reta (1) mostra típica tendência toleítica dos anfibolitos e alguns xistos encaixantes, enquanto a reta (2) com tendência cálcio-alcalina devido às alterações hidrotermais e/ou metassomáticas. 


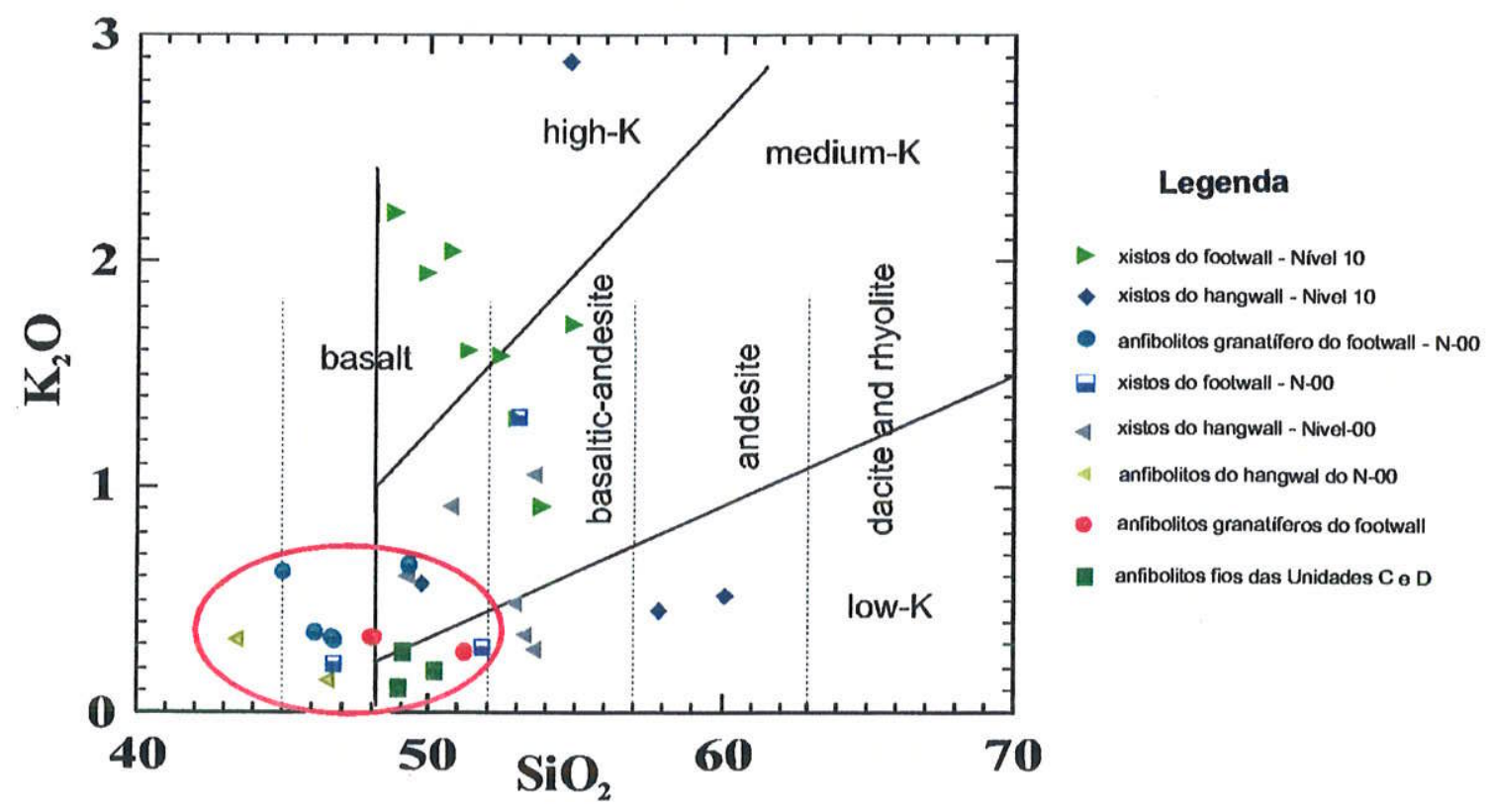

Figura 31: Diagrama de Le Maitre (1989), mostrando que nos xistos encaixantes ocorrem grandes variações de $\mathrm{K}_{2} \mathrm{O}$ para rochas com teores de $\mathrm{SiO}_{2}$ relativamente constantes, sugerindo protólitos distintos ou alterações potássicas pronunciadas. Os anfibolitos, dentro da elípse vermelha, caem normalmente no campo dos basaltos de baixo a médio $\mathrm{K}$.

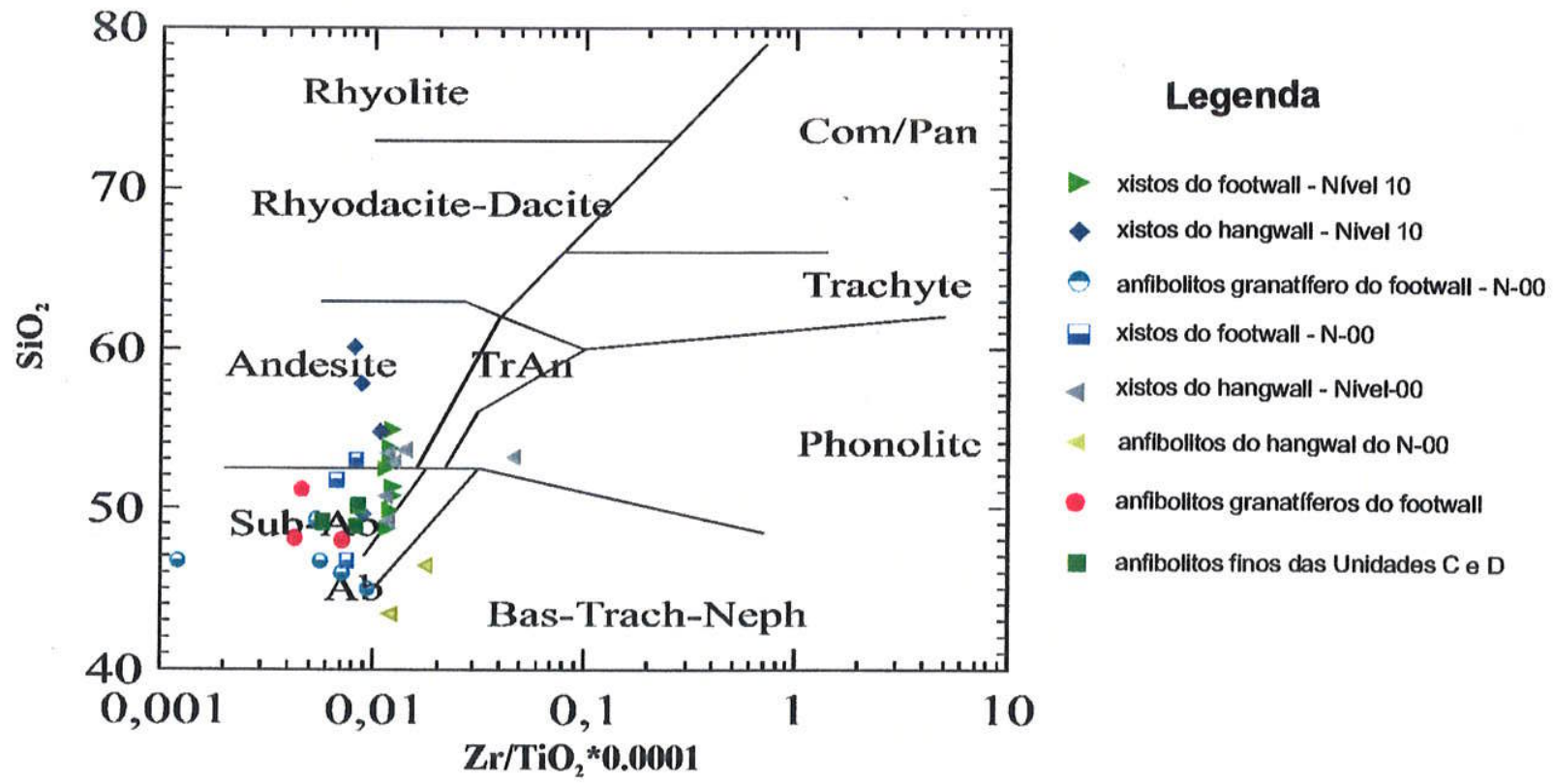

Figura 32: Diagrama de Winchester e Floyd (1977) mostrando que maior parte das rochas analisadas da mina do Pari se concentram nos campos dos basaltos subalcalinos/toléticos e dos andesitos pouco variáveis, $\mathrm{em} \mathrm{Zr} / \mathrm{Ti}$. 


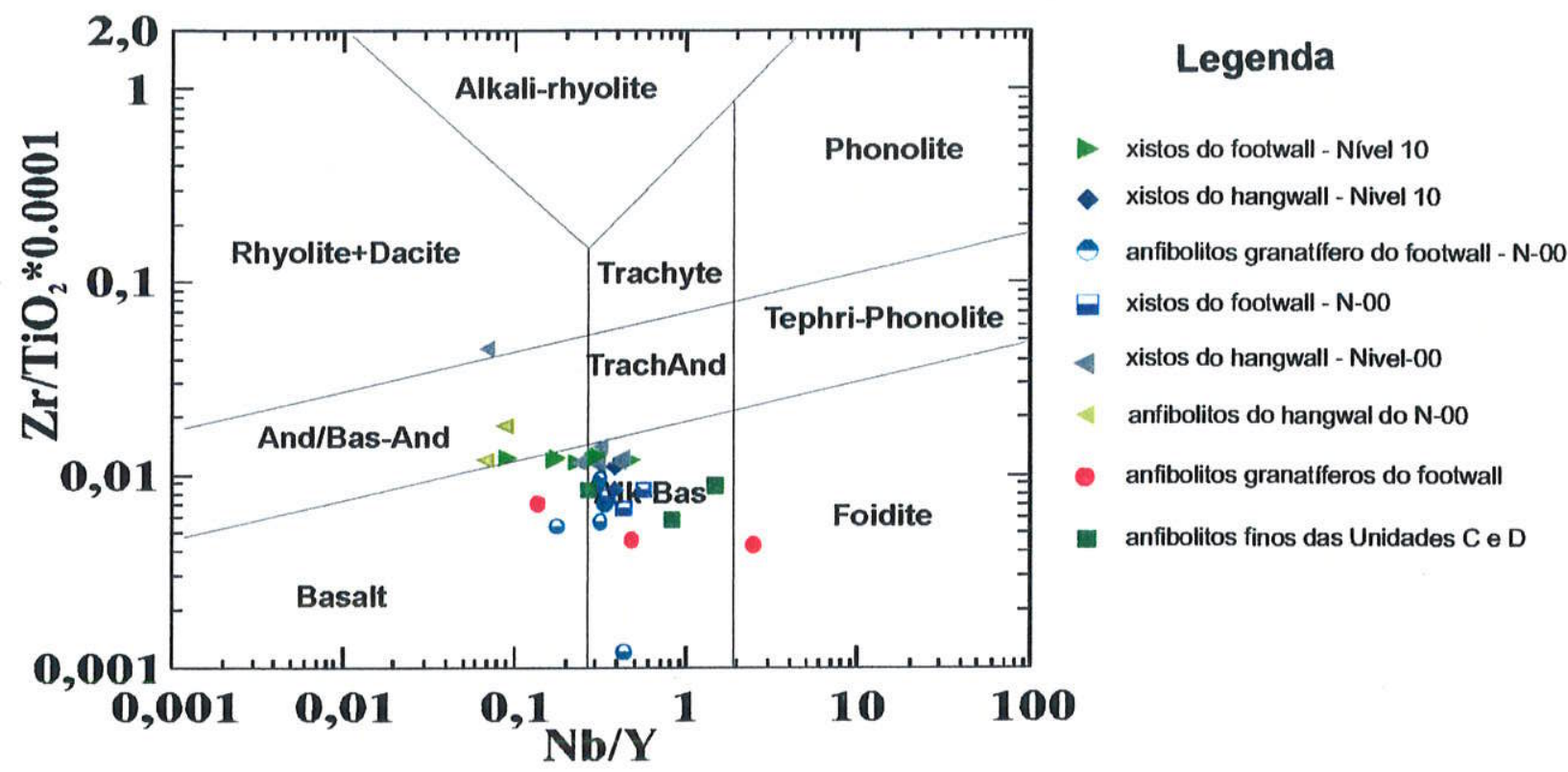

Figura 33: Diagrama de Winchester \& Floyd (1977) de elementos imóveis, mostrando uma dispersão maior de $\mathrm{Nb} / \mathrm{Y}$, em relação a $\mathrm{Zr} / \mathrm{Ti}$. O conjunto das amostras segue uma tendência comum e bem definida, inclusive dos anfibolitos finos e granatíferos (menos alterados), eventualmente representativa da filiaçãoo toleítica do conjunto.

$\mathrm{Na}$ figura 33, também um diagrama de razões de elementos imóveis segundo Winchester e Floyd (1977), os litotipos da mina do Pari apresentam uma certa dispersão e variação maior da razão $\mathrm{Nb} / \mathrm{Y}$, o que poderia indicar uma mobilidade de $\mathrm{Nb}$ ou $\mathrm{Y}$, ou ainda, a presença de alguns litotipos, provavelmente metavulcanossedimentares, afetados por um ou mais processos de alteração, associados ou não a mineralização. Nota-se, ainda, que mesmo os anfibolitos se dispersam ao longo do eixo de $\mathrm{Nb} / \mathrm{Y}$.

Assim, o tratamento geoquímico para essas rochas, sobretudo as encaixantes xistosas imediatas de lapa (FW) e capa (HW), deverá ser detalhado utilizando diagramas de variação de tipo Harker e, ainda, diagramas de variação segundo os perfis das amostragens seriadas.

\section{V.2. Geoquímica dos Perfis de Amostragens Contínuas (N-O0 e N10)}

Nas figuras de $34 a$ e b até $37 a$ e b são apresentados diagramas de variação de todos os elementos maiores e traço (dosados por ICP-MS) dos perfis de amostragens seriadas contínuas, dos níveis de entrada (N-00) e 10 (N-10) (figuras $04,05)$. O procedimento adotado, bastante simples, consistiu em lançar os valores 
(absolutos) dos resultados analíticos versus a posição de coleta da amostra no perfil, em distancias relativas proporcionais; assim podendo-se observar o comportamento dos elementos analisados em perfis geoquímicos construidos com base nas sucessões litoestratigráficas reais da mina.

Os resultados mais notáveis dizem respeito às assimetrias encontradas para muitos elementos, os quais possuem comportamento distinto entre a lapa e a capa da mineralização aurífera.

Outro fato marcante é o enriquecimento nas encaixantes, sempre no sentido dos anfibolitos para os xistos (isto é, em direção à mineralização aurifera), de elementos como $\mathrm{Na}, \mathrm{Mg}$ e $\mathrm{K}$, entre outros, de forma oposta ao que muitas vezes é demonstrado em zonas de cisalhamento (p.ex. Yonkee et al., 2003), ou até mesmo em mineralizações de Au em greenstone belt com encaixantes e grau metamórfico semelhantes à mina do Pari (MacGeehan e Hodgson, 1980; Hodgson, 1993). Já outros elementos, como $\circ \mathrm{Fe}, \mathrm{Al}, \mathrm{Mn}$ e $\mathrm{Ca}$ tendem a empobrecer-se nesta mesma direção.

$\mathrm{Na}$ mineralização em si, observam-se fortes enriquecimentos em $\mathrm{Fe}$ e terras raras (REE), além da forte correlação positiva do Au com os metais base, $\mathrm{Zn}$ e Cu, e Ba. Outros elementos menos comuns, como $\mathrm{Zr}$, Th, Sb, Se, Ga e platinóides, também apresentam tendências de enriquecimento junto à mineralização. Todos esses diagramas de distribuição dos elementos revelam nítidas diferenças litogeoquímicas entre as rochas da capa, lapa e do minério da mina do Pari, indicando diferenças originais entre seus protolitos. As marcantes diferenças litogeoquímicas e as fortes assimetrias para alguns elementos, por exemplo, de $\mathrm{Na}$ e $\mathrm{Mg}$, entre a capa e lapa próximas a mineralização, já são indicativos de litotipos originalmente diferentes, e há ainda fortes indícios de processos de espilitização na lapa $(F W)$ da mineralização. Também se observaram evidências indicativas da formação de cumulados magmáticos nas rochas da capa, conforme sugerem os comportamentos de $\mathrm{Mg}, \mathrm{Cr}$ e Ni.

Estes padrões geoquímicos observados na mina do Pari não condizem àqueles relatados de mineralizações auríferas em zonas de cisalhamento, nas quais os fluidos mineralizantes percolaram, reagindo com as rochas encaixantes, e assim geraram a mineralização aurifera. Normalmente, relata-se que em zonas de cisalhamento há lixiviação de $\mathrm{Na}$ e $\mathrm{Mg}$, com enriquecimento de $\mathrm{Al}$, Ca e $\mathrm{Fe}$ (Macgeehan \& Hodgson, 1980; e Hodgson, 1993; Yonkee et al, 2003). Os indicativos litogeoquímicos da mina do Pari, muito pelo contrário, refletem tendências evolutivas sem as lixiviações descritas em zonas de cisalhamento. A natureza original, vulcanosedimentar básica, dos litotipos encontrados, com certa imposição de processos 
cumuláticos de diferenciação magmática e de alterações de fundo oceânico (espilítica e palagonítica) pré-metamórficas, parecem dominar sobre alterações metamórfico-hidrotermais posteriores.

\section{V.2.1. Fe (Figuras $34 a$ e 34b)}

A variação do $\mathrm{Fe}$, tanto no nível 00 quanto no nível 10 , mostra substancial enriquecimento desse elemento na zona mineralizada em relação às encaixantes da capa e lapa. De fato, trata-se de uma formação ferrífera (BIF) de tipo Algoma. No nível 10 a concentração em média um pouco maior de ferro na zona mineralizada, retrata a maior abundância de sulfetos, principalmente pirrotita e arsenopirita, além de niveis de BIF com magnetita intercalados. Observa-se, ainda, sobretudo no $\mathrm{N}-00$, onde a amostragem alcançou litotipos anfibolíticos mais distantes da mineralização, que há, nas rochas encaixantes uma tendência à diminuição do $\mathrm{Fe}$ com a aproximação da mineralização.

No nivel 10, as encaixantes de lapa e capa diferenciam-se muito pouco em seus teores de $\mathrm{Fe}$, sendo apenas as amostras da capa (HW), mais próximas à mineralização, algo enriquecidas; dai para o topo, o Fe segue decrescendo com o afastamento do minério.

\section{V.2.2. Elementos Maiores ( $\mathrm{K}, \mathrm{Mg}, \mathrm{Mn}, \mathrm{Al}, \mathrm{Ca}$ e $\mathrm{Na}$ ) (Figuras 34a e 34b).}

Estes elementos, em geral, tendem a ter menores concentrações na zona mineralizada, talvez pela maior abundância de $\mathrm{SiO}_{2}$ e de $\mathrm{Fe}$ (em sulfetos e magnetita).

O Ca está mais concentrado na lapa que na capa, e apresenta ainda enriquecimentos nos xistos próximos da mineralização. Na capa, ao contrário, empobrece em direção a mineralização.

Os demais elementos mostram comportamentos nitidamente diferentes entre si. $\mathrm{Mg}$ e $\mathrm{K}$, no nível 10 , são menos abundantes na lapa do que na capa; já no nível de entrada apresentam comportamento contrário.

$\mathrm{Na}$ e Al mostram-se enriquecidos na lapa em relação à capa. O Mn mostra-se constante, com baixas concentrações, tanto na lapa, quanto na capa da mineralização. 
Evolução Petrogenética e Metalogenética da Mina de Au do Pari e Arredores, NE do Q. F.

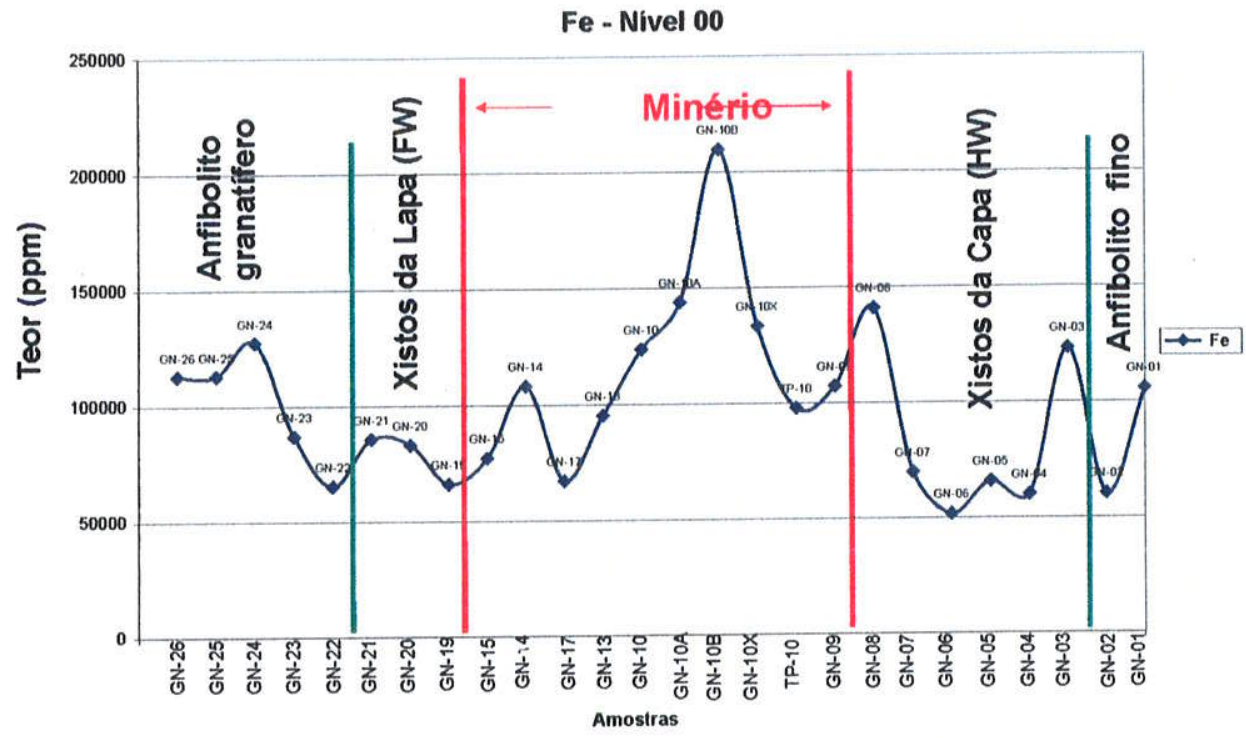

K, Mg, Mn, Al, Ca e Na do Nivel 00
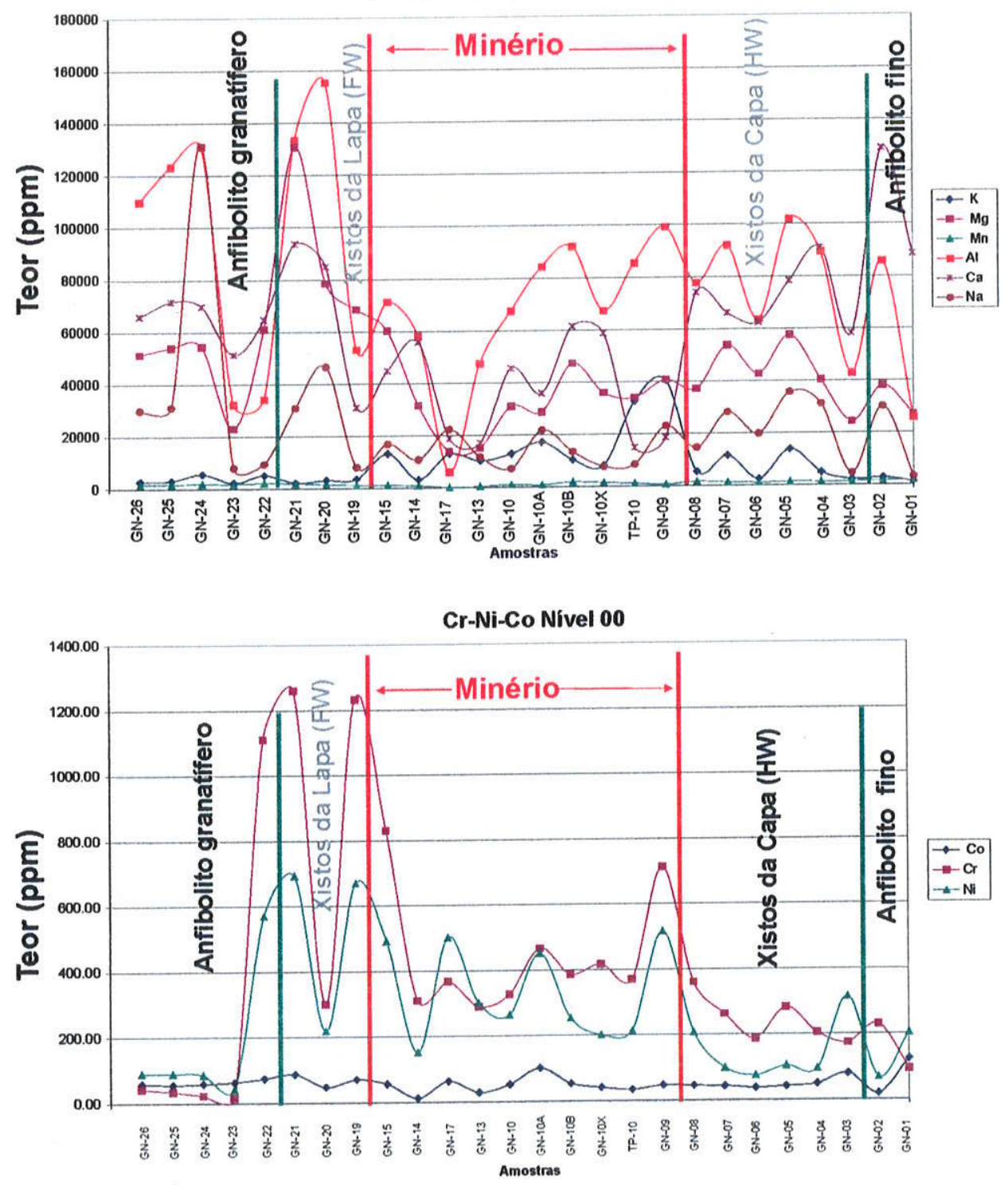

Figura 34a: Distribuição de Fe, Elementos Maiores e Co-Cr-Ni, no perfil Nível 00. 
Evolução Petrogenética e Metalogenética da Mina de Au do Pari e Arredores, NE do Q. F.
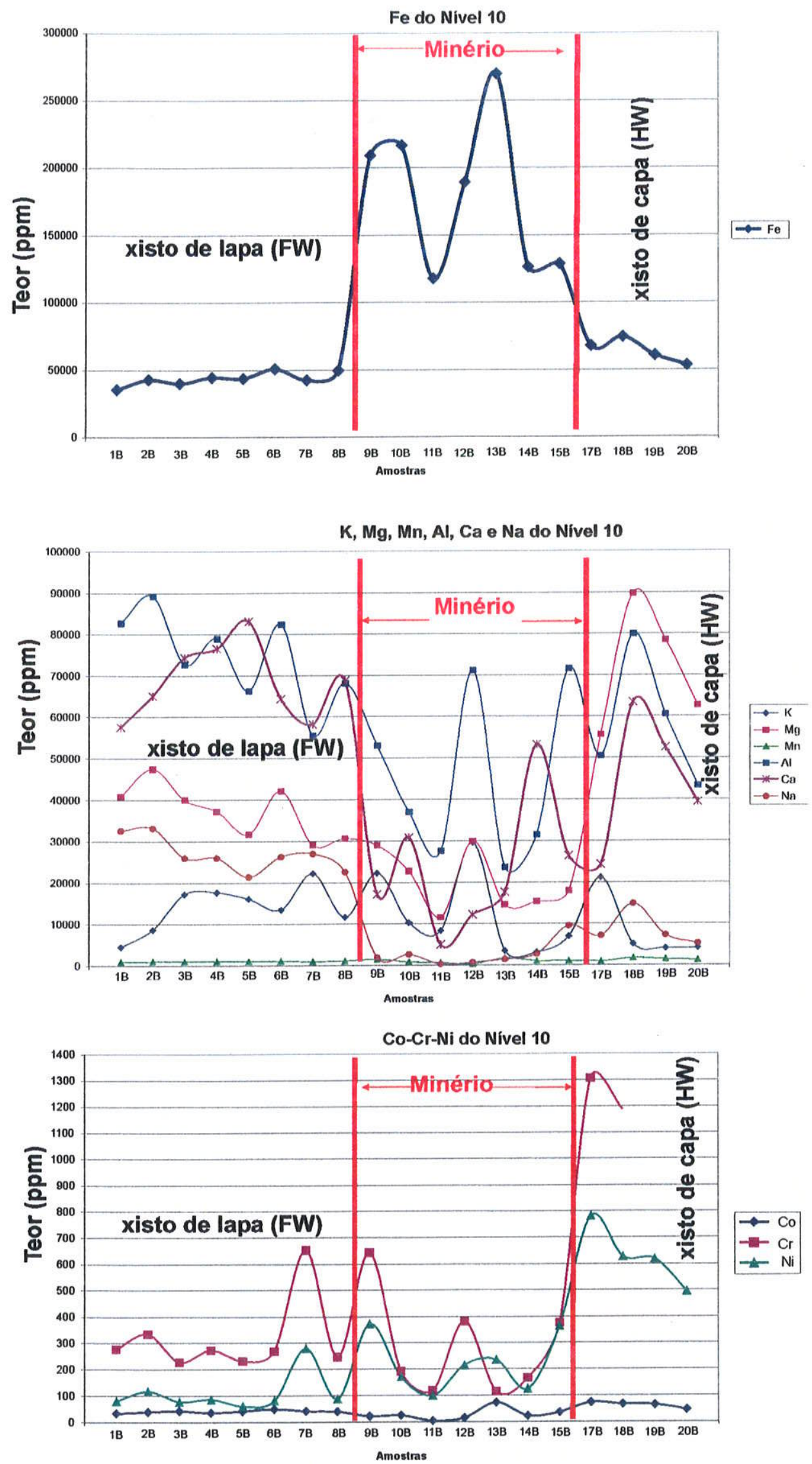

Figura 34b: Distribuição de Fe, elementos Maiores e Co-Cr-Ni do perfil do 


\section{V.2.3. $\mathrm{Cr}, \mathrm{Ni}$, Co (figuras $34 \mathrm{a}$ e $34 \mathrm{~b}$ )}

O Cr e Ni mostram fortes variações e notáveis diferenças entre a capa e a lapa da mineralização aurifera. $\mathrm{O} \mathrm{Co}$, com teores e variações muito menores, apresenta apenas pequenos picos de enriquecimento dentro da zona mineralizada, acompanhando o $\mathrm{Ni}$. No nível de entrada $(\mathrm{N}-00), \mathrm{Cr}$ e $\mathrm{Ni}$ apresentam concentrações maiores nas rochas da lapa, contrariamente ao nível 10 . $\mathrm{Cr}$ e $\mathrm{Ni}$ são elementos que em processos de diferenciação por cristalização fracionada de magmas máficos e ultramáficos, mostram comportamentos similares, concentrando-se em cumulados, respectivamente de cromita e olivina, na base dos corpos ígneos, sejam intrusivos ou extrusivos. Os enriquecimentos de $\mathrm{Cr}$ e $\mathrm{Ni}$ muito bem correlacionam às rochas encaixantes da capa da mineralização do Pari, sugerindo serem bases cumuláticas de derrames básicos. Já as rochas encaixantes da capa do $\mathrm{N}-10$, pelos teores elevados de $\mathrm{Cr}$, $\mathrm{Ni}$ e $\mathrm{Mg}$, indicam derivação de protolitos mais máficos, diferentes das encaixantes da lapa.

V.2.4. Ba, Cu e $\mathrm{Zn}$ (figuras $35 \mathrm{a}$ e $35 \mathrm{~b}$ ).

Esses três elementos tendem a concentrações mais fortes na zona mineralizada do que nas encaixantes, estando intimamente associados à mineralização aurífera. $\mathrm{Zn}$ e Cu ocorrem em maiores concentrações nos sulfetos, como esfalerita e calcopirita.

O Ba apresenta concentrações apenas ligeiramente superiores às encaixantes, que na zona mineralizada, entretanto, como também o $\mathrm{Zn}$ e Cu não estão diretamente correlacionadas ao ouro.

O Cu no N-00 possui ainda alguns picos de maior concentração nos anfibolitos da capa, também mostrados por $\mathrm{Au}$ e $\mathrm{Ag}$, e assim, mais provavelmente reflitam remobilizações posteriores.

V.2.5. Au e Ag (figuras $35 a$ e $35 b)$.

$\mathrm{O} \mathrm{Au}$ e $\mathrm{Ag}$ estão presentes na liga natural electrum e deveriam manter relação constante, caso a liga natural Au-Ag tivesse sido formada num único processo genético, ou ainda, sofrido uma completa rehomogenização.

No nível 10, na zona do minério, a relação $\mathrm{Au} / \mathrm{Ag}$, nas amostras de mais elevados

teores de $\mathrm{Au}$, mostra maior variação que nas amostras do nivel de entrada, no 


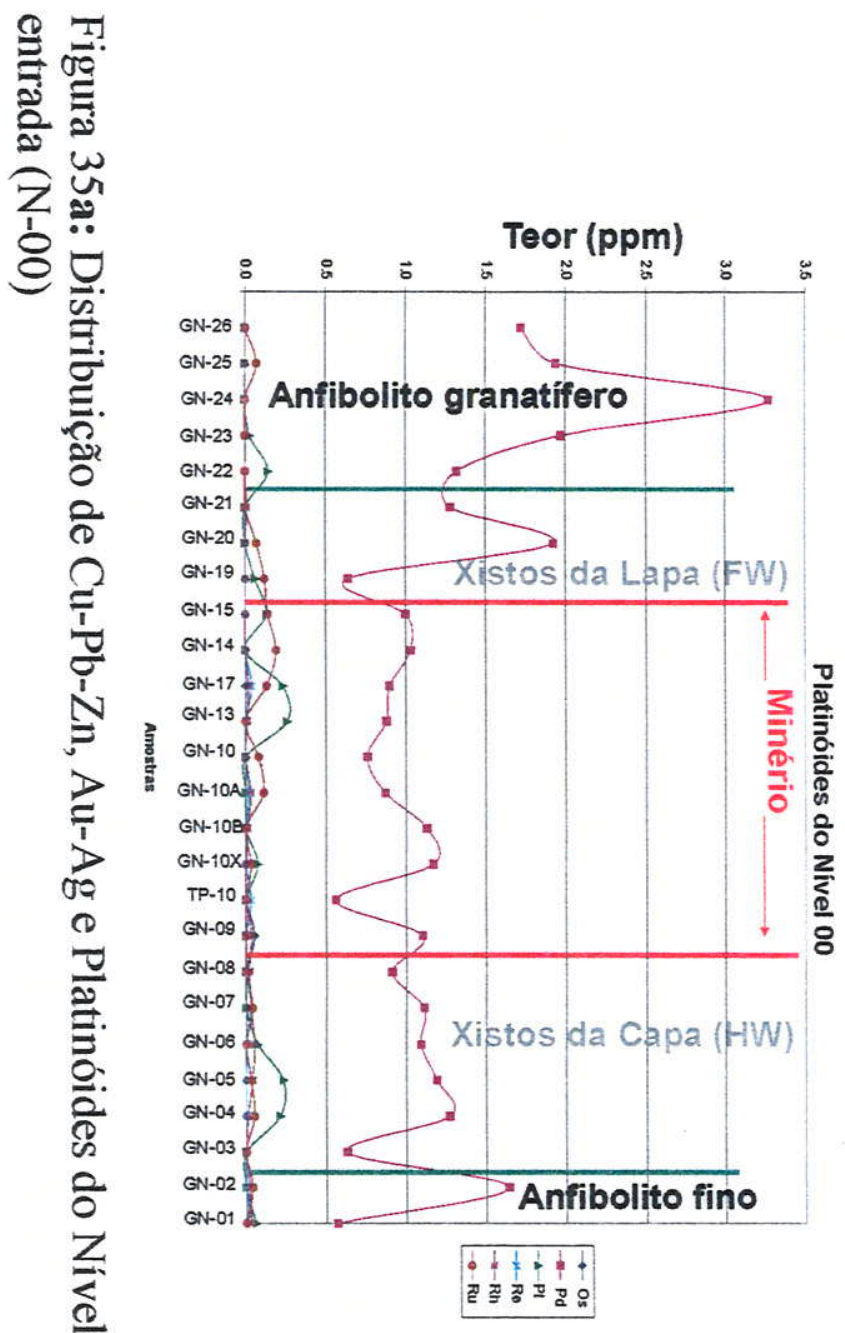

\%
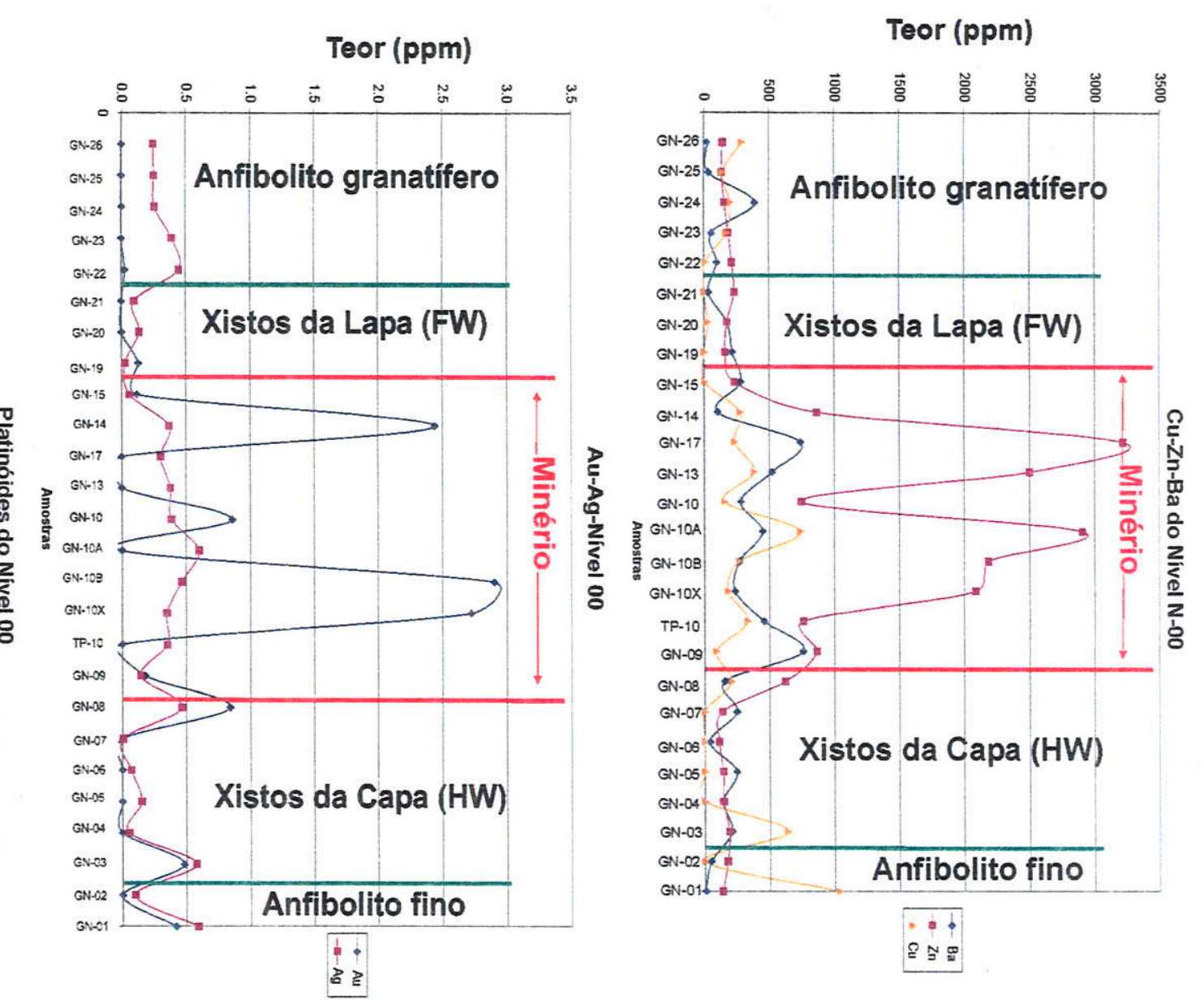
Evolução Petrogenética e Metalogenética da Mina de Au do Pari e Arredores, NE do Q. F.
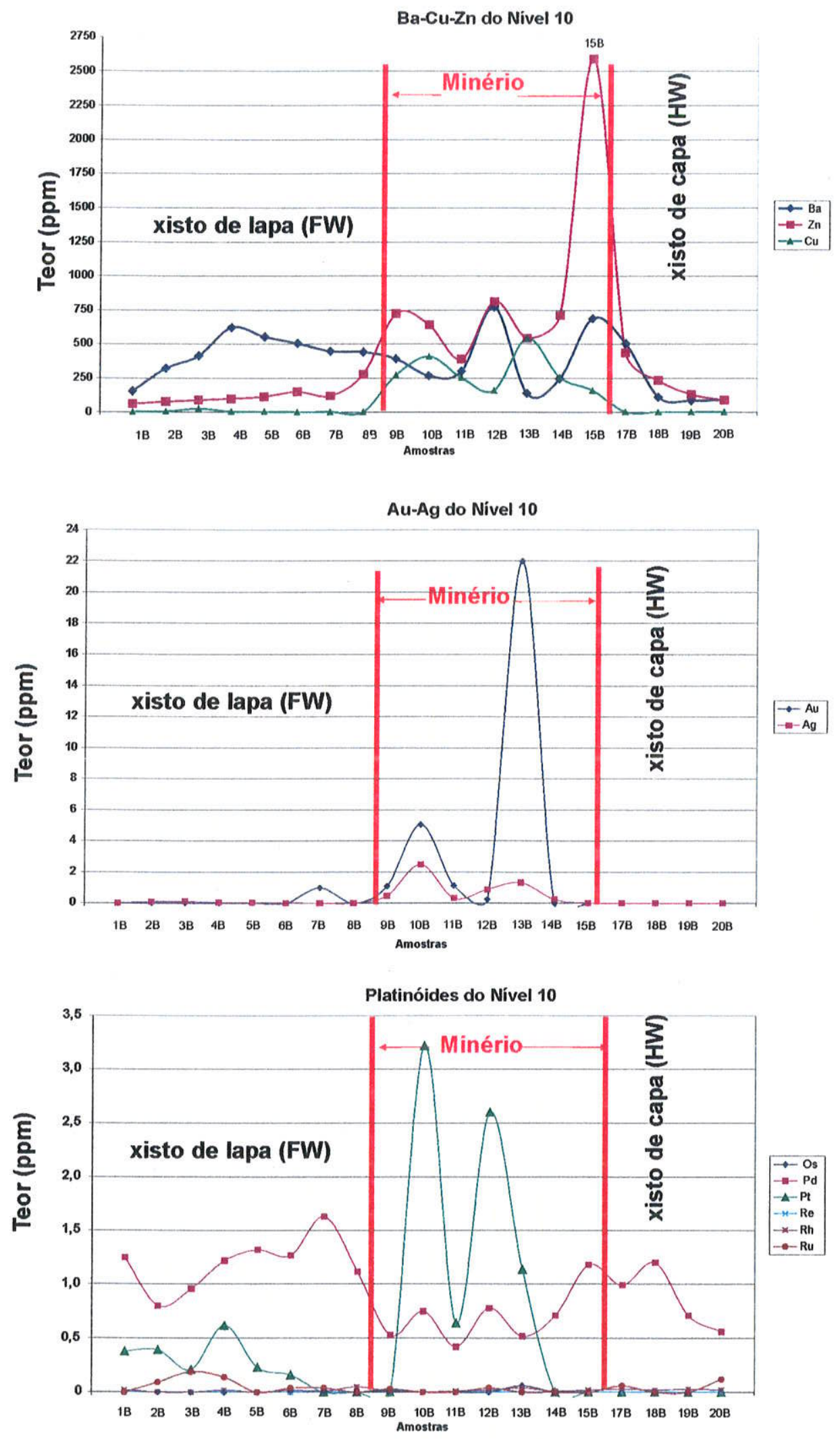

Figura 35b: Distribuição de $\mathrm{Cu}-\mathrm{Pb}-\mathrm{Zn}, \mathrm{Au}-\mathrm{Ag}$ e Platinóides no perfil do Nível 10 (N-10) 
entanto, Au e Ag ocorrem apenas na zona do minério, sendo este um dos locais mais ricos em Au da mineralização do Pari, tanto em teor quanto em espessura. Diferentemente, no nível de entrada as concentrações na zona mineralizada são menores que no nivel 10 , porém as encaixantes também se mostram portadoras de $\mathrm{Au}$ e $\mathrm{Ag}$, e ainda têm uma relação $\mathrm{Au} / \mathrm{Ag}$ bastante constante. Notam-se, também, diferenças e assimetrias na distribuição de $\mathrm{Au}-\mathrm{Ag}$, nas duas intersecções do horizonte do minério, indicando variações laterais nos processos mineralizantes.

V.2.6. Platina e Platinóides (figuras 35 a e $35 \mathrm{~b}$ ).

Pd e Pt são os elementos deste grupo que se destacam, porém apresentam comportamentos geoquímicos opostos entre si, e também entre os dois niveis estudados ( $\mathrm{N}-00$ e $\mathrm{N}-10$ ). $\mathrm{Pd}$ atinge suas maiores concentrações nas encaixantes enquanto a $\mathrm{Pt}$ tem seus maiores picos na zona mineralizada. Pd varia nas rochas encaixantes da capa e da lapa, estando nestas últimas, ligeiramente mais enriquecido. Entretanto, devem-se levar em consideração possíveis imprecisões analíticas para os elementos do grupo da Platina, sobretudo aqueles presentes em teores muito baixos, como $\mathrm{Os}, \mathrm{Re}, \mathrm{Rh}$ e $\mathrm{Ru}$, que nos gráficos mostram apenas esporádicos picos mínimos.

V.2.7. Li, Rb, Nb, Y e W (figuras 36a e 36b).

Este grupo de elementos foi tratado conjuntamente por suas concentrações bastante próximas e questões decorrentes de representação e escalas gráficas. Não necessariamente se trata de análogos geoquímicos.

$\mathrm{Li}$ e Rb tem suas maiores concentrações junto à mineralização do Nivel 00 . No Nível 10 há apenas maiores concentrações na zona mineralizada, principalmente do Li.

O W tem comportamento fortemente variável em ambos os niveis, podendo indicar presença de scheelita. $\mathrm{O} \mathrm{Nb}$ apresenta concentrações baixas e comportamento bastante constante, com pequenas variações na zona mineralizada. Já o Y mostra variações maiores com teores mais altos na zona mineralizada e mais baixos nos xistos encaixantes próximos. 

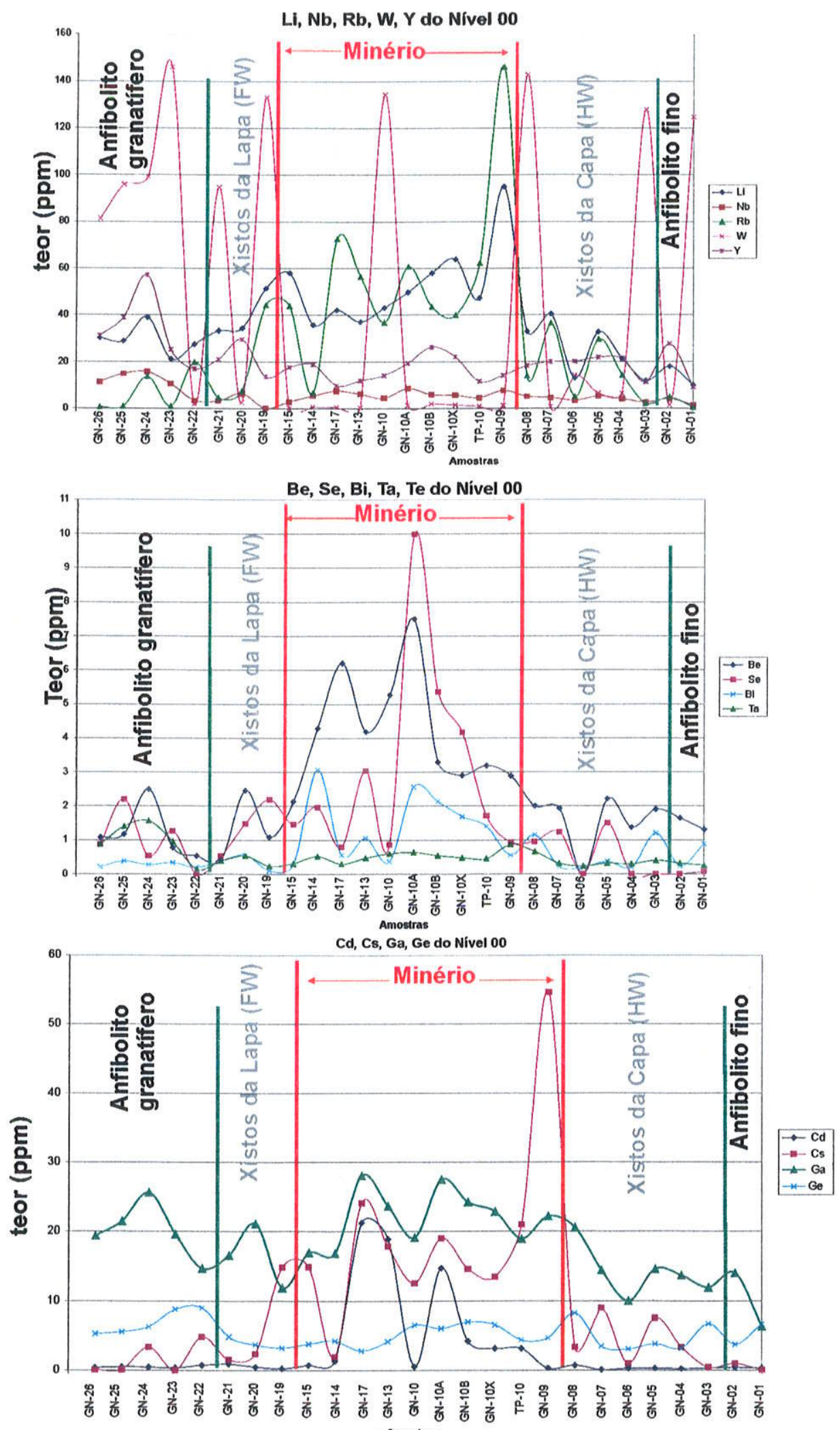

Figura 36a: Distribuição de Li-Rb-W-Nb-Y, Be-Se-Ta-Te-Bi, e Cd-Cs-GaGe no perfil do Nível de Entrada (N-00) 

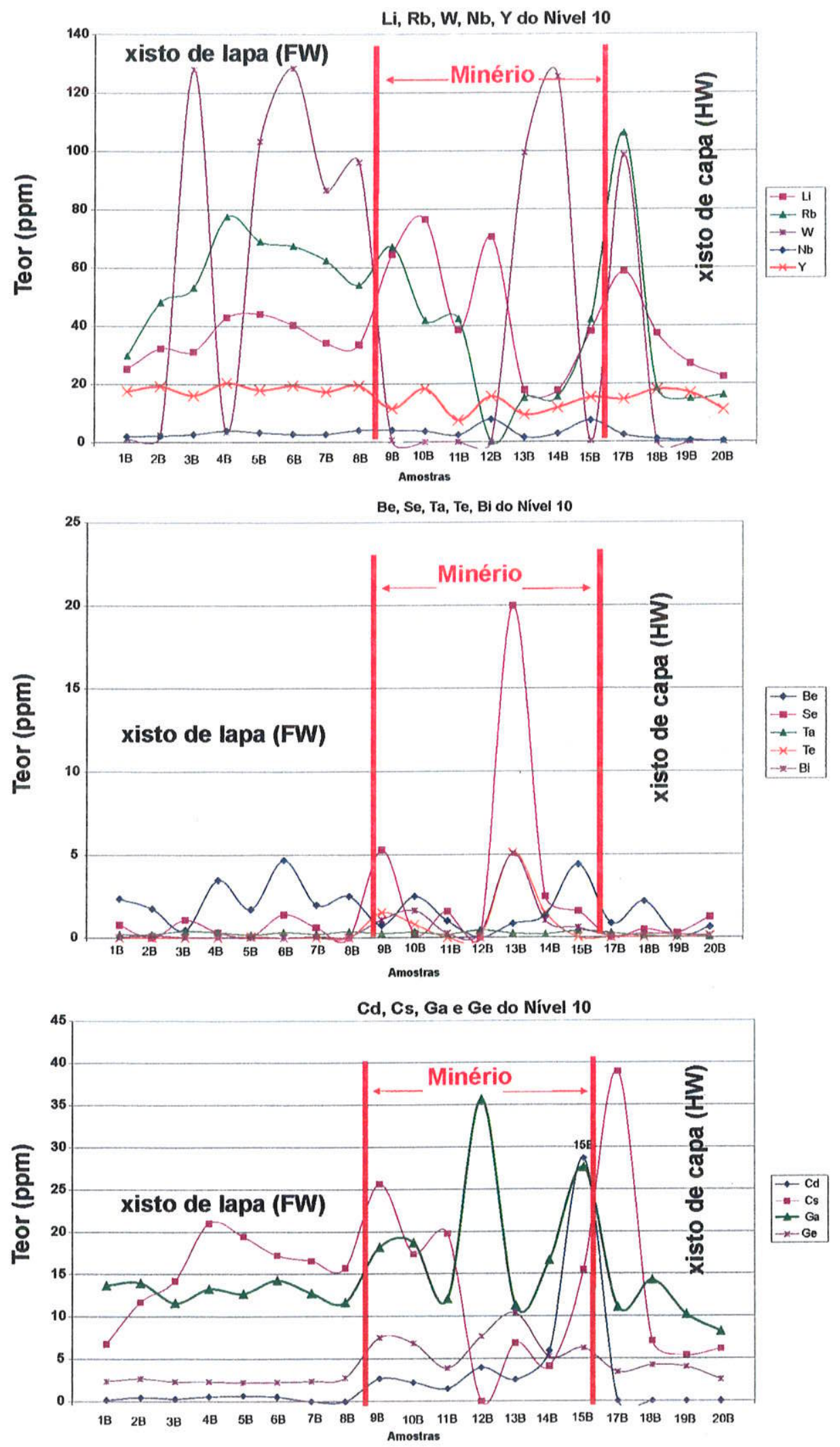

Figura 36b: Distribuição de Li-Rb-W-Nb-Y, Be-Se-Ta-Te-Bi, e Cd-CsGa-Ge do perfil do nível $10(\mathrm{~N}-10)$ 
V.2.8. Be, Se, Bi, Ta e Te (figuras 36a e 36b).

Este grupo de elementos também foi tratado conjuntamente por questões de representação e escala gráfica; apenas $\mathrm{Se}$, $\mathrm{Te}$ e $\mathrm{Bi}$ apresentam analogias geoquímicas.

No Nivel 00 há maiores concentrações de $\mathrm{Be}, \mathrm{Se}, \mathrm{Bi}$ e Te na zona mineralizada do que nas encaixantes. No nível 10 notam-se apenas concentrações mais significativas de $\mathrm{Se}, \mathrm{Te}$ e $\mathrm{Bi}$. Estes três elementos em geral também mostram correlações positivas com o Au (figuras $35 \mathrm{a}$ e $35 \mathrm{~b}$ ).

Ta, sempre, se apresenta em teores mínimos e sem variações significantes.

V.2.9. Cd, Cs, Ga e Ge (figuras 36a e 36b).

Estes elementos também foram tratados conjuntamente pelos motivos acima expostos, gráficos e não geoquímicos.

$\mathrm{Cd}$ e Ga aparecem enriquecidos na zona mineralizada de ambos os niveis; são análogos geoquímicos do $\mathrm{Zn}$ e $\mathrm{Al}$, respectivamente, e mostram correlações positivas com estes. O Cs na zona mineralizada tem comportamento diferente entre os níveis, sendo enriquecido no nível 00 e empobrecido no nivel 10. De um modo geral apresenta similaridades geoquímicas e correlações positivas com o Rb. Entretanto, em algumas amostras do minério e das encaixantes imediatas ainda mostra comportamento similar ao $\mathrm{Cr}$. $\mathrm{O}$ Ge apresenta-se constante no nivel 00 e enriquecido na zona do minério do nível 10.

\section{V.2.10. Elementos Terras Raras (REE) (figuras 37a e 37).}

Os REE variam sistematicamente em seus teores absolutos de $<2 \mathrm{ppm}$, no caso dos REE menos freqüentes, até valores máximos de 40-50 ppm para o Ce e também de REE totais, que de um modo geral se encontram nos minérios de ouro; entre si, seguem na ordem da abundância natural cósmica, exceção feita para La e Nd.

As rochas do nivel de entrada $(\mathrm{N}-00)$ mostram um comportamento ligeiramente assimétrico das terras raras na capa e na lapa da mineralização. Os anfibolitos da lapa possuem as maiores concentrações de ETR, sendo neste nível, anfibolitos granatiferos ( $\mathrm{GN}-24, \mathrm{GN}-25$ e $\mathrm{GN}-26$ ). Os xistos encaixantes imediatos da lapa e da apresentam teores similares e simétricos de ETR, crescentes em direção aos minérios. No nível 10 os xistos encaixantes da lapa apresentam teores de ETR mais elevados e constantes, pouco variáveis, até o contato com o minério aurífero; já os 
xistos da capa mostram teores rapidamente decrescentes de ETR em geral e principalmente dos ETRL (Ce, La, Nd) (amostras 17B a 20B).

Os minérios de ouro dos níveis $\mathrm{N}-00$ e N-10 apresentam teores e padrões similares bastante variáveis de ETR. Em relação aos xistos encaixantes imediatos, os minérios são mais ricos em ETR e ainda apresentam ao contrário dos xistos, teores de $\mathrm{La}>\mathrm{Nd}$.

V.2.11. Hf, U, The $\mathrm{Zr}$ (figuras $37 \mathrm{a}$ e $37 \mathrm{~b}$ ).

Nesse grupo de elementos, Hf e Zr são análogos geoquímicos, e adicionalmente existem também relações de isomorfia entre todos eles ( $\mathrm{Zr}, \mathrm{Hf}, \mathrm{U}$ e $\mathrm{Th}$ ), tanto em silicatos quanto na forma de óxidos.

Hf e U mostram concentrações baixas e variações pequenas e insignificantes nos dois perfis estudados (niveis 00 e 10).

O Zr apresenta-se com forte assimetria entre xistos da capa e da lapa, dos níveis 00 e 10 , sendo os anfibolitos do nível 00 as rochas mais ricas em $\mathrm{Zr}$, possuindo quase as mesmas concentrações que a zona mineralizada.

O Th é mais concentrado e melhor correlacionado com o $U$ na zona mineralizada; não mostra assimetrias entre os xistos da capa e da lapa.

V.2.12. Sb, Sc e Sn (figuras 37 a e $37 b$ ).

Estes elementos também foram tratados conjuntamente por motivos de escala gráfica, não se tratando de análogos geoquímicos.

$\mathrm{Sb}$ tende a ser mais concentrado na zona mineralizada e, no nivel 10 , mostra correlação positiva perfeita com o $\mathrm{Au}$ (e Ag); já no nivel 00 essa correlação é mais fraca. Sc no nivel 00 varia de forma irregular, entre 15 e $45 \mathrm{ppm}$, tanto nas rochas encaixantes quanto no minério; no nivel 10 é claramente empobrecido no minério em relação aos xistos encaixantes. $S n$ varia muito mostrando picos esporádicos com teores de 10-20 ppm, além de teores zero, tanto nas encaixantes quanto nos minérios, sem correlações evidentes com outros elementos. 

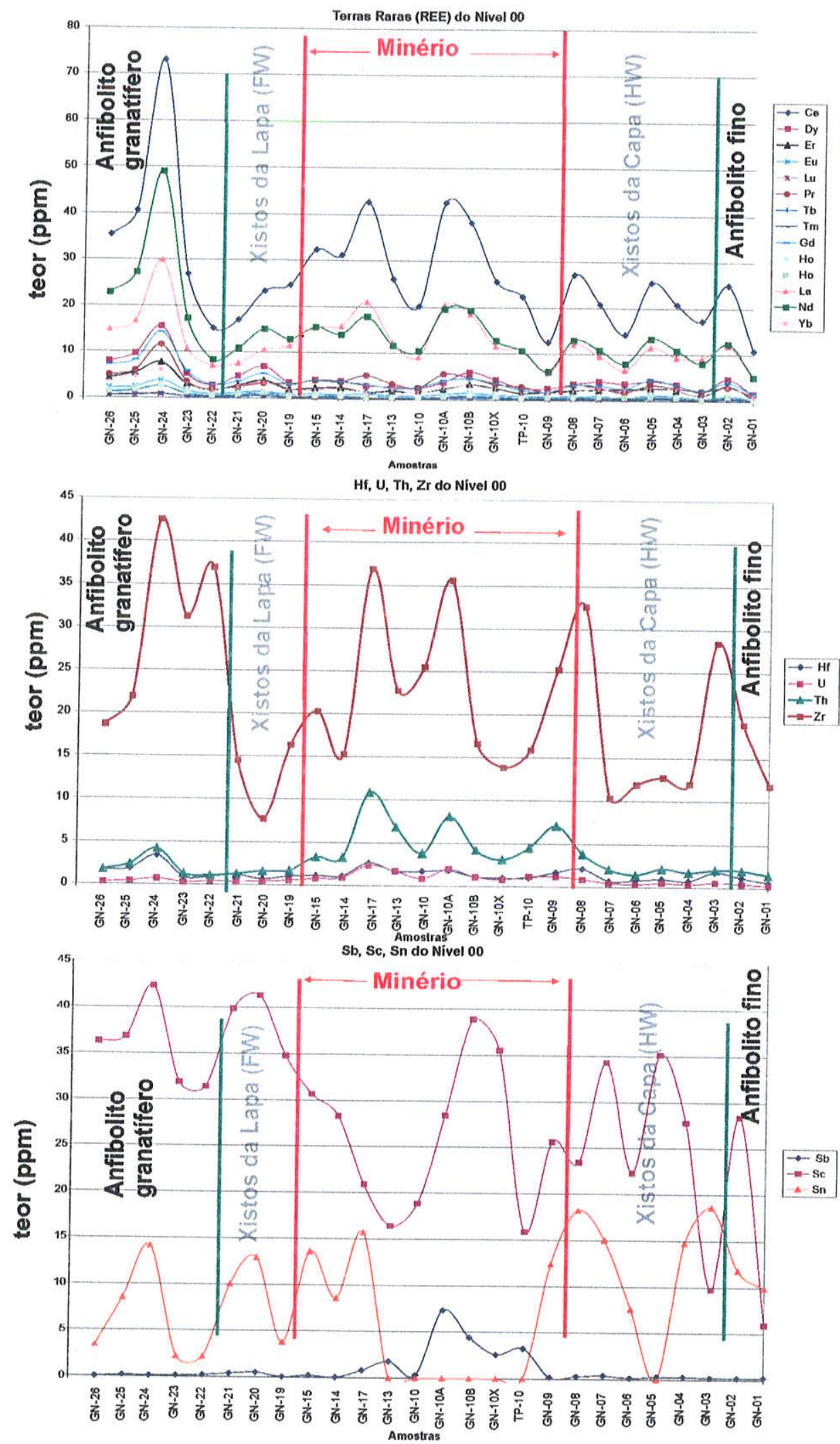

Figura 37a: Distribuição de REE, Hf, U, Th, Zr e SB, Sc, SN no perfil do Nível de Entrada (N-00) 

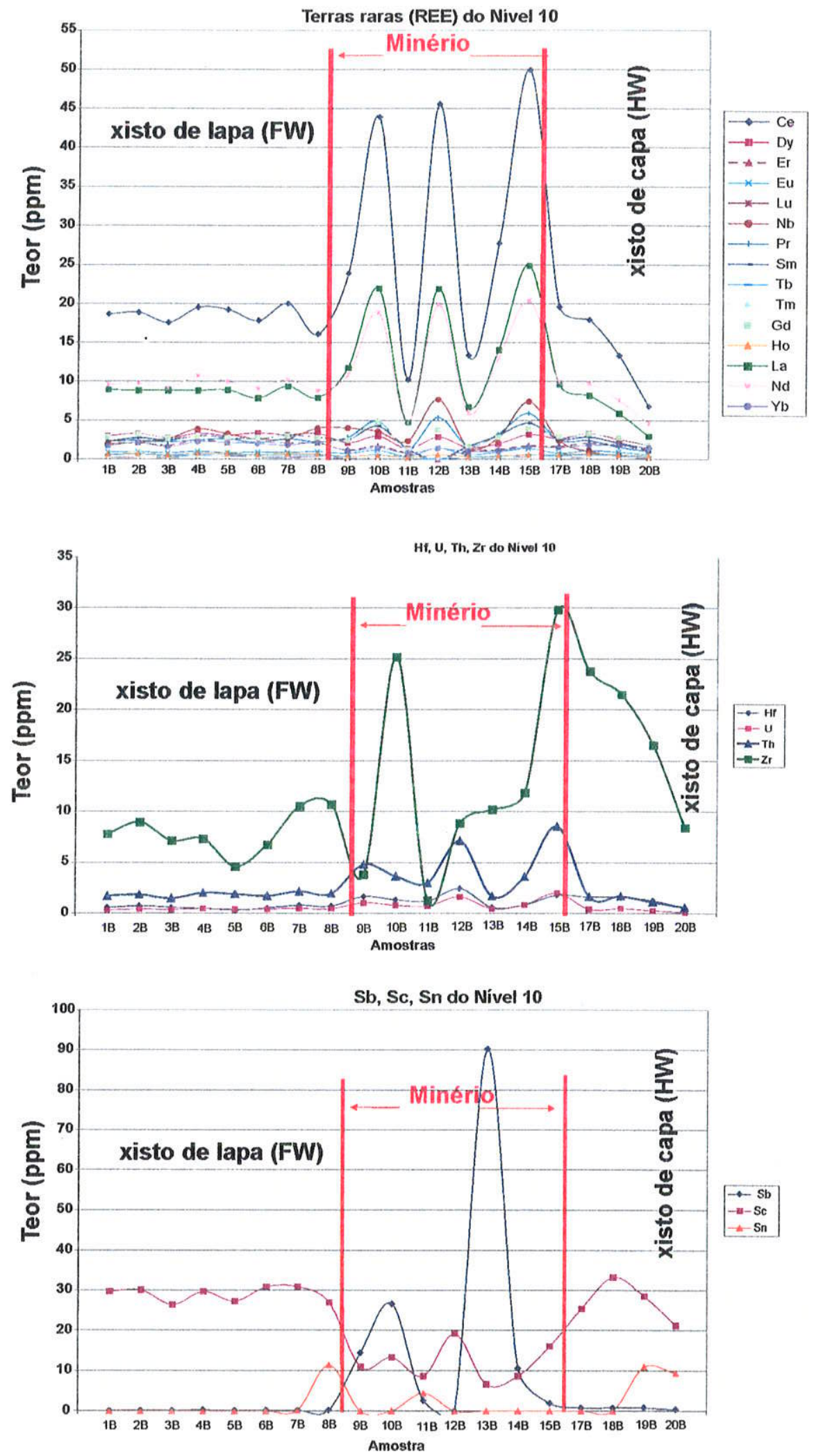

Figura 37b: Distribuição de REE, Hf-U-Th-Zr do perfil do nível $10(\mathrm{~N}-10)$. 


\section{V.3. Diagramas de Harker e Ternários}

$\mathrm{Na}$ figura 38 são analisadas em diagramas, segundo Harker (óxidos maiores $\times \mathrm{SiO}_{2}$ ), amostras da mineralização, encaixantes próximas e anfibolitos (da capa e da lapa) mais distantes da mineralização, para verificar possiveis tendências geoquímicas características sejam de alteração ou não, dos anfibolitos distantes como litotipos mais preservados para os xistos mais alterados encaixantes imediatos da capa e da lapa da mineralização. É interessante observar que, na maioria dos diagramas existem caminhos distintos para as rochas da capa e da lapa. Alguns óxidos, como $\mathrm{K}_{2} \mathrm{O}, \mathrm{CaO}, \mathrm{Na}_{2} \mathrm{O}$ e $\mathrm{MgO}$ mostram até caminhos geoquímicos opostos. No caso específico do $\mathrm{Na}_{2} \mathrm{O}$, é marcante seu comportamento nas amostras da lapa (FW), indicando processos de espilitização, que afetaram os protolitos. Já o MgO que é marcantemente enriquecido nas amostras da capa (HW), pode ser interpretado como base cumulática de um novo derrame que extrudiu sobre a mineralização aurífera pré-existente.

Na figura 39, usando elementos menores e traço, também foram traçados os caminhos da variação geoquímica dos litotipos da capa e da lapa indicando tendências opostas. O Ba mostrou comportamentos distintos entre a capa e a lapa. O diagrama $\mathrm{S}+\mathrm{As}$ versus $\mathrm{SiO}_{2}$ mostra duas tendências distintas nas amostras da mineralização, e que são distintas, também, da tendência indicada pela linha azul que representa as encaixantes.

Nas figuras 40 a 42, foram construidos diagramas tipo Harker de elementos maiores e traço versus $\mathrm{Al}_{2} \mathrm{O}_{3}$, com 0 intuito de observar variações na mobilidade dos elementos, haja visto a menor mobilidade da alumina. Assim também, observam-se tendências opostas entre capa (linhas verdes) e lapa (linhas amarelas). A mineralização, marcada com linhas vermelhas tracejadas, quase sempre segue caminhos diferentes da capa e da lapa, ou ainda intermediários.

$\mathrm{Na}$ figura 42 , os diagramas de elementos menores e traço, são ainda mais ilustrativos dos sentidos opostos e produtos finais distintos na lapa e na capa. 

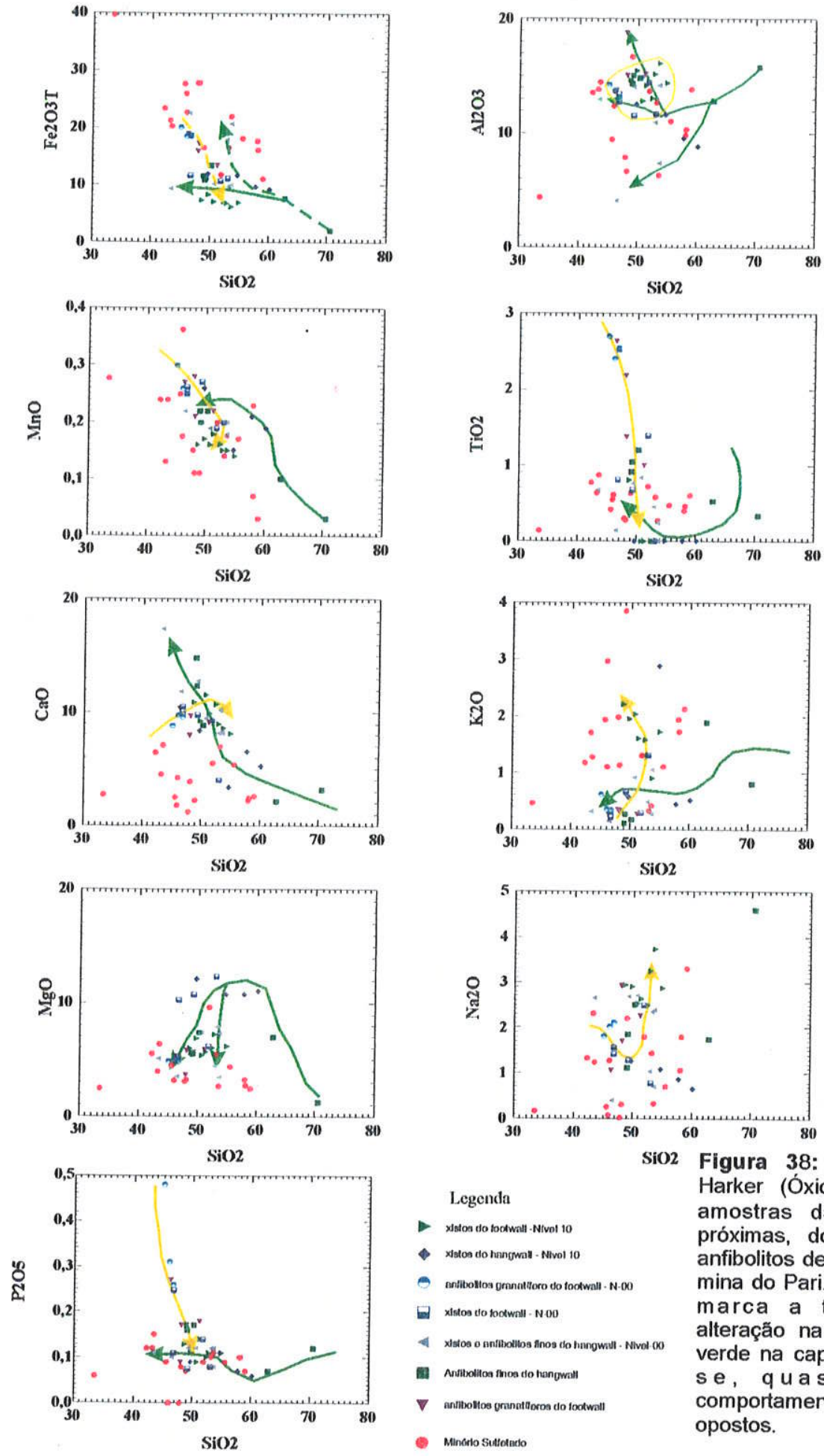

38: Diagramas de Harker (Óxidos $\times \mathrm{SiO}_{2}$ ) de amostras das encaixantes próximas, do minério e de anfibolitos de capa e lapa, da mina do Pari. A linha amarela marca a tendencia de alteração na lapa (FW) e a verde na capa (HW). Notamse, quase sempre, comportamentos geoquímicos opostos. 
Evolução Petrogenética e Metalogenética da Mina de Au do Pari e Arredores, NE do Q. F.
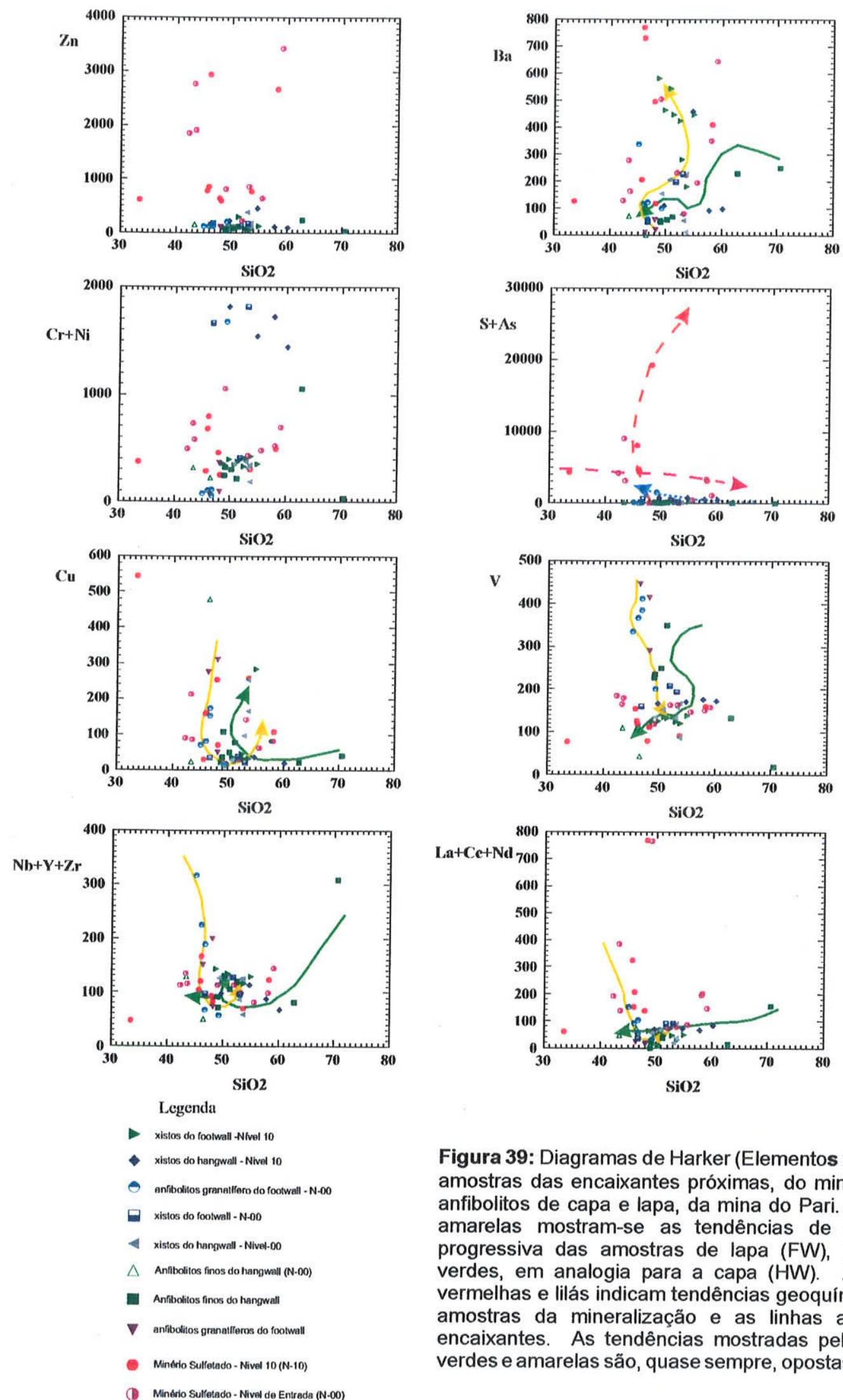

Figura 39: Diagramas de Harker (Elementos $\times \mathrm{SiO}_{2}$ ) de amostras das encaixantes próximas, do minério e de anfibolitos de capa e lapa, da mina do Pari. As linhas amarelas mostram-se as tendências de alteração progressiva das amostras de lapa (FW), as linhas verdes, em analogia para a capa (HW). As linhas vermelhas e lilás indicam tendências geoquímicas das amostras da mineralização e as linhas azuis das encaixantes. As tendências mostradas pelas linhas verdes e amarelas são, quase sempre, opostas. 
Evolução Petrogenética e Metalogenética da Mina de Au do Pari e Arredores, NE do Q.F.
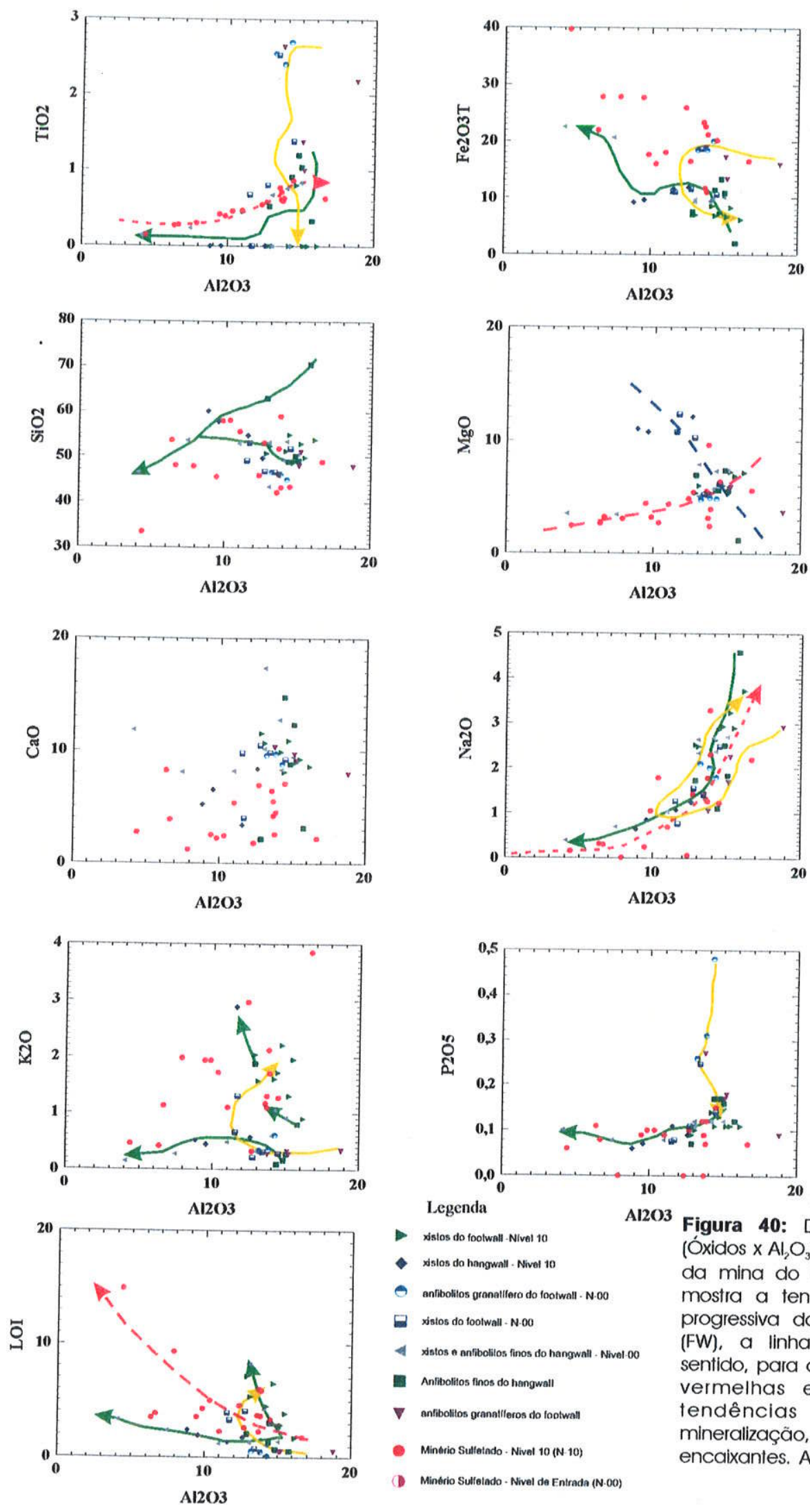

1203 Figura 40: Diagramas de Harker (Óxidos $\times \mathrm{Al}_{2} \mathrm{O}_{3}$ ) de amostras diversas da mina do Pari. A linha amarela mostra a tendência de alteraçäo progressiva das amostras de lapa (FW), a linha verde, de mesmo sentido, para a capa (HW). As linhas vermelhas e lilás tratam das tendências das amostras da mineralização, e as linhas azuis das encaixantes. As tendências entre as 
Evolução Petrogenética e Metalogenética da Mina de Au do Pari e Arredores, NE do Q. F.
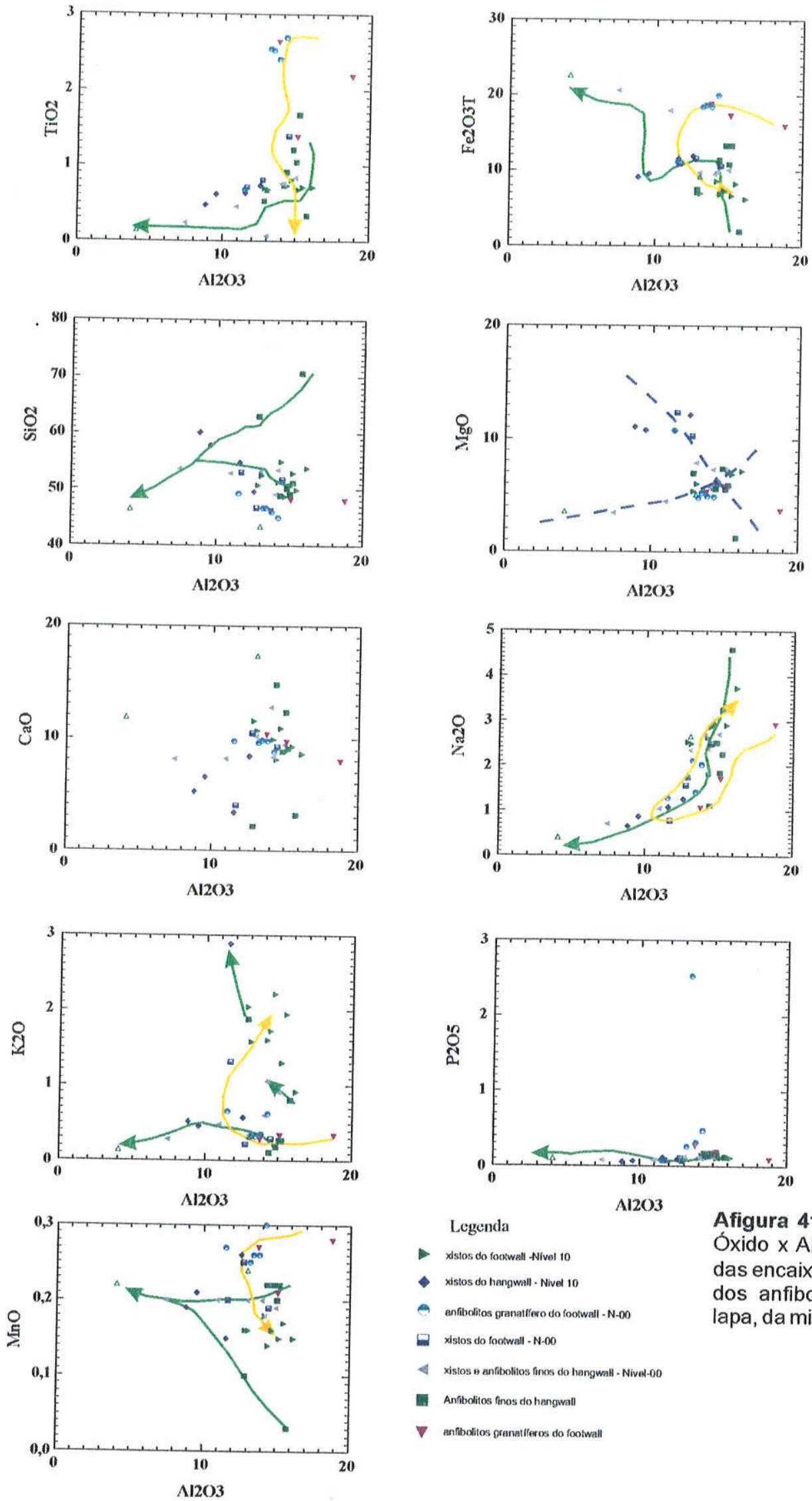

Afigura 41: Diagramas de Óxido $\times \mathrm{Al}_{2} \mathrm{O}_{3}$ de amostras das encaixantes próximas e dos anfibolitos de capa e lapa, da mina do Pari.

anfibolitos granalleno do gotwall - N-9m 

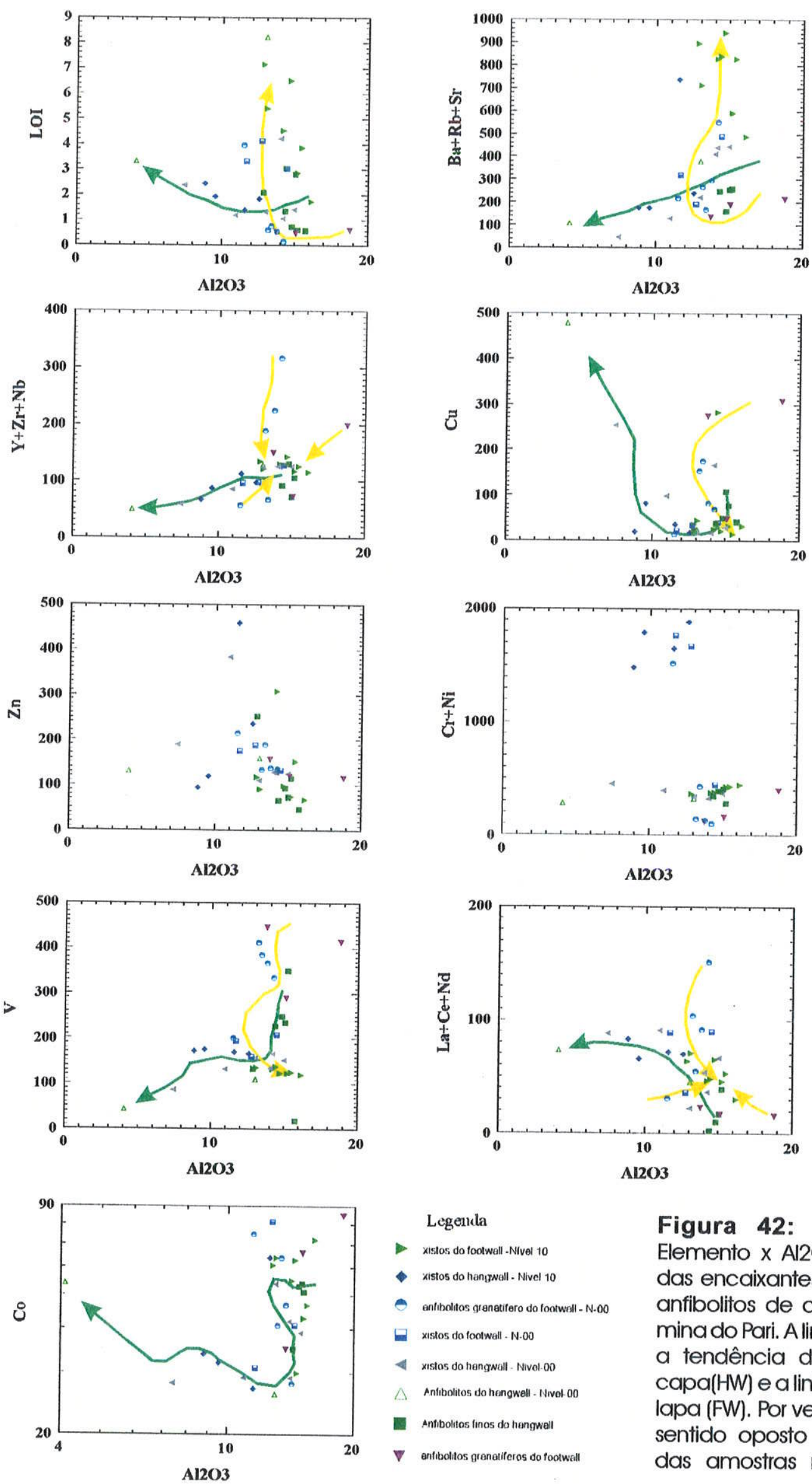

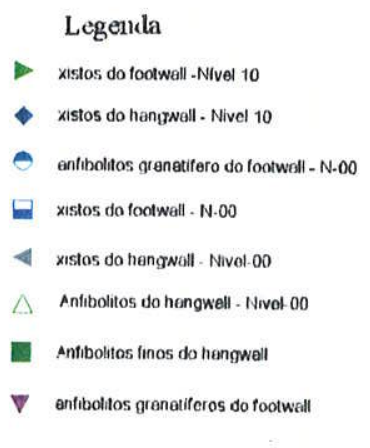

Figura 42: Diagramas de Elemento $x$ Al2O3 de amostras das encaixantes próximas e dos anfibolitos de capa e lapa, da mina do Pari. A linha verde mostra a tendência das amostras da capa(HW) e a linha amarela a da lapa (FW). Por vezes observa-se o sentido oposto das tendências das amostras menos para as 
$\mathrm{Na}$ figura 43, as representações de $\mathrm{Au}, \mathrm{Ag}, \mathrm{As}, \mathrm{S}$ versus $\mathrm{Al}_{2} \mathrm{O}_{3}$, permitiram verificar que na mineralização, e mesmo nas encaixantes, $A u, S$ e As têm comportamento oposto ao da alumina, ou seja, o minério é pobre em Al, e muito provavelmente, processos que geram enriquecimento de $\mathrm{Al}_{2} \mathrm{O}_{3}$, tal como shear zones não atuaram na mineralização aurifera sulfetada da mina do Pari, o que se observa, também no comportamento dos litotipos encaixantes que acompanham a mineralização (ver também os diagramas de elementos versus sílica dos figura 39 e 43). Já a prata ( $\mathrm{Ag})$ mostra comportamentos diferentes em relação aos demais elementos do "grupo do $\mathrm{Au}$ " apresentando distribuição bimodal (figura 39). Nos minérios ocorrem concentrações baixas quase constantes independentemente dos teores de Au; nas encaixantes a $\mathrm{Ag}$ atinge seus teores máximos com tendências evolutivas similares ao Cu e $\mathrm{Zn}$ (figura 42). 
Evolução Petrogenética e Metalogenética da Mina de Au do Pari e Arredores, NE do Q. F.
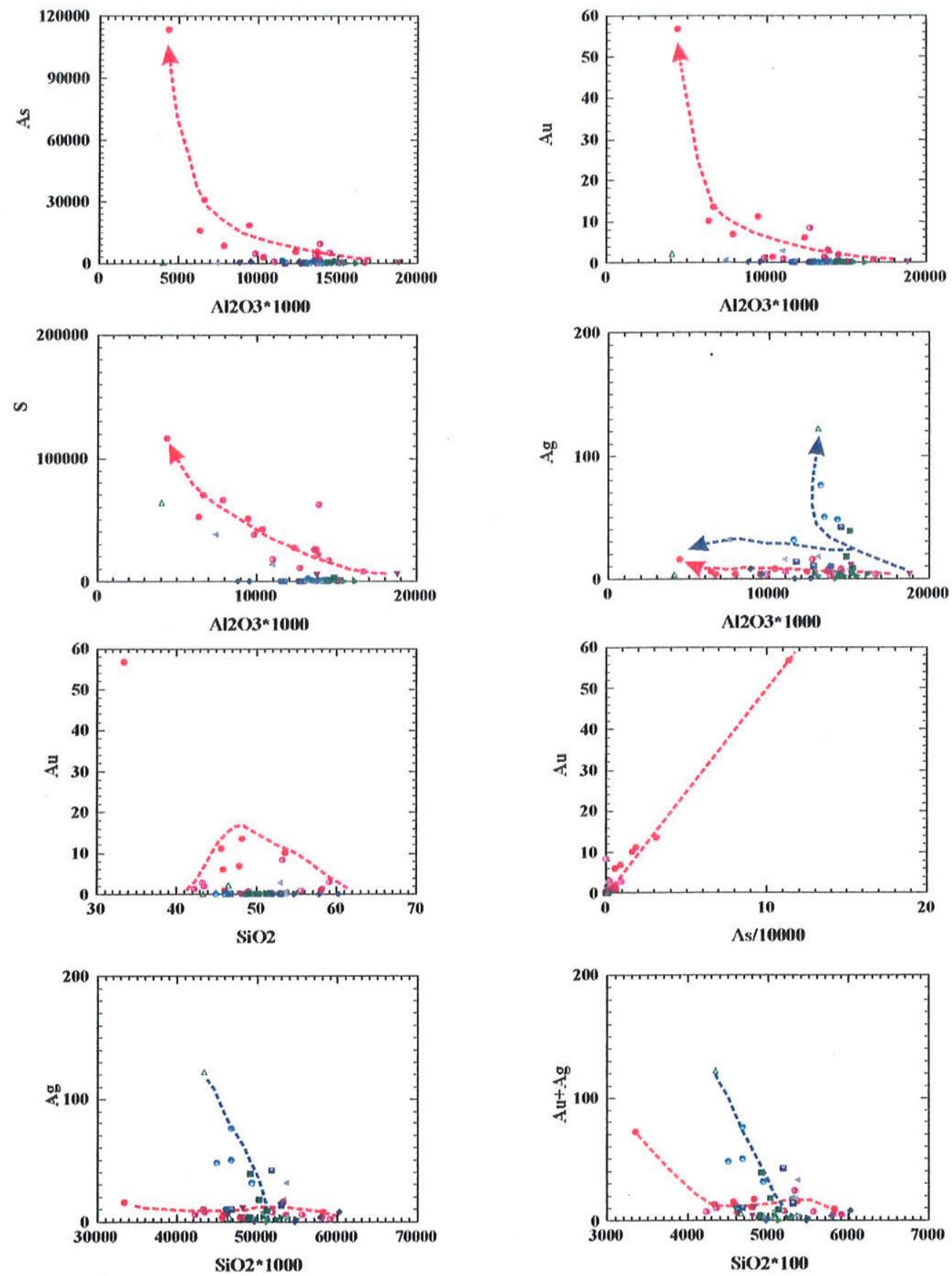

Legenda

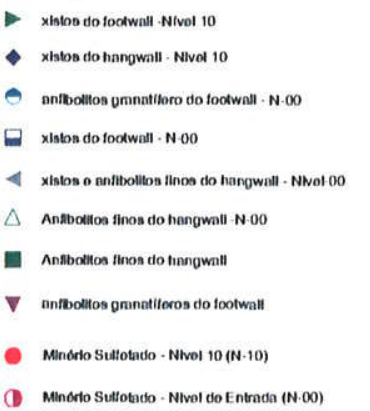

Figura 43: Diagramas Binários ( $\mathrm{Au}, \mathrm{Ag}, \mathrm{S}, \mathrm{As} \times \mathrm{Al}_{2} \mathrm{O}_{3}$ e $\mathrm{SiO}_{2}$ ) de amostras das encaixantes próximas, do minério e de anfibolitos de capa e lapa, da mina do Pari. As linhas vermelhas tracejadas mostram as tendências da evolução geoquímica das amostras da mineralização e as linhas azuis, para as amostras das encaixantes. Apenas em alguns diagramas observam-se comportamentos distintos entre as amostras da mineralização e encaixantes, a exemplo de $\mathrm{Ag}, \mathrm{Au}+\mathrm{Ag} \times \mathrm{Al} 2 \mathrm{O} 3$ ou $\mathrm{SiO} 2$, ou $\mathrm{Au} x$ $\mathrm{SiO} 2$. 


\section{V.4. Diagramas Normalizados de Terras Raras (ETR)}

Os ETR foram tratados em diagramas de distribuição padronizados utilizando diversos fatores de normalização, e mostraram diferenças, mas também, interrelacionamentos no comportamento geoquímico entre as rochas da capa, lapa e da zona mineralizada, bem como entre os anfibolitos granatiferos da base (Anf-FW) e os anfibolitos finos do topo (capa $=$ Anf-HW) do horizonte Pari.

$\mathrm{Na}$ figura 44 Sao apresentados diagramas de distribuição dos ETR com normalização condrítica (Condrito $\mathrm{C} 1$ ); demais diagramas, utilizando outras normalizações, encontram-se nos anexo 7.

O comportamento geral dos ETR, na grande maioria das rochas e dos minérios estudados (Figura 44), é bastante parecido, mostrando fracionamentos mais acentuados dos ETR-leves (La até $\mathrm{Nd}$ ou $\mathrm{Sm}$ ), diminuindo progressivamente nos ETR-médios ( $\mathrm{Gd}$ até Ho) e diminuindo ainda mais, em casos até zero, para os ETRpesados, ou mesmo evidenciando enriquecimentos destes últimos, principalmente de Lu, ou de $\mathrm{Yb}$ e Lu. Anomalias de Eu são em geral inexistentes ou pouco expressivas, positivas ou negativas.

A maioria dos anfibolitos granatíferos da lapa (Anf-FW) e um anfibolito fino da capa (Anf-HW) mostram-se caracterizados por decréscimos essencialmente constantes de La até Lu, em dois casos atenuados e com pequenas anomalias positivas de ETR-pesados, sem anomalias de Eu, resultando em padrões escalonados, em linhas subparalelas de evolução, indicativos de derrames diferenciados. Apenas 2 anfibolitos, um granatífero (da lapa) e um fino (da capa), apresentam fracionamentos maiores de ETR-leves e pequenos enriquecimentos de ETR-pesados mais condizentes com protolitos basálticos cálcio-alcalinos (Condie, 1981).

De um modo geral os espectros de ETR dos anfibolitos predominantes da base e do topo do horizonte Pari são bastante semelhantes aos observados nos toleiítos arqueanos de muitos dos greenstone belts mundialmente conhecidos (Hermann et al., 1976; Kerrich, 1983; entre outros), sobretudo aqueles que sofreram algum tipo de alteração de fundo oceânico. Os espectros de ETR dos anfibolitos da mina do Pari, também se encaixam de forma bastante satisfatória na faixa de variação dos toleítos arqueanos de tipo TH2 (ou EAT) de Condie (1981). Nesse caso também, pequenas diferenças eventuais, podem ter sido causadas por processos de alteração de fundo oceânico, de espilitização ou mineralização; assim, por exemplo, no caso da amostra GN-01, de um anfibolito fino da capa, que se apresenta mineralizado com teores elevados de Cu e S (Anexo 4). 
Os xistos da lapa (Xisto-FW) e da capa (Xisto-HW) mostram padrões de ETR-leves nitidamente fracionados, com fracionamento decrescente até o desaparecimento nos ETR-médios e padrões constantes ou mesmo com leves enriquecimentos dos ETRpesados. Algumas poucas exceções apresentam fracionamentos mais contínuos, mesmo assim de tendências decrescentes, desde os ETR-leves até pesados. Anomalias de Eu são predominantemente ausentes; quando existentes são pouco expressivas, ora positivas ora negativas (Figura 44). Tais espectros de ETR são típicos de sedimentos arqueanos e foram interpretados, ou indicativos da derivação dos sedimentos de rochas vulcânicas básicas a intermediárias cálcio-alcalinas (Jakes e Taylor, 1974; Nance e Taylor, 1976), ou como misturas de sedimentos derivados de suítes vulcânicas bimodais, félsicas e básicas toleiíticas (Condie, 1981).

Os padrões de ETR dos minérios de ouro do horizonte Pari apresentam-se com traçados caracteristicamente similares aos xistos encaixantes imediatos da capa e da lapa deste horizonte, entretanto, são enriquecidos em ETR-leves em relação aos xistos (Figura 44). Comparados com outros BIF arqueanos de fácies óxido (com magnetita), carbonato, carbonato-silicato e sulfeto do mundo (Fryer, 1983) e da mina São Bento (Valladares, 2004) apresentam-se enriquecidos em ETR-leves, apresentando maiores analogias com os BIF volcanogénicos da Socoman Iron Formation (Fryer, 1983) e com os BIF de fácies silicato da mina São Bento (Valladares, 2004). Estas características coincidem com a natureza petrográfica de BIF de fácies mista (sulfeto, carbonato, silicato e óxido com magnetita), alumínicos e impuros por contaminações, em proporções variáveis, com finos vulcânicos (tufos) e lou vulcano-sedimentares (tufitos). 

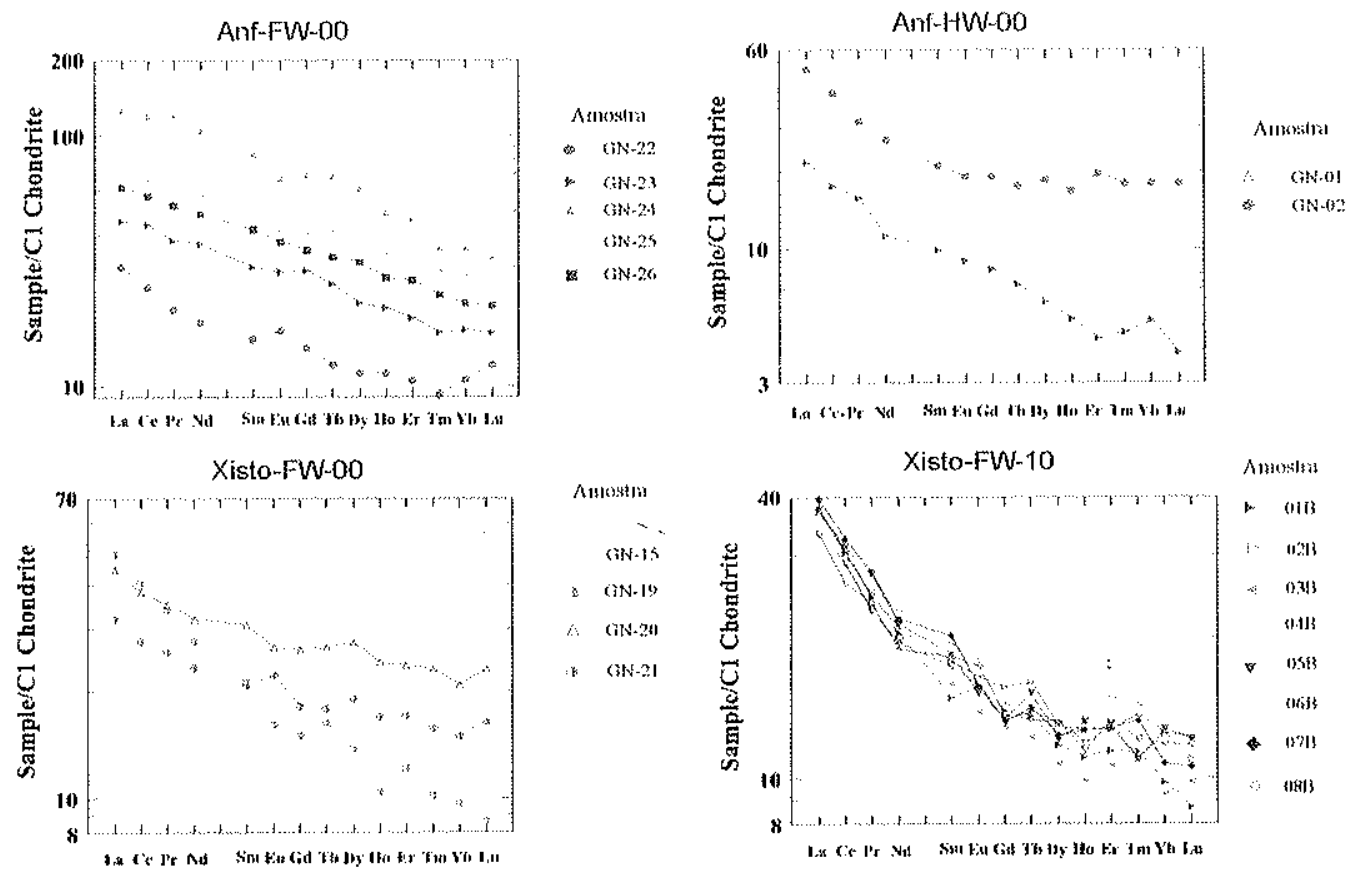

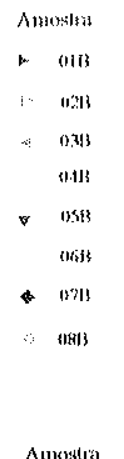
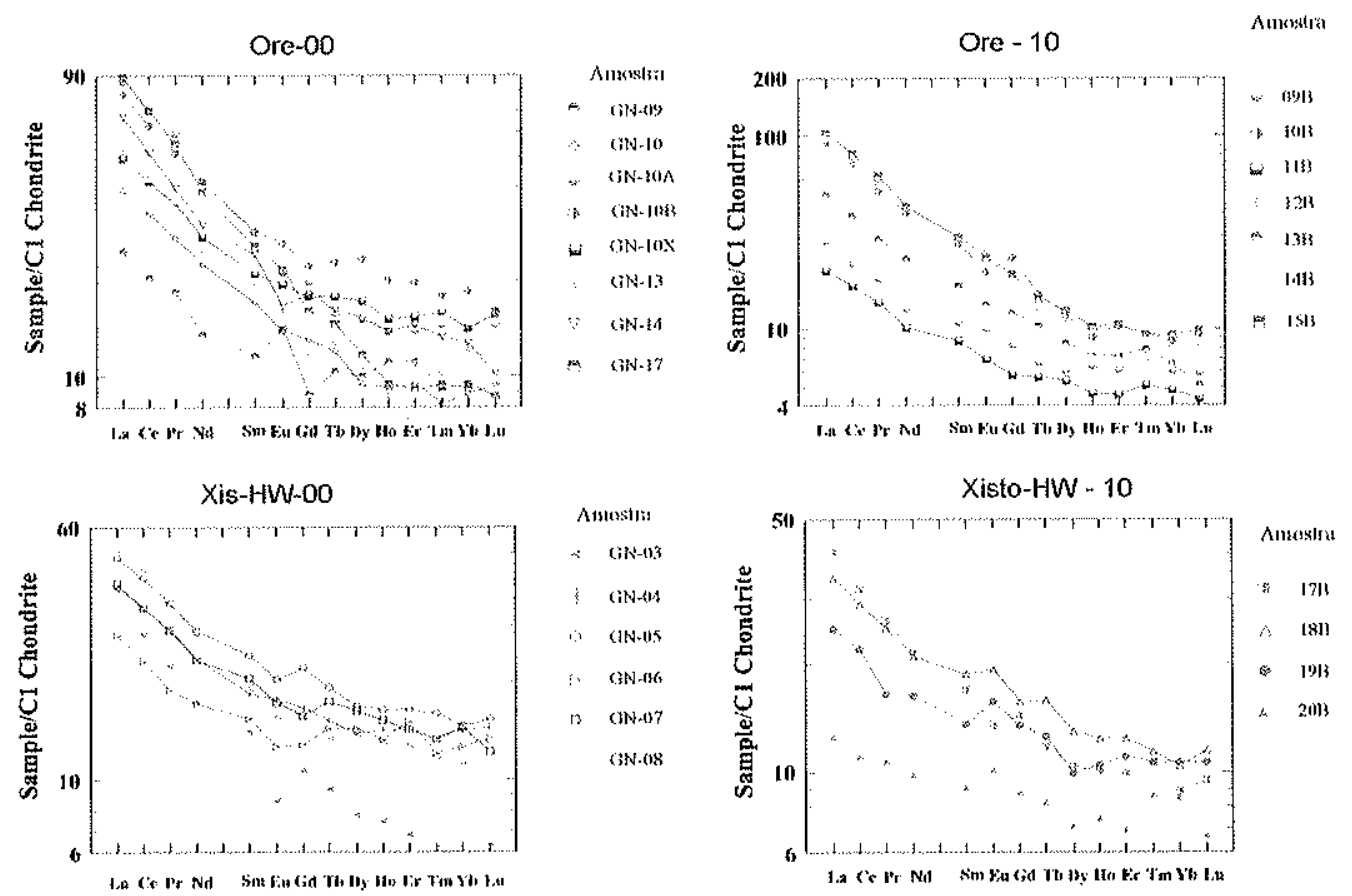

Figura 44: Diagramas normalizados de ETR para os litotipos encaixantes, anfibolitos da capa e da lapa, e os minérios de Au dos niveis 10 el de entrada (N-00) da mina do Pari. 


\section{V.5. Coeficientes de Correlação (Anexo 8)}

Dados de estatística básica e coeficientes de correlação foram calculados para as amostras analisadas por Fluorescência de raios $X(X R F)$ e por fire assay/absorção atômica (Anexo 4).

Os coeficientes de correlação foram tratados em conjunto destacando-se a forte correlação do Au com As e $\mathrm{S}$. Também se observam as fortes correlações (positivas e negativas) entre $\mathrm{V}$ e $\mathrm{TiO}_{2}, \mathrm{Fe}_{2} \mathrm{O}_{3 \mathrm{~T}}$ e $\mathrm{S}, \mathrm{Rb}$ e $\mathrm{K}_{2} \mathrm{O}, \mathrm{Na}_{2} \mathrm{O}$ e $\mathrm{Sr}, \mathrm{Al}_{2} \mathrm{O}_{3}$ e $\mathrm{Na}_{2} \mathrm{O}, \mathrm{Cu}$ e $\mathrm{S}$, e $\mathrm{Ni}$ e $\mathrm{Cr}$.

Nas amostras da mineralização, o Au correlaciona-se muito bem com $\mathrm{Fe}_{2} \mathrm{O}_{3 \mathrm{~T}}$, LOI (perda ao fogo), $\mathrm{S}$ e As. O $\mathrm{S}$ tem fortes correlações com $\mathrm{TiO}_{2}, \mathrm{Al}_{2} \mathrm{O}_{3}, \mathrm{LOI}, \mathrm{Cu}$ e As. Além dessas, destacam-se ainda boas correlações de $\mathrm{SiO}_{2}$ e $\mathrm{Fe}_{2} \mathrm{O}_{3}$ r; $\mathrm{TiO}_{2}$ e $\mathrm{Al}_{2} \mathrm{O}_{3}$; $\mathrm{TiO}_{2}$ e V; $\mathrm{Al}_{2} \mathrm{O}_{3}$ e Cr; $\mathrm{Fe}_{2} \mathrm{O}_{3}$ e As, LOI e $\mathrm{Na}_{2} \mathrm{O} ; \mathrm{Na}_{2} \mathrm{O}$ e Sr; LOI e As; Sr com Zn e Ni; $\mathrm{Zr}$ e $\mathrm{Zn} ; \mathrm{V}$ e $\mathrm{U} ;$ e de $\mathrm{Co}$ com As.Já nas encaixantes diminui o número de correlações. O próprio Au possui correlações sempre abaixo de 0,6 ; apenas para $S$ de 0,71. Neste caso destacam-se as correlações entre $\mathrm{Al}_{2} \mathrm{O}_{3}$ e $\mathrm{La} ; \mathrm{TiO}_{2}$ e V; $\mathrm{Al}_{2} \mathrm{O}_{3}$ e $\mathrm{Na}_{2} \mathrm{O} ; \mathrm{MgO}$ com $\mathrm{Cr}$ e Ni; $\mathrm{Na}_{2} \mathrm{O}$ e $\mathrm{Sr} ; \mathrm{K}_{2} \mathrm{O}$ com $\mathrm{Rb}$ e Ba; Cu e S; e de $\mathrm{Cr}$ e Ni, típicas de rochas de filiação básica/metabásica e suas mineralizações, assim como, de elementos análogos geoquímicos.

\section{V.6. Balanço de Massa}

Com os dados geoquímicos de rocha total, por XRF (elementos maiores e traços) efetuou-se um estudo hipotético usando diagramas ISOCON, tentando-se avaliar a derivação por alteração de protolitos similares ou distintos dos xistos do FW e HW, como encaixantes imediatas da mineralização aurifera.

Para tanto partiu-se das hipóteses: a)-que os xistos encaixantes poderiam ser derivados dos anfibolitos próximos da capa e da lapa, por meio de um processo de alteração envolvendo trocas geoquímicas, ou b)-que poderiam ser produtos metamórficos originais e isoquímicos de protolitos próprios, distintos dos anfibolitos. No primeiro caso de processos posteriores à formação das rochas, ou seja, epigenéticos, o balanço de massa, tanto para os xistos e anfibolitos da capa quanto da lapa deveriam ser iguais, ou pelo menos bastante similares, em função da similaridade dos anfibolitos protolíticos reagindo com o mesmo fluido transformante. Já no caso de serem os xistos derivados de protolitos próprios, distintos dos anfibolitos não haveria esta identidade ou similaridade nos balanços de massa. 
O estudo do balanço de massa envolveu a comparação entre litotipos escolhidos preliminarmente como protolitos que eventualmente poderiam ter dado origem às encaixantes próximas do minério. Após vários testes com elementos possivelmente imóveis e avaliando-se cada coeficiente de correlação $R 2$, pode-se observar a excelente correlação linear entre $\mathrm{Al}_{2} \mathrm{O}_{3}, \mathrm{TiO}_{2}, \mathrm{P}_{2} \mathrm{O}_{5}, \mathrm{Zr}$ e $\mathrm{Nb}$. Com estes considerados elementos imóveis com R2 próximo a 1,0 foram inicialmente construidos diagramas de correlação para as amostras pouco ou não alteradas e aquelas consideradas muito alteradas.

Desta forma foram verificados os balanços de massa hipotéticos (perdas e ganhos) de cada uma das unidades estudadas, da capa e da lapa dos níveis 00 e 10, conforme proposto por Grant (1986), a partir de equações modificadas de Gresens (1967). Método semelhante foi utilizado por Chiarini (2001), que estudou espilitos, keratófiros e mineralizações associadas do greenstone belt de Piumhi, MG.

Uma vez definida, foi ajustada a reta ISOCON, passando pela origem $(0,0)$ do diagrama e a variação na concentração do elemento pode ser calculada a partir da equação de Grant (1986):

$$
C_{i}^{a}=\left(M^{o} / M^{a}\right)^{*}\left(C_{i}^{o}+\Delta C_{i}^{a}\right)
$$

\begin{tabular}{|c|c|}
\hline $\begin{array}{l}c_{1}{ }^{a}=\text { concentração do elemento } i \text { na rocha } \\
\text { alterada }\end{array}$ & $\mathrm{c}_{l}^{\circ}=$ conc. do elemento i na rocha não alterada \\
\hline $\begin{array}{l}M^{0} / M^{a} \text { minclinação da reta ISOCON=coeficiente } \\
\text { b }\end{array}$ & $\begin{array}{l}\Delta \mathrm{C}_{\mathrm{l}}{ }^{\mathrm{a}}=\text { variação da conc. do elemento i na rocha } \\
\text { alterada em relação a rocha não alterada }\end{array}$ \\
\hline
\end{tabular}

A razão $\left(M^{\circ} / M^{a}\right)=$ coeficiente $b$, obtida pelas retas ajustadas $(y=b x+a)$, foi utilizada nos cálculos de perdas e ganhos pela equação $\Delta \mathrm{Ci}=(\mathrm{Ci} / \mathrm{b})-\mathrm{Ci}^{\circ}$ em porcentagens. Assim, a média de 03 amostras de anfibolitos finos da capa (HW) foi comparada à média dos xistos adjacentes da capa (HW) (Figuras 45 e 46). Em seguida, a média de 03 anfibolitos granatiferos da lapa (FW) foi comparada com a média dos xistos da lapa (FW) (Figuras 51 e 52). Para os cálculos das composições médias utilizou-se o procedimento sugerido por Baumgartner \& Olsen (1995) e Sanchez-España et al. (2000), tanto para o N-00 quanto para o N-10.

Nas figuras $47,48,49$ e 50 são apresentados os diagramas de perdas e ganhos para os anfibolitos granatíferos da lapa (AnfG-FW) e os xistos da lapa (FW). 
Evolução Petrogenética e Metalogenética da Mina de Au do Pari e Arredores, NE do Q.F.

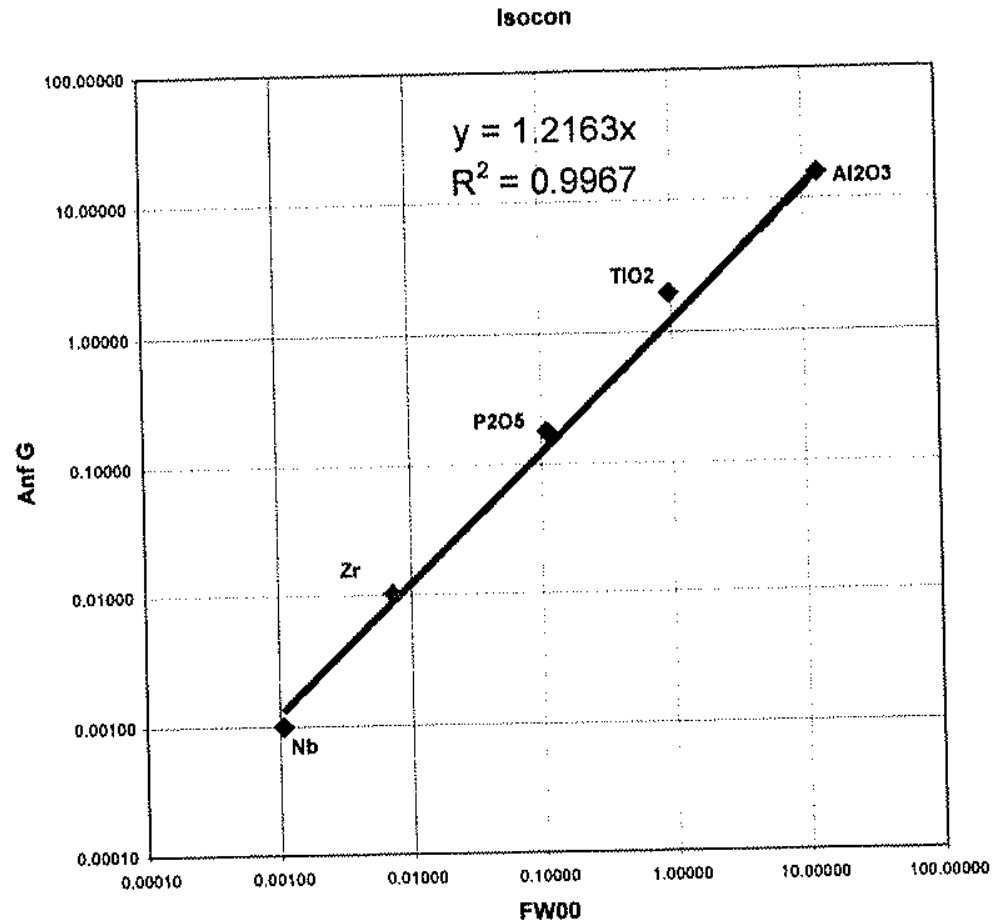

Figura 45: Elementos imóveis definindo reta isocon para os anfibolitos granatiferos do footwall (AnfG) e os xistos do footwall do nivel 00 (xistos FW00). Nos cálculos e plotagem foram usadas as médias das amostras. O valor de R2 (coeficiente de correlação) próximo a l, mostra excelente correlação.

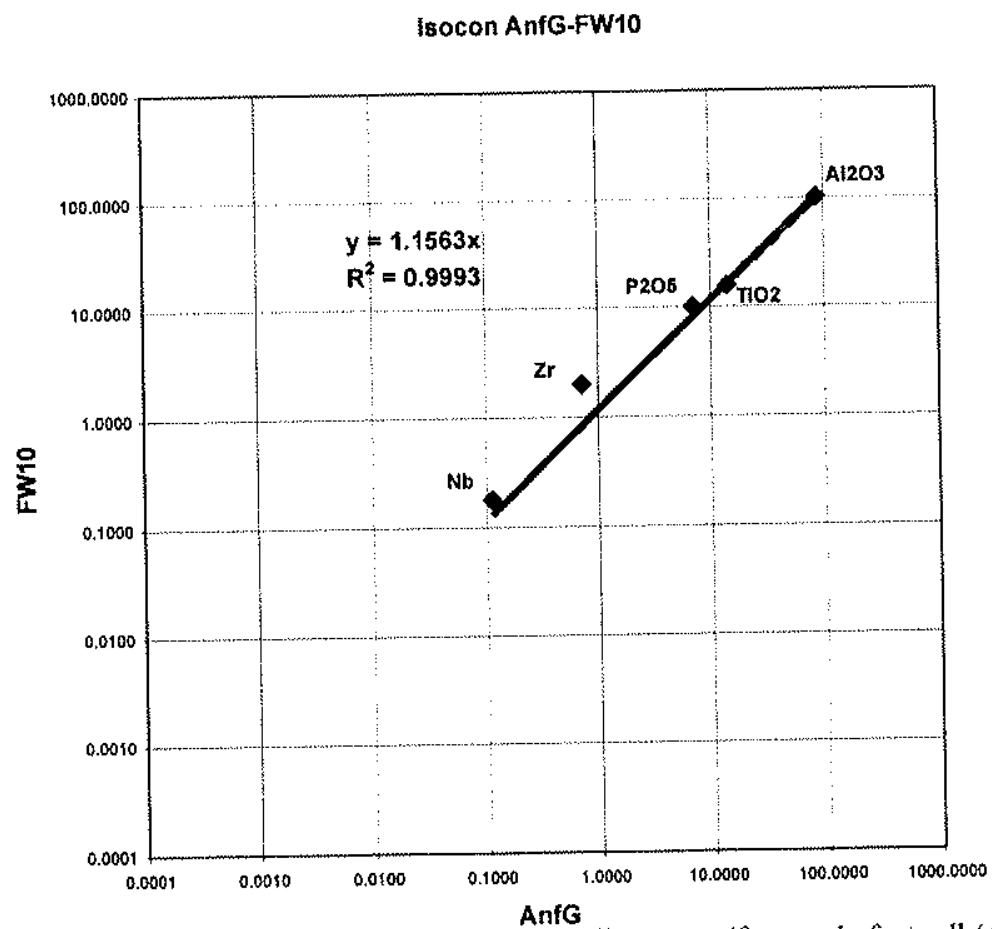

Figura 46: Elementos imóveis definindo reta isocon para os anfibolitos granatíferosos do footwall (AnfG) e os xistos do footwall do nivel 10 (xistos FW10). Nos cálculos e plotagem foram usadas as médias das amostras. O valor de R2 (coeficiente de correlação) de quase 1 , mostra excelente correlação. 
Evolução Petrogenética e Metalogenética da Mina de Au do Pari e Arredores, NE do Q. F.

Perdas e Ganhos - AnfG e FW00

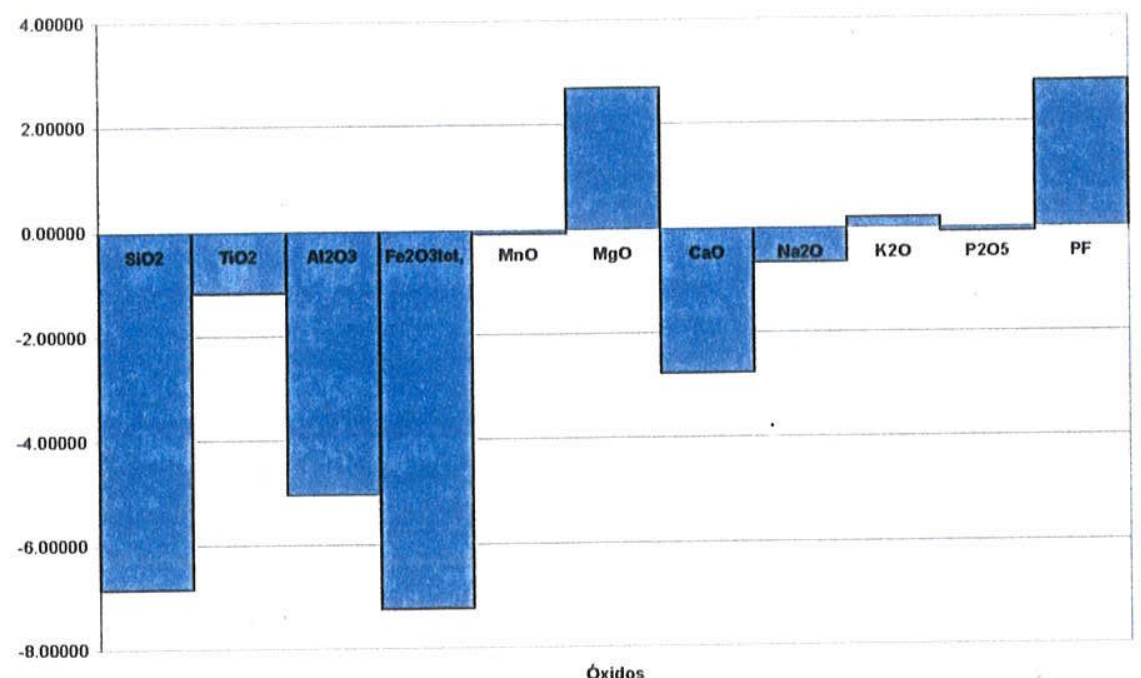

Figura 47: Perdas e ganhos de óxidos maiores dos xistos do footwall do nivel 00 da mineralização aurifera da Mina do Pari $(\mathrm{F} \cdot \mathrm{W}-00)$, comparativamente aos anfibolitos granatiferos ( $\mathrm{Anf} \mathrm{G})$

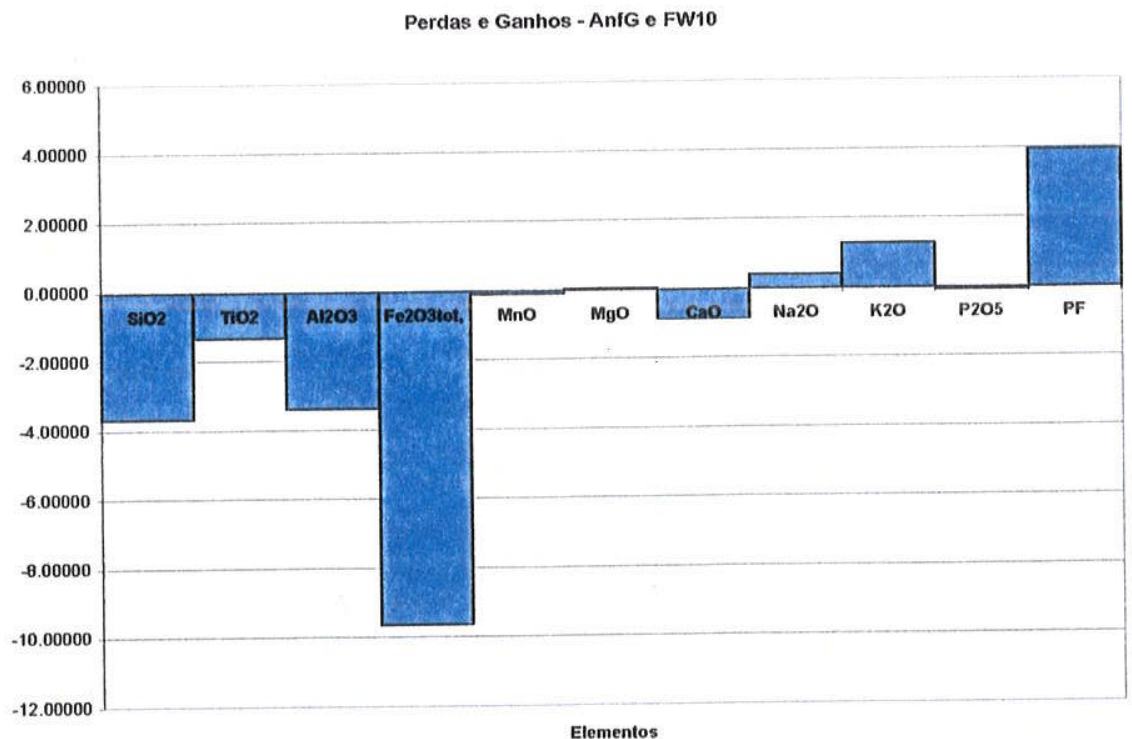

Fïgura 48: Perdas e ganhos de óxidos maiores dos xistos do footwall do nivel 10 da mineralização aurifera da Mina do Pari (FW-10), comparativamente aos anfibolitos granatiferos (AnfG). 
Perdas e Ganhos entre AnfG e FW-00

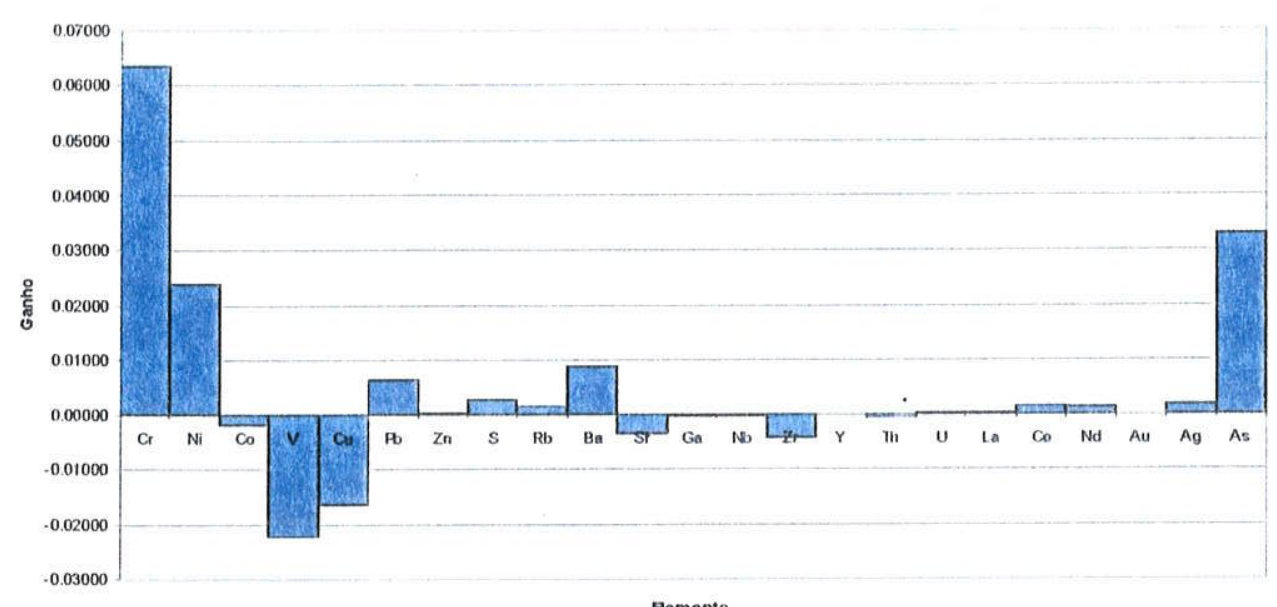

Fïgura 49: Perdas e ganhos de elementos traço dos xisıs do footwall do nivel 00 da mineralização aurifera da Mina do Pari (FW-00), comparativamente aos anfibolitos da lapa.

Perdas e Ganhos entre AnfG e FW- 10

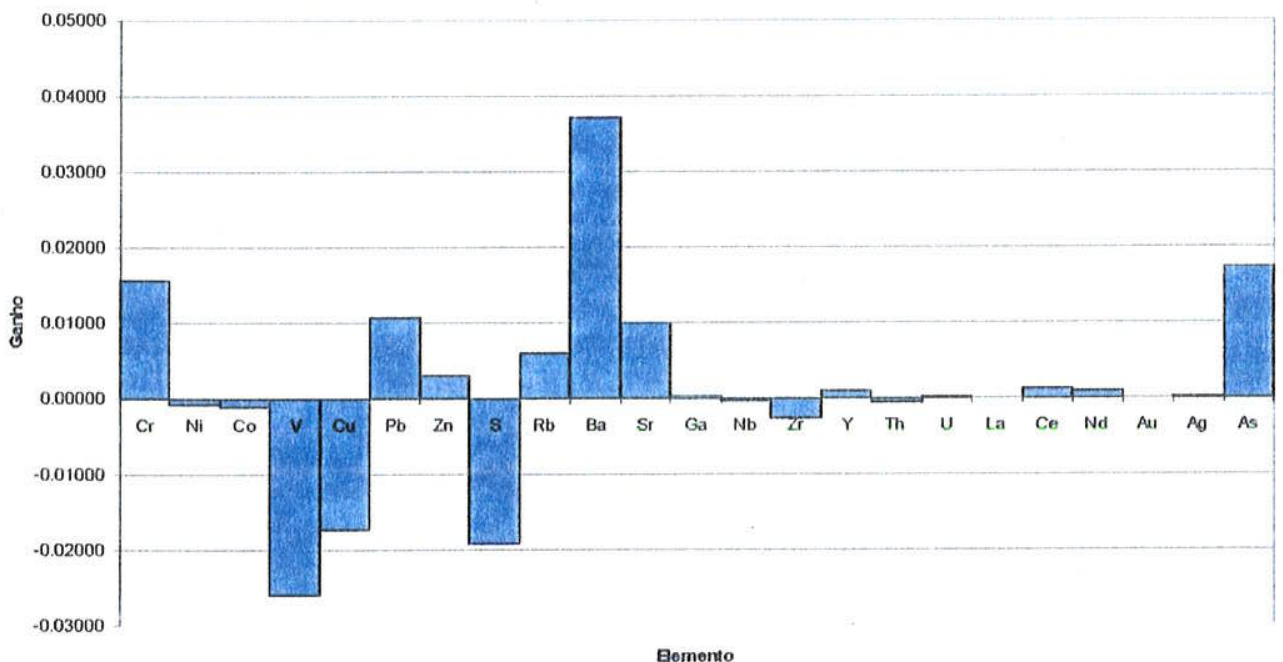

Figura 50: Perdas e ganhos de clementos traço dos xistos do footwall do nivel 10 da mincralização aurifera da Mina do Pari (FW-10), comparativamente aos anfibolitos da lapa. 
Os diagramas dos elementos maiores (Figuras 47 e 48), tanto do $\mathrm{N}-00$ quanto do $\mathrm{N}$ 10 mostram-se muito semelhantes, com pequenas diferenças quanto as trocas de $\mathrm{MgO}$ (ganhos no $\mathrm{N}-00$ ) e $\mathrm{Na}_{2} \mathrm{O}$ (perdas no $\mathrm{N}-00$ ). Os diagramas de elementos traço (Figuras 49 e 50), mostram apenas pequenas diferenças na intensidade das trocas, porém a quase perfeita identidade quanto aos tipos de perdas e ganhos entre AnfG e os xistos da lapa (FW), tanto para N-00 quanto para $\mathrm{N}-10$.

Em analogia, nas figuras 51 e 52 são mostradas as construções das retas ISOCON para os anfibolitos finos e xistos do HW e nas figuras $53,54,55$ e 56 são apresentados os diagramas de perdas e ganhos para os anfibolitos finos da capa (Anf-HW) e os xistos da capa (HW). Os diagramas dos elementos maiores (Figuras 53 e 54), tanto do $\mathrm{N}-00$ quanto do $\mathrm{N}-10$ mostram-se muito semelhantes, com pequenas diferenças quanto as trocas de $\mathrm{Na}_{2} \mathrm{O}$ (pequeno ganho no $\mathrm{N}-00$ ). Nos diagramas de elementos traço (Figuras 55 e 56), observam-se grandes diferenças nas intensidades das trocas sobretudo quanto ao $\mathrm{Cr}$ e $\mathrm{Ni}$ (prováveis componentes herdados, já enriquecidos no protolito), porém, também, a quase perfeita identidade entre os tipos de perdas e ganhos para os anfibolitos finos e os xistos da capa (HW), tanto para N-00 quanto para N-10.

Entretanto, ao comparar os diagramas de perdas e ganhos do FW (Figuras 47 a 50 ) e do HW (Figuras 53 a 56), nota-se que os comportamentos geoquímicos calculados para as trocas entre os anfibolitos granatiferos (AnfG) e os xistos da lapa (FW) são completamente opostos daquelas entre os anfibolitos finos (Anf) e os xistos da capa (HW). Assim, é praticamente impossivel que um fluido mineralizante circulando numa falha, ou mesmo num contato entre dois derrames causaria alterações com balanços de massa tão desiguais nas rochas adjacentes similares. Os balanços de massa indicam diferenças nítidas entre os pares de rochas (anfibolitos e xistos) da lapa e da capa, da mineralização não compativeis com um processo de alteração único e conjunto afetando protolitos tão similares, como representados pelos anfibolitos finos da capa e os anfibolitos granatíferos da lapa dos minérios auríferos.

\section{V.7 Considerações sobre a Litogeoquímica}

Considerando o exposto nos itens anteriores, juntamente com as observações geológicas e petrográficas elaboraram-se algumas interpretações.

$\mathrm{Na}$ figura 57 foram traçados diversos caminhos da possivel evolução geoquímica da mineralização aurífera da mina do Pari. As linhas vermelhas representam a 


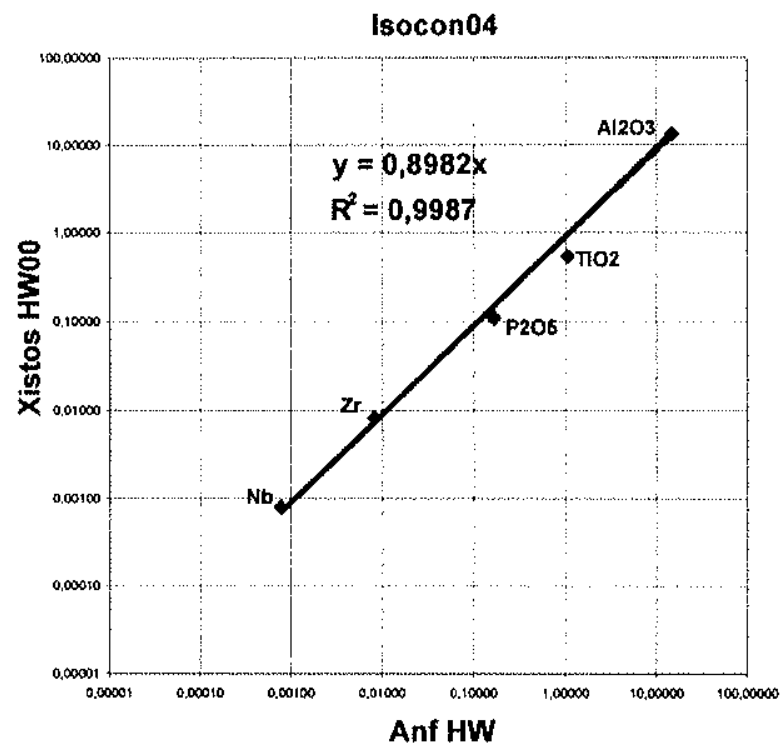

Figura 51: Elementos imóveis definindo reta isocon para os anfibolitos finos do hangwall (AnfHW) e os xistos do hangwall do nivel 00 (xistos HW). Para os cálculos e plotagem foram usadas as médias das amostras. O valor de R2 (coeficiente de correlaçăo) próximo a 1 , mostra excelente correlação.

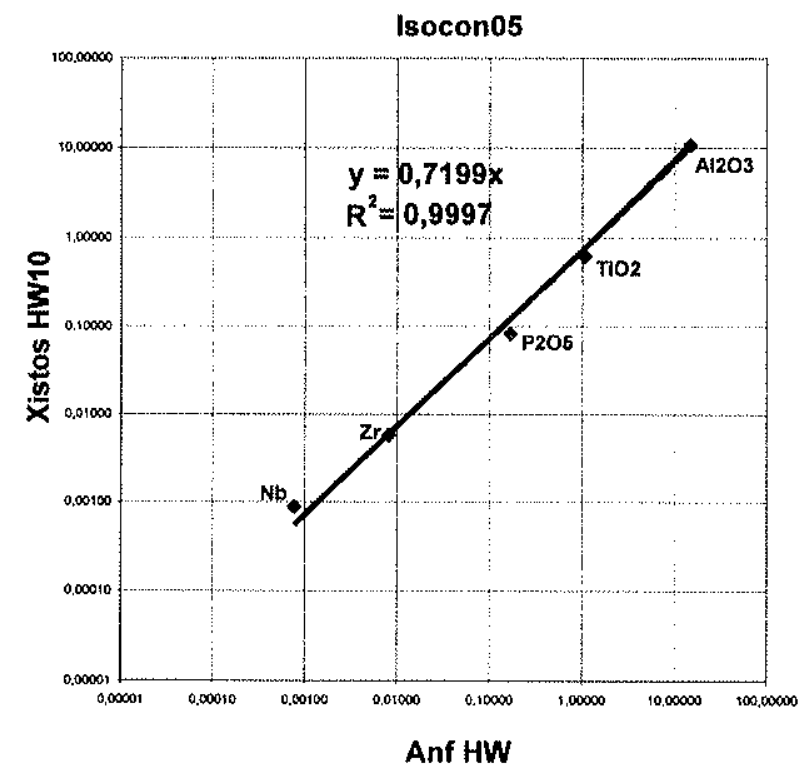

Figura 52: Elementos imoveis definindo reta isocon para os anfibolitos finos do hangwall (AnfHW) es xistos do hangwall do nivel 10 (xistos HW 10). Para os cálculos e plotagem foram usadas as médias das amostras. O valor de R2 (coeficiente de correlação) próximo a 1, mostra excelente correlação. 
Perdas e Ganhos - Xisto HW00

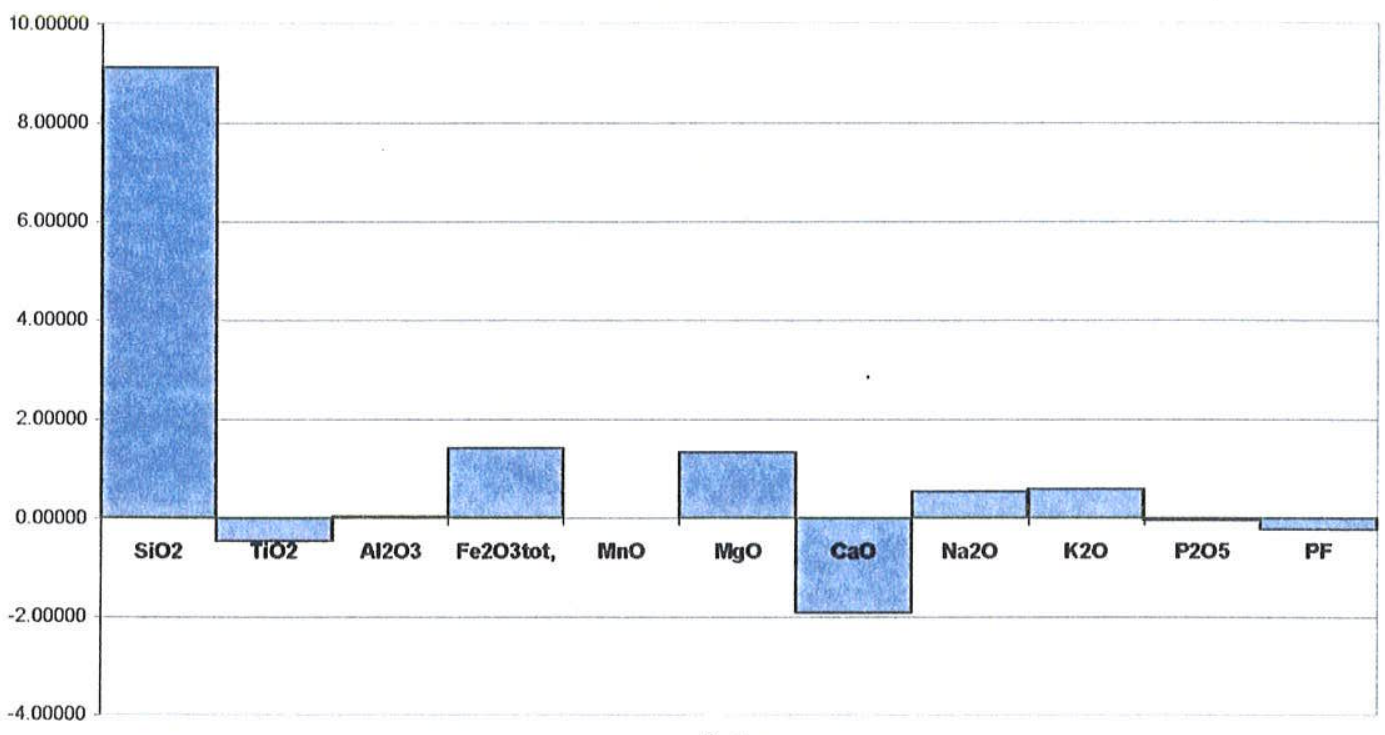

óxidos

Figura 53: Perdas e ganhos de óxidos maiores dos xistos encaixantes da mineralização aurífera da Mina do Pari do nivel 00 em relação aos anfibolitos finos (Anf HW).

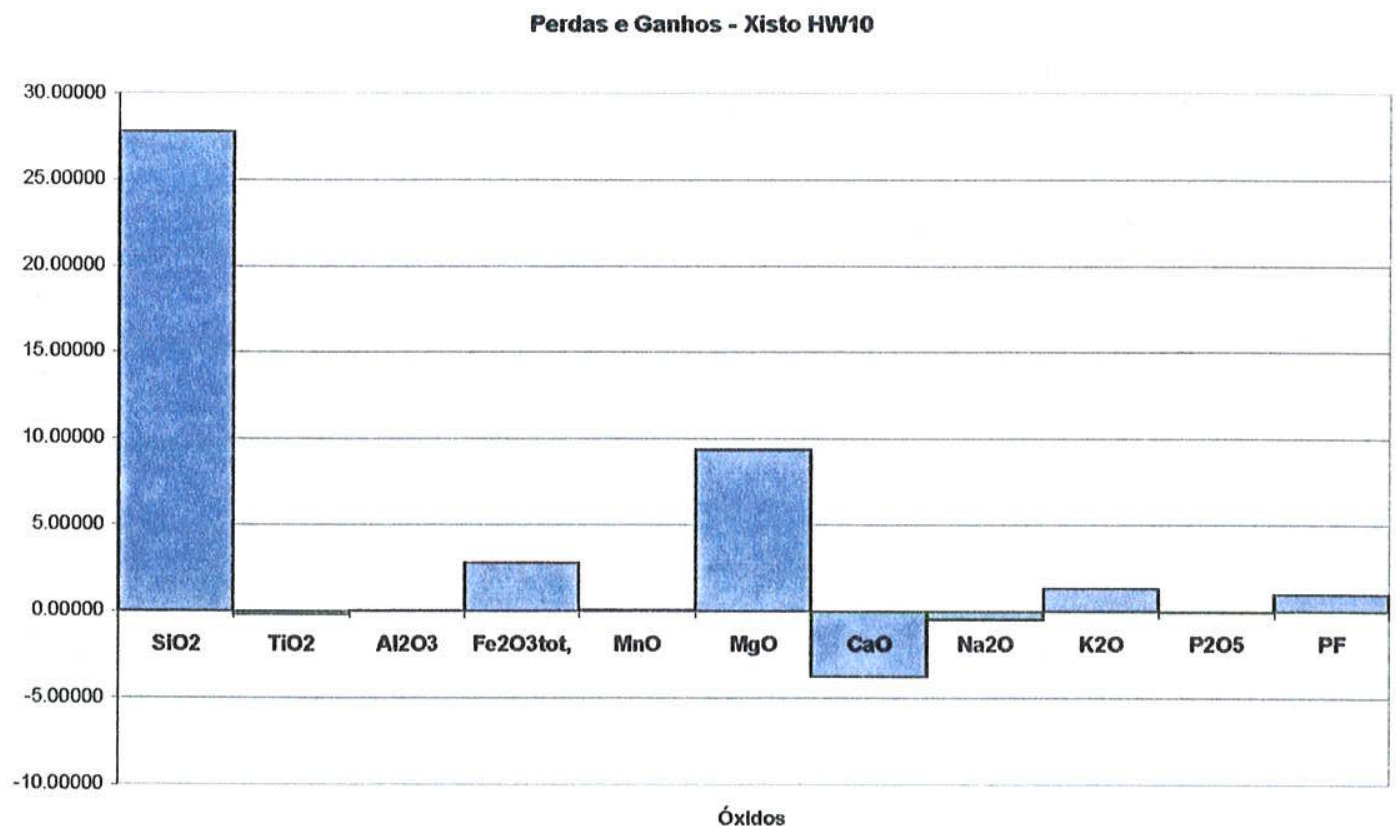

Figura 54: Perdas e ganhos de óxidos maiores dos xistos encaixantes da mineralização aurífera da Mina do Pari do nivel 10 em relação aos anfibolitos finos (Anf $\mathrm{HW}$ ). 
Perdas e Ganhos entre Anfib. Fino e Xisto HW-00

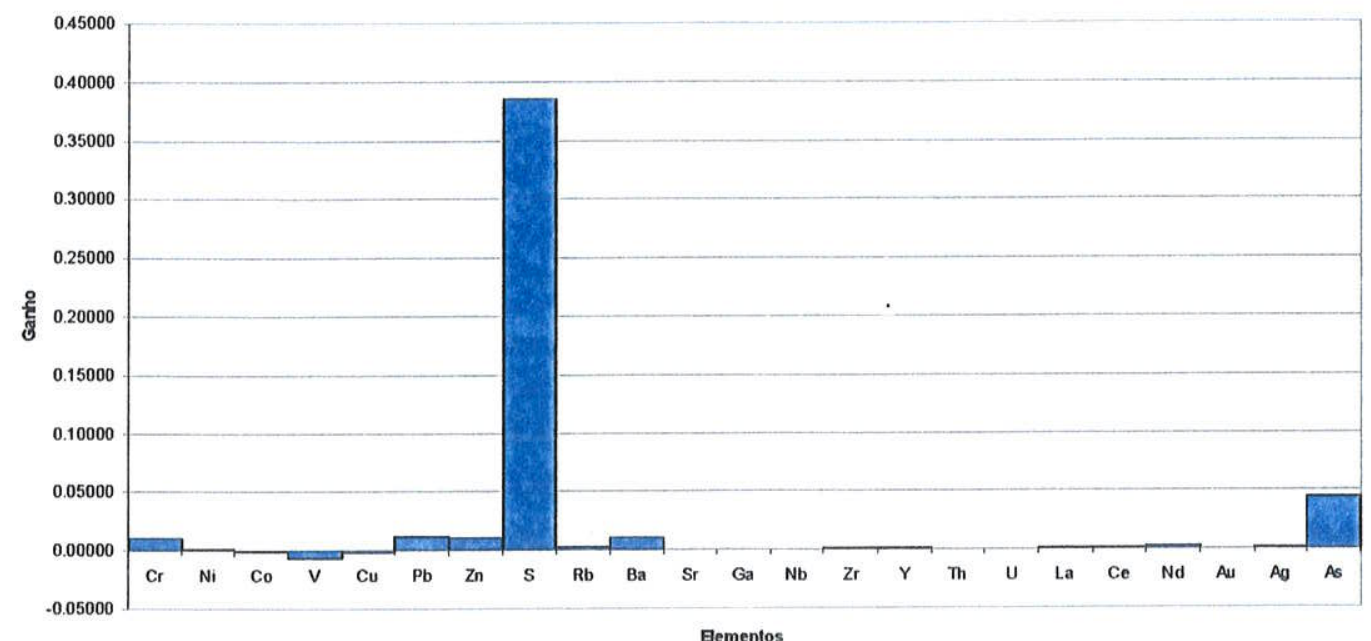

Figura 55: Perdas e ganhos de elementos traço dos xistos encaixantes do nivel 00 da mineralização aurífera da Mina do Pari (xistos hangwall-nivel 00), comparativamente aos anfibolitos finos (AnfHW).

Perdas e Ganhos entre Anfib. Fino e Xisto HW-10

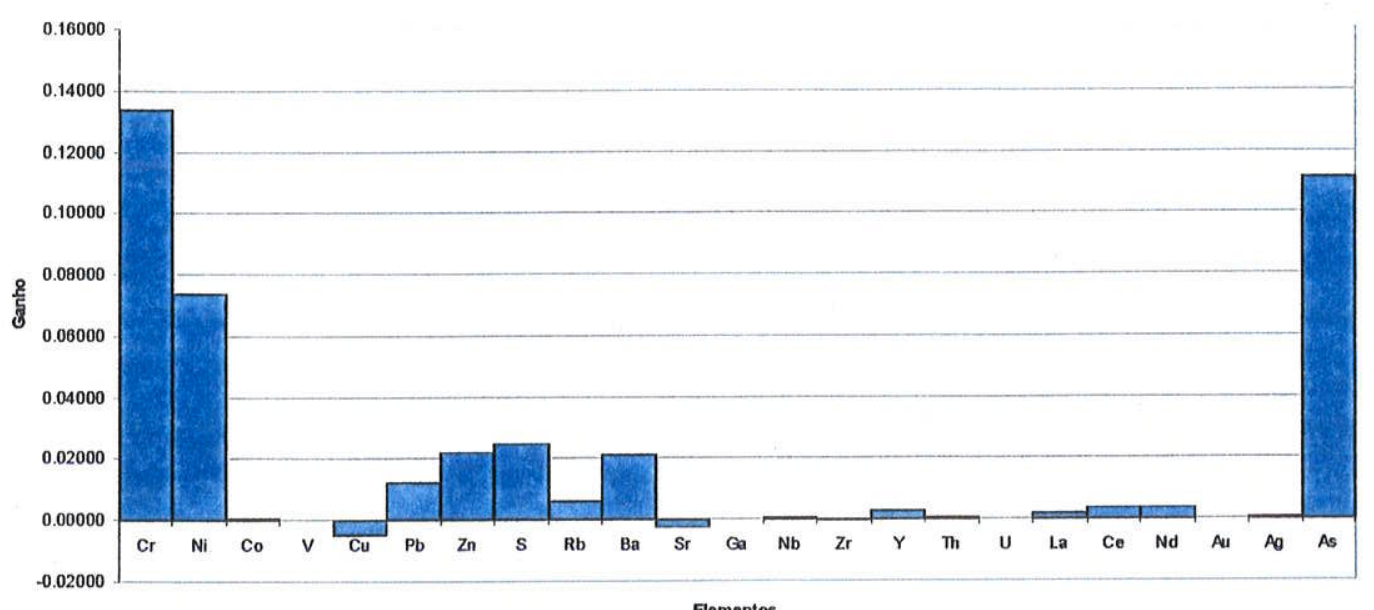

Elementos

Fïgura 56: Perdas e ganhos de clementos traço dos xistos encaixantes do nivel 10 da mincralização aurifera da Mina do Pari (xistos hangwall-nivel 10) comparativamente aos anfibolitos finos (Anf HW). 

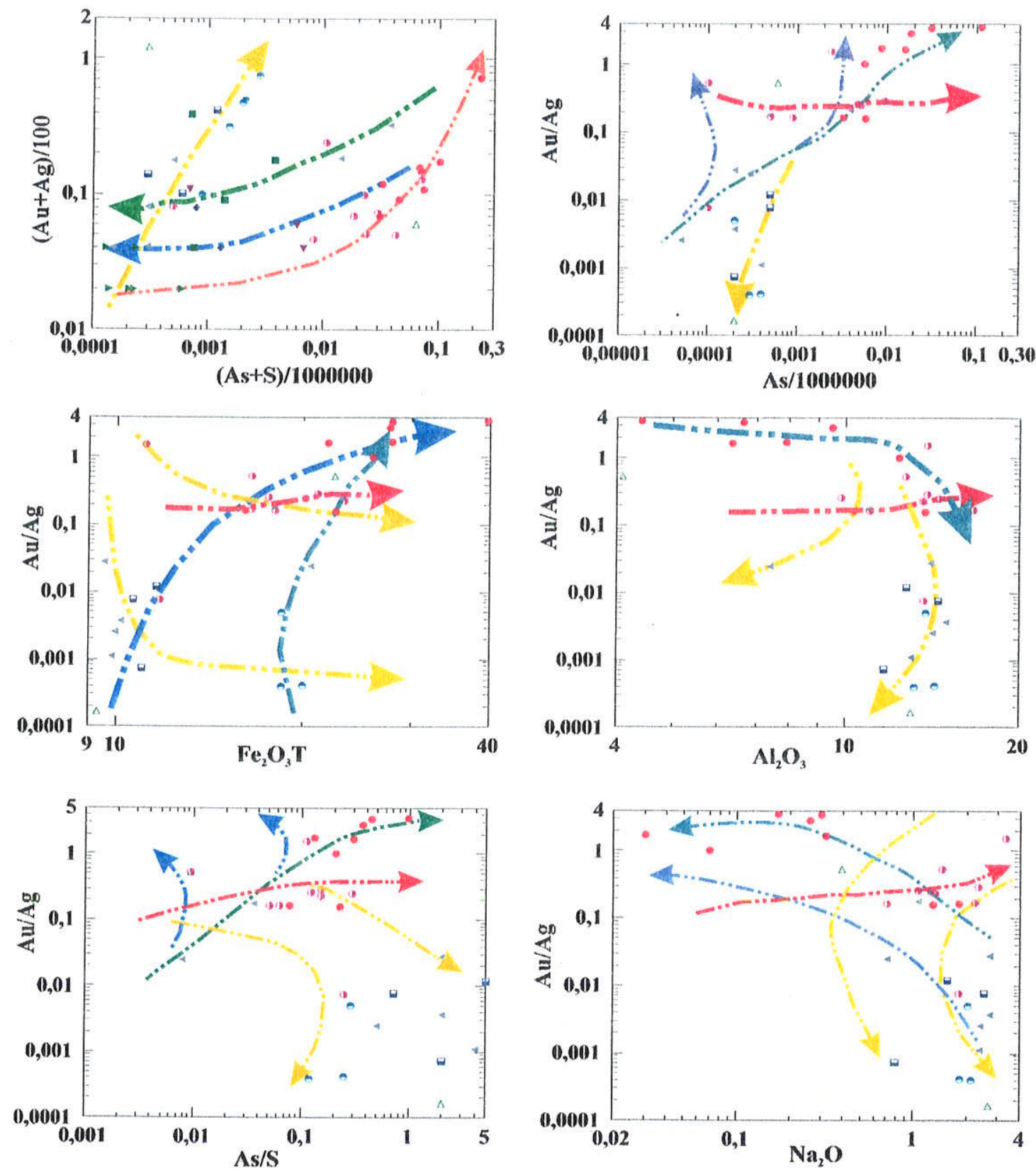

Legenda
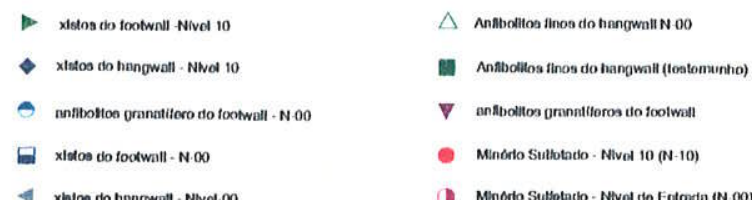

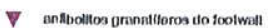

- Menorlo Sultutato - Nivel 10 (N-10)

(D) Minorto Suthotado - NNvot to Entradn (N 00)

Figura 57: Diagramas binários para xistos encaixantes, minério e anfibolitos de capa e lapa, da mina do Pari, com os possiveis caminhos evolutivos dos processos formadores da mineralização: vulcano-exalativo (vermelho), alteração de fundo oceânico nas encaixantes ( aranja), e metamorfismo ( $\mathbf{M}_{1}$ - azul, $\mathbf{M}_{2}$ - verde). 
deposição do minério em fundo oceânico, juntamente com os BIF tipo algoma, considerando-se a mineralização, ou seu protominério, como sendo o próprio BIF, com predominância da fácies sulfetada. Nota-se que este caminho segue em patamares de razões $\mathrm{Au} / \mathrm{Ag}$ relativamente constantes, e de $A u+A G$ ascendentes.

As linhas amarelas representam a alteração das encaixantes por processos exalativos/hidrotermais de fundo oceânico, agindo quase que exclusivamente nas rochas da lapa da mineralização (FW), notando-se a alta mobilidade da $\mathrm{Ag}$, bem como as alterações sódicas (de espilitização), seguidas por enriquecimentos de $\mathrm{Fe}_{2} \mathrm{O}_{3 T}$ e S.

Duas linhas interpretadas como representativas da possivel evolução polimetamórfica também foram traçadas. O metamorfismo $M-1$ (linhas azuis), agiu sempre com um característico aumento na razão $\mathrm{Au} / \mathrm{Ag}$, porém acompanhado de um incremento de $S$ maior que de As.

$O$ segundo evento metamórfico $\mathrm{M}-2$ (linhas verdes) é sempre mais marcante que o M-1. Relaciona-se fortemente com as amostras de mineralização mais rica $(\mathrm{N}-10)$ e também estabelece uma direção marcada pelo aumento da relação $\mathrm{Au} / \mathrm{Ag}$ proporcional ao aumento de As, que estaria relacionado à recristalização dos sulfetos já em temperaturas maiores que em M1, formando inclusive Arsenopiritas mais ricas em As.

Os dois eventos metamórficos sempre apresentam tendências contrárias à formação da mineralização e/ou das alterações de fundo oceânico, sobretudo em relação ao comportamento de $\mathrm{Na}_{2} \mathrm{O}, \mathrm{Al}_{2} \mathrm{O}_{3}$ e do $\mathrm{S}$, bem como das razões $\mathrm{As} / \mathrm{S}$.

Na figura $58 \mathrm{E}$ é nítida a relação da mineralização mais rica $(\mathrm{N}-10)$ com razões bem definidas de S/As e $\mathrm{Zn} / \mathrm{Cu}$, crescentes gradativamente com as relações de $\mathrm{Au} / \mathrm{Ag}$, enquanto as amostras da mineralização mais pobre $(\mathrm{N}-00)$, na extremidade norte do corpo tendem a mostrar baixas razões de $\mathrm{Au} / \mathrm{Ag}$, razões variáveis de $\mathrm{S} / \mathrm{As}$ e $\mathrm{Zn} / \mathrm{Cu}$. As figuras $58 \mathrm{~A}, \mathrm{~B}, \mathrm{C}$ e $\mathrm{D}$ ao contrário desta tendência, indicam que as amostras do minério rico evoluem em direção a altos teores de As e $S$, mostrando a forte correlação do Au com sulfetos, sobretudo com a arsenopirita. As amostras mais pobres em Au mostram sempre correlações complementares com $\mathrm{Zn}$ e Cu.

Os diagramas ternários da figura 59 também mostram tendências opostas no comportamento geoquímico de alguns elementos na capa e na lapa da mineralização. Fica evidente que nas amostras da lapa (FW) os processos enriquecedores de sódio são mais marcantes que na capa (HW), e decorrentes, mais provavelmente, de alterações de espilitização, de fundo oceânico, pré- a singenéticos à deposição das BIF da mineralização aurífera (Figura 57); já na capa 

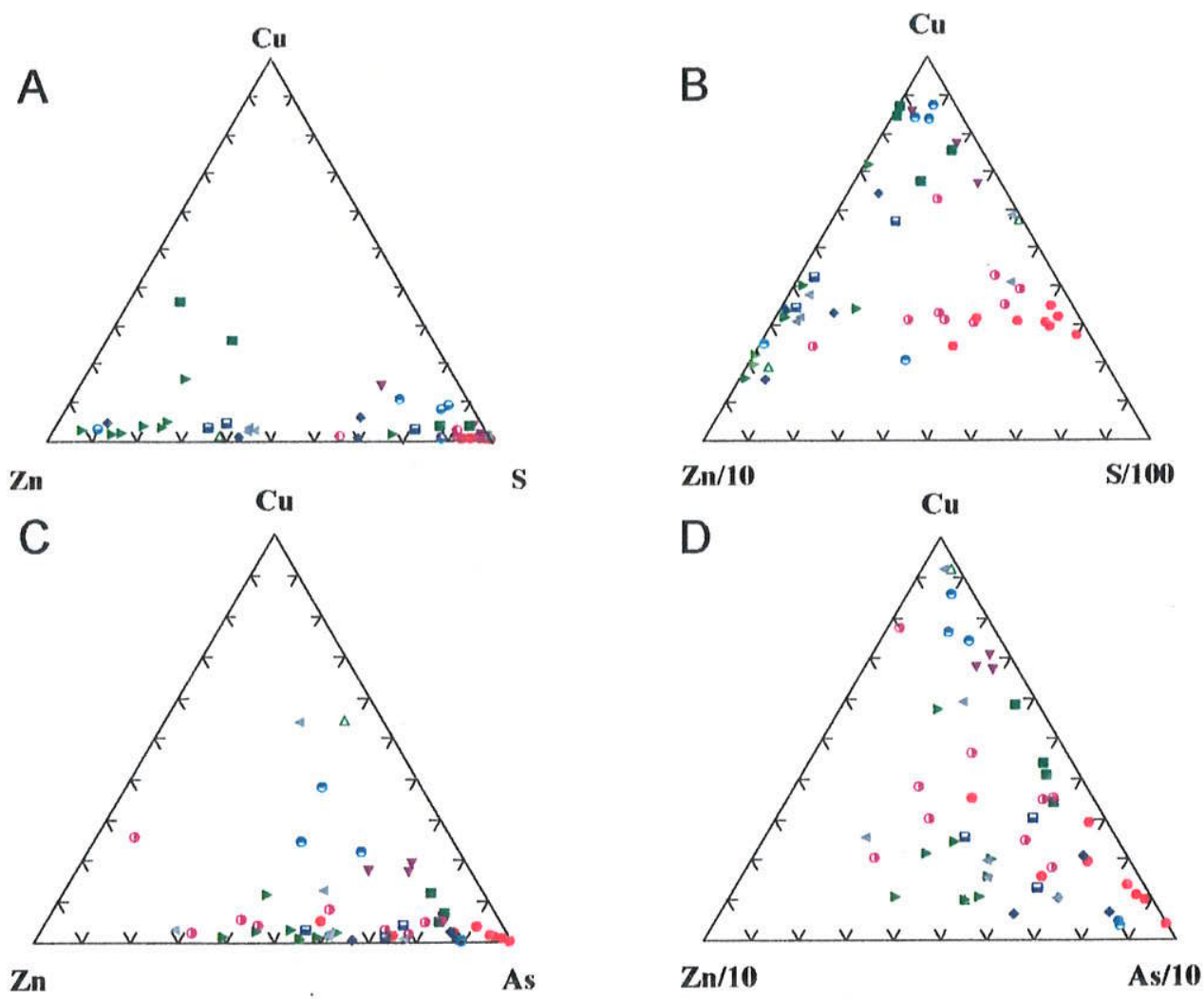

$\mathbf{Z n}$

As
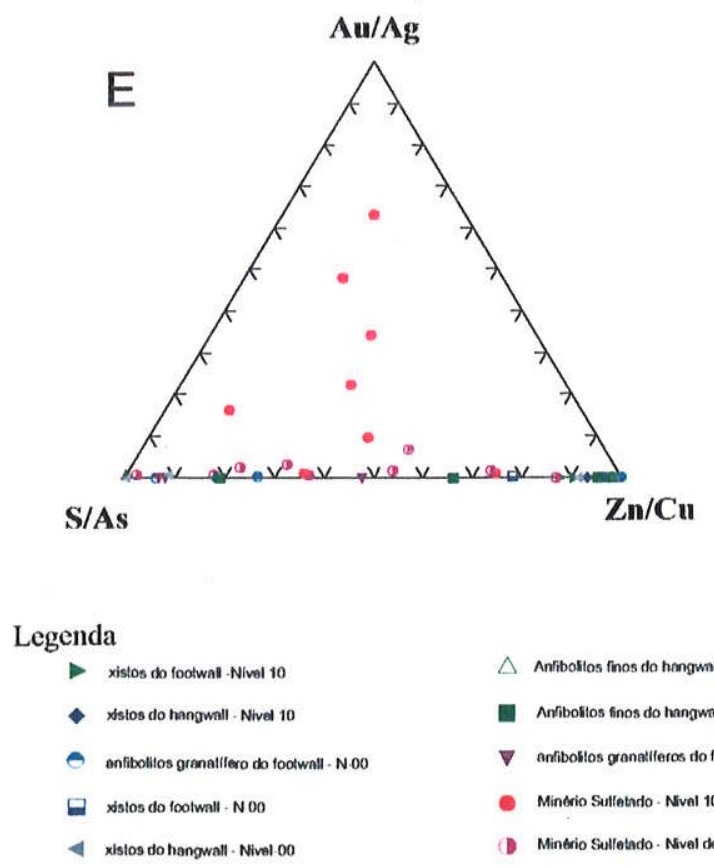

$\triangle$ Anfibosilos finos do hangwall N 00

- Anfibofitos finos do hangwall(1estemunhos)

$\nabla$ anfibohlios granalleros do foowall

- Minerio Sultatndo - Nval 10 (N 10)

(1) Mintrio Sulletado - Nuvel de Entrada (N. .0)

Figura 58: Diagramas ternários de amostras das encaixantes próximas, do minério e de anfibolitos de capa e lapa, da mina do Pari. A) Cu-Zn-S, é redesenhado em $B$ mostrando que as amostras mineralizadas tendem a possuir mais $S$, quanto mais ricas em $\mathrm{Au}$, porém há nítida separação entre encaixantes e minério. C e D) (Cu-Zn-As), também há forte correlação da mineralização com o As. E) as razões indicam maior pureza de Au e razőes definidas para S/As e $\mathrm{Zn} / \mathrm{Cu}$, para as amostras do $\mathrm{N}-10$, enquanto as amotras do $\mathrm{N}-00$ possuem razões bastante variadas de S/As e $\mathrm{Zn} / \mathrm{Cu}$, e maior teor em prata. 
da mineralização são notáveis anfibolitos enriquecidos em $\mathrm{MgO}$, de protolitos basálticos cumuláticos que soterraram a mineralização.
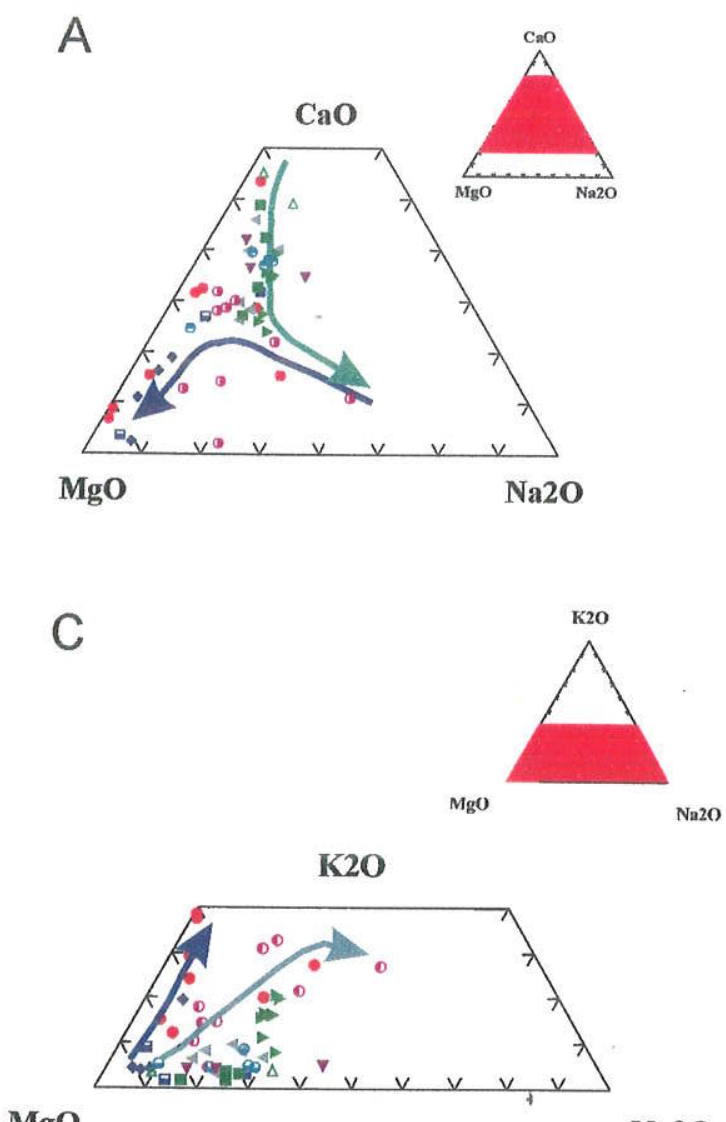

MgO

$\mathrm{Na2O}$

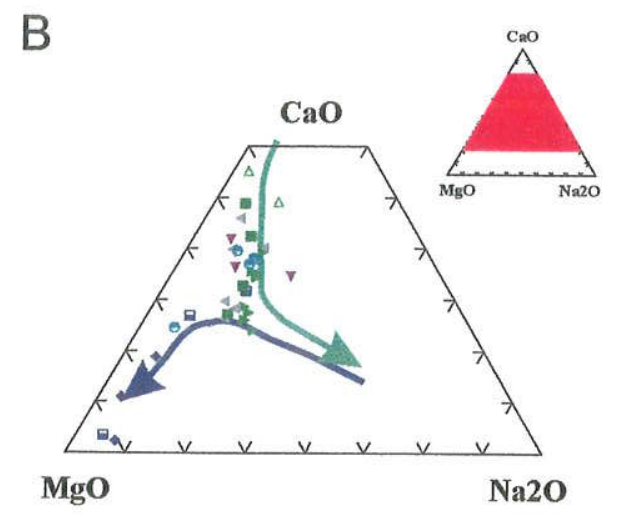

D

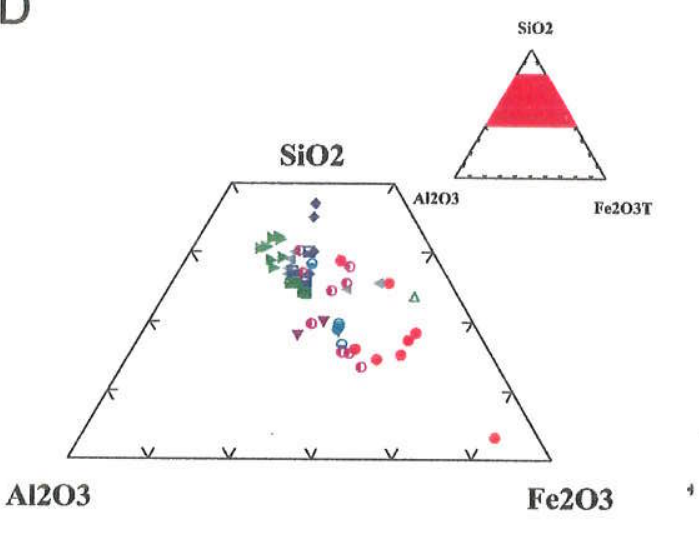

\section{Legenda}

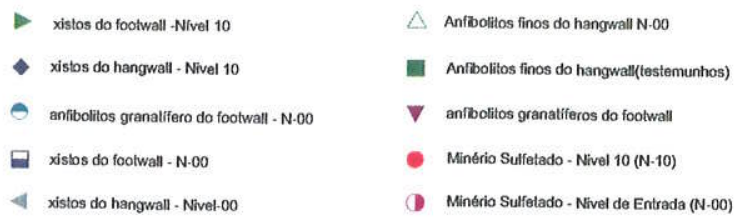

Figura 59: Diagramas ternários de amostras das encaixantes próximas, do minério e de anfibolitos de capa e lapa, da mina do Pari., mostrando-se o comportamento de alguns óxidos principais relacionados a mineralização. A e B) a linha verde mostra o enriquecimento em $\mathrm{Na}$ das encaixantes de lapa (possível espilitização; a linha azul descreve o caminho metamórfico. C) o caminho da espilitização(verde) e o metamorfismo (azul). D) A forte correlação entre as amostras mineralizadas com $\mathrm{SiO}_{2}$ e $\mathrm{Fe}_{2} \mathrm{O}_{3 \text { Total }}$ (BIF tipo algoma). 


\section{Capítulo VI: Química Mineral}

Estudos de química mineral foram realizados via microssonda eletrônica em minerais selecionados. Normalmente, foram medidos dois pontos, um central e outro na borda de cada grão. Os dados foram tratados e modelados em gráficos usando o programa MinPet v. 2.02 (Richard, 1995). As amostras foram divididas em grupos litológicos distintos: minérios; anfibolitos granatíferos da lapa (FW); anfibolitos finos da capa (HW); xistos encaixantes imediatos da lapa $(F W)$ e da capa (HW), e metaultramáficas do Grupo Quebra Osso.

\section{VI.1. Biotitas}

Os resultados analíticos e os cálculos da fórmula estrutural considerando o Fe Total como $\mathrm{Fe}^{2+}$, com base em 24 oxigênios $(\mathrm{O}+\mathrm{OH}+\mathrm{F})$, segundo Deer et al. (1992) são apresentados no anexo 5 (Tabela 1).

No diagrama da figura 60a nota-se a ocorrência de termos bastante próximos de flogopitas nas rochas metaultramáficas do Gr. Quebra Osso. Nas demais amostras de anfibolitos, xistos e no minério são encontradas biotitas intermediárias entre flogopita e annita, porém com 0 conteúdo de $\mathrm{Al}^{\mathrm{IV}}$ superior às biotitas metaultramáficas.

$\mathrm{Na}$ figura $60 \mathrm{~b}$ ainda observam-se dois grupos distintos de biotitas com razões $\mathrm{Na} / \mathrm{Na}+\mathrm{Ca}+\mathrm{K}$ aproximadamente constantes. Nos anfibolitos e xistos encaixantes ou próximos do minério e no próprio minério não se observam tendências de enriquecimento nas relações $\mathrm{Mg} / \mathrm{Fe}+\mathrm{Mg}$ no sentido dos anfibolitos em direção a mineralização. Na figura $60 \mathrm{c}$, em relação à figura anterior, observam-se tendências contrárias em relação a $\mathrm{Fe} / \mathrm{Fe}+\mathrm{Mg}$, e também um patamar $\mathrm{Na} / \mathrm{Na}+\mathrm{Ca}+\mathrm{K}+\mathrm{Ba}$ constante. Por fim, na figura $60 \mathrm{~d}$ observa-se a boa discriminação das biotitas por grupos litológicos com base nas razões $\mathrm{K} / \mathrm{Na}+\mathrm{Ca}+\mathrm{K}$ e $\mathrm{Fe} / \mathrm{Fe}+\mathrm{Mg}$. As mais notáveis diferenças ocorrem entre as amostras da lapa (FW: grupo E) e capa (HW: grupos $C$ e D). 

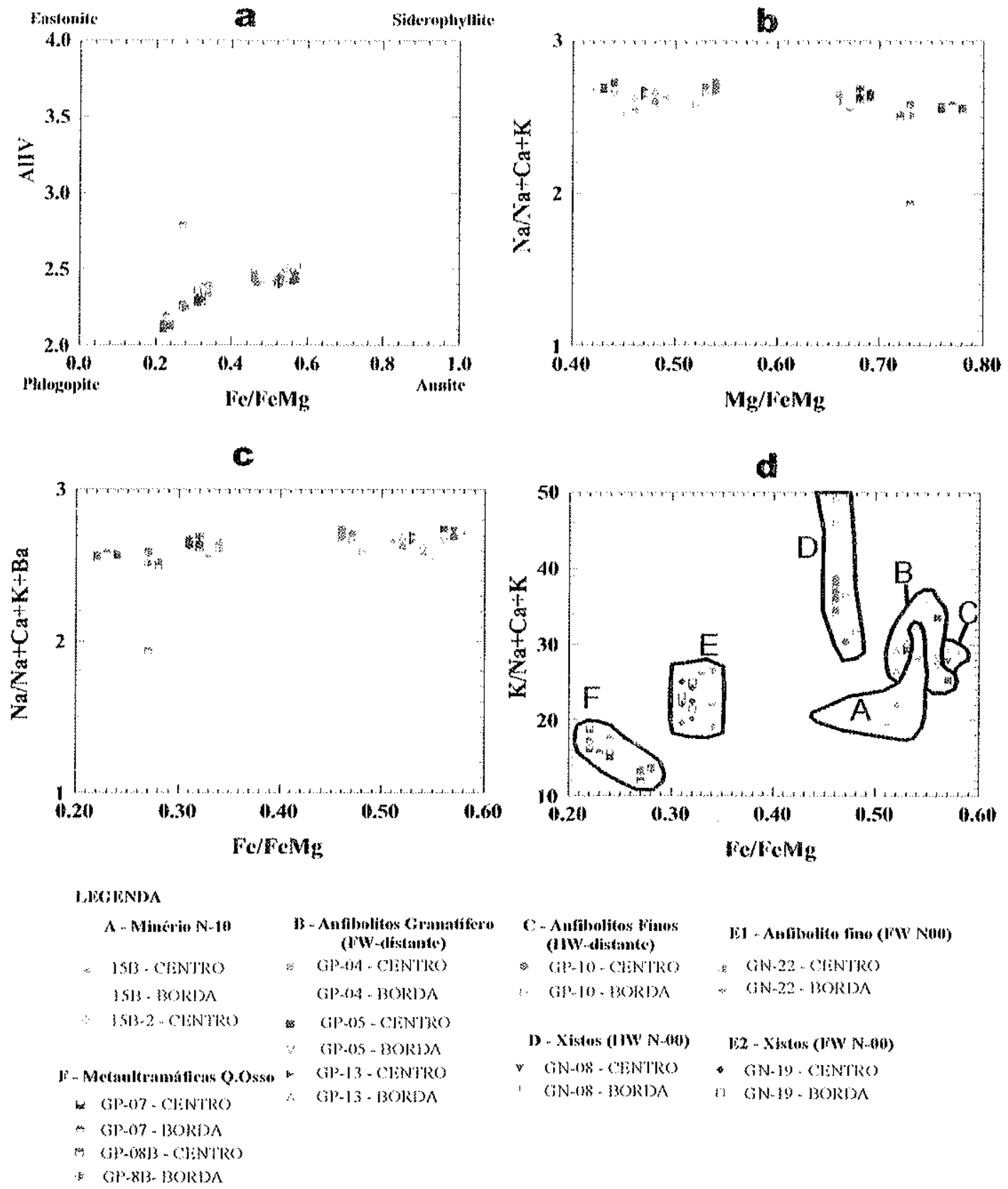

Figura 60: Caracterização química das biotitas. a) Classificaçăo das biotitas dos litotipos da mina do Pari. b)Diagrama binário, com as flogopitas das metaultramáficas do lado rico em Mg e as demais biotitas dos xistos e anfibolitos do lado rico em Fe; c e d) Säo diagramas binarios de variaçäo composicional das biotitas os quais permitem uma separação por grupos distintos de ocorrencia. 


\section{V1.2 Cloritas}

Os dados analíticos e cálculos de fórmula estrutural são encontrados no anexo 5 (Tabela 2). A fórmula estrutural foi calculada considerando o $\mathrm{Fe}$ Total como $\mathrm{Fe}^{2+}, \mathrm{e}$ com base em 36 oxigênios $(\mathrm{O}+\mathrm{OH}+\mathrm{F})$ sendo 16 para os grupos hidroxila $(\mathrm{OH})$, conforme Deer et al. (1992).

Foram analisadas cloritas de três litotipos distintos: anfibolitos finos (HW), anfibolitos finos (FW-N-00) e xistos (FW-N-00). Os resultados são apresentados na figura 61. Foram encontradas, na grande maioria das vezes cloritas de tipo ripidolita, e apenas uma amostra com pycnocloritas (tratando-se, no caso, mais provavelmente de um erro analítico). As ripidolitas evidenciam, ainda, pequenas diferenças composicionais entre as rochas da capa e da lapa.

\section{VI.3. Muscovitas}

Os dados analíticos e cálculos de fórmula são apresentados no anexo 5 (Tabela 3). A fórmula estrutural da muscovita foi calculada considerando o $\mathrm{Fe}$ Total como $\mathrm{Fe}^{2+}$, com base em 24 oxigênios $(\mathrm{O}+\mathrm{OH}+\mathrm{F})$, sendo 4 para os grupos $\mathrm{OH}$, conforme Deer et al. (1992). Analisou-se apenas a amostra GP.02, um enclave de TTG encontrado nos testemunhos do furo BR-76.

A Figura 62 observam-se pequenas variações da razão $\mathrm{K} / \mathrm{Na}+\mathrm{Ca}+\mathrm{K}$ em relação a constante razão $\mathrm{Fe}^{2} / \mathrm{Fe}^{2+} \mathrm{Mg}$.

\section{VI.4. Anfibólios}

A petrografia mostrou os seguintes tipos de anfibólios: nas rochas metaultramáficas, anfibólios incolores a pouco pleocróicos; nos anfibolitos, anfibólios verdes pleocróicos; no minério e nos xistos encaixantes dois tipos de anfibólios distintos, um incolor e outro verde pleocróico, por vezes com cores azuladas. Os resultados analíticos foram recalculados para a fórmula estrutural, segundo Schumaker (in Leaker, 1997) conforme abaixo explicado (Anexo 5, Tabela 4). 
Evolução Petrogenética e Metalogenética da Mina de Au do Pari e Arredores, NE do Q. F.

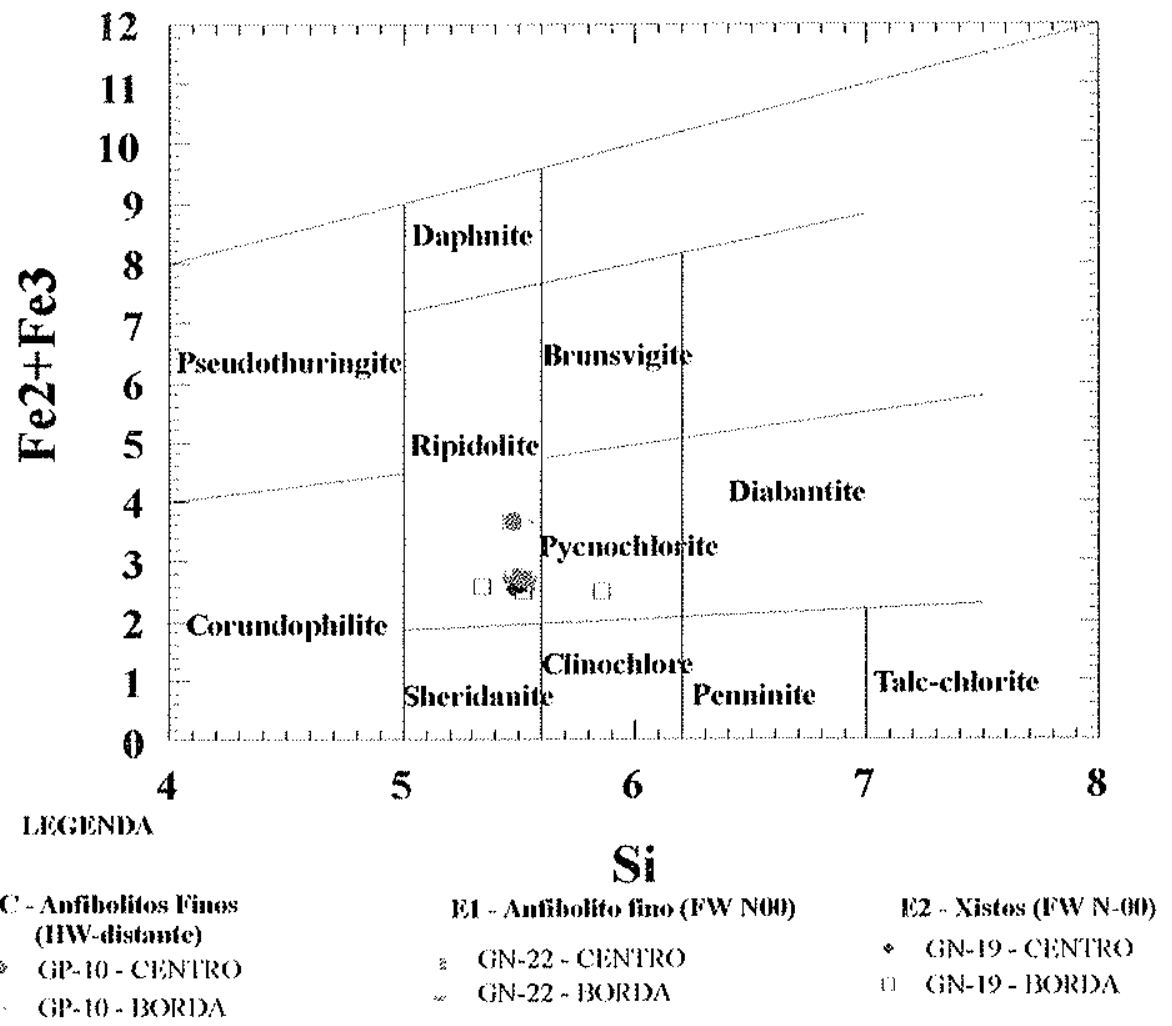

Figura 61: Caracterização química das cloritas.

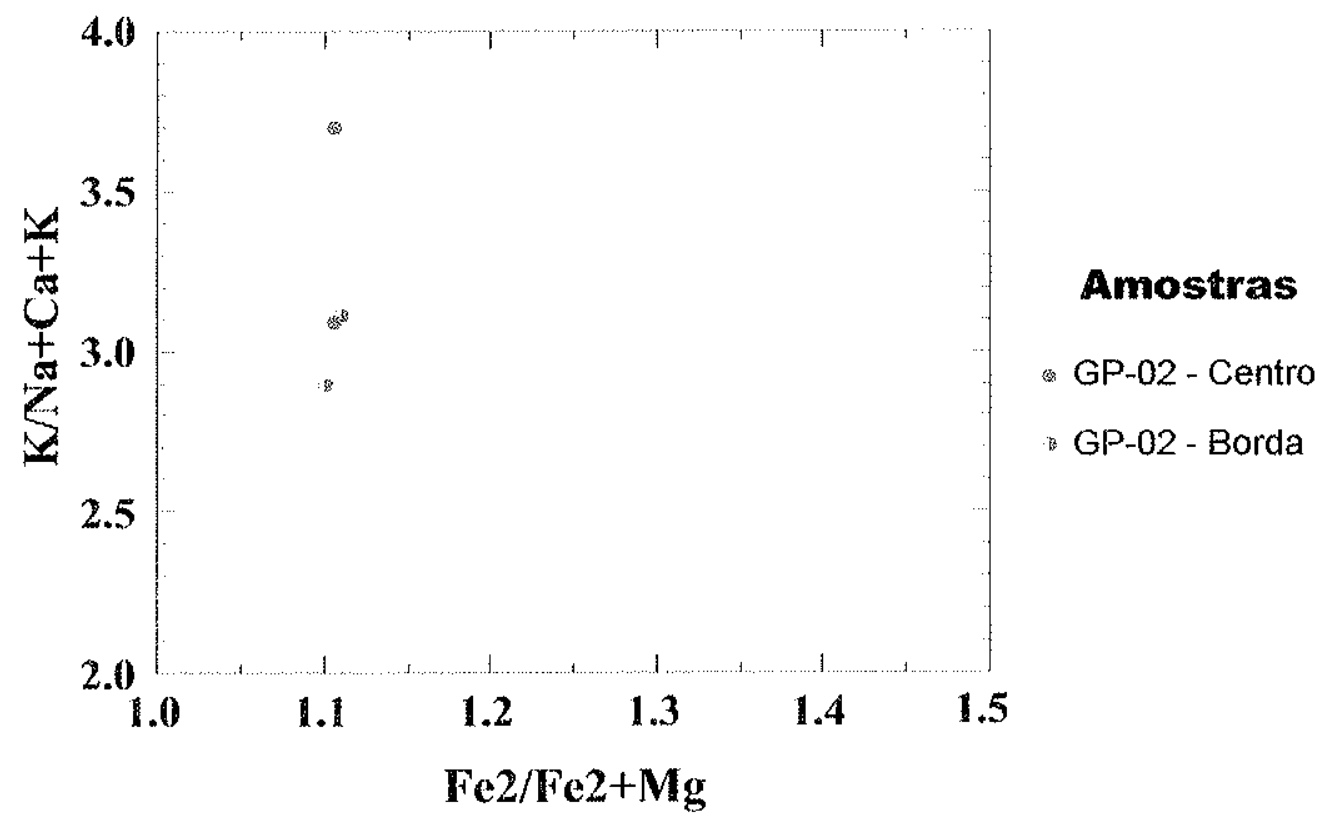

Figura 62: Caracterização química das muscovitas. 
-Anfibólios ferro-magnesianos: pelo método $15 \mathrm{eNK}$, sendo $\mathrm{Si}+\mathrm{Al}+\mathrm{Ti}+\mathrm{Mg}+\mathrm{Fe}+\mathrm{Mn}+\mathrm{Ca}$ = 15; e todo $\mathrm{Na}+\mathrm{K}$ no sítio $\mathrm{A}$ (nenhum $\mathrm{Na}$ no sítio M4), com base em 23 oxigênios $(\mathrm{O}+\mathrm{OH}+\mathrm{F})$ (Spear, 1993);

-Anfibólios cálcicos pela média das estimativas $15 \mathrm{eNK}$ e $13 \mathrm{eCK}$, sendo $\mathrm{Si}+\mathrm{Al}+\mathrm{Ti}+\mathrm{Mg}+\mathrm{Mn}=13$; e não permitindo $\mathrm{Mg}$, Fe ou $\mathrm{Mn}$ no sítio $\mathrm{M4}$, com base em 23 oxigênios $(\mathrm{O}+\mathrm{OH}+\mathrm{F})($ Spear, 1993).

Nas figuras 63,64 e 65 observa-se o amplo espectro de variação dos anfibólios analisados. Nas rochas metaultramáficas do Grupo Quebra Osso ocorrem tremolitas. Os anfibólios dos anfibolitos finos e granatíferos do N-00 e N-10, ou ainda de amostras mais distantes da mineralização sempre pertencem à variedade cálcica tschermakita, porém com pouca variação nos teores de sua componente $\mathrm{Na}$.

Os xistos encaixantes mostram variação composicional bastante grande, desde hornblendas até tschermakitas, em alinhamentos muito bem definidos (Figura 64) e com grande variação nos teores de $\mathrm{Na}_{2} \mathrm{O}$.

As amostras da mineralização aurífera mostram vários tipos de anfibólios muito bem definidos, hornblendas com baixos teores de $\mathrm{Na}$ e $\mathrm{K}_{\mathrm{t}}$ tschermakitas com grande variação de $\mathrm{Na}$ e uma pargasita. Ainda na mineralização é possivel distinguir dois grupos de anfibólios ferro-magnesianos da série grunerita-cummingtonita (Figura 65).

\section{VI.5. Granadas}

Foram analisadas granadas de litotipos da mineralização, de anfibolitos granatíferos, anfibolitos finos (com granadas microscópicas) e xistos encaixantes da mineralização (Anexo 5, Tabela 5).

Os recálculos do Fe total foram feitos segundo Droop (1987), com base em 24 oxigênios. Os membros finais foram calculados segundo Rickwood (1968).

A figura 66 mostra diagramas ternários de classificação das granadas. Observa-se a predominância da almandina com pequenos teores de grossularita e espessartita. Composições de piropo e andradita são bastante raros a inexistentes. Os xistos encaixantes imediatos e do minério possuem granadas com maiores quantidades do membro final Almandina, devido aos maiores teores de Fe desses litotipos. 


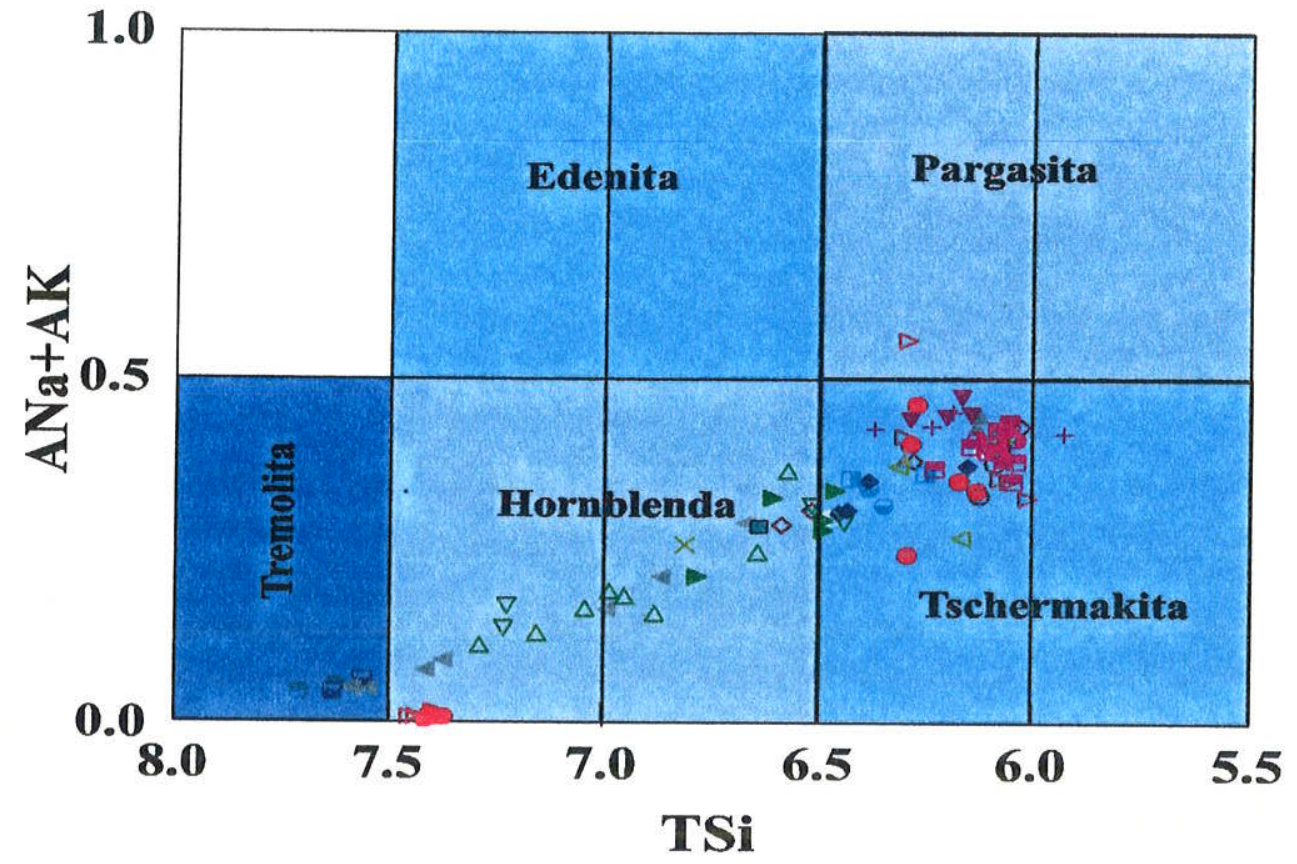

\section{LEGENDA}

A - Metaultramáficas Q.Osso

G GP-07 - CENTRO

- GP-07 - BORDA

4 GP-8B - CENTRO

$\triangle \quad$ GP-8B - BORDA

F - Anfibolitos Finos (HW-NOO)

- GN-01 - CENTRO

$\times$ GN-01 - BORDA
B - Minério N-10

- 15A-CENTRO

O 15A-MEDIANA

$\triangleright$ 15A-BORDA

- 14B - CENTRO

$\diamond \quad$ 14B - BORDA

\section{G - Anfibolitos Finos} (HW-NOO)

GP-10-CENTRO

- GP-10-BORDA
C - Anfibolitos Granatífero (FW-distante, e FW-contato)

v GP-13 - CENTRO

+ GP-13 - BORDA

III GN-22 - CENTRO

$\theta$ GN-22-BORDA
D - Xistos (FW N-00)

- GN-19-CENTRO

$\nabla \quad$ GN-19 - BORDA

E - Xistos (HW N-00)

(1) GN-08 - CENTRO

O GN-08 - BORDA

Figura 63: Caracterização química dos anfibólios. 
(a)

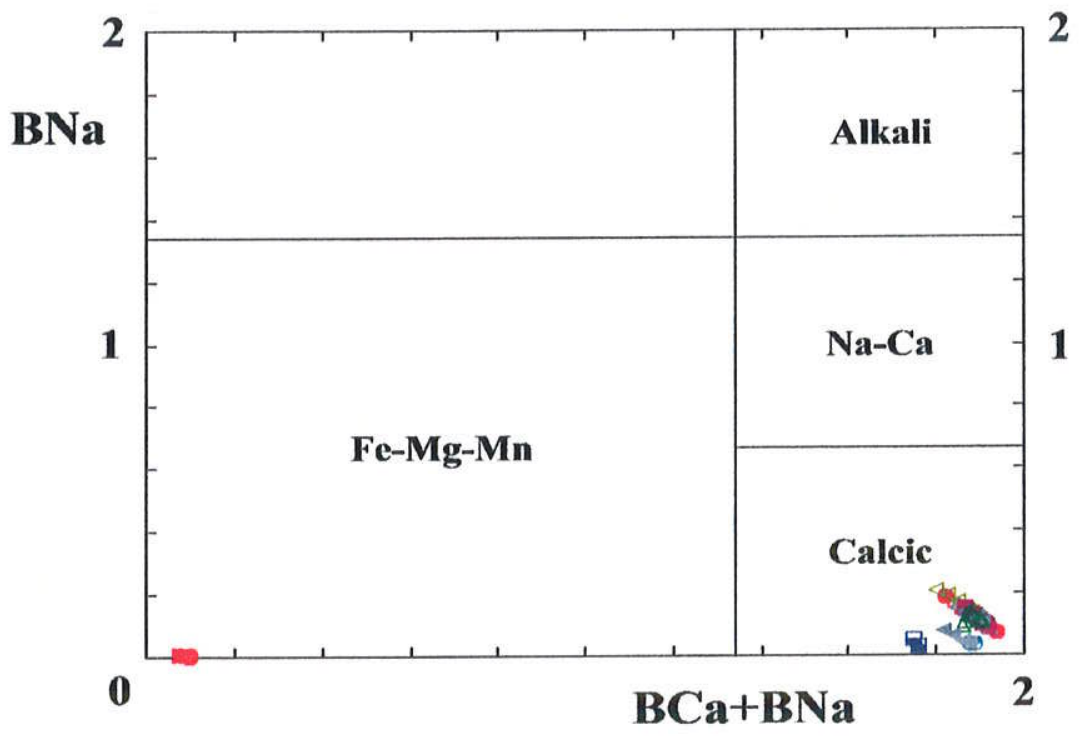

(b)

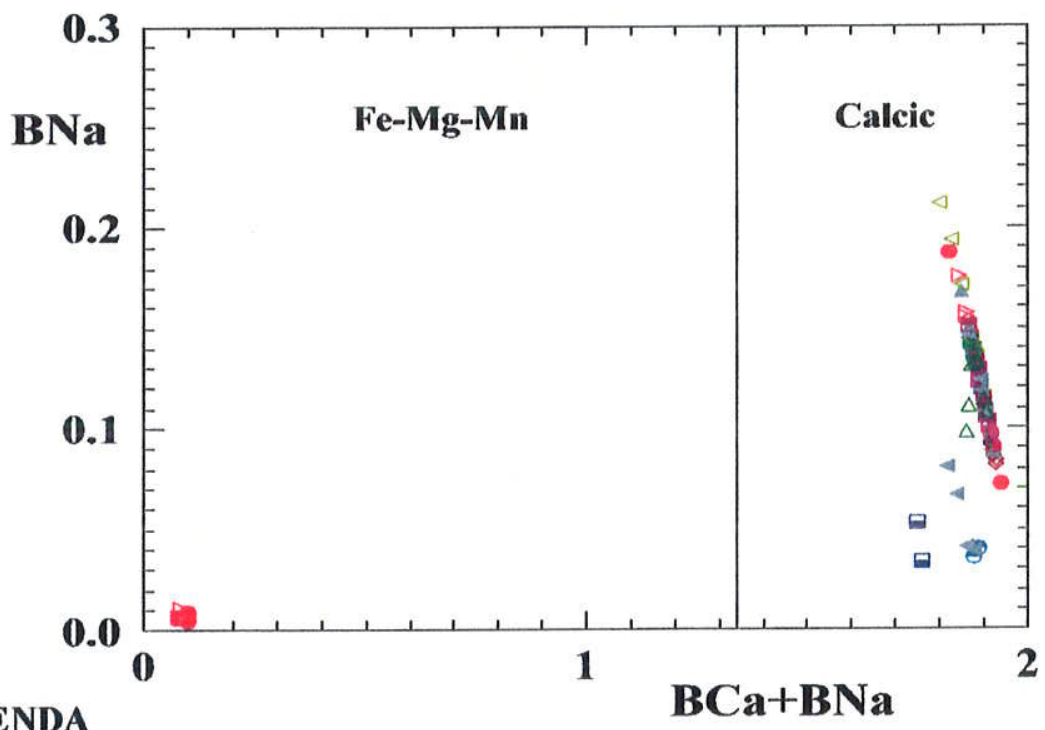

\section{LEGENDA}

A - Metaultramáficas Q.Osso

G GP-07 - CENTRO

- GP-07 - BORDA

4 GP-8B - CENTRO

$\triangle \quad$ GP-8B - BORDA
B - Minério N-10

- $15 A-$ CENTRO

O 15A-MEDIANA

$D \quad 15 \mathrm{~A}-\mathrm{BORDA}$

- 14B-CENTRO

$\triangle \quad 14 \mathrm{~B}-\mathrm{BORDA}$
C - Anfibolitos Granatifero (FW-distante, e FW-contato)

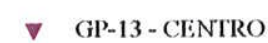

+ GP-13-BORDA

II GN-22-CENTRO

- GN-22-BORDA 
Evoluçâo Petrogenética e Metalogenética da Mina de Au do Pari e Arredores, NE do Q. F.

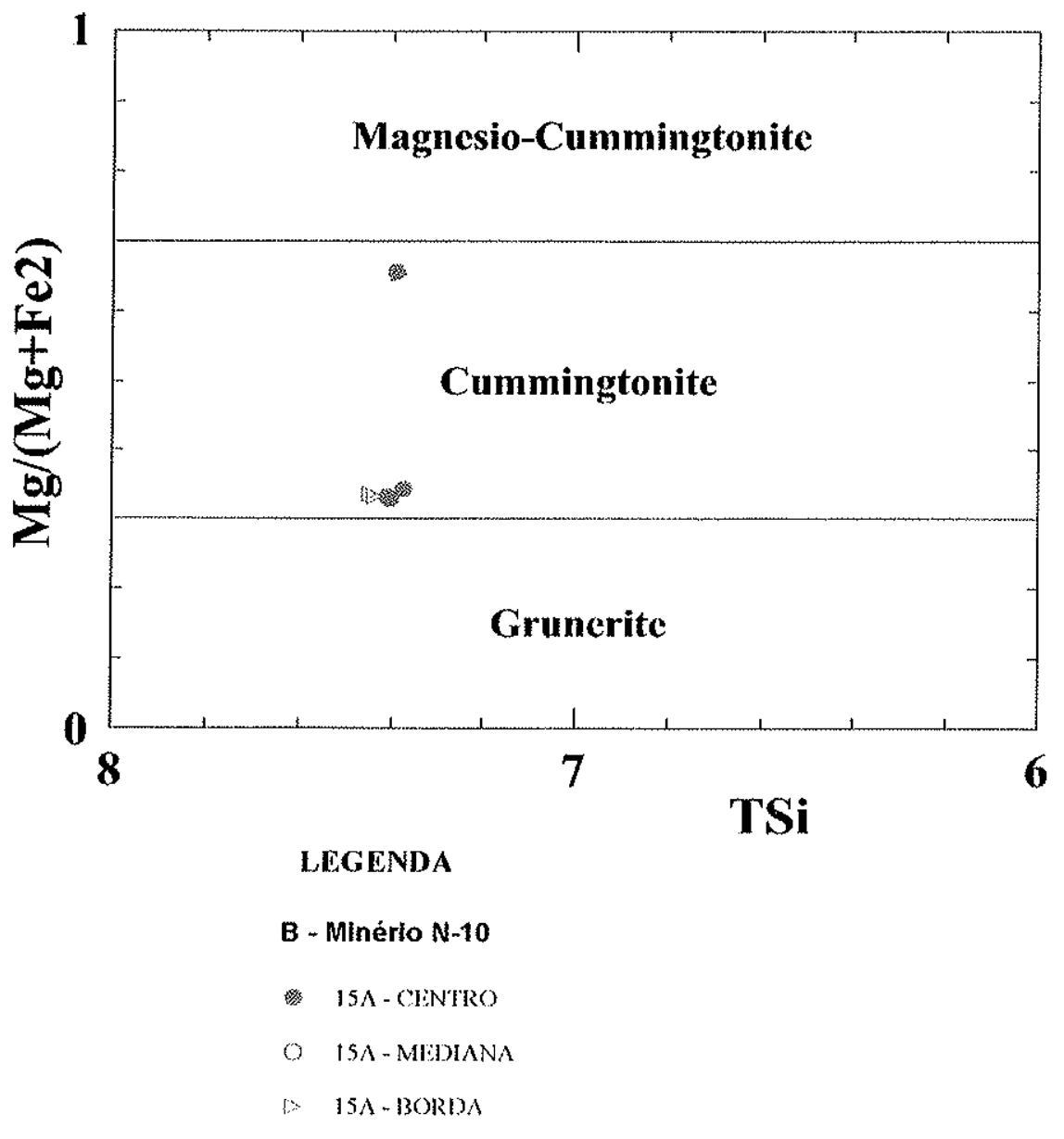

Figura 65: Caracterização química dos anfibólios Ferro-Magnesianos. Observam-se dosi grupos de anfibólios da série Grunerita-Cummingtonita na mineralização aurifera da mina do Pari. 

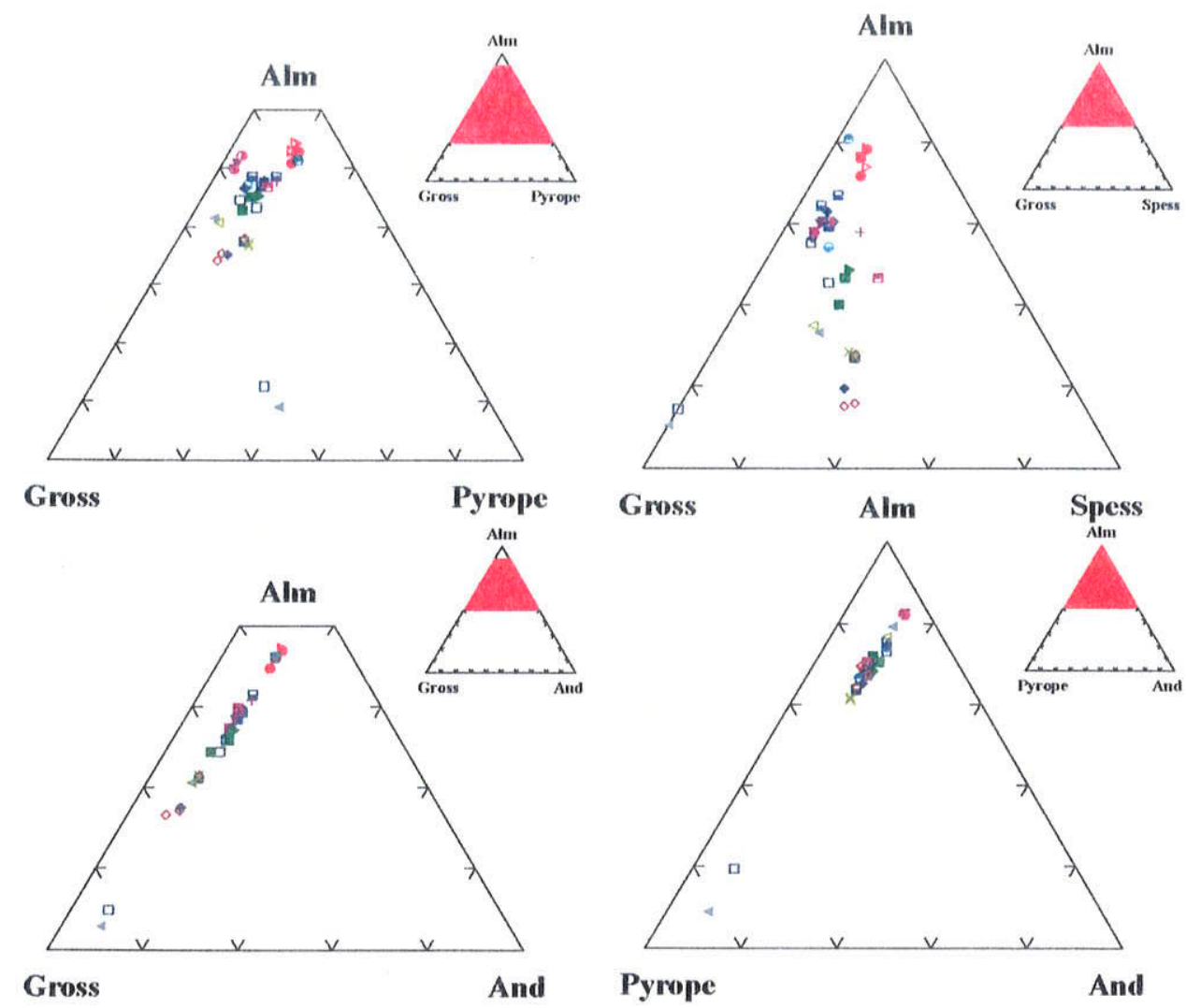

\begin{tabular}{|c|c|c|c|}
\hline \multirow{9}{*}{ LEGENDA } & $B$ - Minério N-10 & $\begin{array}{l}\text { C - Anfibolitos Granatifero } \\
\text { (FW-distante, e FW-contato) }\end{array}$ & D - Xistos (FW N-00) \\
\hline & IAB-BORDA & $\begin{array}{l}\text { GP-04-CENTRO } \\
+\quad \text { GP-04-BORDA }\end{array}$ & $\nabla \quad$ GN-19-BORDA \\
\hline & $\checkmark \quad$ ISA-CENTRO & - GP-05B-CENTRO & \multirow[b]{2}{*}{ E - Xistos (HW N-00) } \\
\hline & D $15 A-B O R D A$ & GP-05B-BORDA & \\
\hline & $4 \quad$ 15B-1-CENTRO & & - GN-08-CENTRO \\
\hline & 15B-1 - MEDIANA & $\begin{array}{c}\text { G - Anfibolitos Finos } \\
\text { (HW-NO0) }\end{array}$ & - $\quad G N-08 \cdot B O R D A$ \\
\hline & D $\quad 15 \mathrm{~B}-1$ - BORDA & GP-10 - CENTRO & \\
\hline & a $\quad 15 B-2 \cdot$ CENTRO & GP-10 - BORDA & \\
\hline & o $\quad 15 \mathrm{~B}-2-\mathrm{BORDA}$ & & \\
\hline
\end{tabular}

Figura 66: Caracterização químicq das Granadas da mina do Pari. Observa-se a predominância de almandinas com terores variáveis de Espessartita e de Grossularina. 


\section{VI.6. Carbonatos e óxidos de $\mathrm{Fe}$ e $\mathrm{Fe}-\mathrm{Ti}$}

Também foram analisados grãos minerais de carbonatos, magnetitas e ilmenitas. Os dados analíticos e cálculos das fórmulas dos carbonatos e de ilmenitas são encontrados no anexo 5 (Tabela 6 e 7). Na figura 67 foram expostos os resultados obtidos em grãos de carbonatos os quais apresentaram-se compostos, em mais de $90 \%$, da molécula calcita, possuindo $\mathrm{FeO}, \mathrm{MnO}$ e $\mathrm{MgO}$, como componentes menores. Não foram apresentados diagramas dos óxidos de $\mathrm{Fe}$ e $\mathrm{Fe}-\mathrm{Ti}$, tratando-se de magnetitas e ilmenitas essencialmente puras.

\section{VI.7. Sulfetos (Arsenopirita, Pirita, Pirrotita, Esfalerita e Calcopirita)}

Nos anexo 5 são apresentados os dados obtidos via microssonda eletrônica dos sulfetos da mina do Pari e da mina São Bento: arsenopirita (Tabela 8), pirita (Tabela 9), pirrotita (Tabela 10), calcopirita (Tabela 11) e esfalerita (Tabela 12).

As arsenopiritas analisadas são apresentadas na figura 68. As arsenopiritas da mina do Pari destacam-se por mais altos teores de As que as da Mina São Bento. As bordas das arsenopiritas em geral têm teores superiores de As que seus núcleos.

O grupo das arsenopiritas da mina São Bento foi selecionado conforme mostrado nas fotografias 62 e 63 , separando sulfetos concordantes de discordantes para os estudos microgeoquímicos. As fases discordantes são nitidamente remobilizadas, cortando o bandamento da formação ferrífera e aparecem com freqüência nas zonas de charneiras de dobras fechadas a isoclinais.

Além da marcante distinção entre as arsenopiritas de Pari e São Bento, nota-se que, estatisticamente, as zonas remobilizadas da Mina São Bento apresentam as arsenopiritas de mais baixos conteúdos de As, indicativo de zonas das mais baixas temperaturas, muito provavelmente associados a eventos tardios de menor temperatura.

Infelizmente, a péssima qualidade das seções polidas confeccionadas nos laboratórios do IGC-USP não permitiu observar e analisar as composições da liga natural de Au-Ag e suas características nestas zonas. 

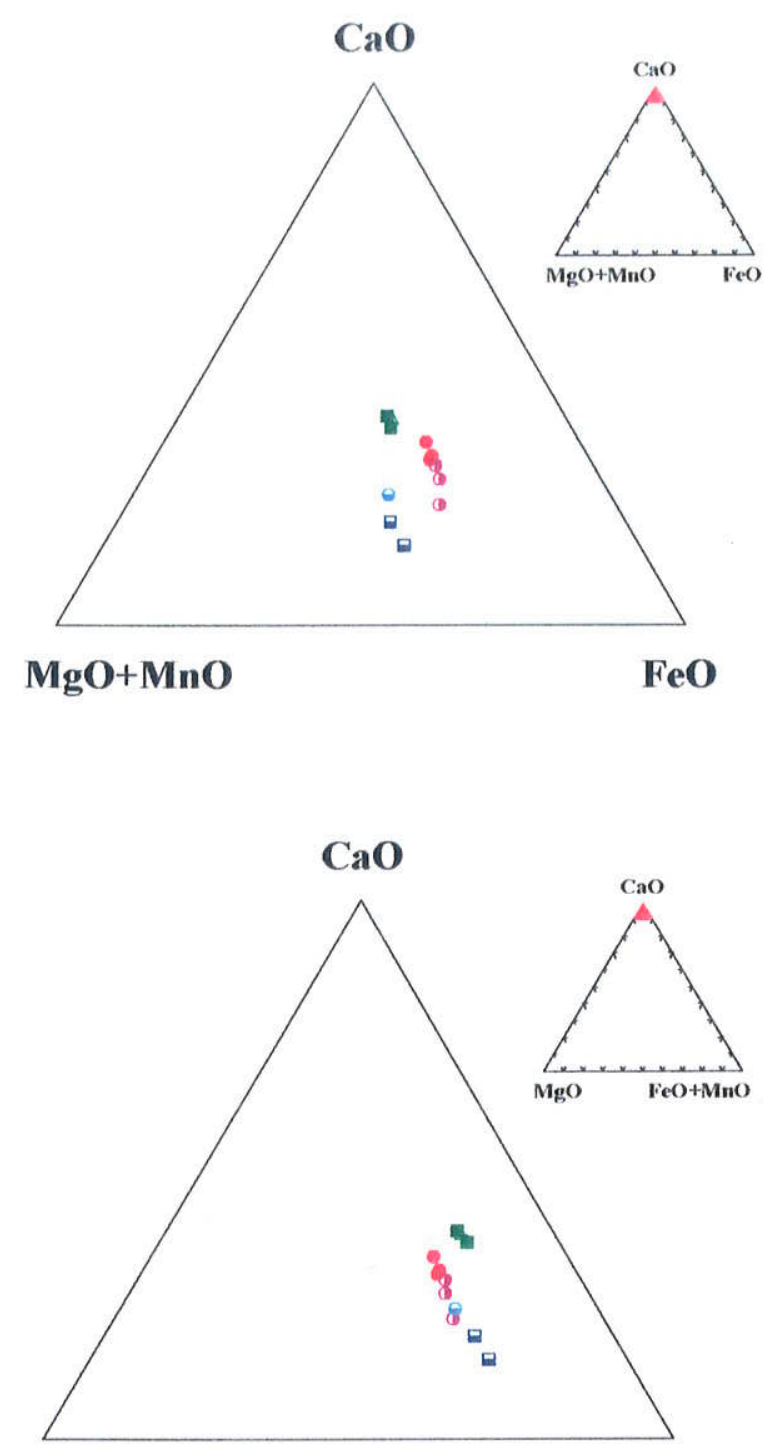

\section{Legenda}

Capa da Mineralização (HW)

- $\mathrm{GN}-01$ - centro

$\triangle \mathrm{GN}-01$ - borda

\section{Minério}

- 14B-centro

- $14 \mathrm{~B}$ - borda

Lapa da Mineralização (FW)

- GP-13-centro

- GP-13 - borda

\section{MgO}

$\mathrm{FeO}+\mathrm{MnO}$

Figura 67: Caracterização química dos carbonatos da mina do Pari. Observa-se o predomínio da molécula calcíta, mais de $90 \% ; \mathrm{Mg}$, Fe e $\mathrm{Mn}$ são apenas constituintes menores. 


\section{São Bento}

$\checkmark$ Remobilizado Centro

$\checkmark$ Remobilizado Borda

« Remob. Rico Centro

Remob. Rico Borda

- Bandado Centro

- Bandado Borda

- Bandado Mag. Centro

$\diamond$ Bandado Mag. Borda
Pari
- Centro
- Borda
- Intermediário

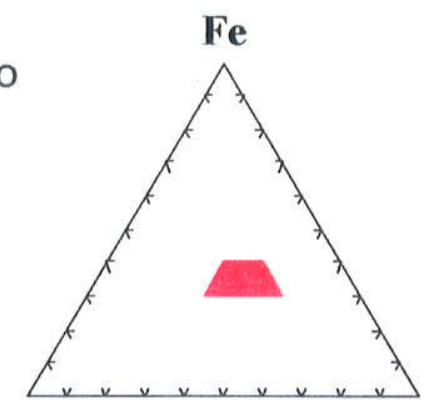

As S

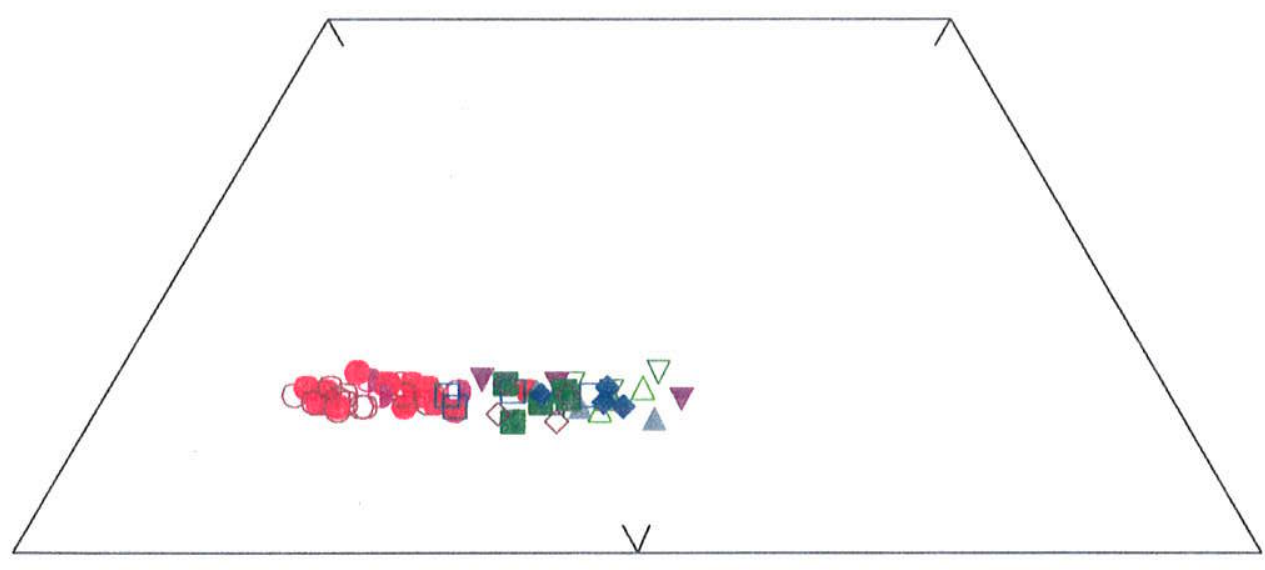

\section{As}

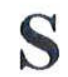

Figura 68: Variação composicional das arsenopiritas da mina São Bento e da mina do Pari. Dados em \% atômicos recalculados a 100\%. Nota-se a nítida diferença nos teores de arsênio entre as arsenopiritas das duas minas, sendo às da mina do Pari mais ricas em As. Estatisticamente, as arsenopiritas provenientes de veios remobilizados da mina São Bento são as de mais baixos teores de As.

As piritas e calcopiritas analisadas mostraram-se bastante puras e, assim, sem quaisquer diferenças significativas entre as minas São Bento e Pari. 


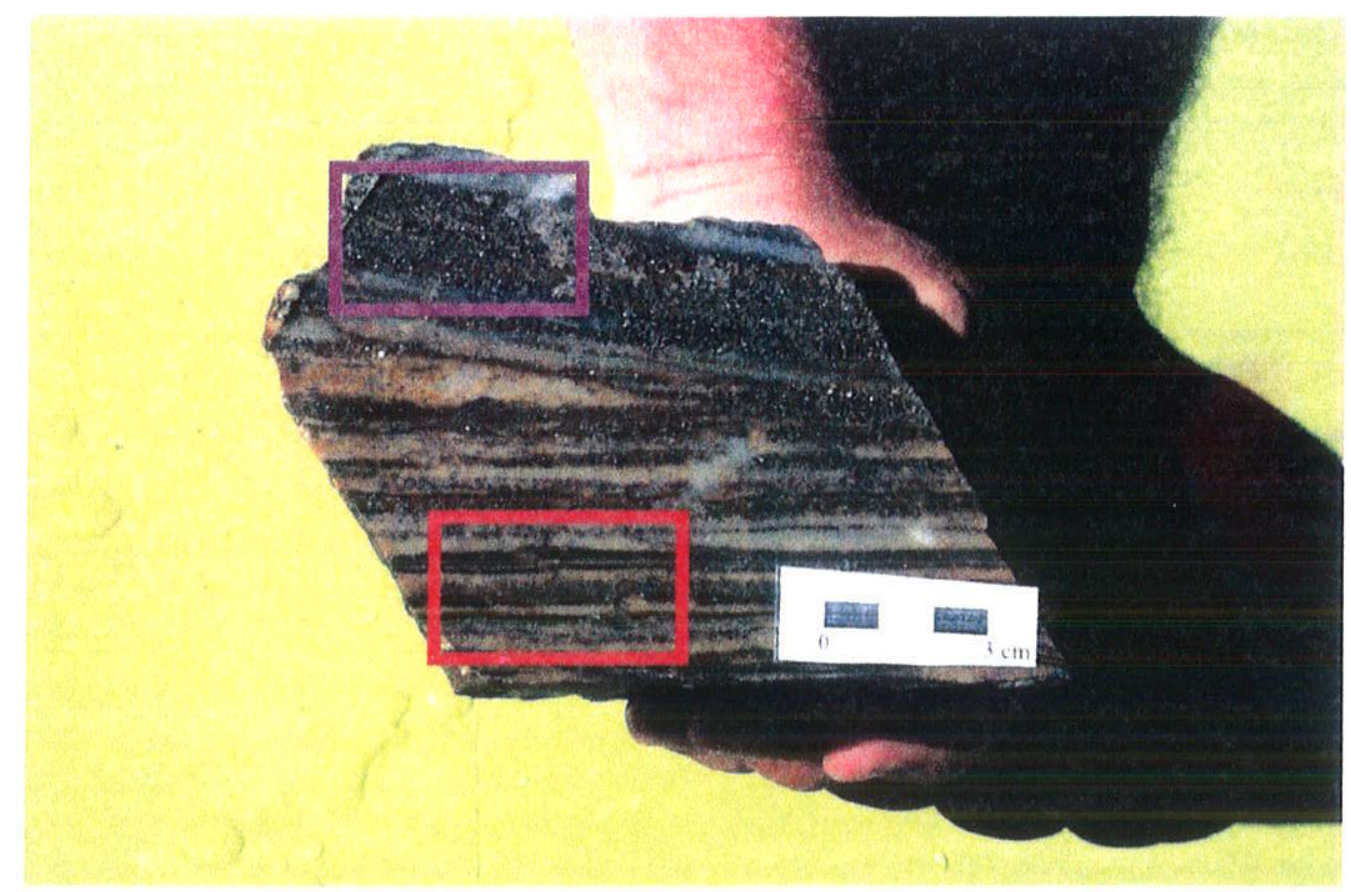

Fotografia 62: Minério bandado da mina São Bento, mostrando paralelismo marcante das bandas sulfetadas, silico-carbonáticas e magnetíticas. No retângulo roxo o minério bandado, e no vermelho o minério bandado magnetítico.

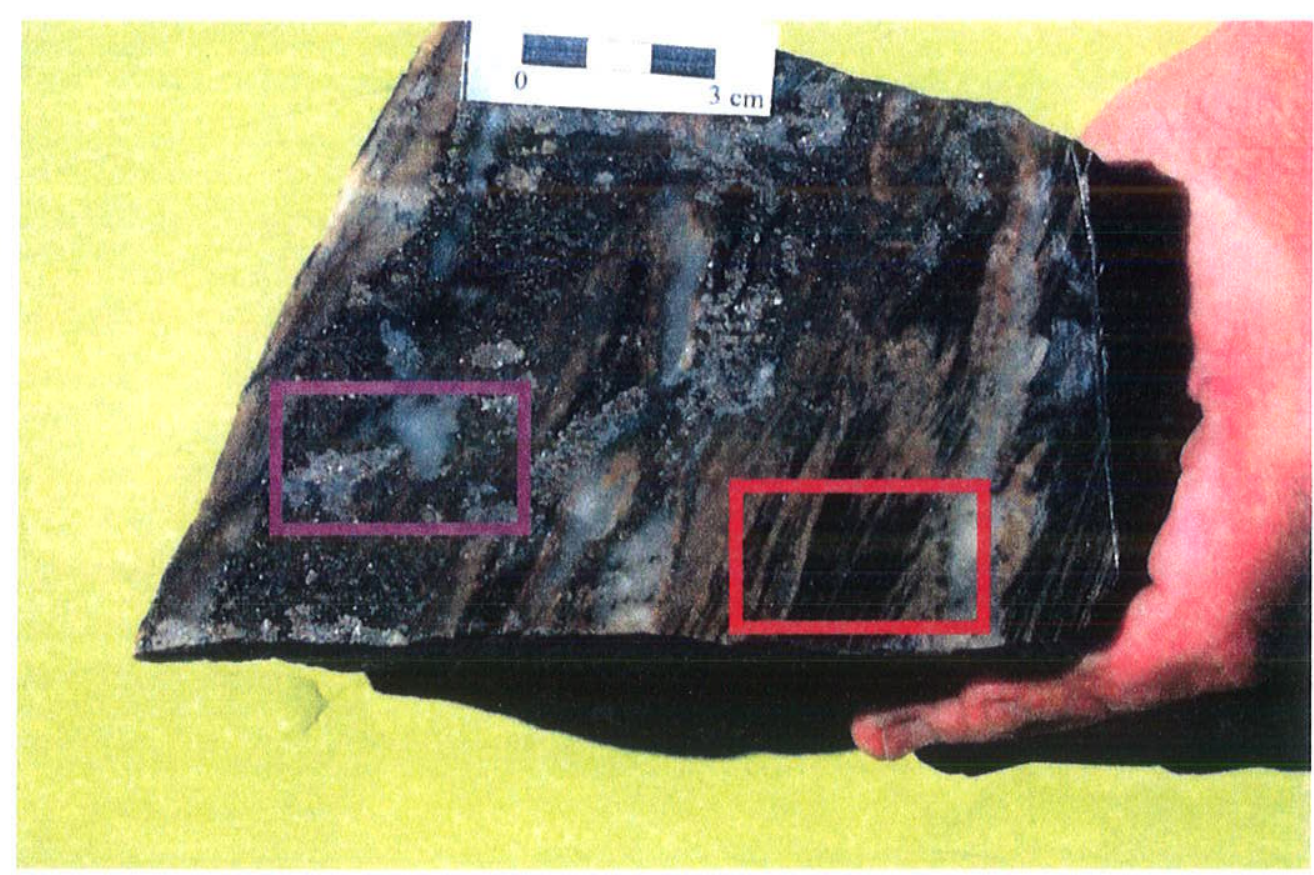

Fotografia 63: Minério remobilizadoado da mina São Bento. No retângulo roxo o minério remobilizado rico, e no vermelho o minério remobilizado (cortanto as bandas magnetiticas). 
Esfaleritas só foram dosadas na amostra G-8A da mina do Pari, sendo apresentadas na figura 69. O baixo número de análises foi devido à quebra da microssonda eletrônica do IGc-USP, o que impediu a continuidade dos trabalhos com esses sulfetos e as comparações com a mina São Bento.

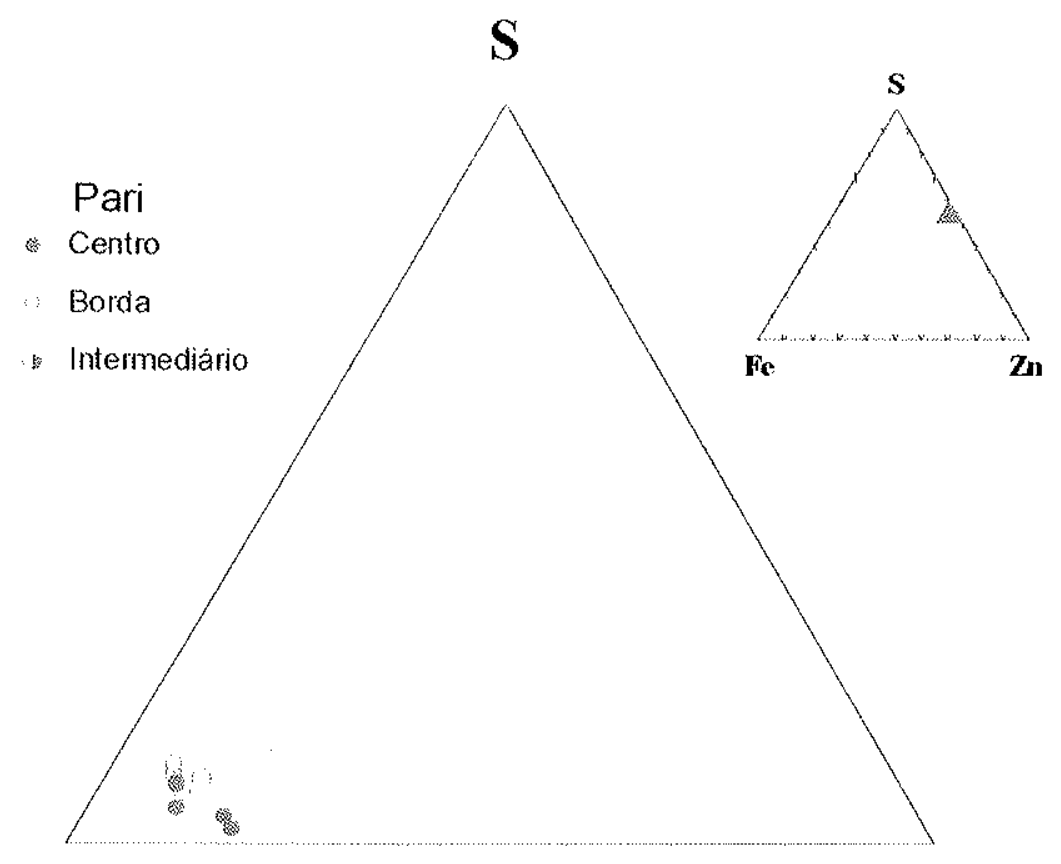

$\mathrm{Fe}$

\section{Zn}

Figura 69: A variação composicional das esfaleritas da mina do Pari é pequena, calculando-se em \% molares de FeS entre 15 e $17 \%$.

As análises das pirrotitas, apresentadas na fịura 60 , mostram uma dispersão no diagrama Fe versus S (\% atm) variando o Fe de 47 a $45 \%$, aproximadamente, e o S de 53 a $55,2 \%$. Mostram comportamento análogo às arsenopiritas, porém com uma dispersão maior das amostras da mina do Pari. As pirrotitas de São Bento, dos niveis bandados, diferenciam-se dos locais remobilizados e estas últimas tendem a possuir teores de Fe mais baixos. 


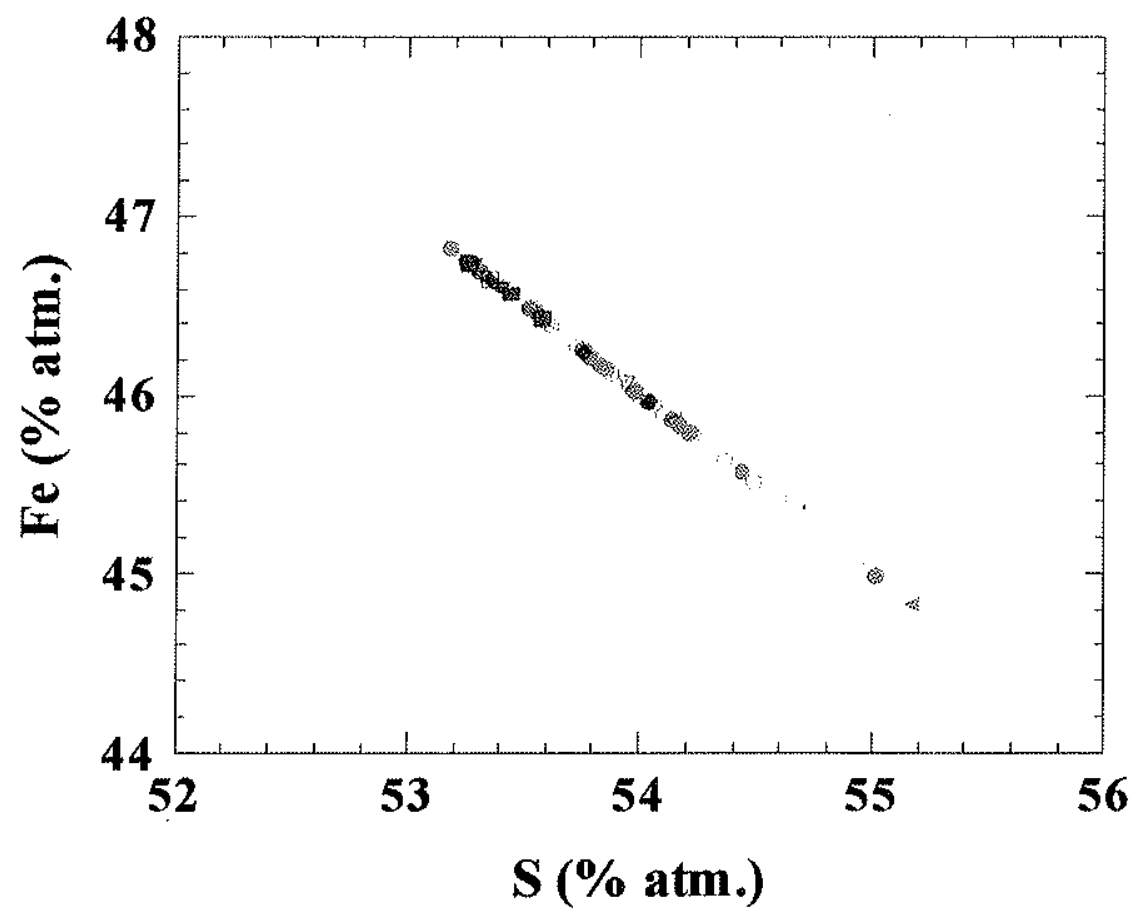

\begin{tabular}{llll}
\multicolumn{2}{c}{ São Bento } & Pari \\
* Remobilizado Centro & Bandado Centro & Centro \\
Remobilizado Borda & Bandado Borda & Borda \\
Remob. Rico Centro & Bandado Mag. Centro & Intemediário \\
Remob. Rico Borda & Bandado Mag. Borda &
\end{tabular}

Figura 70: Diagrama de variação de $\mathrm{Fe}$ e $\mathrm{S}$ (\%atm.), comparando-se pirrotitas de minérios de Au da mina São Bento e da mina do Pari.

\section{VI.8. Geotermômetros Granada-Anfibólio e Granada-Biotita (Grt-Amf e Grt-Bio)}

A partir dos dados de análises química pontuais de paragêneses silicáticas, foram realizados cálculos de estimativas de temperatura e pressão empregando-se os métodos geotermobarométricos convencionais, utilizando as planilhas GTP (Reche e Martinez, 1995) e o programa Ptmafic (Soto, 1992) os quais reúnem geotermômetros de granada-biotita (Grt-Bio) e granada-anfibólio (Grt-Amf) de diversos autores (ex. Perchuk et al, 1985; Ganguly e Saxena, 1984 e Graham e Powell, 1984, entre outros). Estimativas de pressão não foram possíveis devido à ausência de bons cristais de plagioclásio.

Os cálculos geotermobarométricos foram realizados observando, sempre, rigorosamente os critérios paragenéticos e texturais (centros e bordas de grãos 
livres de inclusões) e cristaloquímicos (perfeição das fórmulas estruturais) e são apresentados na íntegra nos anexo 9.

O geotermômetro Grt-Amf de Graham e Powell (1984) propiciou resultados que variam numa faixa de até $94^{\circ} \mathrm{C}$, a depender do litotipo analisado, bem como entre centros e bordas de grãos. Assim, observa-se, na figura 71, que, sobretudo nas amostras da mineralização, as temperaturas obtidas são bastante inferiores aos demais litotipos. Isso deve estar ocorrendo por tratar-se de litotipos bastante ricos em Fe e redutores, no caso, de BIF tipo algoma, ricos em magnetita e sulfetos com $\mathrm{Fe}$, o que poderia modificar as atividades no sentido de aumentar a estabilidade do $\mathrm{Fe}^{2+}$ nos silicatos, de forma que a calibração desse geotermômetro para tais litologias seja inadequada. De maneira geral, as temperaturas, segundo Graham e Powell (1984), dos centros dos minerais variam entre 480 a $559^{\circ} \mathrm{C}$, e nas bordas de 486 a $574^{\circ} \mathrm{C}$.

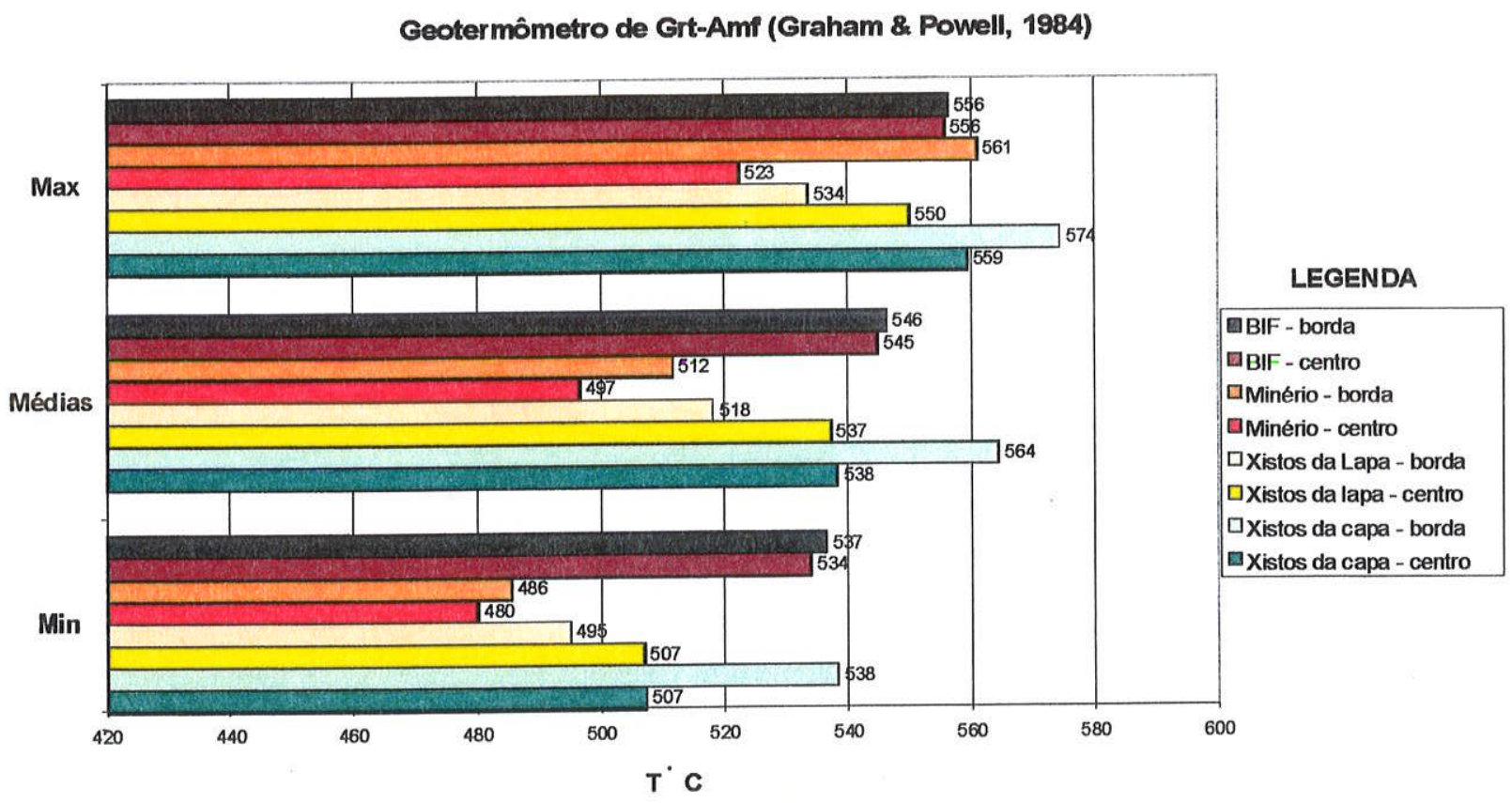

Figura 71: Temperaturas obtidas com o geotermômetro granada-anfibólio de Graham e Powell (1984) nos diversos litotipos da mina do Pari, minérios, xistos encaixantes e BIF. Nota-se que há diferenças de temperaturas entre os litotipos, e se analisados bordas ou centros de minerais.

O geotermômetro Grt-Amf de Perchuk et al. (1985) também apresenta temperaturas menores nos litotipos da mineralização, assim como diferenças por litotipos e entre centros e bordas dos cristais analisados, variando de 439 a $566^{\circ} \mathrm{C}$. A diferença máxima entre as temperaturas obtidas é de $127^{\circ} \mathrm{C}$ (Figra 72). 


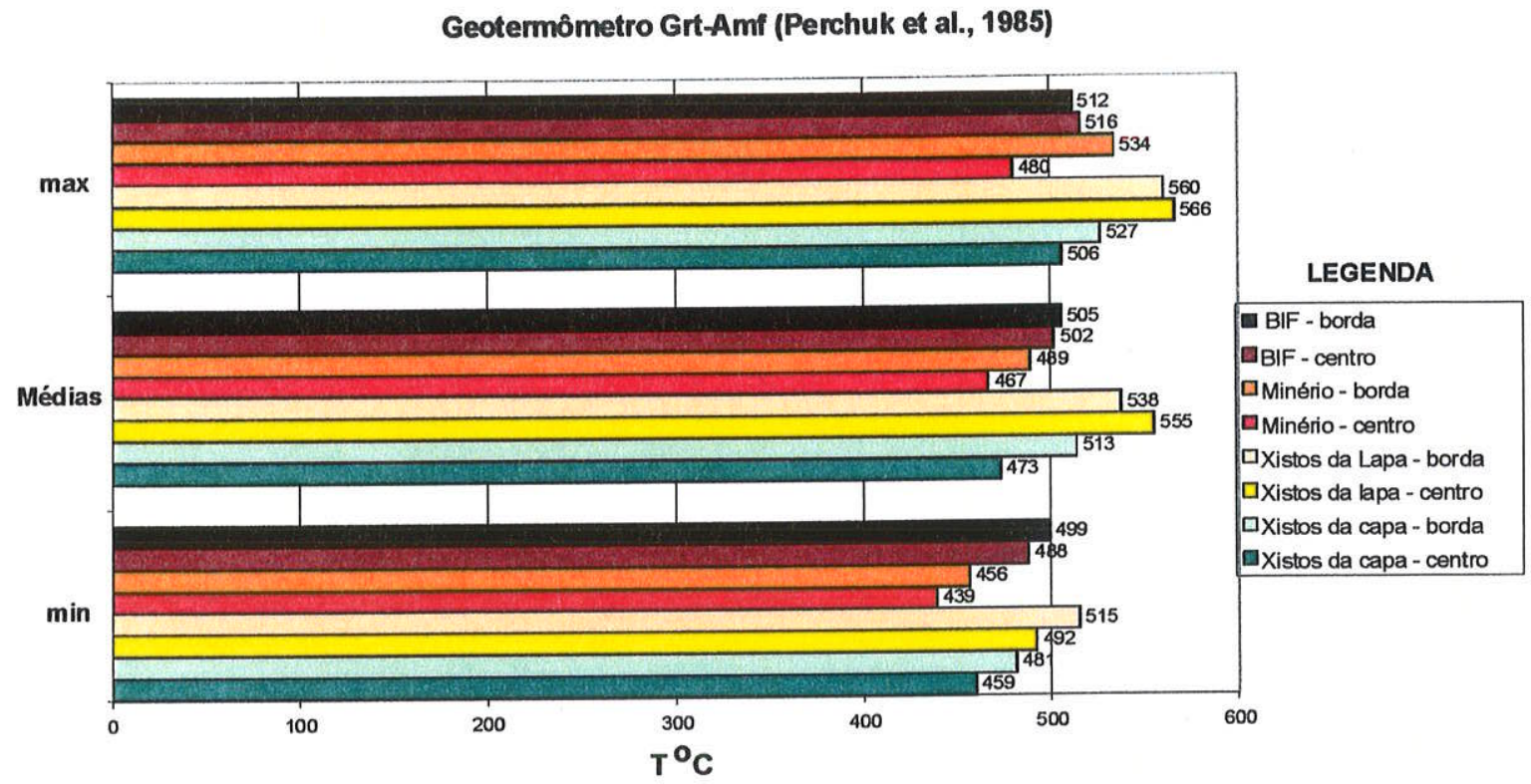

Figura 72: Temperaturas obtidas com o geotermômetro (Grt-Amf) de Perchuk et al. (1985) nos litotipos da mina do Pari. Notam-se variações de temperaturas entre os diferentes litotipos, e se analisado borda ou centro do mineral.

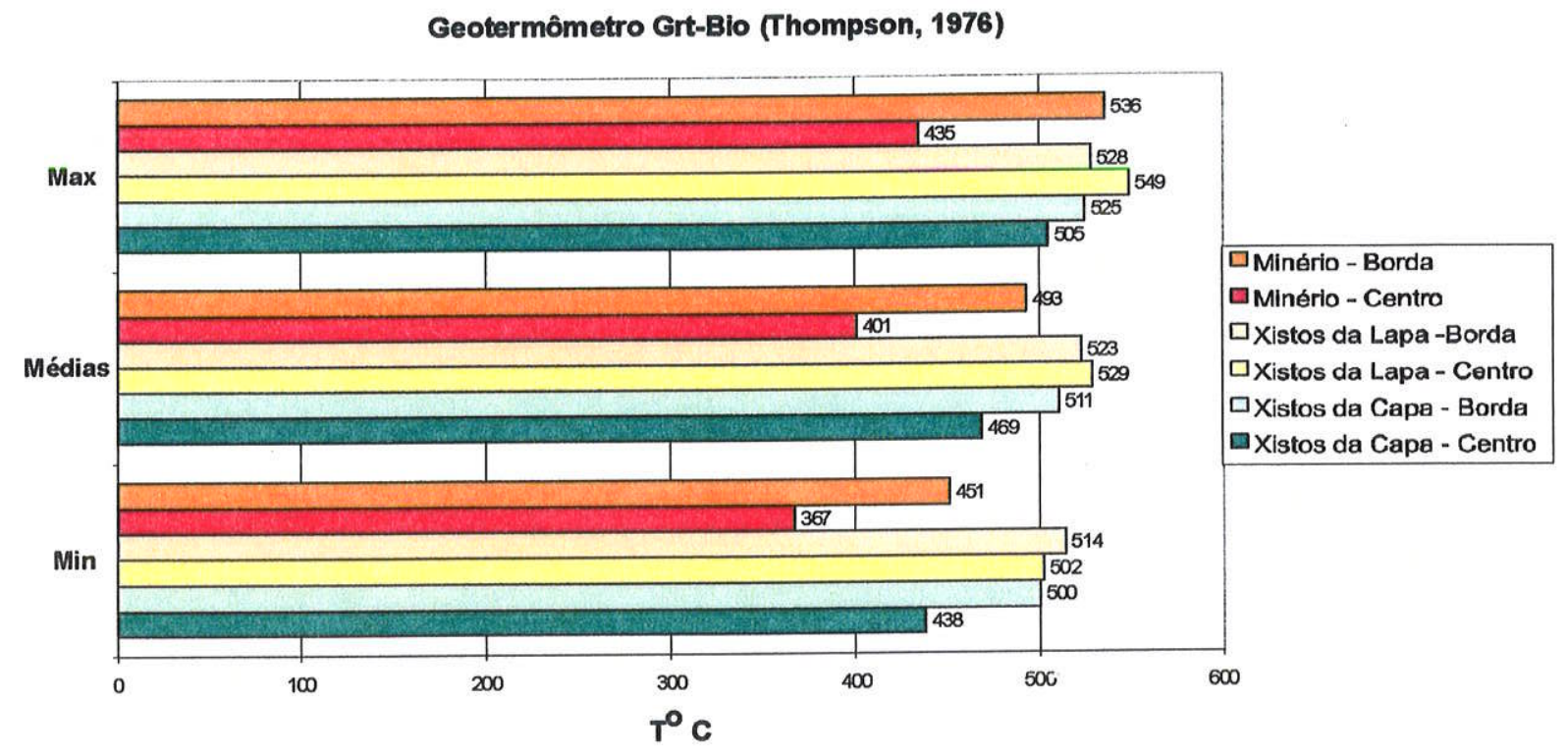

Figura 73: Geotermômetro de granada-biotita (Grt-Bio), segundo Thompson (1976), calculado para amostras do minério e dos xistos encaixantes da lapa e da capa.

Os geotermômetros de granada-biotita (Grt-Bio) também resultaram em temperaturas bastante variáveis. Pelo geotermômetro (Grt-Bio) de Thompson (1976) a variação máxima é $182^{\circ} \mathrm{C}$ (considerando todos os litotipos, as bordas e centros de grãos). Os centros dos grãos apresentaram temperaturas entre 367 e $549^{\circ} \mathrm{C}$ e as bordas entre 451 a $536{ }^{\circ} \mathrm{C}$ (Figura 73). Pelo geotermômetro Grt-Bio de Goldman e 
Albee (1977) as variações de temperaturas atingem $126^{\circ} \mathrm{C}$. Os centros dos grãos apresentaram temperaturas entre 391 e $502{ }^{\circ} \mathrm{C}$ e as bordas entre 449 e $517^{\circ} \mathrm{C}$ (Figura 74).

Todos os geotermômetros de Grt-Bio e Grt-Amf utilizados resultaram em temperaturas distintas para cada uma das unidades estudadas, entretanto, com variações análogas. A mineralização aurífera e mesmo os BIF estéreis apresentam tanto paragêneses de bordas mais "quentes" que dos núcleos dos grãos, quanto ocorre o contrário. Já as encaixantes da lapa (FW), na grande maioria das vezes, apresentam para as bordas dos minerais $T$ mais frias que nos núcleos. As encaixantes da capa (HW) têm o comportamento contrário, sempre indicam nas bordas dos minerais $\mathrm{T}$ mais quentes que nos núcleos.

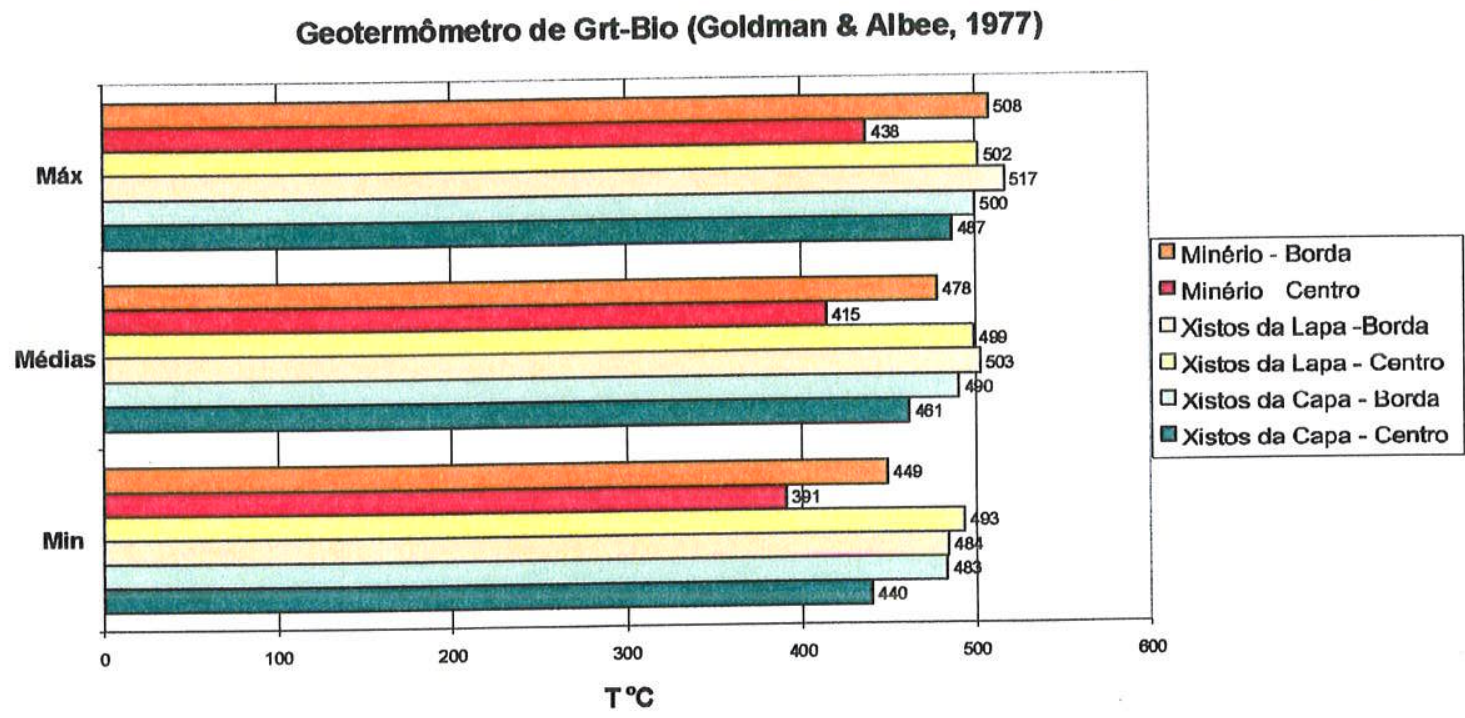

Figura 74: Geotermômetro Grt-Bio, segundo Goldman \& Albee (1977), para amostras do minério e xistos encaixantes da lapa (FW) e da capa (HW).

Os resultados permitem interpretações preliminares a despeito das diferenças consideráveis nas temperaturas metamórficas obtidas. A tendência de litotipos mais ricos em $\mathrm{Fe}$ mostrarem temperaturas menores que os mais pobres em $\mathrm{Fe}$ (e mais ricos em $\mathrm{Mg}$ ) deve-se ao estado redutor, à riqueza em $\mathrm{Fe}^{2+}$ e $\mathrm{S}^{--}$dessas rochas.

Porém, todos os dados até agora disponíveis indicam temperaturas transicionais da fácies xisto-verde alta para a fácies anfibolito. Isso vem a corroborar com os resultados petrográficos e dos estudos geotermométricos iniciais de arsenopirita de Abreu (1995). Quanto às variações, por vezes, irregulares das paragêneses com biotita de centros e bordas de cristais, deve-se considerar a fácil reequilibração retrometamórfica das biotitas em comparação às granadas e aos anfibólios, principalmente em se tratando de bordas de cristais. 
Um outro fato que muitas vezes pode estar passando sem a devida consideração, diz respeito à natureza policíclica de evolução polimetamórfica da região estudada. As rochas e os minérios de Au primários da mina do Pari sofreram um metamorfismo arqueano no final da evolução do greenstone belt Rio das Velhas, de fácies xisto verde baixo a médio, indicado apenas pelas estruturas $\mathrm{Sn}-1$. Seguiu-se o metamorfismo regional principal progressivo, que gerou as paragêneses de pico metamórfico petrograficamente predominantes e por fim, o evento tectono-termal Brasiliano, que regionalmente causou reequilibrações retrometamórficas e isotópicas sob T variáveis na faixa de $300-400^{\circ} \mathrm{C}$ (Schorscher, 1975; 1992). Assim, um grão mineral pode ter experimentado muitas fases de cristalização, recristalização e reequilibração parciais a totais metamórficas, e o ponto analisado em um mineral em dado litotipo, pode não estar sendo perfeitamente correlacionado ao ponto analítico do mineral par na mesma rocha ou, ainda, aos pontos analíticos num outro litotipo, ainda que proximamente associado.

\section{VI.9. Geotermômetro de Arsenopirita}

Foi utilizado o diagrama da figura 75 , referente ao geotermômetro de As em arsenopirita, segundo Sharp et al. (1985), comparando-se amostras da mina São Bento e da mina do Pari.

As temperaturas obtidas para a mina do Pari variam entre 500 e $550^{\circ} \mathrm{C}$, aproximadamente, considerando-se as paragêneses do minério, de arsenopirita e pirrotita, exclusivamente (sem pirita).

Os valores são bastante compatíveis face à coexistência de granada e grunerita junto à mineralização. Observou-se, no entanto, em uma boa parcela dos grãos estudados de arsenopirita, que estes apresentavam em suas porções intermediárias (entre centro e borda), temperaturas muitas vezes superiores à borda. 


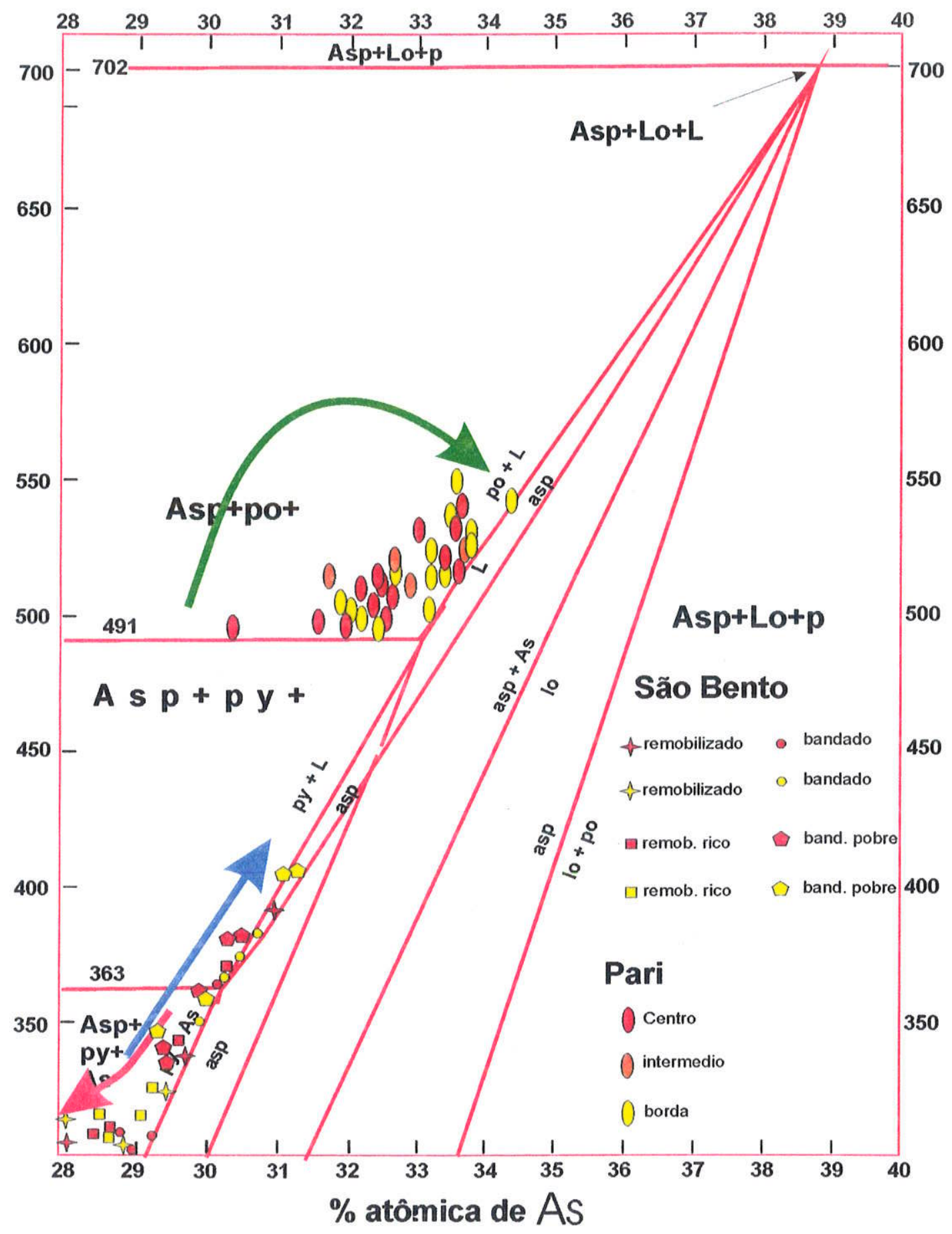

Figura 75: Geotermômetro de "As em Arsenopirita", segundo Sharp et al.(1985), mostrando dados das minas de Au Pari e São Bento. A linha vermelha indica, de centro a borda do grão uma tendência de queda na temperatura nas zonas remobilizadas (sulfetos discordantes) da mina São Bento. A linha azul, mostra o incremento da temperatura do centro para a borda dos sulfetos bandados da mina São Bento. Em Pari, a linha verde mostra temperaturas ascendentes, porém, com algumarrefecimento às bordas. 
Nas amostras da mina São Bento observaram-se temperaturas variando entre $300 \mathrm{e}$ $415^{\circ} \mathrm{C}$, compativeis com a fácies xisto verde inferior (até média?) do local e as paragêneses de clorita + sericita + Fe-stilpnomelano. As arsenopiritas do minério bandado (concordante, fotografia 62) atingem, em média, as temperaturas mais altas, enquanto nas zonas de minério remobilizado (discordante, fotografia 63) as temperaturas tendem a ser mais baixas. E preciso destacar mais uma vez que esses minérios remobilizados, quase sempre, ocorrem em zonas de rompimento de charneiras de dobras apertadas a isoclinais.

\section{VI.10. Geotermômetro da Pirrotita}

$\mathrm{Na}$ figura 76 apresentam-se os dados geotermométricos das pirrotitas das minas do Pari e São Bento. Nota-se que os valores variam entre 450 e $700^{\circ} \mathrm{C}$, sendo os valores de $600-700^{\circ} \mathrm{C}$ certamente incompatíveis, demasiado elevados, para as paragêneses encontradas em ambas as minas estudadas. No entanto, considerando-se que não foram consideradas as condições geobarométricas, o diagrama mostra tendências gerais compatíveis com os resultados das arsenopiritas, de temperaturas mais altas para as amostras da mina do Pari, bem como de variações análogas de temperaturas para os diferentes tipos de minérios examinados da mina São Bento.

\section{VI.11. Considerações sobre a Química Mineral}

\section{VI.11.1. Silicatos}

As biotitas do Gr. Nova Lima, da lapa e da capa da mineralização da mina do Pari apresentam diferenças, sendo as primeiras enriquecidas em $\mathrm{Mg}$, $\mathrm{Na}$ e empobrecidas em $\mathrm{Fe}$, enquanto as últimas são enriquecidas em $\mathrm{K}$ e $\mathrm{Fe}$. Os anfibolitos, tanto granatíferos da lapa quanto da unidade $D$, apresentam biotitas de composições bastante próximas.

Nas rochas metaultramáficas do Gr. Quebra Osso as biotitas são flogopíticas, devido ao alto teor de $\mathrm{Mg}$ dos protolitos komatíticos.

As cloritas apresentam diferenças apenas entre as rochas da lapa e da capa. Os xistos e anfibolitos de lapa possuem cloritas com baixo Fe e maior variação no de $\mathrm{TSi}$, enquanto os anfibolitos do capa tem as cloritas mais ricas em Fe. 


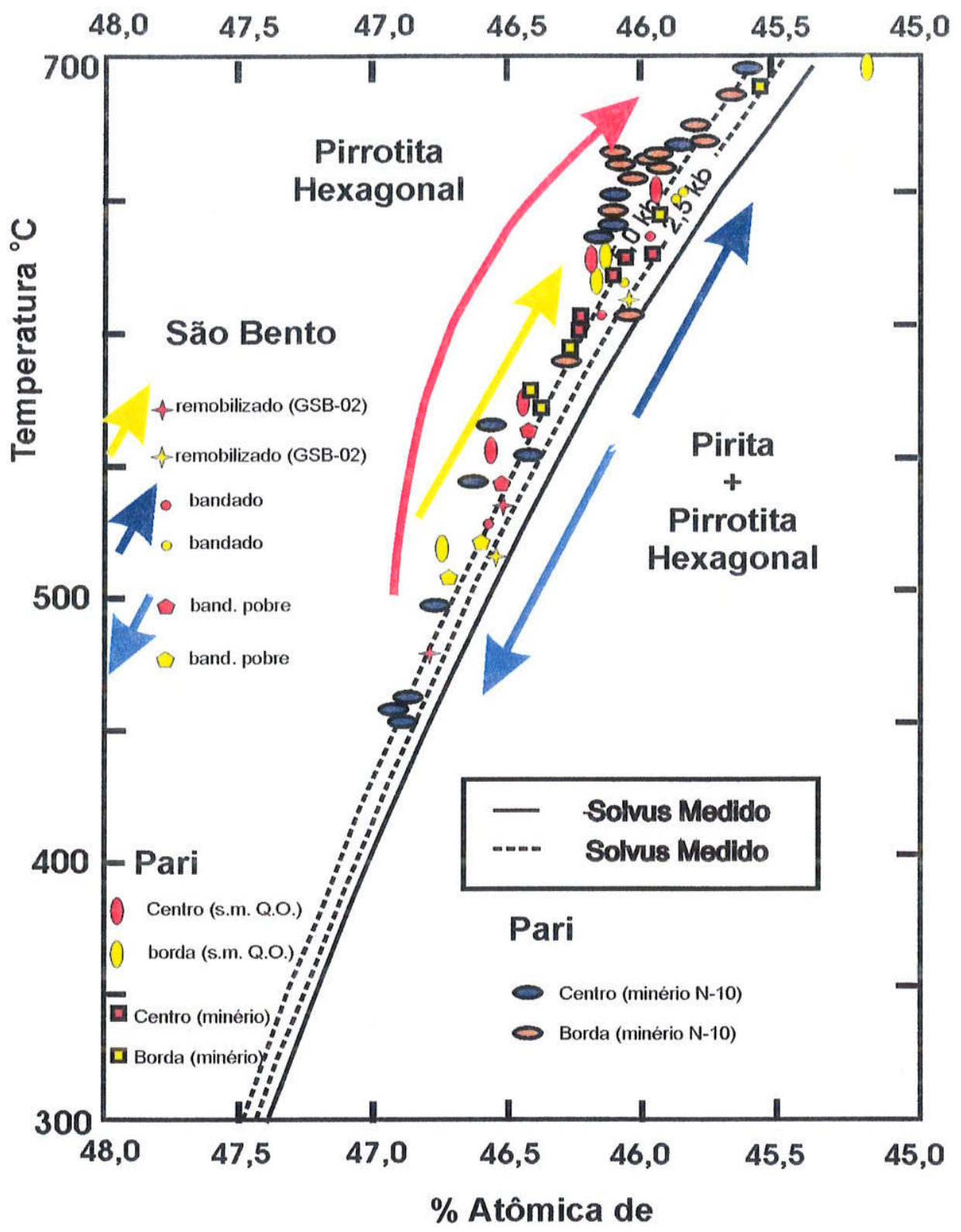

Figura 76: Diagrama T - X do solvus pirita + pirrotita hexagonal (Craig e Scott, 1974) 2500 e 5000 bar utilizado como geotermômetro. As setas azuis representam a evolução do minério bandado da mina S.Bento; a seta amarela as zonas de sulfetos remobilizados. A seta vemelha traça a evolução do minério da mina do Pari. 
Os anfibólios analisados distribuem-se em vários grupos, predominando os cálcicos que apresentam grande variabilidade composicional. Nas metaultramáficas ocorrem tremolitas e hornblendas. Os anfibolitos granatíferos apresentaram apenas tschermakitas, enquanto os anfibolitos finos da capa também apresentam hornblendas. Os xistos encaixantes próximos ao minério possuem anfibólios distintos na lapa e capa. Nos xistos da capa são tschermakitas e nos da lapa, predominantemente hornblendas. No minério observam-se até três tipos de anfibólios cálcicos, as hornblendas de baixo $\mathrm{Na}$, as tschermakitas, e as pargasitas com Na mais alto ocorrendo, normalmente, como bordas nas tschermakitas.

Além disso, no minério ainda ocorrem anfibólios ferro-magnesianos da série cummingtonita-grunerita, predominando os termos mais ricos em Fe.

As granadas são genericamente almandinas porém, soluções sólidas, em proporções variáveis de almandina(56-91) - grossularitaária(8-44) - espessartita(020) - Piropo(1-30) - Andradita(2-2,5).

Os carbonatos analisados apresentaram-se bastante puros, predominantemente calcíticos, com menos de $10 \%$ de $\mathrm{Fe}, \mathrm{Mn}$ e $\mathrm{Mg}$ em solução sólida, na ordem decrescente.

\section{VI.11.2. Sulfetos}

As arsenopiritas da mina do Pari mostraram-se predominantemente distintas das da mina São Bento, com conteúdos maiores de As, o que é compativel com condições metamórficas de grau maior.

As arsenopiritas de São Bento, por sua vez, dividiram-se em dois grupos, sendo que as que ocorrem nas zonas remobilizadas e discordantes à mineralização são as de menor conteúdo de As, indicando que possivelmente se formaram em temperaturas mais baixas, junto às zonas de alivio, relacionadas às zonas de fraqueza e rompimento tectônico inclusive de charneiras de dobras. É interessante nesse ponto salientar que, nos mapeamentos da mina São Bento, desde sua reabertura em 1984, relata-se uma maior abundância de veios sulfetados/mineralizados discordantes nos niveis mais profundos da mina, interpretados como possivelmente indicativos da aproximação da zona de charneira da dobra hipotética sinformal maior, que conectaria a formação ferrifera São Bento com a formação ferrífera Barão de Cocais, a NW. 
As esfaleritas da mina do Pari têm composição aproximadamente constante, mal atingindo $10 \%$ (atm.) de $\mathrm{Fe}$.

A grande variabilidade das pirrotitas, tanto da mina do Pari quanto da Mina São Bento reflete a facilidade deste mineral em adaptar-se às diferentes condições de $P$ e T. Porém, suas composições também parecem indicar que os mesmos eventos afetaram as duas minas, claro que com intensidades distintas, principalmente, quanto ao evento metamórfico regional principal, como verificado em outros parâmetros geotermobarométricos.

\section{VI.11.3. Geotermometria}

O uso de vários métodos de geotermometria metamórfica nas rochas e nos minérios das minas de Pari e São Bento, baseados em vários autores, propiciou resultados muito variáveis. Era esperado que, a depender do método utilizado, os valores obtidos não seriam iguais, pois dependeriam muito dos litotipos utilizados nos estudos dos autores. Nesse sentido, ressalta como observação interessante a temperatura sistematicamente mais baixa obtida nos litotipos do minério aurífero sulfetado e rico em $\mathrm{Fe}$, indicando que rochas redutoras com elevadas concentrações de $\mathrm{Fe}^{2+}$ e $\mathrm{S}$ influenciariam os métodos, desviando para $\mathrm{T}$ menores daquelas propostas por calibrações em paragêneses silicáticas, outrossim, análogas.

Apesar da grande variabilidade das temperaturas obtidas, o fato é que os litotipos da mina do Pari encontram-se, indubitavelmente, na zona metamórfica de transição da fácies xisto verde para anfibolito, caracterizando o grau médio de metamorfismo (Tabela 11). Esse grau metamórfico distingue-se claramente do grau fraco da mina São Bento.

Como na outra observação constataram-se normalmente temperaturas de paragêneses de bordas de grãos maiores que de seus núcleos, à exceção das amostras da lapa da mineralização onde ocorre o inverso. As primeiras são compativeis com a natureza progressiva do principal evento metamórfico regional, as segundas podem indicar reequilibrações retrometamórficas mais ativas nas encaixantes da lapa, seja por composições dos litotipos, seja por cisalhamento diferencial. 
O uso de geotermometria mostrou-se muito mais como uma metodologia auxiliar do que fundamental e diagnóstica para a evolução policíclica. O mapeamento detalhado em superfície e das galerias, e a petrografia são fundamentais para o estudo e entendimento da evolução metamórfica das minas de ouro do Quadrilátero Ferrífero.

\begin{tabular}{|c|c|c|c|c|c|c|c|c|c|c|}
\hline Mina & Litotipo & método & \multicolumn{3}{|c|}{ Autor } & \multicolumn{3}{|c|}{ Centro } & \multicolumn{3}{c|}{ Borda } & Diferença \\
\hline & & & & $T$ min & Tmáx & Tmédia & Tmin & Tmáx & T media & Borda-Centra \\
\hline Pari & Minério & Grt-Anf & Graham \&Powell (1984) & 480 & 523 & 497 & 486 & 561 & 512 & 15 \\
\hline Pari & Minério & Grt-Anf & Perchuk et al. (1985) & 439 & 480 & 467 & 456 & 534 & 489 & 22 \\
\hline Pari & Minério & Grt-Bio & Thompson (1976) & 367 & 435 & 401 & 451 & 536 & 493 & 92 \\
\hline Pari & Minério & Grt-Bio & Goldman \& Albee (1977) & 391 & 438 & 415 & 449 & 508 & 478 & 63 \\
\hline
\end{tabular}

\begin{tabular}{|c|c|c|c|c|c|c|c|c|c|c|}
\hline Pari & Minério & Asp & Sharp et al. (1985) & 495 & 540 & 525 & 495 & 555 & 530 & 5 \\
\hline Pari & Minério & Po & Craig \& Scott (1974) & 450 & 700 & 600 & 520 & 645 & 620 & 20 \\
\hline
\end{tabular}

\begin{tabular}{|c|c|c|c|c|c|c|c|c|c|c|}
\hline Pari & S.Mac QO & Po & Craig \& Scott (1974) & 550 & 650 & 600 & 520 & 700 & 620 & 20 \\
\hline Pari & BIF & Grt-Anf & Graham \&Powell (1984) & 534 & 556 & 545 & 537 & 556 & 546 & 1 \\
\hline Pari & $\mathrm{BIF}$ & Grt-Anf & Perchuk et al.(1985) & 488 & 516 & 502 & 499 & 512 & 505 & 3 \\
\hline & & & Medias & 511 & 536 & 524 & 518 & 534 & 526 & 2 \\
\hline
\end{tabular}

\begin{tabular}{|c|c|c|c|c|c|c|c|c|c|c|}
\hline Pari & Lapa-FW & Grt-Anf & Graham \&Powell (1984) & 507 & 550 & 537 & 495 & 534 & 518 & -19 \\
\hline Pari & Lapa-FW & Grt-Anf & Perchuk et al.(1985) & 492 & 566 & 555 & 515 & 560 & 538 & -17 \\
\hline Pari & Lapa-FW & Grt-Bio & Thompson (1976) & 502 & 549 & 529 & 514 & 528 & 523 & -6 \\
\hline Pari & Lapa-FW & Grt-Bio & Goldman \& Albee (1977) & 484 & 517 & 503 & 493 & 502 & 499 & -4 \\
\hline
\end{tabular}

\begin{tabular}{|c|c|c|c|c|c|c|c|c|c|c|}
\hline Pari & Capa-HWW & Grt-Anf & Graham \&Powall (1984) & 507 & 559 & 538 & 538 & 574 & 564 & 26 \\
\hline Pari & Capa-HW & Gri-Anf & Perchuk at al.(1985) & 459 & 506 & 473 & 481 & 527 & 513 & 40 \\
\hline Pari & Capa-HW & Grit-Bio & Thompson (1976) & 438 & 505 & 469 & 500 & 525 & 511 & 42 \\
\hline Pari & Capa-HW & Grt-Bio & Goldman \& Albee (1977) & 440 & 487 & 461 & 483 & 500 & 490 & 29 \\
\hline
\end{tabular}

Obs.: Grt=granada; Anfmanflbolło; Aspzarsenopirita; Pompirrotita; Blo=blotita

Tabela 11: Resumo das temperaturas obtidas com os diversos geotermômetros utilizado nos estudos da mina do Pari. 


\section{Capítulo VII: ANALOGIAS A OUTRAS MINAS E DISTRITOS AURIFEROS}

As mineralizações auriferas da quadricula de Florália apresentam peculiaridades que as distinguem da grande maioria das mineralizações auríferas em greenstone belts do Brasil e também das demais mineralizações de ouro do Quadrilátero Ferrifero. Citam-se, como principais, aspectos da alteração das rochas encaixantes, a petrografia dos minérios, incluindo sulfetos, óxidos - magnetitas, silicatos e carbonatos, suas relações genéticas mútuas, assim como o grau metamórfico relativamente alto. Seus efeitos que contribuíram, principalmente, para enobrecer a mineralização pré-existente, tanto aumentando o teor de Au na liga natural do metal, quanto liberando-o em grande quantidade na textura dos minérios. Da bibliografia sobre a metalogênese do ouro em greenstone belts arqueanos, um tema vastíssimo, entretanto, foi possível selecionar alguns exemplos que serão brevemente comparados à mina do Pari.

As mineralizações, cujas características mais se aproximam da mina do Pari, são aquelas que ocorrem na própria Quadrícula de Florália, descritas no capitulo IV desta tese, que são: Pari Norte, Patrimônio e Gambá. Todas essas mineralizações sustentaram pequenas lavras no passado. Por falta de amostras frescas e de trabalhos de sondagem rotativa diamantada, essas áreas apenas foram mapeadas e amostradas em superficie durante os trabalhos de pesquisa da UNAMGEN Min. e Met. S.A.. Apresentam situação litoestratigráfica muito semelhante, com uma boa continuidade das principais unidades $B, C$ e D, do Gr. Nova Lima, desde a mina do Pari, e todas elas caracterizam-se como extensões, muitas vezes descontínuas, do BIF mineralizado do Horizonte Pari. Na localidade da mina do Gambá, o horizonte mineralizado apresenta duas BIF separadas, os ângulos de mergulho se tornam mais baixos $\left(<45^{\circ}\right)$ e as encaixantes próximas apresentam teores mais baixos de Au. As características litoestruturais e macro-petrográficas regionais foram bem reconhecidas nos afloramentos de campo e permanecem contínuas desde Pari até pouco a norte da mina do Gambá.

A mina do Bahú, mais a norte que a do Gambá, encontra-se em dominio predominantemente metassedimentar do $\mathrm{Gr}$. Nova Lima, sendo raras as intercalações metavulcânicas, porém com abundância de BIF de direção aproximada ENE. Apesar da falta de afloramentos da mineralização aurifera de Bahú em si, hoje com suas escavações aterradas, foi encontrado ouro em quartzo de veio leitoso em 
pilhas de rejeito das escavações antigas, provenientes, possivelmente, de veieiros de natureza discordante dos BIF.

A mina São Bento localiza-se em um paleoambiente arqueano exclusivamente sedimentar. Até hoje não foram encontradas rochas vulcânicas associadas aos metassedimentos ou à evolução do Greenstone belt Rio das Velhas neste local. $O$ metamorfismo é de grau mais baixo que na mina de Pari, porém também foram observados efeitos de remobilização de quartzo, carbonatos e sulfetos em veios com ou sem Au, discordantes. Nesse sentido, cabe recordar que o geotermômetro de arsenopirita das zonas de sulfetos remobilizados em charneira de dobras rompidas das BIF tende a registrar temperaturas mais baixas que nos sulfetos do minério bandado. Schorscher et al. (1991) já havia salientado várias gerações distintas (pelo menos 3) de Au e também de arsenopiritas na mina São Bento. Fato interessante que tem sido observado ao longo da história recente da mina São Bento é a abundância crescente de zonas remobilizadas nos niveis mais profundos (niveis 18 a 25) do que nos niveis mais rasos (niveis 11 a 16) da mina. Isso levou aqui à interpretação de que a formação ferrífera São Bento, que está em posição invertida (Valladares, 2000; 2004), consistiria no flanco inverso e seria, possivelmente, ligada por uma charneira de dobra sinformal em profundidade à formação ferrifera Barão de Cocais, a NW, que seria o flanco normal. Trabalhos exploratórios em andamento na mina São Bento confirmaram indícios de mineralizações auríferas sulfetadas na BIF Barão de Cocais. A controvérsia singênese versus epigênese sempre foi aventada para a mina São Bento, desde Abreu et al. (1988). Martins Pereira (1995), Lobato et al. (1998 a,b) defendem que a principal fase mineralizante seria arqueana, porém de natureza pós pico metamórfico, apoiados em dados essencialmente estruturais, porém salientam a possibilidade dessa mineralização por remobilização de uma protomineralização sinsedimentar na BIF São Bento. Schorscher et al. (1991), Schorscher e Valladares (2001), Valladares $(2000,2004)$ e de Witt et al. (1994, 2004) apresentam evidências singenéticas através de dados geoquímicos e microgeoquímicos, incluindo padrões de terras raras. Esses estudos mostram que a mineralização e os BIF estéreis (magnetíticos) são de origem semelhante e indicam que a deposição da mineralização aurífera ocorreu em sincronia com a sedimentação química das formações ferríferas.

A mina Morro Velho, conforme Ladeira (1980, 1988 e 1991), juntamente com as minas Bicalho (Vial, 1980a), Honório, Faria (Moreschi, 1972) e Raposos (Godoy, 1994), têm contexto geológico semelhantes entre si e localizam-se no distrito de 
Nova Lima-MG, na porção NW do greenstone belt Rio das Velhas. Os BIF e a formação Lapa Seca (rocha de quartzo-ankerita-dolomita maciça ou xistosa, de fato, BIF de fácies carbonato) que contêm as mineralizações auríferas mostram-se em situação estrutural distinta das mineralizações da borda NE do Q.F. Porém, o ouro natural da mina de Morro Velho (dados de Ladeira 1991) mostra populações Au-Ag muito semelhantes às da mina do Pari, a despeito do grau metamórfico ser mais baixo (Figuras 77 e 78). Dados de geotermometria da mina Raposos (Godoy, 1994) indicam temperaturas intermediárias entre as das minas São Bento e Pari. Neste caso, suspeita-se também de efeitos de múltiplos estágios no distrito de Nova Lima, com remobilização do Au e sulfetos em condições metamórficas intermediárias (xisto verde médio, zona da biotita), muito provavelmente, devido ao condicionamento estrutural, o qual permitiu a formação de zonas de fraqueza E-W em charneiras de dobras, condicionando baixa pressão litostática e alta pressão de fluidos. Assim, como foi observado na Mina São Bento, ainda que em situações restritas a locais específicos de charneiras de dobras rompidas, possivelmente a mineralização por remobilização, na região de Nova Lima também ocorreria em temperaturas mais baixas.

Sobre a metalogênese dos depósitos auríferos no distrito de Nova Lima existem duas principais correntes de pensamento: uma advogando processos singenéticos sinsedimentares, fundamentada por Ladeira (1980), e a outra processos hidrotermais-orogênicos, defendida por Lobato et al. (1998 a,b), Viera (1988 e 1991) e Vial et al. (1987).

No Brasil, da mina de Crixás, foram descritas condições metamórficas semelhantes às da mina do Pari, porém, segundo Thomson (1991) e Magalhães \& Nilson (1993a), a mineralização associar-se-ia a um evento retrometamórfico que gerou alteração nas fases minerais de maior temperatura como, por exemplo, nas granadas e estaurolitas. Estudos mais recentes detalhados por Petersen Jr (2003), na mina de Crixás, mais precisamente no Corpo $\mathrm{IV}$, petrográficos e geotermobarométricos, mostraram que a mineralização se associa a um evento antigo $\mathrm{D} 1\left(\mathrm{~T}=225\right.$ a $350^{\circ} \mathrm{C}$, $\mathrm{P}=2-4,2 \mathrm{~kb}$, interpretado como paleoproterozóico), que foi remobilizada intensamente num evento $\mathrm{D} 2\left(\mathrm{~T}=425\right.$ a $475^{\circ} \mathrm{C}, \mathrm{P}=5,8$ a $\left.10 \mathrm{~kb}\right)$ com a formação de granada $\mathrm{e}$ biotita, e também afetada por um evento final $D 3\left(T=225\right.$ a $325^{\circ} \mathrm{C}, P=0,5$ a $\left.1,2 \mathrm{~kb}\right)$. No evento final (D4), considerado neoproterozóico, houve a reestruturação dos corpos mineralizados por cisalhamentos, que, porém, não remobilizaram o Au. 


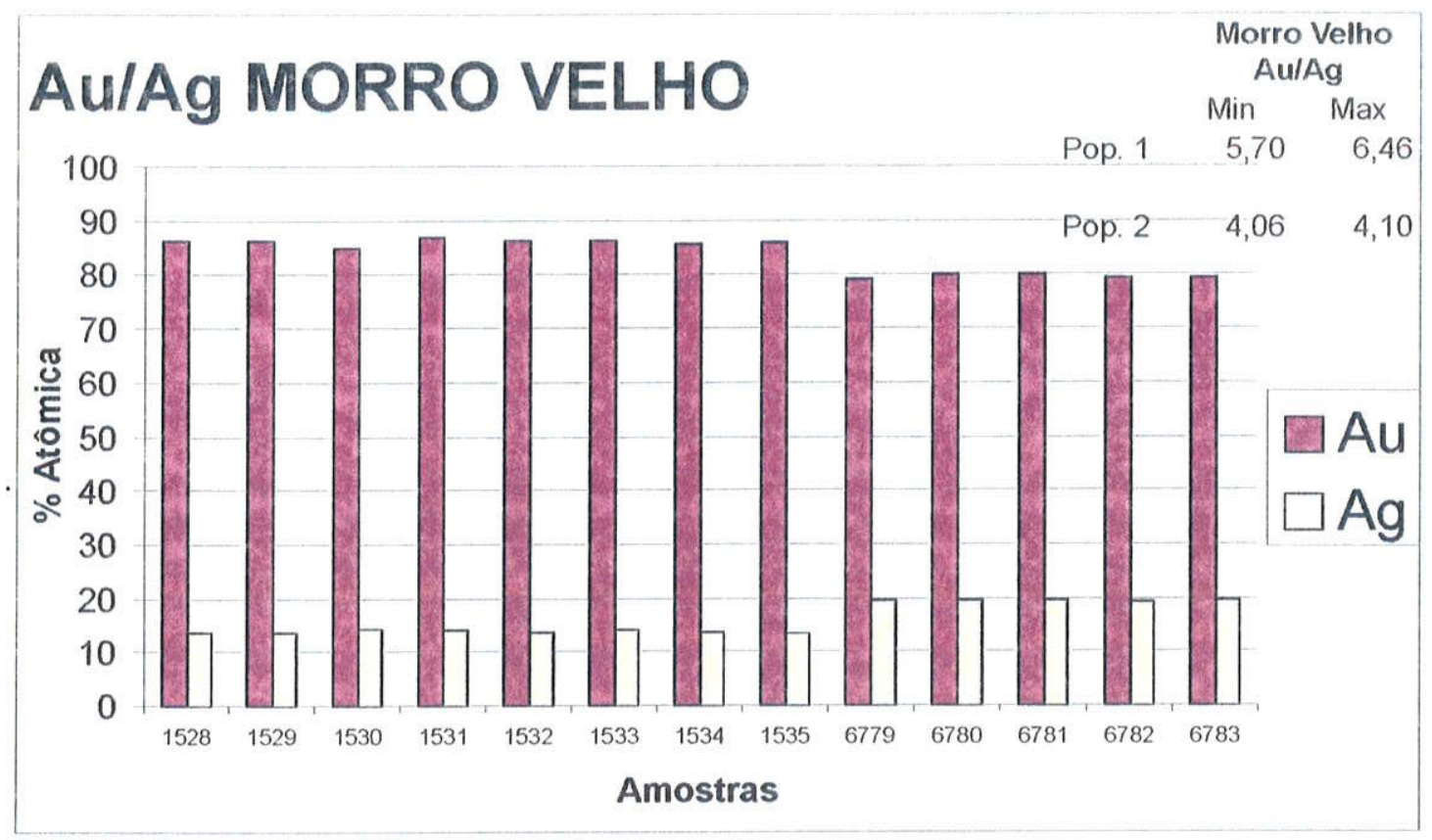

Figura 77: Diagrama de Composição do ouro natural (\% atômica) da mina de Morro Velho. Distribuição em duas populaçốes (dados de Ladeira, 1988). No canto superior direito da figura apresenta-se a relação Au/Ag.

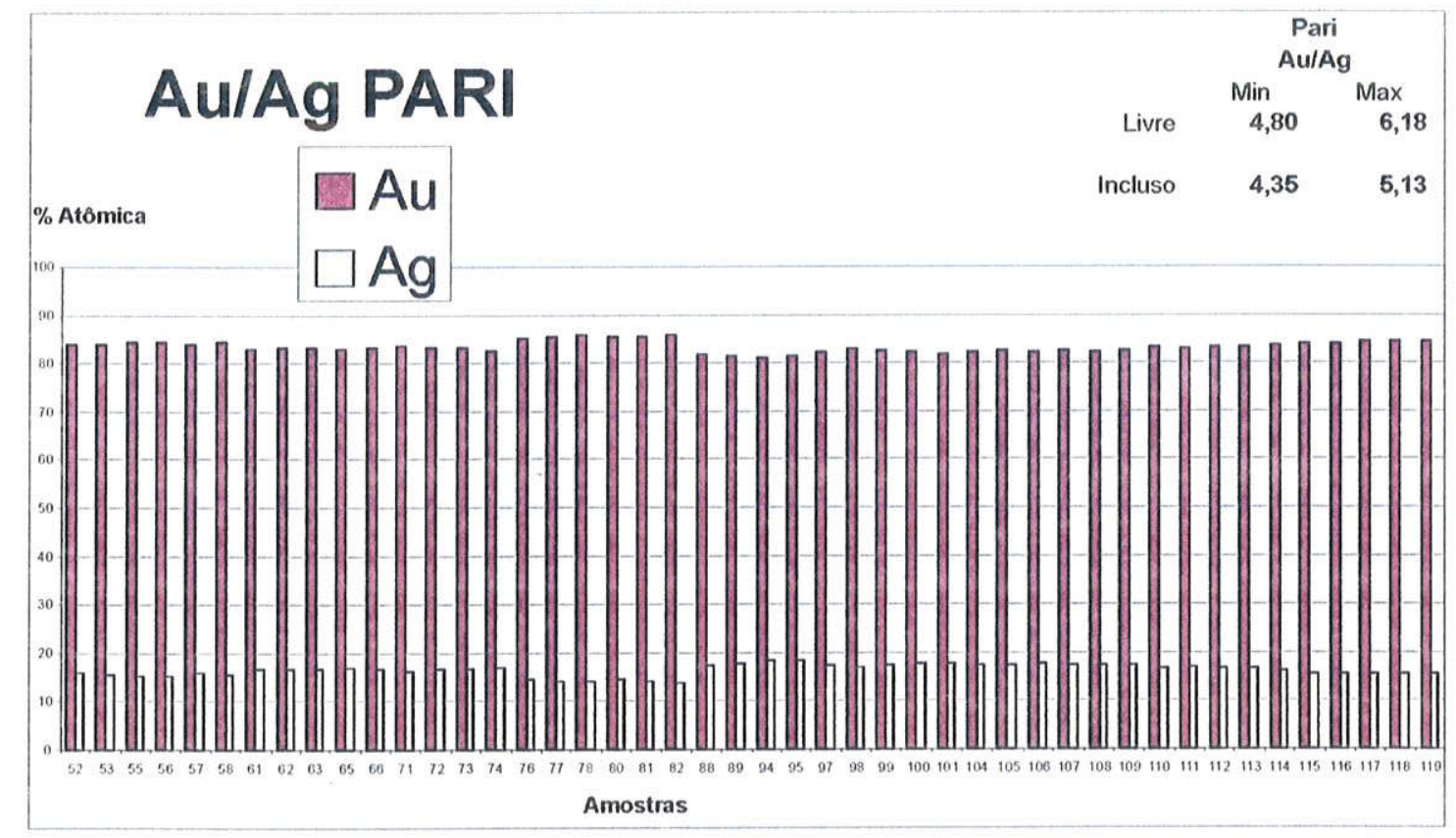

Figura 78: Diagrama de Composição do ouro natural (\% atômica) da mina do Pari. Distribuição em duas populações composicionais e texturais (Livre e incluso) (dados de Schorscher e al. (1991), in Abreu, (1995). No canto superior direito. da figura apresenta-se a relação $\mathrm{Au} / \mathrm{Ag}$ 
Aspectos metalogenéticos do ouro relacionados a processos de retrometamorfismo em rochas de fácies anfibolito também foram descritos da mina de Ouro Fino, de Riacho dos Machados, localizada no norte do Estado de Minas Gerais (Fonseca et al., 1991), onde a mineralização está contida em quartzo-muscovita xistos e as encaixantes são metassedimentos com granada e estaurolita. Na mina do Pari, entretanto, os efeitos petrográficos de retrometamorfismo são muito fracos a ausentes, tanto nos minérios quanto nas rochas encaixantes e/ou associadas da seqüência metavulcano-sedimentar. Quando muito, ocorrem remobilizações menores e sem importância metalogenética.

Mundialmente, existem diversas mineralizações de Au que se assemelham à mina do Pari.

No Kolar Gold Field, India, Narayanaswami et al. (1960) descrevem mineralizações muito semelhantes ao Pari quanto ao grau metamórfico e às características petrográficas das principais litologias. No entanto, ocorrem dois tipos principais de mineralização. O economicamente mais importante, denominado tipo Champion, consiste de veios de quartzo com raros sulfetos e carbonatos (Narayanaswami et al. (1960) e Hamilton \& Hodgson (1987), associados a zonas de cisalhamento dúctilrúptil, sendo epigenéticos. Os minérios do tipo Champion correlacionar-se-iam, na mina do Pari, ao tipo subordinado de mineralização, encontrado no veio de quartzo da unidade $C$. O segundo tipo de Kolar, chamado de Oriental, constitui-se em mineralizações sulfetadas, semelhantes à mineralização principal do Pari, e estudos termodinâmico-metalogenéticos em sulfetos (Anil et al., 1991) têm encontrado evidências indicando a formação/deposição sinvulcânica dos protominérios dessas mineralizações em temperaturas próximas a $320^{\circ} \mathrm{C}$.

As minas de Campbell e Dickenson, no distrito de Red Lake, Canadá, são outros exemplos de mineralizações bastante semelhantes à mina do Pari. Encontram-se encaixadas em rochas metavulcânicas básicas e possuem paragêneses de minerais de ganga e de minérios análogas.

MacGeehan \& Hodgson (1980) descreveram regionalmente três eventos de formação de sulfetos e conseqüente mineralização aurifera os quais seriam, inicialmente, vulcano-exalativos e metamórficos, nos tempos finais de geração dos depósitos.

Em estudos mais recentes, Mathieson \& Hodgson (1984) levantaram aspectos, indicando que o evento metamórfico-deformacional final foi preponderante na gênese e caracterização da mineralização. Mostraram que as encaixantes alteradas 
hidrotermalmente sofreram lixiviação de $\mathrm{Na}$ e $\mathrm{Mg}$, e enriquecimento em $\mathrm{Fe}, \mathrm{Mn}$ e $\mathrm{Ca}$, diferentemente do que ocorre nas encaixantes do minério da mina do Pari.

A tendência de autores que trabalham sobre a metalogênese do ouro em terrenos de tipo greenstone belt arqueanos como, por exemplo, Kerrich (1983) ou Phillips \& Groves (1993), Goldfarb et al. (2001), Fyon et al. (1988) e Colvine (1989), entre muitos outros, é de defender o modelo metamórfico para a gênese dos depósitos, argumentando que nas zonas mais profundas (das "raizes") desses terrenos haveria lixiviação de Au e outros elementos, seguida de transporte para níveis crustais mais rasos e redeposição nos terrenos de mais baixo grau.

Assim, de um modo geral, processos de natureza epigenética para a geração dos depósitos auriferos nos terrenos greenstone belt arqueanos são defendidos pela maioria dos autores nos seus trabalhos mais recentes (cf.: Boyle, 1979, 1987; entre outros).

Outros autores, representados por Hutchinson (1973, 1993), Fyfe \& Kerrich (1984) e Oberthür et al. (1990), entre outros e, no Brasil, por exemplo, por Ladeira (1980), Schorscher et al. (1982, 1986, 1991), e, mais recentemente, de Wit (2004), divergem dessa tendência, defendendo processos singenéticos, vulcano-exalativos, vulcanosedimentares e/ou sedimentares para a formação de determinados tipos de depósitos auríferos.

No caso da mineralização de ouro da mina do Pari, nota-se que uma série de processos diferentes contribuiram e influenciaram na constituição do depósito. Há os efeitos tectono-metamórficos predominantes da principal orogênese que afetou toda a região da borda SE do Cráton do São Francisco, de idade paleoproterozóica superior (Schorscher, 1992; Noce, 1995; Teixeira et al., 1996 e 2000). metamorfismo regional foi de fácies xistos verdes superior transicional para anfibolito (subfácies epidoto-anfibolito) e, claramente, posterior em relação à origem (primária) dos protominérios e minérios do Pari. O metamorfismo afetou os minérios de formas múltiplas: texturalmente, por cristaloblastese, recristalização e neocristalização metamórfica, causando a liberação e o crescimento granulométrico relativamente grosso da maior parte do ouro e, composicionalmente, por reequilibração geoquímica e o decorrente aumento do teor de Au na sua liga Au-Ag natural.

$\mathrm{Na}$ análise da deformação tectônica nota-se sempre e de forma bilateral-simétrica em relação ao horizonte do minério, a foliação mais forte das encaixantes imediatas da mineralização. Seguem-se os anfibolitos da seqüência vulcano-sedimentar com deformação mais fraca e, por último, os próprios minérios sulfetados com ouro, onde a foliação (principal) é mínima, passando, localmente, a imperceptível. Esses 
exibem, ainda, relações de intensidade da foliação principal $\left(S_{n}\right)$ inversamente proporcionais aos teores totais de sulfetos, principalmente, quando predomina a arsenopirita.

Fica assim evidente que, analogamente ao metamorfismo, a deformação principal também se superimpôs a uma seqüência litologicamente heterogênea, sedimentar ou metassedimentar (de grau mais fraco em relação ao metamorfismo regional principal), compreendendo os minérios sulfetados de ouro, como o horizonte mais litificado e competente.

As condições termais, conforme indicadas pelos dois tipos texturais diferentes de arsenopiritas e as composições das ligas naturais de ouro dos minérios do Pari, caracterizam duas gerações geneticamente distintas de arsenopiritas e, pelo menos, três gerações texturais de ouro.

A segunda geração de arsenopiritas metamórficas do Pari ocorre ou em cristais individuais idiomórficos, pobres ou isentos de inclusões, ou ainda como bordas de crescimento idioblásticas, também sem inclusões, sobre restos, preservados como núcleos em seu interior, de arsenopiritas da primeira geração, ricas em minúsculas inclusões de outros sulfetos, ouro e minerais de ganga. As composições do ouro do Pari, quando incluso em arsenopiritas ou na forma livre, variam dentro da mesma faixa composicional, bastante estreita, notando-se ainda uma leve, mas nitida tendência a uma maior pureza do ouro livre (Figura 78). Essa faixa é a mesma mostrada também pelo ouro incluso nas piritas (metamórficas) e o raro ouro livre de São Bento, assim como pelo ouro livre de Bahú e no Grupo Quebra Osso, na pedreira Micon, representando ouro metamórfico mais puro, com teores mais elevados de Au na liga ( $80-90 \%$-atômicos), se comparado com o ouro incluso nas arsenopiritas de São Bento, que varia tendo 65-70\%-atômicos de Au na liga natural (Figuras 79 e 80).

Fica evidente, assim, que o modelo metalogenético de multi-estágios (e multiprocessos) é o que melhor se adequa às características da mineralização aurífera da mina do Pari. Esse modelo, desde Hutchinson \& Burlington (1984), é aplicado para explicar muitas mineralizações associadas a metassedimentos químicos arqueanos (por ex::Oberthür et al., 1990; entre outros) e foi, mais recentemente, reapresentado e complementado com dados novos por Hutchinson (1993).

Com base nesse modelo, consideramse o depósito aurifero do Pari como sendo de características primárias vulcano-exalativas, singenético-sinsedimentar quanto à gênese dos protominérios e/ou minérios, proximal em relação ao foco magmático das rochas basálticas de fundo oceânico associadas no Grupo Nova Lima do 


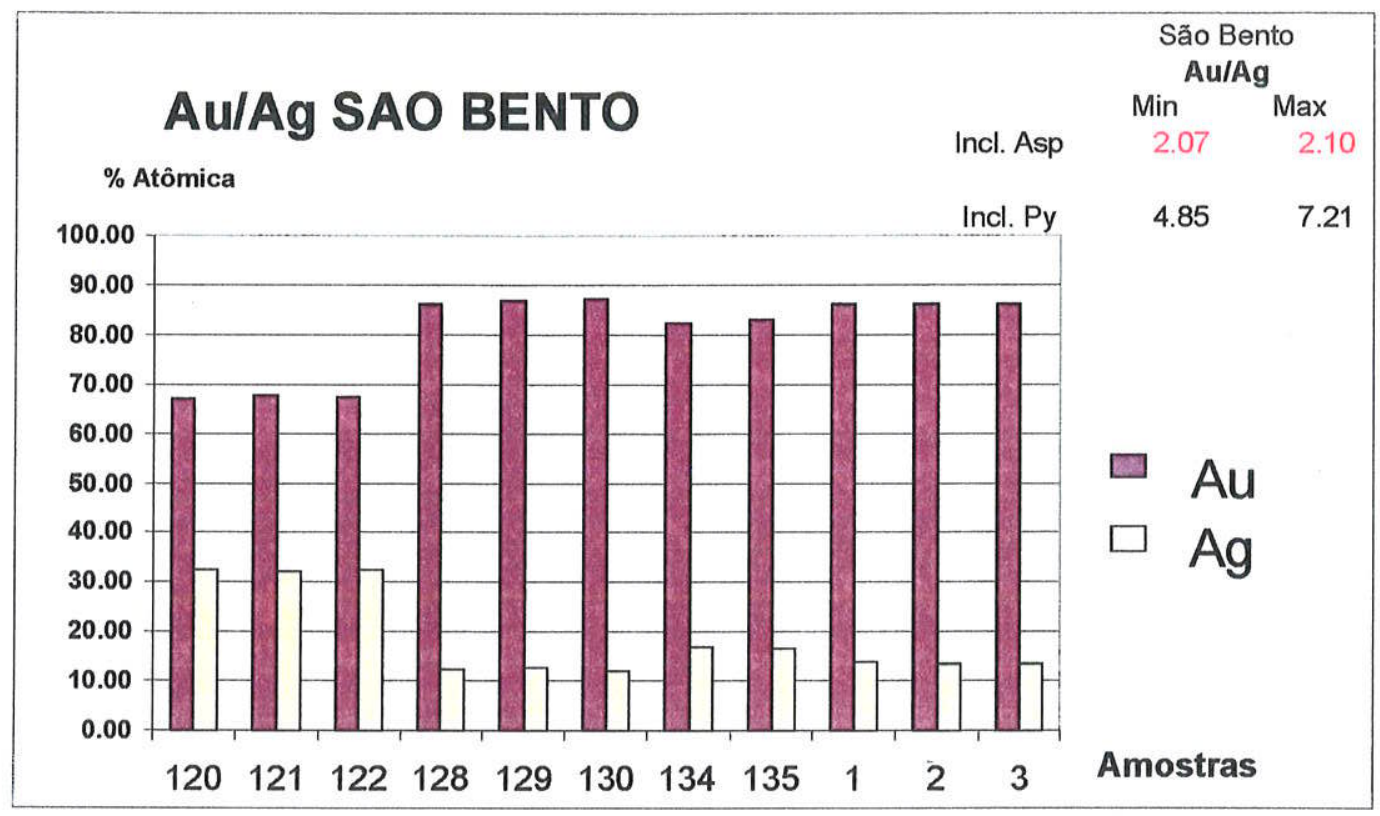

Figura 79: Diagrama de Composição do ouro natural (\% atômica) da mina da mina São Bento de inclusões de arsenopiritas (dados de Schorscher e al. (1991), in Abreu, (1995)). No canto superior direito da figura a relação Au/Ag.

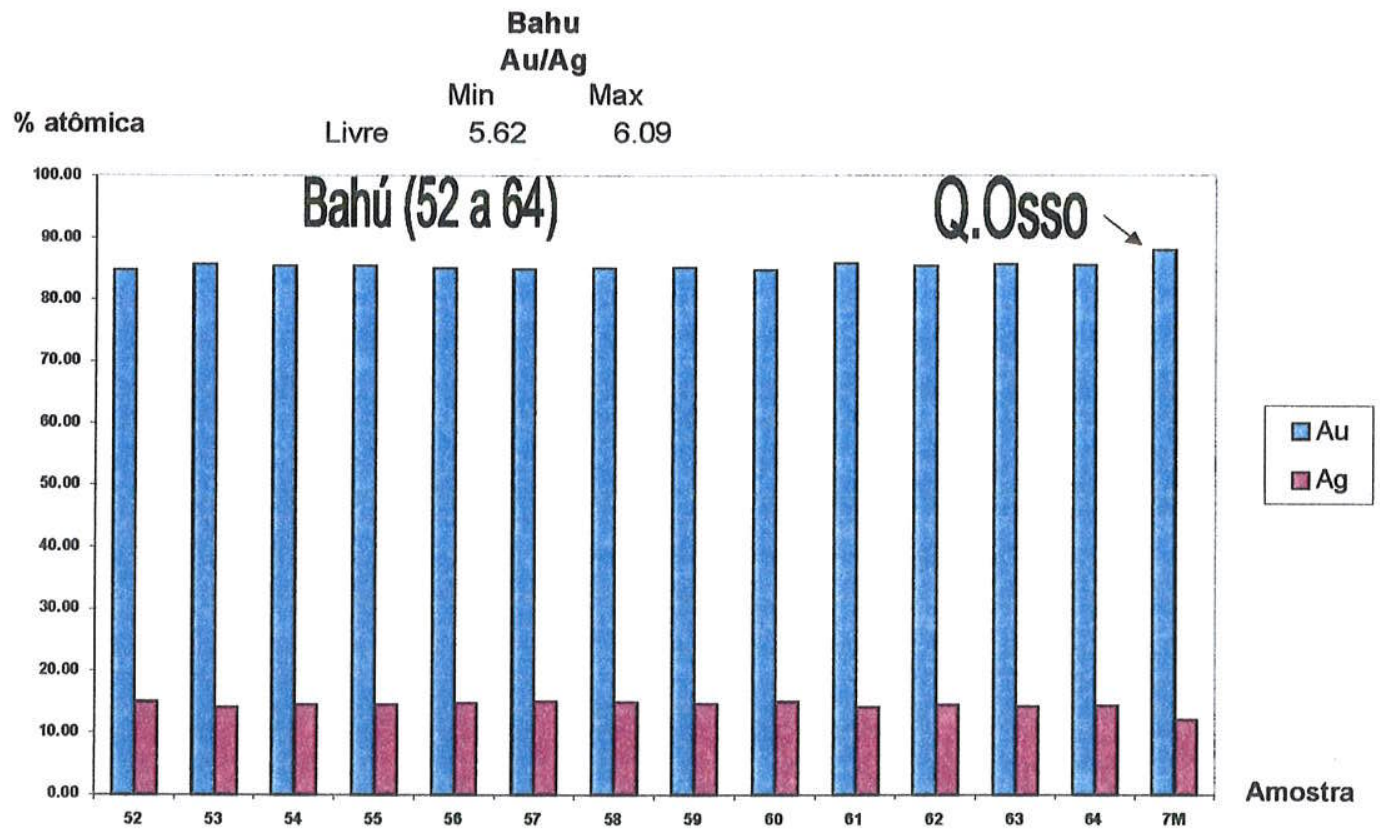

Figura 80: Diagrama de Composição do ouro natural (\% atômica) da mina do Bahú (Amostras 52 a 64) e pepita de Au em veio de magnesita da Pedreira Micon (Amostra 7M) Gr. Quebra Osso. Observar a distribuição em uma classe apenas (Au livre) (dados de Schorscher e al. (1991), in Abreu, (1995)) e a relação Au/Ag. 
greenstone belt arqueano Rio das Velhas. A mineralização primária e seu contexto litológico da seqüência vulcano-sedimentar sofreu, posteriormente, processos termotectônicos e hidrotermais relacionados, no mínimo, aos três ciclos orogênicos principais que afetaram a região da borda E-SE do Cráton do São Francisco: o primeiro, final da evolução greenstone belt arqueana do SGr. Rio das Velhas; o segundo proterozóico inferior, incluindo o principal evento metamórfico regional dínamo-termal, final do Ciclo Minas/Espinhaço (Schorscher, 1992) ou Transamazônico (Noce, 1995); e o terceiro proterozóico superior do Ciclo Brasiliano. Predominantemente o principal evento metamórfico regional progressivo enobreceu as características mineralógicas e texturais dos minérios pela recristalização/reconstituição dos sulfetos a liberação e 0 crescimento granulométrico dos grãos de ouro, aliados ao enriquecimento do Au na liga natural Au-Ag do metal nobre. As transformações mineralógicas e os respectivos transportes geoquímicos metamórficos, entretanto, ocorreram tanto nos minérios de ouro quanto nas rochas encaixantes e associadas à mineralização, praticamente in situ, sem causar maiores dispersões e/ou contaminações nos conjuntos petrometalogenéticos estudados. 


\section{Capitulo VIII: CONCLUSÕES E RECOMENDAÇÕES}

\section{VIII.1 Considerações Geológicas e Metalogenéticas Fundamentais}

A natureza policíclica da região NE do Quadrilátero Ferrífero, as principais estruturas deformacionais indicando cinemáticas ortogonais, as diversas idades geocronológicas caracteristicas na porção sul do Cráton do São Francisco como um todo, e compreendendo a quadrícula de Florália extensões do Supergrupo Rio das Velhas, contendo várias mineralizações auriferas associadas aos BIF tipo algoma arqueanos, evidenciam, por si só, a influência de diversos eventos termo-tectônicos relacionados aos principais ciclos orogênicos regionais e que, consequentemente, também geraram e afetaram as mineralizações auríferas. Os diversos estudos sobre a metalogênese do Au das minas do Pari e São Bento convergem no sentido de origens sinsedimentares de suas mineralizações, salientando assinaturas singenéticas, mesmo que de protominérios pré-existentes aos eventos termotectônicos registrados em suas litologias (Abreu A. et al., 1988; Schorscher et al., 1991; Abreu G., 1995, Martins Pereira, 1995; de Witt et al., 1998, 2004; Valladares, 2000, 2004).

No Quadrilátero Ferrifero ocorrem diversas mineralizações auriferas arqueanas, hospedadas em BIF tipo algoma, sendo a grande maioria dessas minas em fácies xisto verde, ou seja, em grau metamórfico mais baixo que Pari. Os efeitos multiestágios nessas mineralizações auríferas não são referendados pela maioria dos autores. Porém, alguns dados extraídos da literatura podem ser reinterpretados como efeitos de diversos processos posteriores à deposição principal da mineralização.

Os estudos realizados permitem algumas conclusões que confirmam a proposta inicial do trabalho. Pode-se observar e caracterizar mais de um processo que afetou a mineralização aurífera da mina do Pari, e que tais processos, por suas relações geotectônicas regionais, também devem ter afetado as demais mineralizações auríferas arqueanas próximas, assim como do Quadrilátero Ferrífero, em geral. Porém, a quantificação mais precisa de cada um desses estágios é muito mais complicada. Hoje são observados, principalmente, os resultados finais de diversos processos que atuaram na mesma região, sobretudo dos eventos mais marcantes e/ou finais. Somente trabalhos ainda mais detalhados, objetivando a busca de locais 
ainda mais preservados, típicos de alguns desses processos, poderão contribuir para equacionar melhor as influências qualitativas e quantitativas de cada um dos eventos envolvidos. Porém, para tais estudos, é imprescindivel dispor de mapas litoestruturais de detalhe e amostragens especificas representativas de cada uma das possiveis fases.

As mineralizações auríferas em BIF tipo algoma arqueano são comuns nos mais diversos greenstone belts mundiais. Crocket (1991) salienta que as formações ferriferas tipo algoma mostram as principais anomalias de Au em rochas da crosta, principalmente naquelas de idade arqueana, com uma média de $38 \mathrm{ppb}$ de Au. Em sua listagem, compilou dados de diversos greenstone belts dos escudos Canadense, da África do Sul e da W-Austrália. Um estudo sistemático de avaliação dos BIF do Q.F. ainda não foi feito. No entanto, nos relatórios internos da UNAMGEN Min. e Met. S.A. consta que quase todas as formações ferriferas da quadrícula de Florália, inseridas dentro da seqüência do Supergrupo Rio das Velhas, mostram anomalias de 0,1 a 0,7 ppm de Au (Schorscher, 1988b; Abreu, G. 1995).

Muitos autores advogam a baixa potencialidade aurífera de terrenos de médio e alto grau metamórfico (Phillips \& Groves, 1983; Phillips, 1985; Groves \& Batt, 1984; Hodgson, 1989 e 1993; Lobato et al., 1998a,b), baseando-se em modelos metamórficos e/ou hidrotermais de lixiviação de vários elementos inclusive dos metais nobres das zonas mais profundas e de maior grau metamórfico da crosta. Esses modelos metamórficos (Kerrich et al. 1983, Groves et al., 1987) e de desvolatilização de crosta (Colvine et al., 1984), bem como o modelo mais moderno de "orogenic gold" (Goldfarb et al., 2001), desconsideram os terrenos de médio e alto grau metamórficos como potenciais de mineralizações auríferas de grande porte/classe mundial, a despeito dos exemplos existentes (comentados a seguir). Assim, muitas vezes, acabaram desencorajando investimentos em prospecção e pesquisa, quando, de fato, ainda falta muito a fazer nesses terrenos, sobretudo no Brasil, a começar pela geologia básica de campo e por trabalhos de reconhecimento litológico e geoquímico.

Muitos dos terrenos greenstone belt mundialmente conhecidos contêm mineralizações auriferas econômicas em áreas de médio a alto grau metamórfico, várias destas sustentando minas de ouro de classe mundial, a exemplo de Hemlo, no greesntone belt de Wawa (Mason, 1995; Kuhns et al., 1986), Dickenson e Campbell, no distrito Red Lake, Canadá; Renabie, Lennox, Bar 20 e Remco no 
Zimbabwe (Fripp, 1976a,b; Tabert, 1987, Oberthür at al., 2000), além de diversas minas no Kolar Gold Field, na India (Narayanaswami et al., 1960). No Brasil, também ocorrem várias minas de Au em grau médio, a exemplo de Fazenda Brasileiro, em Teofilandia, Bahia (Alves da Silva et al., 1998; Nascimento et al. 1998; Geraldes et al., 2000) e Riacho dos Machados, Minas Gerais (Fonseca et al., 1991), entre outras.

Nesse quadro, considera-se a mina do Pari caracterizada como uma mineralização aurifera arqueana, hospedada num domínio de rochas metavulcânicas básicas, toleiiticas de fundo oceânico. O minério de ouro da mina do Pari caracteriza-se como típica formação ferrifera algoma vulcanogênica mista, com predominância da fácies sulfeto (arsenopirita e pirrotita), encaixada em xistos e anfibolitos que sofreram processos de alteração de fundo oceânico e transformações posteriores por processos termo-tectônicos, orogênicos superimpostos, arqueanos, paleo e neoproterozóicos.

\section{VIII.2 Conclusões do Estudo}

- No contexto geológico do Grupo Nova Lima na quadrícula Florália (1:25.000), as subunidades litoestratigráficas informais $B, C$ e D e a mineralização aurífera da mina do Pari, mostram continuidade desde o morro do Pari, como local da mina homônima, até pouco a norte da mina do Gambá, numa extensão de cerca de $5 \mathrm{~km}$. Nesta porção, há continuidade mapeável do Grupo Quebra Osso em posição normal na base da seqüência do Gr. Nova Lima, aqui formado por anfibolitos de basaltos toleíticos de fundo oceânico. As mineralizações auríferas hospedam-se em BIF do tipo algoma vulcanogênicos de fácies mista predominando sulfeto, posicionadas no contato entre pacotes de derrames metabásicos (anfibolitos) das unidades B e C do Gr. Nova Lima.

- Sob aspectos petrográficos, as paragêneses de silicatos e sulfetos dos minérios à base de granada + grunerita + biotita e de arsenopirita + pirrotita (sem pirita), são indicativos da fácies xisto verde superior transicional à fácies anfibolito como o grau metamórfico máximo atingido na região. Este evento metamórfico regional principal superpõe-se à mineralização aurifera sulfetada preexistente e já metamórfica por um evento anterior mais fraco, como indicam grãos de ouro incluídos em granadas, e estruturas e texturas palimpsésticas de uma foliação tectono-metamórfica pretérita $(S n-1)$. 
- As demais ocorrências auriferas da quadrícula de Florália semelhantes à mina do Pari, Pari Norte, Patrimônio e Gambá foram reconhecidas por mapeamento geológico e petrografia macroscópica de campo, sendo continuações do Horizonte Pari, da mina objeto central desta pesquisa.

- A litogeoquímica classificou os principais anfibolitos do morro do Pari como metabasaltos toleíticos, indicando, ainda, que principalmente aqueles associados à base da mineralização aurífera sofreram processos mais fortes de alteração de fundo oceânico, do tipo espilitização, evidenciados por teores de $\mathrm{Na}$ e $\mathrm{Mg}$ contrastantes entre a lapa e a capa da mineralização.

- Os padrões da evolução geoquímica nas rochas da lapa e da capa da mineralização, como verificados, por exemplo, em diagramas do tipo Harker e perfis geológico-geoquímicos (estratigráficos), mostram quase sempre caminhos distintos e até opostos, que claramente contradizem os modelos simplificados de alterações hidrotermais por fluidos metamórficos associados a zonas de cisalhamento.

- Os ETR também mostraram distinções entre as rochas da lapa e da capa; já na mineralização aurífera do Pari aproximam-se bastante de padrões de BIF sulfetados de Isua e, principalmente, de BIF vulcanogênicos mistos tipo Socoman iron formation.

- Cálculos de balanços de massa para os anfibolitos e xistos encaixantes próximos da mineralização mostraram que trocas inversas teriam ocorrido na capa e na lapa. Os efeitos de espilitização são mais marcantes na lapa que na capa. A capa da mineralização deve ter sido afetada por soluções ascendentes, expelidos por compactação durante a diagênese da BIF aurifera do Horizonte Pari.

- A química mineral das biotitas e dos anfibólios mostrou nítida separação por unidades litoestratigráficas identificadas. Esses minerais são também distintos entre as encaixantes da lapa e da capa da mineralização, sugerindo protolitos prémetamórficos de composições diferentes.

- A geotermometria com base em química mineral para a mina do Pari indicou temperaturas variadas, conforme o método utilizado e o litotipo. Na mineralização, as temperaturas médias obtidas pelos geotermômetros de Granada-Anfibólio e Granada-Biotita em centros e bordas de grãos são de 445 e $493^{\circ} \mathrm{C}$, 
respectivamente. O geotermômetro de pirrotita, no minério, apresentou temperaturas médias mais altas, próximas às obtidas nos sulfetos maciços do Grupo Quebra Osso. O Geotermômetro da arsenopirita indicou temperaturas entre 495 e $555^{\circ} \mathrm{C}$, respectivamente para centros e bordas. Comparando-se aos dados de Schorscher et al. (1991), as temperaturas do minério da mina do Pari são compativeis com as condições metamórficas regionais. Há diferenças de temperaturas ascendentes dos núcleos às bordas dos minerais, bem como entre arsenopiritas da primeira (T 495 C) e da segunda geração $\left(T>500^{\circ} \mathrm{C}\right)$, compativeis com um processo de metamorfismo regional progressivo.

- Na mina São Bento, de forma geral, foram obtidas temperaturas mais baixas, condizentes com a fácies xisto verde $\left(300\right.$ a $\left.410^{\circ} \mathrm{C}\right)$. No entanto, as arsenopiritas dos minérios bandados apresentam temperaturas maiores $\left(340\right.$ a $410^{\circ} \mathrm{C}$ ) que as dos minérios discordantes (remobilizados) (300 a $390^{\circ} \mathrm{C}$ ). Isso indica, que as fases remobilizadas associadas a processos rúpteis (como charneiras de dobras rompidas) e sem foliação evidente, são mais tardias, pós pico tectono-metamórfico em relação ao evento regional principal.

- As ligas naturais de Au apresentam uma relação direta entre sua pureza (fineness) e o grau metamórfico regional progressivo, sendo notáveis as diferenças entre as ligas naturais Au-Ag das minas do Pari e São Bento.

- O modelo evolutivo proposto para a mineralização da mina do Pari inclui as seguintes fases:

1-Pré-minério: vulcanismo basáltico toleítico de fundo oceânico.

2-Deposição de Au e sulfetos diversos, juntamente à formação ferrifera tipo algoma em período de calmaria vulcânica, por processos sedimentares hidrotermaisexalativos. Durante a deposição da BIF já ocorreram processos de contaminação das rochas da lapa, enriquecendo-as em $\mathrm{SiO}_{2}$ e $\mathrm{Fe}$, eventualmente associadas a processos de espilitização dos derrames basálticos subjacentes.

3-Erupção de novo derrame toleiitico sobre a BIF aurifera. Neste ocorreram processos magmáticos cumuláticos, conforme indicam amostras da base do derrame, enriquecidas em $\mathrm{Mg}$, $\mathrm{Ni}$ e $\mathrm{Cr}$.

4-Metamorfismos e deformações por eventos orogênicos superimpostos dos ciclos Rio das Velhas - arqueano, Minas/Espinhaço (ou Transamazônico) paleoproterozóico superior, e Brasiliano - neoproterozóico superior a eopaleozóico (o Ciclo Uruaçuano - mesoproterozóico, não esta confirmado na região estudada), 
que modificaram a forma original dos corpos mineralizados e causaram a destruição parcial de assinaturas geoquímicas sedimentares vulcano-sedimentares e/ou magmáticas primárias e de alterações de fundo oceânico.

5-Como resultados dessa evolução, existem na região estudada 5 áreas principais com mineralizações de ouro confirmadas (além de outras ocorrências menores, sem dados confiáveis) representando um potencial de reservas de minérios de ouro avaliado nesse trabalho, com cálculos estimativos, a totalizar 1,15 Moz (milhões de onças), ou seja, cerca de 44 toneladas de Au.

\section{VIII.3 Algumas Recomendações para a Exploração Mineral}

- Terrenos de médio e alto grau metamórficos podem ser tão potenciais para mineralizações auriferas quanto os de baixo grau. Parece haver uma relação estatística direta entre mineralizações de $\mathrm{Au}$ e áreas de ocorrência de rochas supracrustais de greenstone belts arqueanos no mundo e no Brasil. Muitos autores e também empresas de exploração consideram áreas de médio e alto grau metamórfico como de baixo potencial para depósitos de ouro de portes maiores, com base em modelos teóricos; a realidade da mineração, porém, mostra muitas minas de Au de classe mundial, cujos minérios e litologias hospedeiras encontramse em grau médio a alto.

- Processos tectono-metamórficos podem alterar os padrões morfológicos e geoquímicos das mineralizações auríferas, mas não necessariamente são processos metalogenéticos exclusivos, nem sequer preponderantes.

- Na quadrícula de Florália existem diversas ocorrências auríferas; dessas, somente a mina do Pari foi investigada até certa profundidade. As reservas da mina do Pari e das mineralizações associadas na continuação para $\mathrm{N}$ do Horizonte Pari foram aqui estimadas em cerca de $44 \mathrm{t}$ de Au. Isso abre oportunidades novas de prospecção e pesquisa para o ouro, tanto na quadrícula Florália, quanto em outras partes do Sgr. Rio das Velhas no Quadrilátero Ferrífero, bem como em outros greenstone belts do Brasil.

- Processos tectono-metamórficos mais vigorosos, além de modificarem aspectos primários das mineralizações arqueanas, podem transformá-las, dando-lhes caracteríşicas metalúrgicas melhores quanto à granulometria, ao grau de liberação e à pureza do ouro, agregando valores econômicos decisivos em depósitos, 
Evolução Petrogenética e Metalogenética da Mina de Au do Pari e Arredores, NE do $Q$. F.

outrossim limítrofes ou não-econômicos, e valorizando ainda mais os depósitos e as jazidas de qualidade. 


\section{IX- Referências Bibliográficas}

ABREU, A.S., DINIZ, H.B., PRADO, M.G.B., SANTOS, S.P. (1988): Mina de ouro de São Bento, Santa Bárbara, Minas Gerais. In: Schobbenhaus, C., Coetho, C. E.S. (Eds.): Principais depósitos minerais do Brasil, metais básicos não ferrosos, ouro e alumínio, 3: 393-411.

ABREU, G.C. (1991): Estudo Comparativo entre as alterações hidrotermais da Mina do Pari, Quadrilátero Ferrífero, MG, Brasil e Mina Dickenson (Red LakeCanadá) - Seminários Gerais de pós-grad. (niv. Mestrado): 15pp., IG-USP (inédito).

ABREU, G.C. (1995): Geologia e Metalogênese do Ouro da Mina do Pari, NE do Quadrilátero Ferrífero-MG. Diss. Mestrado, 162pp., ilust., IG-USP, São Paulo. ABREU, G.C (1996): Ouro da Mina do Pari. In. SBG, $39^{\circ}$ Congr. Bras. Geol., Vol. 3, pg. 117, Salvador.

ABREU, G.C., SCHORSCHER, J.H.D. (2001): Metalogênese do Au da Mina do Pari, NE do Q.F., MG. An. VII Simp. De Geol. Do SE, Rio de Janeiro, v. (1), Sessão poster.

ABREU, G.C., SCHORSCHER, J.H.D. (2001): Gold Metallogenesis at the Pari Mine, NE-Quadrilátero Ferrifero, MG - Brazil. Annals of Brazilian Academy of Sciences, 74(3): 539. Summ. Commun.

ABREU, G.C., QUEIROGA, N.C.M., SCHORSCHER, J.H.D. (1987): Relatório de mapeamento geológico e levantamentos detalhados de campo (esc.

1:10.000) na região de Florália, MG - Relatório de Pesquisa CNPQ (Proc. 40.4377/85), IG-USP.

ALKMIN, F.F, MARSHAK, S., EVANGELISTA; H.J. , BRUECKNER, H. (1994): Manifestações do evento Transamazônico no Quadrilátero Ferrífero. In: $38^{\circ}$ Cong.Bras.Geol., Camboriú, Anais..., SBG, 1:75-76.

ALMEIDA ABREU, P.A., PFLUG, R. (1994): The geodynamic of the southern Serra do Espinhaço, Minas Gerais, Brazil. Zbl. Geol. Paläont. Teil I, 1993 (1/2):2144. Stuttgart.

ALMEIDA, F.F.M. (1976): Estruturas do Pré-Cambriano Inferior Brasileiro. - In: $29^{\circ}$ Cong. Bras. Geol, Resumos: 201-202, SBG, Ouro Preto/Belo Horizonte.

ALVES, M.G. (1986): Utilização de sensoriamento remoto na obtenção de dados litoestruturais em trabalho geológico de detalhe na região NE do Quadrilátero Ferrífero (MG). - Dissertação de Mestrado, INPE (SERE), São José dos Campos. 
ALVES, J.V. (1995): Estudos das Inclusões fluidas em veios de Quartzo da Mina de Ouro de São Bento, Santa Bárbara, MG. Belo Horizonte, IGc - UFMG, Diss. Mest., $99 p$.

ALVES, J.V., FUZIKAWA, K., LOBATO, L.M., DANTAS, M.S.S., CORNELISSEN, M.G.(1996): Determinação quantitativa dos componentes da fase carbônica das inclusões fluidas aquo-nitro-carbônica da mina de ouro de São Bento, Santa Bárbara, MG. SBG, $39^{\circ}$ Cong. Bras. Geol, Salvador, 7: 467-470.

ALVES da SILVA, F.C. (1994): Étude Structurale du Greenstone belt Paleoproterozoic du Rio Itapicuru (Bahia, Brésil). Importance des granitoides syntectoniques, controle des mineralizations auriferes et evolution geodinamique Transamazonienne $(\sim 2.0 \mathrm{Ga})$ du Craton du São Francisco. Université d'Orleans. France. Doct. Thesis, $338 \mathrm{p}$.

ALVES da SILVA, F.C., CHAUVET, A., FAURE, M. (1998): General features of the gold deposits in the Itapicuru Greenstone Belt (RIGB, NE Brazil), Discussion of origin, Timing and tectonic model. Rev. Bras. Geoc., 28(3): 377-390.

AMARAL, G. , MATTOS, J.T., ALMEIDA FILHO, R., CUNHA, J., PARADELLA, W.R. (1976): Carta Geológica ao Milionésimo da folha Belo Horizonte. In: 29 Cong. Bras. Geol., Ouro Preto, Anais, V.4:229-238.

AMSTUTZ, G.C., ed. (1974): Spilites and Spilitic Rocks. Springer-Verlag, Berlin, $482 p$.

BABINSKI, M., CHEMALE, F, SCHUMUS, W.R. (1991): Geocronologia Pb/Pb em rochas carbonáticas do Supergrupo Minas, Quadrilátero Ferrífero, Minas Gerais, Brasil. In: Cong.Bras.Geoq., 3. São Paulo, SBGq. 2: 628-630.

BABINSKI, M., CHEMALE, F., SCHUMUS, W.R. (1995): The Pb/Pb age of the Minas Supergroup carbonate rocks, Quadrilátero Ferrífero, Minas Gerais, Brazil. Prec. Res., 72: 235-245.

BAMBA, T. (1974): A Series of magmatism Related to the Formation of Spilite. In: Amstutz, G.C.(ed.) Spilites and Spilitics Rocks, Springer-Verlag, 482p.

BARBOSA, A.L.M. (1969): Geology of Mariana and Ouro Preto Quadrangles. In: DORR, J.V.N. (1969): Physiographic, stratigraphic and structural development of the Quadrilátero Ferrifero, Minas Gerais, Brazil. - USGS Prof. Pap. 641-A, 110pp., Washington.

BARBOSA, O. (1954): Évolution du géosynclinal Espinhaço. - In: 19th Inter. Geol. Cong., Sec. XIII, 2. part., Fascicule XIV: 17-36, Alger. 
BARBOSA, M.P. (1988): Estudo do posicionamento genético das feições geológicas da região do Espinhaço Meridional e adjacências(MG). Tese de Doutorado(ined.), 237p., mapas-IG-USP, São Paulo.

BARTON, P.B. (1969): Thermochemical study of the system Fe-As-S. Geoch. Cosmoc. Acta 33: 841-857.

BARTON, P.B., SKINNER, B.J. (1979): Sulphide Minerals stabilities. In: BERNES, H.L. (ed.) Geochemistry of hydrotermal Ore Deposits. John Wilkey and Sons, 1979, p.278-403.

BAUGARTNER, L.P., OLSEN, S,N, (1995): A Least-Squares Approch to Mass Transport Calculations Using the Isocon Method. Economic geology, 90: 1261-1270.

BELO de OLIVEIRA, O. A. (1986): As falhas de empurrão e suas implicações na estratigrafia e metalogênese do Quadrilátero Ferrífero. In: SBG, Congr. Bras. Geol. , 34, Goiânia, Anais, 2: 1074-1087.

BENEVIDES, T. (2003): Geotermobarometria e Evolução metamórfica do Segmento Central do Grupo Dom Silvério, MG. Diss. Mestrado, IGc-USP, São Paulo, $116 p$., anexos

BRITO NEVES, B.B, CORDANI, U.G., KAWASHITA, K., DELHAL, J. (1979): A Evolução Geocronológica da Cordilheira do Espinhaço: Dados Novos e Integração. Rev. Bras. Geoc., 9 (1): 71-85.

BOYLE, R.W. (1987): Gold: History and Genesis of Deposits. Van Nostrand Reinhold, New York, 676p.

CABRI, L.J., NEWVILLE, M., GORDON, R.A., CROZIER, E.D., SUTTON, S.R., McMAHON, G., JIANG, D.T (2000): Chemical speciation of gold in arsenopirite. Canad. Mineral. 38: 1265-1281.

CALÓGERAS, J.P. (1904): As minas do Brasil e sua legislação. Rio de ajneiro, Imprensa Nacional. 3v., 627p.

CARNEIRO, M.A., TEIXEIRA, W. (1992): Discordância de idades radiométricas U-Pb e Rb-Sr no Cráton do São Francisco meridional: evidências a partir do Complexo Metamórfico Bonfim setentrional, Quadrilátero Ferrífero, Minas Gerais. - In: 37o Cong. Bras. Geol., Resumos: 189-190, SBG, São Paulo.

CARNEIRO, M.A., TEIXEIRA, W., MACHADO, N. (1993): Evolução geológica policíclica de terrenos granito greenstone do Arqueano Superior do Cráton do São Francisco Meridional: um exemplo a partir do Complexo Metamórfico de Bonfim Setentrional. - In: II Simp. Cráton do São Francisco, Anais: 70-74, Salvador. 
CASTRO, R.D. (1998): Analogy between Minas Supergroup and Campos Basin stratigraphic sequences. In: XL Cong.Bras.Geol, Belo Horizonte, Anais.

CORDANI, U.G., MILANI, E.J., THOMAZ FILHO, A., CAMPOS, D.A. (2000): Tectonic Evolution of Southamerica. $31^{\text {st }}$ Intern. Geol.Cong., Rio de Janeiro, $856 p$.

CEMIG (1989): Levantamentos Aerofotogramétricos de Minas Gerais. Escala 1:30.000, Minas Gerais, Brazil. Prec. Res. 65: 25-54.

CHAVET, A., PIAMONTE, P., BARBANSON, L., NEHLIG, P., PEDROLETTI, I.(2001): Gold Deposit Formation during Collapse Tectonics: Structural, Mineralogical, Geocronological and Fluid Inclusion Constraints in Ouro Preto Gold Mines, Quadrilátero Ferrífero, Brazil. Econ. Geol. 96: 25-48.

CHEMALE, F. Jr. (1987): Gênese das rochas graniticas do tipo Borrachudos. SBGq, Cong. Bras. Geoquímica, Porto Alegre, 1: 171-186.

CHEMALE, F. Jr., ROSIÉRE, C.A., ENDO, I. (1994): The tectonic evolution of Quadrilátero Ferrifero, Minas Gerais, Brazil. Prec. Research, 65: 2-54.

CHIARINI, A.P. (2001): Geologia da Porção basal do "greenstone belt " de Piunhi MG. Dissert. Mestrado, Igc-USP, 172p., anexos.

CHOWN, N'DAH, MUELLER, W.U. (2000): The relation between iron-formation and low temperature hydrotermal alteration in an Archean volcanic enviroment. Prec. Research 101: 263-275.

CLARKE, D. (1993): NEWPET. Department of earth Sciences, Memorial University of Newfoundland, Canada.

CLARK, L.A. (1960): The Fe-As-S system: Phase relation and applications. Econ, Geol. 55, Part I: 1345-1381, Part. II: 1631-1652.

COLVINE, A.C. (1989): An empirical model for the formation of archean gold deposits: products of final cratonisation of Superior Province, Canada. Ontario Geol. Survey, Misc. Paper, 37-53.

COLVINE, A.C., ANDREWS, A.J., CHERRY, M.E., DUROCHER, M.E., FYON, A.J., LAVIGNE, M.J. MACDONALD, A.J., MARMONT, S., POULSEN, K.H., SPRINGER, J.S. and TROOP, D.G. (1984): An Integrated Model for Origin of Archean Lode Gold Deposits: Ontario Geological Survey, Open File Report 5524, 99p.

COMIG (1994a): Mapa Geológico do Estado de Minas Gerais, 1:1.000.000 SEME/COMIG, Belo Horizonte.

COMIG (1994b): Nota explicativa do mapa metalogenético e de ocorrências minerais do Estado de Minas Gerais (1:1.000.000), 97p., SEME-COMIG, Belo Horizonte. 
CONDIE, K.C. (1981): Archean Greenstone Belts. Elsivier, Amsterdam, 434p.

COSTA SENA, P. (1881): Análise de minérios auríferos de algumas minas de Minas

Gerais. - Annaes Escola de Minas de Ouro Preto, 1: 114-117, Ouro Preto.

COX, K.G., BELL, J.D., PANKHURST, R.J. (1979): Compositional Variation in Magmas. In: Interpretation of the igneous rocks. George Allen \& Unwin.

CRAIG, H. (1953): The geochemistry of the stable carbon isotopes. Geoch. Cosmoc. Acta, 3:53-92.

CRAIG, J.R and SCOTT, S.D. (1974): Sulfide Phase Equilibria. In: Ribbe, P.H., Ed, (1974), Vol. 1 Chap. 5: Reviews in Mineralogy ("Short Course Notes" Sulfide Mineralogy). Mineralogical Society of America, p:CS-1-CS-110.

CROCCO-RODRIGUES, F.R., COSTA, D.I., SOUZA, R.A.C., ROSIÉRE, C.A (1989):

Sistemas de cavalgamento do NE do Quadrilátero Ferrífero, MG. SBG, Minas

Gerais, $5^{\circ}$ Simp. Geol. Minas Gerais, Belo Horizonte, Anais 6-10.

CROCKET, J.H. (1993): Distribution of Gold in the Earth Crust. In: FOSTER, R.P.

(Ed.): Gold metallogeny and exploration, Blackie, London, 1-36.

DARDENE, M.A., SCHOBBENHAUS, C. (2001): Metalogênese do Brasil. Ed. UNB, $392 p$.

DAVIES, H.P.K. (1993): Geologia da Quadrícula Bateias, MG. 150p. (Dissertação de Mestrado), IG-USP.

DAVIES, H.P.K., ABREU, G.C, POHL, L.L., ALVES, M.G., SCHORSCHER, J.H.D.(1994): Geologie des Blattes Bateias - 1:25.000. Östliches Eisernes Vierek, Minas Gerais, Brasilien. In: 14 Geoswiss. Lateinamerika - Kolloquium, Tübingen, Terra Nostra 2/94: 15-16- Alfred Wegener - Stiftung, Bonn.

DAVIES,H.P.K., SCHORSCHER, J.H.D. (1991): Geologia e mineralizações na

Quadrícula a sul da Quadrícula de Florália, Quadrilátero Ferrífero-MG. $1^{\circ}$ Rel. Cient. FAPESP, Proc. 89/3836-1, 240p., IG-USP.

DEER, W.A, HOWIE, R.A, ZUSMANN, J. (1992): An Introduction to the rock-forming minerals ( $2^{\text {nd }} E d$.). Longman, Amsterdam, 696p.

DERBY, O.A. (1881): Contribuição para o estudo da geologia do Valle do São Francisco. - Archivos do Museu Nacional do Rio de Janeiro, 4: 87-119.

DERBY, O.A. (1906): The Serra do Espinhaço, Brazil. - J. Geol., 14(5): 374-401.

DE WIT, E., LANDIS, G.P., ZARTMAN, R.E., GARAYP, E., MARTINS PEREIRA, S.L., PRADO, M.G.B., VIEIRA, F.W., THORMAN, C.H. (1994): Isotopic and fluid inclusion data on the age and origin of São Bento and Morro Velho Gold Deposits, Minas Gerais, Brazil. In: UGSG, TOTH, M.I., DAY, W.C. (Eds): USGS Reserch and Mineral resources, Part A: Program and Abstracts, C. 
1103-A, p27-28, Meeting, Ninth V.E. McKelvey forum on mineral and energy resources. Tucson, AZ, USA, Feb/1993.

DE WIT, E., THORMAN, C.H., LADEIRA, E.A. (2004): Exploration strategies for discovery of syngenetic versus epigenetic gold deposits in the Quadrilátero Ferrífero, Brazil. SIMEX, I Simp. Bras.Explor. Min., Ouro Preto, Sessão poster, Ouro Preto, MG.

DNPM-CPRM (1996) Projeto Rio das Velhas. Programa de estudos de Distritos Mineiros. Mapa Geológico Integrado (1:100.000), Texto Explicativo, Belo Horizonte, 115p. Anexos.

DORR, J.V.N. (1966): Stratigraphy. - Pr. IV-2-IV-5, in: Outline of the Geology of the Quadrilátero Ferrífero, Minas Gerais, Brazil., Amer. Geol. Inst., Brazil, Washington 1966.

DORR, J.V.N. (1969): Physiographic, stratigraphic and structural development of the Quadrilátero Ferrífero, Minas Gerais, Brazil. - USGS Prof. Pap. 641-A, 110pp., Washington.

DORR, J.V.N. (1973): Iron Formation in South America. Econ. Geol. 68:1005-1022.

DORR, J.V.N. (1974): Discussions: "The "consanguineous" origin of a tourmalinebearing gold deposit: Passagem de Mariana (Brazil). Econ. Geol. 69: 416422

DORR, J.V.N, BARBOSA, A.L.M. (1963): Geology and ore deposits of the Itabira Districts, Minas Gerais, Brazil. USGS Prof. Pap. 341-C, 110p., Washington.

DORR, J.V.N., GAIR, J.E., POMERENE, J.B., RYNEARSON, G.A. (1957): Revisão da estratigrafia pré-cambriana do Quadrilátero Ferrifero. - DNPM, Div. Fom. Min., Avulso 81, 31pp., Rio de Janeiro.

DRAKE JR., A.A., MORGAN, B.A. (1980): Tectonic studies in the Brazilian Shield. USGS Prof. Pap. 1119-B: 1-19, Washington.

DROOP, G.T.R. (1987): A general equation for estimating Fe3+ in ferromagnesian silicates e oxides from microprobe analysis, using stoichiometric criteria. Mineralogical magazine, 51: 431-437.

DUSSIN, I.A. (1994): Evolution structurale de la region de l' Espinhaço meridional, bordure sud-est du craton São Francisco, Brésil. 250p. (Tese de Doutoramento _ Université D'Órleans)

DUSSIN, I.A., DUSSIN, T.M. (1995): Supergrupo Espinhaço: modelo de evolução geodinâminca. Geonomos, 3:19-26.

ESCHWEGE, W.L. (1825): Notícias e reflexões estatísticas a respeito da província de Minas Gerais. Mem. da Acad. Real de Sci. de Lisboa, vol. IX, pp. 1-27. 
Re-edição (1899): Ocorrências e Jazidas de Ouro. - Arch. Publ. Mineiro, col IV, Ouro Preto- Belo Horizonte, pp. 773-762.

ESCHWEGE, W.L. (1833): Pluto Brasiliensis. - 2 vol., 622pp., G. Reimer, Berlin. (tradução de Figueiredo Murta).

ENDO, I. (1997): Regimes Tectônicos do Arqueano e proterozóico no interior da placa Sanfranciscana, Quadrilátero Ferrifero e Áreas Adjacentes, Minas Gerais-São Paulo. Ph. D. thesis, IG-USP, São Paulo, 243p.

ENDO, I., MACHADO, R. (2002): Reavaliação e Novos dados Geocronológicos ( $\mathrm{Pb} / \mathrm{Pb}$ e K/Ar) da Região do Quadrilátero Ferrífero e Adjacências. Rev. Inst. Geoc-USP, Série Cient., v.2: 23-40.

FAURE, G. (1986): Principles of Isotope Geology., John Wiley \& Sons, New York, $2^{\text {nd }}$ Ed. , 589p.

FERNANDES, M.L.S., MARCIANO, V.R.P.R.O., OLIVEIRA, R.C., CORREIA NEVES, J.M., DILASCIO, M.V.(1995a) Granito Borrachudos: um exemplo de granitogênese. Anorogênese na porção centrtal do Estado de Minas Gerais. Geonomos, v.2, 2:23-29.

FERNANDES, M.L.S., BILAU, E., CORREIA NEVES, J.M., GIRET, A., COSTA, K.V.(1995b): Estimativa das condições de cristalização do granito borrachudos na região de Dores de Guanhães, MG. SBG, Simp. De Geol. De Minas Gerais, 8, Diamantina. 13: 64-66.

FERRAND, P. (1894): L'or a Minas Geraes, Brésil. - Imprensa Oficial do Est. de Minas Gerais, Vol. I: 163pp., Vol.II: 141pp.

FLEISCHER, R. (1971): Le gisement aurifère à tourmaline de Passagem de mariana ( Minas Gerais - Brésil) et son cadre. Influence de l' évolution structurale et du métamorphisme sur une minéralisation syngénétique familière. Tese de doutoram., 110 p., Paris.

FLEISCHER, R., ROUTHIER, P. (1973): The "consanguineous" origin of a tourmaline-bearing gold deposits: Passagem de Mariana (Brazil). Econ. Geol. 69(1): 11-22.

FOGAÇA, A.C.C., ALMEIDA ABREU, P.A., SCHORSCHER, J.H.D. (1984): Estratigrafia da seqüência supracrustal arqueana na porção mediana-central da Serra do Espinhaço, Minas Gerais - In: $33^{\circ}$ Cong. Bras. Geol., Rio de Janeiro- Anais, V.6:2654-2667.

FONSECA, E., GUIMARÃES, P.J., DUTRA LEAL, E., MEDEIROS SILVA, H. (1991):

The Ouro Fino Gold deposit, Minas Gerais, Brazil. In: Ldeira, E.A. (Ed.), Brasil Gold '91, Balkem, Rotterdam, 499-505.

FOSTER, R.P. (1991): Gold metallogeny and exploration. - 432pp., Blackie, London. 
FOUQUET, Y., STACKELBERG, U.V., CHARLOU, J.L., ERZINGER, J., HERZIG, P.M., MÜHE, R., WIEDICKE, M.(1993): Metallogenesis in Back Arc environments: The Lau Basin example. - Econ. Geol. 88: 2154-2181.

FREYBERG, B.v. (1932): Ergebnisse geologischer Forschungen in Minas Gerais (Brasilien) - N. Jb. Min., Sonderbd. 2, 403p.

FREYBERG, B.v. (1934): Die Bodenschaetze des Staates Minas Gerais. 453p. Ed. Schweizerbart, Stuttgart.

FRIPP, R.E.P. (1976a): Stratabound gold deposits in Archean banded iron formation, Rhodesia. Econ. Geol (71): 58-75.

FRIPP, R.E.P. (1976b): Gold metallogeny in the Archean of Rhodesia. In. B.F. Windley (Ed.): The Early History of the Earth, Wiley, London, 455-466.

FRYER, B.J. (1983): Rare Earth Elements in Iron-Formation. In: TREND, A.F., MORRIS, R.C., Eds. (1983): Iron-Formation: Facts and Problems. Developments in Prec. Geology 6: 345-358.

FYFE, W.S., KERRICH, R. (1984): Gold: Natural concentration processes. - Pp. 99127, in R. P. Foster (ed.): Gold'82.

FYFE, W.S., LONDSDALE, P. (1982): Ocean Floor Hydroterml Activity. In Emiliani, C. Ed. The Sea: The Oceanic Lithosphere, Vol. 7: 589-638, John Wiley \& Sons. New York.

FYON, J.A., MacDONALD, A.J., MARMONTONT, S., TROOP, D.G. (1988): Shieldwide introduction of gold into archean crust, Superior Province, Ontario: Coupling between mantle initiated magmatism and lower crustal maturation. Geol. Soc. Australia, Abstracts, 22: 313-318.

GAIR, J.E. (1958): Age of gold Mineralization at Morro Velho and Raposos Mines, Minas Gerais. Bol. Soc. Bras. Geol., v. 7 (2): 40-45.

GAIR,J.(1962): Geology and ore Deposits of the Nova Lima and Rio Acima Quadrangles, Minas Gerais, Brazil. USGS Prof. Paper 341-A,65p.

GANGULY, J., SAXENA, F.S. (1984): Mixing properties of aluminosilicate garnets: constraints from natural and experimental data, aand application to geotermobarometry. American Mineralogist, 69: 88-97.

GERALDES, M.C., ABREU, G. C., PIRES, P.R., MELLO, E., IYER, S. (2000): Sulfur Isotope Characteristics Of Mesothermal Gold Deposits: Results Of An Investigation On Rio Itapicuru Region, Bahia, Brazil. SBG, In: Simp. Geol. do Nordeste, resumos, Bol.16, Recife.

GERMAN, C.R., HERGT,J., PALMER, M.R., EDMOND, J.M. (1999): Geochemistry of hidrotermal sediment core from the OBS vent-fiel, $21^{\circ} \mathrm{N}$ East Pacific Rise. Chem. Geol. 155: 65-75. 
GODOY, M.A.M. (1995): Caracterização mineralógica do minério, concentrado e rejeito da flotação da Mina São Bento (MG). Inst. Geoc. UNB, M.Sc., Brasilia, 204p.

GODOY, M.L.S. (1994): Evolução tectono-metamórfica da Mineralização Aurífera de Raposos (MG).Inst. Geoc. E Cienc. Exatas, UNESP Rio Claro. M. Sc. 98p.

GOLDFARB, R.J., GROVES, D.I., GARDOLL, S. (2001): Orogenic gold and geologic time, a global synthesis. Ore Geol. Reviews, 18:1-75.

GOLDMAN, D.S., ALBEE, A.L. (1977): Correlation of Mg-Fe partitioning between garnet and biotite with partitioning between quartz and magnetite. Amer. Journ. Scienc. , 277(6): 750-767.

GORCEIX, H.(1885): Estudos sobre a monazita e a xenotima da Brasil. Esc.Min. de Ouro Preto. Anais, 4:29-49.

GRAHAM, C.M., POWELL, R. (1984): A garnet-hornblende geothermomether: calibration, testing and application to the Pelona Schist, Southern California. Journ Metam. Geology, 2:13-31

GRANT, J.A. (1986): The Isocon Diagram - A simple solution to Gresens' Equations for Metasomatic Alteration. Ecomonic geology, 81: 1976-1982.

GRESENS, R.L. (1967): Compositions-Volume relationships of Metasomatism. Chemical Geology, 2: 47-65.

GROSS, G.A. (1980): A Classification of Iron-Formation Based on Depositional Enviroments. Can. Miner. , 18: 215-222.

GROSS, G.A. (1986): The Metallogenetic Significance of Iron-Formation and Related Stratafer Rocks. Journ. Geolog. Soc. India, 28: 92-108.

GROSS, G.A. (1991): Genetic concepts for iron-formation and associated metalliferous sediments. Econ. Geol. Monograph 8, 51-81.

GROSSI SAD, J.H., CHIODI FILHO, C., SANTOS, J.F., MAGALHÃES, J.M.M., CARELOS, P.M. (1990): Geoquímica e origem da formação ferrífera Guanhães, Distrito de Guanhães, MG, Brasil. In: SBG, Cong. Bras. Geol, 36, Natal, 3: 1241-1253.

GROVES, D.I., BATT, W.D. (1984): Spatial and temporal variations of Archean metallogenic associations in terms of evolution of granitoid-greenstone terrains with particular emphasis on Western Australia. In: A. Kröner, G.M. Hanson, A.M. Goodwin (eds,): Archean Geochemistry. Springer-Verlag, Berlin, pp. 73-98. 
GROVES, D.I. and FOSTER, R.P. (1991): Archean Lode Gold Deposits. In: FOSTER, R.P. (Ed): Gold metallogeny and exploration, Blackie, London, 63103.

GROVES, D.I, PHILLIPS, N., HO, S.E., HOUSTON, S.M., STANDING, C.A. (1987): Craton-Scale Distribuition of Archean Greenstone Gold Deposits: Predictive Capacity of the Metamorphic Model. Economic Geology, 82: 2045-2058.

GUBA, I. (1982): Tektonik, texturen und mineralogie der präkambrischen eisenerze und nebengesteinssrien der lagerstäte Morro Agudo im NE des Quadrilátero Ferrifero/Minas Gerais, Brasilien. Tese de doutorado, Technischen Universität Clausthal, 342p.

GUARNIERI, L.B. (2003): Geologia Precambriana da Região de Nova Era, Extremo Ne do Quadrilátero Ferrifero - MG. Diss. Mestrado, IGc-USP, 117p, Anexos (Inédito).

GUIMARÃES, M.L.V. (1992): Petrogênese das rochas precambrianas da região de Itabira-Morro do Pilar, borda SE da Serra do Espinhaço Meridional, Minas Gerais. São Paulo, 138p. (Dissertação de Mestrado) - IG-USP.

GUY, C., DAUX, V., SCHOTT, J. (1999): Behavior of rare earth elements during seawater/basalt iteractions in the Mururoa Massif. Chemical Geology, 158: 21-35.

HAMIL.TON, J.V., HODGSON, C.J. (1987): Mineralisation and structure of Kolar Gold Field, India. - Pp. 270-283, in: Gold'86.

HANNINGTON, M.D., SCOTT, S.D. (1988): Gold mineralization in volcanogenic massive sulfides: implications of data from active hydrotermal vents on the modern sea floor. - Econ. Geol. Monograph, 6: 491-507.

HANCHAR,J.M., HOSKIM, P.W.O. (2003): Zircon. Reviews in Mineralogy \& Geochemistry. Vol. 53. Min. Soc. Of America and Geoch. Society, 500p.

HANNINGTON, M.D., HERZIG, P.M. and SCOTT, S.D. (1991): Auriferous Hydrotermal Precipitates on the Modern Seafloor. In: FOSTER, R.P. (Ed.): Gold metallogeny and exploration. Blackie, London, 249-282.

HARDER, E.C., CHAMBERLIN, R.T. (1915): The Geology of central Minas Geraes, Brazil. - J. Geol., 23: 341-378 e 385-424.

HERRMANN, A. G., BLANCHARD, D.P., HASKIN, L.A., JACOBS, J.W., KNAKE, D.,KOROTEV, R.L. AND BRANNON, J.C. (1976): Major, Minor and Trace Element Compositions of Peridotitic and Basaltic komatiites from the Precambrian Crust of Southern Africa. Contib. Mineral. Petrol. 59: 1-12.

HERZ, N. (1978): Metamorphic rocks of the Quadrilatero Ferrifero, Minas Gerais, Brazil. - USGS Prof.Pap., 641-C, 81pp., Washington. 
HERZ, N.(1970): Gneissic and igneous rocks of the Quadrilatero Ferrifero, Minas Gerais, Brazil. - USGS Prof. Pap., 641-B, 58pp., Washington.

HERZ, N, HURLEY, P.M., PINSON, W.H., FAIRBAIRN, H.W. (1961): Age mesurements from a part of the Brazilian Shield. Geol. Soc.Amer., Bull 72:1111-1120.

HERZIG, P.M., HANNINGTON, M.D. (1995): Polymetallic massive sulfides at the modern seafloor - A review. Ore Geol. Ver. 10 (2) 95-115.

HERZIG, P.M., HANNINGTON, M.D., FOUQUET, Y., STACKELBERG, U.V., PETERSEN, S. (1993): Gold-rich polymetallic sulfides from the Lau Back Arc and implication for the geochemistry of gold in sea-floor hydrotermal systems of the southwest Pacific. - Econ. Geol., 88: 2182-2209.

HODGSON, C. J. (1989): The structure of shear-related, vein tipe gold deposits - A review: Ore Geology Reviews, v.4 , p. 231-273.

HODGSON, C. J. (1993): Mesotermal lode-gold deposits. In: Kirkhan et al.(1993): Mineral Deposit Modeling, Geol. Assoc. of Canada, Special Paper 40: 635678.

HUGHES, C.J. (1973): Spilites, keratophyres and the igneous spectrum. geological magazine, 109(6): 513-527.

HUSTON, D.L., LARGE, R.R (1989): A chemical model for the concentration of gold in volcanogenic massive sulfide deposits. Ore Geol. ver., 4: 171-200.

HUTCHINSON, R.W. (1973): Volcanogenic sulphide deposits and their metallogenetic significance. Econ. Geol. 68: 1223-1246.

HUTCHINSON, R.W. (1993): A multi-stage, multi-process genetic hypothesis for greenstone-hosted gold lodes. Ore Geology Reviews, 8: 394-382.

HUTCHINSON, R. W., BURLINGTON, J. L. (1984): Some broad characteristics of greenstone belt gold lodes. pp. 339-372, in R. P. Foster (ed.): Gold'82: The Geology, Geochemistry and Genesis of Gold Deposits (Geol. Soc. Of Zimbabwe, Special publication 1), A.A.Balkema, Rotterdam, The Netherlands, $753 p$.

INDA, H.A.V., SCHORSCHER, J.H.D., DARDENNE, M.A., SCHOBBENHAUS, C., HARALYI, N.C.E., BRANCO, P.C.A., RAMALHO, R. (1984): O Cráton do São Francisco e a Faixa de Dobramentos Araçuaí. - Pp. 193-248, in: C. Schobbenhaus, D.D.A. Campos, G.R. Derze, H.E. Asmus (coords.), Geologia do Brasil, DNPM, Div. Geol. Min., Brasília.

IWATA, S.A. (2000): Aspectos genéticos e características mineralógicas do crisoberilo das lavras de esmeraldas de Ferros e Hematita - MG. Tese de Doutorado, IG-USP, São Paulo, 131 p. 
JAHN, B.M, AUVRAY, B., BLAIS, S., CAPDEVILA, R., CORNICHET, J., VIDAL, F., HAMEURT, J., (1980): Trace element geochemistry and petrogenesis of Finnish Greenstone belts. Jour. Petrol. 21: 201-244.

JONES, C.E., HALLIDAY, A.N., REA, D.K., OWEN, R.M. (1994): Neodymium isotopic variations in the North Pacific modern silicate sediment and the insignificance of detrital REE contributions to seawater. Earth Plan. Acien. Lett., 127: 55-66.

JULIANI, C. (1993): Geologia, Petrogênese e Aspectos Metalogenéticos dos Grupos Serra do Itaberaba e são Roque na Região das Serras do Itaberaba e Pedra Branca, NE da Cidade de São Paulo. Tese de Doutorado, 2 vol., 803p.

KERRICH, R. (1983): Geochemistry of gold deposits in the Abitibi greenstone belt. Can. Inst. Min. Met., Spec. Vol.: 27-75.

KERRICH, R. (1989): Models of archean mesothermal gold deposits: a critical evaluation from new data. In: Annual meeting, Geol and Miner. Assoc. Can., Abstracts A-45.

KERRICH, R., FRYER, B.J., MILNER, K.J, PEIRCE, M.G. (1981): The Geochemistry of gold-bearing chemical sediments. Dickenson Mine, Ontario: A Reconnaisance study. Can. J. Earth Sci., 18: 624-637.

KERSWILL, J.A. (1993): Models of iron formation hosted gold deposits. In: Kirkhan et al. (1993): Mineral Deposit Modeling. Geol. Assoc. of Canada, Special Paper 40: 171-199.

KIRKHAN, R.V., SINCLAIR, W.D., THORPE, R.I., DUKE, J.M., eds. (1993): Mineral Deposit Modeling. Geol. Assoc. of canada, Special paper 40, 770p.

KNEIDL, V., SCHORSCHER, J.H.D. (1972): Faziesuebergaege der Minas-Serie im Raum zwishen Itabira und Altamira (Minas Gerais, Brasilien). Neues Jahrbuch fuer Geologie und Palaentologie, 4:224-235.

KLEIN, C. (1983): Diagenesis and Metamorphism of Precambrian Banded IronFormation. In: TREND, A.F., MORRIS, R.C., Eds. (1983): Iron-Formation: Facts and Problems. Developments in Prec. Geology 6: 417-470.

KRETSCHMAR, U., SCOTT, S.D. (1976): Phase relation involving arsenopirite in the system Fe-As-S and their applications. Can. Miner. 14: 364-386.

KUHNS, R.J., SAWKINS, F.J. and ITO, E. (1986): Alteration Associated With The Golden Giant Deposit: Hemlo, Ontario: Geological Association of Canada, Annual Meeting, Program with Abstracts, 11: 91.

LADEIRA, E.A. (1980): Metallogenesis of gold at the Morro Velho Mine and in the Nova Lima District, Quadrilátero Ferrifero, Minas Gerais, Brazil. - 272pp., Tese de Doutorado, Univ. of Western Ontario. 
LADEIRA, E.A. (1988): Metalogenia dos depósitos de Ouro do Quadrilátero Ferrífero, Minas Gerais. In: C. Schobbenhaus, C.E.S. Coelho (Eds):. Principais Depósitos Minerais do Brasil-Metais Básicos Não Ferrosos, Ouro e Alumínio. Brasilia. DNPM/CVRD, 3(25): 301-375.

LADEIRA, E.A.(1991): Genesis of gold in Quadrilátero Ferrifero: A remakable case of permanency, reclycling and inheritance - A tribute to Djalma Guimarães, Pirre Routhier and Hans Ramberg, In Ladeira, E.A.ed., "Proceedings of Gold'91, an Intern. Symposium on the Economics, Geology, Geochemistry and Genesis of Gold Depositis, Belo Horizonte, Brazil: A.A Balkema, Rotterdam, The Netherlands, p.11-30.

LADEIRA, E.A., VIVEIROS, J.F.M. (1984): Hipótese sobre a Estruturação do Quadrilátero Ferrifero com Base em dados disponiveis. Belo Horizonte, SBG, Simp. Geol. Minas Gerais, Bol.4: 14p.

LEAKER, B.E., Ed.(1997): Nomenclature of Amphiboles: report of the Subcommitee on Amphiboles of international Mineralogical Association Commission on New Minerals and Minerals Names. Contrib. To Mineral. And petrol., 61: 295-321.

LE MAITRE, R.W. (1976): Some problems of projection of chemical data into mineralogical classificatoions. Contr.Mineral. Petrol., 56: 181-189.

LE MAITRE, R.W. (1989): A classification of igneous rocks and glossary of terms. Recommendations of the International Union of Geological Sciences Subcomission on the Sistematics of Igneuos Rocks. Blackwell Scientific Publications, 193p.

LOBATO, L.M., VIEIRA, F.W.R, RIBEIRO-RODRIGUES, L.C., PEREIRA, L.M.M., MENEZES, M.G., JUNQUEIRA, P.A., MARTINS PEREIRA, S.L. (1998a): Styles of hidrotermal alteration and gold mineralizations associated with the Nova Lima Group of the Quadrilatero Ferrifero: Part 1, Descripption of selected gold deposits. Rev. Bras. Geoc. 28(3): 339-354.

LOBATO, L.M., VIEIRA, F.W.R. (1998b): Styles of hidrotermal alteration and gold mineralizations associated with the Nova Lima Group of the Quadrilatero Ferrifero: Part II, The archean Mesothermal Gold-bearing hydrotermal system. Rev. Bras. Geoc. 28(3): 355-366.

LUCHESI, I. (1991): Evolução Petrogenética e metalogenética da Serra da Boa Vista, Quadrilátero Ferrifero-MG. Diss. Mestrado, IG-USP, 134p.

MACGEEHAN, P.J., HODGSON, C.J. (1980): Environments of gold mineralisation in the Campbell Red Lake and Dickenson Mines, Red Lake District, Ontario. Pp. 184-207, in: R.W. Holder and W. Petruk (eds.):, Geology of Canada, Proceedings C.I.M. Gold Symp.. 
MACHADO, G.A.A.(1994): Geologia da região e aspectos genéticos das jazidas de esmeraldas de Capoeirana e Belmont, Nova Era - Itabira, MG. São Paulo, 134p., IG-USP, Dissertação de Mestrado.

MACHADO, G.A.A.(1998): Jazidas de Esmeralda de Capoeirana e Belmont -MG: Geologia, Petrogênese e Metalogênese. Tese de Doutorado, IG-USP, São Paulo. 196p. Anexos.

MACHADO, G.A.A., SCHORSCHER, H.D. (1998): Rochas metaultramáficas nas jazidas de esmeralda de Capoeirana e Belmont (Estado de Minas Gerais Brasil) In: CONGRESO URUGUAYO DE GEOLOGIA, 2., Punta del leste, 1997. Uruguay, Socied Uruguaya de Geologia. Faculdad de Ciencias.

MACHADO, N., CARNEIRO, M.A. (1992): U-Pb evidence of late Archean tectonothermal activity in the southern São Francisco Shield, Brazil. - Can. J. Earth Sci., 29: 2341-2346.

MACHADO, N., NOCE, C.M.(1993): A evolução do setor sul do Cráton do São Francisco entre 3.1 e 0,5 G.a., baseada em geocronologia U-Pb. - Pp. 100102, in: Anais do ll Simp. sobre o Cráton do São Francisco, Salvador.

MACHADO, N., SCHRANK, A., ABREU, F.R., KNAUER, L.G., ALMEIDA ABREU, P.A. (1989): Resultados preliminares da geocronologia U/Pb na Serra do Espinhaço Meridional. Bol.Soc.Bras.Geoc., Nucleo Minas Gerais, 10: $171-$ 174.

MACHADO, N., SCHRANK, A., NOCE, C.M., GAUTHIER, G. (1996): Ages of detrital zircon from Archean-paleoproterozoic sequences: Implications for greenstone belt setting and evolution of a transamazonian foreland basin in Quadrilatero Ferrifero, southest, Brazil. Earth Plan. Sci. Let. 141:259-276.

MAGALHÃES, L.F., NILSON, A.A. (1993): Controle litoestrutural e características da Mineralizaçào aurífera da região do Córrego Geral-Meia Pataca, Crixas (GO). SBG, Rev.Bras. Geoc., Bol. 16: 25-49.

MARTINS PEREIRA, S.L. (1995): Controles Litoestruturais da Mineralização Aurífera no Distrito de Santa Bárbara, Quadrilátero Ferrifero, M.G.: Mina São Bento. Inst. Geoc., UFMG, BH, Dissert. de Mestrado, 158p.

MARTINI, S.L. (1998): Na overview of main auriferous regions of Brazil. SBG, Ver. Bras. Geoc. 28(3): 307-314.

MASON, R (1992): Felsic intrusion and hydrotermal gold deposits: A tectonic perspective. In: Basements Tectonics 8, Characterization and comparisson of ancient and Mesozoic continental margins. Proc. Of the 8th Intern. Conf. On basem. Tectonics. M.J Bartholomew, D.W. Hyndman, D.W. Mogk and R.Mason (Eds.), pp. 679-687, Riedel Publ.. 
MASON, R (1995): Gold Metallogeny, Seminar Notes. Queen's University, Kingston, Ontario, Canada. Curso Proferido na CVRD, Teofilândia, BA. 148p..

MASON, R., HELMSTAEDT, H.H. (1992): Structural controls during formation and deformation of Archean lode-gold deposits in the Canadian Shield. In: International Basement tectonics Association Publication no 8, pp 625-631.

MATHESON, A.F. (1956): The St John del Rey Mining Company, Ltd., Minas Gerais, Brazil. History, geology and mineral resources. Can. Inst. Min. Met. Bull. 49(523): 37-43.

MATHIESON, N.A., HODGASON, C.J. (1984): Alteration, Mineralization and Metamorphism on the area of the East South " $C$ " ore zone, $24^{\text {th }}$ level of the Dickenson Mine, Red Lake, NW Ontario. Can. Journ. Earth Sci., 21: 35-52.

MAXWELL, C.H. (1972): Geology and Ore Deposits of the Alegria Distict, Minas Gerais, Brazil. USGS, Prof. Pap. 341-J, 72p.

MCLENNAN, S.M., TAYLOR, S.R. (1984): Archaean sedimentary rocks and their relation to the composition of the Archaean Continental Crust. - Pp. 48-72, in: A. Kröner et al. (eds.): Archaen Geochemistry - The Origin and Evolution of the Archaean Continental Crust. Springer, Berlin, Heidelberg, N.Y..

MEL'NIK, Y.P. (1982): Precambrian Banded Iron-Formation. Physicochemical Conditions of Formation. Develop. In Prec. Geology 5, Elsivier 310p.

MENEZES, M.G. (1996): Evolução mineralógica das encaixantes da mineralização aurifera na Mina de Santana, Marina, Quadrilátero Ferrifero, MG. In: SBG, Congr. Bras. Geol., 39, Salvador, Anais. 3: 320-322.

MENEZES, M.G. (1999): Estudos dos Controles Estruturais e Geoquímicos da Mineralização Aurífera de Santana. Inst. Geoc., UNB, Tese de Doutorado.

MENEZES, M.G. , LEONARDOS, O. H. (1992): a ocorr6encia aurifera no Grupo Maquiné, Quadrilátero Ferrífero, MG. In: Simp. Geol. Minas Gerais, 6, Ouro Preto, 1991, Ver, Esc. Minas O. P., 45 (1/2): 128-130.

MICHARD, A., ALBAREDE, F., MICHARD, G., MINSTER, J.F., CHARLOU, J.L. (1983): Rare -earth elements and Uranium in high-temperature solutions from East Pacific Rise hydrotermal vent fild $\left(13^{\circ} \mathrm{N}\right)$. Nature, 303: 795-797.

MILLS, R.A., ELDERFIELD, H. (1995): Rare earth element geochemistry of hydrotermal deposits from active TAG, 260N Mid-Atlantic Ridge. Geoch, Comoc. Acta, 59(17): 3511-3524.

MINTER, W.E.L. (1991): Ancient Placer Gold Deposits. In: FOSTER, R.P. (Ed.): Gold metallogeny and exploration. Blackie, London, 283-308. 
MINTER, W.E.L, RENGER, F.E. and SIEGERS, A. (1990): Early Proterozoic goldnplacers of the Moeda Formation within the Gandarela Syncline, Minas Gerais, Brazil: Econ. Geol. v.(85):943-951.

MÖLLER, P., RHEDE, D., SASTRI, C.S. (1997):The Chemical controls of gold deposition at arsenopyrite surfaces. Mineral deposits, 249-251.

MÖLLER, P., SASTRI, C.S., KLUCKNER, M., RHEDE, D., ORTNER, H.M. (1997): Evidence for Electrochemical deposition of gold into Arsenopyrite. Eur. J. Mineral., v. 9: 1217-1226.

MOORE, S.L. (1969): Geology and Ore Deposits of the Antônio do Santos, Gongo Sôco and Conceição do Rio Acima Quadrangles, Minas Gerais, Brazil. USGS Prof. Pap. 341-I, 148p.

MORAES, L.J., BARBOSA, O. (1939): Ouro no Centro de Minas Gerais. - DNPM., Div. Fom. Prod. Mineral, Bol. 38, 185pp., Rio de Janeiro.

MORESCHI, J.B. (1972): Geologia da Mina do Faria - MG. Tese de Doutoramento. IGc-USP, São Paulo, 115p.

MOTHÉ-F. , H.F.(1996): Contribuição a geologia da região de Florália/MG. 189p. (Dissertação de Mestrado), IG-UFRJ, Rio de Janeiro.

MOTTL, M.J., MCCONACHY, T.F. (1990): Chemical process in buoyant hydrothermal plumes on the East Pacific Rise near 210 N. Geoch, Comoc. Acta, 54: 1911-1927.

MUNHA, J., KERRICH, R. (1980): Sea water interaction in spilites from the Iberian Pyrite Belt. Contribution Mineralogy and Petrology, 73:191-200.

NASCIMENTO, H.S. , SENA, F.O , GOMES, F.C.A , ABREU, G.C. (1998): Mapa Geológico 1:40.000 do sul do GBRI: Novos Dados e sua aplicação na caracterização geológica dos ambientes relacionados a mina de ouro de Fazenda Brasileiro, Bahia. In: SBG - Anais do XL Congr. Bras. de Geol., EXPOGEO 98, p.145.

NARAYANASWAMI, S., ZIAUDDIN, M., RAMACHANDRA, A.V. (1960): Structural control and localization of gold-bearing lodes, Kolar Gold Field, India. - Econ. Geol., 55: 1429-1459.

NASH, W.P.(1984): Chapter 6: Phosphate mineral in terrestrial igneous and metamorphic rocks. In: Nriagu, J.O, Moore, P.B. Phosphate minerals, p. 215241, Springer-Verlag.

NATARAJAN, W.K., MUKHERJEE, M.M. (1986): A Note on The Auriferous Banded Iron-Formation of Kolar Schist Belt. Journ. Geolog. Soc. India, 28: 218-222. 
NEVES, B.B.B., KAWASHITA, K., CORDANI, U.G., DELHAL, J. (1979): A evolução geocronológica da cordilheira do Espinhaço: dados novos e integração. R.B.G., 9(1): 71-85.

NOCE, C.M. (1995): Geocronologia dos eventos magmáticos, sedimentares e metamórficos na região do Quadrilátero Ferrífero, Minas Gerais. Tese de Doutorado, IG-USP, 128p.

NOCE, C.M., MACHADO, N., TEIXEIRA, W. (1998): U-Pb geocronology of gneisses and granitoids in the Quadrilatero Ferrifero (Southern São francisco Craton): Age constraints for archean and paleoproterozoic magmatism and metamorphism. SBG, Rev. Bras. Geoc.,28(1): 95-102.

OBERTHÜR, T., BLEINKINSOP, T.G., HEIN, U.F., HÖPPNER, M., HÖHNDORF, A., WEISER, T.W. (2000): Gold mieralization in the Mazowe area, HarareBindura-Shamwa greenstone belt, Zimbabwe: II. Genetic relationships deduced from mineralogical, fluid inclusion and stable isotope studies, and $\mathrm{Sm}-\mathrm{Nd}$ isotopic composition of scheelites. Mineralium Deposita, 35(2-3): 138156.

OBERTHÜR, T., SAAGER, R., TOMSCHI, H.P. (1990): Geological, mineralogical and geochemical aspects of Archean banded iron formation hosted gold deposits: some examples from Southern Africa. - Mineralium Deposita, 25: 125-135.

OFTEDAHL, C. (1958): A theory of exhalative-sedimentary ores. - Geol. Fören. Förh., 80(H.1): 1-19.

OLIVEIRA, A.I. (1956): Brazil. - In: W.F. Jenks (ed.) - Handbook of South American Geology - Geol. Soc. Am., Mem., 65: 1-62.

OLSEN, S.N., GRANT, J.A. (1991): Isocon analysis of migmatization in the Front Range, Colorado, USA. Journal of Metam. Geology, 9: 151-164.

OVERSTREET, W.C. (1967): The geologic ocurrence of monazite. U.S.G.S Prof. Pap. 530, 327p..

PADILHA, A.V., VIEIRA, V.S., HEINECK, C.A. (2000): Itabira, Folha SE.23-Z-D-IV, MG, Escala 1:100.000. Prog. Levant. Geol. Básicos do Brasil, CPRM - Serv. Geol. do Brasil, Belo Horizonte, CD-ROM.

PARRISH, R.R. (1990): U-Pb dating of monazite and this application to geological problems. Can.J.Earth Sci., 27: 1431-1450.

PATTAN, J.N., RAO, C.M., HIGGS, N.C., COLLEY, S., PARTHIIBAN, G. (1995): Distribution of major, trace and rare earth element in surface sediments of the Wharton Basin, Indian Ocean. Chemical Geology 121: 201-215. 
PERCHUK, LI.L., ARANOVICH, L.Y., PODLESSKII, K.K., LAVRENT'EVA, I.V., GERASIMOV, V.Y., FED'KIN, V.V., KITSUI, V.I., KARASAKOV, L.P., BERDNIKOV, N.V. (1985): Precambrian granulites of the Aldan Shield, eastern Siberia,USSR. Journ. metam. Geology, 3(3): 265-310..

PEREIRA, E.L.S. (1996): Controles e evolução da mineralização aurífera da mina de São Bento, greenstone belt Rio das Velhas, MG. Unpub. M.Sc. thesis, UFOP, Ouro Preto.

PEREZ-AGUILAR, A. (2001): Petrologia e litoquímica de rochas de paleossistemas hidrotermais oceânicos mesoproterozóicos da seqüência Metavulcanossedimentar do Grupo Serra do Itaberaba, SP. Tese de Doutoramento, Igc-USP, São Paulo, 223p.

PETERSEN Jr, K.J. (2003): Estudo das Mineralizações Auriferas do Corpo IV e V da Estrutura IV do Greenstone Belt de Crixas. Tese Doutorado, IGc-USP186p., anexos.

PFLUG, R. (1968): Observações sobre a Série Minas na região de Diamantina, Minas Gerais. Rio de Janeiro, DNPM/DGM. Notas preliminares e Estudos. 142. $55 p$.

PFLUG, R, RENGER, F. (1973): A evolução Geológica da margem SE do Craon do Sanfranciscano. In: $27^{\circ}$ Cong. Bras. Geol., Aracaju, Anais, v.2: 5-19.

PHILLIPS, N.G. (1985): Archean Gold Deposits of Australia. Ciclo de Palestras sobre Metalogenia do Ouro. IGC-UFMG, 43p.

PHILLIPS, N.G., GROVES, D.I. (1983): The nature of Archean gold-bearing fluids as deduced from gold deposits of Western Australia. J. Geol. Soc. Aust. , 30: 2539.

PISSIS, A. (1842): Mémoire sur la position géologique des terrains de la partie australe du Brésil et sur les soulévements Qui. A diverses époques, ont cahngé le relief de cette contrée. Men. Inst. France, Tome X, 253-313.

POWELL, R. HOLLAAND, T.J.B. (1998): An internally consistent thermodinamic data set for phases of petrological interest. J. Met. Geology, 16:309.

QUEIROGA, N.C.M., ABREU, G.C., TAMURA,R.M., SCHORSCHER, J.H.D. (1988): Mapeamento lito-estrutural do Grupo Quebra Osso. Relatório Final, 20p., 2 mapas, FAPESP, Proc. No 87/0128-0, IG-USP, São Paulo.

QUÉMENEUR, J. (1984): Contribuição a Tectônica e ao Metamorfismo da Região de Rocrigo Silva a Oeste de Ouro Preto - MG. Cong. Bras. Geol., 33, An., v. 7: 3307-3318, Rio de Janeiro.

RADASKRISHNA, B.P., DEVARAJU, T.C. and MAHABALESWAR, B (1986): Banded Iron-Formation of India. Jour. Geolog. Socie. India, 28: 71-91. 
RAMDOHR, P. (1969): The ore mineral and their intergrowths. Pergamon Press, Oxford, 1174p.

RANKAMA, K. (1963): Progress in Isotope Geology. Jonh Wiley \& Sons, Intersciences Publ., Monog., London, 705p.

RECHE, J., MARTINEZ, F.J. (1995): GPT: An Excel spreadsheet for thermobarometric calculations in Metapelitic Rocks. Comp. \& Geosciences, 22(7): 775-784.

REEVES, R.G. (1966): Geology and Mineral Resourses of Monlevade and Piracicaba quadrangles, Minas Gerais, Brazil. USGS-Prof. Paper, v. 341-E, p.1-58.

RETTINGER, R. (1998): Thermometamorphic characterization of the transition zone between the Archean São Francisco Craton and the Proterozoic mobile belt, Minas Gerais, Brazil. 116p. Tese de Doutorado - Universität Postdam.

RETTINGER, R., OBERHÄNSLI, R., DÜRKOP, C. (1998): Thermodimanic characterization of the transition zone between the Archean São Francisco Craton and the Neoproterozoic mobile belt, Minas Gerais, Brazil. Zbl. Geol. Paäont. Teil I, (3-6): 721-738.

RETTINGER, R., SCHORSCHER, H.D., OBERHÄNSLI, R. (1996): Geothermobarometric correlation of geothermobarometers and petrogenetic modelling in NE-Quadrilátero Ferrifero, Minas Gerais, Brazil. Zentralblatt für geologie und paläontologie. Teil 1, n7/8, p. 613-625.

RIBEIRO-RODRIGUES, L.C. (1998): Gold in Archean Banded Iron formation of the Quadrilátero Ferrífer, Minas Gerais, Brazil - The Cuiabá Mine. Aachen Univ. Techn., Aachen, Germany, Aachener Geowissenschaftliche Beiträge, Band 27, Ph. D. Thesis, $264 \mathrm{p}$.

RIBEIRO-RODRIGUES, L.C., FRIEDRICH, G., OLIVEIRA, C.G., VIEIRA, F.W., BIASI, E.F., CALLEGARI, L.A. (1996): The BIF-hosted Cuiabá gold deposit, Iron Quadrangle, Minas Gerais, Brazil: Characteriscs, controls and genesis. In: SBG, Congr. Bras. Geol., 39, salvador, 7: 224-228.

RICHARD, L.R. (1995): Minpet Geological Software Version 2.02. Quebec. Canada. RICCOMINI, C. (1982): Geologia Regional do Quadrilátero Ferrifero (MG, Brasil): Uma tentativa de síntese e novas idéias. In: 320 Cong. Bras. Geol., SBG, An. , $\mathrm{v}-1: 199-213$

RICCOMINI, C. (1983): Estudo Comparativo entre diferentes métodos e sensores aplicados a análise litoestrutural no Quadrilátero Ferrífero, M.G. Dissert. Mestrado, INPE, S.J.Campos, 198p. 
RICKWOOD, P/C. (1968): Contributions to Mineralogy and Petrology. Spronger Intern., New York, 18, 2: 175-198.

RIGG, D.M. (1980): Relationship between structure and gold mineralization in the Campbell - Red Lake District, Ontario. Msc Thesis, Queen's University, Kingston, Ontario, 153p.

ROBERTS, R.G. (1987): Ore Deposit Models \#11: Archean Lode Gold Deposits. Geoscience Canada, 14(1): 37-52.

ROLLINSON, H. (1993): Using Geochemical Data: Evaluation, Presentation, Interpretation. Longman Group, UK, Ltd.

RONA, P, SCOTT, S.D (1993): A special issue on sea floor, hydrotermal mineralization: new perspectives. Econ. Geol. 88(8): 1935-1975.

ROUTHIER, P. (1963): Les Gisements métalliferes: géologie er principles de recherche. Paris, Masson, $2 \mathrm{v}$.

RYNEARSON, G.A., POMERENE, J.B., DORR, J.V.N. (1954): Contato basal da Série Minas na parte oriental do Quadrilátero Ferrífero, Minas Gerais, Brasil. DNPM, Div. Geol. e Miner., Avulso 34, 18p.

SÁNCHES-ESPAÑA, J., VELASCO, F., YUSTA, I. (2000): Hydrotermal alteration of felsic volcanic rocks associeted with massive sulphide deposition in the northern Iberian Pyrite Belt (SW Spain). Applied Geochemistry, 15: 12651290.

SANGSTER, D.F.(1972): Precambriam vulcanogenic massive sulphide deposits of Canada: A review, Canada Geol. Survey Paper 72-22, 44p.

SANT'ANNA, L. G., SCHORSCHER, H. D. (1997): Estratigrafia e mineralogia dos depósitos Cenozóicos da região da Bacia de Fonseca, estado de Minas Gerais, Brasil - An. Acad. Bras. Ci. Rio de Janeiro,, 69 (2): 211-226.

SANT'ANNA, L. G., SCHORSCHER, H.D., RICCOMINI, C. (1997): Cenozoic tectonics of the Fonseca Basin region, eastern Quadrilatero Ferrifero, MG, Brazil. - J. South American Earth Sciences, 10 (3-4): 275-284, 1997.

SANTOS, A. R.(1986): Estudos sobre a tectônica de fraturamento na região do Quadrilátero Ferrífero e em partes do Complexo Migmatítico-granulítico de Minas Gerais com base em sensoriamento remoto. São Paulo, 172p. (tese de Doutorado), IG-USP.

SANTOS R.V., CLAYTON, R.N.(1995): Variations of oxygen and carbon isotopes in carbonatites: A study of Brazilian alkaline complexes. Geoch.Cosmoc. Acta, 59 (7): 1339-1352.

SANTOS R.V., ALVARENGA, C.J.S., DARDENNE, M.A., SIAL, A.N., FERREIRA, V.P.(2000): Carbon and oxygen isotope profiles across Meso-Neoproterozoic 
limestones from central Brazil: Bambuí and Paranoá Groups. Precambriam Reserch, 104: 107-122.

SCHOBBENHAUS, C., COELHO, C.E.S. (1988): Metais básicos não-ferrosos, Ouro e Alumínio. - Principais depósitos minerais do Brasil, Vol.III, 670 pp., DNPMCVRD, Brasilia.

SCHOBBENHAUS, C., CAMPOS, D.A., DERZE, G.R., ASMUS, H.E. (1984): Mapa Geológico do Brasil a área oceânica adjacente incluindo Depósitos Minerais, escala 1:2.500.000. Efls, DNPM, MMN, Brasília, DF. 501p.

SCHNEIDERHOHN, H. (1961): Die Pegmatite. Velag-Stuttgart, 720p.

SCHORSCHER, H.D. (1973): Levantamento Geológico da Região de Itabira, 1:20.000 - Conv. Inst. Eschwege CVRD. Relatório Final, 48p., 4mapas. Inst. Eschwege, Diamantina/CVRD, Belo Horizonte.

SCHORSCHER, H.D. (1973): Zur liegenden Abgrenzung der präkambrischen MinasGruppe, am Beispiel des Raumes Itabira, Minas Gerais, Brasilien. Münster. Forsch. Geol. Palaont., 31/32, 29-53.

SCHORSCHER, H.D. (1973): Zur Bildung der metamorphen, itabiritischen Reicherze im Raum Itabira, Minas Gerais, Brasilien. Fortschr. Min., 53, Beith.1, S. 73.

SCHORSCHER, H.D. (1975): Entwicklung des polymetamorphen präkambrischen Raumes Itabira, Minas Gerais, Brasilien. Tese de Doutorado (ined.) 304p., 11 mapas. Universidade de Heidelberg.

SCHORSCHER, H.D. (1976a): Polimetamorfismo do Pré-Cambriano na região de Itabira, Minas Gerais, Brasil. - In: $29^{\circ}$ Cong. Bras. Geol., Resumos: 194-195, SBG., Ouro Preto/Belo Horizonte.

SCHORSCHER, H.D. (1976b): Alpinotype Deckentektonik im Präkambrium des Eisernen Vierecks, Minas Gerais, Brasilien. - In: 5. Geowiss. LateinamerikaKolloquium, Tagungsunterl.: 33-35, Clausthal-Zellerfeld.

SCHORSCHER, H.D. (1978): Komatiitos na estrutura "Greenstone Belt" Série Rio das Velhas, Quadrilátero Ferrifero, Minas Gerais, Brasil. - In: 300 Cong. Bras. Geol., Resumos: 292-293, SBG., Recife.

SCHORSCHER, H.D. (1979a): Evolução geotectônica e petrogenética do embasamento arqueano do Quadrilátero Ferrifero. - Acad. Bras. Ci., Anais, 51(4):767-768.

SCHORSCHER, H.D. (1979b): Evolução arqueana e proterozóica do Quadrilátero Ferrifero e de partes meridionais da Serra do Espinhaço. - Simp. sobre a Geologia do Cráton do São Francisco e de suas faixas marginais, Resumos, Salvador. 
SCHORSCHER, H.D. (1980a): Geotectonic evolution of the Quadrilatero Ferrifero, Brazil. - 26th Inter. Geol. Congress, Abstracts, v. 2: 613, Paris.

SCHORSCHER, H.D. (1980b): Zinc - a useful element for the prospection of precambrian chromitites ? - 8th. Inter. Geochem. Explor. Symp., Abstracts: 47, Hannover.

SCHORSCHER, H.D. (1980c): Contribuiçäo a estratigrafia proterozóica do Quadrilátero Ferrifero. - Acad. Bras. Ci., Anais, 52(1):195.

SCHORSCHER, H.D. (1988a): Quadrilátero Ferrifero and adjacent areas. - Inter. Conf. Geochemical Evolution of the Continental Crust, Guidebook: 96pp., Poços de Caldas.

SCHORSCHER, H.D. (1988b): Geology of the Floralia District with details on the Morro do Pari área, Minas Gerais, Brazil. - Relatório de pesquisa e mapeamento geológico (esc. 1:13.600) da região da Mina do Pari. 24 pág., anexos, relat. inéd. interno para UNAMGEN Min. Met. Ltd., IG-USP.

SCHORSCHER, J.H.D. (1991a): Quadrilátero Ferrífero e Espinhaço Meridional. In: III Cong. Bras. Geoq. e I Cong. de Geoq. dos Países de Língua Portuguesa, Guia de Excursões, p. 37-87, São Paulo.

SCHORSCHER, J.H.D. (1991b): Mafic Dykes from Southern Sao Francisco craton, MG, Brazil. An. Symposiun on mafic Dykes, In: III Cong. Bras. Geoq. e I Cong. de Geoq. dos Paises de Língua Portuguesa, 87-88pp.

SCHORSCHER, J.H.D. (1992): Arcabouço petrográfico e evolução crustal de terrenos precambrianos do sudeste de Minas Gerais, Quadrilátero Ferrifero, Espinhaço meridional e Dominios granito-gnáissicos adjacentes. Tese de Livre Docência, IG-USP, São Paulo, 2 vols., 394pp.

SCHORSCHER, J.H.D., GUIMARÃES, P.F. (1976): Estratigrafia e tectônica do Supergrupo Minas e geologia do Distrito Ferrifero de Itabira. XXIX Cong. Bras. Geol., Ouro Preto, MG, Roteiro das Excursões, p.75-86.

SCHORSCHER, J.H.D., LETERRIER, J. (1980): Metassomatic formation of granitic rocks: Petrology and Chemistry. 26th Inter. Geol. Cong., Paris, Abstracts, 1:87.

SCHORSCHER, J.H.D., MULLER, G. (1977): Granitisation tiefkrustaler Mylonite durch metasomatische Feldspatisierung im Präkambrium E-Brasilien. Forschr. Min. 55, Beith. 1, 123-124.

SCHORSCHER, J.H.D., ALVES, M.G., DAVIES, H.P.K.(1997): Geologia da Quadrícula de São Gonçalo do Rio Abaixo 1:25.000, parte NE do Quadrilátero Ferrífero, MG. In: Simposio de Geologia de Minas Gerais, 9., Ouro Preto. Anais. SBG-Núcleo Minas Gerais. Boletim, n. 14, p.50-52. 
SCHORSCHER, J.H.D., LUCHESI, I., QUEIROGA, N.C.M., ABREU, G.C., TAMURA, R.M. (1990): Evolução precambriana da região do Quebra Osso, Quadrilátero Ferrifero, MG. SBG, Cong. Bras. Geol., Res. 331-332, Natal.

SCHORSCHER, J.H.D., SANTANA, F.C., POLÓNIA,J.C., MOREIRA, J.M.P. (1982):

Quadrilátero Ferrifero-Minas Gerais State: Rio das Velhas greenstone belt and Proterozoic rocks. ISAP, SME/BA.

SCHORSCHER, H.D., MOTHE F $F^{O}$, H.F. (1983): Mapa geológico preliminar (esc. 1:25.000) da Quadrícula de Florália, MG. - Projeto LATERITAS, Subprojeto Minas Gerais, projeto de pesquisa de Cooperação Internacional CNPQ-KFA, IG-USP, 1983.

SCHORSCHER, J.H.D., MOTHE Fo., H.F., DAVIES, H.P.K., ABREU, G.C., QUEIROGA, N.C.M.(1986): Metalogenia arqueana do ouro na Mina do Pari e arredores de Florália, MG. 340 Cong. Bras. Geol., Bol. 1 - Res. Breves Comun., p.232, Goiânia.

SCHORSCHER, J.H.D., ABREU, G.C., QUEIROGA N.C.M., LUCHESI, I., DAVIES, H.P.K., MOTHÉ Fo., H.F., ALVES, M.G. (1990): Geologia da Quadrícula de Florália(1:25000), Quadrilátero Ferrífero, Minas Gerais. In: $36^{\circ}$ Cong. Bras. Geol., Res. das comun., p.342, Natal.

SCHORSCHER, J.H.D., ABREU, G.C., LUCHESI, I., SANT'ANNA, L.G., QUEIROGA, N.C.M. (1991): Microgeoquímica do ouro arqueano e proterozóico da região NE do Quadrilátero Ferrífero, Minas Gerais, In: III Cong. Bras. Geoq. e I Cong. de Geoq. dos Países de Língua Portuguesa, Resumos, Vol. 1, pp. 574.

SCHRANK, A., OLIVEIRA, F.R., TOLEDO, C.L.B., ABREU, F.R. (1996): The nature of hydrodynamic gold deposits related to Archean Rio das Velhas Greenstone Belt and overlalying Paleoproterozoic Minas Basin. In: SBG, Symp. Archean Terranes of South American Platform, Brasilia, Extended Abstract Vol., 60-61. SCHRANK, A., MACHADO, N. (1996a): Idades U-Pb em monazitas e zircões das minas de Morro Velho e Passagem de Mariana. Quadrilátero Ferrifero (MG). In: SBG, Cong. Bras. Geol. 39, Salvador, Anais, 6:470-472.

SCHRANK, A., MACHADO, N. (1996b): Idades U-Pb em monazitas e zircões das minas de Cuiabá e do Depósito de Carrapato - Quadrilátero Ferrífero (MG). In: SBG, Cong. Bras. Geol. 39, Salvador, Anais, 6:473-474.

SCOTT, S.D., BARNES, H.L. (1971): Sphalerite Geothermometry and Geobarometry. Econ. Geol., vol.66: 653-669.

SEWARD, T.M. (1991): The hydrotermal geochemistry of gold. In: Foster, R.P. (Ed.):, Gold Metallogeny and Exploration, Black and Son Ltd, London, 37-62. 
SHARP, Z.D., ESSENE, E.J., KELLY, W.C. (1985): A re-examination of the arsenopirite gepthermometer: Pressure considerations and applications to natural assemblages. Can. Mineral., 23(4):517-534.

SICHEL, S.E. (1983): Geologia das rochas precambrianas da região de Barão de Cocais e geoquímica preliminar dos komatiltos do Supergrupo Rio das Velhas, Quadrilátero Ferrifero, Minas Gerais - Dissert. Mestrado (inéd.), 232p., mapas, IG-UFRJ, Rio de Janeiro.

SIMMONS, G.C, MAXWELL, C.H. (1961): Grupo Tamanduá da Série Rio das Velhas: Brazil. DNPM, bol. 211,31p.

SIMMONS, G.C. (1968): Geology and Mineral Resources of the Barão de Cocais Area, Minas Gerais, Brazil. USGS Prof. Pap. 341-H.

SILVA, G.L., XAVIER, R.P. (1997): The gold-carbonaceous matter association in Lode Deposits of the Rio Itapicuru Greenstone belt, Northeastern Brazil. Intern. Geol. review, 39: 688-702.

SOTO, J.I. (1992): Program for thermobarometry \& activity calculation with mafic and ultramafic assemblage. Granada University, Granada, Spain.

SOUZA, J. L. (1988): Mineralogia e geologia da Esmeralda da jazida de Itabira, M.G.. Diss. Mest., Igc-USP, São Paulo, 192p.

SPEAR, F.S. (1989): Petrologic determination of metamorphic pressure-temperaturetime paths. In: Spear, F.S., Peacock, S.M., 1989 - Metamorphic pressuretemperature-time Paths. Short Course I Geology. Inter. Geol. Congr., Washington, DC, 7:1-55.

SPEAR, F.S. (1993): Metamorphic phase equilibria and pressure-temperature-time paths. Washington, Mineralogical Society of America, 799p. (Monography)

STANTON, R.L. (1959): Mineralogical Features and Possible mode of emplacement of the Brunswick Mining and Smelting orebodies, Gloucerster County, New Brunswick, Canadian Inst. Min. Metall.. Bull. 52 (570): 631-643.

STANTON, R.L. (1960): General Features of conformable pyritic orebodies, Part I Field association, Canadian Inst. Min. Metall. Bull. 53 (573): 24-29, Part II Mineralogy, Canadian Inst. Min. Metall. Bull. 53 (574): 66-74.

TABERT, C.F. (1987): Controls to deposition of gold, copper and bismuth at Renco mine, Zimbabwe. African Mining Inst. Of Min. and Metall., London, 347-363.

TAUBENECK, W.H. (1957): Zircons in the metamorphic aureole of the Bald mountain batholith, Elkhorn Mountains, Northeastern Oregon. Bull.Geol. Soc. Amer., Abst., 68: 1803-1804.

TEIXEIRA, W. (1982): Geocronology of southern part of São Francisco Craton. RBG, v. 12, n. $1-3$, p. $268-277$. 
TEIXEIRA, W. (1985): A evolução geotectônica da porção meridional do Craton do São Francisco, com base em interpretação geocronológica. São Paulo, 207p. (Tese de Doutorado).

TEIXEIRA, W., CANZIAN, F.S. (1994): A evolução tectonotermal Proterozóica do Craton do São Francisco com base em interpretações geocronológicas $\mathrm{K}-\mathrm{Ar}$ em rochas do embasamento. Bol. IGc-USP, Série Ciemtífica, 25: 61-80.

TEIXEIRA, W., CARNEIRO, M.A., NOCE, C.M., MACHADO, N., SATO, K., TAYLOR, P.N.. (1996): $\mathrm{Pb}-\mathrm{Sr}$ and $\mathrm{Nd}$ isotope constrainst on the archean evolution of gneissic-granitoid complexes in the southern São Francisco Craton, Brazil. Prec. Res., 78:151-164.

TEIXEIRA, W, CORDANI, U.G., NUTMAN, A.P., SATO,K. (1998): Polyphase Archean Evolution in the Campo Belo metamorphic complex, Southern São Francisco Craton, Brazil: Shrimp U-Pb zircon evidence. J. Of South Am. Earth Sciences, vol. 11, 3: 279-289.

TEIXEIRA, W., MARTINS, V.T.S (1996): Granitos Paleoproterozoicos da Porção Meridional do Craton do São Francisco: Estudos Isotópicos de Sr e Nd. São Paulo, USP/FAPESP. Rel. Proj. Pesq.(ined.) 28p.

TEIXEIRA, W., SABATE, P., NOCE, C.M, CARNEIRO, M.A.(2000): Archean and paleoproterozoic tectonic evolution of the Sao Francisco Craton. In: Cordani et al. (2000): Tectonic Evolution of Southamerica. $31^{\text {st }}$ Intern. Geol. Congr., Rio de Janeiro, 101-138.

TOLBERT, G.E. (1964): Geology of Raposos Mine, Minas Gerais, Brazil. Econ. Geol. 59:775-798.

TOLEDO, C.L.B. (1997): Controle Estrutural da Mineralização Aurífera na Mina Cuiabá, Setor Noroeste do Greenstone belt Rio das Velhas, Quadrilátero Ferrífero. Inst. Geoc., UNICAMP, Campinas, Dissert. de Mestrado, 166p.

TOLEDO, C.L.B., XAVIER, R.P., SCHRANK, A., VIEIRA, F.W., LA ROSA, M.T., SIL.VA, D.(1998): The fluid-carbonaceus matter interaction and deposition of gold at Cuiabá Mine, SE Brazil .In: SBG, Cong. Bras. Geol., 40, Belo Horizonte, p.177.

THOMPSON, A.B. (1976): Mineral Reactions in pelitic rocks: II. Calculation of some p-t-x (Fe-Mg) Phase Relations. American Journ. of Sciences, 276: 425-454.

THOMSON, M.L.(1991): Wall-rock alteration to the mineralization in the low amphibolite facies: Crixás gold Mine, Goiás, Brazil. In: Canadian Mineralogist, Vol. 29:461-480.

THORPE, R.I., CUMMING, G.L., KRSTIC, D.(1984): Lead isotope evidence regarding age of gold deposits in the Nova Lima district, Minas Gerais, Brazil. Rev. Bras. Geoc., 14(3):147-152. 
TREND, A.F., MORRIS, R.C., Eds. (1983): Iron-Formation: Facts and Problems. Developments in Prec. Geology 6, Elsivier, 558p.

UTZMANN, A., HANSTEEN, T.H., SCHMINCKE, H.U. (2002): Trace element mobility during sub-seafloor alteration of basaltic glass from Ocean Drilling Program site 953 (off Gran Canaria). J. Earth Sci (Geol Rundsch.), 91: 661-679.

VALLADARES, F.B. (2000): Geologia e Petro-Metalogênese da Mineralização Aurífera da Mina São Bento, Quadrilátero Ferrífero, MG. Monog. de trab. Form., TF2000/9, IGc-USP, São Paulo, 33p., anexos.

VALLADARES, F.B. (2004): Geologia e Petro-Metalogênese da Mineralização Aurifera da Mina São Bento, Quadrilátero Ferrífero, MG.Dissertação de Mestrado, IGc-USP, $55 \mathrm{p}$.

VALLADARES, F.B., SCHORSCHER, J.H.D (2001): Metalogenia do Au da Mina São Bento, NE do Q.F., MG. An. VII Simp. De Geol. Do SE, Rio de Janeiro, v. (1), Sessão poster.

VAUGHAN, D.J., CRAIG, J.R. (1978): Mineral chemistry of metal Sulfides. Cambridge Uni. Press, 493p.

VENEZIANI, P. (1987): Análise dos movimentos da tectônica rúpil e rúptil-dúctil através da interpretação de produtos de sensores remotos da região do Espinhaço Meridional (MG): uma correlação comprocessos evolutivos. São Paulo, 186p. (tese de Doutorado), IG-USP.

VIAL, D.S., FERREIRA Jr, M.G., FERRARI, P.G. (1987): A lapa seca na mina de Morro Velho: metavulcanitos alterados hidrotermalmente. SBG, Simp. Geol. Minas Gerais, 4, BH, Anais, 7: 369-390.

VIAL, D.S. (1980a): Geologia da mina de ouro de Bicalho. SBG, Congr. Bras.Geol., 31, Camboriú, 3: 1831-1850.

VIAL, D.S. (1980b): Geologia da mina de ouro de Raposos. SBG, Congr. Bras.Geol., 31, Camboriú, 3: 1851-1866.

VIAL, D.S. (1988): Mina de Ouro de Passagem, Mariana. Minas Gerais. In: C. Schobbenhaus, C.E. Coelho, (eds) (1988): Principais Depósitos Minerais do Brasil: Metais Básicos Não Ferrosos, Ouro e Alumínio, Brasília, DNPM/CVRD, 3: 421-430.

VIAL, D.S. (1988): Geology of the Cuiaba gold mine, Quadrilatero Ferrifero, Minas Gerais, Brazil (ext. abstr.), in: Poster programme, v.1, Bicentennial Gold'88, Melbourne, Victoria, Geol. Soc. Of Australia, Abstracts 23: 134-136.

VIEIRA, F.W.R.(1988): Processos epigenéticos da formação dos depósitos auríferos e zonas de alteração hidrotermal do Grupo Nova Lima, Quadrilátero Ferrífero, Minas Gerais. In: SBG, Cong. Bras. Geol., 35, Belém, Anais: 1: 76-86. 
VIEIRA, F.W.R. (1991): Textures and processes of hydrotermal alteration and mineralization in the Nova Lima Group, Minas Gerais, Brazil. In: E.A.Ladeira(ed.): Proceedings of Brazil GOLD'91, The Economics, Geology , Geochemistry and Genesis of the Gold Deposits. Proceed., Rotterdam, A.A. Balkema, 319-325.

VILLAÇA, J.N., MOURA, L.A.M. (1981): Uranium in Precambrian Moeda formation, Minas Gerais, Brazil. In: Armstrong, F.C ed.(1981): Genesis of Uranium and Gold-bearing Precambrian Quartz-pebble Conglomerate: USGS, Prof.Paper 1161-A-BB, p. T1-14.

WAHLE, C.W.(1943): Estudos de alguns minérios de ouro dos municípios de Santa Bárbara, Caeté e Mariana, Minas Gerais. Lab. Prod. Min., Rio e Janeiro, Bol. 8:71-82.

WENDT, J.I, REGELOUS, M., NIU, Y., HÉKINIAN, R., COLLERSON, K.D. (1999): Geochemistry of lavas from the Garret Transform Fault: insights into mantle heterogeneity beneath the eastern Pacific. Eart Plan. Scie. Lett., 173: 271284.

WHITFORD, D.J., ARNDT, N.T. (1978): Rare Earth Element abundances in a thick, layered komatitite lava flow from Ontario, Canada. Earth Plan, Sci. Lett., 41: 188-196.

WIEDEMANN, C.M., SCHORSCHER, J.H.D. (1978): Zinco nas rochas ultrabásicas e nos cromititos da região de Itabira, Minas Gerais, Brasil. 300 Cong. Bras. Geol., Res. Das Comunicações, 211-212, Recife.

WILLIAMS, P. (1997): A metamorphosed, stratabound-epigenetic origin for a gruneritic Archan gold deposit, Barberton, South Africa. Ore Geol. Rev. 12:135-151.

WILLIAMS, M.L., GRAMBLING, J.A.(1990): Manganese, ferric iron and equilibrium between garnet and biotite. Ameriacan Mineralogist, 75: 886-908.

WINCHESTER, J.A., FLOYD, P.A. (1977): Geochemical discrimination of diferent magam series and their differentiation products using immmobile elements. Chemical Geology, 20: 325-343.

WINKLER, H.G.F. (1977): Petrogênese das Rochas Metamórficas, Ed. Edgar Blücher, URGS, Porto Alegre, 256p.

WYMAN, D.A., KERRICH, R. (1989): Noble metal Au-related trace element abundances of archean shoshonitic lamprophires: significance for gold mineralization. In: Annual meeting, Geol and Miner. Assoc. Can., Abstracts A46. 
YAO, Y., MORTEANI, G., TRUMBULL, R.B. (1999): Fluid inclusion microtermometry and the P.T evolution of gold-bearing hydrotermal fluids in the Niuxinshan gold deposit, eastern Hebei province, NE China. Mineralium Deposita, vol 34 (4): 348-365.

YONKEE, W.A, PARRY, W.T, and BRUHN, R.L (2003): Relations Between Progressive Deformation And Fluid-Rock Interaction During Shear-Zone Growth In A Basement-Cored Thrust Sheet Orogenic Belt, Utah. Am. Journ. Of Science, 303: 1-59. 
Anexo 1: Mapa Geológico Compilado da Borda NE do Quadrilátero Ferrífero (esc.: 1:100.000) 


\begin{tabular}{|c|c|c|c|c|c|c|c|c|c|c|c|c|c|c|}
\hline IDNT & $2 O N$ & EEASTING & NORTHING & Altitude & Local & Litotipo & $S n$ & $\underline{L n}$ & So & Fraturas & Amostras & Descrição da amostra & Fotos & Prancha \\
\hline$\frac{P A-1}{P A-2}$ & $\frac{23 K}{23 K}$ & $\frac{677187}{677262}$ & $\begin{array}{l}7793322 \\
7793397\end{array}$ & $\frac{781}{790}$ & $\frac{\text { Patrimbnio }}{\text { Patrimsnio }}$ & \begin{tabular}{|l|} 
Anfif \\
Anfibolito
\end{tabular} & & & & & & & & \\
\hline$\frac{P A-2}{P A-3}$ & $23 \mathrm{~K}$ & 677309 & $\frac{1700591}{7793438}$ & 808 & $\begin{array}{l}\text { Partimonio } \\
\text { Património }\end{array}$ & \begin{tabular}{|l} 
Anfibolito \\
ser-clor-xisto
\end{tabular} & & & & & & & & \\
\hline PA-4 & $23 \mathrm{~K}$ & 677022 & 7793508 & 748 & Patrim\&nio & Gal. Mine(talco-xisto) & & & & & & & & \\
\hline PA-5 & $23 K$ & 678010 & 7792160 & & Min.Pari & Anfibolito (gal. Mina do Pari) & & & & & & & 21 & 2 \\
\hline PA-6 & $23 \mathrm{~K}$ & 679611 & 7792306 & & Pari Leste & Talco-clorita-xisto/B IF mag & & & & & GCA-2003-001 & Bif oxidado & & \\
\hline PA-7 & $23 \mathrm{~K}$ & 679706 & 7792223 & & Pari Leste & TTG - solo branco & & & & & & & & \\
\hline PA-8 & $23 \mathrm{~K}$ & 679332 & 7792216 & & Pari Leste & Anfibolito grosso & & & & & & & & \\
\hline PA-9 & $23 \mathrm{~K}$ & 679386 & 7791827 & & Parl Leste & & & & & & & & & \\
\hline PA-10 & $23 \mathrm{~K}$ & 679226 & 7791972 & & Pari Leste & Anfibolito grosso & & & & & & & & \\
\hline PA-11 & $23 K$ & 879210 & 7791743 & & Pari Leste & Talco-clorita-xisto o/ Gossan & & & & & GCA-2003-002 & gossan de sulfeto oxidado & & \\
\hline PA-12 & $23 \mathrm{~K}$ & 679162 & 7791929 & & Parl Leste & BiF o/ magnetita & & & & & & & & \\
\hline PA-13 & $\frac{23 K}{23 K}$ & 679189 & 7792033 & 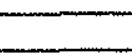 & Pari Lesto & talco-xisto o/ spinifex & & & & & & & & \\
\hline $\mathrm{PA}-14$ & $23 \mathrm{~K}$ & 879172 & 7792050 & & Pari Leste & BIF & $90 / 60$ & & & $260 / 50$ & GCA-2003-003 & bif ol granada, magnetita e quartzo & & \\
\hline PA-15 & $23 \mathrm{~K}$ & 679741 & 7792568 & 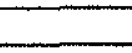 & Pari Leste & Anfibolito/xistos ultramáf./gnaisse & $90 / 45$ & & & & & & & \\
\hline PA-16 & $23 \mathrm{~K}$ & 679763 & 7792505 & & Pari Leste & clorita-xisto/biff/anfibolitos $(N . L)$. & & & & & & & & \\
\hline PA-17 & $23 \mathrm{~K}$ & 679763 & 7792491 & & Pari Leste & BIF & $90 / 65$ & & & & GCA-2003-004 & & & \\
\hline PA-18 & $23 \mathrm{~K}$ & 662337 & 7782787 & & Port of Cenibra & Quebra Osso & & & & & & & & \\
\hline PA-19 & $23 \mathrm{~K}$ & 662186 & 7783262 & & Port 02 Cenlbra & Contato Q. Osso/ Nova Lima & $79 / 60$ & & & & & & & \\
\hline PA-20 & $23 \mathrm{~K}$ & 662190 & 7783330 & & Tanque Preto & Contato Q. Osso/ Nova Lima & $90 / 55$ & & & & & & & \\
\hline PA-21 & $23 \mathrm{~K}$ & 662013 & 7782693 & & Tanque Preto & Gal. Abandonada & & & & & & & & \\
\hline PA-22 & $23 K$ & 661973 & 7782858 & 830 & Tanque Preto & Bifurcaço (N. Lima) & & & & & & & & \\
\hline PA-23 & $\frac{23 K}{23 K}$ & 661513 & 7782397 & & Tanque Preto & Bifurcacio (N. Lima) & & & & & & & & \\
\hline PA-24 & $23 \mathrm{~K}$ & 660826 & 7783280 & 752 & Tanque Preto & Nova Lim:a-BIF & & & & & & & & \\
\hline PA-25 & $23 \mathrm{~K}$ & 860683 & 7782826 & 765 & Tanque Preto & BIF/Quartzitos a Conglomerados Maquiń & $52 / 55$ & & $65 / 55$ & & & & & \\
\hline PA-26 & $23 \mathrm{~K}$ & 660584 & 7782733 & & Tanque Preto & Qzitos ol estratos cruzados & $40 / 70$ & & $46 / 70$ & & & & & \\
\hline$P A-27$ & $23 \mathrm{~K}$ & 660469 & 7782707 & 797 & Tanque Preto & Conglom. Maq. (soixo de qzo-porifiro) & 44150 & & $42 / 58$ & & & & & \\
\hline PA-28 & $23 \mathrm{~K}$ & 660462 & 7782693 & 808 & Tanque Preto & Conglom. Maq. (solxosde qzo-póffiro, $\theta$ talc-xist.) & & & $38 / 52$ & & & & & \\
\hline PA-29 & $23 \mathrm{~K}$ & 860453 & 7782674 & 809 & Tangue Preto & Conglom Mag. & & & $42 / 55$ & 162770 & & & & \\
\hline PA-30 & $23 \mathrm{~K}$ & 660459 & 7782650 & 810 & Tanque Preto & Arenito fing & 32155 & & & 162770 & & & & \\
\hline PA-31 & $23 \mathrm{~K}$ & 660447 & 7782637 & 821 & Tanque Preto & Conglom Maq. & & & $52 / 60$ & & & & & \\
\hline PA-32 & $23 \mathrm{~K}$ & 660439 & 7782594 & 824 & Caraça & Conglom Mag. & & & $73 / 50$ & & & & & \\
\hline PA-33 & $23 \mathrm{~K}$ & 660431 & 7782521 & 836 & Caraça & Conglom. Maq. & & & 53150 & & & & & \\
\hline PA-34 & $23 \mathrm{~K}$ & 660488 & 7782327 & & Caraça & Quartzito Maq. & $48 / 45$ & $05 / 50(S n+1)$ & $86 / 53$ & & & & & \\
\hline PA-35 & $23 \mathrm{~K}$ & 660595 & 7782131 & 857 & Caraça & Quartzito Meq. Rico em Cianita & $330 / 40$ & $25 / 20$ & & & & & & \\
\hline PA-36 & $23 \mathrm{~K}$ & 660540 & 7782064 & 874 & Caraca & Metaultramáfica brechada $c /$ spinifiex & $281 / 70$ & & & & & & & \\
\hline PA-37 & $23 \mathrm{~K}$ & 660516 & 7782000 & 885 & Caraça & Quartzito Maq. & & & & & & & & \\
\hline PA-38 & $23 \mathrm{~K}$ & 660545 & 7781879 & & Caraça & Quartzito Maq. & 60158 & & $72 / 64$ & & & & & \\
\hline PA-39 & $23 \mathrm{~K}$ & 660570 & 7781816 & & Caraçe & Conglom. Maq. (Seixos diversos-Q-porf. E bif) & $85 / 55$ & & & & SAC-0001 & & & \\
\hline PA-40 & $23 \mathrm{~K}$ & 660493 & 7781707 & & Caraça & Conglom. Maq. (Selxos diversos-Q-porf. E bif) & & & & & & & & \\
\hline PA-41 & $23 \mathrm{~K}$ & 660504 & 7781674 & 950 & Caraça & Quartzitos e Conglom. Intercalados & $70 / 65$ & & $354 / 55$ & & & & & \\
\hline PA-42 & $23 \mathrm{~K}$ & 660488 & 7781751 & 929 & Caraça & Quartzites a Conglom. Intercalados & $90 / 74-46 / 65$ & & $06 / 36$ & & & & & \\
\hline PA-43 & $23 k$ & 660451 & 7781671 & 931 & Caraça & Dique básico & $70 / 75$ & & & 88770 & & & & \\
\hline PA-44 & $23 \mathrm{~K}$ & 660550 & 7781568 & 930 & Caraça & Anffibolito Diabasóide freco & & & & & SAC-0002 & & & \\
\hline PA-45 & $23 \mathrm{~K}$ & 660618 & 7781474 & 935 & Caraça & Quartzitos a Conglom. Intercalados & 351770 & & $56 / 84$ & & & & & \\
\hline PA-46 & $23 \mathrm{~K}$ & 660807 & 7781277 & 1000 & Caraça & Quartzito Espinhaço & $350 / 55$ & & & & SAC-0003 & & & \\
\hline PA-47 & $23 \mathrm{~K}$ & 660755 & 7781249 & & Caraça & Quartzito Espinhaço (estrat cruzada invertida, peq. Porte) & & & & & & & & \\
\hline $\mathrm{PA}-4 \mathrm{~B}$ & $23 \mathrm{~K}$ & 660732 & 7781243 & & Caraça & Quartzito Espinhaço (estrat cruzada invertida, peq. Porte) & & & & & & & & \\
\hline PA-49 & $23 \mathrm{~K}$ & 660944 & 7781138 & 1035 & Caraça & Quartzito Espinhaço (Conglomerado monomítico) & & & & & & & & \\
\hline PA-50 & $23 \mathrm{~K}$ & 660939 & 7781118 & 1065 & Caraça & Quartzito Espinhaço & & & & & & & & \\
\hline PA-51 & $23 \mathrm{~K}$ & 660963 & 7781115 & 1100 & Caraça & Quartzito Espinhaço (micáceo) & $50 / 70$ & & $92 / 85$ & & & & & \\
\hline PA-52 & $23 \mathrm{~K}$ & 860720 & 7780913 & 1300 & Caraça & Quartzite Espinhaço (estrat cruzada invertida, méd. Porte) & $70 / 70$ & & & & & & & \\
\hline PA-53 & $23 \mathrm{~K}$ & 661396 & 7782068 & & Rib. Caraça & grafita-xisto & & & & & & & & \\
\hline PA.54 & $23 K$ & 658274 & 7783796 & & Rib. Caraça & Porteira Cininho-Nova Lima sericta-xistos & & & & & & & & \\
\hline PA-55 & $23 \mathrm{~K}$ & 658110 & 7782421 & & Rib. Caraça & solo-vermelhos & & & & & & & & \\
\hline PA-56 & $23 \mathrm{~K}$ & 657932 & 7782381 & & Rib. Caraça & Py (Blocos rolados) & 317770 & & & & & & & \\
\hline PA-57 & $23 \mathrm{~K}$ & 657679 & 7782079 & & Rib. Caraça & solo-vermelho argiloso N. Lima & & & & & & & & \\
\hline PA-58 & $23 \mathrm{~K}$ & 657799 & 7782234 & & Rib. Caraça & metapelitos ferruginosos N.L. & & & & & & & & \\
\hline PA-59 & $23 \mathrm{~K}$ & 658271 & 7782620 & & Rib. Caraça & aluvibes do Cór. Caraça & & & & & & & & \\
\hline PA-60 & $23 K$ & 658963 & 7782544 & & Rib. Caraça & aluviöes do Cor. Caraça & & & & & & & & \\
\hline PA-61 & $23 k$ & 658809 & 7782268 & & Rib. Caraça & aluviôes do Cór. Caraça & & & & & & & & \\
\hline PA-62 & $23 \mathrm{~K}$ & 658633 & 7781854] & & Rib. Caraça & Blocos do Maq. & $48 / 70$ & & & & & & & \\
\hline
\end{tabular}


Anexo 2: Tabela 1 - Relaçăo de Afloramentos da Área da Mina do Pari e Arredores (cont.)

\begin{tabular}{|c|c|c|c|c|c|c|c|c|c|c|c|c|c|c|}
\hline IDNT & ZON & DEEASTING & NORTHING & Altifude & Local & Litotipo & $\mathrm{sn}$ & $\operatorname{Ln}$ & so & Fraturas & Amostras & Descricăo da amostra & Fotos & Prancha \\
\hline PA-63 & $23 \mathrm{~K}$ & 658642 & 7781772 & & Rib. Caraça & Conglom: e quartzitos & $46 / 70$ & & $46 / 70$ & & & & & \\
\hline PA-64 & $23 \mathrm{~K}$ & 658629 & 7781753 & & Rib. Caraça & Conglom. $\theta$ quartzitos & $15 / 80$ & 290140 & $15 / 80$ & & & & & \\
\hline PA-65 & $23 \mathrm{~K}$ & 658636 & 7781575 & & Rib. Caraça & Quartzito conglomerático, ol Py & $45 / 40$ & & $45 / 40$ & $250 / 90$ e $350 / 90$ & & & & \\
\hline PA-66 & $23 \mathrm{~K}$ & 658670 & 7781528 & & Rib. Caraça & Quartzito conglomerático, c/ Py (estrat. Cruz normais) & 22156 & & $05 / 56$ & & & & & \\
\hline PA-67 & $23 \mathrm{~K}$ & 658712 & 7781471 & & Rib. Caraça & $\begin{array}{l}\text { Quartzito } \\
\end{array}$ & & & $00 / 72$ & & & & & \\
\hline PA-68 & $23 \mathrm{~K}$ & 658750 & 7781440 & & Rib. Caraça & Quartzito & $20 / 70$ & & $40 / 50$ & & & & & \\
\hline PA-69 & $23 \mathrm{~K}$ & 658810 & 7781386 & & Rib. Caraça & Quartzito & & & $340 / 68$ & & & & & \\
\hline PA-70 & $23 \mathrm{~K}$ & 658782 & 7781351 & & Rib. Caraça & talco-xisto do Q.Osso & $355 / 60$ & & & & & & & \\
\hline PA-71 & $23 \mathrm{~K}$ & 658663 & 7781192 & & Rib. Caraça & Quartzito conglomerático, cl Py & & & $348 / 40$ & 125/55(dique) & & & & \\
\hline PA-72 & $23 \mathrm{~K}$ & 658808 & 7781397 & & Rib. Caraça & Dique básico porfiritico & & & & & & & & \\
\hline PA-73 & $23 \mathrm{~K}$ & 652407 & 7795373 & & Gongo Soco & Conglomerado Nova Lima & & & & & & & & \\
\hline PA-74 & $23 \mathrm{~K}$ & 669615 & 7802853 & & Brucutu & Banco 940-Itabirito & $350 / 10$ & $75 / 20$ & & & & & & \\
\hline PA-75 & $23 \mathrm{~K}$ & 669513 & 7803036 & & Brucutu & intrusiva b́assica intemperizada & $196 / 05$ & & & & & & & \\
\hline PA-76 & $23 \mathrm{~K}$ & 671488 & 7803956 & & Brucutu & $\mid$ & & & & & & & & \\
\hline PA-77 & $23 K$ & 671723 & 7804136 & & Brucutu & Canga & & & & & & & & \\
\hline PA-78 & $23 \mathrm{~K}$ & 671772 & 7804272 & & Brucutu & Solo argiloso marrom do N.Lima & & & & & & & & \\
\hline PA.79 & $23 K$ & 671597 & 7803884 & & Brucutu & Nova Lima- anfiboitos e xistos micáceos & & & & & & & & \\
\hline PA-80 & $23 K$ & 670787 & 7803903 & & Brucutu & Ittabirito rico, silicoso & & & & & & & & \\
\hline PA-81 & $23 \mathrm{~K}$ & 670434 & 7804021 & & Brucutu & Canga hamatítica rica & & & & & & & & \\
\hline PA-82 & $23 \mathrm{~K}$ & 670111 & 7804133 & & Brucutu & Itabirito & & & & & & & & \\
\hline PA-83 & $23 \mathrm{~K}$ & 669888 & 7804060 & & Brucutu & FD-007, azm 85, dip $85 \mathrm{~N}, 51 \mathrm{~m}$ de itabirito & & & & & & & & \\
\hline PA-84 & $23 \mathrm{~K}$ & 668171 & 7803039 & & Brucutu & |itabirito & & & & & & & & \\
\hline PA-85 & $23 K$ & 667976 & 7802836 & & Brucutu & |tabirito Friàvel & & & & & & & & \\
\hline PA-86 & $23 \mathrm{~K}$ & 668105 & 7803072 & & Brucutu & Contato Itabirito sobre qzo-mica-xisto (milonito) & & & & & & & & \\
\hline PA-87 & $23 \mathrm{~K}$ & 679363 & 7792305 & & Pari Leste & anfibolito & & & & & GCA-2003-006 & Anfibolito grosso carbonatado & & \\
\hline PA-88 & $23 \mathrm{~K}$ & 679995 & 7792736 & & Pari Leste & solo TTG & & & & & & & & \\
\hline PA-89 & $23 \mathrm{~K}$ & 679924 & 7792760 & & Pari Leste & solo marrom escuro, com ressanto na topografia & & & & & & & & \\
\hline PA-90 & $23 k$ & 679865 & 7792791 & & Pari Leste & solo marrom escuro & & & & & & & & \\
\hline PA-91 & $23 \mathrm{~K}$ & 666501 & 7792542 & & ITTG Sta Bárbara & TTS & & & & & GCA-2003-008 & & & \\
\hline
\end{tabular}




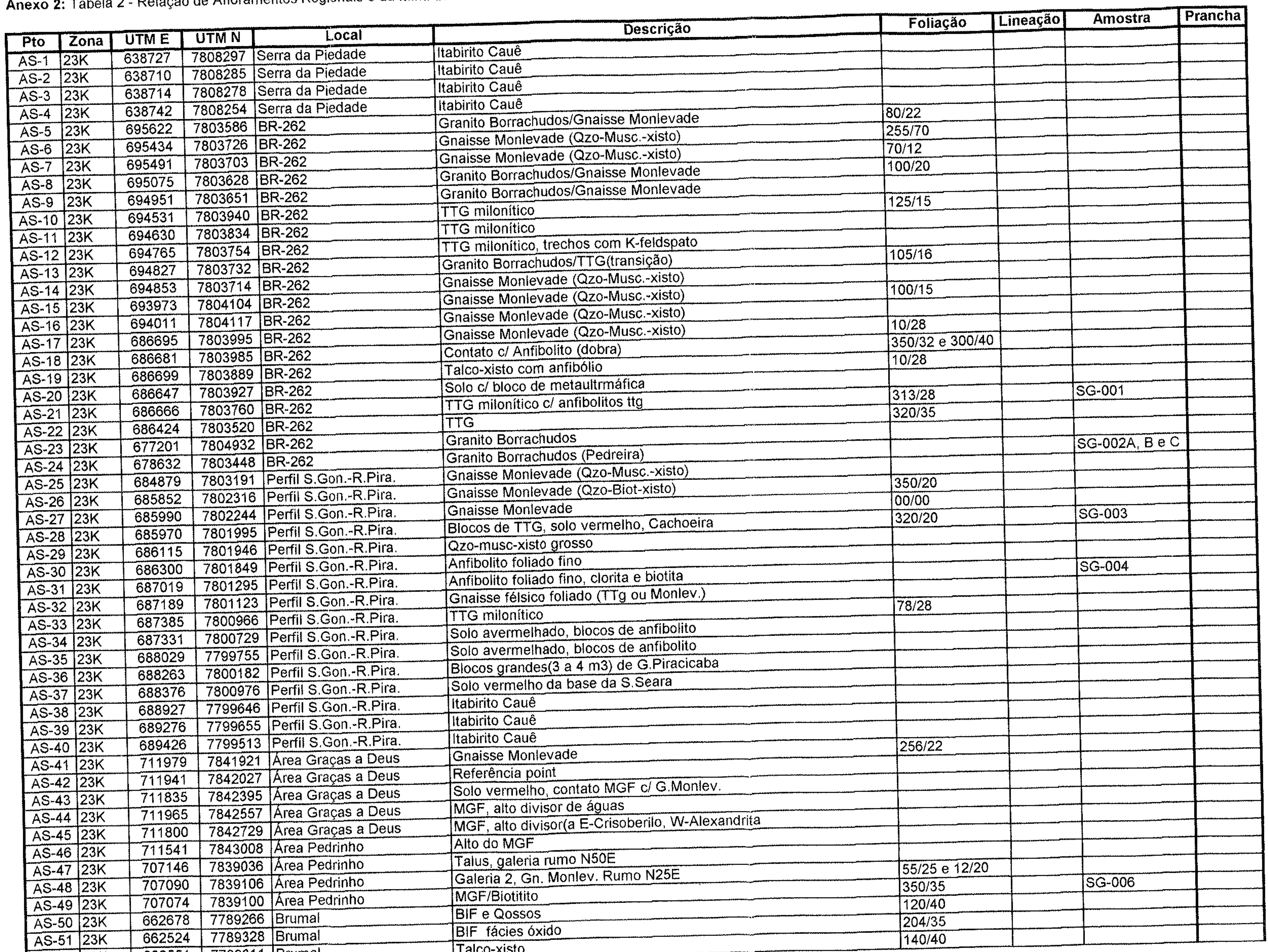

\begin{tabular}{|l|l|l|l|l|}
\hline AS-51 & $23 \mathrm{~K}$ & 662524 & 7789328 & Brumal \\
\hline AS-52 & $23 \mathrm{~K}$ & 662551 & 7789311 & Brumal \\
\hline
\end{tabular}

Talco-xisto 
Anexo 2: Tabela 2 - Relação de Afloramentos Regionais e da Mina do Pari e Arredores

\begin{tabular}{|c|c|c|c|c|c|c|c|c|c|}
\hline Pto & Zona & UTME & UTMN & Local & Descrição & Foliação & Lineação & Amostra & Prancha \\
\hline AS-53 & $23 \mathrm{~K}$ & 662592 & 7789258 & Brumal & Talco-xisto mixed & $140 / 52$ & & & \\
\hline AS-54 & $23 \mathrm{~K}$ & 662610 & 7788903 & Brumal & Solo do Q.OSso, Vista para o Caraça e C. Sítio & & & & \\
\hline AS-55 & $23 \mathrm{~K}$ & 663156 & 7789082 & Brumal & BIF & $100 / 55$ & & & \\
\hline AS-56 & $23 \mathrm{~K}$ & 663170 & 7789129 & Brumal & $\mathrm{BIF}$ & & & & \\
\hline AS-57 & $23 \mathrm{~K}$ & 662240 & 7789023 & Brumal & 2 Poços, BIF a $1 \mathrm{~m}$ de prof. & $120 / 50$ & & & \\
\hline AS-58 & $23 \mathrm{~K}$ & 662213 & 7789071 & Brumal & BIF com 2 foliaçōes, dobrado & $110 / 40$ e $120 / 60$ & $145 / 35$ & & \\
\hline AS-59 & $23 \mathrm{~K}$ & 661670 & 7788548 & Brumal & Bif c/Filitos N.Lima & $130 / 71$ & & & \\
\hline AS-60 & $23 \mathrm{~K}$ & 661604 & 7788553 & Perfil Brumal Quebra Osso & Metabásica do Nova Lima & & & & \\
\hline AS-61 & $23 \mathrm{~K}$ & 661688 & 7788524 & Perfil Brumal Quebra Osso & Contato $\mathrm{C} /$ Metaultramáfica do $Q{ }^{\circ}$ & $125 / 47$ & & & \\
\hline AS-62 & $23 \mathrm{~K}$ & 661812 & 7788399 & Perfil Brumal Quebra Osso & Quebra Osso & & & & \\
\hline AS-63 & $23 \mathrm{~K}$ & 661941 & 7788334 & Perfil Brumal Quebra Osso & Solo Vermelho do Q.OSso & & & & \\
\hline AS-64 & $23 \mathrm{~K}$ & 662067 & 7788277 & Perfil Brumal Quebra Osso & Solo Vermetho, formigueiro c/ frag amarelo e veio de Qzo(exudação) & & & & \\
\hline AS-65 & $23 \mathrm{~K}$ & 663150 & 7792991 & Perfil Brumal Quebra Osso & Garimpo do Lacinho, Bif e Grafita-xisto venulado & & & & \\
\hline AS-66 & $23 \mathrm{~K}$ & 663011 & 7793060 & Perfil Brumal Quebra Osso & Contato BIF e Grafita-xisto & $128 / 30$, fal. $42 / 62$ & $130 / 45$ & & \\
\hline AS-67 & $23 \mathrm{~K}$ & 663811 & 7787371 & Perfil Brumal Quebra Osso & TTG & & & & \\
\hline AS-68 & $23 \mathrm{~K}$ & 664476 & 7786116 & Perfil Brumal Quebra Osso & TTG & & & & \\
\hline AS-69 & $23 \mathrm{~K}$ & 662951 & 7786580 & Perfil Brumal Quebra Osso & Sericita-quartzito da S. Boa Vista & $80 / 80$ & & & \\
\hline AS-70 & $23 \mathrm{~K}$ & 662891 & 7786523 & Perfil Brumal Quebra Osso & Blocos do Quebra Osso & & & & \\
\hline AS-71 & $23 \mathrm{~K}$ & 662566 & 7786554 & Perfil Brumal Quebra Osso & Blocos do Quebra Osso(contato escavado) & & & & \\
\hline AS-72 & $23 \mathrm{~K}$ & 662354 & 7786673 & Perfil Brumal Quebra Osso & Cloritito e talco-xistos & & & & \\
\hline AS-73 & $23 \mathrm{~K}$ & 662267 & 7786833 & Perfil Brumal Quebra Osso & Talco-xistos & & & & \\
\hline AS-74 & $23 \mathrm{~K}$ & 662194 & 7787150 & Perfil Brumal Quebra Osso & Talco-xistos & $114 / 60$ & & & \\
\hline AS-75 & $23 \mathrm{~K}$ & 661550 & 7788176 & Perfil Brumal Quebra Osso & Talco-xisto & $120 / 75$ & & & \\
\hline AS-76 & $23 \mathrm{~K}$ & 661400 & 7788157 & Perfil Brumal Quebra Osso & Talco-xisto & $125 / 90$ & & & \\
\hline AS-77 & $23 \mathrm{~K}$ & 661368 & 7788161 & Perfil Brumal Quebra Osso & xisto vermelho quartzoso do $\mathrm{N}$. Lima & $120 / 85$ & & & \\
\hline
\end{tabular}


Anexo 2: Tabela 3 - Relação de Afloramentos da área do Gongo Soco

\begin{tabular}{|c|c|c|c|c|c|c|c|c|c|c|c|c|c|}
\hline Ponto & $\begin{array}{c}\text { Coord } \\
\text { Latitude } \\
\end{array}$ & \begin{tabular}{|l} 
nadas \\
Longitude \\
\end{tabular} & $\mathrm{E}^{\mathrm{UT}}$ & $\mathrm{N}$ & $\begin{array}{c}\text { Altitude } \\
(\mathrm{m})\end{array}$ & $\begin{array}{l}\text { Unidade } \\
\text { Litoestrat. }\end{array}$ & \begin{tabular}{c|} 
Foliação $\mathrm{Sn}$ \\
$\mathrm{M}$ \\
\end{tabular} & $\begin{array}{l}\text { Eixo de } \\
\text { Dobra } \\
\end{array}$ & \begin{tabular}{c|} 
Eixo de \\
Crenulação
\end{tabular} & $\begin{array}{c}\text { Lineação } \\
\text { Mineral } \\
\end{array}$ & Descrição & Fotos & Prancha \\
\hline GS-1 & W $43^{\circ} 32^{2} 57.015^{\prime \prime}$ & $519^{\circ} 57^{\prime \prime 16.953 "}$ & 651844 & 7792885 & & Gandarela & & & & & Canga ferruginosa sobre as rochas da formação Gandarela & & \\
\hline GS-2 & W $43^{\circ} 33^{\prime} 48.633^{\prime \prime}$ & S $19^{\circ} 56^{\prime} 59.257^{\prime \prime}$ & 650348 & 7793442 & & Cauê & & & & & Itabirito Cauê & & \\
\hline GS-3 & W $43^{\circ} 33^{\prime} 44.632^{\prime \prime}$ & S $19^{\circ} 55^{\prime} 44.516^{\prime \prime}$ & 650484 & 7795739 & & Nova Lima & & & & & Xisto & & \\
\hline GS-4 & W $43^{\circ} 33^{\prime} 19.080^{\prime \prime}$ & S $19^{\circ} 55^{\circ} 55.724^{\prime \prime}$ & 651224 & 7795388 & & Espinhaço & $130 / 45$ & & & & Ortoquartzito com estratificaçâao de médio porte & & \\
\hline GS-5 & W $43^{\circ} 33^{\prime} 17.756^{\prime \prime}$ & S 19 $56^{\circ} 27.783^{\prime \prime}$ & 651254 & 7794402 & & Nova Lima & $135 / 55$ & & & & Bif tipo algoma, fácies óxido & & \\
\hline GS-6 & W $43^{\circ} 33^{\prime} 09.452^{\prime \prime}$ & S $19^{\circ} 56^{\prime} 37.082^{\prime \prime}$ & 651493 & 7794114 & & Gandarela & & & & & Itabirito macigo hematitico (antiga lavra Gongo Soco) & & \\
\hline GS.7 & W $43^{\circ} 32^{\prime} 39.935^{\prime \prime}$ & S $19^{\circ} 56^{\prime 2} 26.498^{\prime \prime}$ & 652354 & 7794432 & & Cauê & $140 / 25$ & & & & Itabirito hemattitico (Mineraçäo Barra Mansa) & & \\
\hline GS-8 & $W 43^{\circ} 30^{\circ} 18.237^{\prime \prime}$ & S $19^{\circ} 55^{\prime} 13.086^{\prime \prime}$ & 656494 & 7796653 & & Espinhaço & & & & & Conglomerado Sopa Brumadinho & & \\
\hline GS-9 & W $43^{\circ} 33^{\prime} 12.767^{\prime \prime}$ & S 19 $19^{\circ} 56^{\prime 2} 28.035^{\prime \prime}$ & 651399 & 7794393 & $1130 \mathrm{~m}$ & Nova Lima & $90 / 30$ & & & & Xisto filás rolado (xisto Nova Lima) & & \\
\hline GS-10 & W 43 $33^{\circ} 10.744^{\prime \prime}$ & S $19^{\circ} 56^{\prime 2} 27.400^{\prime \prime}$ & 651458 & 7794412 & & Nova Lima & $155 / 50$ & & & & Bif tipo algoma (Nova Lima) & & \\
\hline GS-11 & W $43^{\circ} 33^{\prime} 05.765^{\prime \prime}$ & $S 19^{\circ} 56^{\prime 2} 26.449^{\prime \prime}$ & 651603 & 7794440 & $1158 \mathrm{~m}$ & Canga & & & & & Canga lateritica & & \\
\hline GS-12 & W 43 $3^{\circ} 32^{\prime} 04.182^{\prime \prime}$ & S $19^{\circ} 56^{\prime 2} 28.448^{\prime \prime}$ & 653393 & 7794363 & $1195 \mathrm{~m}$ & Cauê & $142 / 32$ & & & & Itabirito rico (chapinha) & & \\
\hline GS-13 & W $43^{\circ} 33^{\prime} 05.294^{\prime \prime}$ & $519^{\circ} 56^{\prime 2} 29.080^{\prime \prime}$ & 651616 & 7794359 & $1185 \mathrm{~m}$ & Cauê-Gandarela & & & & & |tabirito chapinha (borda de antiga cava) & & \\
\hline GS-14 & W $43^{\circ} 33^{\prime} 00.507^{\prime \prime}$ & S $19^{\circ} 56^{\prime} 29.789^{\prime \prime}$ & 651755 & 7794336 & $1159 \mathrm{~m}$ & Canga & & & & & Canga fina de itabirito & & \\
\hline GS-15 & IW 43 $33^{\circ} 32^{\prime} 58.433^{\prime \prime}$ & S $19^{\circ} 56^{\prime} 30.910^{\prime \prime}$ & 651815 & 7794301 & $1157 \mathrm{~m}$ & Canga & & & & & Solo laranja com fragmentos de bif & & \\
\hline GS-16 & W $43^{\circ} 32^{\prime} 55.922^{\prime \prime}$ & $519^{\circ} 56^{\prime} 30.922^{\prime \prime}$ & 651888 & 7794300 & $1143 \mathrm{~m}$ & Gandarela & $260 / 20$ & & & & Bif misto com feldspato; fácies óxido e carbonato & & \\
\hline GS-17 & $W 43^{\circ} 32^{\prime} 52.758^{\prime \prime}$ & $519^{\circ} 56^{\prime \prime} 30.929^{\prime \prime}$ & 651980 & 7794299 & $1128 \mathrm{~m}$ & Canga & & & & & Canga de itabirito & & \\
\hline GS-18 & $W 43^{\circ} 32^{\prime} 49.179^{\prime \prime}$ & $S 19^{\circ} 56^{\prime \prime} 31.160^{\prime \prime}$ & 652084 & 7794291 & $1096 \mathrm{~m}$ & Canga & $130 / 25$ & & & & Canga de itabirito & & \\
\hline GS-19 & W $43^{\circ} 32^{\prime} 46.924^{\prime \prime}$ & $519^{\circ} 56^{\prime 3} 33.255^{\prime \prime}$ & 652149 & 7794226 & $1068 \mathrm{~m}$ & Gandarela & & & & & Canga ocre & & \\
\hline GS-20 & W $43^{\circ} 32^{\prime} 40.999^{\prime \prime}$ & $S 19^{\circ} 56^{\prime} 34.248^{\prime \prime}$ & 652321 & 7794194 & $1031 \mathrm{~m}$ & Canga & & & & & Canga ferruginosa & & \\
\hline GS-21 & $W 43^{\circ} 32^{\prime} 37.795^{\prime \prime}$ & $\$ 19^{\circ} 56^{\prime} 34.807^{*}$ & 652414 & 7794176 & $973 \mathrm{~m}$ & Cauê-Gandarela & $145 / 20$ & & & & Zona de transição: bif facies carbonato-bif fácies óxido & & \\
\hline GS-22 & $W 43^{\circ} 32^{\prime} 43.047^{\prime \prime}$ & S $19^{\circ} 56^{\prime} 35.956^{\prime \prime}$ & 652261 & 7794142 & $997 \mathrm{~m}$ & Gandarela & $120 / 45,112 / 12$ & & & & Xistos róseos intemperizados com zona de turmalinito & & \\
\hline 65-23 & $W 43^{\circ} 32^{\prime} 42.868^{\prime \prime}$ & $519^{\circ} 56^{\prime} 36.800^{\prime \prime}$ & 652266 & 7794116 & $969 \mathrm{~m}$ & Gandarela & $155 / 20$ & & & & Zona de transiçăo; bif fácies carbonato-bif fácies óxido & & \\
\hline GS-24 & $W 43^{\circ} 32^{\prime} 45.119^{\prime \prime}$ & S $19^{\circ} 56^{\prime \prime} 36.800^{\prime \prime}$ & 652202 & 7794285 & $966 \mathrm{~m}$ & Cauê-Gandarela & $160 / 13,120 / 20$ & & & $80 / 15$ & Itabirito misto; fácies oxido e carbonato & & \\
\hline GS-25 & $W 43^{\circ} 32^{\prime} 47.456^{\prime \prime}$ & $519^{\circ} 56^{\prime 2} 27.731^{\prime \prime}$ & 652135 & 7794396 & $960 \mathrm{~m}$ & Gandarela & $121 / 23$ & & & & Itabirito misto; fácies óxido e carbonato & & \\
\hline GS-26 & $W 43^{\circ} 32^{\prime} 47.873^{\prime \prime}$ & $S 19^{\circ} 56^{\prime 2} 27.246^{\prime \prime}$ & 652123 & 7794411 & $938 \mathrm{~m}$ & Cauê-Gandarela & $235 / 25$ & & & & Itabirito misto; fácies óxido e carbonato & & \\
\hline GS-27 & W 43 $33^{\circ} 47.590^{\prime \prime}$ & $519^{\circ} 56^{\prime 2} 20.674^{\prime \prime}$ & 652133 & 7794613 & $1009 \mathrm{~m}$ & Nova Lima & $151 / 28$ & & & & Itabirito misto; fácies óxido e carbonato & & \\
\hline GS-28 & $W 43^{\circ} 32^{\prime} 50.416^{\prime \prime}$ & $519^{\circ} 56^{\prime \prime} 19.949^{\prime \prime}$ & 652051 & 7794636 & & Nova Lima & $146 / 35$ & & $195 / 21$ & & Xisto feldspático róseo crenulado & & \\
\hline GS-29 & W 43 $33^{\circ} 31.652^{\prime \prime}$ & $519^{\circ} 56^{\prime 2} 20.187^{\prime \prime}$ & 652015 & 7794629 & $1031 \mathrm{~m}$ & Nova Lima & & & & & Canga itabiritica rolada. Solo com plaquetas de xisto verde & & \\
\hline GS-30 & W 43 $33^{\circ} 51.879^{\prime \prime}$ & S 19 $59^{\circ} 21.685^{\prime \prime}$ & 652008 & 7794583 & $1047 \mathrm{~m}$ & Nova Lima & & & & & \begin{tabular}{|l} 
Solo laranja avermethado \\
\end{tabular} & & \\
\hline GS-31 & $W 43^{\circ} 32^{\prime} 54.412^{\prime \prime}$ & S 19 $56^{\circ} 23.071^{\prime \prime}$ & 651934 & 7794541 & $1065 \mathrm{~m}$ & Nova Lima & & & & & Solo laranja avermelhado & & \\
\hline GS-32 & $W 43^{\circ} 32^{\prime} 55.425^{\prime \prime}$ & $S 19^{\circ} 56^{\prime 2} 25.096^{\prime \prime}$ & 651904 & 7794479 & $1073 \mathrm{~m}$ & Nova Lima & & & & & Metabásica, clorita xisto & & \\
\hline GS-33 & $W_{4} 43^{\circ} 32^{\prime} 57.246^{\prime \prime}$ & $519^{\circ} 56^{\prime 25.274^{\prime \prime}}$ & 651851 & 7794474 & $1088 \mathrm{~m}$ & Nova Lima & & & & & Blocos de xistos verdes & & \\
\hline GS-34 & W $43^{\circ} 3259.1111^{\prime \prime}$ & $519^{\circ} 56^{\prime} 24.508^{\prime \prime}$ & 651797 & 7794498 & $1113 \mathrm{~m}$ & Canga & & & & & Canga lateritica ocre avermelhada & 10 & 1 \\
\hline GS-35 & W $43^{\circ} 33^{\prime} 01.845^{\prime \prime}$ & $S 19^{\circ} 56^{\prime} 26.319^{\prime \prime}$ & 651717 & 7794443 & $1132 \mathrm{~m}$ & Canga & & & & & Bancadas de canga & & \\
\hline GS-36 & 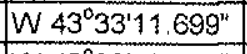 & $519^{\circ} 56^{\prime 28} .254^{\prime \prime}$ & 651430 & 7794386 & $1121 \mathrm{~m}$ & Nova Lima & & & & & Xisto feldspático cinza & & \\
\hline GS-37 & W $43^{\circ} 33^{\prime} 10.115^{\prime \prime}$ & $519^{\circ} 56^{\prime 28.501 "}$ & 651476 & 7794378 & $1127 \mathrm{~m}$ & Nova Lima & $137 / 50,142 / 35$ & $190 / 35$ & & & Xisto sericítico prateado & & \\
\hline GS-38 & 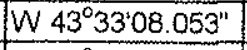 & $S 19^{\circ} 56^{\prime} 28.289^{\prime \prime}$ & 651536 & 7794384 & & Gandarela & $170 / 45$ & & & & Itabirito misto com magnetita; fácies óxido-fácies carbonato & & \\
\hline GS-39 & $W 43^{\circ} 33^{\circ} 07.427^{\prime \prime}$ & $S 19^{\circ} 566^{\prime 2} 28.999^{\prime \prime}$ & 651554 & 7794362 & $1129 \mathrm{~m}$ & Gandarela & & & & & Itabirito misto com magnetita; f́cieies óxido-fácies carbonato & & \\
\hline GS-40 & W 43 $3^{\circ} 33^{\circ} 07.575^{\prime \prime}$ & S 19 $9^{\circ} 56^{\prime} 31.668^{\prime \prime}$ & 651549 & 7794280 & $1130 \mathrm{~m}$ & Gandarela & $160 / 45$ & & & & tabirito misto com magnetita; fácies óxido-fácies carbonato & & \\
\hline GS-41 & W $43^{\circ} 33^{\circ} 08.889^{\prime \prime}$ & $S 19^{\circ} 56^{\prime 3} 34.638^{\prime \prime}$ & 651510 & 7794189 & $1108 \mathrm{~m}$ & Gandarela & $160 / 25$ & & & & Itabirito misto com magnetita; fácies óxido-fácies carbonato & & \\
\hline GS-42 & W 4 43 $33^{\circ} 09.399^{\prime \prime}$ & $S 19^{\circ} 56^{\prime} 35.325^{\prime \prime}$ & 651495 & 7794168 & $1109 \mathrm{~m}$ & Gandarela & $126 / 30$ & & & & tabirito intemperizado ocre & & \\
\hline GS-43 & $W 43^{\circ} 333^{\prime} 09.345^{\prime \prime}$ & S $19^{\circ} 56^{\prime} 37.406^{\prime \prime}$ & 651496 & 7794104 & $1117 \mathrm{~m}$ & Cauê & $135 / 50$ & & & $90 / 30$ & ttabirito misto; fácies oxido & & \\
\hline 6S-44 & W 4 $43^{\circ} 33^{\circ} 08.858^{\prime \prime}$ & $519^{\circ} 56^{\prime} 38.118^{\prime \prime}$ & 651510 & 7794082 & $1109 \mathrm{~m}$ & Caúé & $170 / 70$ & & & $108 / 05$ & Itabirito misto; fácies óxido & & \\
\hline GS-45 & W $43^{\circ} 33^{\prime} 10.378^{\prime \prime}$ & $519^{\circ} 56^{\prime 3} 37.285^{\prime \prime}$ & 651466 & 7794108 & $1125 \mathrm{~m}$ & Cauê & $132 / 35$ & & & $90 / 24$ & Itabirito misto; fácies $6 x i d o$ & & \\
\hline GS-46 & W 4 $43^{\circ} 33^{\prime} 05.252^{\prime \prime}$ & $S 19^{\circ} 56^{\prime} 41.308^{\prime \prime}$ & 651614 & 7793983 & $1082 \mathrm{~m}$ & Cauê-Gandarela & $127 / 25$ & & & $90 / 15$ & Itabirito misto; fácies oxido-fácies carbonato & & \\
\hline GS-47 & W $43^{\circ} 33^{\prime} 06.903^{\prime \prime}$ & S $19^{\circ} 56^{\prime} 44.997^{\prime \prime}$ & 651565 & 7793870 & $1068 \mathrm{~m}$ & Cauê-Gandarela & $192 / 28$ & & & $105 / 05$ & ftabirito misto; fácies óxido-fácies carbonato & & \\
\hline GS-48 & W $43^{\circ} 33^{\prime} 12.390^{\prime \prime}$ & $519^{\circ} 56^{\prime} 46.766^{\prime \prime}$ & 651405 & 7793817 & $1057 \mathrm{~m}$ & Cauê-Gandarela & $140 / 15$ & & & 102112 & tabirito misto; fácies oxido-facies carbonato & & \\
\hline GS-49 & 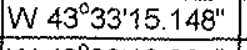 & $519^{\circ} 56^{\prime} 49.845^{\prime \prime}$ & 651324 & 7793723 & $1009 \mathrm{~m}$ & Cauê-Gandarela & $165 / 21$ & $220 / 14$ & & & Itabirito misto; fácies oxido-fácies carbonato & & \\
\hline GS-50 & W $43^{\circ} 33^{\prime} 16.023^{\prime \prime}$ & $519^{\circ} 56^{\prime} 48.194^{\prime \prime}$ & 651299 & 7793774 & $1012 \mathrm{~m}$ & Cauê-Gandarela & $165 / 15$ & & & $120 / 12$ & Itabirito misto; fácies óxido-fácies carbonato & & \\
\hline GS-51 & 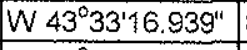 & $519^{\circ} 56^{\circ} 45,730^{\prime \prime}$ & 651273 & 7793850 & $1032 \mathrm{~m}$ & Cauê-Gandarela & $144 / 30,146 / 26$ & & & & tabirito misto; fácies oxido-fácies carbonato & & \\
\hline GS-52 & 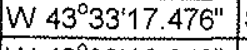 & $S 19^{\circ} 56^{\prime} 43.490^{\prime \prime}$ & 651258 & 7793919 & $1021 \mathrm{~m}$ & Cauê-Gandarela & $150 / 11$ & $100 / 10$ & & & tabirito misto; fácies óxido-fácies carbonato & & \\
\hline GS-53 & 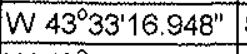 & $519^{\circ} 56^{\prime} 44.819^{\prime \prime}$ & 651273 & 7793878 & $1027 \mathrm{~m}$ & Cauê-Gandarela & $112 / 35$ & & $135 / 28$ & & Itabirito fácies óxido & & \\
\hline GS-54 & 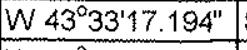 & $519^{\circ} 56^{\prime} 44.203^{\prime \prime}$ & 651266 & 7793897 & $1023 \mathrm{~m}$ & Cauê-Gandarela & $160 / 40$ & & & & Itabirito intemperizado ocre fácies carbonato & & \\
\hline GS-55 & 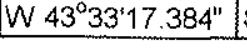 & S $19^{\circ} 56^{\prime} 38.480^{\prime \prime}$ & 651262 & 7794073 & $1022 \mathrm{~m}$ & Cauê-Gandarela & $130 / 20,134 / 30$ & & & & Itabirito misto; fácies óxido-fácies carbonato & & \\
\hline
\end{tabular}




\begin{tabular}{|c|c|c|c|c|c|c|c|c|c|c|c|c|c|}
\hline Ponto & $\begin{array}{l}\text { Coorde } \\
\text { Latitude }\end{array}$ & $\begin{array}{l}\text { enadas } \\
\begin{array}{|l}\text { Longitude } \\
\end{array}\end{array}$ & $E^{U T}$ & $\mathrm{~N}$ & $\begin{array}{c}\text { Altitude } \\
(\mathrm{m})\end{array}$ & $\begin{array}{l}\text { Unidade } \\
\text { Litoestrat. }\end{array}$ & $\begin{array}{c}\text { Follação Sn } \\
M \\
\end{array}$ & $\begin{array}{l}\text { Eixo de } \\
\text { Dobra }\end{array}$ & \begin{tabular}{c|} 
Eixo de \\
Crenulação
\end{tabular} & $\begin{array}{l}\text { Lineação } \\
\text { Mineral }\end{array}$ & Descrição & Fotos & Prancha \\
\hline GS-56 & $W 43^{\circ} 33^{\prime} 21.189^{\prime \prime}$ & $519^{\circ} 56^{\prime} 36.071^{\prime \prime}$ & 651152 & 7794148 & $1024 \mathrm{~m}$ & Nova Lima & $150 / 52$ & & & $80 / 20$ & Xisto cloritico & & \\
\hline GS-57 & $W 43^{\circ} 33^{\prime} 22.050^{\prime \prime}$ & Is $19^{\circ} 56^{\prime} 35.916^{\prime \prime}$ & 651127 & 7794153 & $1030 \mathrm{~m}$ & Nova Lima & $140 / 25$ & $95 / 20$ & & & Chert com limonita $\theta$ goetita & & \\
\hline GS-58 & $W 43^{\circ} 33^{\prime} 24.918^{\prime \prime}$ & $519^{\circ} 56^{\prime \prime} 34.476^{\prime \prime}$ & 651044 & 7794198 & $1018 \mathrm{~m}$ & Nova Lima & $120 / 40$ & & & & Xisto clorítico & & \\
\hline GS-59 & $W 43^{\circ} 33^{\circ} 02.005^{\prime \prime}$ & $519^{\circ} 56^{\prime} 46.486^{\prime \prime}$ & 651707 & 7793823 & $1020 \mathrm{~m}$ & Nova Lima & $172 / 25$ & 222112 & & & Xisto cortado por plano de falha $(178 / 40)$ preenchido por quartzo & & \\
\hline GS-60 & $W 43^{\circ} 3257.776^{\prime \prime}$ & $S 19^{\circ} 56^{\prime 3} 38.873^{\prime \prime}$ & 651832 & 7794056 & $1006 \mathrm{~m}$ & Cauê-Gandarela & $340 / 60$ & & & & Itabirito misto; fácies oxido-fácies carbonato e algum sulfeto & & \\
\hline GS-61 & $W_{43^{\circ} 32^{\prime} 53.763^{\prime \prime}}$ & $519^{\circ} 56^{\prime} 41.312^{\prime \prime}$ & 651948 & 7793980 & $1009 \mathrm{~m}$ & Cauê-Gandarela & $155 / 35$ & & & & Itabirito misto; fácies óxido-fácies carbonato & & \\
\hline GS-62 & 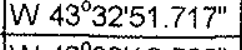 & $519^{\circ} 56^{\prime} 43.182^{\prime \prime}$ & 652007 & 7793922 & $1018 \mathrm{~m}$ & Cauê-Gandarela & $220 / 40$ & & $325 / 15$ & & Zona de transiçăá, itabirito de fácies carbonato-óxido & & \\
\hline GS-63 & [W 43 $\left.3^{\circ} 33^{\prime} 16.599^{\prime \prime}\right]$ & $S 19^{\circ} 56^{\prime \prime 26.407 "}$ & 651288 & 7794444 & 1130.65 & Nova Lima & & & & & Marco de referência: Estaca 0 - Linha Base Bif tipo algoma & & \\
\hline GS-64 & W $43^{\circ} 33^{\prime} 17.472^{\prime \prime}$ & $519^{\circ} 56^{\prime 2} 21.275^{\prime \prime}$ & 651264 & 7794602 & $1137 \mathrm{~m}$ & Nova Lima & & & & & Solo vermetho argiloso & & \\
\hline GS-65 & W $43^{\circ} 33^{\prime} 17.606^{\prime \prime}$ & $519^{\circ} 56^{\prime 1} 17.862^{\prime \prime}$ & 651261 & 7794707 & $1147 \mathrm{~m}$ & Nova Lima & $140 / 55$ & & & & Xistos róseos intemperizados e xisto lilás & & \\
\hline GS-66 & W $43^{\circ} 33^{\prime} 18.348^{\prime \prime}$ & $S 19^{\circ} 56^{\prime} 15.721^{\prime \prime}$ & 651240 & 7794773 & $1152 \mathrm{~m}$ & Nova Lima & $350 / 25$ & & & & Bif tipo algoma & & \\
\hline GS-67 & W 4 $3^{\circ} 33^{\prime} 16.571^{\prime \prime}$ & $\$ 19^{\circ} 56^{\prime} 14.438^{\prime \prime}$ & 651292 & 7794812 & $1167 \mathrm{~m}$ & Nova Lima & $20 / 40$ & & & & Xisto ocre intemperizado & & \\
\hline GS-68 & W 43․ $33^{\prime 1} 18.972^{\prime \prime}$ & S $19^{\circ} 56^{\prime} 11.400^{\prime \prime}$ & 651223 & 7794906 & $1153 \mathrm{~m}$ & Nova Lima & 00190 & & & & Xisto sericítico filás. Solo ocre laranja & & \\
\hline GS-69 & W $43^{\circ} 33^{\prime} 20.633^{\prime \prime}$ & $S 19^{\circ} 56^{\prime \prime} 10.210^{\prime \prime}$ & 651175 & 7794943 & $1135 \mathrm{~m}$ & Nova Lima & $170 / 45$ & & & & Xisto róseo intemperizado & & \\
\hline GS-70 & $W 43^{\circ} 33^{\prime} 22.484^{\prime \prime}$ & S $19^{\circ} 56^{\prime} 07.168^{\prime \prime}$ & 651122 & 7795037 & $1123 \mathrm{~m}$ & Nova Lima & & & & & Blocos de xisto lilás sericítico em meio ao solo & & \\
\hline GS-71 & W 43 $33^{\circ} 32.876^{\prime \prime}$ & $519^{\circ} 56^{\circ} 05.708^{\prime \prime}$ & 651111 & 7795082 & $1117 \mathrm{~m}$ & Nova Lima & $130 / 75$ & $190 / 65$ & & & Xisto carbonoso manganesifero & & \\
\hline GS-72 & W $43^{\circ} 33^{\prime} 23.791^{\prime \prime}$ & $519^{\circ} 56^{\prime} 03.341^{\prime \prime}$ & 651085 & 7795155 & $1117 \mathrm{~m}$ & Nova Lima & $97 / 52$ & & & & Bloco de bif do tipo algoma com limonita-goetita & & \\
\hline GS-73 & $W 43^{\circ} 33^{\prime} 22.839^{\prime \prime}$ & $\$ 19^{\circ} 56^{\prime} 02.195^{\prime \prime}$ & 651113 & 7795190 & $1117 \mathrm{~m}$ & Nova Lima & & & & & Bloco de bif do tipo algoma & & \\
\hline GS.74 & $W 43^{\circ} 33^{\prime} 24.298^{\prime \prime}$ & S $19^{\circ} 56^{\prime} 00.580^{\prime \prime}$ & 651071 & 7795240 & $1104 \mathrm{~m}$ & Nova Lima & $98 / 90$ & & & & Bloco de quartzito micáceo & & \\
\hline GS-75 & $W 43^{\circ} 33^{\prime} 24.585^{\prime \prime}$ & $519^{\circ} 55^{\prime} 59.282^{\prime \prime}$ & 651063 & 7795280 & $1110 \mathrm{~m}$ & Nova Lima & $160 / 49$ & & & & Xisto clorítico & & \\
\hline GS-76 & 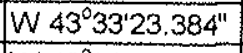 & $519^{\circ} 55^{\prime} 59.012^{\prime \prime}$ & 651098 & 7795288 & $1098 \mathrm{~m}$ & Espinhaço & $140 / 60$ & & & & Quartzito puro & & \\
\hline GS-77 & 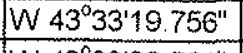 & $\$ 19^{\circ} 55^{\prime} 56.998^{\prime \prime}$ & 651204 & 7795349 & $1104 \mathrm{~m}$ & Espinhaço & $160 / 49$ & & & & Quartzito micáceo & & \\
\hline GS-78 & W $43^{\circ} 33^{\circ} 22.561^{\prime \prime}$ & $\$ 19^{\circ} 55^{\prime} 47.361^{\prime \prime}$ & 651125 & 7795646 & $1131 \mathrm{~m}$ & Nova Lima & & & & & Solo areno-argiloso laranja averelhado & & \\
\hline GS-79 & W 4 43 3321.5011 & $\$ 19^{\circ} 55^{\prime} 42.864^{\prime \prime}$ & 651157 & 7795784 & $1136 \mathrm{~m}$ & Nova Lima & $115 / 55$ & & & & Xisto lilás intemperizado & & \\
\hline GS-80 & W 43 $3^{\circ} 33^{\prime} 22.555^{\prime \prime}$ & $519^{\circ} 55^{\prime} 36.596^{\prime \prime}$ & 651128 & 7795977 & $1139 \mathrm{~m}$ & Nova Lima & & & & & Xisto argiloso sericítico amarelo & & \\
\hline GS-81 & W 43 $3^{\circ} 33^{\prime} 18.606^{\prime \prime}$ & S $19^{\circ} 55^{\prime \prime} 39.816^{\prime \prime}$ & 651242 & 7795877 & $1159 \mathrm{~m}$ & Nova Lima & & & & & Solo marrom com placas de sericita xisto prateado & & \\
\hline GS-82 & $W 43^{\circ} 33^{\prime} 16.646^{\prime \prime}$ & $519^{\circ} 55^{\prime} 43.573^{\prime \prime}$ & 651298 & 7795761 & $1158 \mathrm{~m}$ & Nova Lima & & & & & Solo marrom avermelhado escuro & & \\
\hline GS-83 & $W^{\prime} 43^{\circ} 33^{\prime} 16.397^{\prime \prime}$ & $519^{\circ} 55^{\prime} 48.222^{\prime \prime}$ & 651304 & 7795618 & $1119 \mathrm{~m}$ & Nova Lima & $110 / 60$ & $90 / 55$ & & & Xisto sericitico vermelho ocre dobrado & & \\
\hline GS-84 & $W 43^{\circ} 33^{\prime \prime} 15.296^{\prime \prime}$ & $S 19^{\circ} 55^{\prime} 51.986^{\prime \prime}$ & 651335 & 7795502 & $1117 \mathrm{~m}$ & Nova Lima & $120 / 54$ & & & $90 / 55$ & Xisto fliás intemperizado & & \\
\hline GS-85 & $W_{43^{\circ} 33^{\prime} 14.535^{\prime \prime}}$ & $519^{\circ} 55^{\prime} 52.435^{\prime \prime}$ & 651357 & 7795488 & $1115 \mathrm{~m}$ & Nova Lima & & & & & Fragmentos de veio de quartzo leitoso & & \\
\hline GS-86 & $W_{4} 43^{\circ} 33^{\prime} 03.393^{\prime \prime}$ & $519^{\circ} 55^{\prime} 33.545^{\prime \prime}$ & 651686 & 7796066 & $1146 \mathrm{~m}$ & TTG & $115 / 30$ & & & & TTG intemperizado & & \\
\hline GS-87 & $W 43^{\circ} 33^{\circ} 04.027^{\prime \prime}$ & $S 19^{\circ} 55^{\prime} 35.664^{\prime \prime}$ & 651667 & 7796001 & $1114 \mathrm{~m}$ & TTG-Nova Lima & $125 / 46$ & & & & Zona de contato & & \\
\hline GS-88 & W $43^{\circ} 33^{\prime} 03.877^{\prime \prime}$ & $519^{\circ} 55^{\prime} 37.094^{\prime \prime}$ & 651671 & 7795957 & $1143 \mathrm{~m}$ & Nova Lima & $126 / 23$ & & & & Xisto intemperizado & & \\
\hline GS-89 & W $43^{\circ} 33^{\prime} 04.845^{\prime \prime}$ & $519^{\circ} 55^{\circ} 40.224^{\prime \prime}$ & 651642 & 7795861 & $1137 \mathrm{~m}$ & Nova Lima & & & & & Solo vermelho argiloso & & \\
\hline GS-90 & W 4 $3^{\circ} 33^{\circ} 02.076^{\prime \prime}$ & $S 19^{\circ} 55^{\prime} 42.218^{\prime \prime}$ & 651722 & 7795799 & $1127 \mathrm{~m}$ & Nova Lima & $145 / 35$ & & $90 / 20$ & & Xisto ocre avermilhado & & \\
\hline GS-91 & 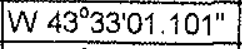 & $519^{\circ} 55^{\prime} 39.706^{\prime \prime}$ & 651751 & 7795876 & $1118 \mathrm{~m}$ & Nova Lima & $128 / 30$ & & $120 / 40$ & & Xisto variegado & & \\
\hline GS-92 & W $43^{\circ} 32^{\prime} 55.198^{\prime \prime}$ & $519^{\circ} 55^{\prime} 42.130^{\prime \prime}$ & 651922 & 7795800 & $1101 \mathrm{~m}$ & Nova Lima & $128 / 46$ & & & & Quartzo clorita xisto ferruginoso & & \\
\hline GS-93 & W 43 $3^{\circ} 32^{\prime} 51.244^{\prime \prime}$ & $519^{\circ} 55^{\prime} 45.838^{\prime \prime}$ & 652036 & 7795685 & $1093 \mathrm{~m}$ & Nova Lima & & & & & Blocos rolados de xistos variados. Solo ocre argiloso & & \\
\hline GS-94 & W $43^{\circ} 32^{\prime} 50.361^{\prime \prime}$ & $519^{\circ} 55^{\prime} 48.367^{\prime \prime}$ & 652061 & 7795607 & $1098 \mathrm{~m}$ & Espinhaço & $135 / 57$ & & & & Quartzito & & \\
\hline GS-95 & $W 43^{\circ} 32^{\prime} 49.423^{\prime \prime}$ & S $19^{\circ} 55^{\prime} 49.465^{\prime \prime}$ & 652088 & 7795573 & $1084 \mathrm{~m}$ & Espinhaso & $128 / 21$ & & & & Quartzitos micáceo & & \\
\hline GS-96 & $W 43^{\circ} 32^{\prime} 47.424^{\prime \prime}$ & $519^{\circ} 55^{\prime} 49.872^{\prime \prime}$ & 652146 & 7795560 & $1083 \mathrm{~m}$ & Espinhaso & $148 / 40$ & & & & Sericita-quartzo xistos milonítico & & \\
\hline GS-97 & $W 43^{\circ} 32^{\prime} 43.480^{\prime \prime}$ & $519^{\circ} 55^{\prime} 48.636^{\prime \prime}$ & 652261 & 7795597 & $1059 \mathrm{~m}$ & Espinhaço & $130 / 41$ & & & & Quartzito & & \\
\hline GS-98 & $W 43^{\circ} 32^{\prime} 41.673^{\prime \prime}$ & $S 19^{\circ} 55^{\prime} 54.476^{\prime \prime}$ & 652312 & 7795417 & $1063 \mathrm{~m}$ & Espinhaço & $134 / 20$ & & & & Sericita-quartzo xisto & & \\
\hline 6S-99 & $W 43^{\circ} 32^{4} 49.787^{\prime \prime}$ & $519^{\circ} 55^{\prime} 58.478^{\prime \prime}$ & 652075 & 7795296 & $1046 \mathrm{~m}$ & Nova Lima & & & & & Solo ocre laranja & & \\
\hline GS-100 & 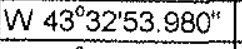 & $519^{\circ} 55^{\prime} 58.837^{\prime \prime}$ & 651953 & 7795286 & $1025 \mathrm{~m}$ & Espinhaço & $120 / 43$ & & & & Quartzito com niveis micáceos e niveis com hematita estirada & & \\
\hline GS-101 & $W 43^{\circ} 33^{\circ} 00.151^{\prime \prime}$ & $\$ 19^{\circ} 55^{\prime} 57.196^{\prime \prime}$ & 651774 & 7795338 & $1094 \mathrm{~m}$ & Espinhaço & & & & & Solo claro com fragmentos de quartzo. Solo amarelo argiloso a cinza & 101 & 1 \\
\hline GS-102 & W $43^{\circ} 33^{\prime} 01.791^{\prime \prime}$ & $519^{\circ} 55^{\prime} 58.316^{\prime \prime}$ & 651726 & 7795304 & $1104 \mathrm{~m}$ & Nova Lima & & & & & Xistos sericíiticos róseos a lilás & & \\
\hline GS-103 & W $43^{\circ} 33^{\circ} 03.881^{\prime \prime}$ & $519^{\circ} 55^{\prime} 51.730^{\prime \prime}$ & 651667 & 7795507 & $1127 \mathrm{~m}$ & Espinhaço & $150 / 26$ & & & $90 / 19$ & Quartzito micáceo & & \\
\hline GS-104 & 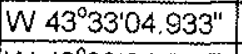 & $519^{\circ} 55^{\circ} 49.430^{\prime \prime}$ & 651637 & 7795578 & $1137 \mathrm{~m}$ & Nova Lima & & & & & Solo laranja avermelhado escuro argiloso & & \\
\hline GS-105 & $W 43^{\circ} 33^{\circ} 04.847^{\prime \prime}$ & $S 19^{\circ} 55^{\prime} 47.608^{\prime \prime}$ & 651640 & 7795634 & $1141 \mathrm{~m}$ & Nova Lima & & & & & Solo velmelho argiloso com fragmentos, blocos rolados do xisto Nova Lima & & \\
\hline GS-106 & W4 $43^{\circ} 33^{\circ} 04.881^{\prime \prime}$ & $519^{\circ} 55^{\prime} 43.802^{\prime \prime}$ & 651640 & 7795751 & $1145 \mathrm{~m}$ & Nova Lima & & & & & Solo vermeltho argiloso & & \\
\hline GS-107 & 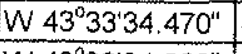 & S $19^{\circ} 55^{\prime} 46.319^{\prime \prime}$ & 650779 & 7795681 & $1175 \mathrm{~m}$ & Nova Lima & & & & & Solo laranja argiloso, fragmentos de sericita xisto carbonoso sedoso prateado & & \\
\hline GS-108 & 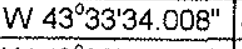 & $519^{\circ} 55^{\prime} 47.975^{\prime \prime}$ & 650792 & 7795630 & $1188 \mathrm{~m}$ & Espinhaço & $124 / 35$ & & & & Quartzito & & \\
\hline GS-109 & 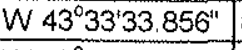 & $519^{\circ} 55^{\prime} 49.469^{\prime \prime}$ & 650796 & 7795584 & $1120 \mathrm{~m}$ & Espinhaço & $115 / 55$ & & & & Quartzito & & \\
\hline GS-110 & 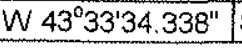 & $\$ 19^{\circ} 55^{4} 49.473^{\prime \prime}$ & 650782 & 7795584 & $1227 \mathrm{~m}$ & Espinhaço & & & & & Quartzito com estratificaçăo cruzada de $1,0 \mathrm{~m}$ & 8 & 1 \\
\hline
\end{tabular}


Anexo 2: Tabela 3 - Relação de Afloramentos da área do Gongo Soco (cont.)

\begin{tabular}{|c|c|c|c|c|c|c|c|c|c|c|c|c|c|}
\hline Ponto & $\begin{array}{l}\text { Coord } \\
\text { Latitude } \\
\end{array}$ & $\begin{array}{l}\text { enadas } \\
\quad \text { Longitude }\end{array}$ & $E^{\mathrm{UT}}$ & $\mathrm{N}$ & $\begin{array}{c}\text { Altitude } \\
(\mathrm{m})\end{array}$ & $\begin{array}{l}\text { Unidade } \\
\text { Litoestrat. }\end{array}$ & $\begin{array}{c}\text { Foliaçăo Sn } \\
M\end{array}$ & $\begin{array}{l}\text { Elxo de } \\
\text { Dobra }\end{array}$ & $\begin{array}{l}\text { Eixo de } \\
\text { Crenulação }\end{array}$ & $\begin{array}{l}\text { Lineaçăo } \\
\text { Mineral }\end{array}$ & Descriçăo & Fotos & Prancha \\
\hline GS-111 & W $43^{\circ} 33^{\prime} 35.162^{11}$ & $519^{\circ} 55^{\prime} 53.448^{\prime \prime}$ & 650757 & 7795462 & $1189 \mathrm{~m}$ & Espinhaşo & & & & & Quartzitos com veios de quartzo recristalizado & & \\
\hline GS-112 & W $43^{\circ} 33^{\prime} 34.297^{\prime \prime}$ & $519^{\circ} 55^{154.026^{\prime \prime}}$ & 650782 & 7795444 & $1169 \mathrm{~m}$ & Espinhaşo & $130 / 20$ & & & $130 / 20$ & Ortoquartzito fino & & \\
\hline GS-113 & W $43^{\circ} 33^{\prime} 32.150^{\prime \prime}$ & S $19^{\circ} 55^{\prime} 55.570^{\prime \prime}$ & 650844 & 7795396 & $1151 \mathrm{~m}$ & Espinhaço & $10 / 70$ & & & & Ortoquartzito fino & & \\
\hline GS-114 & W $43^{\circ} 33^{\prime} 30.806^{\prime \prime}$ & $519^{\circ} 55^{\prime} 55.917^{\prime \prime}$ & 650883 & 7795385 & $1132 \mathrm{~m}$ & Espinhaco & $145 / 50,130 / 45$ & & & & Ortoquarzzito fino. 10 metros a sul, mica xisto cizalhado. & & \\
\hline GS-115 & W $43^{\circ} 33^{\prime} 29.397^{\prime \prime}$ & $519^{\circ} 55^{\prime} 55.776^{\prime \prime}$ & 650924 & 7795389 & $1122 \mathrm{~m}$ & Espinhaso & $100 / 35$ & & & $100 / 30$ & Quartzito & & \\
\hline GS-116 & W $43^{\circ} 33^{\prime} 27.848^{\prime \prime}$ & $519^{\circ} 55^{\prime} 55.926^{\prime \prime}$ & 650969 & 7795384 & $1153 \mathrm{~m}$ & Espinhaço & $\$ 10 / 40$ & & & & Quartzito micáceo & & \\
\hline GS-117 & $W 43^{\circ} 33^{\prime} 07.819^{\prime \prime}$ & $519^{\circ} 56^{\prime} 35.052^{\prime \prime}$ & 651541 & 7794176 & $1122 \mathrm{~m}$ & Nova Lima & $122 / 55$ & & & & Bif tipo algoma & & \\
\hline GS-118 & W $43^{\circ} 33^{\prime} 03.297^{\prime \prime}$ & $519^{\circ} 56^{\prime} 35.052^{\prime \prime}$ & 651672 & 7794118 & $1033 \mathrm{~m}$ & Nova Lima & & & & & Material misto. Blocos rolados do Minas e Nova Lima & & \\
\hline GS-119 & W $43^{\circ} 33^{\prime} 03.325^{\prime \prime}$ & S $19^{\circ} 56^{\prime} 37.487^{\prime \prime}$ & 651671 & 7794100 & $1041 \mathrm{~m}$ & Nova Lima & $145 / 25$ & & & & Bif tipo algoma $\theta$ chert & & \\
\hline GS-120 & W $43^{\circ} 33^{\circ} 03.749^{\prime \prime}$ & $519^{\circ} 56^{\prime 36.320^{\prime \prime}}$ & 651659 & 7794136 & $1063 \mathrm{~m}$ & Nova Lima & $180 / 15$ & & & & Contato bif tipo algoma com clorita xisto com niveis de chert & & \\
\hline GS-121 & W $43^{\circ} 33^{\prime} 04.405^{\prime \prime}$ & $S 19^{\circ} 56^{\prime} 32.227^{\prime \prime}$ & 651641 & 7794262 & $1069 \mathrm{~m}$ & Nova Lima & $140 / 35$ & & & & Xisto cloritico com intercalaçōes de níveis carbonáticos & & \\
\hline GS-122 & $W 43^{\circ} 33^{\prime} 04.920^{\prime \prime}$ & $519^{\circ} 56^{\circ} 32.426^{\prime \prime}$ & 651626 & 7794256 & $1127 \mathrm{~m}$ & Nova Lima & $152 / 15$ & & & & Xisto bandado & & \\
\hline GS-123 & 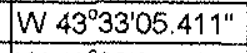 & $519^{\circ} 56^{\prime} 31.325^{\prime \prime}$ & 651612 & 7794290 & $1115 \mathrm{~m}$ & Nova Lima & $152 / 25$ & & & & Xisto ocre & & \\
\hline GS-124 & W $43^{\circ} 33^{\circ} 04.864^{\prime \prime}$ & S $19^{\circ} 56^{\prime} 30.995^{\prime \prime}$ & 651628 & 7794300 & $1112 \mathrm{~m}$ & Cauê & $172 / 22$ & $120 / 15$ & & & itabirito & & \\
\hline GS-125 & $W 43^{\circ} 33^{\prime} 06.348^{\prime \prime}$ & $519^{\circ} 56^{\prime} 30.389^{\prime \prime}$ & 651585 & 7794319 & $1142 \mathrm{~m}$ & Caué & & & & & litabirito no alto da crista, divisor de drenagem & & \\
\hline GS-126 & W $43^{\circ} 33^{\prime} 15.691^{\prime \prime}$ & $519^{\circ} 56^{\prime} 16.643^{\prime \prime}$ & 651317 & 7794744 & $1107 \mathrm{~m}$ & Nova Lima & & & & & Solo laranja avermelhado argiloso & & \\
\hline GS-127 & $W 43^{\circ} 33^{\prime} 13.346^{\prime \prime}$ & $S 19^{\circ} 56^{\prime} 17.371^{\prime \prime}$ & 651385 & 7794721 & $1070 \mathrm{~m}$ & Nova Lima & & & & & Solo vermetho argiloso & & \\
\hline GS-128 & W 4 $43^{\circ} 33^{\prime} 08.626^{\prime \prime}$ & $519^{\circ} 56^{\prime} 17.371^{\prime \prime}$ & 651499 & 7794778 & $1040 \mathrm{~m}$ & Nova Lima & $125 / 20$ & & & & Xisto ocre quartzoso & & \\
\hline GS-129 & W $43^{\circ} 33^{\circ} 07.981^{\prime \prime}$ & $S 19^{\circ} 56^{\prime} 13.555^{\prime \prime}$ & 651542 & 7794837 & $1053 \mathrm{~m}$ & Nova Lima & & & & & Blocos diversos garimpados. (Garimpo antigo) & & \\
\hline GS-130 & $1643^{\circ} 33^{\prime} 07.711^{\prime \prime}$ & $519^{\circ} 56^{\prime} 12.935^{\prime \prime}$ & 651550 & 7794856 & $1056 \mathrm{~m}$ & Nova Lima & & & & & Solo marrom & & \\
\hline GS-131 & $W 43^{\circ} 33^{\prime} 07.150^{\prime \prime}$ & $S 19^{\circ} 56^{\prime 1} 10.328^{\prime \prime}$ & 651567 & 7794936 & $1077 \mathrm{~m}$ & Nova Lima & & & & & Solo argiloso alaranjado-cinza & & \\
\hline GS-132 & $W 43^{\circ} 33^{\prime} 05.773^{\prime \prime}$ & $519^{\circ} 56^{\circ} 06.739^{\prime \prime}$ & 651608 & 7795046 & $1039 \mathrm{~m}$ & Nova Lima & & & & & Solo argiloso ocre alaranjiado & & \\
\hline GS-133 & $w 43^{\circ} 33^{\circ} 05.414^{\prime \prime}$ & $S 19^{\circ} 56^{\prime} 04.655^{\prime \prime}$ & 651619 & 7795110 & $1050 \mathrm{~m}$ & Maquiné & $135 / 65,125 / 20$ & & & & Xisto prateado com porç̧oses conglomeráticas & & \\
\hline GS-134 & $W 43^{\circ} 33^{\prime} 09.366^{\prime \prime}$ & $519^{\circ} 56^{\circ} 04.980^{\prime \prime}$ & 651504 & 7795101 & $1044 \mathrm{~m}$ & Maquiné & $120 / 35$ & & & & Xisto argiloso. Blocos de ortoquartzito & & \\
\hline OS-135 & $W 43^{\circ} 33^{\prime} 11.149^{\prime \prime}$ & S19 $59^{\circ} 01.742^{\prime \prime}$ & 651453 & 7795201 & $1048 \mathrm{~m}$ & Espinhaço & $140 / 40$ & & & & Sericita-quartzo xisto com niveis micáceos & & \\
\hline GS-136 & $W 43^{\circ} 33^{\prime} 13.978^{\prime \prime}$ & $S 19^{\circ} 56^{\prime} 00.789^{\prime \prime}$ & 651371 & 7795231 & $1045 \mathrm{~m}$ & Espinhaço & $135 / 50$ & & & & Xisto feldspático deformado & & \\
\hline GS-137 & W $43^{\circ} 33^{\prime} 16.895^{\prime \prime}$ & $S 19^{\circ} 56^{\prime} 01.463^{\prime \prime}$ & 651299 & 7797041 & $1047 \mathrm{~m}$ & Nova Lima & & & & & Blocos de bif tipo algoma rolados & & \\
\hline GS-138 & $W 43^{\circ} 33^{\prime} 19.918^{\prime \prime}$ & $S 19^{\circ} 56^{\prime} 01.911^{\prime \prime}$ & 651198 & 7795198 & $1058 \mathrm{~m}$ & Nova Lima & $150 / 60$ & & & & Xisto ocre clorítico & & \\
\hline GS-139 & $W 43^{\circ} 33^{\prime} 19.695^{\prime \prime}$ & $S 19^{\circ} 55^{\prime} 59.925^{\prime \prime}$ & 651205 & 7795259 & $1064 \mathrm{~m}$ & Espinhaço & $150 / 60$ & & & & Ortoquartzito branco & & \\
\hline GS-140 & 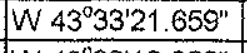 & S 19 $9^{\circ} 55^{\prime} 59.550^{\prime \prime}$ & 651148 & 7795271 & $1063 \mathrm{~m}$ & Espinhasco & $125 / 40$ & & & & Ortoguartzito branco & & \\
\hline GS-141 & $W 43^{\circ} 33^{\prime} 12.823^{\prime \prime}$ & $519^{\circ} 57^{\circ} 03.487^{\prime \prime}$ & 651388 & 7793303 & $893 \mathrm{~m}$ & Gandarela & $190 / 20$ & & & $180 / 18$ & Labirito misto; fácies óxido-fácies carbonato & & \\
\hline GS-142 & W $43^{\circ} 33^{\prime} 10.08^{\prime \prime}$ & $519^{\circ} 56^{\prime} 57.838^{\prime \prime}$ & 651469 & 7793476 & $927 \mathrm{~m}$ & Gandarela & & & & & trabirito misto; fácies óxido-fácies carbonato & & \\
\hline GS-143 & 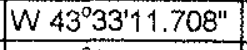 & $519^{\circ} 56^{\prime} 57.493^{\prime \prime}$ & 651422 & 7793487 & $938 \mathrm{~m}$ & Gandarela & $160 / 15$ & & & & tabibitito misto; fácies óxido-fácies carbonato & & \\
\hline GS-144 & 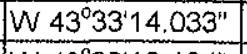 & $519^{\circ} 56^{\prime} 55.170^{\prime \prime}$ & 651355 & 7793559 & $962 \mathrm{~m}$ & Gandarela & & & & & ltabirito misto; fácies oxido-fácies carbonato & & \\
\hline GS-145 & 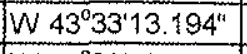 & $519^{\circ} 56^{\prime} 52.854^{\prime \prime}$ & 651380 & 7793630 & $969 \mathrm{~m}$ & Gandarela & & & & & litabirito misto; fácies oxido-fácies carbonato & & \\
\hline GS-146 & 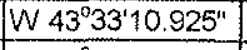 & S 19 $59^{\circ} 52.771^{\prime \prime}$ & 651446 & 7793632 & $968 \mathrm{~m}$ & Gandarela & $150 / 22$ & & & & Itabirito misto; fácies óxido-fácies carbonato & & \\
\hline GS-147 & $W_{4} 43^{\circ} 33^{\circ} 09.688^{\prime \prime}$ & $519^{\circ} 56^{\prime} 52.663^{\prime \prime}$ & 651482 & 7793635 & $967 \mathrm{~mm}$ & Gandarela & $148 / 25$ & & & & Itabirito misto Veio de quartzo discordante com hematita especular & & \\
\hline GS-148 & 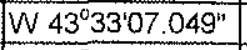 & $519^{\circ} 56^{\prime} 51.601^{\prime \prime}$ & 651559 & 7793667 & $968 \mathrm{~m}$ & Gandarela & $157 / 30$ & & & & Ltabirito misto; fácies óxido-fácies carbonato & & \\
\hline GS-149 & W $43^{\circ} 33^{\circ} 03.691^{\prime \prime}$ & $\$ 19^{\circ} 56^{\prime} 50.207^{\prime \prime}$ & 651657 & 7793709 & $963 \mathrm{~m}$ & Gandarela & $168 / 32$ & & & & ftabirito misto. Veio de quartzo discordanto e goetita botrioidal & & \\
\hline GS-150 & 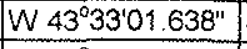 & $519^{\circ} 56^{\prime} 49.085^{\prime \prime}$ & 651717 & 7793743 & $963 \mathrm{~m}$ & Gandarela & $136 / 27$ & & & & Itabirito misto. Goetta botrioidal e algum sulfeto & & \\
\hline GS-151 & W $43^{\circ} 29^{\prime} 34.458^{\prime \prime}$ & $519^{\circ} 52^{\prime} 18.909^{\prime \prime}$ & 657815 & 7801997 & $1046 \mathrm{~m}$ & Espinhaço & & & & & Quartzitos com mega estratificacóos cruzadas (S. das Cambotas) & 9 & 1 \\
\hline GS-152 & $W 43^{\circ} 29^{\prime} 14.833^{\prime \prime}$ & $519^{\circ} 52^{\prime} 47.429^{\prime \prime}$ & 658378 & 7801115 & $983 \mathrm{~m}$ & Espinhaço & & & & & Quartzitos com mega estratificaçóes cruzadas (S. das Cambotas) & & \\
\hline GS-153 & 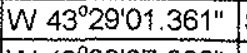 & $519^{\circ} 52.35 .963^{\prime \prime}$ & 658773 & 7801464 & $897 \mathrm{~m}$ & Espinhacco & & & & & Dique básico (diabasoide) fortemente foliado de direçáo340/30 & & \\
\hline GS-154 & 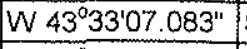 & $519^{\circ} 56 " 25.256^{\prime \prime}$ & 651565 & 7794477 & $1176 \mathrm{~m}$ & Caué & & & & & Canga laterítica & & \\
\hline GS-155 & 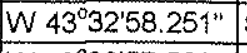 & $519^{\circ} 56^{\prime} 47.073^{\prime \prime}$ & 651816 & 7793804 & $968 \mathrm{~m}$ & Gandarela & & & & & Itabirito; fácies óxido. Quartzo preenchendo fraturas de distenção & & \\
\hline GS-156 & $W 43^{\circ} 26^{\prime} 57.506^{\prime \prime}$ & $519^{\circ} 52^{\prime} 48.882^{\prime \prime}$ & 662372 & 7801034 & $917 \mathrm{~m}$ & Gandarela-Embasamento & & & & & Zona de contato milonítica Gandarela-Embasamento & $13,14,15$ & 102 \\
\hline PA & $W 43^{\circ} 32^{2} 47.087^{\prime \prime}$ & $S 19^{\circ} 56^{\prime \prime 22} .947^{\prime \prime} \mid$ & 652147 [ & 7794543 & & & & & & & Ponto de amarração (antiga estrada de Ferro Central do Brasil EFCB) & & \\
\hline
\end{tabular}


Anexo 2: Tabela 4 - Relação de Afloramentos da área da Serra do Seara

\begin{tabular}{|c|c|c|c|c|c|c|c|c|c|c|c|c|c|}
\hline Pto. & \multicolumn{2}{|c|}{ Coordenadas } & \multicolumn{2}{|c|}{ UTM } & Altitude & Unidade & Fol. $\mathrm{Sn}$ & Fol. $S n+1$ & TipoEixo & Eixo & Descrição & Fotos & Prancha \\
\hline & Latitude & Longitude & E & $\mathrm{N}$ & (m) & Litoestrat. & $M$ & Posterior & & & & & \\
\hline SE-1 & $519^{\circ} 52^{\prime} 29.0^{\prime \prime}$ & W443011'67.1' & 689064 & 7801735 & 1345 & Piracicaba & $314 / 44$ & & crenul. & $25 / 14$ & muscovita-quartzito, próximo Torre CVRD & & \\
\hline $\mathrm{SE}-2$ & $519^{\circ} 52^{\prime} 30.9^{\prime \prime}$ & W443011'69.9" & 689013 & 7801700 & 1348 & Piracicaba & $114 / 45$ & & dobra & $300 / 20$ & muscovita quartzito & & \\
\hline $\mathrm{SE}-3$ & $S 19^{\circ} 52^{\prime} 33,6^{\prime \prime}$ & W43011'77.3" & 688884 & 7801653 & 1334 & Piracicaba & & & & & muscovita quartzito, encosta W & & \\
\hline SE-4 & $S 19^{\circ} 52^{\prime} 38,6^{\prime \prime}$ & W4 $43^{\circ} 11^{\prime} 80.2^{\prime \prime}$ & 688832 & 7801561 & 1326 & Piracicaba & $80 / 25$ & $316 / 30$ & crenul. & $40 / 25$ & muscovita quartzito & & \\
\hline SE-5 & $519^{\circ} 52^{\prime} 48.5^{\prime \prime}$ & W43011'79.8" & 688838 & 7801378 & 1273 & Piracicaba & $202 / 20$ & & crenul. & $45 / 10$ & muscovita quartzito & & \\
\hline SE-6 & $519^{\circ} 52^{\prime} 54.7^{\prime \prime}$ & $W 43^{\circ} 11^{\prime} 72.7^{\prime \prime}$ & 688960 & 7801262 & 1206 & Piracicaba & $127 / 32$ & & & & muscovita quartzito & & \\
\hline SE-7 & $519^{\circ} 52^{\prime} 62.3^{\prime \prime}$ & W43011'61.9" & 689148 & 7801120 & 1165 & Cauế & $175 / 12$ & $18 / 03$ & crenul. & $316 / 38$ & BIF & & \\
\hline SE-8 & $519^{\circ} 52^{\circ} 07.7^{\prime \prime}$ & $W 43^{\circ} 1 f^{\prime 2} 28.1^{\prime \prime}$ & 689748 & 7802121 & 1300 & Piracicaba & $116 / 30$ & & & & muscovita quartzito & & \\
\hline SE-9 & $519^{\circ} 52^{\prime 22} .9^{\prime \prime}$ & W4 $43^{\circ} 11^{\prime} 04.4^{\prime \prime}$ & 690159 & 7801836 & 1205 & Cauê & & & crenul. & $125 / 15$ & $\mathrm{BIF}$ & & \\
\hline SE-10 & $519^{\circ} 51^{\prime} 80.1^{11}$ & W4 $3^{\circ} 10^{\prime} 27.3^{\prime \prime}$ & 691513 & 7802611 & 1060 & Cauế & & & Lin.Min. & $312 / 10$ & $\mathrm{BIF}$ & & \\
\hline SE-11 & $519^{\circ} 51^{\prime} 94.6^{\prime \prime}$ & W4 $43^{\circ} 09^{\prime} 91.2^{\prime \prime}$ & 692139 & 7802336 & & Montevade & $122 / 17$ & & & & Biotita-muscovita xisto feldspático & & \\
\hline $\mathrm{SE}-12$ & $519^{\circ} 51^{\prime} 97.6^{\prime \prime}$ & W43010'10.2" & 691809 & 7802286 & 1060 & Caué & & & & & Blocos de BIF & & \\
\hline SE-13 & $510^{\circ} 51^{\prime} 94.2^{\prime \prime}$ & $W 43^{\circ} 10^{\prime} 23.6^{\prime \prime}$ & 691575 & 7802351 & 1079 & Monlevade & $00 / 30$ & & dobra & $30 / 30$ & Biotita-muscovita gnaisse & & \\
\hline$S E-14$ & $519^{\circ} 51^{\prime} 98.2^{\prime \prime}$ & W43010'32.2" & 691424 & 7802278 & 1062 & Monlevade & $350 / 30$ & & & & Gnaisse micáceo & & \\
\hline SE-15 & $519^{\circ} 52^{\prime} 00.0^{\prime \prime}$ & W4 $43^{\circ} 10^{\prime} 33.9^{\prime \prime}$ & 691394 & 7802245 & 1060 & Monlevade & $310 / 25$ & & & & Granada gnaisse micáceo & & \\
\hline $\mathrm{SE}-16$ & $519^{\circ} 52^{\prime} 11.4^{\prime \prime}$ & W4 $43^{\circ} 10^{\prime} 41.0^{\prime \prime}$ & 691268 & 7802037 & 1040 & Monlevade & $44 / 12$ & & & & Quartzo-mica xisto com magnetita & & \\
\hline SE-17 & $519^{\circ} 52^{117.2^{\prime \prime}}$ & W43 $3^{\circ} 10^{\prime} 56.5^{\prime \prime}$ & 690996 & 7801932 & 1025 & Monlevade & $155 / 45$ & & & & Gnaisse micáceo & & \\
\hline SE-18 & $519^{\circ} 52^{\prime} 25.5^{\prime \prime}$ & $W 43^{\circ} 10^{\prime} 62.9^{\prime \prime}$ & 690883 & 7801780 & 1041 & Monlevade & $80 / 14$ & & & & Niuscovita-quartzo xisto & & \\
\hline SE-19 & $519^{\circ} 52^{\prime} 37.8^{\prime \prime}$ & W4 $43^{\circ} 10^{\prime} 80.3^{\prime \prime}$ & 690576 & 7801557 & 1056 & Monlevade & $118 / 19$ & & & & Muscovita-quartzo xisto com nódulos feldspáticos & & \\
\hline SE-20 & $519^{\circ} 52^{\prime 2} 29.0^{\prime \prime}$ & W4301079.1" & 690599 & 7801719 & 1090 & Cauê & $270 / 40(?)$ & & & & Blocos de Itabirito & & \\
\hline SE-21 & $\$ 19^{\circ} 52^{1} 12.0^{\prime \prime}$ & W4 $43^{\circ} 10^{\prime} 63.6^{\prime \prime}$ & 690873 & 7802030 & 1106 & Monlevade & $50 / 25$ & & & & Quartzo-muscovita xisto com magnetita & & \\
\hline SE-22 & $519^{\circ} 52^{\prime 21.8^{\prime \prime}}$ & W43010'94.3" & 690334 & 7801855 & 1205 & Piracicaba & $90 / 25$ & & & & Quartzito muscovifico & & \\
\hline SE-23 & $\$ 19^{\circ} 52^{\prime 2} 20.5^{\prime \prime}$ & $W_{4} 3^{\circ} 10^{\prime} 99.5^{\prime \prime}$ & 690245 & 7801879 & 1212 & Caué & $80 / 20$ & & dobra & $86 / 12$ & \begin{tabular}{|l} 
Itabirito \\
\end{tabular} & & \\
\hline SE-24 & $519^{\circ} 522^{\prime 24.1^{\prime \prime}}$ & W4 $43^{\circ} 11^{\prime} 09.1^{\prime \prime}$ & 690077 & 7801815 & 1197 & Cauê/Piracicaba & & & & & Contato entre Itabirito $(E)$ e Muscovita quartzito $(W)$ & & \\
\hline SE-25 & $S 19^{\circ} 52^{\prime} 18.6^{\prime \prime}$ & W04031'15.9" & 689784 & 7801920 & 1214 & Piracicaba & $124 / 30$ & & & & Muscovita quartzito & & \\
\hline SE-26 & $\$ 19^{\circ} 52^{\prime 15} .^{\prime \prime \prime}$ & $W^{\prime} 3^{\circ} 11^{\prime 2} 28.7^{\prime \prime}$ & 689736 & 7801971 & 1217 & Piracicaba & $120 / 18$ & & dobra & $60 / 00$ & Quartzito muscovitico & & \\
\hline SE-27 & $\$ 19^{\circ} 52^{\prime} 16.8^{\prime \prime}$ & W4 $43^{\circ} 11^{\prime} 33.1^{\prime \prime}$ & 689659 & 7801954 & 1240 & Piracicaba & $270 / 30$ & & & & Muscovita quartzito & & \\
\hline SE-28 & $\$ 19^{\circ} 52^{\prime} 25.0^{\prime \prime}$ & $W 43^{\circ} 1139.2^{\prime \prime}$ & 689550 & 7801804 & 1265 & Piracicaba & $140 / 28$ & & & & Muscovita quartzito & & \\
\hline SE-29 & $519^{\circ} 52^{\prime 2} 24.8^{\prime \prime}$ & W43011'49.4" & 689372 & 7801810 & & Piracicaba & $150 / 35$ & & & & Muscovita quartzito & & \\
\hline SE-30 & $519^{\circ} 52^{\prime} 44.4^{\prime \prime}$ & W4 $43^{\circ} 10^{\prime} 66.5^{\prime \prime}$ & 690815 & 7801432 & 956 & Monlevade & $60 / 55$ & & & & Muscovita gnaisse e quartzo-muscovita xisto feldspático & & \\
\hline SE-31 & $519^{\circ} 52^{\prime} 45.6^{\prime \prime}$ & W43 $3^{\circ} 10^{\prime} 58.7^{\prime \prime}$ & 690952 & 7801410 & 955 & Monlevade & & & dobra & $42 / 05$ & Gnaisse micáceo quartzoso & & \\
\hline SE-32 & $519^{\circ} 52^{\prime} 42.2^{\prime \prime}$ & $W_{4}^{\circ} 10^{\prime} 54.5^{\prime \prime}$ & 691025 & 7801471 & 967 & Monlevade & & & & & Muscovita gnaisse quartzoso & & \\
\hline SE-33 & $519^{\circ} 52^{\prime} 366^{\prime \prime}$ & $W / 43^{\circ} 10^{\prime} 52.7^{\prime \prime}$ & 691058 & 7801573 & 977 & Monlevade & $35 / 25$ & & & & Muscovita gnaisse quartzoso & & \\
\hline SE-34 & $519^{\circ} 52^{118.8^{\prime \prime}}$ & W4 $43^{\circ} 10^{\prime} 54.2^{\prime \prime}$ & 691032 & 7801621 & 982 & Monlevade & $150 / 20$ & & & & Quartzo-muscovita-feldspato xisto & & \\
\hline SE-35 & $519^{\circ} 5229.0^{\prime \prime}$ & W43.10'52.5" & 691064 & 7801714 & 1000 & Monlevade & & & & & Magnetita-mica xisto com cianita & & \\
\hline SE-36 & $519^{\circ} 52^{\prime 22.8^{\prime \prime}}$ & $W_{4} 3^{\circ} 10^{\prime} 53.8^{\prime \prime}$ & 691042 & 7801828 & 1010 & Monlevade & $122 / 10$ & & & & Xistos micáceos intercalados com finos niveis de BIF & & \\
\hline SE-37 & $519^{\circ} 52^{\prime} 42.7^{\prime \prime}$ & W4 $43^{\circ} 10^{\prime} 68.3^{\prime \prime}$ & 690785 & 7801464 & 983 & Monlevade & $140 / 20$ & & & & Gnaisse micáceo com veios recristalizados & & \\
\hline $\mathrm{SE}-38$ & $519^{\circ} 522^{\prime 22.3^{\prime \prime}}$ & W4 $43^{\circ} 10^{\prime} 68.7^{\prime \prime}$ & 690778 & 7801530 & 1000 & Monlevade & $60 / 10$ & & & & Gnaisses micáceos e muscovita xistos com nivel de BIF & & \\
\hline SE-39 & $\$ 19^{\circ} 52 \cdot 38.5^{\prime \prime}$ & $W_{43^{\circ}} 10^{\prime} 67.8^{\prime \prime}$ & 690794 & 7801541 & & Monlevade & $135 / 20$ & & & & Muscovita gnaisse quartzoso & & \\
\hline SE-40 & $519^{\circ} 52^{\prime} 37.0^{\prime \prime}$ & W43 $13^{\circ} 66.4^{\prime \prime}$ & 690820 & 7801569 & & Monlevade & $78 / 20$ & & & & Muscovita gnaisse quartzoso & & \\
\hline SE-41 & $\$ 19^{\circ} 52^{\prime} 35.1^{\prime \prime}$ & W44 $3^{\circ} 10^{\prime} 67.6^{\prime \prime}$ & 690799 & 7801604 & & Monlevade & $120 / 15$ & & & & Muscovita gnaisse quartzoso & & \\
\hline$S E-42$ & $519^{\circ} 52^{\prime} 33.3^{\prime \prime}$ & $W_{43^{\circ} 10^{\prime} 69.4^{\prime \prime}}$ & 690768 & 7801638 & 1025 & Monlevade & $40 / 30$ & & & & Muscovita xistos com magnetita porfiroblástica & & \\
\hline SE-43 & $519^{\circ} 52^{\prime} 37.2^{\prime \prime}$ & $W 43^{\circ} 10^{\prime} 71.1^{\prime \prime}$ & 690737 & 7801567 & 1010 & Monlevade & $170 / 05$ & & dobra & $84 / 10$ & Quartzo-muscovita xistos & & \\
\hline SE-44 & $S 19^{\circ} 52^{\prime} 42.5^{\prime \prime}$ & $W_{43^{\circ} 10^{\prime} 71.6^{\prime \prime}}$ & 690727 & 7801469 & 1000 & Monlevade & $50 / 45$ & & & & Muscovita gnaisse quartzoso & & \\
\hline SE-45 & $\$ 19^{\circ} 52^{\prime} 47.2^{\prime \prime}$ & $W 43^{\circ} 10^{\prime} 68.2^{\prime \prime}$ & 690785 & 7801382 & 982 & Monlevade & $82 / 20$ & & & & Muscovita xistos & & \\
\hline SE-46 & $\$ 19^{0} 52^{\prime} 49.5^{\prime \prime}$ & $W_{43^{\circ} 10^{\prime} 62.5^{\prime \prime}}$ & 690884 & 7801338 & 965 & Monlevade & $100 / 15$ & & crenuli. & $00 / 10$ & Mica xistos com granada & & \\
\hline$S E-47$ & $\$ 19^{\circ} 52^{\prime} 50.6^{\prime \prime}$ & $W_{43^{\circ} 10^{\prime} 60.3^{\prime \prime}}$ & 690922 & 7801317 & 953 & Monlevade & $90 / 20$ & & & & Mica -quartzo xisto & & \\
\hline SE-48 & $519^{\circ} 52^{\prime} 51.3^{\prime \prime}$ & $W^{\prime} 43^{\circ} 10^{\prime} 59.0^{\prime \prime}$ & 690946 & 7801303 & 947 & Monlevade & $140 / 10$ & & crenuil. & $10 / 10$ & Muscovita xisto prateado & & \\
\hline SE-49 & $S 19^{\circ} 52^{\prime} 56.5^{\prime \prime}$ & W4 $43^{\circ} 10^{\prime} 55.1^{\prime \prime}$ & 691012 & 7801208 & & Monlevade & $120 / 10$ & & crenull. & $40 / 05$ & Mica xisto & & \\
\hline SE-50 & $519^{\circ} 52^{\prime} 73.1^{\prime \prime}$ & W4 $43^{\circ}+0^{\prime} 54.8^{\prime \prime}$ & & 7800900 & 920 & Monlevade & $28 / 55$ & & & & Mica -quartzo xisto & & \\
\hline SE-51 & $519^{\circ} 52^{\prime} 72.6^{\prime \prime}$ & $\begin{array}{ll}W_{4} 3^{\circ} 10^{\prime} 51.8^{\prime \prime} \\
\end{array}$ & 691066 & 7800909 & 911 & Monlevade & & & & & Muscovita gnaisse feldspático (refusão?) & & \\
\hline SE-52 & $519^{\circ} 54^{\prime} 96.1^{\prime \prime}$ & $\begin{array}{ll}W 43^{\circ} 10^{\prime} 76.5^{\prime \prime} \\
400\end{array}$ & 690591 & 7796790 & & Cercadinho & $90 / 10$ & & & & Muscovita-quartzo xisto bandado com niveis finos de hematita & & \\
\hline SE-53 & $519^{\circ} 53^{\prime} 89.4^{\prime \prime}$ & W43 $13^{\circ} 76.9^{\prime \prime}$ & 690606 & 7798759 & & Borrachudos & $128 / 20$ & & Lin.Min & $80 / 20$ & Gnaisse tonalífico a granodioritico milonitizado & 16 & 2 \\
\hline SE-54 & $519^{\circ} 53^{\prime} 48.6^{\prime \prime}$ & W43 $3^{\circ} 11^{\prime} 34.5^{\prime \prime}$ & 689608 & 7799523 & & Cauế & $85 / 25$ & & dobra & $70 / 15$ & Itabirito & & \\
\hline SE-55 & $519^{\circ} 53^{\prime} 18.4^{\prime \prime}$ & W43 $3^{\circ} 11^{\prime} 31.8^{\prime \prime}$ & 689662 & 7800079 & & Cauê & $210 / 15$ & & dobra & $70 / 30$ & Itabirito com magnetita & & \\
\hline
\end{tabular}


Anexo 2: Tabela 4 - Relação de Afloramentos da área da Serra do Seara (cont.)

\begin{tabular}{|c|c|c|c|c|c|c|c|c|c|c|c|c|c|}
\hline Pto. & \multicolumn{2}{|c|}{ Coordenadas } & \multicolumn{2}{|c|}{ UTM } & Altitude & Unidade & Fol. $\mathrm{Sn}$ & Fol. $\mathrm{Sn}+1$ & Tipo Eixo & Eixo & Descriçãó & Fotos & Prancha \\
\hline SE-56 & $519^{\circ} 53^{\prime} 09.3^{\prime \prime}$ & $\frac{\text { Longitude }}{\text { W4 }}$ & $\frac{E}{689872}$ & $\frac{\mathrm{N}}{7800246}$ & $(\mathrm{~m})$ & $\frac{\text { Litoestrat. }}{\text { Monlevade/Cauêt }}$ & & Posterior & & & & & \\
\hline$S E-57$ & $\$ 19^{\circ} 53^{\prime} 28.2^{\prime \prime}$ & W4 $43^{\circ} 11^{\prime} 37.5^{\prime \prime}$ & $\frac{00012}{689560}$ & $\frac{7800246}{7799899}$ & 892 & $\frac{\text { Monlevade/Cauê }}{\text { Monlevade }}$ & $\frac{102 / 20}{110 / 20}$ & & & & Contato entre Gnaisses Monlevade e Itabiritos Cauê & & \\
\hline SE-58 & $519^{\circ} 51^{\prime} 89.9^{\prime \prime}$ & $W_{43^{\circ} 12^{\prime} 02.8^{\prime \prime}}$ & 688447 & 7802463 & & $\frac{\text { Monlevade }}{\text { Monlevade }}$ & $\frac{110 / 30}{90 / 10}$ & & & & Gnaisse com biotita e grafita & & \\
\hline$S E-59$ & $519^{\circ} 52^{\prime} 01.4^{\prime \prime}$ & W4 $43^{\circ} 12^{\prime} 03.5^{\prime \prime}$ & 688433 & 7802251 & & Monlevade & $\frac{90 / 10}{90 / 15}$ & & & & \begin{tabular}{|l} 
Gnaisse felisico \\
Gnaisse felsico
\end{tabular} & & \\
\hline SE-60 & $519^{\circ} 52^{\prime} 42.0^{\prime \prime}$ & $W 43^{\circ} 11^{\prime} 88.0^{\prime \prime}$ & 688696 & 7801499 & 1182 & Caraça & $140 / 25$ & & dobra & $105 / 15$ & \begin{tabular}{|l} 
Gnaisse felsico \\
Ortoquartzito/BIF/Muscovita quartzito
\end{tabular} & & \\
\hline SE-61 & S19052'38.5" & W4 $3^{\circ} 11^{\prime} 85.2^{\prime \prime}$ & 688745 & 7801563 & 1211 & Caraça/Monlevade & $130 / 25$ & & & & \begin{tabular}{|l} 
Ortoquartzito/BIF/Muscovita quartzito \\
Ortoquartzito/Meta básica com granada
\end{tabular} & & \\
\hline $\mathrm{SE}-62$ & $519^{\circ} 52^{\prime} 34.0^{\prime \prime}$ & W4 $43^{\circ} 11^{\prime} 81.5^{\prime \prime}$ & 688810 & 7801646 & 1200 & Cauê & $130 / 12$ & & & & $\begin{array}{l}\text { Otroquartzitio/Meta basica com granada } \\
\text { Itabirito rico em especularita } \\
\end{array}$ & & \\
\hline SE-63 & $519^{\circ} 52^{\prime} 33.4^{\prime \prime}$ & $W 43^{\circ} 12^{\prime} 08.8^{\prime \prime}$ & 688334 & 7801662 & 1301 & Monlevade & & & & & Solo Vermetho - Meta básica & & \\
\hline SE-64 & $519^{\circ} 52^{\prime} 50.8^{\prime \prime}$ & W4 $43^{\circ} 11^{\prime} 855^{\prime \prime}$ & 688737 & 7801336 & 1286 & Piracicaba & $85 / 35$ & & & & Quartzo-muscovita xisto & & \\
\hline SE-65 & $\frac{519^{\circ} 52^{\prime} 59.8^{\prime \prime}}{910060^{\prime \prime}}$ & $W 43^{\circ}+11^{\prime} 80.6^{\prime \prime}$ & 688822 & 7801170 & 1185 & Piracicaba & $136 / 35$ & & dobra & $200 / 05$ & Quartzo-muscovita xisto & & \\
\hline SE-66 & $519^{\circ} 52^{\prime} 64.7^{\prime \prime}$ & W43011'78.4" & 688859 & 7801078 & 1134 & Piracicaba & $135 / 25$ & & dobra & $85 / 20$ & Quartzo-muscovita xisto & & \\
\hline SE-67 & $519^{\circ} 52^{7} 73.2^{\prime \prime}$ & W4301174.0" & 688934 & 7800922 & 1088 & Piracicaba & $205 / 25$ & & dobra & $50 / 10$ & Quartzo-muscovita xisto o/ especularita & & \\
\hline$\frac{S E-68}{S E-69}$ & $\frac{519^{\circ} 52^{\prime} 77.6^{\prime \prime}}{S 19^{\circ} 2^{\prime} 86^{\prime \prime \prime}}$ & 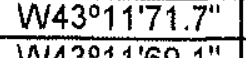 & 688972 & 7800840 & & Cauê & & & & & Blocos de canga e BIF & & \\
\hline$\frac{S E-69}{S E-70}$ & $\frac{S 19^{\circ} 52^{\prime} 86.5^{\prime \prime}}{S 19^{\circ} 52^{\prime} 905^{\prime \prime}}$ & $\frac{W 43^{\circ} 11^{\prime} 69.1^{\prime \prime}}{W 43^{\circ} 11^{\prime 70}}$ & 689016 & 7800674 & 1011 & Piracicaba & $95 / 15$ & & & & Quartzo-muscovita xisto & & \\
\hline$\frac{S E-70}{\text { SE-71 }}$ & $\frac{S 19^{\circ} 52^{\prime} 90.5^{\prime \prime}}{S 11^{\circ} 5^{\prime 2} 935^{\prime \prime}}$ & $\frac{W 43^{\circ} 1170.4^{\prime \prime}}{\mid-10}$ & 688994 & 7800601 & 990 & Piracicaba & $95 / 20$ & & & & Quartzo-muscovita xisto & & \\
\hline$\frac{S E-71}{S E-72}$ & $\frac{S 19^{\circ} 52^{\prime} 93.5^{\prime \prime}}{S 19^{\circ} 52^{\prime \prime} 99.3^{\prime \prime}}$ & $\frac{W 43^{\circ} 11^{\prime 72} .2^{\prime \prime}}{W 43^{\circ} 11^{\prime 7}+1^{\prime \prime}}$ & 688961 & 7800546 & 982 & Piracicaba & $290 / 10$ & & & & Muscovita quartzito com niveis finos de especularita & & \\
\hline$\frac{S E-72}{S E-73}$ & $\frac{S 19^{\circ} 52^{\prime} 99.3^{\prime \prime}}{S 19^{\circ} 53^{\prime} 02.8^{\prime \prime}}$ & $\frac{W 43^{\circ} 11^{\prime} 70.1^{\prime \prime}}{W 43^{\circ} 11^{\prime 671^{\prime \prime}}}$ & 688997 & 7800438 & 941 & Cauê & $120 / 08$ & & & & Itabirito pobre com muscovita & & \\
\hline SE-74 & $519^{\circ} 53^{\prime} 07.8^{\prime \prime}$ & $\frac{W 43^{\circ} 11^{\prime} 67.1^{\prime \prime}}{W 43^{\circ} 11^{\prime} 65.5^{\prime \prime}}$ & $\frac{689048}{689076}$ & $\frac{7800374}{7800281}$ & & $\frac{\text { Piracicaba/Caué }}{\text { Cauê }}$ & $\frac{160 / 15}{204 / 05}$ & & & & Contato entre ltabirito e quartzo-muscovita xisto & & \\
\hline SE-75 & $519^{\circ} 53^{\prime} 17.0^{\prime \prime}$ & W43 $11^{\circ} 64.7^{\prime \prime}$ & 689088 & 7800112 & 879 & Caué & $\frac{204 / 05}{40 / 05}$ & & & & |tabirito compacto & & \\
\hline SE-76 & $519^{\circ} 53^{\prime} 03.8^{\prime \prime}$ & W43011'60.0" & 689172 & 7800353 & 890 & & 40100 & & & & & & \\
\hline SE-77 & $519^{\circ} 53^{\prime} 03.5^{\prime \prime}$ & W43 $13^{\circ} 54.6^{\prime \prime}$ & 689267 & 7800359 & 980 & Piracicaba & & & & & $\begin{array}{l}\text { Solo claro rico em quartzo e muscovita } \\
\text { Solo com fragmentos de muscovita, quartzito e itabirito }\end{array}$ & & \\
\hline SE-78 & $519^{\circ} 53^{\prime} 06.8^{\prime \prime}$ & W43.11'53.3" & 689289 & 7800297 & 976 & Caué & & & & & Canga detrítica & & \\
\hline SE-79 & $519^{\circ} 52^{\prime} 94.5^{\prime \prime}$ & W4 $3^{\circ} 11^{\prime} 54.7^{\prime \prime}$ & 689266 & 7800525 & 1016 & Cauê & $174 / 45(?)$ & & & & Canga detritica e itabirito & & \\
\hline$\frac{S E-80}{C 501}$ & $519^{\circ} 52^{\prime} 82.2^{\prime \prime}$ & W04 $31^{\prime} 11.8^{\prime \prime}$ & 689145 & 7800753 & 1040 & Cauế & & & & & Canga detritica e itabirito & & \\
\hline SE-81 & $519^{\circ} 52^{\prime} 80.1^{\prime \prime}$ & W43 $3^{\circ} 11^{\prime} 62.2^{\prime \prime}$ & 689138 & 7800791 & 1048 & Piracicaba & $154 / 07$ & & & & Muscovita quartzito com niveis finos de especularita & & \\
\hline SE-82 & $519^{\circ} 52^{\prime} 64.6^{\prime \prime}$ & W43 $3^{\circ} 11^{172.7^{\prime \prime}}$ & 688957 & 7801079 & 1112 & Piracicaba & & & dobra & $225 / 05$ & Quartzito rico em muscovita & & \\
\hline$\frac{S E-83}{C 501}$ & $\frac{519^{\circ} 52^{\prime} 60.8^{\prime \prime}}{910^{\prime \prime}}$ & W43011'73.4" & 688946 & 7801149 & 1141 & Piracicaba & $154 / 40$ & & & & Quartzo-muscovita xisto & & \\
\hline$\frac{S E-84}{S E-85}$ & $519^{\circ} 52^{\prime} 57.0^{\prime \prime}$ & W43 $3^{\circ} 1176.1^{\prime \prime}$ & 688900 & 7801220 & 1190 & Piracicaba & $140 / 50$ & & & & Quartzo-muscovita xisto & & \\
\hline$\frac{S E-85}{C E-86}$ & $519^{\circ} 53^{\prime} 07.7^{\prime \prime}$ & W43011'17.1" & 689920 & 7800274 & 870 & Monlevade/Cauê & $165 / 20$ & & dobra & $135 / 15$ & Contato entre Gnaisses Monlevade e ltabiritos Cauê & 11 & 1 \\
\hline$\frac{S E-86}{S E-87}$ & $\frac{519^{\circ} 53^{\prime} 00.2^{\prime \prime}}{0.00530}$ & W4301122.7" & 689824 & 7800414 & 879 & Piracicaba & $60 / 20$ & & & & Muscovita-quartzo xisto prateado & & \\
\hline $\begin{array}{l}\text { SE-87 } \\
\text { SE-88 }\end{array}$ & $\frac{519^{\circ} 52^{\prime} 99.9^{\prime \prime}}{S 10050^{20}}$ & $W 43^{\circ} 11^{\prime 2} 25.9^{\prime \prime}$ & 689768 & 7800420 & 885 & Piracicaba & $170 / 10$ & & & & Muscovita xisto & & \\
\hline$\frac{S E-88}{S E-89}$ & $\frac{S 19^{\circ} 52^{\prime} 98.0^{\prime \prime \prime}}{S^{10050101}}$ & $W 43^{\circ} 1128.2^{\prime \prime}$ & 689728 & 7800455 & 892 & Piracicaba & $62 / 20$ & & & & Muscovita xisto prateado & & \\
\hline $\begin{array}{l}\text { SE- } 89 \\
\text { SE-90 }\end{array}$ & $\frac{S 19^{\circ} 52^{\prime} 94.4^{\prime \prime}}{S 19^{\circ} 52^{\prime} 916^{\prime \prime}}$ & $\frac{W 43^{\circ} 11^{\prime 28.9^{\prime \prime}}}{W 43^{\circ} 11^{\prime 2} 287^{\prime \prime}}$ & $\frac{689717}{689721}$ & 7800521 & 889 & Piracicaba & $130 / 20$ & & & & Muscovita xisto prateado & & \\
\hline SE-91 & $\frac{5190291.6}{S 19^{\circ} 52^{\prime} 89.8^{\prime \prime}}$ & $\frac{W 43^{\circ} 1128.7^{n}}{W 43^{\circ} 11^{\prime \prime 30} 5^{n}}$ & $\frac{689721}{689690}$ & $\frac{7800572}{7700607}$ & $\frac{884}{914}$ & Caué & $125 / 10$ & & & & Itabirito pobire com especularita e muscovita & & \\
\hline SE-92 & $519^{\circ} 52^{\prime} 86.5^{\prime \prime}$ & W4 $43^{\circ} 11^{\prime} 34.0^{\prime \prime}$ & 689629 & $\frac{7800607}{7800668}$ & $\frac{914}{911}$ & $\frac{\text { Caué }}{\text { Caué }}$ & $\frac{130 / 10}{220 / 10}$ & & veio & $10 / 70$ & Itabirito pobire & & \\
\hline SE-93 & $\$ 19^{\circ} 52^{\prime} 84.5^{\prime \prime}$ & W4 $43^{\circ} 11 \cdot 35.6^{\prime \prime}$ & 689601 & 7800705 & 927 & Piracicaba & $\frac{220 / 10}{280 / 12}$ & & & [工 & $\frac{\text { Itabirito pobre }}{\text { Muscovita cuartzito }}$ & & \\
\hline SE-94 & $\$ 19^{\circ} 52^{\prime} 79.6^{\prime \prime}$ & W4 $43^{\circ} 11^{\prime} 37.9^{\prime \prime}$ & 689563 & 7800796 & 958 & Piracicaba & $85 / 10$ & & crenul. & $08 / 10$ & $\begin{array}{l}\text { Muscovita quartzito } \\
\text { Muscovita-quartzo xisto }\end{array}$ & & \\
\hline SE-95 & $519^{\circ} 52^{\prime} 73.9^{\prime \prime}$ & W4 $43^{\circ} 11^{1} 37.9^{\prime \prime}$ & 689564 & 7800901 & 1021 & Piracicaba & $110 / 10$ & & & & Muscovita-quartzo xisto & & \\
\hline SE-96 & $519^{\circ} 5272.7^{\prime \prime}$ & $W 43^{\circ} 11^{\prime} 40.3^{\prime \prime}$ & 689522 & 7800924 & 1020 & Cauế & $126 / 05$ & & & & Itabirito pobre com magnetita & & \\
\hline SE-97 & $519^{\circ} 52^{\prime} 71.3^{\prime \prime}$ & W43011'45." & 689441 & 7800951 & 1031 & Piracicaba/Cauê & $150 / 15$ & & veio & $165 / 75$ & Contato entre Itabirito e quartzo-muscovita xisto & & \\
\hline SE-98 & $519^{\circ} 52^{\prime} 68.7^{\prime \prime}$ & $W 43^{\circ} 11^{\prime} 46.2^{\prime \prime}$ & 689419 & 7800999 & 1016 & Cauê & $135 / 10$ & & dobra & $18 / 10$ & Itabirito pobire & & \\
\hline SE-99 & $519^{\circ} 52^{\prime} 66.3^{\prime \prime}$ & $W 43^{\circ} 11^{\prime} 49.0^{\prime \prime}$ & 689372 & 7801044 & 1056 & Caué & $130 / 10$ & & veio & $345 / 50$ & |tabirito pobire & & \\
\hline SE-100 & $519^{\circ} 52^{\prime} 60.8^{\prime \prime}$ & $W 43^{\circ} 11^{\prime} 52.9^{\prime \prime}$ & 689305 & 7801146 & 1082 & Piracicaba & $185 / 15$ & & & & Quartzo-muscovita xisto com especularita rara & & \\
\hline SE-101 & $519^{\circ} 52^{\prime} 57.1^{\prime \prime}$ & W4 $3^{\circ} 11^{\prime} 56.9^{\prime \prime}$ & 689236 & 7801215 & 1106 & Piracicaba & $145 / 40$ & & crenul. & $18 / 05$ & Muscovita-quartzo xisto & & \\
\hline$\frac{S E-102}{\mathrm{CE}-123}$ & $\frac{519^{\circ} 52^{\prime} 54.4^{\prime \prime \prime}}{C^{10055^{\prime}-1^{\prime \prime \prime}}}$ & W43011'62.2" & 689143 & 7801266 & 1140 & Piracicaba & & & crenul. & $40 / 20$ & Muscovita quartzito & & \\
\hline$\frac{S E-103}{S F-104}$ & $\frac{S 19^{\circ} 52^{\prime} 51.8^{\prime \prime}}{S 10050^{\prime} 10^{11}}$ & W4 $43^{\circ} 11^{\prime} 65.5^{\prime \prime}$ & 689087 & 7801315 & 1170 & Piracicaba & & & crenul. & $40 / 15$ & Muscovita quartzito & & \\
\hline SE-104 & $519^{\circ} 52^{\prime} 48.1^{\prime \prime \prime}$ & W43011'70.7" & 688996 & 7801384 & 1233 & Piracicaba & $150 / 35$ & & dobra & $240 / 10$ & Muscovita quartzito & & \\
\hline$\frac{S E-105}{S E-106}$ & $\frac{S 19^{\circ} 52^{\prime \prime} 39.8^{\prime \prime}}{c 1000^{\prime 2}}$ & W43011'77. & 688883 & 7801538 & 1319 & Piracicaba & $40 / 30$ & $320 / 30$ & crenul. & $60 / 10$ & Muscovita quartzito & & \\
\hline$\frac{S E-106}{S E-107}$ & $\frac{S 19^{\circ} 52^{\prime 2} 24.8^{\prime \prime}}{S 10052101^{\prime \prime}}$ & W43011.07.9" & 690097 & 7801802 & 1184 & Cauê & & & & & Blocos de itabirito e canga & & \\
\hline SE-107 & $519^{\circ} 52^{\prime 2} 29.1^{\prime \prime}$ & $W 43^{\circ} 11^{\prime} 03.7^{\prime \prime}$ & 690170 & 7801721 & 1130 & Caué & $205 / 40$ & & crenul. & $110 / 10$ & |tabirito pobire e itabirito & & \\
\hline$\frac{S E-108}{S C .109}$ & $\frac{S 19^{\circ} 52^{\prime \prime} 31.1^{\prime \prime}}{c 100312}$ & W43 $3^{\circ} 11^{\prime} 05.1^{\prime \prime}$ & 690144 & 7801686 & 1111 & Cauê & $125 / 15$ & & crenul. & $115 / 05$ & Itabirito com especularita dobrado & & \\
\hline$\frac{S E-109}{S E-110}$ & $\frac{S 19^{\circ} 52^{\prime} 34.5^{\prime \prime}}{S 19^{\circ} 2^{\prime 2}}$ & $W_{43^{\circ} 11^{\prime} 04.2^{\prime \prime}}$ & $\frac{690160}{6001174}$ & 7801622 & 1084 & Cauế & $170 / 15$ & & crenul. & $100 / 02$ & Itabirito rico em especularita e com magnetita & & \\
\hline & 5195236.4 & W43 $3^{\circ} 11^{\prime} 03.4^{\prime \prime}$ & 690174 & 7801586 & 1074 & Cauê & $80 / 15$ & & & & Itabirito pobir & & \\
\hline
\end{tabular}


Anexo 2: Tabela 4 - Relação de Afloramentos da área da Serra do Seara (cont.)

\begin{tabular}{|c|c|c|c|c|c|c|c|c|c|c|c|c|c|}
\hline Pto. & \multicolumn{2}{|c|}{ Coordenadas } & \multicolumn{2}{|c|}{ UTM } & Altitude & Unidade & Fol. Sn & Fol. $\mathrm{S} n+1$ & Tipo Eixo & Eixo & Descrição & Fotos & Prancha \\
\hline & Latitude & Longitude & $E$ & $\mathrm{~N}$ & $(\mathrm{~m})$ & Litoestrat. & $M$ & Posterior & & & & & \\
\hline SE-111 & $519^{\circ} 52^{\prime} 38.9^{\prime \prime}$ & W4 $3^{\circ} 11^{\prime} 04.7^{\prime \prime}$ & 690150 & 7801542 & 1068 & Cauề & $130 / 20$ & & & & Itabirito pobre com magnetita & & \\
\hline $\mathrm{SE}-112$ & $519^{\circ} 52^{\prime} 42.3^{\prime \prime}$ & W4301101.0" & 690214 & 7801477 & 1033 & Cauê & $120 / 10$ & & & & Itabirito pobre & & \\
\hline $\mathrm{SE}-113$ & $519^{\circ} 52^{\prime} 45.8^{\prime \prime}$ & W43010'99.3" & 690244 & 7801412 & 1016 & Cauê & $145 / 10$ & & & & Itabirito pobre & & \\
\hline SE-114 & $S 19^{\circ} 52^{\prime} 49.4^{\prime \prime}$ & 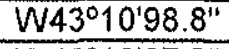 & 690251 & 7801346 & 985 & Cauê & $170 / 20$ & & & & |tabirito pobre & & \\
\hline SE-115 & $519^{\circ} 52^{\prime} 54.9^{\prime \prime}$ & W4 $43^{\circ} 10^{\prime} 97.3^{\prime \prime}$ & 690276 & 7801244 & 970 & Cauê & $15 / 10$ & & & & Itabirito pobre & & \\
\hline SE-116 & $519^{\circ} 52^{1} 59.1^{11}$ & 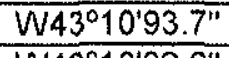 & 690337 & 7801166 & 942 & Piracicaba & $05 / 10$ & & & & Intercalaçóes de muscovita quartzitos e itabiritos pobres & & \\
\hline SE-117 & $519^{\circ} 52^{\prime} 62.7^{\prime \prime}$ & W43 $3^{\circ} 10^{\prime} 92.6^{\prime \prime}$ & 690356 & 7801099 & 910 & Piracicaba & $90 / 05$ & & Fratura & $315 / 60$ & Itabiritos pobres e quartzitos com mica e especularita & & \\
\hline SE-118 & $519^{\circ} 52^{\prime} 67.0^{\prime \prime}$ & W43 $10^{\prime} 90.0^{\prime \prime}$ & 690401 & 7801020 & 910 & Piracicaba & $130 / 15$ & & veio & $350 / 30$ & Quartzito com hematita e quartzo-mica xisto & & \\
\hline SE-119 & $519^{\circ} 52^{\prime} 69.4^{\prime \prime}$ & W43010'89.6" & 690408 & 7800976 & 901 & Piracicaba & $124 / 15$ & & dobra & $45 / 10$ & Quartzito micáceo com hematita & & \\
\hline $\mathrm{SE}-120$ & $519^{\circ} 52^{\prime} 72.7^{\prime \prime}$ & $W 43^{\circ} 10^{\prime} 88.0^{\prime \prime}$ & 690435 & 7800915 & 915 & Cauê & $110 / 15$ & & & & Itabirito rico & 12 & 1 \\
\hline $\mathrm{SE}-121$ & $519^{\circ} 52^{\prime} 77.0^{\prime \prime}$ & W4 $43^{\circ} 10^{\prime} 85.3^{\prime \prime}$ & 690481 & 7800834 & 905 & Cauế & $210 / 10$ & & & & Itabirito rico & & \\
\hline SE-122 & $519^{\circ} 52^{1} 83.0^{\prime \prime}$ & $W 43^{\circ} 10^{1} 87.9^{11}$ & 690434 & 7800724 & 828 & Cauê/Piracicaba & $30 / 15$ & & & & Contato entre Itabirito e quartzo-muscovita xisto com hematita rara & & \\
\hline SE-123 & $519^{\circ} 52^{1} 85.6^{\prime \prime}$ & $643^{\circ} 11^{1} 00.3^{\prime \prime}$ & 690217 & 7800678 & 878 & & & & & & Solo vermelho argiloso & & \\
\hline SE-124 & $519^{0} 52^{\prime} 86.1^{11}$ & W4 $43^{\circ} 11^{\prime} 03.2^{\prime \prime}$ & 690166 & 7800670 & 875 & Monlevade & $64 / 10$ & & & & Xisto ferruginoso rico em quartzo & & \\
\hline SE-125 & $519^{\circ} 52^{\prime} 90.3^{\prime \prime}$ & W4 $43^{\circ} 11^{\prime} 05.1^{\prime \prime}$ & 690133 & 7800593 & 890 & & & & & & Solo vermelho argiloso & & \\
\hline SE-126 & $519^{\circ} 52^{\prime} 97.5^{\prime \prime}$ & W4 $43^{\circ} 11^{\prime} 14.8^{\prime \prime \prime}$ & 689962 & 7800461 & 852 & Monlevade(?) & $120 / 20$ & & & & Quartzo-muscovita xisto & & \\
\hline SE-127 & $519^{\circ} 52^{\prime} 99.6^{\prime \prime}$ & W4 $43^{\circ} 11^{\prime} 14.0^{\prime \prime}$ & 689976 & 7800423 & 876 & Monlevade(?) & $125 / 20$ & & & & Quartzo-muscovita xisto & & \\
\hline SE-128 & $519^{\circ} 52^{\prime} 17.4^{\prime \prime}$ & 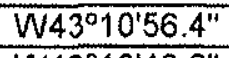 & 690997 & 7801929 & & Monlevade & $125 / 10$ & & & & Gnaisse Monlevade com granada e cianita & & \\
\hline SE-129 & $519^{\circ} 52^{\prime} 42.8^{\prime \prime}$ & W4 $43^{\circ} 10^{\prime} 48.6^{\prime \prime}$ & 691129 & 7801459 & 927 & Monlevade & & & dobra & $40 / 15$ & Quartzo-muscovita xisto & & \\
\hline SE-130 & $519^{\circ} 52^{\prime} 91.4^{\prime \prime}$ & $\mathrm{W}_{4} 3^{\circ} 10^{\prime} 06.2^{\prime \prime}$ & 691859 & 7800554 & 850 & Monlevade & $162 / 45$ & & & & Muscovita xisto com porçōes feldspáticas remobilizadas & 17 & 2 \\
\hline SE-131 & $519^{\circ} 52^{\prime} 97.3^{\prime \prime}$ & W43010'22.6" & 691572 & 7800448 & 869 & Monlevade & $172 / 18$ & & & & Muscovita xistos com veio pegmatóide quartzo feldspático & & \\
\hline SE-132 & $519^{\circ} 52^{\prime} 96.1^{\prime \prime}$ & $W 43^{\circ} 09^{\prime} 97.3^{\prime \prime}$ & 692014 & 7800466 & 820 & Monlevade & & & & & Muscovita xisto feldspático e blocos de canga limonítica & & \\
\hline $\mathrm{SE}-133$ & $519^{\circ} 53^{\prime} 10.9^{\prime \prime}$ & $\mathrm{W} 43^{\circ} 10^{\prime} 23.0^{\prime \prime}$ & 691562 & 7800197 & 888 & Monlevade & $100 / 28$ & & contato & $340 / 22$ & Muscovita xisto feldspático com bolsão pegmatitico quartzo feldspático & $18 \mathrm{e} 19$ & 2 \\
\hline SE-134 & $519^{\circ} 52^{7} 73.1^{\prime \prime}$ & W4 $43^{\circ} 10^{\prime} 39.7^{\prime \prime}$ & 691277 & 7800898 & 911 & nlevade/Borrachuq & $70 / 05$ & & & & Quartzo-mica xisto com porçoes de rocha fanerífica média com biotita & 29 & 2 \\
\hline SE-135 & $\$ 19^{\circ} 52^{\prime} 72.1^{\prime \prime}$ & $W 43^{\circ} 10^{\prime} 48.0^{\prime \prime}$ & 691133 & 7800918 & 893 & inlevade/Borrachuo & $45 / 40$ & & & & Muscovita xistos e granitódes finos feldspáticos & & \\
\hline SE-136 & $519^{\circ} 53^{\prime} 79.8^{\prime \prime}$ & W44 $43^{\circ} 10^{\prime} 71.7^{\prime \prime}$ & 690698 & 7798935 & 778 & Borrachudos & $120 / 15$ & & Lin.Min. & $95 / 10$ & Granito Borrachudos & & \\
\hline SE-137 & $519^{0} 53^{\prime \prime} 34.9^{\prime \prime}$ & W43011'33.1" & 689636 & 7799776 & 890 & Caué & $135 / 18$ & & & & Itabirito rico & & \\
\hline $\mathrm{SE}-138$ & $519^{\circ} 53^{\prime} 34.6^{\prime \prime}$ & $W 43^{\circ} 11^{\prime} 36.2^{1 \prime}$ & 689582 & 7799780 & 878 & Cauê/Monlevade & $142 / 25$ & & & & Contato entre Gnaisses Monlevade e ltabiritos Cauê & & \\
\hline SE-139 & $519^{\circ} 53^{\prime 2} 27.7^{\prime \prime}$ & W4 $43^{\circ} 11^{\prime} 35.8^{\prime \prime}$ & 689589 & 7799909 & 892 & Caué & Subhorizontal & & & & tabiritos & & \\
\hline SE-140 & $519^{\circ} 53^{\prime} 06.8^{\prime \prime}$ & W43010'98.1" & 690251 & 7800286 & 853 & Monlevade & $120 / 15$ & & & & Muscovita-quartzo xisto & & \\
\hline SE-141 & $519^{\circ} 52^{\prime} 86.6^{\prime \prime}$ & W4 $43^{\circ} 10^{\prime} 80.1^{\prime \prime}$ & 690570 & 7800656 & 845 & & & & & & Solo vermelho argiloso & & \\
\hline SE-142 & $519^{\circ} 52^{\prime} 78.3^{\prime \prime}$ & $\mathrm{W} 43^{\circ} 10^{\prime} 72.7^{\prime \prime}$ & 690700 & 7800808 & 859 & Monlevade & & & & & Solo claro ríco em quartzo e muscovita & & \\
\hline SE-143 & $519^{\circ} 52^{\prime} 79.0^{\prime \prime}$ & 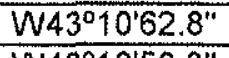 & 690873 & 7800793 & 928 & & & & & & Solo areno-argiloso & & \\
\hline SE-144 & $519^{\circ} 52^{\prime} 79.0^{\prime \prime}$ & $W 43^{\circ} 10^{\prime} 58.3^{\prime \prime}$ & 690953 & 7800793 & 971 & & & & & & Solo cinza arrgilo-arenoso & & \\
\hline$S E-145$ & $519^{\circ 52} 73.1^{\prime \prime}$ & 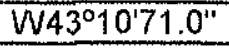 & 690731 & 7800904 & 937 & Montevade & & & & & Muscovita-quartzo xisto e blocos de itabirito & & \\
\hline$S E-146$ & $519^{\circ} 52^{\prime} 74.8^{\prime \prime}$ & $\mathrm{W}_{43^{\circ} 10^{\prime} 75.5^{\prime \prime}}$ & 690652 & 7800873 & 930 & Monlevade & $140 / 15$ & & & & BIF tipo algoma & & \\
\hline SE-147 & $519^{\circ} 53^{\prime} 02.1^{\prime \prime}$ & $W 43^{\circ} 10^{\prime} 98.3^{\prime \prime}$ & 690250 & 7800374 & 763 & Cauê & $180 / 25$ & & crenul. & $130 / 17$ & Itabirito & & \\
\hline$S E-148$ & $519^{\circ} 53^{\prime} 05.8^{\prime \prime}$ & W4 $43^{\circ} 10^{\prime} 99.4^{\prime \prime}$ & 690229 & 7800306 & 887 & raca/Piracicab & $158 / 30$ & & crenu & $70 / 08$ & & & \\
\hline
\end{tabular}


Anexo 3: Relação de Amostras, das Análises Laboratoriais e Resumo dos Estudos Petrográficos 


\section{ANEXO 3: Legenda da Tabela 1}

Coluna 1: No. da amostra

Coluna 2: No. da lamina petrográfica com estudos microscópicos mineralógicos e petrográficos

Coluna 3: No. da seção polida com estudos de microscopia de minérios

Coluna 4: Análises laboratoriais realizadas (sem microscopia petrográfica e de minérios), códigos numéricos das subcolunas

4/1-Difração de raios $X(D R X)$

4/2-Fluorescência de raios $X$ (FRX)

4/3-Microssonda eletrônica

4/4-Fire Assay (Fusão e Copelação)

4/5-Extração c. Água Régia / Absorção Atômica

4/6-ICP-MS

Coluna 5: Localização das amostras, abreviações

NE $(=\mathrm{N}-00)$ - Nivel de Entrada da Mina do Pari (Fotos 3-5; Figs. 4, 6)

Salão Principal - Nível de Entrada da Mina do Pari (Fotos 3-5; Fig. 4)

N10 (=N-10) - Nível 10 da Mina do Pari (Figs. 5,6$)$

N11 (=N-11) - Nivel 11 da Mina do Pari (Figs. 5, 6)

NI (=NI) - Nivel Intermediário (10/11) da Mina do Pari

HW (=hang wall) - Rochas da Capa do minério de Au da Mina do Pari (="Horizonte Pari")

Minério de Au - Minérios de ouro da Mina do Pari ("Horizonte Pari")

FW (=foot wall) - Rochas da Capa do minério de Au da Mina do Pari (="Horizonte Pari")

$B R-N^{\circ}-x y m$, ou $(x-y)$ - Sondagem rotativa diamantada $\left(N^{\circ}\right.$.) do Morro do Pari com testemunho amostrado (profundidade em metros)

Brumal $(x-y)$ - Sondagem rotativa diamantada da Área de Brumal com testemunho amostrado (profundidade em metros)

Coluna 6: Litotipo, 6/1-Unidades Litoestratigráficas (UNID.); 6/2-Petrografia

6/1-Unidades Litoestratigráficas:

NL - Grupo Nova Lima

QO - Grupo Quebra Osso

GNT - Gnaisses s.l. Graníticos do topo da Seqüência MetavulcanoSedimentar do Sgr. Rio das Velhas do Morro do Pari

GNB - Gnaisses s.l. Graníticos da Base da Seqüência MetavulcanoSedimentar do Sgr. Rio das Velhas do Morro do Pari

6/2-Petrografia, abreviações mineralógicas e petrográficas:

Minerais: Q-quartzo; B-biotita; C-clorita; A-anfibólios; T-talco; GRgranada; Cc-carbonato; Gf-grafita; Mg-magnetita; S-sulfetos

Rochas: GT-gnáisse tonalítico; GN-gnáisse granodiorítico; GGgnáisse granítico; GD-enclaves metamáfico-ultramáficos; $X$ xisto; AF-anfibolito fino; AG-anfibolito grosso; QA-quartzo anfibolito; P-pegmatito; M-metachert; FF ou BIF-formações ferríferas bandadas tipo Algoma; $V$-veio

Exemplo: QBAX cI S e GR - quartzo-biotitamanfibólio xisto com sulfetos e granada 


\begin{tabular}{|c|c|c|c|c|c|c|c|c|c|c|c|c|}
\hline \multirow{3}{*}{$\begin{array}{c}\text { Anexo } 3 \\
\text { AMOSTRA } \\
\text { No. }\end{array}$} & \multicolumn{12}{|l|}{ Tabela 1} \\
\hline & \multirow{2}{*}{$\begin{array}{l}\text { LÂMINA } \\
\text { Petrog. No. }\end{array}$} & \multirow{2}{*}{$\begin{array}{l}\text { SEÇÃO } \\
\text { Pol. No. }\end{array}$} & \multicolumn{6}{|c|}{ ANÁLISES } & \multirow[t]{2}{*}{ LOCALIZAÇÃO } & \multicolumn{2}{|c|}{ LITOTIPO } & \multirow[t]{2}{*}{ OBSERVAÇÕES } \\
\hline & & & 1 & 2 & 3 & 4 & 5 & 6 & & UNID. & PETROGRAFIA & \\
\hline GN-01 & GN-01A & & & $\mathrm{x}$ & $\mathrm{x}$ & & & & NE, SALÃO PRINCIPAL, HW & $\mathrm{NL}$ & QBAX & \\
\hline & GN-01B & & & & & & & & IDEM & $\mathrm{NL}$ & IDEM & \\
\hline GN-02 & GN-02 & & & $\bar{x}$ & & & & & & $\frac{\mathrm{NL}}{\mathrm{NL}}$ & $\overline{A F}$ & \\
\hline \multirow[t]{2}{*}{ GN-03 } & GN-03A & $\mathrm{GN}-3$ & & $\mathrm{x}$ & & & & & $\frac{\text { IDEM }}{\text { IDEM }}$ & $\frac{N L}{N \pi}$ & QBAX CIGR & \\
\hline & GN-03B & & & & & & & & IDEM & $\frac{\mathrm{NL}}{\mathrm{NL}}$ & IDEM & \\
\hline GN-04 & GN-04 & & & $\underline{x}$ & & & & & $\frac{\text { IDEM }}{\text { IDEM }}$ & $\frac{\mathrm{NL}}{\mathrm{NL}}$ & $\frac{\mathrm{ABX}}{\mathrm{QBAX}}$ & \\
\hline GN-05 & GN-05 & & & $\mathrm{x}$ & & & & & $\begin{array}{l}\text { IDEM } \\
\text { IDEM }\end{array}$ & $\frac{\mathrm{NL}}{\mathrm{NL}}$ & $\frac{\text { QBAX }}{\text { IDEM }}$ & \\
\hline GN-06 & GN-06 & & & $x$ & & & & & IDEM & $\mathrm{NL}$ & $\mathrm{QBCAX}$ & \\
\hline GN-07 & GN-07 & & & $x$ & & & & & IDEM & $\mathrm{NL}$ & IDEM & \\
\hline \multirow[t]{9}{*}{$\mathrm{GN}-08$} & GN-08Aa & & & $x$ & $\mathrm{X}$ & & & & IDEM & NL & IDEM & \\
\hline & GN-08Ab & & & & & & & & IDEM & $\mathrm{NL}$ & IDEM & \\
\hline & GN-08B & & & & & & & & IDEM & NL & IDEM & \\
\hline & GN-08Ca & & & & & & & & IDEM & NL & IDEM & \\
\hline & $\frac{\text { GN-08Cb }}{\text { GN-08Da }}$ & & & & & & & & IDEM & NL & IDEM & \\
\hline & $\frac{\mathrm{GN}-08 \mathrm{Da}}{\mathrm{GN}-08 \mathrm{Db}}$ & & & & & & & & IDEM & $\mathrm{NL}$ & IDEM & \\
\hline & $\frac{\text { GN-08Db }}{\text { GN-08E }}$ & & & & & & & & IDEM & $\mathrm{NL}$ & IDEM & \\
\hline & $\frac{\text { GN-08E }}{\text { GN-08F }}$ & & & & & & & & IDEM & $\mathrm{NL}$ & IDEM & \\
\hline & GN-08G & & & & & & & & IDEM & $\mathrm{NL}$ & QBAGRX ClS & \\
\hline \multirow[t]{11}{*}{ GN-09 } & $\mathrm{GN}-09 \mathrm{Aa}$ & $\mathrm{H}-36(\mathrm{~A}, \mathrm{~B})$ & & $\mathrm{X}$ & & & & & IDEM, MINÉRIO de Au & $\mathrm{NL}$ & IDEM & \\
\hline & GN-09Ab & & & & & & & & IDEM & $\mathrm{NL}$ & IDEM & \\
\hline & GN-09Ac & & & & & & & & IDEM & NL & IDEM & \\
\hline & GN-09Ad & & & & & & & & IDEM & NL & IDEM & \\
\hline & $\mathrm{GN}-09 \mathrm{Ae}$ & $\mathrm{H}-40$ & & & & & & & IDEM & $\mathrm{NL}$ & IDEM & \\
\hline & GN-09Af & $\mathrm{H}-41$ & & & & & & & IDEM & NL & IDEM & \\
\hline & GN-09Ag & $\mathrm{H}-42$ & & & & & & & IDEM & $\mathrm{NL}$ & IDEM & \\
\hline & GN-09Ah & $\mathrm{H}-43$ & & & & & & & IDEM & NL & IDEM & \\
\hline & GN-09AJ & $\mathrm{H}-44$ & & & & & & & IDEM & $\mathrm{NL}$ & IDEM & \\
\hline & GN-09AI & $\mathrm{H}-45$ & & & & & & & IDEM & $\mathrm{NL}$ & IDEM & \\
\hline & GN-09B & & & & & & & & IDEM & $\mathrm{NL}$ & IDEM & \\
\hline \multirow[t]{2}{*}{ GN-10 } & GN-10A & & & $\mathrm{x}$ & & & & & IDEM & NL & QBAX $\backslash S$ S GR & \\
\hline & GN-10B & $\mathrm{H}-21 / \mathrm{V}-\mathrm{A}$ & & & & & & & IDEM & NL & QBAX $\backslash S$ & \\
\hline \multirow[t]{2}{*}{ TP-10 } & GNTOP-01 & H-88/TP-1 & & $\mathrm{X}$ & & & & & IDEM & $\mathrm{NL}$ & IDEM & \\
\hline & GNTOP-02 & $\mathrm{H}-89 / \mathrm{TP}-2$ & & & & & & & IDEM & NL & IDEM & \\
\hline
\end{tabular}




\begin{tabular}{|c|c|c|c|c|c|c|c|c|c|c|c|}
\hline \multirow{2}{*}{$\begin{array}{c}\text { AMOSTRA } \\
\text { No. }\end{array}$} & \multirow{2}{*}{$\begin{array}{l}\text { LÂMINA } \\
\text { Petrog. No. }\end{array}$} & \multirow{2}{*}{$\begin{array}{l}\text { SEÇÃO } \\
\text { Pol. No. }\end{array}$} & \multicolumn{5}{|c|}{ ANÁLISES } & \multirow{2}{*}{ LOCALIZAÇÃO } & \multirow{2}{*}{\multicolumn{2}{|c|}{ LITOTIPO }} & \\
\hline & & & 1 & 25 & 74 & & $5 \sqrt{6}$ & & UNID. & & \multirow[t]{2}{*}{ OBSERVAÇÕES } \\
\hline & GNTOP-03 & $\mathrm{H}-90$ & & & & & & IDEM & $\mathrm{NL}$ & PETROGRAFIA & \\
\hline & GNTOP-04 & $\mathrm{H}-91$ & & & & & & IDEM & & IDEM & \\
\hline & GNTOP 05 & $\mathrm{H}-92$ & & & & & & IDEM & $\mathrm{NL}$ & IDEM & \\
\hline \multirow{2}{*}{ GN-11 } & $\mathrm{GN}-11 \mathrm{~B}$ & $\mathrm{H}-22$ & & & & & & IDEM & NL & IDEM & \\
\hline & & & & $\mathrm{X}$ & & & & IDEM & NL & IDEM & \\
\hline & GN-11X & & & $\mathrm{x}$ & & & & IDEM & $\mathrm{NL}$ & $Q C c B G R X \mathrm{c} \backslash \mathrm{S}$ & \\
\hline GN-12 & $\mathrm{GN}=12$ & $\mathrm{H}-23$ & & & & & & IDEM & NL & $\mathrm{ABQX} \mathrm{ClS}$ & \\
\hline \multirow{3}{*}{ GN-13 } & GN-13A & H-49 & & $\mathrm{x}$ & & & & IDEM & NL & QBCX CIS & \\
\hline & GN-13B & $\mathrm{H}-24$ & & & & & & IDEM & $\mathrm{NL}$ & IDEM & \\
\hline & GN-13X & H-25 & & & & & & DEM & $\mathrm{NL}$ & IDEM & \\
\hline \multirow[t]{11}{*}{ GN-14 } & $\mathrm{GN}-14 \mathrm{X}$ & & $\underline{X}$ & $x$ & & & & IDEM, FW & NL & QBAX & \\
\hline & GN-14A & $\mathrm{H}-14 \mathrm{~A}$ & & & & & & IDEM & NL & IDEM & \\
\hline & GN-14B & & & & & & & IDEM & NL & IDEM & \\
\hline & GN-14C & & & & & & & IDEM & $\mathrm{NL}$ & IDEM & \\
\hline & GN-14D & $\mathrm{H}-53$ & & & & & & IDEM & NL & IDEM & \\
\hline & $\mathrm{GN}-14 \mathrm{E}$ & $\mathrm{H}-54$ & & & & & & IDEM & $\mathrm{NL}$ & IDEM & \\
\hline & $\mathrm{GN}-14 \mathrm{~F}$ & $\mathrm{H}-55$ & & & & & & IDEM & NL & IDEM & \\
\hline & $\mathrm{GN}-14 \mathrm{G}$ & H-56 & & & & & & IDEM & $\mathrm{NL}$ & IDEM & \\
\hline & GN-14H & $\mathrm{H}-57$ & & & & & & IDEM & $\mathrm{NL}$ & IDEM & \\
\hline & GN14i & $\mathrm{H}-58$ & & & & & & IDEM & NL & DEM & \\
\hline & $\mathrm{GN}-14 \mathrm{~J}$ & H-59 & & & & & & IDEM & $\mathrm{NL}$ & IDEM & \\
\hline \multirow{9}{*}{ GN-15 } & GN-15A & & & $\mathrm{x}$ & & & & IDEM & $\mathrm{NL}$ & IDEM & \\
\hline & GN-15B & & & & & & & IDEM & NL & IDEM & \\
\hline & GN-15C & $\mathrm{H}-62$ & & & & & & IDEM & NL & IDEM & \\
\hline & GN-15D & & & & & & & IDEM & $\mathrm{NL}$ & IDEM & \\
\hline & GN-15E & & & & & & & IDEM & $\mathrm{NL}$ & IDEM & \\
\hline & GN-15F & & & & & & & IDEM & NL & IDEM & \\
\hline & $\mathrm{GN}-15 \mathrm{G}$ & & & & & & & IDEM & $\mathrm{NL}$ & IDEM & \\
\hline & GN-15H & & & & & & & IDEM & NL & IDEM & \\
\hline & GN-15i & & & & & & & IDEM & $\mathrm{NL}$ & IDEM & \\
\hline GN-16 & $\mathrm{GN}-16$ & $\mathrm{H}-27$ & & $\mathrm{x}$ & & & & IDEM, MINÉRIO de Au & NL & $\mathrm{QBCX} \backslash \mathrm{S}$ & \\
\hline \multirow[t]{3}{*}{$\mathrm{GN}-17$} & GN-17A & $\mathrm{H}-28$ & & $\mathrm{x}$ & & & & IDEM & $\mathrm{NL}$ & $\mathrm{QBX} \backslash \mathrm{S}$ & \\
\hline & GN-17B & $\mathrm{H}-29$ & & & & & & IDEM & $\mathrm{NL}$ & IDEM & \\
\hline & GN-17C & $\mathrm{H}-30$ & & & & & & IDEM & NL & IDEM & \\
\hline
\end{tabular}




\begin{tabular}{|c|c|c|c|c|c|c|c|c|c|c|c|c|}
\hline \multirow{2}{*}{$\begin{array}{c}\text { AMOSTRA } \\
\text { No. } \\
\end{array}$} & \multirow{2}{*}{$\begin{array}{r}\text { LÂMINA } \\
\text { Petrog. No. }\end{array}$} & \multirow{2}{*}{$\begin{array}{l}\text { SEÇÃO } \\
\text { Pol. No. }\end{array}$} & \multicolumn{6}{|c|}{ ANÁLISES } & \multirow{2}{*}{ LOCALIZAÇÃO } & \multicolumn{2}{|c|}{ LITOTIPO } & \multirow{2}{*}{ OBSERVAÇÕES } \\
\hline & & & 1 & 2 & 3 & 4 & 5 & 6 & & UNID. & PETROGRAFIA & \\
\hline & GN-17D & $\mathrm{H}-31$ & & & & & & & IDEM & $\mathrm{NL}$ & IDEM & \\
\hline & GN-17E & $\mathrm{H}-32$ & & & & & & & IDEM & $\mathrm{NL}$ & IDEM & \\
\hline & GN-17X & $\mathrm{H}-69$ & & & & & & & IDEM & NL & IDEM & \\
\hline \multirow{2}{*}{ GN-18 } & GN-18A & & & $\mathrm{x}$ & & & & & IDEM & NL & IDEM & \\
\hline & $\mathrm{GN}-18 \mathrm{~B}$ & $\mathrm{H}-93$ & & & & & & & IDEM & NL & IDEM & \\
\hline GN-19 & GN-19 & & & $\mathrm{x}$ & $\mathrm{x}$ & & & & IDEM, FW & NL & QBAX Cl GR & \\
\hline GN-20A & GN-20A & & & $\mathrm{X}$ & & & & & IDEM & $\mathrm{NL}$ & IDEM & \\
\hline \multirow[t]{3}{*}{ GN-20B } & $\mathrm{GN}-20 \mathrm{Ba}$ & & & $\mathrm{x}$ & & & & & IDEM & $\mathrm{NL}$ & IDEM & \\
\hline & $\mathrm{GN}-20 \mathrm{Bb}$ & & & & & & & & IDEM & $\mathrm{NL}$ & IDEM & \\
\hline & $\mathrm{GN}-20 \mathrm{Bc}$ & & & & & & & & IDEM & NL & IDEM & \\
\hline \multirow[t]{2}{*}{ GN-21 } & GN-21A & & & $\mathrm{x}$ & & & & & IDEM & $\mathrm{NL}$ & $\mathrm{AG}$ & \\
\hline & GN-21B & & & & & & & & IDEM & $\mathrm{NL}$ & IDEM & \\
\hline \multirow[t]{2}{*}{$\mathrm{GN}-22$} & GN-22A & & & $\mathrm{x}$ & $\mathrm{x}$ & $\mathrm{x}$ & & $\mathrm{x}$ & IDEM & $\mathrm{NL}$ & IDEM & \\
\hline & $\mathrm{GN}-22 \mathrm{~B}$ & & & & & & & & IDEM & $\mathrm{NL}$ & IDEM & \\
\hline \multirow[t]{2}{*}{ GN-23 } & GN-23A & & & $\mathrm{x}$ & & $\mathrm{X}$ & & $\mathrm{x}$ & IDEM & NL & IDEM & \\
\hline & GN-23B & & & & & & & & IDEM & $\mathrm{NL}$ & IDEM & \\
\hline \multirow[t]{2}{*}{ GN-24 } & GN-24A & & & $\mathrm{X}$ & & & & & IDEM & $\mathrm{NL}$ & QAFX c/GR & \\
\hline & $\mathrm{GN}-24 \mathrm{~B}$ & $\mathrm{H}-80$ & & & & & & & IDEM & $\mathrm{NL}$ & IDEM & \\
\hline $\mathrm{GN}-25$ & GN-25 & $\mathrm{H}-94$ & & $\mathrm{x}$ & & & & & IDEM & NL & A & \\
\hline GN-26 & GN-26 & & & $\mathrm{x}$ & $\mathrm{x}$ & & & & IDEM & NL & $\mathrm{A}$ & \\
\hline \multirow[t]{7}{*}{ E-1 } & E-1A & $\mathrm{H}-81 / \mathrm{IB}$ & & & & & & & IDEM, MINÉRIO de $\mathrm{Au}$ & $\mathrm{NL}$ & ABQX $\backslash \backslash \mathrm{S}$ & \\
\hline & $E-1 B$ & $\mathrm{H}-82 / \mathrm{IIA}$ & & & & & & & IDEM & NL & IDEM & \\
\hline & $\mathrm{E}-2 \mathrm{~A}$ & $\mathrm{H}-83 / \mathrm{E}-\mathrm{A} / \mathrm{E}-\mathrm{B}$ & & & & & & & IDEM & NL & IDEM & \\
\hline & E-2B & $\mathrm{H}-84 / \mathrm{E}-\mathrm{C} / \mathrm{V}-\mathrm{A}$ & & & & & & & IDEM & NL & IDEM & \\
\hline & E-3A & H-85/III-A & & & & & & & IDEM & $\mathrm{NL}$ & IDEM & \\
\hline & $\mathrm{E}-3 \mathrm{~B}$ & H-86/IV-A & & & & & & & IDEM & $\mathrm{NL}$ & IDEM & \\
\hline & E-4B & $\mathrm{H}-87$ & & & & & & & IDEM & $\mathrm{NL}$ & IDEM & \\
\hline $1 \mathrm{~B}$ & $\mathrm{~A}$ & & & $\mathrm{X}$ & & $\mathrm{X}$ & & & $\mathrm{N} 10, \mathrm{FW}$ & NL & $\mathrm{QBXF} \mathrm{clCc}$ & \\
\hline $2 \mathrm{~B}$ & A & & & $\mathrm{X}$ & & $\mathrm{X}$ & & & IDEM & NL & QABX & \\
\hline $3 \mathrm{~B}$ & $\mathrm{~A}, \mathrm{~B}$ & & & $\mathrm{x}$ & & $\mathrm{x}$ & & & IDEM & $\mathrm{NL}$ & IDEM & \\
\hline 4B & & & & $\mathrm{X}$ & & $\mathrm{x}$ & & & IDEM & NL & IDEM & \\
\hline $5 \mathrm{~B}$ & $\mathrm{~A}, \mathrm{~B}$ & $5 \mathrm{~B}$ & & $\mathrm{X}$ & & $\mathrm{X}$ & & & IDEM & $\mathrm{NL}$ & CcQABX & \\
\hline $6 \mathrm{~B}$ & $\overline{A, B}$ & & & $\mathrm{X}$ & & $\mathrm{x}$ & & & IDEM & NL & IDEM & \\
\hline
\end{tabular}




\begin{tabular}{|c|c|c|c|c|c|c|c|c|c|c|c|c|}
\hline \multirow{2}{*}{$\begin{array}{c}\text { AMOSTRA } \\
\text { No. } \\
\end{array}$} & \multirow{2}{*}{$\begin{array}{r}\text { LÂMINA } \\
\text { Petrog. No. } \\
\end{array}$} & \multirow{2}{*}{$\begin{array}{l}\text { SEÇÃO } \\
\text { Pol. No. }\end{array}$} & \multicolumn{6}{|c|}{ ANÁLISES } & \multirow[t]{2}{*}{ LOCALIZAÇÃO } & \multicolumn{2}{|c|}{ LITOTIPO } & \multirow{2}{*}{ OBSERVAÇÕES } \\
\hline & & & 1 & 2 & 3 & 4 & 5 & 6 & & UNID. & PETROGRAFIA & \\
\hline $7 \mathrm{~B}$ & & & & $\mathrm{X}$ & & $\mathrm{X}$ & & & IDEM & NL & IDEM & \\
\hline $8 \mathrm{~B}$ & $\mathrm{~A}, \mathrm{~B}, \mathrm{C}, \mathrm{D}, \mathrm{E}$ & $8 \mathrm{BA}, 8 \mathrm{BB}$ & & $\mathrm{x}$ & & $\mathrm{X}$ & & & IDEM & $\mathrm{NL}$ & IDEM & \\
\hline $9 \mathrm{~B}$ & $\mathrm{BC}, \mathrm{BB}, \mathrm{BA}$ & 9BA,9BC & $\mathrm{X}$ & $\mathrm{x}$ & & $\mathrm{X}$ & & & N10, MINÉRIO RICO de Au & NL & QBGRX $\backslash \backslash S$ & DRX: GRANADA \\
\hline $10 \mathrm{~B}$ & $b a, b b, b c, b d$ & $10 \mathrm{BA}, 10 \mathrm{BC}$ & $\mathrm{x}$ & $\mathrm{x}$ & & $\mathrm{x}$ & & & IDEM & NL & $\mathrm{IDEM}+\mathrm{Q}$ & DRX: GRANADA \\
\hline $11 \mathrm{~B}$ & $\mathrm{BA}, \mathrm{BB}, \mathrm{BC}$ & $11 \mathrm{BA}, 11 \mathrm{BC}$ & & $\mathrm{x}$ & & $\mathrm{x}$ & & & IDEM & NL & IDEM & \\
\hline $12 \mathrm{~B}$ & BA, BB & $12 \mathrm{BA}, 12 \mathrm{BB}$ & & $\mathrm{x}$ & & $\mathrm{x}$ & & & IDEM & $\mathrm{NL}$ & BGRX cls & \\
\hline \multirow[t]{4}{*}{$13 \mathrm{~B}$} & & $13 \mathrm{BA}, 13 \mathrm{BB}$ & & $\mathrm{X}$ & & $\mathrm{x}$ & & & IDEM & NL & $\mathrm{QBX} \backslash \backslash \mathrm{S}$ & \\
\hline & $13 \mathrm{BA}$ & $13 \mathrm{BC}, 13 \mathrm{BE}$ & & & & & & & IDEM & NL & IDEM & \\
\hline & $13 \mathrm{BB}$ & $13 \mathrm{BF}, 13 \mathrm{BH}$ & & & & & & & IDEM & NL & IDEM & \\
\hline & $13 \mathrm{BD}$ & 13BK & & & & & & & IDEM & NL & IDEM & \\
\hline \multirow[t]{2}{*}{$14 \mathrm{~B}$} & $\mathrm{BB}, \mathrm{BA}$ & $14 \mathrm{BA}, 14 \mathrm{BB}$ & & $\mathrm{X}$ & $\mathrm{x}$ & $\mathrm{x}$ & & & IDEM & NL & $\mathrm{BQX} \backslash \mathrm{s}$ & \\
\hline & & $14 \mathrm{BC}, 14 \mathrm{~B}$ & & & & & & & IDEM & NL & IDEM & \\
\hline $15 \mathrm{~B}$ & & & & $\mathrm{x}$ & $\mathrm{X}$ & $\mathrm{X}$ & & & IDEM & NL & BGfX cl-s & \\
\hline $16 \mathrm{~B}$ & $\mathrm{BA}, \mathrm{BB}$ & & & $\mathrm{X}$ & & $\mathrm{X}$ & & & $\mathrm{N} 10, \mathrm{HW}$ & NL & $\mathrm{BQX} \mathrm{cl} \mathrm{GR}+\mathrm{Mg}$ & \\
\hline $17 \mathrm{~B}$ & & & & $\mathrm{x}$ & & $\mathrm{x}$ & & & IDEM & NL & $\mathrm{QBCX}$ & \\
\hline $18 \mathrm{~B}$ & $\mathrm{BA}, \mathrm{BB}$ & & & $\mathrm{x}$ & & $\mathrm{x}$ & & & IDEM & NL & IDEM & \\
\hline $19 \mathrm{~B}$ & & & & $\mathrm{x}$ & & $\mathrm{X}$ & & & IDEM & $\mathrm{NL}$ & IDEM & \\
\hline $20 \mathrm{~B}$ & $\mathrm{BA}, \mathrm{BB}$ & & & $\mathrm{x}$ & & $\mathrm{x}$ & & & IDEM & NL & IDEM & \\
\hline$T-1$ & & & & & & & & & BR-76-177m & GNT & GN/CTX & \\
\hline $\mathrm{T}-2$ & & & & & & & & & $\mathrm{BR}-76-179,7 \mathrm{~m}$ & GNT & CTX & \\
\hline$T-3$ & & & & & & & & & BR-76-181,3m & NL & $\mathrm{AX}$ & \\
\hline$T-4$ & & & & & & & & & BR-76-185,5m & $\mathrm{NL}$ & $\mathrm{AX}$ & \\
\hline$T-5$ & & & & & & & & & BR-76-193m & NL & $\mathrm{AX}$ & \\
\hline $\mathrm{T}-6$ & & & & & & & & & BR-76-389m & GNT/NL & GN/CTX & \\
\hline $\mathrm{T}-7$ & & & & & & & & & BR-67 - 390m & NL & CTX & \\
\hline $\mathrm{T}-8$ & & & & & & & & & BR- $67-390,5 \mathrm{~m}$ & NL & CTX/BAXF & \\
\hline$T-9$ & $T-9$ & & & $\mathrm{X}$ & & & & & BR-57-75m & GNT & GN/GT & \\
\hline $\mathrm{T}-10$ & & & & & & & & & BR- $57.82 \mathrm{~m}$ & GNT & $\mathrm{P}$ & \\
\hline$T-11$ & $T-11$ & & & $\mathrm{x}$ & & & & & BR- $57-85 m$ & GNT & $\mathrm{GG}$ & \\
\hline$T-12$ & & & & & & & & & BR- $57-88 m$ & GNT & $\mathrm{GD} / \mathrm{P}$ & \\
\hline $\mathrm{T}-12 \mathrm{~A}$ & $\mathrm{~A}$ & & & $\mathrm{x}$ & & & & & BR- $57-87,5 \mathrm{~m}$ & GNT & GD & \\
\hline$T-12 B$ & $\mathrm{~B}, \mathrm{C}$ & & & $\mathrm{x}$ & & & & & BR-57 - 89,5m & GNT & $\mathrm{GD}$ & \\
\hline $\mathrm{T}-13$ & $\mathrm{~T}-13$ & & & $\mathrm{x}$ & & & & & BR-57-91m & GNT & GT & \\
\hline
\end{tabular}




\begin{tabular}{|c|c|c|c|c|c|c|c|c|c|c|c|}
\hline \multirow{2}{*}{$\begin{array}{c}\text { AMOSTRA } \\
\text { No. } \\
\end{array}$} & \multirow{2}{*}{$\begin{array}{r}\text { LÂMINA } \\
\text { Petrog. No. } \\
\end{array}$} & \multirow{2}{*}{$\begin{array}{l}\text { SEÇÃO } \\
\text { Pol. No. } \\
\end{array}$} & \multicolumn{5}{|c|}{ ANÁLISES } & \multirow[t]{2}{*}{ LOCALIZAÇÃO } & \multicolumn{2}{|c|}{ LITOTIPO } & \multirow[t]{2}{*}{ OBSERVAÇÕES } \\
\hline & & & 112 & 25 & $3 \lcm{4}$ & & 6 & & UNID. & PETROGRAFIA & \\
\hline $\mathrm{T}-14$ & $\mathrm{~T}-14$ & & & & & & & BR- $57-113,5 \mathrm{~m}$ & GNT & $\mathrm{P}$ & \\
\hline $\mathrm{T}-15$ & T.15 & & & & & & & $\mathrm{BR}-57-126,5 \mathrm{~m}$ & GNT & $\mathrm{GD} / \mathrm{P}$ & \\
\hline $\mathrm{T}-16$ & $\mathrm{~T}-16$ & & $\underline{X}$ & & & & & BR-57-128m & GNT & $\mathrm{BCX}+\mathrm{P}$ & \\
\hline$T-17$ & $T-17$ & & & & & & & $\mathrm{BR}-57-142 \mathrm{~m}$ & GNT & GT & \\
\hline$T-18$ & $\mathrm{~T}-18 \mathrm{~A}, \mathrm{~B}$ & & $\underline{X}$ & $\mathrm{x}$ & & & & BR-57 - 148m & GNT & GT & \\
\hline $\mathrm{T}-19$ & & & & & & & & BR-57-157m & GNT & $\mathrm{VQ}$ & \\
\hline $\mathrm{T}-20$ & & & & & & & & $\mathrm{BR}-57-178,5 \mathrm{~m}$ & GNT & GRX & \\
\hline$T-21$ & & & & & & & & BR-57-191,5m & GNT & $\mathrm{GN}$ & \\
\hline$T-22$ & & & & & & & & BR- $57-225,5 \mathrm{~m}$ & GNT & GT & \\
\hline$T-23$ & $\mathrm{~T}-23$ & & & & & & & BR-57-248m & GNT & GG & \\
\hline $\mathrm{T}-23 \mathrm{~A}$ & & & $\underline{x}$ & $\underline{x}$ & & & & BR- $57-249,5 \mathrm{~m}$ & GNT & GN & \\
\hline $\mathrm{T}-24$ & $\mathrm{~T}-24$ & & $\underline{x}$ & $\mathrm{x}$ & & & & BR-57-251m & GNT & GT & \\
\hline $\mathrm{T}-24 \mathrm{~A}$ & & & & & & & & BR- $57-256,5 \mathrm{~m}$ & GNT & $P$ & \\
\hline$T-25$ & & & & & & & & BR-57-259m & GNT & GT & \\
\hline$T-26$ & $T-26$ & & & $x$ & & & & BR-57-265m & GNT & GT & Quartzoso, branco \\
\hline$T-27$ & & & & & & & & BR-57-267m & GNT & GT & IDEM \\
\hline $\mathrm{T}-28$ & & & & & & & & BR-57 - 283m & GNT & $\mathrm{X}$ & \\
\hline $\mathrm{T}-28 \mathrm{~A}$ & $\mathrm{~T}-28 \mathrm{~A}$ & & $\underline{x}$ & $\mathrm{x}$ & & & & BR-57 - 288,5m & GNT & GD cls & \\
\hline $\mathrm{T}-29$ & $T-29$ & & & & & & & BR- $57-289,5 \mathrm{~m}$ & GNT & GT & Quartzoso, branco \\
\hline$T-30$ & & & & & & & & BR-57 - 291m & GNT & GT & IDEM \\
\hline$T-31$ & $\mathrm{~T}-31 \mathrm{~A}$ & & $\underline{x}$ & $\mathrm{x}$ & & & & BR- $57-294 m$ & GNT/NL & GT/TX & \\
\hline $\mathrm{T}-32$ & & & & & & & & BR-57 - 294,5m & NL & $\mathrm{TX}$ & \\
\hline$T-33$ & $T-33$ & & $\underline{X}$ & 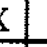 & & & & BR-57 - 296,5m & NL & $\mathrm{QBCX}$ & \\
\hline $\mathrm{T}-34$ & & & & & & & & BR-57-301m & $\mathrm{NL}$ & GRAG & \\
\hline $\mathrm{T}-35$ & & & & & & & & BR-57-302m & $\mathrm{NL}$ & A & \\
\hline$T-36$ & T-36 & & $\underline{x}$ & 1 & & & & BR- $57-307 \mathrm{~m}$ & $\mathrm{NL}$ & $\mathrm{ACBX}$ & \\
\hline$T-37$ & $\mathrm{~T}-37$ & & & & & & & BR-57 - 307,5m & $\mathrm{NL}$ & IDEM & \\
\hline $\mathrm{T}-38$ & & & & & & & & BR-57-313m & NL & $\mathrm{AF}$ & \\
\hline $\mathrm{T}-39$ & $\mathrm{~T}-39$ & & $\underline{X}$ & 1 & & & & BR-57-314m & NL & $\mathrm{AF}$ & \\
\hline $\mathrm{T}-40$ & & & & & & & & BR-57 - 327m & NL & $\mathrm{QA}$ & \\
\hline$T-41$ & $T-41$ & & $\underline{x}$ & 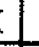 & & & & BR-57 - 335m & NL & $\mathrm{A}$ & \\
\hline $\mathrm{T}-42$ & $\mathrm{~T}-42$ & & $\underline{x}$ & ] & & & & BR- $57-347,5 m$ & NL & $\mathrm{QA}$ & \\
\hline $\mathrm{T}-43$ & & & & & & & & BR-57-357m & NL & QA & \\
\hline
\end{tabular}




\begin{tabular}{|c|c|c|c|c|c|c|c|c|c|c|c|c|}
\hline \multirow{2}{*}{$\begin{array}{c}\text { AMOSTRA } \\
\text { №. } \\
\end{array}$} & \multirow{2}{*}{$\begin{array}{l}\text { LÂMINA } \\
\text { Petrog. No. }\end{array}$} & \multirow{2}{*}{$\begin{array}{l}\text { SEÇÃO } \\
\text { Pol. No. }\end{array}$} & \multicolumn{6}{|c|}{ ANÁLISES } & \multirow[t]{2}{*}{ LOCALIZAÇÃO } & \multicolumn{2}{|c|}{ LITOTIPO } & \multirow{2}{*}{ OBSERVAÇÕES } \\
\hline & & & 1 & 2 & 3 & 4 & 5 & 6 & & UNID. & PETROGRAFIA & \\
\hline $\mathrm{T}-44$ & & & & & & & & & BR-57-362m & $\mathrm{NL}$ & $\mathrm{AG}$ & \\
\hline $\mathrm{T}-45$ & & & & & & & & & BR-57- $402,5 \mathrm{~m}$ & NL & $\mathrm{AF}$ & \\
\hline$T-46$ & $T-46$ & & & & & & & & BR- $57-405,5 \mathrm{~m}$ & NL & QAF & \\
\hline$T-47$ & & & & & & & & & BR $-57-407 \mathrm{~m}$ & NL & $\mathrm{A} / \mathrm{VQ}$ & \\
\hline T-48 & $\mathrm{T}-48 \mathrm{~A}, \mathrm{~B}$ & & & & & & & & BR-57- $458,5 \mathrm{~m}$ & $\mathrm{NL}$ & $\mathrm{VQ}$ & \\
\hline$T-49$ & & & & & & & & & BR- $57-470,7 \mathrm{~m}$ & NL & $\mathrm{VQ} / \mathrm{Cc}$ & \\
\hline T.50 & T.50 & & & $\mathrm{X}$ & & & & & BR-57-478m & NL & M/A & \\
\hline$T-51$ & & & & & & & & & BR-57-482m & $\mathrm{NL}$ & $\mathrm{QBCX}$ & \\
\hline T-52 & & & & & & & & & BR-57-492m & NL & $\mathrm{VQ}$ & \\
\hline $\mathrm{T}-53$ & $T-53$ & & & $\mathrm{X}$ & & & & & BR-57-497,5m & NL & $\mathrm{BCAX}$ & \\
\hline$T-54$ & T.54 & & & $\mathrm{x}$ & & & & & $\mathrm{BR}-57-501,5 \mathrm{~m}$ & $\mathrm{NL}$ & IDEM & \\
\hline T-55 & $T-55$ & & & & & & & & BR-57-502,5m & NL & $\mathrm{BCX} \subset \backslash \mathrm{GR}$ & \\
\hline $\mathrm{T}-56$ & T.56 & & & $\mathrm{x}$ & & & & & $\mathrm{BR}-57-511 \mathrm{~m}$ & NL & A & \\
\hline T-57 & & & & & & & & & $\mathrm{BR}-57 \cdot 517 \mathrm{~m}$ & NL & $\mathrm{BCAX}$ & \\
\hline T. 58 & T-58 & & & $\mathrm{x}$ & & & & & BR-57 - 521,5m & NL & IDEM & \\
\hline T-59 & $T-59$ & & & & & & & & BR- $57-528,5 \mathrm{~m}$ & NL & GRAX & \\
\hline$T-60$ & $\mathrm{~T}-60 \mathrm{~A}, \mathrm{~B}, \mathrm{C}$ & & & $x$ & & & & & BR-57-530m & NL & $\mathrm{ACc}+\mathrm{S}$ & \\
\hline$T-61$ & & & & & & & & & BR-57- $599,5 \mathrm{~m}$ & $\mathrm{NL}$ & GRQAX & \\
\hline $\mathrm{T}-62$ & & & & & & & & & BR-57- $620,5 \mathrm{~m}$ & $\mathrm{NL}$ & IDEM & \\
\hline$T-63$ & $T-63 A, B$ & & & $\mathrm{X}$ & & & & & $\mathrm{BR}-57-661 \mathrm{~m}$ & NL & GRQAX/FF & \\
\hline $\mathrm{T}-64$ & $T-64$ & & & $\begin{array}{l}\mathrm{X} \\
\end{array}$ & & & & & BR-57-662m & NL & $\mathrm{FF}+\mathrm{GR}+\mathrm{MG}$ & \\
\hline$T-65$ & $T-65$ & & & $\mathrm{x}$ & & & & & BR-57-664m & $\mathrm{NL}$ & FF/A & \\
\hline T-66 & $T-66$ & & & $\mathrm{X}$ & & & & & BR- $57-665,5 \mathrm{~m}$ & NL & A & \\
\hline$T-67$ & T.67 & & & $\mathrm{X}$ & & & & & BR-57-701m & NL & $\mathrm{QBX}$ & \\
\hline$T-68$ & $\mathrm{~T}-68$ & & & $\mathrm{x}$ & & & & & BR-57-703m & $\mathrm{NL}$ & GRQBX & \\
\hline T.69 & T.69 & & & $x$ & & & & & BR-57-704m & $\mathrm{NL} / \mathrm{QO}$ & GRQBX/CTX & \\
\hline $\mathrm{T}-70$ & T-70 & & 2 & $\mathrm{x}$ & & & & & BR-57-706m & $\mathrm{QO}$ & CTX & \\
\hline$T-71$ & T-71D,C & & & & & & & & $\mathrm{BR}-57 \cdot 712 \mathrm{~m}$ & QO/GNB & $\mathrm{CTX} / \mathrm{GG}$ & \\
\hline $\mathrm{T}-72$ & $T-72$ & & 2 & $\mathrm{X}$ & & & & & BR-57-713m & GNB & GT & \\
\hline$T-73$ & & & & & & & $\mathrm{X}$ & & BR-76-m & $\mathrm{QO}$ & CTX & \\
\hline T-74 & & & & & & & $\mathrm{x}$ & & $\mathrm{BR}-76-\mathrm{m}$ & $\mathrm{QO}$ & CTX & \\
\hline$T-75$ & & & & & & & $\mathrm{X}$ & & BR-76-m & $\mathrm{QO}$ & CTX & \\
\hline$T-76$ & & & & & & & $\mathrm{X}$ & & $\mathrm{BR}-76-\mathrm{m}$ & QO & $\mathrm{S}$ maciço & \\
\hline
\end{tabular}




\begin{tabular}{|c|c|c|c|c|c|c|c|c|c|c|c|c|}
\hline \multirow{2}{*}{$\begin{array}{c}\text { AMOXO 3 } \\
\text { AMOSTRA } \\
\text { No. }\end{array}$} & \multirow{2}{*}{$\begin{array}{l}\text { LÂMINA } \\
\text { Petrog. No. }\end{array}$} & \multirow{2}{*}{$\begin{array}{l}\text { SEÇ̃̃o } \\
\text { Pol. No. } \\
\end{array}$} & \multicolumn{6}{|c|}{ ANÁLISES } & \multirow{3}{*}{ LOCALIZAÇÃO } & \multicolumn{2}{|c|}{ LITOTIPO } & \\
\hline & & & 1 & 2 & 3 & 4 & 5 & 6 & & & & \multirow{2}{*}{ OBSERVAÇÕES } \\
\hline T-77 & & & & & & & & & & UNID. & PETROGRAFIA & \\
\hline$T-78$ & & & & & & & & & BR-76-m & $\mathrm{QO}$ & CTX & \\
\hline$T-79$ & & & & & & & $\mathrm{x}$ & & BR-76-m & $\mathrm{QO}$ & CTX & \\
\hline & & & & & & & $\mathrm{x}$ & & BR-76-m & QO & CTX & \\
\hline & & & & & & & & & N10, FW & NL & $\mathrm{AF}$ & \\
\hline$\overline{\mathrm{G}-3}$ & & & & & & & & & IDEM & $\mathrm{NL}$ & $\mathrm{QBCX}$ & \\
\hline G-4 & & & & $\mathrm{X}$ & & & & & IDEM & NL & VQ discordante & \\
\hline$\overline{G-5}$ & & SG-4 & & & & & & & IDEM & NL & QBGRX $\backslash S$ & \\
\hline$G-6$ & & & & & & & & & IDEM & NL & BGRX + S & \\
\hline & & SG-6 & & $\mathrm{x}$ & & & & & IDEM & NL & IDEM & \\
\hline & & SG-7,SG-7A & & $\mathrm{X}$ & & & & & IDEM & $\mathrm{NL}$ & IDEM & \\
\hline & & SG-7B & & & & & & & IDEM & NL & S maciço & \\
\hline G-8 & & SG-8A & & & & & & & IDEM & NL & MS & \\
\hline G-9 & & SG-8B & & & & & & & IDEM & NL & MS & \\
\hline & & & & & & & & & IDEM & NL & $\mathrm{M}$ & \\
\hline & & SG-10 & & & & & & & $\mathrm{NI}$ & NL & XS & \\
\hline & & SG-11A & & & & & & & IDEM & NL & $\mathrm{XS}$ & \\
\hline \multirow{3}{*}{ G-12 } & & SG-11B & & & & & & & IDEM & NL & $\mathrm{XS}$ & \\
\hline & $L G-12 A$ & SG-12A & & & & & & & N10 & NL & GRXS & \\
\hline & LG-12B & SG-12B & & & & & & & IDEM & NL & GRXS & \\
\hline & & SG-12BB & & & & & & & IDEM & NL & GRXS & \\
\hline & & & & & & & & & IDEM & NL & GRXS & \\
\hline \multirow{3}{*}{ G-13 } & LG-12BB & & & & & & & & IDEM & NL & GRX & \\
\hline & LG-13 & & & & & & & & IDEM & NL & $\mathrm{M}+\mathrm{GRBNX}$ & \\
\hline & LG-13A & & & & & & & & IDEM & NL & IDEM & \\
\hline \multirow{3}{*}{ G-14 } & LG-13B & & & & & & & & IDEM & $\mathrm{NL}$ & IDE & \\
\hline & & SG-14A & & & & & & & N11 & NL & $\mathrm{s}$ & \\
\hline & & SG-14B & & & & & & & IDEM & NL & $\mathrm{s}$ & \\
\hline \multirow{3}{*}{ G-15 } & LG-15 & SG-14 & & & & & & & IDEM & NL & $\mathrm{S}$ & \\
\hline & LG-15A & SG-15A & & & & & & & N10 & NL & $\mathrm{s}$ & \\
\hline & & SG-15B & & & & & & & IDEM & NL & $\mathrm{s}$ & \\
\hline G-16 & LG-16 & SG-15 & & & & & & & IDEM & NL & $\mathrm{BGRX} \backslash \mathrm{S}$ & \\
\hline G-17 & LG-17 & $\frac{S G-16 / E I}{S G-17}$ & $\mathrm{x}$ & & & & & & NE & NL & $\mathrm{FF}(\mathrm{Mg}+\mathrm{GR})$ & DRX: GRANADA \\
\hline & & SG-17 & & $\mathrm{X}$ & & & & & IDEM & NL & IDEM & \\
\hline
\end{tabular}




\begin{tabular}{|c|c|c|c|c|c|c|c|c|c|c|}
\hline \multirow{2}{*}{$\begin{array}{l}\text { AMOSTRA } \\
\text { No. } \\
\end{array}$} & \multirow{2}{*}{$\begin{array}{l}\text { LAMINA } \\
\text { Petrog. No. }\end{array}$} & \multirow{2}{*}{$\begin{array}{l}\text { SEÇAO } \\
\text { Pol. No. }\end{array}$} & \multicolumn{4}{|c|}{ ANALISES } & \multirow{2}{*}{ LOCALIZAÇAO } & \multicolumn{2}{|r|}{ LITOTPO } & \multirow{2}{*}{ OBSERVAÇOES } \\
\hline & & & 112 & $3]$ & \begin{tabular}{l|l}
4 & 5 \\
\end{tabular} & 56 & & UNID. & PETROGRAFIA & \\
\hline & LG-17A & & & & & & IDEM & $\mathrm{NL}$ & IDEM & \\
\hline \multirow{2}{*}{ G-18 } & LG 18 & SG-18 & & & & & IDEM & $\mathrm{NL}$ & IDEM & \\
\hline & LG-18A & SG-18A & & & & & IDEM & NL & IDEM & \\
\hline \multirow[t]{2}{*}{ G-19 } & LG-19 & & $\mathrm{X}$ & & & & N10, PARTE NORTE & NL & $\mathrm{Cc}+\mathrm{Q}$ & \\
\hline & LG-19A & & & & & & IDEM & $\mathrm{NL}$ & IDEM & \\
\hline \multirow[t]{2}{*}{ G-20 } & LG-20 & SG-20 & & & & & IDEM & NL & $s$ & \\
\hline & & $\mathrm{SG}-20 \mathrm{~A}$ & & & & & IDEM & $\mathrm{NL}$ & $\underline{S}$ & \\
\hline \multirow[t]{9}{*}{ S/AMOS. } & & $\mathrm{A}$ & & & & & NE, SALÃO PRINCIPAL & NL & MINÉRIO PARI & \\
\hline & & B & & & & & IDEM & NL & IDEM & \\
\hline & & $\mathrm{C}$ & & & & & IDEM & NL & IDEM & \\
\hline & & $\mathrm{D}$ & & & & & IDEM & $\mathrm{NL}$ & IDEM & \\
\hline & & $\mathrm{E}$ & & & & & IDEM & $\mathrm{NL}$ & IDEM & \\
\hline & & $\mathrm{F}$ & & & & & IDEM & $\mathrm{NL}$ & IDEM & \\
\hline & & G & & & & & IDEM & $\mathrm{NL}$ & IDEM & \\
\hline & & $\mathrm{I}-\mathrm{A}$ & & & & & IDEM & $\mathrm{NL}$ & IDEM & \\
\hline & & I-B & & & & & IDEM & $\mathrm{NL}$ & IDEM & \\
\hline P-1A & & P-1A & & $\mathrm{X}$ & & & N10, MINÉRIO PARI & $\mathrm{NL}$ & IDEM & \\
\hline $\mathrm{P}-1 \mathrm{~B}$ & & P1-B & & $\mathrm{x}$ & & & IDEM & $\mathrm{NL}$ & IDEM & \\
\hline $\mathrm{P}-2$ & & $\mathrm{P}-2$ & & $\mathrm{x}$ & & & IDEM & NL & IDEM & \\
\hline P-5B & & $P-5 B$ & & $\mathrm{x}$ & & & IDEM & NL & IDEM & \\
\hline \multirow[t]{2}{*}{ S/No } & & BAHU & & $\mathrm{X}$ & & & MINA BAHU & NL & REJ, VQ & \\
\hline & SB-01 & SÃO BENTO & & & & & MINA SÃO BENTO & & & \\
\hline SL-01 & & SÃO BENTO & $\mathrm{X}$ & & & & MINA SÃO BENTO & $\mathrm{NL}$ & MIN, MS & \\
\hline$S-36 / 3 A$ & & S-36/3A & & $\mathrm{X}$ & & & IDEM & NL & IDEM & \\
\hline S-36/1 & & S-36/1 & & $\mathrm{X}$ & & & IDEM & $\mathrm{NL}$ & IDEM & \\
\hline $39 / 1$ & L-1 & $\mathrm{S}-1$ & & & & & BR-39 & $\mathrm{NL}$ & $?$ & \\
\hline $39 / 2$ & $\mathrm{~L}-2$ & $s-2$ & & & & & IDEM & NL & $?$ & \\
\hline $39 / 3$ & $\mathrm{~L}-3$ & S-3 & & & & & IDEM & NL & $?$ & \\
\hline $39 / 4$ & $\mathrm{~L}-4$ & S-4 & & & & & IDEM & $\mathrm{NL}$ & $?$ & \\
\hline $39 / 5$ & $\mathrm{~L}-5$ & S-5 & & & & & IDEM & $\mathrm{NL}$ & $?$ & \\
\hline $39 / 6$ & $\mathrm{~L}-6$ & S.6 & & & & & IDEM & $\mathrm{NL}$ & $?$ & \\
\hline $39 / 7$ & $\mathrm{~L}-7$ & $\mathrm{~S}-7$ & & & & & IDEM & $\mathrm{NL}$ & $?$ & \\
\hline $39 / 8$ & $\mathrm{~L}-8$ & S-8 & & & & & IDEM & $\mathrm{NL}$ & $?$ & \\
\hline $39 / 9$ & L-9 & S-9 & & & & & IDEM & $\mathrm{NL}$ & $?$ & \\
\hline
\end{tabular}




\begin{tabular}{|c|c|c|c|c|c|c|c|c|c|c|c|c|}
\hline \multirow{2}{*}{$\begin{array}{c}\text { AMOSTRA } \\
\text { No. } \\
\end{array}$} & \multirow{2}{*}{$\begin{array}{l}\text { LÂMINA } \\
\text { Petrog. No. }\end{array}$} & \multirow{2}{*}{$\begin{array}{l}\text { SEÇãO } \\
\text { Pol. No. } \\
\end{array}$} & \multicolumn{6}{|c|}{ ANÁLISES } & \multirow[t]{2}{*}{ LOCALIZAÇÃO } & \multicolumn{2}{|c|}{ LITOTIPO } & \multirow{2}{*}{ OBSERVAÇÕES } \\
\hline & & & 1 & 2 & 3 & 4 & 5 & 6 & & UNID. & PETROGRAFIA & \\
\hline $39 / 10$ & $\mathrm{~L}-10$ & $\mathrm{~S}-10$ & & & & & & & IDEM & NL & $?$ & \\
\hline $\mathrm{F}-1$ & & & & & & & $\mathrm{x}$ & $\mathrm{x}$ & BR-55 (354,5-355) & $\mathrm{NL}$ & QBAXG & \\
\hline $\mathrm{F}-2$ & & & & & & & $\mathrm{X}$ & $\mathrm{x}$ & BR-55 (355-355,5) & $\mathrm{NL}$ & IDEM & \\
\hline $\mathrm{F}-3$ & & & & & & & $\mathrm{X}$ & $\mathrm{x}$ & BR-55 $(355,5-356)$ & NL & IDEM & \\
\hline$F-4$ & & & & & & & $\mathrm{X}$ & $\mathrm{x}$ & BR-55 (356 356,5) & $\mathrm{NL}$ & IDEM & \\
\hline$F-5$ & & & & & & & $\mathrm{X}$ & $\mathrm{x}$ & BR-55 $(356,5-357)$ & NL & IDEM & \\
\hline $\mathrm{F}-6$ & & & & & & & $\mathrm{x}$ & $\mathrm{x}$ & BR-55 $(357-357,5)$ & NL & IDEM & \\
\hline F-7 & & & & & & & $\mathrm{X}$ & $\mathrm{x}$ & BR-55 (357,5-358) & NL & IDEM & \\
\hline$F-8$ & & & & & & & $\mathrm{X}$ & $\mathrm{X}$ & BR-55 (358-358,5) & NL & IDEM & \\
\hline F-9 & & & & & & & $\mathrm{x}$ & $\mathrm{x}$ & BR-55 $(358,5-359)$ & NL & IDEM & \\
\hline$F-10$ & & & & & & & $\mathrm{x}$ & $\mathrm{x}$ & BR-55 (359-359,5) & $\mathrm{NL}$ & $\mathrm{IDEM}$ & \\
\hline$F-11$ & & & & & & & $\mathrm{x}$ & $\mathrm{x}$ & BR-55 $(359,5-360)$ & $\mathrm{NL}$ & IDEM & \\
\hline $\mathrm{F}-12$ & & & & & & & $\mathrm{x}$ & $\mathrm{x}$ & BR-55 (360-360,5) & NL & IDEM & \\
\hline$F-13$ & & & & & & & $\mathrm{X}$ & $\mathrm{x}$ & BR-55 $(360,5-361)$ & NL & IDEM & \\
\hline$F \cdot 14$ & & & & & & & $\mathrm{X}$ & $\mathrm{x}$ & BR-55 (361-361,5) & $\mathrm{NL}$ & IDEM & \\
\hline$F=15$ & & & & & & & $\mathrm{x}$ & $\mathrm{x}$ & BR-55 $(361,5-362)$ & NL & IDEM & \\
\hline F-16 & & & & & & & $\mathrm{X}$ & $\mathrm{x}$ & BR-55 $(362-362,5)$ & $\mathrm{NL}$ & IDEM & \\
\hline$F-17$ & & & & & & & $\mathrm{X}$ & $\mathrm{x}$ & BR-55 (362,5-363) & $\mathrm{NL}$ & IDEM & \\
\hline $\mathrm{F}-18$ & & & & & & & $\mathrm{X}$ & $\mathrm{x}$ & BR-55 (363-363,5) & NL & DEM & \\
\hline$F-19$ & & & & & & & $\mathrm{x}$ & $\mathrm{x}$ & BR-55 (363,5-364) & $\mathrm{NL}$ & QGRBHX & \\
\hline $\mathrm{F}-20$ & & & & & & & $\mathrm{x}$ & $\mathrm{x}$ & BR-55 $(364-364,5)$ & NL & IDEM & \\
\hline$F-20$ & & & & & & & $\mathrm{x}$ & $\mathrm{x}$ & BR-55 (364-364,5) & NL & IDEM & \\
\hline$F-21$ & & & & & & & $\mathrm{x}$ & $\mathrm{x}$ & BR-55 (364,5-365) & NL & IDEM & \\
\hline $\mathrm{F}-22$ & & & & & & & $\mathrm{x}$ & $\mathrm{X}$ & BR-55 (365-365,5) & $\mathrm{NL}$ & IDEM & \\
\hline$F-23$ & & & & & & & $\mathrm{x}$ & $\mathrm{x}$ & BR-55 $(365,5-366)$ & NL & IDEM & \\
\hline F-24 & & & & & & & $\mathrm{x}$ & $\mathrm{x}$ & BR-55 $(366-366,5)$ & NL & IDEM & \\
\hline F-25 & & & & & & & $\mathrm{X}$ & $\mathrm{x}$ & BR-55 (366,5-367) & NL & QBHX & \\
\hline $\mathrm{F}-26$ & & & & & & & $\mathrm{X}$ & $\mathrm{x}$ & BR-55 $(367-367,5)$ & $\mathrm{NL}$ & QBHX & \\
\hline$F=27$ & & & & & & & $\mathrm{X}$ & $\mathrm{x}$ & BR-55 (367,5-368) & NL & IDEM & \\
\hline $\mathrm{F}-28$ & & & & & & & $\mathrm{X}$ & $\mathrm{X}$ & BR-55 $(368-368,5)$ & NL & IDEM & \\
\hline F-29 & & & & & & & $\mathrm{x}$ & $\mathrm{x}$ & BR-55 (368,5-369) & NL & IDEM & \\
\hline $\mathrm{F}-30$ & & & & & & & $\mathrm{X}$ & $x$ & BR-55 (369-369,5) & NL & IDEM & \\
\hline F-31 & & & & & & & $\mathrm{X}$ & $x$ & BR-55 $(369,5-370)$ & NL & IDEM & \\
\hline
\end{tabular}




\begin{tabular}{|c|c|c|c|c|c|c|c|c|c|c|}
\hline AMOSTRA & LAMINA & SEÇAO & & NALIS & & & LOCALIZAÇAO' & & TOTPPO & OBSERVACOOES \\
\hline No. & Petrog. No. & Pol. No. & $1 / 2$ & \begin{tabular}{|l|l}
3 & 4 \\
\end{tabular} & 5 & 6 & & UNID. & PETROGRAFIA & \\
\hline F-32 & & & & & $\mathrm{x}$ & $\mathrm{X}$ & BR-55 $(370-370,5)$ & NL & IDEM & \\
\hline F.33 & & & & & $\mathrm{x}$ & $\mathrm{X}$ & BR-55 (370,5-371) & NL & IDEM & \\
\hline F-34 & & & & & $\mathrm{x}$ & $\mathrm{x}$ & BR-55 (371-371,5) & NL & IDEM & \\
\hline$F-35$ & & & & & $\mathrm{X}$ & $\mathrm{X}$ & BR-55 (371,5-372) & $\mathrm{NL}$ & IDEM & \\
\hline $\mathrm{F}=36$ & & & & & $\mathrm{X}$ & $\mathrm{X}$ & BR-55 (372-372,5) & $\mathrm{NL}$ & IDEM & \\
\hline$F-37$ & & & & & $\mathrm{X}$ & $\mathrm{X}$ & BR-55 (372,5-373) & $\mathrm{NL}$ & IDEM & \\
\hline F-38 & & & & & $\mathrm{X}$ & $\mathrm{X}$ & BR-55 (373-373,5) & NL & IDEM & \\
\hline F.39 & & & & & $\mathrm{x}$ & $\mathrm{x}$ & BR-55 $(373,5-374)$ & NL & IDEM & \\
\hline$F-40$ & & & & & $\mathrm{x}$ & $\mathrm{x}$ & BR-55 (374-374,33) & NL & QBGRX CIS & \\
\hline $\begin{array}{l}F-41 \\
F-42\end{array}$ & & & & & $\begin{array}{l}\mathrm{X} \\
\mathrm{x}\end{array}$ & $\begin{array}{l}x \\
x\end{array}$ & $\begin{array}{c}\text { BR-55 }(374,33-374,6) \\
\text { BR-55 }(374,6-375)\end{array}$ & $\begin{array}{l}\mathrm{NL} \\
\mathrm{NL}\end{array}$ & $\begin{array}{l}\text { IDEM } \\
\text { IDEM }\end{array}$ & \\
\hline F-43 & & & & & $\mathrm{X}$ & $x$ & BR-55 $(375-375,39)$ & $\mathrm{NL}$ & IDEM & \\
\hline F -44 & & & & & $\mathrm{X}$ & $x$ & BR-55 $(375,39-375,74)$ & NL & IDEM & \\
\hline F-45 & & & & & $\mathrm{x}$ & $\mathrm{X}$ & BR-55 $(375,74-376,05)$ & $\mathrm{NL}$ & IDEM & \\
\hline$F-46$ & & & & & $\mathrm{X}$ & $\mathrm{X}$ & BR-55 $(376,05-376,34)$ & NL & IDEM & \\
\hline$F-47$ & & & & & $\mathrm{x}$ & $\mathrm{X}$ & BR-55 $(376,34-376,76)$ & $\mathrm{NL}$ & IDEM & \\
\hline F -48 & & & & & $\mathrm{x}$ & $\mathrm{x}$ & BR-55 $(376,76-377,21)$ & $\mathrm{NL}$ & IDEM & \\
\hline$F-49$ & & & & & $\mathrm{X}$ & $\mathrm{x}$ & BR-55 $(377,21-377,63)$ & NL & IDEM & \\
\hline F-50 & & & & & $\mathrm{x}$ & $\mathrm{x}$ & BR-55 (377,63-378) & NL & $\mathrm{HCX}$ & \\
\hline F-51 & & & & & $\mathrm{X}$ & $\mathrm{X}$ & BR-55 (378-378,5) & NL & $\mathrm{BHX} \backslash \mathrm{S}$ & \\
\hline F-52 & & & & & $\mathrm{x}$ & $\mathrm{X}$ & BR-55 (378,5-379) & NL & QBHX & \\
\hline $\mathrm{F}-53$ & & & & & $\mathrm{x}$ & $\mathrm{x}$ & BR-55 $(379-379,5)$ & NL & IDEM & \\
\hline F -54 & & & & & $\mathrm{X}$ & $\mathrm{x}$ & BR-55 (379,5-380) & NL & IDEM & \\
\hline F-55 & & & & & $\mathrm{x}$ & $\mathrm{x}$ & BR-55 (380-380,5) & NL & IDEM & \\
\hline F-56 & & & & & $\mathrm{X}$ & $\mathrm{X}$ & BR-55 (380,5-381) & $\mathrm{NL}$ & IDEM & \\
\hline$F-57$ & & & & & $\mathrm{X}$ & $\mathrm{x}$ & BR-55 (381-381,5) & NL & IDEM & \\
\hline F-58 & & & & & $\mathrm{x}$ & $\mathrm{x}$ & BR-55 (381,5-382) & NL & IDEM & \\
\hline F-59 & & & & & $\mathrm{x}$ & $\mathrm{x}$ & BR-55 (382-382,5) & NL & IDEM & \\
\hline$F-60$ & & & & & $\mathrm{x}$ & $\mathrm{X}$ & BR-55 (382,5-383) & NL & IDEM & \\
\hline$F-61$ & & & & & $\mathrm{x}$ & $\mathrm{X}$ & BR-55 (383-383,5) & NL & IDEM & \\
\hline $\mathrm{F}-62$ & & & & & $\mathrm{X}$ & $\mathrm{X}$ & BR-55 (383,5-384) & NL & IDEM & \\
\hline $\mathrm{F}-63$ & & & & & $\mathrm{X}$ & $\mathrm{X}$ & BR-55 (384-384,5) & NL & IDEM & \\
\hline$F-64$ & & & & & $\mathrm{x}$ & $\mathrm{x}$ & BR-55 (384,5-385) & NL & IDEM & \\
\hline
\end{tabular}




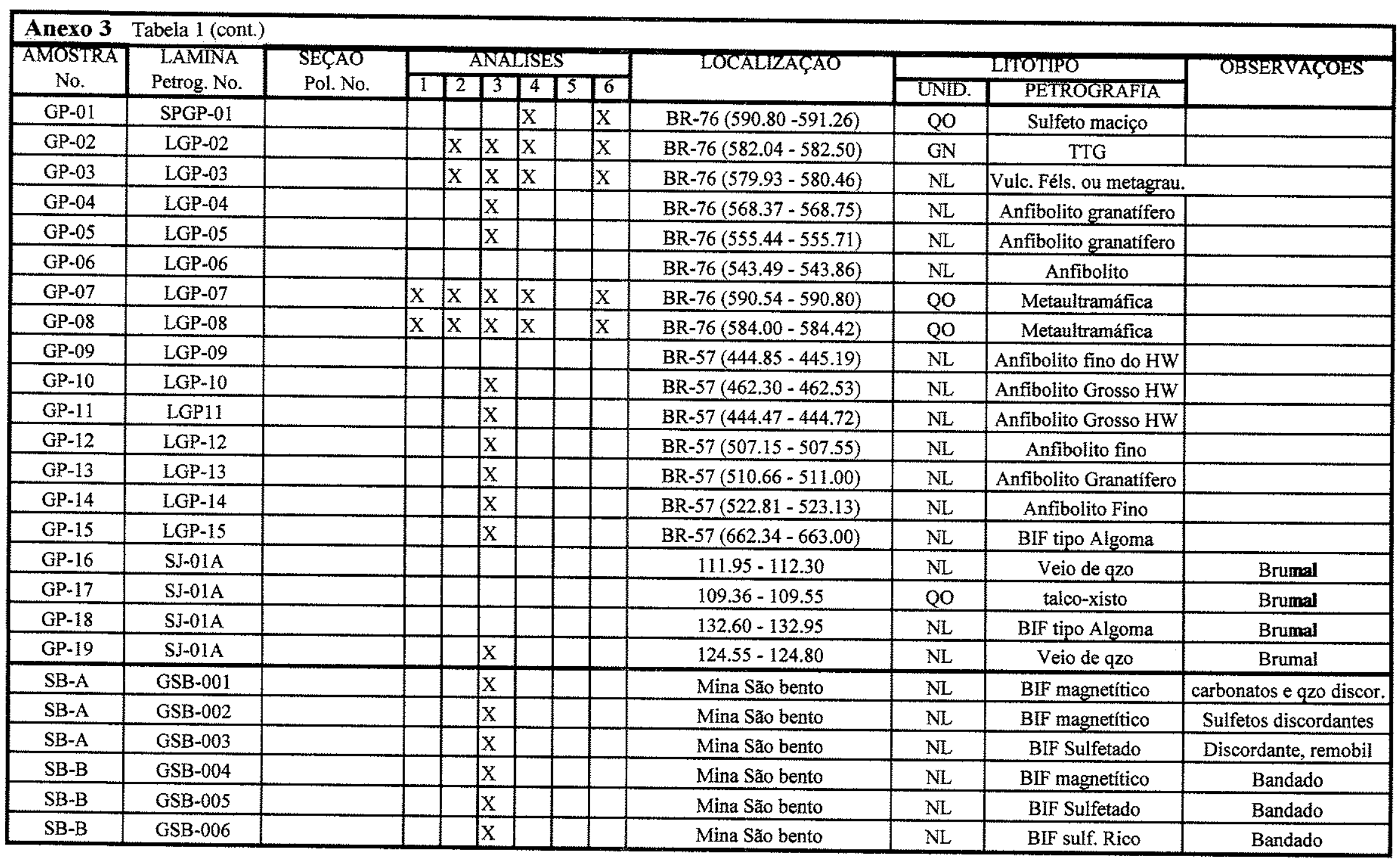




\begin{tabular}{|c|c|c|c|}
\hline Coluna & $\begin{array}{l}\text { Tipo } \\
\text { L- Lâmina } \\
\text { S- Seção polida } \\
\text { D- Seção delgada e polida } \\
\text { M- Minério } \\
\text { C- Sulfeto maciço }\end{array}$ & & \\
\hline \multicolumn{4}{|c|}{ Coluna Mineralogia } \\
\hline Símbolo & Mineral & \multirow[b]{2}{*}{\begin{tabular}{|l} 
Símbolo \\
Epí. \\
Sulf. \\
Au. \\
Po. \\
Tche \\
cumm. \\
Mag. \\
Ilm. \\
Py. \\
Asp. \\
Ccp. \\
Graf. \\
Sp. \\
Pn \\
\end{tabular}} & Mineral \\
\hline $\begin{array}{l}\text { Hb } \\
\text { Trem } \\
\text { Bio } \\
\text { Clo } \\
\text { kfel } \\
\text { Carb } \\
\text { ms } \\
\text { Gra } \\
\text { Plag } \\
\text { Qzo } \\
\text { Grun } \\
\text { fluot } \\
\text { Opa. } \\
\text { Flo. } \\
\end{array}$ & $\begin{array}{l}\text { Hornblenda } \\
\text { tremolita } \\
\text { Biotita } \\
\text { clorita } \\
\text { K-Feldspato } \\
\text { Carbonato } \\
\text { Muscovita } \\
\text { Granada } \\
\text { Plagioclásio } \\
\text { Quartzo } \\
\text { Grunerita } \\
\text { Fluorita } \\
\text { Opacos } \\
\text { Flogopita }\end{array}$ & & $\begin{array}{l}\text { Epídoto } \\
\text { Sulfeto } \\
\text { Ouro } \\
\text { Pirrotita } \\
\text { Tchermakita } \\
\text { Cumingtonita } \\
\text { Magnetita } \\
\text { IImenita } \\
\text { Pirita } \\
\text { Arsenopirita } \\
\text { Calcopirita } \\
\text { Grafita } \\
\text { Esfalerita } \\
\text { Pentlandita }\end{array}$ \\
\hline
\end{tabular}




\title{
Coluna Estrutura
}

\author{
f-foliada \\ m-maciça \\ $\mathrm{x}$-xistosa \\ b-bandada \\ d-dobras intrafoliares \\ c-crenulações \\ e-equigranular \\ $r$-reliquiar \\ dd-dobrada \\ mc-milonítica cisalhada \\ bc-bandamento composicional \\ fc-foliado com bandas carbonáticas
}

\section{Coluna Textura}

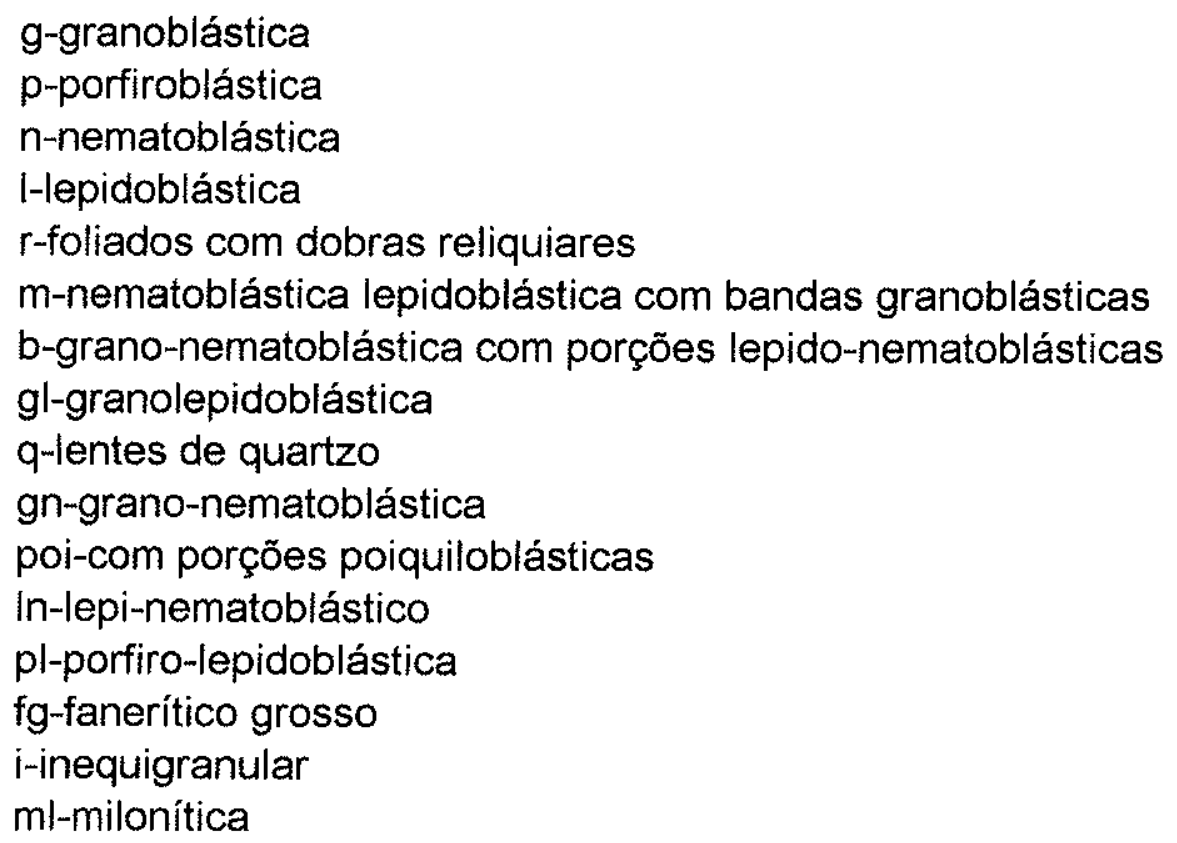




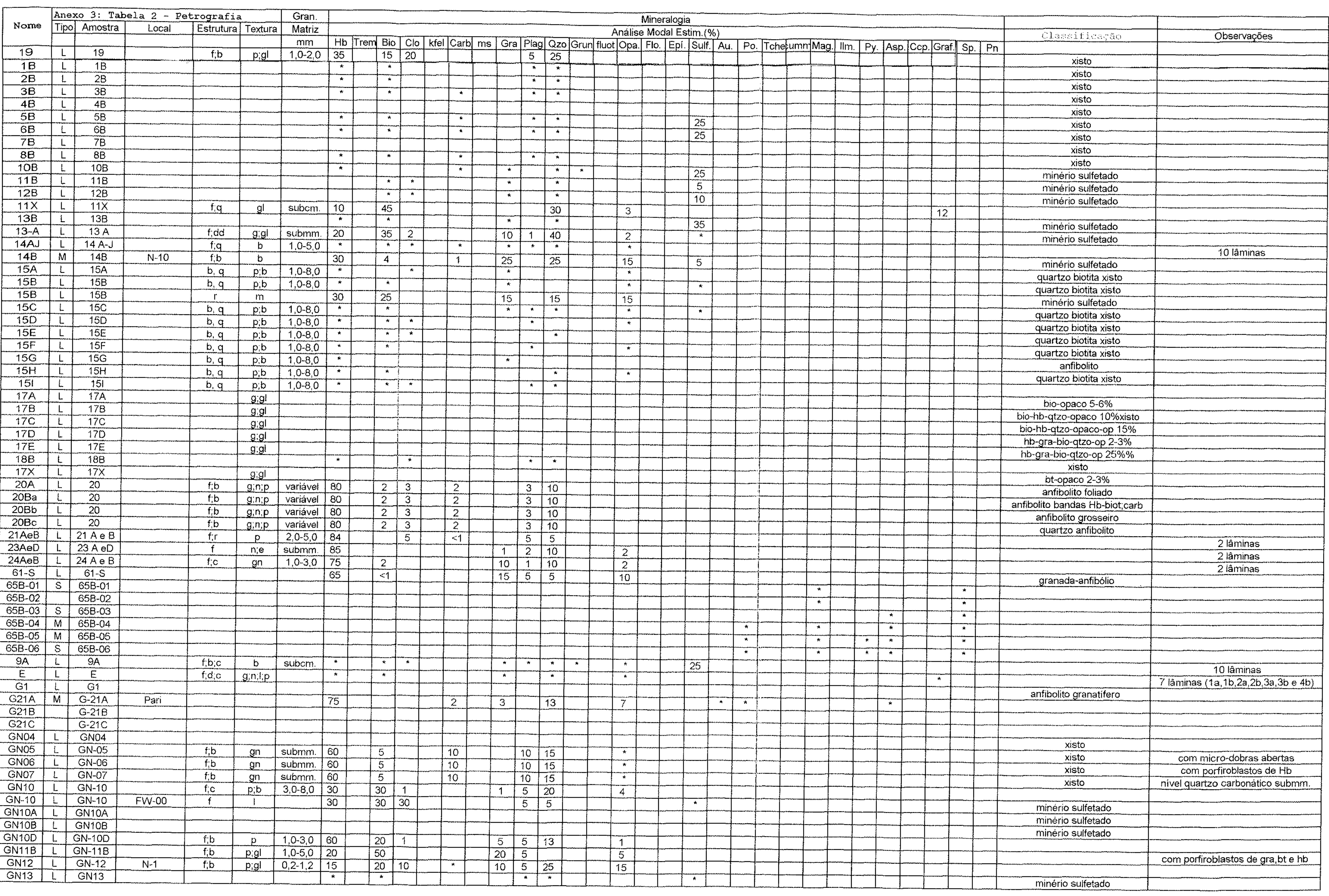




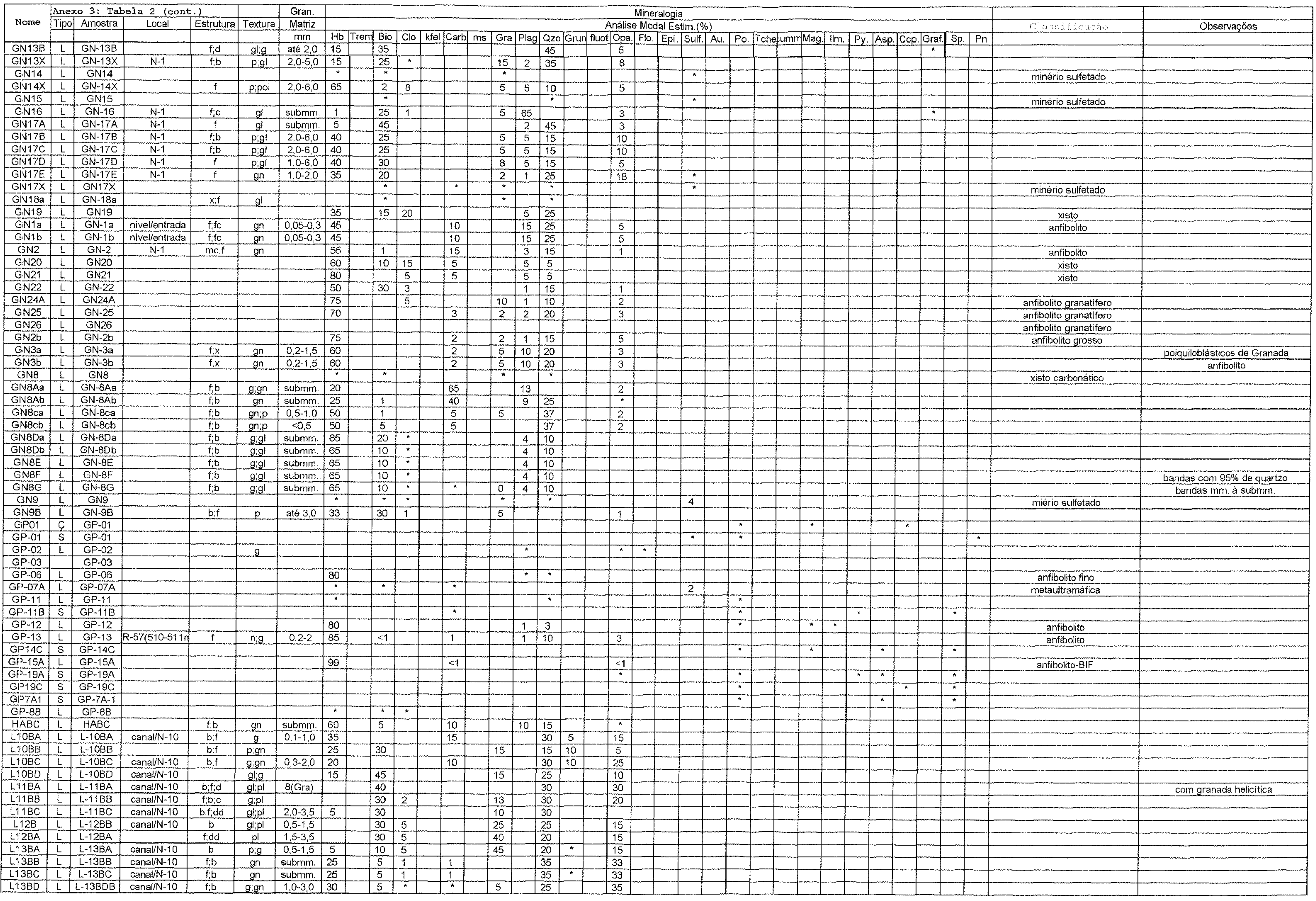




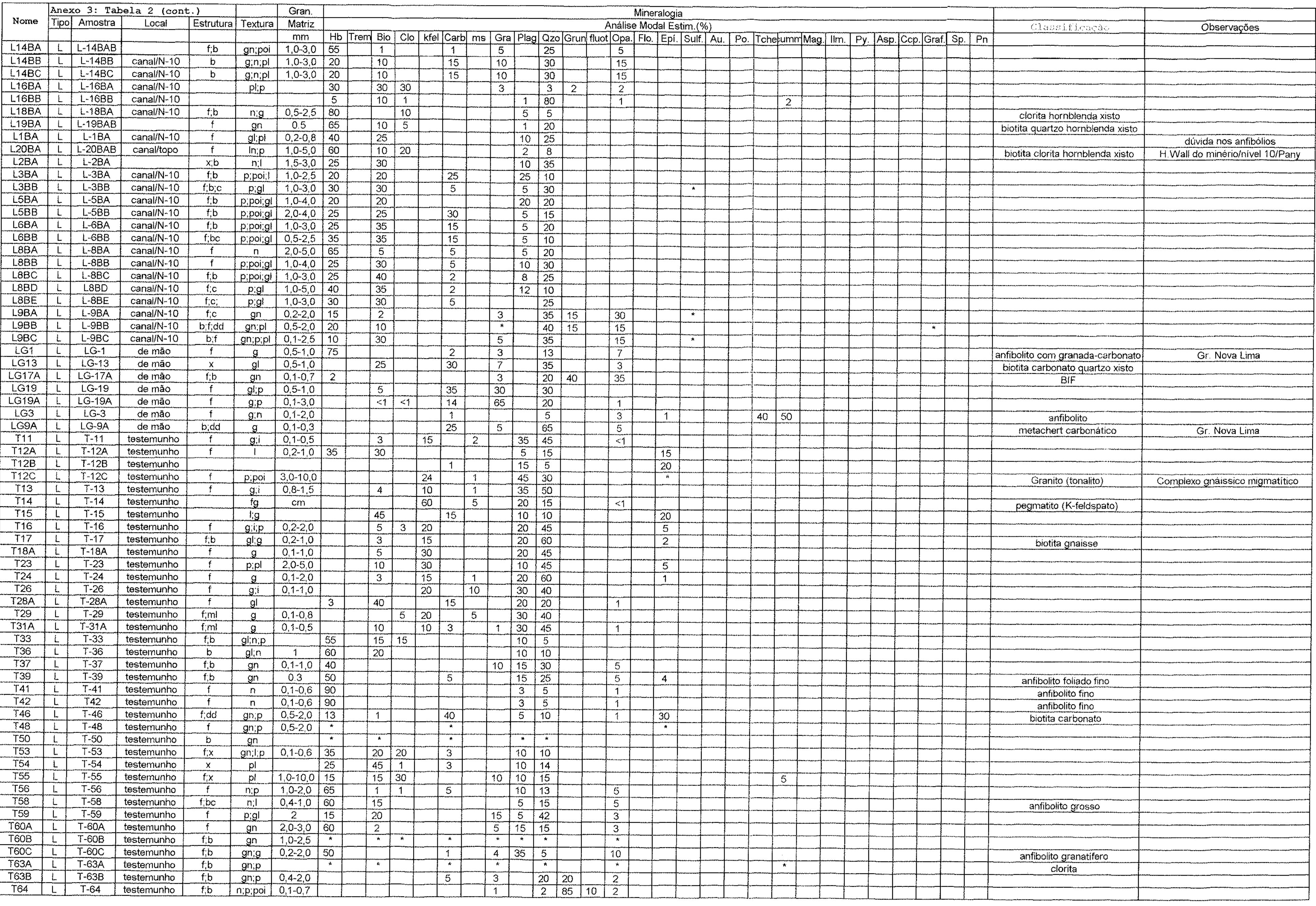




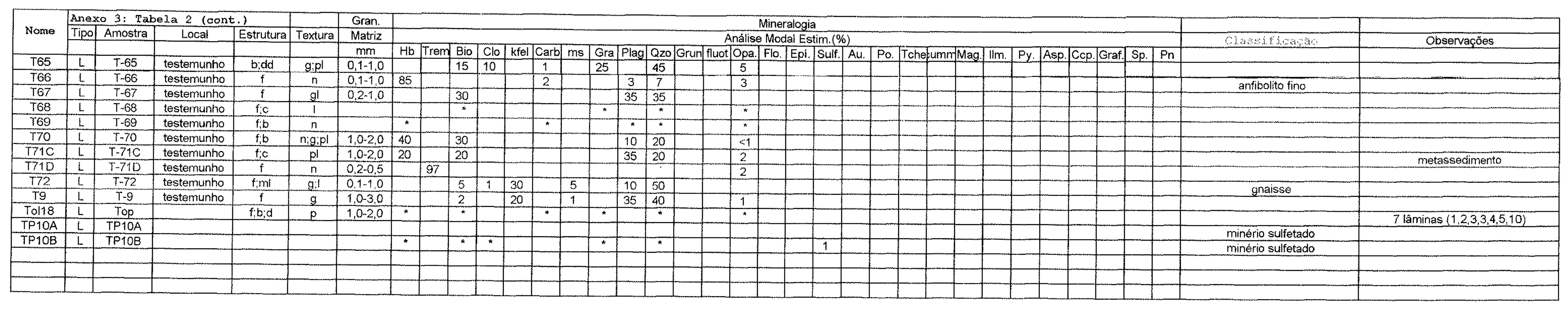


Anexo 3: Tabela 3 - Análises Modais das Amostras do Nível de Entrada (N-00) da Mina do Pari

\begin{tabular}{|c|c|c|c|c|c|c|c|c|c|c|c|c|c|c|}
\hline $\begin{array}{c}\text { Amostra } \\
\text { No. }\end{array}$ & $\begin{array}{c}\begin{array}{c}\text { Hornblenda } \\
\mathbf{H b}\end{array} \\
\end{array}$ & $\begin{array}{l}\text { Clorita } \\
\mathrm{Cl}\end{array}$ & $\begin{array}{c}\text { Biotita } \\
\text { Bi }\end{array}$ & $\begin{array}{c}\text { Quartzo } \\
Q z\end{array}$ & $\begin{array}{c}\text { Granada } \\
\text { Gr }\end{array}$ & \begin{tabular}{|c} 
Carbonato \\
$\mathrm{Cb}$
\end{tabular} & $\begin{array}{c}\text { Plagiocl. } \\
\text { PI }\end{array}$ & $\begin{array}{c}\text { Grun/Fluot } \\
\text { GF }\end{array}$ & $\begin{array}{c}\text { Opacos } \\
\text { Op }\end{array}$ & & $\begin{array}{l}\text { Petro- } \\
\text { grafia }\end{array}$ & $\frac{\text { Lâminas }}{\text { Total }}$ & $\begin{array}{c}\text { Antigas } \\
1995\end{array}$ & $\frac{\text { Novas }}{2002}$ \\
\hline 1 & 50,0 & 0,0 & 0,0 & 25,0 & 0,0 & 10,0 & 10,0 & 0,0 & 5,0 & 1 & & 3 & $\frac{1995}{2}$ & $\frac{2002}{1}$ \\
\hline 2 & 65,0 & 0,0 & 1,0 & 15,0 & 0,0 & 15,0 & 3,0 & 0,0 & 1,0 & 2 & AnfHW & 1 & $\frac{2}{1}$ & 0 \\
\hline 3 & 60,0 & 0,0 & 0,0 & 20,0 & 5,0 & 2,0 & 10,0 & 0,0 & 3,0 & 3 & & 2 & 2 & $\frac{\pi}{0}$ \\
\hline 4 & 70.0 & 0.0 & 4.0 & 12.0 & 0.0 & 2.0 & 10.0 & 0.0 & 2.0 & 4 & C & 1 & 1 & 0 \\
\hline 5 & 63.0 & 0.0 & 7.0 & 15.0 & 0.0 & 6.0 & 8.0 & 0.0 & 1.0 & 5 & a & 1 & 1 & 0 \\
\hline 6 & 65.0 & 0.0 & 3.0 & 15.0 & 0.0 & 5.0 & 10.0 & 0.0 & 2.0 & 6 & p & 1 & 1 & 0 \\
\hline 7 & 60.0 & 0.0 & 5.0 & 15.0 & 0.0 & 10.0 & 10.0 & 0.0 & 0.0 & 7 & a & 1 & 1 & 0 \\
\hline 8 & 60.0 & 5.0 & 5.0 & 15.0 & 3.0 & 1.0 & 10.0 & 0.0 & 1.0 & 8 & & 11 & 10 & 1 \\
\hline 9 & 33.0 & 1.0 & 30.0 & 30.0 & 5.0 & 0.0 & 0.0 & 0.0 & 1.0 & 9 & & 11 & 11 & 0 \\
\hline 12 & 10.0 & 10.0 & 20.0 & 25.0 & 10.0 & 1.0 & 5.0 & 5.0 & 14.0 & 12 & M & 1 & 1 & 0 \\
\hline 10 & 29.0 & 1.0 & 30.0 & 20.0 & 10.0 & 0.0 & 5.0 & 1.0 & 4.0 & 10 & $\mathbf{i}$ & 3 & 3 & 0 \\
\hline 11 & 5.0 & 0.0 & 40.0 & 29.0 & 5.0 & 0.0 & 1.0 & 5.0 & 15.0 & 11 & $n$ & 2 & 2 & 0 \\
\hline 18 & 3.0 & 0.0 & 30.0 & 30.0 & 30.0 & 0.0 & 0.0 & 2.0 & 5.0 & 18 & é & 1 & 1 & 0 \\
\hline 16 & 1.0 & 1.0 & 25.0 & 65.0 & 5.0 & 0.0 & 0.0 & 0.0 & 3.0 & 16 & $r$ & 1 & 1 & 0 \\
\hline 13 & 15.0 & 3.0 & 25.0 & 35.0 & 10.0 & 1.0 & 1.0 & 5.0 & 5.0 & 13 & i & 3 & 3 & 0 \\
\hline 17 & 20.0 & 3.0 & 30.0 & 20.0 & 10.0 & 0.0 & 1.0 & 2.0 & 14.0 & 17 & 0 & 6 & 6 & 0 \\
\hline 14 & 30.0 & 20.0 & 15.0 & 22.0 & 3.0 & 0.0 & 1.0 & 5.0 & 4.0 & 14 & & 11 & 11 & 0 \\
\hline 15 & 30.0 & 20.0 & 20.0 & 25.0 & 1.0 & 0.0 & 1.0 & 0.0 & 3.0 & 15 & L & 9 & 9 & 0 \\
\hline 19 & 35.0 & 20.0 & 20.0 & 20.0 & 0.0 & 0.0 & 5.0 & 0.0 & 0.0 & 19 & a & 2 & 1 & 1 \\
\hline 20 & 80.0 & 3.0 & 2.0 & 10.0 & 0.0 & 2.0 & 3.0 & 0.0 & 0.0 & 20 & $p$ & 4 & 4 & 0 \\
\hline 21 & 84.0 & 5.0 & 0.0 & 5.0 & 0.0 & 1.0 & 5.0 & 0.0 & 0.0 & 21 & a & 2 & 2 & 0 \\
\hline 22 & 50.0 & 3.0 & 30.0 & 15.0 & 0.0 & 0.0 & 1.0 & 0.0 & 1.0 & 22 & $\bar{A}$ & 3 & 2 & 1 \\
\hline 23 & 84.0 & 0.0 & 0.0 & 10.0 & 1.0 & 1.0 & 2.0 & 0.0 & 2.0 & 23 & $n$ & 2 & 2 & 0 \\
\hline 24 & 75.0 & 0.0 & 2.0 & 10.0 & 10.0 & 0.0 & 1.0 & 0.0 & 2.0 & 24 & $f$ & 2 & 2 & 0 \\
\hline 25 & 70.0 & 0.0 & 0.0 & 20.0 & 2.0 & 3.0 & 2.0 & 0.0 & 3.0 & 25 & $F$ & 2 & 2 & 0 \\
\hline 26 & 75.0 & 0.0 & 0.0 & 15.0 & 2.0 & 2.0 & 1.0 & 0.0 & 5.0 & 26 & w & 2 & 1 & 1 \\
\hline
\end{tabular}

Anexo 3: Tabela 3 - Análises Modais das Amostras do Nível $10(\mathrm{~N}-10)$ da Mina do Parì

\begin{tabular}{|c|c|c|c|c|c|c|c|c|c|c|c|c|c|c|}
\hline $\begin{array}{c}\text { Amostra } \\
\text { No. }\end{array}$ & \begin{tabular}{|c|} 
Hornblenda \\
$\mathrm{Hb}$
\end{tabular} & $\begin{array}{l}\text { Clorita } \\
\mathrm{Cl}\end{array}$ & $\begin{array}{c}\text { Biotita } \\
\text { Bi }\end{array}$ & $\begin{array}{c}\text { Quartzo } \\
\text { Qz }\end{array}$ & $\begin{array}{c}\text { Granada } \\
\text { Gr }\end{array}$ & \begin{tabular}{|c|} 
Carbonato \\
$\mathrm{Cb}$
\end{tabular} & $\begin{array}{c}\text { Plagiocl. } \\
\text { PI }\end{array}$ & $\begin{array}{c}\text { Grun/Fluot } \\
\text { GF }\end{array}$ & $\begin{array}{c}\text { Opacos } \\
\text { Op }\end{array}$ & & $\begin{array}{l}\text { Petro- } \\
\text { grafia }\end{array}$ & $\frac{\text { Lâminas }}{\text { Total }}$ & $\frac{\text { Antigas }}{1995}$ & $\frac{\text { Novas }}{2002}$ \\
\hline $20 \mathrm{~B}$ & 60,0 & 20,0 & 10,0 & 8,0 & 0,0 & 0,0 & 2,0 & 0,0 & 0,0 & \multirow{5}{*}{$\begin{array}{l}20 \mathrm{~B} \\
19 \mathrm{~B} \\
18 \mathrm{~B} \\
178 \\
16 \mathrm{~B} \\
\end{array}$} & \multirow{5}{*}{$\begin{array}{l}\text { c } \\
\text { a } \\
\text { p } \\
\text { a }\end{array}$} & 1 & 1 & \\
\hline 198 & 63.0 & 5.0 & 10.0 & 20.0 & 0.0 & 1.0 & 0.0 & 0.0 & 1.0 & & & 2 & 2 & \\
\hline $18 \mathrm{~B}$ & 78.0 & 10.0 & 1.0 & 5.0 & 0.0 & 0.0 & 5.0 & 0.0 & 1.0 & & & 1 & 1 & \\
\hline $17 \mathrm{~B}$ & & & & & & & & & & & & 0 & 0 & \\
\hline 168 & 30.0 & 30.0 & 30.0 & 3.0 & 3.0 & 0.0 & 0.0 & 2.0 & 2.0 & & & 2 & 2 & \\
\hline $15 B$ & 29.0 & 0.0 & 25.0 & 15.0 & 15.0 & 1.0 & 0.0 & 0.0 & 15.0 & \multirow{7}{*}{$\begin{array}{l}15 \mathrm{~B} \\
14 \mathrm{~B} \\
13 \mathrm{~B} \\
12 \mathrm{~B} \\
11 \mathrm{~B} \\
10 \mathrm{~B} \\
09 \mathrm{~B} \\
\end{array}$} & \multirow{7}{*}{$\begin{array}{l}\mathbf{W} \\
\mathbf{i} \\
\mathbf{n} \\
\mathbf{e} \\
\mathbf{r} \\
\mathbf{i} \\
\mathbf{o}\end{array}$} & 1 & 0 & 1 \\
\hline $14 \mathrm{~B}$ & 20.0 & 0.0 & 10.0 & 30.0 & 10.0 & 15.0 & 0.0 & 0.0 & 15.0 & & & 4 & 3 & 1 \\
\hline $13 \mathrm{~B}$ & 3.0 & 0.5 & 4.5 & 24.0 & 5.0 & 0.5 & 0.0 & 30.0 & 32.5 & & & 5 & 5 & \\
\hline 12B & 2.0 & 1.0 & 30.0 & 30.0 & 20.0 & 0.0 & 0.0 & 2.0 & 15.0 & & & 2 & 2 & \\
\hline 11B & 0.5 & 3.0 & 11.0 & 55.0 & 10.0 & 2.0 & 0.0 & 6.0 & 12.5 & & & 3 & 3 & \\
\hline $10 B$ & 18.0 & 1.0 & 16.0 & 20.0 & 5.0 & 10.0 & 0.0 & 10.0 & 20.0 & & & 5 & 5 & \\
\hline 09B & 5.0 & 0.0 & 20.0 & 35.0 & 20.0 & 0.0 & 0.0 & 5.0 & 15.0 & & & 3 & 3 & \\
\hline $08 \mathrm{~B}$ & 65.0 & 2.5 & 2.5 & 20.0 & 0.0 & 5.0 & 5.0 & 0.0 & 0.0 & \multirow{8}{*}{$\begin{array}{l}07 B \\
06 B \\
06 B \\
05 B \\
04 B \\
03 B \\
02 B \\
02 B \\
01 B\end{array}$} & \multirow[t]{8}{*}{ 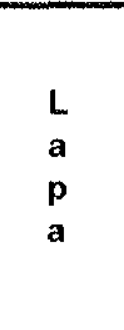 } & 7 & 7 & \\
\hline 07B & 60.0 & 5.0 & 4.0 & 20.0 & 0.0 & 5.0 & 5.0 & 0.0 & 1.0 & & & 1 & 0 & 1 \\
\hline 06B & 30.0 & 1.0 & 35.0 & 15.0 & 0.0 & 15.0 & 4.0 & 0.0 & 0.0 & & & 4 & 4 & \\
\hline 05B & 30.0 & 1.0 & 35.0 & 15.0 & 0.0 & 15.0 & 4.0 & 0.0 & 0.0 & & & 5 & 5 & \\
\hline $04 \mathrm{~B}$ & 30.0 & 1.0 & 35.0 & 15.0 & 0.0 & 15.0 & 4.0 & 0.0 & 0.0 & & & 2 & 2 & \\
\hline O3B & 25.0 & 5.0 & 20.0 & 10.0 & 0.0 & 15.0 & 15.0 & 0.0 & 10.0 & & & 4 & 4 & \\
\hline 02B & 25.0 & 0.0 & 30.0 & 35.0 & 0.0 & 0.0 & 9.0 & 0.0 & 1.0 & & & 1 & 1 & \\
\hline $01 \mathrm{~B}$ & 40.0 & 1.0 & 24.0 & 25.0 & 0.0 & 0.0 & 9.0 & 0.0 & 1.0 & & & 2 & 2 & \\
\hline
\end{tabular}


Anexo 4: Tabelas de Dados Geoquímicos de Rochas e Minérios (FRX, ICP-MS, Fire Assay-AAS) 
Anexo 4: Tabela 1 - Análises via Florescência de raios $X \ominus$ de As, Au $\theta$ Ag de amostras do Nivel 00 da Mina do Pari

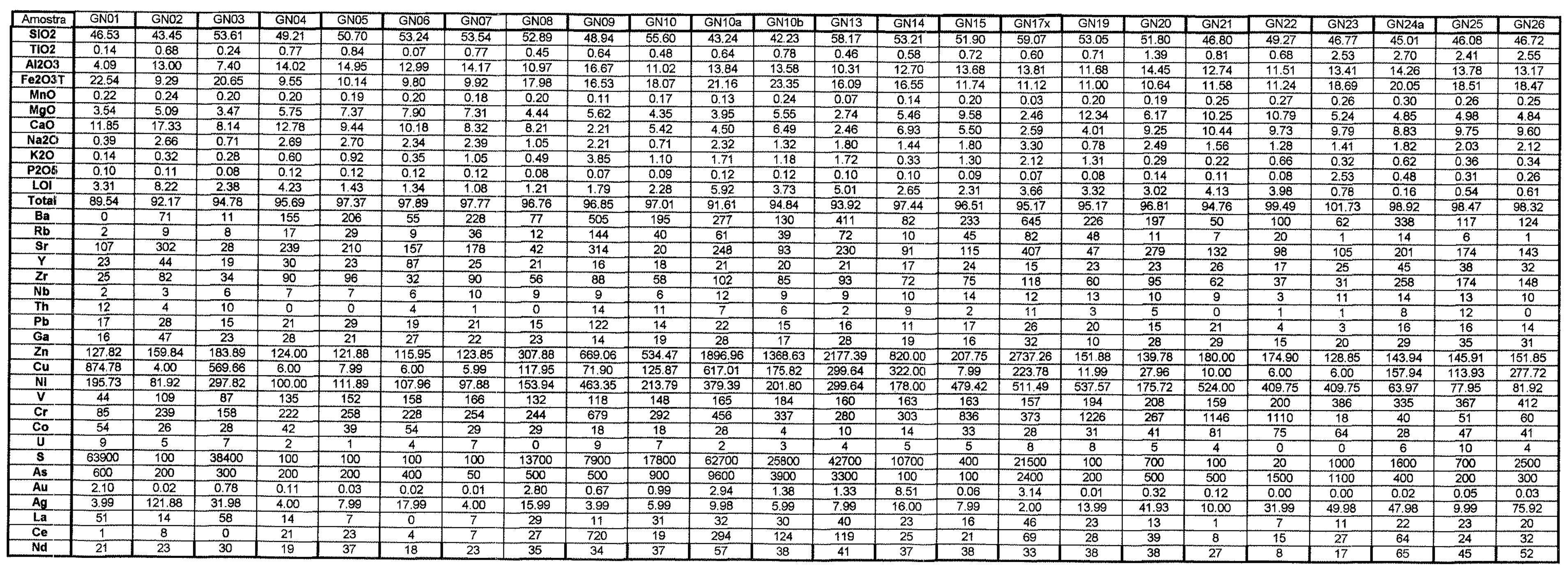


Anexo 4: Tabela 2 - Análises via Florescência de raios Xde Amostras do Nível 10 da Mina do Pari

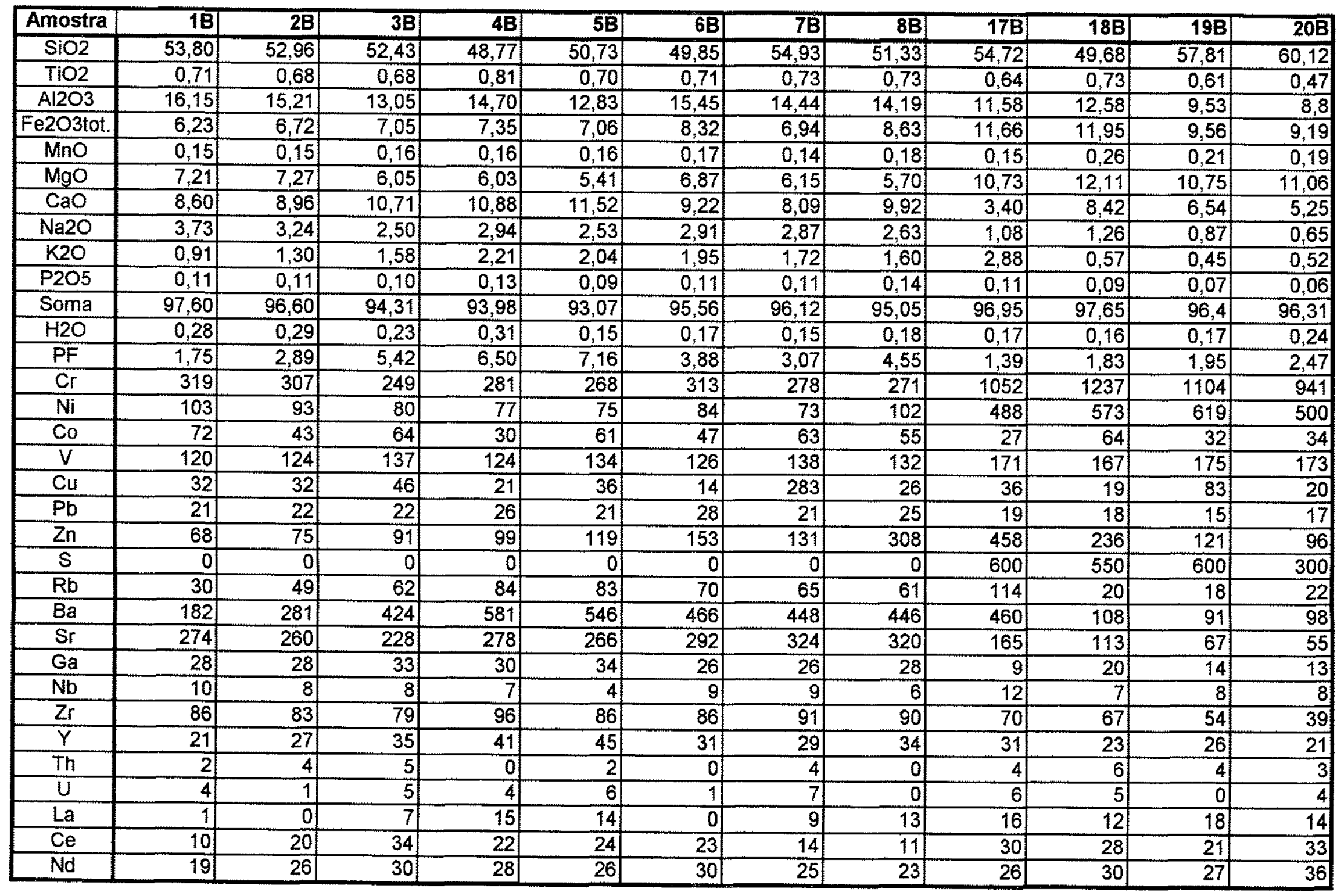


Anexo 4: Tabela 3 - Análises via FRX e de As, Au e Ag de testemunhos e galerias da Mina do Pari n.a. - não analisado

\begin{tabular}{|c|c|c|c|c|c|c|c|c|c|c|}
\hline Amostra & T-39 & $T-41$ & $T-42$ & T-56 & T-58 & $T-60$ & $T-66$ & G-1 & TP10 & TP10b \\
\hline $\mathrm{SiO} 2$ & 49,13 & 50,2 & 48,95 & 48,18 & 51,18 & 48,01 & 48,15 & 46,29 & 43,52 & 58,05 \\
\hline $\mathrm{TiO} 2$ & 1,04 & 1,21 & 0,92 & 2,25 & 1,67 & 2,18 & 1,38 & 2,63 & 0,87 & 0,40 \\
\hline $\mathrm{Al} 2 \mathrm{O} 3$ & 15,04 & 14,82 & 14,36 & 13,79 & 15,21 & 18,75 & 15,07 & 13,77 & 14,48 & 9,82 \\
\hline Fe2O3tot. & 10,88 & 13,38 & 11,44 & 16,97 & 13,29 & 15,93 & 17,28 & 18,87 & 20,17 & 17,60 \\
\hline $\mathrm{MnO}$ & 0,2 & 0,22 & 0,22 & 0,24 & 0,22 & 0,28 & 0,21 & 0,27 & 0,24 & 0,23 \\
\hline $\mathrm{MgO}$ & 5,56 & 7,39 & 5,6 & 5,83 & 5,92 & 3,67 & 5,84 & 5,29 & 6,39 & 3,23 \\
\hline $\mathrm{CaO}$ & 12,36 & 8,79 & 14,8 & 9,88 & 9,1 & 7,96 & 9,7 & 10,31 & 7,08 & 2,22 \\
\hline $\mathrm{Na2O}$ & 1,84 & 2,51 & 1,11 & 1,66 & 2,26 & 2,93 & 1,7 & 1,06 & 1,24 & 1,06 \\
\hline $\mathrm{K} 2 \mathrm{O}$ & 0,27 & 0,18 & 0,11 & 0,38 & 0,27 & 0,34 & 0,33 & 0,28 & 1,28 & 1,93 \\
\hline P2O5 & 0,16 & 0,17 & 0,17 & 0,2 & 0,18 & 0,09 & 0,17 & 0,27 & 0,15 & 0,10 \\
\hline Soma & 96,48 & 98,87 & 97,68 & 99,38 & 99,3 & 100,94 & 99,83 & 99,04 & 95,42 & 94,64 \\
\hline $\mathrm{H} 2 \mathrm{O}$ & 0 & 0 & 0,06 & 0,07 & 0,12 & 0,09 & 0,1 & 0,02 & 0 & 0 \\
\hline PF & 2,81 & 0,75 & 1,35 & 0,92 & 0,61 & 0,62 & 0,5 & 0,54 & 3,38 & 4,28 \\
\hline $\mathrm{Cr}$ & 188 & 168 & 150 & 48 & 122 & 197 & 12 & 19 & 412 & 373 \\
\hline $\mathrm{Ni}$ & 137 & 132 & 92 & 65 & 92 & 167 & 85 & 53 & 205,88 & 197,72 \\
\hline $\mathrm{Co}$ & 54 & 53 & 35 & 45 & 51 & 85 & 66 & 35 & 27 & 6 \\
\hline $\bar{V}$ & 234 & 249 & 228 & 481 & 350 & 413 & 291 & 447 & 180 & 151 \\
\hline $\mathrm{Cu}$ & 107 & 50 & 38 & 227 & 77 & 309 & 49 & 275 & 143,91 & 295,59 \\
\hline $\mathrm{Pb}$ & 11 & 2 & 4 & 0) & 1 & 0 & 7 & 0 & 24 & 17 \\
\hline $\mathrm{Zn}$ & 73 & 93 & 67 & 130 & 115 & 116 & 120 & 157 & 1389,17 & 699,02 \\
\hline$S$ & 0 & 0) & 120 & 0 & 120 & 560 & 0 & 200 & 17500 & 38400 \\
\hline $\mathrm{Rb}$ & 0 & 9 & 0 & 4 & 1 & 1 & 0 & 1 & 43 & 80 \\
\hline $\mathrm{Ba}$ & 48 & 59 & 55 & 46 & 69 & 57 & 22 & 12 & 163 & 349 \\
\hline $\mathrm{Sr}$ & 206 & 95 & 194 & 154 & 188 & 158 & 169 & 123 & 75 & 123 \\
\hline $\mathrm{Ga}$ & 19 & 15 & 21 & 18 & 16 & 21 & 19 & 25 & 29 & 17 \\
\hline $\mathrm{Nb}$ & 5 & 15 & 3 & 17 & 9 & 5 & 10 & 16 & 9 & 8 \\
\hline $\mathrm{Zr}$ & 61 & 106 & 78 & 94 & 78 & 157 & 60 & 113 & 84 & 69 \\
\hline $\bar{Y}$ & 6 & 10 & 11 & 13 & 19 & 37 & 4 & 21 & 23 & 22 \\
\hline Th & 0 & 0 & 5 & O & 10 & 15 & 0 & 0 & 12 & 8 \\
\hline U & 4 & 0 & 7 & 1 & 3 & 0 & 0 & 1 & 6 & 9 \\
\hline $\mathrm{La}$ & 0 & 1. & 2 & 4 & 11 & 1 & 17 & 0 & 23 & 52 \\
\hline $\mathrm{Ce}$ & 0 & 6 & 0 & 0 & 6 & 0 & 0 & 6 & 85 & 108 \\
\hline $\mathrm{Nd}$ & 17 & 3 & 0 & 0 & 22 & 15 & 0 & 17 & 29 & 36 \\
\hline As & n.a. & n.a. & n.a. & n.a. & n.a. & n.a. & n.a. & n.a. & 5200 & 4700 \\
\hline $\mathrm{Au}$ & n.a. & n.a. & n.a. & n.a. & n.a. & n.a. & n.a. & n.a. & 1,99 & 1,03 \\
\hline $\mathrm{Ag}$ & n.a. & n.a. & n.a. & n.a. & n.a. & n.a. & n.a. & n.a. & 8,00 & 3,99 \\
\hline
\end{tabular}




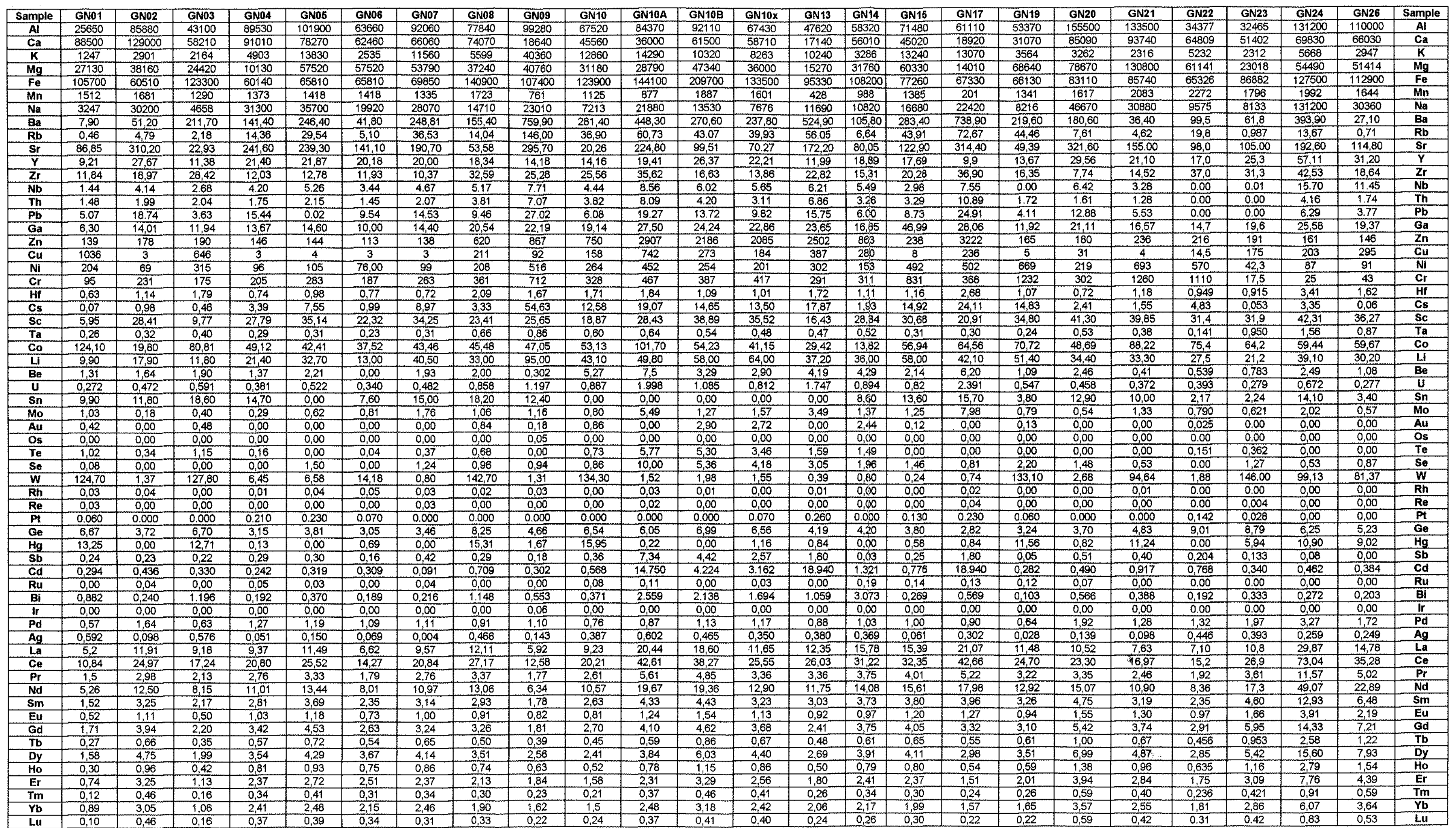


Anexo 4: Tabela 5 - Análises via ICP-MS das amostras do Nível 10 (N-10) da Mina do Pari

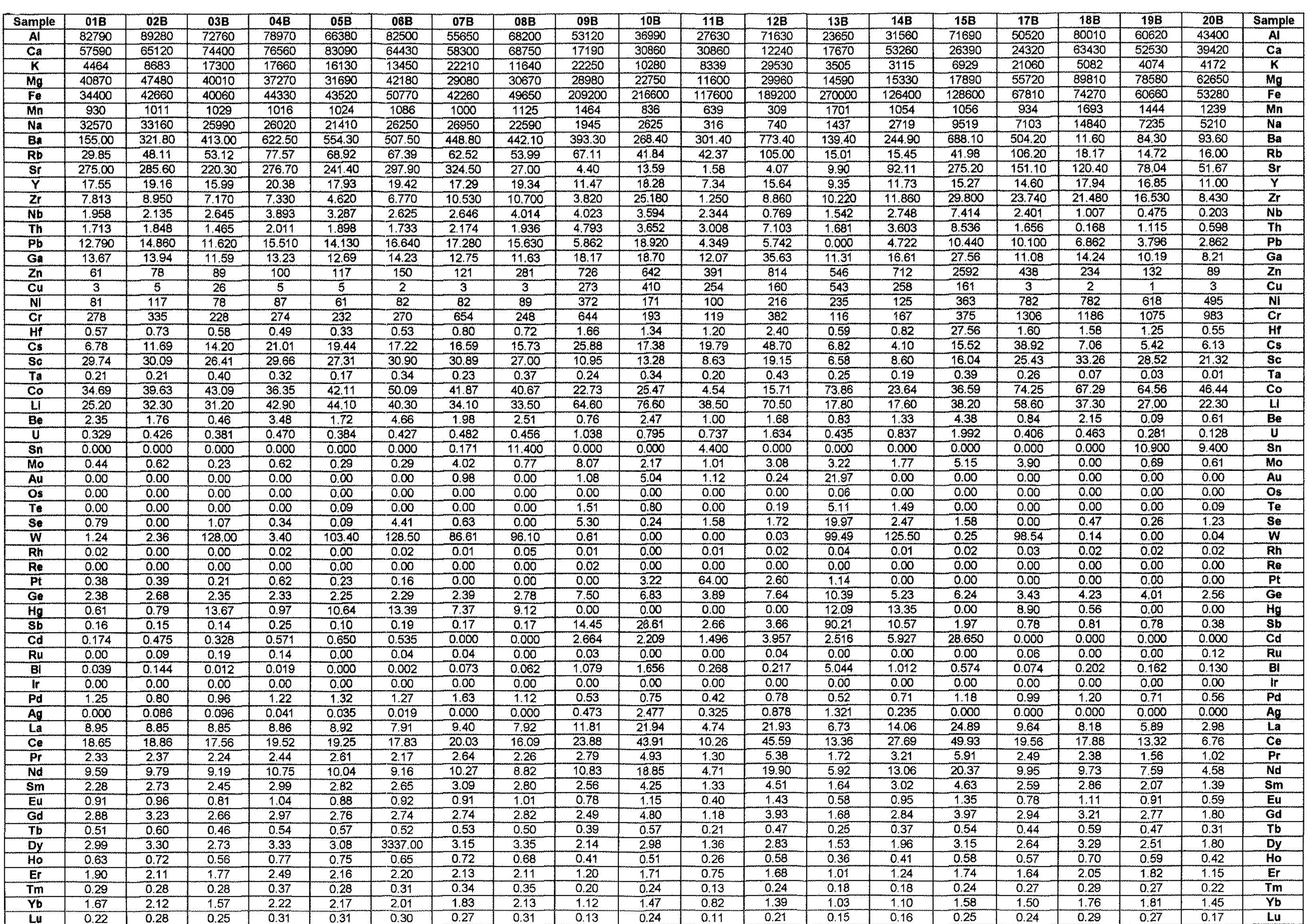


Anexo 5: Tabelas de Dados de Química Mineral (Microssonda Eletrônica) 


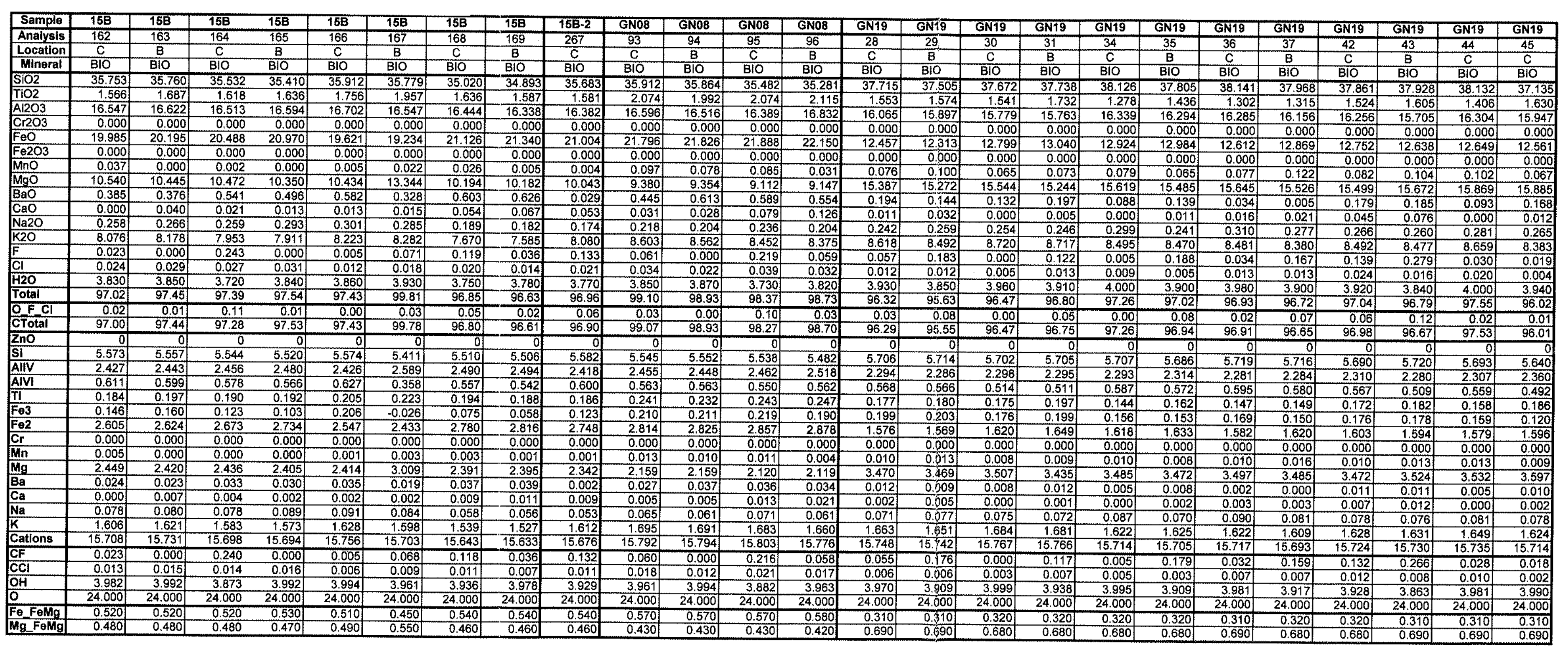




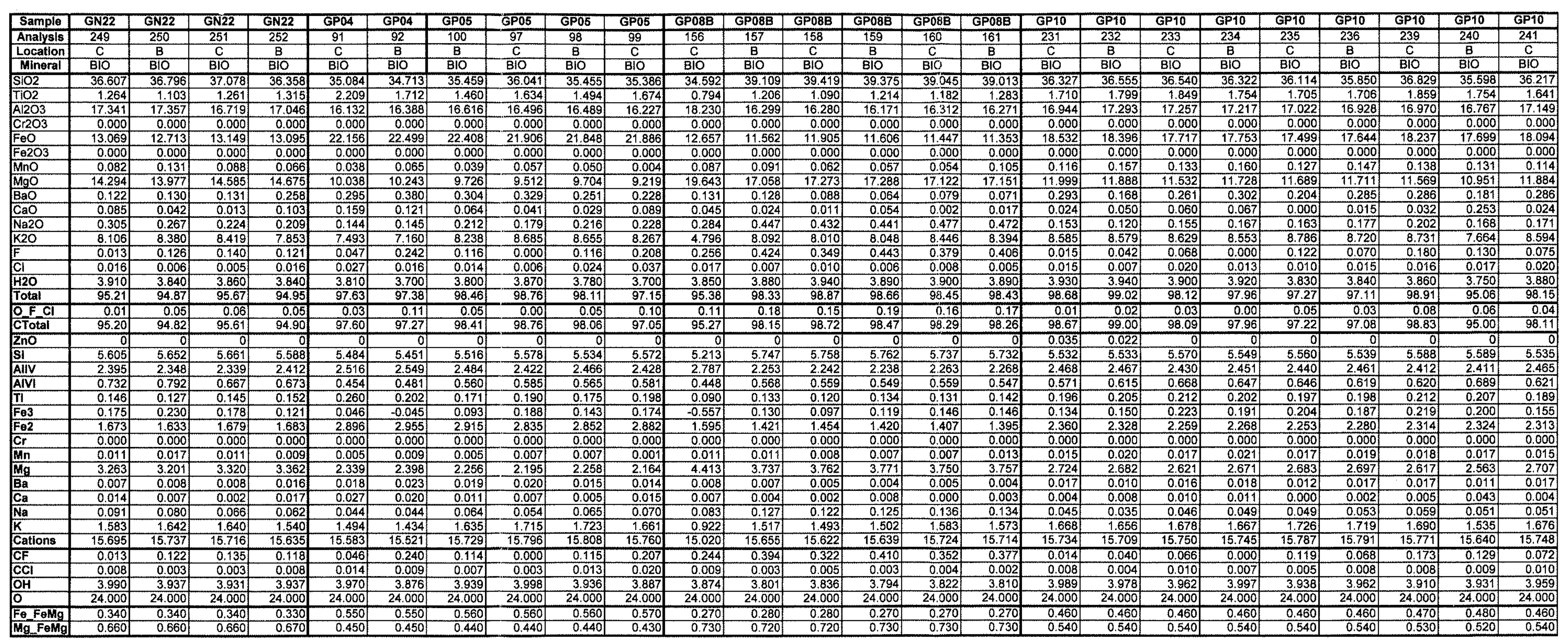


Anexo 5: Tabela 1 - Química Mineral de Biotitas (cont.)

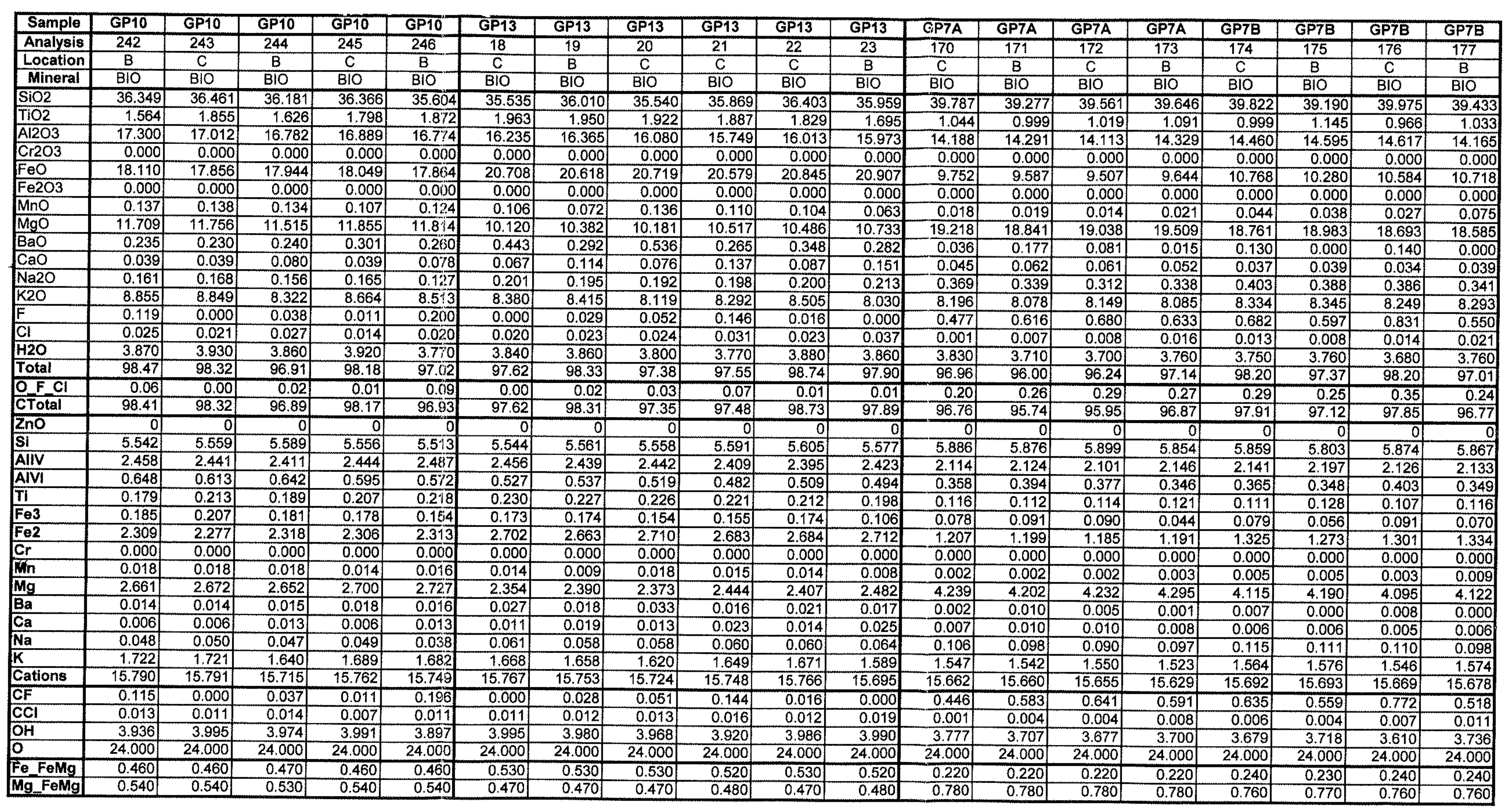




\section{Anexo 5: Tabela 3 - Química Mineral das Muscovitas}

\begin{tabular}{|c|c|c|c|c|}
\hline Sample & GP02 & GP02 & GP02 & $\overline{\mathrm{GPO} 2}$ \\
\hline Analysis & 24 & 25 & 26 & 27 \\
\hline Location & C & $B$ & C & $B$ \\
\hline Mineral & MUS & MUS & MUS & MUS \\
\hline $\mathrm{SiO} 2$ & 46,231 & 46,098 & 46,387 & 46,540 \\
\hline $\mathrm{TiO} 2$ & 0,299 & 0,346 & 0,361 & 0,323 \\
\hline $\mathrm{Al} 2 \mathrm{O} 3$ & 36,878 & 36,831 & 37,248 & 36,948 \\
\hline $\mathrm{FeO}$ & 0,645 & 0,601 & 0,555 & 0,631 \\
\hline Mno & 0,170 & 0,009 & 0,015 & 0,000 \\
\hline $\mathrm{MgO}$ & 0,538 & 0,509 & 0,541 & 0,562 \\
\hline $\mathrm{CaO}$ & 0,018 & 0,000 & 0,057 & 0,055 \\
\hline $\mathrm{Na2O}$ & 2,623 & 2,781 & 2,075 & 2,538 \\
\hline $\mathrm{K} 2 \mathrm{O}$ & 7,361 & 7,151 & 7,629 & 7,267 \\
\hline$F$ & 0,063 & 0,000 & 0,077 & 0,000 \\
\hline $\mathrm{Cl}$ & 0,000 & 0,010 & 0,006 & 0,000 \\
\hline Total & 94,93 & 94,41 & 95,15 & 94,97 \\
\hline $\mathrm{OFCl}$ & 0,03 & 0,00 & 0,03 & 0,00 \\
\hline CTotal & 94,90 & 94,41 & 95,12 & 94,97 \\
\hline $\mathrm{BaO}$ & 0,104 & 0,074 & 0,196 & 0,108 \\
\hline Si & 6,094 & 6,095 & 6,093 & 6,114 \\
\hline AllV & 1,906 & 1,905 & 1,907 & 1,886 \\
\hline Sum_T & 8 & 8 & 8 & 8 \\
\hline AIVI & 3,819 & 3,830 & 3,855 & 3,830 \\
\hline $\mathrm{Ti}$ & 0,030 & 0,034 & 0,036 & 0,032 \\
\hline \multicolumn{5}{|l|}{$\mathrm{Fe} 3$} \\
\hline $\mathrm{Fe} 2$ & 0,071 & 0,066 & 0,061 & 0,069 \\
\hline \multicolumn{5}{|l|}{$\mathrm{Cr}$} \\
\hline $\mathrm{Mn}$ & 0,019 & 0,001 & 0,002 & 0,000 \\
\hline $\mathrm{Mg}$ & 0,106 & 0,100 & 0,106 & 0,110 \\
\hline $\mathrm{Ca}$ & 0,003 & 0,000 & 0,008 & 0,008 \\
\hline $\mathrm{Na}$ & 0,670 & 0,713 & 0,529 & 0,647 \\
\hline $\mathrm{K}$ & 1,238 & 1,206 & 1,278 & 1,218 \\
\hline Cations & & & & \\
\hline $\mathrm{CF}$ & 0,053 & 0 & 0,064 & 0 \\
\hline $\mathrm{CCl}$ & 0 & 0,004 & 0,003 & 0 \\
\hline \multicolumn{5}{|l|}{$\mathrm{OH}$} \\
\hline 0 & 24 & 24 & 24 & 24 \\
\hline Fe FeMg & 0,40 & 0,40 & 0,37 & 0,39 \\
\hline Mg_FeMg & 0,60 & 0,60 & 0,63 & 0,61 \\
\hline
\end{tabular}




\begin{tabular}{|c|c|c|c|c|c|c|c|c|c|c|c|c|c|c|c|c|c|c|c|}
\hline Sample & GN19 & GN19 & GN19 & GN19 & GN19 & GN19 & GN19 & GN19 & GN19 & GN22 & GN22 & GN22 & GN22 & GN22 & GN22 & GP10 & GP10 & GP10 & GP10 \\
\hline Analysis & 32 & 32 & 38 & 39 & 40 & 41 & 46 & 47 & 48 & 253 & 254 & 255 & 256 & 257 & 258 & 237 & 238 & 247 & 248 \\
\hline Location & B & C & $\mathrm{C}$ & $B$ & $\mathrm{C}$ & $B$ & $\mathrm{C}$ & $\bar{B}$ & C & $\mathrm{c}$ & $B$ & $\mathrm{C}$ & $\mathrm{B}$ & c & $B$ & B & c & C & $\mathrm{B}$ \\
\hline Mineral & $\mathrm{CLO}$ & $\mathrm{CLO}$ & CLO & $\mathrm{CLO}$ & CLO & CLO & CLO & CLO & CLO & $\mathrm{CLO}$ & CLO & CLO & CLO & CLO & CLO & $\mathrm{CLO}$ & CLO & CLO & CLO \\
\hline $\mathrm{SiO} 2$ & 28.704 & 26.656 & 26.527 & 26.853 & 26.517 & 26.765 & 26.593 & 24.877 & 26.866 & 26.302 & 26.217 & 26.529 & 26.499 & 26.579 & 26.322 & 26.689 & 26.137 & 26.100 & 26.046 \\
\hline $\mathrm{TiO}_{2}$ & 0.376 & 0.102 & 0.049 & 0.062 & 0.075 & 0.094 & 0.099 & 0.113 & 0.101 & 0.065 & 0.023 & 0.046 & 0.076 & 0.094 & 0.038 & 0.103 & 0.155 & 0.063 & 0.066 \\
\hline $\mathrm{Al} 2 \mathrm{O}$ & 20.318 & 21.411 & 21.300 & 21.443 & 21.248 & 21.487 & 21.473 & 20.487 & 21.290 & 21.556 & 21.355 & 21.486 & 21.276 & 21.299 & 21.261 & 21.425 & 21.323 & 21.086 & 21.225 \\
\hline $\mathrm{FeO}$ & 14.619 & 15.000 & 14.922 & 15.219 & 15.020 & 15.196 & 14.752 & 14.359 & 14.632 & 15.801 & 15.792 & 15.588 & 15.530 & 15.725 & 15.563 & 21.119 & 20.918 & 21.142 & 20.833 \\
\hline $\mathrm{Fe} 2 \mathrm{O} 3$ & 0.000 & 0.000 & 0.000 & 0.000 & 0.000 & 0.000 & 0.000 & 0.000 & 0.000 & 0.000 & 0.000 & 0.000 & 0.000 & 0.000 & 0.000 & 0.000 & 0.000 & 0.000 & 0.000 \\
\hline $\mathrm{MnO}$ & 0.171 & 0.112 & 0.129 & 0.141 & 0.150 & 0.145 & 0.144 & 0.130 & 0.172 & 0.158 & 0.162 & 0.176 & 0.122 & 0.122 & 0.159 & 0.215 & 0.229 & 0.191 & 0.275 \\
\hline $\mathrm{MgO}$ & 20.258 & 21.510 & 21.153 & 21.049 & 21.186 & 21.289 & 21.691 & 21.563 & 21.652 & 20.345 & 20.592 & 20.614 & 20.115 & 20.557 & 20.371 & 17.357 & 17.312 & 17.523 & 17.515 \\
\hline $\mathrm{CaO}$ & 0.009 & 0.022 & 0.021 & 0.009 & 0.011 & 0.025 & 0.026 & 0.000 & 0.038 & 0.012 & 0.027 & 0.006 & 0.018 & 0.045 & 0.031 & 0.044 & 0.045 & 0.018 & 0.032 \\
\hline $\mathrm{Na2O}$ & 0.045 & 0.009 & 0.008 & 0.022 & 0.011 & 0.018 & 0.010 & 0.000 & 0.000 & 0.022 & 0.010 & 0.000 & 0.009 & 0.029 & 0.006 & 0.001 & 0.015 & 0.000 & 0.013 \\
\hline $\mathrm{K} 2 \mathrm{O}$ & 1.346 & 0.050 & 0.017 & 0.012 & 0.008 & 0.004 & 0.002 & 0.011 & 0.007 & 0.026 & 0.001 & 0.013 & 0.000 & 0.005 & 0.002 & 0.068 & 0.039 & 0.023 & 0.009 \\
\hline $\mathbf{F}$ & 0.000 & 0.051 & 0.000 & 0.016 & 0.012 & 0.000 & 0.000 & 0.051 & 0.000 & 0.000 & 0.019 & 0.003 & 0.077 & 0.000 & 0.015 & 0.092 & 0.026 & 0.000 & 0.048 \\
\hline $\mathrm{Cl}$ & 0.000 & 0.002 & 0.003 & 0.011 & 0.011 & 0.015 & 0.006 & 0.001 & 0.008 & 0.003 & 0.007 & 0.004 & 0.000 & 0.006 & 0.007 & 0.000 & 0.004 & 0.041 & 0.011 \\
\hline Total & 85.90 & 84.93 & 84.16 & 84.84 & 84.25 & 85.04 & 84.80 & 81.64 & 84.77 & 84.32 & 84.26 & 84.52 & 83.81 & 84.46 & 83.78 & 87.21 & 86.20 & 86.23 & 86.07 \\
\hline O_F_Cl & 0.000 & 0.020 & 0.000 & 0.010 & 0.010 & 0.000 & 0.000 & 0.020 & 0.000 & 0.000 & 0.010 & 0.000 & 0.030 & 0.000 & 0.010 & 0.040 & 0.010 & 0.010 & 0.020 \\
\hline$\overline{O F}$ & 0.000 & 0.020 & 0.000 & 0.010 & 0.010 & 0.000 & 0.000 & 0.020 & 0.000 & 0.000 & 0.010 & 0.000 & 0.030 & 0.000 & 0.010 & 0.040 & 0.010 & 0.000 & 0.020 \\
\hline $\mathrm{O}$ Cl & 0.000 & 0.000 & 0.000 & 0.000 & 0.000 & 0.000 & 0.000 & 0.000 & 0.000 & 0.000 & 0.000 & 0.000 & 0.000 & 0.000 & 0.000 & 0.000 & 0.000 & 0.010 & 0.000 \\
\hline CTotal & 85.90 & 84.91 & 84.16 & 84.83 & 84.24 & 85.04 & 84.80 & 81.62 & 84.77 & 84.32 & 84.25 & 84.52 & 83.78 & 84.46 & 83.77 & 87.17 & 86.19 & 86.22 & 86.05 \\
\hline $\mathrm{BaO}$ & 0.055 & 0.000 & 0.033 & 0.000 & 0.000 & 0.000 & 0.000 & 0.047 & 0.002 & 0.029 & 0.054 & 0.052 & 0.076 & 0.000 & 0.000 & 0.095 & 0.000 & 0.041 & 0.000 \\
\hline $\mathrm{si}$ & 5.849 & 5.484 & 5.503 & 5.529 & 5.499 & 5.499 & 5.469 & 5.340 & 5.522 & 5.473 & 5.465 & 5.499 & 5.542 & 5.515 & 5.506 & 5.525 & 5.470 & 5.470 & 5.461 \\
\hline AllV & 2.151 & 2.516 & 2.497 & 2.471 & 2.501 & 2.501 & 2.531 & 2.660 & 2.478 & 2.527 & 2.535 & 2.501 & 2.458 & 2.485 & 2.494 & 2.475 & 2.530 & 2.530 & 2.539 \\
\hline Sum_T & & & 8 & 8 & & & 8 & 8 & 8 & 8 & 8 & 8 & 8 & 8 & 8 & 8 & 8 & 8 & \\
\hline AIVI & \begin{tabular}{|l|}
2.725 \\
\end{tabular} & 2.672 & 2.707 & 2.729 & 2.688 & 2.698 & 2.670 & 2.519 & 2.675 & 2.755 & 2.707 & 2.744 & 2.782 & 2.720 & 2.744 & 2.748 & 2.725 & 2.675 & 2.702 \\
\hline $\mathrm{Ti}$ & 0.058 & 0.016 & 0.008 & 0.010 & 0.012 & 0.015 & 0.015 & 0.018 & 0.016 & 0.010 & 0.004 & 0.007 & 0.012 & 0.015 & 0.006 & 0.016 & 0.024 & 0.010 & 0.010 \\
\hline $\mathrm{Fe3}$ & 0.000 & 0.000 & 0.000 & 0.000 & 0.000 & 0.000 & 0.000 & 0.000 & 0.000 & 0.000 & 0.000 & 0.000 & 0.000 & 0.000 & 0.000 & 0.000 & 0.000 & 0.000 & 0.000 \\
\hline $\mathrm{Fe} 2$ & 2.491 & 2.581 & 2.589 & 2.621 & 2.605 & 2.611 & 2.537 & 2.578 & 2.515 & 2.750 & 2.753 & 2.702 & 2.718 & 2.729 & 2.723 & 3.656 & 3.661 & 3.706 & 3.653 \\
\hline $\mathrm{Cr}$ & & & & & & & & & & & & & & & & & & & \\
\hline$\overline{M n}$ & 0.030 & 0.020 & 0.023 & 0.025 & 0.026 & 0.025 & 0.025 & 0.024 & 0.030 & 0.028 & 0.029 & 0.031 & 0.022 & 0.021 & 0.028 & 0.038 & 0.041 & 0.034 & 0.049 \\
\hline $\mathrm{Mg}$ & 6.154 & 6.597 & 6.542 & 6.461 & 6.550 & 6.521 & 6.651 & 6.900 & 6.634 & 6.311 & 6.399 & 6.370 & 6.272 & 6.359 & 6.353 & 5.356 & 5.401 & 5.475 & 5.475 \\
\hline $\mathrm{Ca}$ & 0.002 & 0.005 & 0.005 & 0.002 & 0.002 & 0.006 & 0.006 & 0.000 & 0.008 & 0.003 & 0.006 & 0.001 & 0.004 & 0.010 & 0.007 & 0.010 & 0.010 & 0.004 & 0.007 \\
\hline $\mathrm{Na}$ & 0.018 & 0.004 & 0.003 & 0.009 & 0.004 & 0.007 & 0.004 & 0.000 & 0.000 & 0.009 & 0.004 & 0.000 & 0.004 & 0.012 & 0.002 & 0.000 & 0.006 & 0.000 & 0.005 \\
\hline $\mathrm{K}$ & 0.350 & 0.013 & 0.004 & 0.003 & 0.002 & 0.001 & 0.001 & 0.003 & 0.002 & 0.007 & 0.000 & 0.003 & 0.000 & 0.001 & 0.001 & 0.018 & 0.010 & 0.006 & 0.002 \\
\hline Cations & 19.828 & 19.908 & 19.881 & 19.860 & 19.889 & 19.884 & 19.909 & 20.042 & 19.880 & 19.873 & 19.902 & 19.858 & 19.814 & 19.867 & 19.864 & 19.842 & 19.878 & 19.910 & 19.903 \\
\hline CF & 0.000 & 0.066 & 0.000 & 0.021 & 0.016 & 0.000 & 0.000 & 0.069 & 0.000 & 0.000 & 0.025 & 0.004 & 0.102 & 0.000 & 0.020 & 0.120 & 0.034 & 0.000 & 0.064 \\
\hline $\mathrm{CCl}$ & 0.000 & 0.001 & 0.002 & 0.008 & 0.008 & 0.010 & 0.004 & 0.001 & 0.006 & 0.002 & 0.005 & 0.003 & 0.000 & 0.004 & 0.005 & 0.000 & 0.003 & 0.029 & 0.008 \\
\hline $\mathrm{OH}$ & & & & & & & & & & & & & & & & & & & \\
\hline 0 & 36 & 36 & 36 & 36 & 36 & 36 & 36 & 36 & 36 & 36 & 36 & 36 & 36 & 36 & 36 & 36 & 36 & 36 & 36 \\
\hline $\mathrm{Fe} \_\mathrm{FeMg}$ & 0.29 & 0.28 & 0.28 & 0.29 & 0.28 & 0.29 & 0.28 & 0.27 & 0.27 & 0.30 & 0.30 & 0.30 & 0.30 & 0.30 & 0.30 & 0.41 & 0.40 & 0.40 & 0.40 \\
\hline $\mathrm{Mg} \_$FeMg & 0.71 & 0.72 & 0.72 & 0.71 & 0.72 & 0.71 & 0.72 & 0.73 & 0.73 & 0.70 & 0.70 & 0.70 & 0.70 & 0.70 & 0.70 & 0.59 & 0.60 & 0.60 & 0.60 \\
\hline
\end{tabular}




\begin{tabular}{|c|c|c|c|c|c|c|c|c|c|c|c|c|c|c|c|c|c|c|c|c|c|c|c|c|c|}
\hline ample & 14B & 4B & 14B & 14B & 14B & $\frac{4 B}{12}$ & $\frac{4 B}{414}$ & 告8 & A & 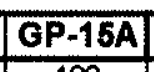 & 100 & 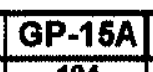 & 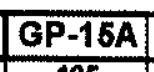 & 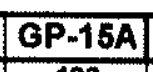 & & - 10 & 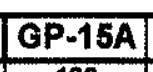 & $S P-15 A$ & 158 & 158 & $15 B$ & $\frac{15 \mathrm{~B}}{124}$ & $\frac{15 B}{125}$ & 158 & $\frac{15 \mathrm{E}}{137}$ \\
\hline & $\mathrm{c}$ & & $\bar{c}$ & 8 & $c$ & $\frac{213}{8}$ & $\frac{214}{c}$ & 告 & $\frac{121}{\mathrm{c}}$ & $\frac{122}{B}$ & $\frac{123}{c}$ & 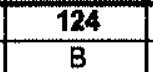 & $\frac{126}{c}$ & $\frac{126}{B}$ & 127 & $\frac{128}{B}$ & $\frac{129}{c}$ & $\frac{130}{8}$ & $\frac{131}{c}$ & $\frac{132}{B}$ & 133 & $\begin{array}{ll}344 \\
B\end{array}$ & 135 & $\frac{136}{B}$ & \\
\hline & $A N$ & ANV & $\frac{\mathrm{ANV}}{\mathrm{ANV}}$ & $\frac{\mathrm{ANV}}{\mathrm{ANV}}$ & $\frac{\mathrm{ANV}}{\mathrm{ANV}}$ & & & $\frac{D}{A N}$ & GRU & $\frac{B}{G R U}$ & $\frac{C}{A N V}$ & $\frac{B}{A N I}$ & $\frac{c}{A N V}$ & $\frac{\mathrm{B}}{\mathrm{ANV}}$ & $\frac{c}{G R}$ & $\frac{B}{G R U}$ & $\frac{c}{\text { GRU }}$ & $\frac{\mathrm{B}}{\mathrm{GRU}}$ & $\frac{c}{\text { GRU }}$ & $\frac{B}{\text { SRU }}$ & $\mathrm{HB}$ & $\frac{D}{8 B}$ & $\mathrm{HB}$ & $\frac{D}{\mathrm{HB}}$ & $\frac{\mathrm{ANV}}{\mathrm{ANV}}$ \\
\hline & $\frac{42.483}{0.395}$ & $\begin{array}{r}-43.401 \\
0.297\end{array}$ & $\frac{42.049}{0.340}$ & $\frac{-30.794}{0.799}$ & $\frac{40.632}{0.335}$ & 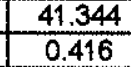 & $\frac{42.486}{0.300}$ & 39.982 & $\frac{49.188}{0.047}$ & $\frac{49.341}{0.0000}$ & $\frac{39.631}{0.250}$ & $\frac{39.699}{0.629}$ & $\frac{39.811}{0.251}$ & $\frac{40.243}{0.257}$ & $\frac{48.442}{0.000}$ & $\frac{0.014}{0.011}$ & 36 & .006 & 0.038 & $\frac{1.649}{0.049}$ & $\frac{40.818}{0.316}$ & $\frac{0.456}{0.0433}$ & & 36 & $\begin{array}{ll}11.993 \\
0.272\end{array}$ \\
\hline$\frac{1203}{1203}$ & $\frac{13.678}{18235}$ & $\begin{array}{l}13.285 \\
18434\end{array}$ & $\frac{14.595}{11890}$ & $\frac{12.285}{18155}$ & $\frac{16.641}{19690}$ & $\frac{15.479}{1806}$ & $\frac{14.097}{18209}$ & $\begin{array}{l}\frac{18.204}{18.201} \\
19012\end{array}$ & $\begin{array}{l}0.525 \\
000505\end{array}$ & $\frac{0.519}{0.519}$ & $\frac{2.530}{2.530}$ & $\frac{1.2614}{27.614}$ & $\frac{\frac{1.2214}{12.214}}{2850}$ & $\frac{\frac{1.258}{12.298}}{3.8900}$ & $\begin{array}{l}\frac{0.066}{0.366} \\
2777^{2}\end{array}$ & $\frac{0.010}{0.508}$ & $\frac{0.000}{0.595}$ & $\frac{\frac{607}{467}}{6929}$ & $\frac{0.030}{0.738}$ & $\frac{0.074}{7.714}$ & $\frac{\frac{15.151}{1.651}}{170010}$ & 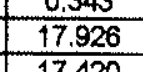 & $\frac{736}{360}$ & 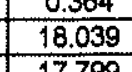 & 5.486 \\
\hline & $\frac{\frac{18.235}{0.225}}{0.225}$ & $\frac{18.436}{0.074}$ & $\frac{18.180}{0.082}$ & $\frac{18.156}{0.088}$ & $\frac{\frac{19.609}{0.093}}{0.093}$ & $\frac{18.068}{0.057}$ & $\frac{18.209}{0.076}$ & $\frac{1912}{949}$ & $\frac{40.05}{0.000}$ & & $\frac{28.255}{0.005}$ & 27.838 & $\frac{28.500}{0.000}$ & $\frac{2.699}{0.059}$ & $\frac{39.773}{0.000}$ & $\frac{39.588}{0.007}$ & $\frac{39.375}{0.036}$ & $\begin{array}{l}39.988 \\
0.019\end{array}$ & 26.820 & 27.042 & $\frac{909}{111}$ & $\begin{array}{ll}7.420 \\
0.075\end{array}$ & $\frac{19.269}{0.060}$ & 7.799 & $\frac{6864}{154}$ \\
\hline & $\frac{0.102}{8.146}$ & $\frac{0.108}{8174}$ & $\frac{0.038}{7589}$ & $\frac{0.054}{8779}$ & $\frac{0.076}{60706}$ & $\frac{0.034}{7157}$ & 0.0555 & 20 & $\frac{0.473}{5.562}$ & $\frac{0.493}{6021}$ & $\frac{0.044}{2.961}$ & $\frac{0.117}{2800}$ & $\frac{0.139}{0.073}$ & $\frac{0.098}{2070}$ & $\frac{0.541}{6.114}$ & $\frac{0.570}{5.553}$ & $\frac{0.518}{57939}$ & & & 105 & & & 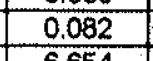 & 048 & 71 \\
\hline & $\frac{0.140}{10.939}$ & $\frac{.0 .14}{1.356}$ & $\frac{7.569}{11.213}$ & $\frac{.019}{11.430}$ & $\frac{0.050}{11.269}$ & $\frac{1.17}{285}$ & & & $\frac{5.962}{0.574}$ & 0.588 & & & $\frac{2.973}{10.716}$ & 10.896 & & $\frac{5.953}{0.577}$ & & & & & & $\frac{7.286}{10607}$ & 6.654 & $\frac{269}{597}$ & $\begin{array}{l}.3744 \\
0.0799\end{array}$ \\
\hline KOC & 1.179 & & 215 & & $\frac{1.245}{0.512}$ & $\frac{1.211}{1.211}$ & $\frac{50}{50}$ & & 0.027 & 0.043 & 288 & 1.605 & $\frac{1.142}{1.142}$ & 1.211 & & $\frac{0.051}{0.050}$ & 0.067 & 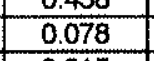 & . .0444 & 0.058 & $\frac{1.130}{1.432}$ & $\frac{1.5066}{1.566}$ & .011 & $\frac{5971}{454}$ & . $\frac{0.157}{307}$ \\
\hline & . & $\frac{0.306}{0.000}$ & .000 & $\frac{0.411}{0.105}$ & $\begin{array}{l}0.512 \\
0.005\end{array}$ & $\begin{array}{l}0.564 \\
0.044\end{array}$ & 500 & . 5000 & $\frac{0.000}{0.063}$ & $\frac{0.000}{0.033}$ & $\frac{0.787}{0.077}$ & $\frac{0.742}{0.000}$ & $\begin{array}{l}0.772 \\
0.000\end{array}$ & $\frac{0.697}{0.007}$ & & 0.002 & $\frac{0.000}{0.000}$ & $\frac{0.015}{0.000}$ & $\frac{0.003}{0.000}$ & $\frac{0.05}{0.0107}$ & $\frac{0.319}{0.002}$ & 0.289 & .407 & 316 & \\
\hline & & .008 & & & & & & & & & & 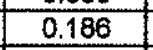 & & & & & & & & & & & & & \\
\hline & $\frac{95.82}{9.82}$ & $\frac{96.63}{963}$ & 95,69 & $\frac{96.45}{95}$ & 96.78 & 96.0 & & 77.01 & $\frac{96.85}{605}$ & 96.59 & .74 & 96.73 & 59 & 97.47 & & 96.39 & 6.18 & 05 & & & & & & & \\
\hline & & $\frac{0.00}{0.00}$ & & 00.05 & $\frac{0.00}{0.00}$ & $\frac{0.0 .}{0.0 .0}$ & $\frac{0.00}{0.00}$ & 0.0 & $\frac{0.03}{0.03}$ & $\frac{0.01}{0.01}$ & 0.04 & $\frac{0.04}{0.00}$ & $\frac{0.01}{0.00}$ & $\frac{0.01}{0.00}$ & 0.11 & $\frac{0.04}{0.04}$ & 0.00 & .000 & $\frac{0.00}{0.00}$ & 0.05 & $\frac{.00}{.00}$ & 0.00 & $\frac{0.00}{000}$ & & \\
\hline & $\frac{0.6}{95}$ & & $\frac{00}{69}$ & $\frac{0.00}{9.640}$ & $\frac{0.00}{9678}$ & 0.000 & $\frac{0.00}{0.5151}$ & $\frac{0.0}{97.7}$ & $\frac{0.00}{9682}$ & $\frac{0.00}{0.08}$ & 66.70 & $\frac{969}{66.69}$ & 9658 & 87.46 & & $\frac{0.00}{0635}$ & $\frac{0.00}{6.18}$ & $\frac{00}{05}$ & $\frac{0.00}{5.37}$ & $\frac{0.00}{9.527}$ & $\frac{0.00}{6.17}$ & $\frac{.00}{311}$ & $\begin{array}{l}\frac{00}{60} \\
65\end{array}$ & 119 & 8 \\
\hline$\overline{\mid S i}$ & 6.433 & $\frac{6.523}{6.523}$ & 6.389 & 6.591 & 6.154 & 6.284 & 6.459 & 33 & 7.411 & 7.447 & & 0.490 & & & & 7.4 & & 7.396 & 393 & 7.386 & 136 & 6.079 & $\frac{180}{180}$ & & \\
\hline $\mathrm{Fe} 3$ & $\frac{1.567}{0.000}$ & $\frac{1.477}{0.000}$ & $\frac{1.611}{.0000}$ & $\frac{1.409}{0.000}$ & $\frac{1.846}{0.000}$ & $\frac{1.716}{0.000}$ & $\frac{1.541}{0.000}$ & 9.970 & $\frac{0.086}{0.504}$ & $\frac{0.066}{0.487}$ & 28 & & & & & & & 4 & $\frac{107}{500}$ & 1506 & $\begin{array}{l}.864 \\
.000\end{array}$ & & m & $m$ & \\
\hline & & $\frac{0.000}{8}$ & $\frac{0.000}{8}$ & $\frac{0.000}{8}$ & $\frac{0.000}{8}$ & $\frac{0.00}{8}$ & 8 & 0.000 & 0.000 & & & 00 & 0.000 & & & & & & 20 & $w$ & .000 & 000 & 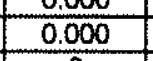 & .000 & \\
\hline & & & & $\frac{8}{0.769}$ & 8 & & & 265 & $\frac{8}{100}$ & & & & & & & & & & 8 & & & & & & \\
\hline $\mathrm{ccr}$ & 0.027 & 0.009 & $\frac{1.007}{0.007}$ & 0.010 & 0.011 & 0.007 & 0.009 & .006 & 0.000 & & & & 0.000 & or & & 0. & 0.0 .004 & 0.000 & $\frac{0.011}{0.000}$ & $\frac{0.0012}{0.001}$ & $\frac{1.177}{0.013}$ & $\frac{1.251}{0.021}$ & . 1.51 & 022 & $\overline{018}$ \\
\hline & $\frac{0.388}{0.045}$ & $\frac{0.309}{0.034}$ & $\frac{0.275}{0.039}$ & $\frac{0.36}{0.045}$ & 0.360 & $\frac{0.265}{0.048}$ & $\frac{0.300}{0.034}$ & .29. & $\frac{1.870}{0.005}$ & $\frac{.838}{.000}$ & $\frac{70}{30}$ & 524 & $\frac{0.776}{0.030}$ & $\frac{0.726}{0.030}$ & & $\frac{1.839}{0.001}$ & $\frac{1.855}{0.004}$ & \begin{tabular}{|l|l|l}
1.873 \\
0.001
\end{tabular} & $\frac{1.007}{0.004}$ & $\frac{1.023}{0.005}$ & $\frac{0.448}{0.036}$ & 0.043 & $\begin{array}{l}.4416 \\
037\end{array}$ & 500 & \\
\hline$\frac{\mathrm{mg}}{\mathrm{mg}}$ & 1.839 & 1.83 & $\frac{1.719}{1.79}$ & 1.956 & 1.422 & 1.622 & 1.743 & 1.376 & $\frac{1.005}{1.339}$ & 1.355 & . & . .686 & $\begin{array}{l}0.050 \\
0.700\end{array}$ & 1694 & $\frac{.006}{1.388}$ & \begin{tabular}{|l|l|}
1.344 \\
\end{tabular} & 1.309 & \begin{tabular}{|l}
1.347 \\
\end{tabular} & 3.230 & .208 & $\frac{0.0060}{1.680}$ & 1.039 & $\frac{38}{495}$ & 327 & \\
\hline & & & 1.956 & 1.879 & 2.045 & 2.001 & $\frac{1.927}{0.004}$ & $\frac{0.027}{0.006}$ & $\frac{1.750}{0.028}$ & \begin{tabular}{|l|}
1.749 \\
0.029
\end{tabular} & & & 220 & 1961 & & 0.034 & \begin{tabular}{|l|l}
1.751 \\
0.031
\end{tabular} & $\frac{1.747}{0.030}$ & $\frac{34}{34}$ & $\frac{0.745}{0.006}$ & 682 & $\frac{31}{031}$ & 389 & 399 & \\
\hline a & $\frac{0.000}{5}$ & & 0.000 & $\frac{0.000}{5}$ & 0.000 & 0.000 & $m$ & .000 & & 0.000 & 0.000 & 0.000 & \begin{tabular}{|l}
0.000 \\
\end{tabular} & 0.000 & 0.000 & \begin{tabular}{|l|l|l}
0.000 \\
\end{tabular} & 0.000 & & 0.000 & 我 & 000 & 000 & 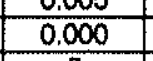 & & \\
\hline & & 0.00 & & 0.00 & 000 & 0.000 & $\frac{5}{0.000}$ & $\frac{1000}{1000}$ & $\frac{5}{0.000}$ & \begin{tabular}{|l}
0.000 \\
\end{tabular} & $\frac{5}{0.000}$ & & \begin{tabular}{|l}
5 \\
0.000 \\
\end{tabular} & \begin{tabular}{|l}
5 \\
0.000 \\
\end{tabular} & & \begin{tabular}{|l}
5 \\
0.000 \\
\end{tabular} & & & & & & & & & \\
\hline & & 74 & 0.079 & 0.070 & 0.076 & 0.074 & 0089 & 1066 & 0.918 & & & & & & & & & & & & & & & & \\
\hline & 1.775 & $\frac{1.828}{1.28}$ & 1.020 & $\frac{1.843}{1.43}$ & $\frac{1.827}{1.82}$ & 1.838 & $\frac{803}{803}$ & $\frac{1.846}{1.46}$ & 0.0900 & \begin{tabular}{|l}
0.095 \\
\end{tabular} & 1.865 & 1.836 & 1.814 & \begin{tabular}{|l}
1.829 \\
\end{tabular} & . & & 92 & \begin{tabular}{|l}
0.071 \\
\end{tabular} & 072 & 668 & 732 & 1.708 & 24 & 1.005 & \\
\hline & $\frac{0.12}{2.0}$ & $\frac{0.092}{2.00}$ & $\frac{0.093}{2.00}$ & 0.084 & $\frac{0.092}{2.00}$ & $\frac{0.066}{2.00}$ & $\frac{0.105}{2.00}$ & $\frac{0.082}{2.00}$ & $\frac{0.004}{1.05}$ & \begin{tabular}{|l}
0.006 \\
1.05
\end{tabular} & $\frac{0.072}{2.00}$ & $\frac{0.088}{2.00}$ & \begin{tabular}{|l}
0.099 \\
.000
\end{tabular} & $\frac{0.091}{2.00}$ & $\frac{0.007}{1.04}$ & \begin{tabular}{|c|}
0.007 \\
1.05
\end{tabular} & $\begin{array}{c}0.099 \\
1.05\end{array}$ & $\frac{11}{44}$ & $\frac{06}{04}$ & & $\frac{42}{10}$ & & $\frac{146}{00}$ & & \\
\hline Wh- & 2 & & 2.0 & 0.000 & $\frac{0.000}{0.007}$ & $\frac{.000}{0.000}$ & 0.000 & 0.000 & 0.000 & 0.000 & 0.000 & .000 & \begin{tabular}{|l}
.000 \\
0.000
\end{tabular} & $\frac{.000}{0.000}$ & $n$ & 0.000 & 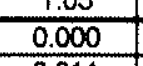 & $\frac{1.04}{0.000}$ & $\frac{10}{00}$ & & 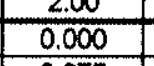 & & $\frac{2.00}{0.000}$ & & \\
\hline & 0.2 & & 0.291 & $\frac{0.271}{0.079}$ & 0.213 & $\frac{0.211}{0.109}$ & & & & & & & & & $\frac{0.0}{0.0}$ & & & & & & & & & & \\
\hline & & & 0.35 & 0.29 & 0.37 & & 0.31 & & & & & & & & & & & & & & & & & & \\
\hline Sum_at! & 15.31 & 15.31 & $\frac{15.35}{0.002}$ & $\frac{15.29}{0.004}$ & $\frac{15.37}{0.001}$ & $\frac{15.38}{0.005}$ & $\frac{15.31}{0.000}$ & $\frac{15.43}{0.002}$ & $\begin{array}{l}14.05 \\
0.000 \\
\end{array}$ & $\begin{array}{l}\frac{14.06}{0.000} \\
0.00\end{array}$ & $\begin{array}{l}15.46 \\
0.009 \\
\end{array}$ & 15.56 & $\frac{15.41}{0.007}$ & 15.42 & 14 & $\begin{array}{l}\frac{14.06}{0.005} \\
0.05\end{array}$ & 14.06 & 4.06 & 4.05 & 4.05 & 5.34 & 36 & $\begin{array}{l}5.35 \\
.001\end{array}$ & 33 & \\
\hline & & & & & & & & & & & & & & & & & & & & & & & & & \\
\hline
\end{tabular}




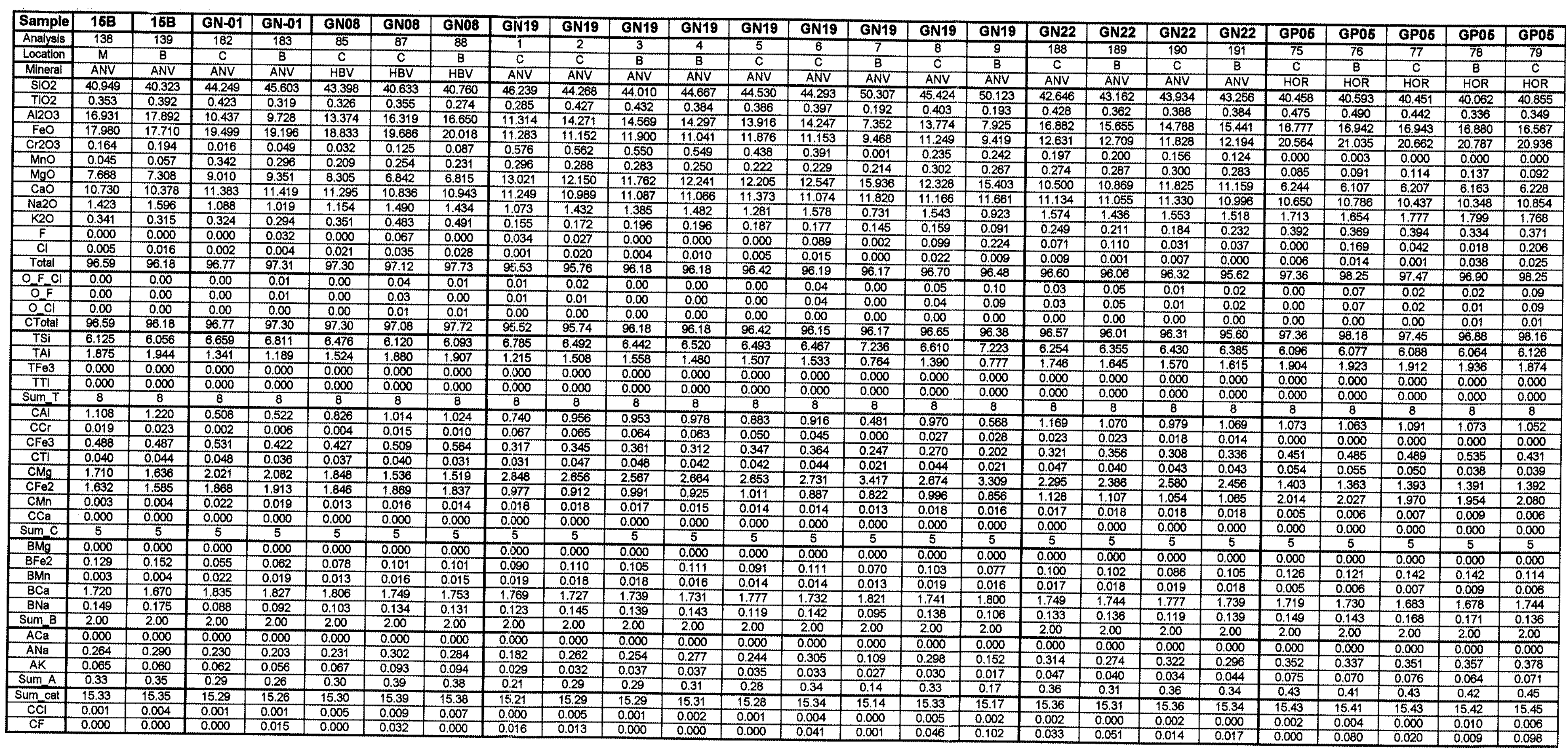




\begin{tabular}{|c|c|c|c|c|c|c|c|c|c|c|c|c|c|c|c|c|c|c|c|c|c|c|c|c|c|}
\hline & & & & & & & & & & & & & & & & & & 10 & P10 & $\begin{array}{l}P 10 \\
\end{array}$ & 10 & $\overline{P 10}$ & 510 & 173 & \\
\hline & & & & $\frac{83}{6}$ & 8 & 89 & & & 193 & - & 195 & 190 & & 198 & & & & 202 & 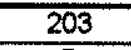 & & 0 & & & 10 & \\
\hline iers & & & $\overline{\mathrm{HB1}}$ & $\mathrm{HBV}$ & $\frac{B}{H B}$ & & $\frac{\mathrm{B}}{\mathrm{BB}}$ & 5 & $\frac{B}{A N I}$ & $\frac{c}{C N V}$ & $\frac{B}{\text { ANV }}$ & $\frac{c}{\text { ANV }}$ & $\frac{B}{\text { ANV }}$ & $\frac{C}{A N V}$ & $\frac{B}{A N V}$ & $c$ & 8 & $\frac{C}{A N V}$ & $\frac{B}{A N W}$ & & 3 & Nov & $\frac{B}{A N Y}$ & $\overrightarrow{N M}$ & $\frac{B}{D N}$ \\
\hline & & 2309 & 0208 & $\frac{4.99}{0.90}$ & w & & & & & & & & & 1.080 & & & & 1.748 & ANV & 1.000 & & & & & \\
\hline & & & & $\frac{0.449}{16.588}$ & & & & 17.7 & $\frac{0.40}{1700}$ & $\frac{1.511}{18.15}$ & & & & & & & & $\frac{446}{205}$ & $\frac{2.421}{8010}$ & 1.420 & .48 & $\frac{.865}{5.805}$ & & & \\
\hline & 20,779 & 20.571 & 21.41 & 20.599 & 2 & 15.480 & N11 & $\mid \begin{array}{ll}5.91 \\
0.01\end{array}$ & 16.046 & $\frac{6.300}{604}$ & 16.652 & & 10 & & & & 5.968 & 10.6 & 0.14 & $\frac{.682}{6.610}$ & & .678 & & $\frac{15.21}{19.01}$ & \\
\hline & & & & & & & & & & & & & $\sqrt{211}$ & & & & 308 & 0.093 & .077 & 5340 & & $\frac{060}{331}$ & & 0.02 & \\
\hline & & & & & & & & & & & & & & & & & & & & & & & & & \\
\hline & & & & & & & & & & & & & & & & & & & & & & & & & \\
\hline & & $034:$ & $\frac{1.494}{0.2911}$ & $\frac{1.1727}{0.32}$ & . & 20 & 200 & & & & & & & & & & & & & & & & & & \\
\hline & 0.179 & 0.015 & 0.060 & $\frac{0.004}{0.004}$ & 0.070 & & $\frac{136}{136}$ & 0.178 & 0.085 & .096 & $\begin{array}{l}0.014 \\
0.083\end{array}$ & .17 & & & & & 44 & $\frac{0.450}{0.000}$ & $\frac{0.553}{0.049}$ & 0.000 & & 0.000 & & & \\
\hline & 98.29 & $\begin{array}{l}0.073 \\
97.45\end{array}$ & 0.0787 & $\begin{array}{l}\frac{0.011}{97.87} \\
97\end{array}$ & $\begin{array}{l}0.018 \\
97.52\end{array}$ & 96.87 & & $\frac{0.07}{97.75}$ & $\frac{0.023}{97.82}$ & 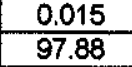 & $\frac{0.005}{98.37}$ & 98.49 & & $\frac{.63}{6.63}$ & & & & $\frac{0.0}{0.07 .4}$ & & 33 & & 7.43 & 7.03 & $\frac{\pi}{d x}$ & \\
\hline & $\frac{0.06}{0.06}$ & 0 & $\begin{array}{l}0.03 \\
0.03\end{array}$ & \begin{tabular}{|l}
0 \\
0
\end{tabular} & $\frac{0.0}{0.0}$ & & & 0.08 & & & & & & $\frac{0.01}{0.01}$ & & & & & 00 & & & 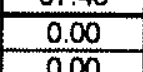 & & 20 & \\
\hline & & $\frac{0.00}{0.014}$ & 070 & 0 & 0.00 & & $0^{01}$ & 0.00 & & & & & & & & & & & 0.0 & & & & & & \\
\hline & & & & & & 96.8 & & & & & & & & & & & & & & & & & & & \\
\hline & 9.889 & & & 1.005 & 1.94 & 1,698 & $\frac{0.305}{1.685}$ & 1.893 & 1.913 & 1.911 & $\frac{6.136}{1.864}$ & 1.939 & 1.915 & 556 & & & 1.954 & $844^{\circ}$ & 1.91 & 1.952 & 932 & 1.766 & 88 & $\frac{78}{78}$ & \\
\hline & 0.0 & & & & & & & & . .000 & & .000 & & & & & & & & & & & & & & \\
\hline & & & & 8 & 8 & 8 & 8 & & 8 & & & & & & & & & 8 & & & & & & & \\
\hline & $\frac{1.04}{0.06}$ & & & $\frac{1 .}{0 .}$ & $\frac{1.028}{0.000}$ & $\frac{0.865}{0.000}$ & $\frac{0.834}{0.007}$ & \begin{tabular}{|l|}
1.197 \\
0.009
\end{tabular} & $\frac{1.20}{0.00}$ & $\frac{1.23}{000}$ & $\frac{1.127}{0.007}$ & $\frac{1.1}{0.0}$ & $\frac{1.1}{0.0}$ & $\frac{1.22}{0, \alpha}$ & $\frac{1.2}{0.0}$ & $\frac{1.1}{00}$ & $\frac{1.2}{0.0}$ & $\frac{1.1}{0.0}$ & & 1.290 & & & & & \\
\hline & 0.459 & $\frac{0.467}{0.457}$ & 0.007 & $\frac{4.636}{4.436}$ & $\begin{array}{l}0.5007 \\
0.579\end{array}$ & 0.451 & $\begin{array}{l}0.011 \\
0.481\end{array}$ & 5 & $\begin{array}{l}0.0034 \\
0.341\end{array}$ & $\begin{array}{l}0.00 \\
0.33\end{array}$ & $\frac{0.6}{0.3}$ & $34^{\prime}$ & 0. & $\frac{0.6}{0.6}$ & $\frac{0.00}{0.36}$ & $\frac{0.01}{0.39}$ & 335 & $\frac{0.01}{0.31}$ & $\sqrt{3.316}$ & 40 & & & & 0.00 & \\
\hline $\mathrm{cMg}$ & 1.410 & 1.402 & 1.474 & $\frac{0.01}{1.424}$ & $\frac{0.017}{1.427}$ & 0.000 & $\begin{array}{l}0.0358 \\
1.688\end{array}$ & 0.028 & 1.04 & 0.0418 & 1.813 & 1.835 & $\begin{array}{l}0.065 \\
1.795\end{array}$ & $\frac{0.0}{1.8}$ & $\begin{array}{l}0.0455 \\
1.835\end{array}$ & 1.830 & 1.794 & $\frac{0.049}{1.873}$ & $\frac{0.047}{1.790}$ & jos & & & & 1.69 & \\
\hline & & & & $\overline{027}$ & 1007 & & $\frac{1.943}{0.014}$ & 1.599 & $\frac{1.549}{0.012}$ & $\frac{1.590}{0.099}$ & $\frac{1.666}{0.020}$ & & 164 & 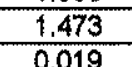 & & & & & & & 0 & & & 20 & \\
\hline & 0.000 & 0.000 & $\frac{0.000}{0.00}$ & .000 & .000 & 0.000 & 0.000 & 0.000 & 0.000 & 0.000 & 0.000 & 0. & $\frac{.0000}{0.000}$ & 0.000 & 0.0 & & & 000 & & & 200 & & & 0.01 & \\
\hline$\frac{s m g}{B M g}$ & 0.0. & $\frac{5}{0.00}$ & & & & & & $\frac{5}{0.000}$ & 0.4 & 0.0 & 0.000 & & & & & & & & & & & & & & \\
\hline & & 0.1133 & 0.18 & & 0.164 & & 0.0 & & & & 0.06 & & & & & & & & & & & & & & \\
\hline & $\frac{1.7}{0.1}$ & 1.145 & 1.588 & $1,1,22$ & $\frac{1.634}{1.634}$ & 1.790 & $\frac{1.7}{1.4}$ & 1.808 & 1.767 & 1 & 1.813 & & 1.83 & & & & & & & & & 806 & & & \\
\hline & $\frac{0.138}{2.00}$ & $\frac{0.136}{2.00}$ & 1.99 & $\frac{0.147}{2.00}$ & 0.1 & $\frac{0.11}{2.00}$ & $\frac{0.1}{2.1}$ & $\frac{0.102}{2.00}$ & $\frac{0.124}{2.00}$ & $\frac{0.123}{2.00}$ & $\frac{0.100}{2.00}$ & $\frac{0.102}{200}$ & $\frac{0.090}{200}$ & $\frac{0.122}{200}$ & $\frac{0.125}{200}$ & $\frac{0.132}{200}$ & $\frac{0.114}{200}$ & $\frac{0.105}{200}$ & 20.0 & $\frac{101}{100}$ & 20 & 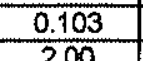 & . & & \\
\hline & 0.0 & 0.000 & 0.000 & 0.000 & & & & 0.00 & 0.000 & $\frac{2.000}{0.000}$ & 0.000 & -4 & & & & & & $\frac{0.00}{0.000}$ & $\frac{0.000}{0.000}$ & & $\frac{10}{000}$ & & $\frac{0}{000}$ & 0.0 & \\
\hline & & & & 0.36 & 0.3 & & & & & & & & & & & & & & & 8 & & 84 & & $\frac{3}{3}$ & \\
\hline & & & & 0.4 & & & & & & & & & & & & & & & & & & & & & \\
\hline $\mathrm{CCl}$ & 0.006 & $\begin{array}{l}15.40 \\
0.003\end{array}$ & 0.005 & $\begin{array}{l}\frac{15.43}{0.003} \\
.000\end{array}$ & $\begin{array}{l}15.40 \\
0.005\end{array}$ & $\begin{array}{l}15.399 \\
0.011\end{array}$ & 0.007 & $\begin{array}{l}\frac{15.40}{0.002} \\
0.00\end{array}$ & $\begin{array}{l}5.42 \\
0.006 \\
\end{array}$ & 0.004 & 0.001 & 0.001 & $\begin{array}{l}10.41 \\
0.004\end{array}$ & 0.001 & 0.006 & $\begin{array}{l}0.01 \\
0.004\end{array}$ & $\frac{15.41}{0.004}$ & $\frac{15.40}{0.002}$ & $\frac{10.40}{0.000}$ & 0.003 & 5.002 & $\frac{0.01}{0.01}$ & & .007 & \\
\hline
\end{tabular}


Anexo 5: Tabela 4 - Química Mineral de Anfibólios (cont.)

\begin{tabular}{|c|c|c|c|c|c|c|c|c|c|c|c|c|c|c|c|c|c|c|c|c|c|c|c|c|c|c|}
\hline pple & $\frac{13}{213}$ & $\frac{13}{13}$ & $\frac{13}{4}$ & $\frac{13}{15}$ & $\frac{173}{16}$ & $\frac{73}{17}$ & $\frac{G P 7}{184}$ & P7B & $7 \bar{B}$ & 778 & 888 & 888 & 888 & $\mathrm{PBE}$ & GP8B & PP8B & PP8B & P8B & GPBB & GP8B & GP8B & PP8B & GP8B & PP8B & P8B & $\mathrm{PBB}$ \\
\hline 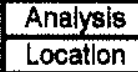 & $\frac{12}{c}$ & $\frac{13}{B}$ & $\frac{14}{c}$ & $\frac{15}{B}$ & $\frac{16}{c}$ & $B$ & $\frac{184}{c}$ & $\frac{185}{8}$ & $\frac{186}{c}$ & 8 & $\frac{140}{c}$ & $\bar{B}$ & $\frac{142}{c}$ & $\frac{143}{\beta}$ & $\frac{144}{S}$ & $\frac{145}{18}$ & 146 & $\frac{147}{8}$ & $\overline{100}$ & 149 & 150 & $\frac{151}{0}$ & 1024 & 10 & 154 & $\frac{155}{8}$ \\
\hline & $\overline{\mathrm{ANV}}$ & & & ANV & $\frac{A N V}{A N V}$ & & & & & $\frac{D}{A N V}$ & & & & & & & $\frac{\mathrm{C}}{\mathrm{ANV}}$ & $\frac{B}{\text { ANV }}$ & & $\frac{B}{\text { ANV }}$ & & & $\frac{C}{\text { ANV }}$ & $\frac{B}{\text { ANV }}$ & $\frac{C}{\text { ANV }}$ & $\frac{B}{\text { ANV }}$ \\
\hline 70 & $\begin{array}{l}41.395 \\
0553\end{array}$ & $\begin{array}{l}40.557 \\
0.673\end{array}$ & $\begin{array}{l}40.618 \\
0.5598\end{array}$ & $\frac{42.079}{0.494}$ & $\frac{41.242}{0.524}$ & $\begin{array}{ll}41.418 \\
0.639\end{array}$ & $\frac{53.297}{0.73}$ & $\frac{53.382}{0.016}$ & $\frac{52.349}{0.015}$ & $\frac{53.366}{0.53}$ & 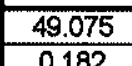 & $\frac{46.572}{0.542}$ & \begin{tabular}{|l}
8.013 \\
0.068
\end{tabular} & $\begin{array}{l}50.421 \\
0190\end{array}$ & \begin{tabular}{|l|l}
46.361 \\
0.365
\end{tabular} & $\frac{45.690}{321}$ & $\frac{282}{282}$ & 51.363 & 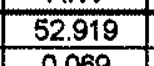 & $\begin{array}{l}47.947 \\
0.978\end{array}$ & 303.1020 & $4 \frac{48.808}{40.31}$ & 2 & $\frac{0044}{24}$ & . 6.674 & $\frac{4.906}{0.906}$ \\
\hline & & & $\frac{0.059}{15.655}$ & $\frac{0.444}{10792}$ & $\frac{0.524}{15.726}$ & $\frac{\frac{0.639}{1494}}{14}$ & $\frac{0.063}{2513}$ & 0.016 & $\frac{0.075}{1.758}$ & & 9.243 & & & & & & & & & & & & & & & 0.299 \\
\hline & 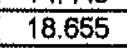 & $\frac{8.424}{8.242}$ & 9.039 & & & & & & & & 10.852 & 135 & $\frac{0.178}{1116}$ & 308 & & & 248 & & & $\frac{201}{1074}$ & & & & & & 8.835 \\
\hline & & & & & 0.008 & $\overline{00}$ & 0.276 & 0.238 & 0.187 & 2 & & 0 & 0.326 & & 107 & & 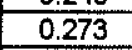 & & & 89 & & & & & & $\frac{990}{1.175}$ \\
\hline & $\frac{0.26}{7.75}$ & .0.241 & $\frac{0.2200}{72380}$ & $\frac{0.221}{7728}$ & $\frac{0.309}{73209}$ & $\frac{0.289}{y^{254}}$ & $\frac{0.242}{1.247}$ & $\frac{1899}{1.930}$ & $\frac{1.236}{234}$ & $\frac{170}{1707}$ & 0.2922 & 0.262 & 0.281 & 0.35 & t. & & & & & 378 & & & & & & $\frac{0.115}{0.336}$ \\
\hline & & & $\frac{1.2059}{10.959}$ & 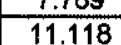 & $\frac{1.004}{10994}$ & $\frac{\frac{1.01}{103}}{1.03}$ & & & $\frac{1.44}{046}$ & & 14.956 & $\begin{array}{l}4.006 \\
11388\end{array}$ & 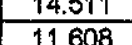 & 11539 & & & & & & 5.593 & & & 139 & & & 7.746 \\
\hline & & & & & & & $0.39 \%$ & & & & & & & & & & $\frac{458}{601}$ & $\frac{580}{175}$ & & $\frac{11.323}{0.950}$ & & & & & & 432 \\
\hline & 0.463 & & .51 & & & & & & & & & & & & & & & & & & & & & 13 & & $\frac{5}{5}$ \\
\hline & & 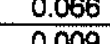 & o. 000 & & 0.0000 & 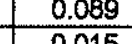 & 0.211 & 0.376 & 0.036 & $\frac{0.016}{100}$ & 0.0000 & 0.182 & 997 & 0.062 & 2.269 & & 244 & & & $\overline{00}$ & 0.242 & & & $\overline{0.44}$ & 51 & $\frac{0}{2}$ \\
\hline tal & 96.14 & 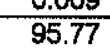 & $\frac{0.67}{96.61}$ & $\frac{60.47}{96.6}$ & $\frac{.078}{98.88}$ & & 96.06 & $\frac{0.5010}{95.57}$ & 0.050 & $\frac{0.050}{948}$ & 0.0000 & $\frac{.0007}{99.95}$ & $\frac{0.022}{904}$ & 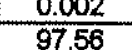 & 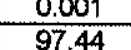 & 0.013 & 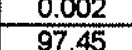 & $\frac{.0000}{9717}$ & $\frac{0.003}{9556}$ & $\begin{array}{l}0.049 \\
9683\end{array}$ & $\frac{.0000}{97.05}$ & 0.0001 & $\frac{0.022}{96020}$ & $\frac{0.048}{9036}$ & 0.0177 & 9 \\
\hline$F$ & 0.01 & 0.03 & 0.00 & 0.04 & 0.00 & 0.04 & 0.09 & 0.16 & 0.04 & 0.01 & 0.00 & 0.08 & 0.04 & 0.03 & 0.11 & 0.06 & 0.10 & 0.06 & 0.00 & 0.00 & 0.10 & 0.14 & .00 & 0.09 & $0.0 r$ & 0.10 \\
\hline & & & & & & & $\frac{0.09}{000}$ & & & & & & & & & & 1.100 & & & & & & & & & .10 \\
\hline crotal & $\frac{6.13}{68.13}$ & 9 & $\frac{96.61}{96.61}$ & $\frac{6.63}{96.63}$ & 9788 & 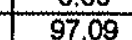 & $\frac{0.97}{95.97}$ & $\frac{95.71}{95.1}$ & 93.89 & $\frac{6.077}{9477}$ & $\frac{9.62}{97.62}$ & 97.87 & $\frac{2.06}{97.60}$ & 97 & $\frac{5120}{752}$ & & & & & $\frac{0.00}{963}$ & $\frac{0.00}{9.95}$ & & $\begin{array}{l}0.00 \\
9070\end{array}$ & & & \\
\hline & 0.28 & 6.189 & $\overline{1.148}$ & 6.370 & 6.170 & 6.240 & 7.564 & 7.821 & 7.634 & 707 & 6.99 & 6.848 & 0.007 & $7.15 t$ & & & & & & & & & & & & \\
\hline & & & & 3.30 & 1.8800 & 1.7060 & 0.384 & $\frac{0.340}{0.340}$ & $\frac{0.295}{.297}$ & 0.277 & 008 & & & & & & 320 & & & & & & & & 100 & 1 \\
\hline & 0 & 0.000 & & 000 & 0000 & $\frac{0.000}{0.000}$ & & & & 1000 & $\frac{10 x}{100}$ & & & & & & & & & $m$ & & $m$ & & & & \\
\hline Sum - & 0 & & & 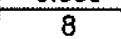 & 8 & 8 & 8 & 8 & 8 & 8 & 8 & & & & & 8 & & 3 & & & & & & & & \\
\hline & 0.87 & 0.897 & 0.93 & .829 & 0.941 & 8.8 & $\sqrt{36}$ & .003 & & & $\overline{0.542}$ & .677 & & $\sqrt{\Delta 18}$ & & 7 & 878 & 8 & & & & & & & & 776 \\
\hline & 50 & . & 17 & 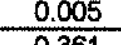 & $\frac{0.001}{.001}$ & 0.000 & 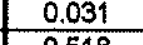 & & & & & & & $\bar{x}$ & & & 0 & & & & & & & & & \\
\hline & $\frac{00}{06}$ & & & . $\frac{.01}{0.56}$ & . & & 0.50 & 1.473 & 549 & & & $\frac{4.44}{0.07}$ & & $\frac{0.391}{0.311}$ & & $\frac{314}{1023}$ & 198 & 394 & 156 & . 5.574 & & & & & & \\
\hline${ }_{C M_{g}}$ & 1.755 & 1.734 & 1.644 & 1.758 & 1.633 & 1.687 & 4.060 & 4.125 & 3.942 & $\frac{.0 .002}{4.002}$ & $\begin{array}{l}3.065 \\
3.185\end{array}$ & $\frac{.0955}{2.995}$ & 3.094 & $\begin{array}{l}0.015 \\
3.386 \\
\end{array}$ & $\frac{0.0099}{2.986}$ & $\frac{0.033}{2.883}$ & 3.764 & 3.620 & 4.064 & 3.337 & 4.002 & 3.355 & 3.829 & 3.463 & 071 & 8356 \\
\hline & $\frac{1.911}{0.917}$ & $\frac{1.866}{0.015}$ & $\frac{1.885}{0.818}$ & $\frac{1.968}{0.96}$ & $\frac{1.922}{1090}$ & $\frac{1.921}{0.0218}$ & $\begin{array}{l}0.333 \\
0.034\end{array}$ & 0 & 0.464 & 0.0613 & 0.837 & 0.076 & 880 & 0.738 & 891 & -0.952 & 0.489 & 0.017 & 0.390 & 0.5622 & 0.477 & .665 & 0.473 & .632 & $\frac{0.396}{0.396}$ & 4.697 \\
\hline & & 0.000 & & 0.000 & & & $\frac{0.000}{0.000}$ & & & & 000 & 1010 & & & & & & & & 0.023 & & & & & 014 & 0.020 \\
\hline & 5 & 5 & 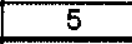 & 5 & 5 & 5 & 5 & 5 & 5 & 5 & 5 & 5 & 5 & 5 & 5 & 5 & 5 & $=$ & & 5 & & 00 & $\frac{1000}{5}$ & $\frac{100}{5}$ & $\frac{100}{5}$ & .000 \\
\hline & & & 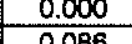 & 78 & 0 & $\frac{0.000}{2009}$ & 0.0000 & & 0.000 & 0.0000 & 0.000 & 1.000 & & 0.000 & & 0.04 & & & & 0.000 & 100 & 000 & & & & 0 \\
\hline & 0.017 & 0.016 & $\frac{0.006}{0.018}$ & 0.014 & & & 0.129 & & $\frac{0.174}{0.015}$ & & $\frac{0.011}{0.018}$ & & 0.086 & 0.09 & 010 & & & & & & $\frac{69}{18}$ & & & $\frac{35}{58}$ & & \\
\hline & 1.796 & & & 1.803 & & $\frac{1.7}{1.7}$ & & & $\frac{1.726}{1.726}$ & & & 1.142 & & 1.755 & & & 1735 & $\frac{0.01}{1762}$ & & $\frac{0.000}{1781}$ & & & & & & \\
\hline & 0.107 & 0.103 & 0.118 & 0.105 & 1126 & 0.116 & 0.053 & 0.040 & 0.033 & 0.036 & 0.124 & 5.137 & 0.118 & & & 08 & 31 & 98 & & 31 & & & 67 & & $\frac{011}{041}$ & \\
\hline & 2.00 & 2.00 & 2.00 & & & & 1.89 & 1.96 & 1.89 & 1.95 & 2.00 & 2.00 & 00 & 1.98 & 00 & & 34 & 7.97 & & 1.99 & $\overline{95}$ & & 94 & & 94 & 200 \\
\hline & 0351 & 48 & 351 & & 36 & 6335 & 0.055 & $\frac{0.000}{100}$ & $\frac{0.000}{0.034}$ & $\frac{0.000}{0.026}$ & $\frac{\infty}{12}$ & & & & & $\frac{10}{a^{2}}$ & . & 0.000 & & & 00 & 0.00 & & $\infty$ & $\infty 0$ & 0000 \\
\hline & 090 & & 0.099 & & & 0.095 & 0.006 & & 0.010 & & $\frac{0.025}{0.025}$ & 0.038 & & & & & & & & & & & & & & \\
\hline Sum_A & 0.44 & 5 & 0.45 & 0.43 & & & 0.06 & & 0.04 & & 0017 & 0 & & 012 & & & & & & $\frac{16}{16}$ & 5 & & & & 5 & \\
\hline Sum c cat & 15.44 & 15.45 & 15.45 & 15.43 & 15.47 & 15.43 & 14.95 & 15.01 & 14.93 & 15.00 & 15.17 & 15.25 & .21 & 15.11 & $\frac{15.29}{15.29}$ & 15.37 & $\frac{15.03}{15.03}$ & 15.08 & 15.00 & 15 & 50 & $\frac{19}{19}$ & 15.02 & $\frac{15.16}{15.1}$ & 99 & \\
\hline & & & & & & & & & & & & & & & & & & & & & & 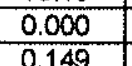 & & & $\frac{04}{0.04}$ & \\
\hline
\end{tabular}




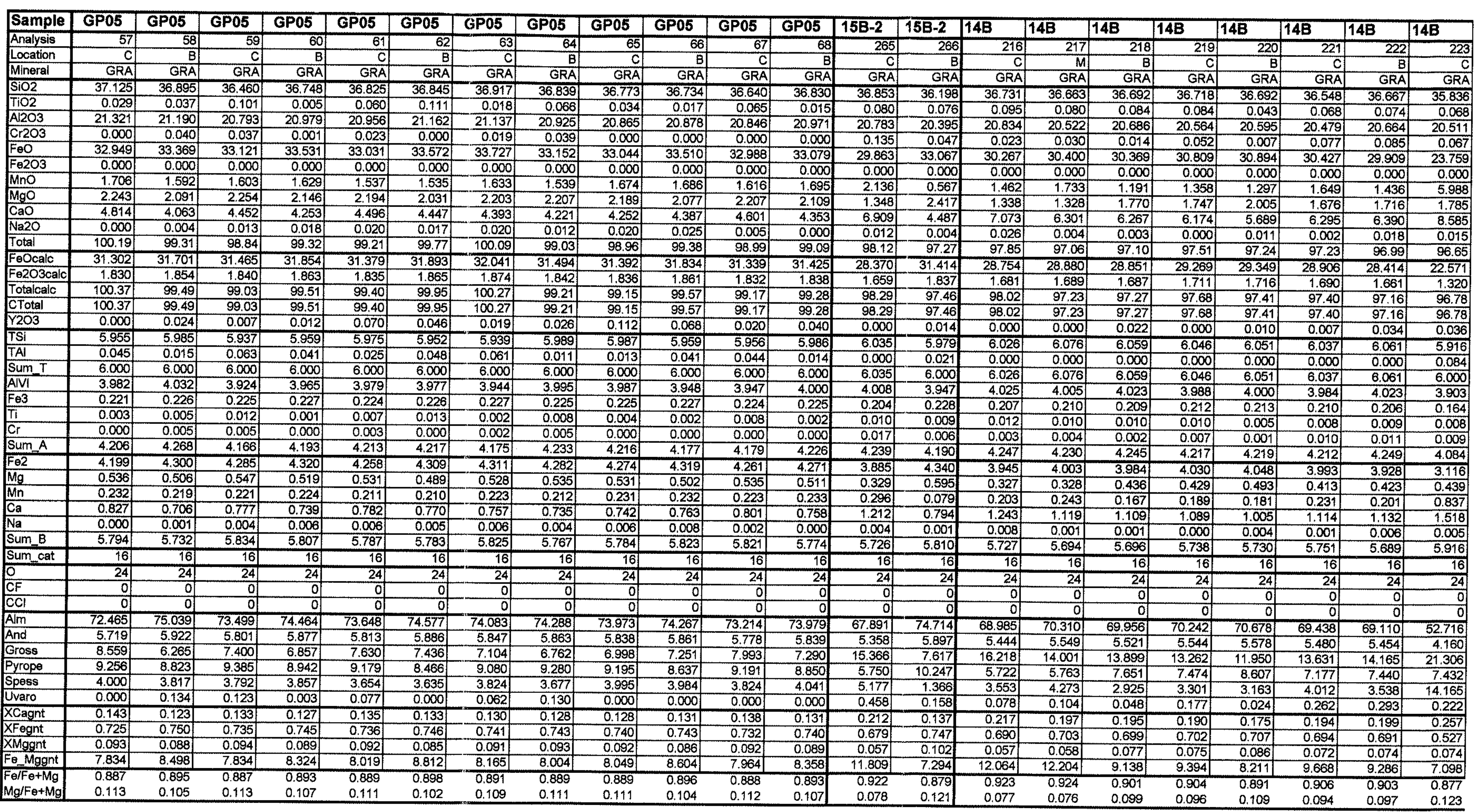


Anexo 5: Tabela 5 - Química Mineral de Granadas (cont.)

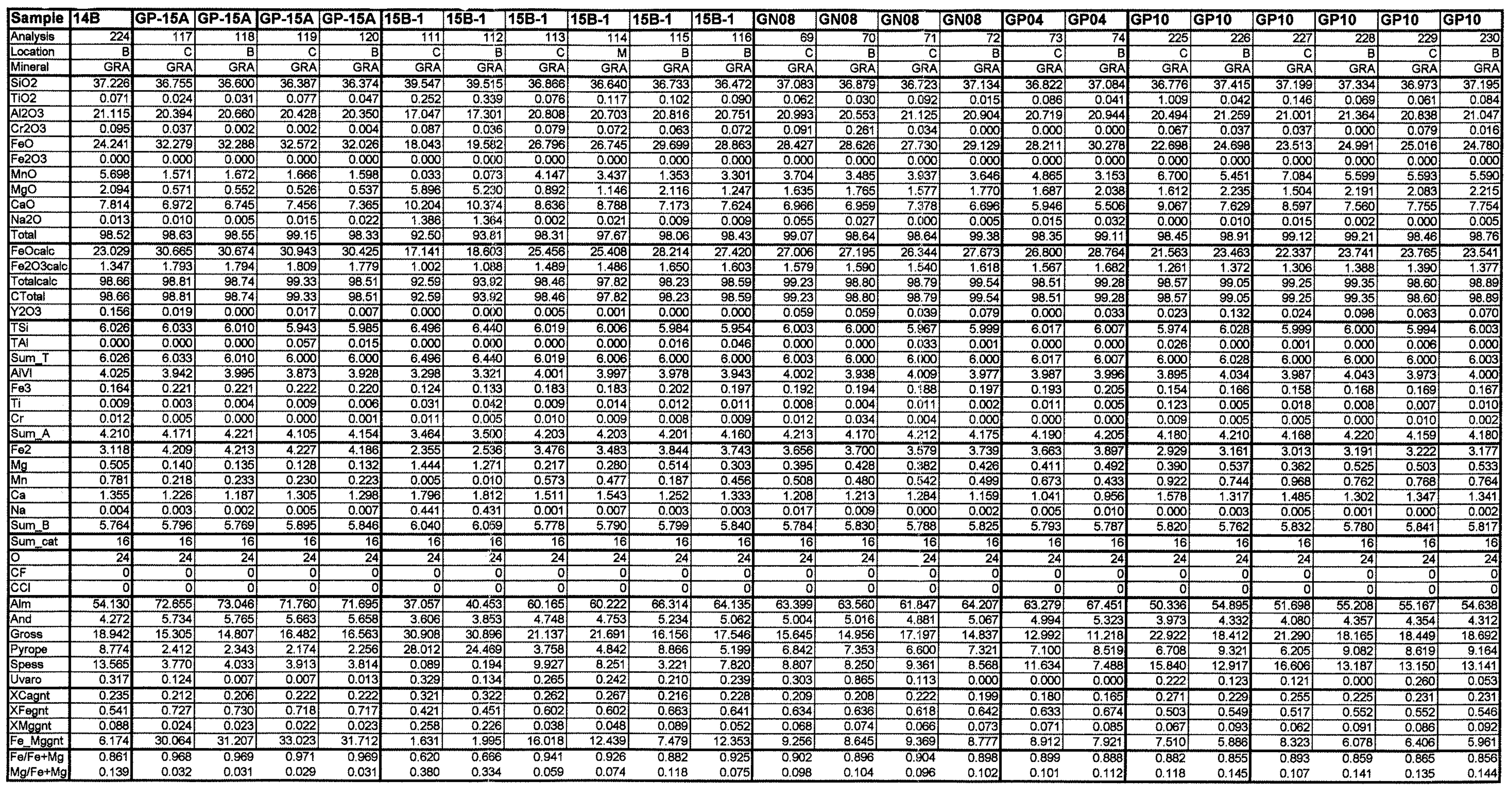


Anexo 5: Tabela 6 - Química Mineral de Carbonatos

\begin{tabular}{|c|c|c|c|c|c|c|c|c|c|c|c|c|c|}
\hline Sample & 14B & 14B & 14B & 14B & 14B & 14B & GN01 & GN01 & GN01 & GN01 & GP13 & GP13 & GP13 \\
\hline Analysis & 259 & 260 & 261 & 262 & 263 & 264 & 178 & 179 & 180 & 181 & 54 & 55 & 56 \\
\hline Location & c & $\mathrm{B}$ & c & B & C & B) & C & $\mathrm{B}$ & C & $B$ & C & C & C \\
\hline Mineral & CAR & CAR & CAR & CAR & CAR & CAR & CAR & CAR & CAR & CAR & CAR & CAR & CAR \\
\hline $\mathrm{SiO} 2$ & 0,038 & 0,043 & 0,022 & 0,022 & 0,016 & 0,109 & 0,062 & 0,111 & 0,041 & 0,080 & 0,016 & 0,013 & 0,022 \\
\hline $\mathrm{FeO}$ & 2,359 & 2,688 & 2,313 & 2,426 & 2,215 & 2,561 & 1,899 & 1,860 & 1,754 & 1,850 & 2,938 & 2,476 & 2,609 \\
\hline $\mathrm{MnO}$ & 0,165 & 0,210 & 0,171 & 0,186 & 0,174 & 0,145 & 0,774 & 0,717 & 0,681 & 0,742 & 0,931 & 0,753 & 0,917 \\
\hline $\mathrm{MgO}$ & 1,210 & 1,296 & 1,142 & 1,158 & 1,128 & 1,240 & 0,802 & 0,800 & 0,809 & 0,776 & 1,367 & 1,393 & 1,329 \\
\hline $\mathrm{CaO}$ & 49,968 & 49,757 & 49,074 & 49,799 & 49,645 & 50,143 & 51,074 & 51,257 & 49,669 & 49,771 & 56,151 & 56,342 & 55,001 \\
\hline $\mathrm{Na2O}$ & 0,005 & 0,003 & 0,006 & 0,012 & 0,000 & 0,022 & 0,000 & 0,005 & 0,000 & 0,000 & 0,000 & 0,000 & 0,000 \\
\hline $\mathrm{K} 2 \mathrm{O}$ & 0,006 & 0,004 & 0,006 & 0,006 & 0,006 & 0,006 & 0,000 & 0,000 & 0,002 & 0,003 & 0,002 & 0,000 & 0,001 \\
\hline TOTOX & 53,75 & 54,00 & 52,73 & 53,61 & 53,18 & 54,23 & 54,61 & 54,75 & 52,96 & 53,22 & 61,41 & 60,98 & 59,88 \\
\hline $\mathrm{CO2}$ & 46,250 & 46,000 & 47,270 & 46,390 & 46,820 & 45,770 & 45,390 & 45,250 & 47,040 & 46,780 & 38,590 & 39,020 & 40,120 \\
\hline Total & 100 & 100 & 100 & 100 & 100 & 100 & 100 & 100 & 100 & 100 & 100 & 100 & 100 \\
\hline $\mathrm{Si4}$ & 0,001 & 0,001 & 0,001 & 0,001 & 0,001 & 0,004 & 0,002 & 0,004 & 0,001 & 0,003 & 0,000 & 0,000 & 0,001 \\
\hline $\mathrm{Fe2}$ & 0,069 & 0,078 & 0,069 & 0,071 & 0,065 & 0,074 & 0,055 & 0,053 & 0,052 & 0,055 & 0,075 & 0,064 & 0,068 \\
\hline Mn2 & 0,005 & 0,006 & 0,005 & 0,005 & 0,005 & 0,004 & 0,023 & 0,021 & 0,020 & 0,022 & 0,024 & 0,020 & 0,024 \\
\hline Mg2 & 0,063 & 0,067 & 0,060 & 0,060 & D,059 & 0,064 & 0,041 & 0,041 & 0,043 & 0,041 & 0,062 & 0,064 & 0,062 \\
\hline $\mathrm{Ca2}$ & 1,862 & 1,847 & 1,864 & 1,862 & 1,870 & 1,853 & 1,880 & 1,881 & 1,884 & 1,879 & 1,838 & 1,853 & 1,845 \\
\hline $\mathrm{Na1}$ & 0,000 & 0,000 & 0,000 & 0,001 & 0,000 & 0,001 & 0,000 & 0,000 & 0,000 & 0,000 & 0,000 & 0,000 & 0,000 \\
\hline $\mathrm{K} 1$ & 0,000 & 0,000 & 0,000 & 0,000 & 0,000 & 0,000 & 0,000 & 0,000 & 0,000 & 0,000 & 0,000 & 0,000 & 0,000 \\
\hline Cations & 2,000 & 1,999 & 1,999 & 2,000 & 2,000 & 2,000 & 2,001 & 2,000 & 2,000 & 2,000 & 1,999 & 2,001 & 2,000 \\
\hline
\end{tabular}


Anexo 5: Tabela 7 - Química Mineral de llmenitas

\begin{tabular}{|c|c|c|c|c|c|c|c|c|c|c|c|c|c|c|}
\hline Sample & GP05 & GP05 & GP05 & GP05 & GP05 & GP05 & GP05 & GP05 & GP05 & GP13 & GP13 & GP13 & GP13 & GP13 \\
\hline Analysis & 102 & 103 & 104 & 105 & 106 & 107 & 108 & 109 & 110 & 49 & 50 & 51 & 52 & 53 \\
\hline Location & $\mathrm{B}$ & C & B & $\mathrm{C}$ & $\bar{B}$ & C & B & C & $\bar{B}$ & C & $C$ & $B$ & C & C \\
\hline Mineral & ILM & ILM & ILM & ILM & ILM & ILM & ILM & ILM & ILM & IL.M & $\overline{\mathrm{ILM}}$ & ILM & ILM & $\mathrm{ILM}$ \\
\hline $\mathrm{SiO} 2$ & 0.058 & 0.041 & 0.081 & 0.018 & 0.036 & 0.019 & 0.035 & 0.022 & 0.028 & 0.024 & 0.000 & 0.000 & 0.056 & 0.051 \\
\hline TiO2 & 51.009 & 51.946 & 52.265 & 51.5225 & 51.469 & 51.904 & 50.751 & 51.449 & 50.779 & 51.406 & 50.801 & 51.457 & 50.515 & 50.777 \\
\hline Al2O3 & 0.015 & 0.008 & 0.013 & 0.000 & 0.036 & 0.017 & 0.028 & 0.000 & 0.018 & 0.028 & 0.005 & 0.020 & 0.018 & 0.023 \\
\hline $\mathrm{FeO}$ & 45.270 & 45.980 & 45.980 & 45.980 & 45.270 & 46.700 & 45.980 & 45.980 & 45.270 & 44.550 & 44.550 & 44.550 & 43.830 & 43.830 \\
\hline $\mathrm{Fe} 2 \mathrm{O} 3$ & 3.100 & 2.040 & 2.330 & 2.390 & 3.120 & 1.730 & 2.120 & 2.650 & 3.190 & 2.180 & 2.410 & 2.040 & 3.010 & 3.400 \\
\hline $\mathrm{Cr} 2 \mathrm{O} 3$ & 0.000 & 0.012 & 0.031 & 0.010 & 0.041 & 0.014 & 0.009 & 0.000 & 0.000 & 0.000 & 0.000 & 0.000 & 0.000 & 0.000 \\
\hline $\mathrm{MnO}$ & 0.360 & 0.357 & 0.358 & 0.332 & 0.302 & 0.343 & 0.308 & 0.310 & 0.356 & 1.156 & 1.101 & 1.114 & 1.172 & 1.191 \\
\hline $\mathrm{MgO}$ & 0.139 & 0.119 & 0.127 & 0.210 & 0.238 & 0.156 & 0.124 & 0.185 & 0.166 & 0.150 & 0.174 & 0.156 & 0.183 & 0.225 \\
\hline $\mathrm{CaO}$ & 0.086 & 0.044 & 0.067 & 0.073 & 0.040 & 0.000 & 0.010 & 0.021 & 0.000 & 0.023 & 0.001 & 0.001 & 0.097 & 0.243 \\
\hline $\mathrm{Nb2O5}$ & 0.003 & 0.000 & 0.064 & 0.048 & 0.000 & 0.025 & 0.072 & 0.046 & 0.045 & 0.019 & 0.043 & 0.029 & 0.000 & 0.045 \\
\hline $\mathrm{ZnO}$ & 0.000 & 0.000 & 0.000 & 0.000 & 0.000 & 0.000 & 0.000 & 0.000 & 0.000 & 0.000 & 0.000 & 0.000 & 0.000 & 0.000 \\
\hline FeOTOT & 48.059 & 47.821 & 48.081 & 48.132 & 48.085 & 48.255 & 47.892 & 48.366 & 48.148 & 46.510 & 46.719 & 46.385 & 46.542 & 46.896 \\
\hline TOTAL & 100.04 & 100.55 & 101.32 & 100.59 & 100.55 & 100.91 & 99.44 & 100.66 & 99.85 & 99.54 & 99.09 & 99.37 & 98.88 & 99.79 \\
\hline Si & 0.003 & 0.002 & 0.004 & 0.001 & 0.002 & 0.001 & 0.002 & 0.001 & 0.001 & 0.001 & 0.000 & 0.000 & 0.003 & 0.003 \\
\hline Al & 0.001 & 0.000 & 0.001 & 0.000 & 0.002 & 0.001 & 0.002 & 0.000 & 0.001 & 0.002 & 0.000 & 0.001 & 0.001 & 0.001 \\
\hline $\mathrm{Ti}$ & 1.937 & 1.961 & 1.956 & 1.947 & 1.941 & 1.957 & 1.943 & 1.943 & 1.933 & 1.960 & 1.949 & 1.964 & 1.939 & 1.931 \\
\hline $\mathrm{Fe} 2$ & 1.911 & 1.930 & 1.914 & 1.932 & 1.899 & 1.957 & 1.958 & 1.931 & 1.916 & 1.888 & 1.900 & 1.891 & 1.871 & 1.853 \\
\hline $\mathrm{Fe} 3$ & 0.118 & 0.077 & 0.087 & 0.090 & 0.118 & 0.065 & 0.081 & 0.100 & 0.121 & 0.083 & 0.092 & 0.078 & 0.115 & 0.129 \\
\hline $\mathrm{Cr}$ & 0.000 & 0.000 & 0.001 & 0.000 & 0.002 & 0.001 & 0.000 & 0.000 & 0.000 & 0.000 & 0.000 & 0.000 & 0.000 & 0.000 \\
\hline $\mathrm{Mn}$ & 0.015 & 0.015 & 0.015 & 0.014 & 0.013 & 0.015 & 0.013 & 0.013 & 0.015 & 0.050 & 0.048 & 0.048 & 0.051 & 0.051 \\
\hline$\overline{M g}$ & 0.010 & 0.009 & 0.009 & 0.018 & 0.018 & 0.012 & 0.009 & 0.014 & 0.013 & 0,011 & 0.013 & 0.012 & 0.014 & 0.017 \\
\hline $\mathrm{Ca}$ & 0.005 & 0.002 & 0.004 & 0.004 & 0.002 & 0.000 & 0.001 & 0.001 & 0.000 & 0.001 & 0.000 & 0.000 & 0.005 & 0.013 \\
\hline $\mathrm{Nb}$ & 0.000 & 0.000 & 0.000 & 0.000 & 0.000 & 0.000 & 0.000 & 0.000 & 0.000 & 0.000 & 0.000 & 0.000 & 0.000 & 0.000 \\
\hline $\mathrm{Zn}$ & 0.000 & 0.000 & 0.000 & 0.000 & 0.000 & 0.000 & 0.000 & 0.000 & 0.000 & 0.000 & 0.000 & 0.000 & 0.000 & 0.000 \\
\hline Cations & 2.06 & 2.04 & 2.04 & 2.06 & 2.06 & 2.05 & 2.07 & 2.06 & 2.07 & 2.04 & 2.05 & 2.03 & 2.06 & 2.07 \\
\hline PMSIO2 & 0.000 & 0.000 & 0.000 & 0.000 & 0.000 & 0.000 & 0.000 & 0.000 & 0.000 & 0,000 & 0.000 & 0.000 & 0.000 & 0.000 \\
\hline \begin{tabular}{|l|} 
PMTIO2 \\
\end{tabular} & 0.640 & 0.650 & 0.650 & 0.650 & 0.640 & 0.650 & 0.640 & 0.640 & 0.640 & 0.640 & 0.640 & 0.640 & 0.630 & 0.640 \\
\hline PMAI2O3 & 0.000 & 0.000 & 0.000 & 0.000 & 0.000 & 0.000 & 0.000 & 0.000 & 0.000 & 0.000 & 0.000 & 0.000 & 0.000 & 0.000 \\
\hline PMNb2O5 & 0.000 & 0.000 & 0.000 & 0.000 & 0.000 & 0.000 & 0.000 & 0.000 & 0.000 & 0.000 & 0.000 & 0.000 & 0.000 & 0.000 \\
\hline PMMnO & 0.010 & 0.010 & 0.010 & 0.000 & 0.000 & 0.000 & 0.000 & 0.000 & 0.010 & 0.020 & 0.020 & 0.020 & 0.020 & 0.020 \\
\hline PMMgO & 0.000 & 0.000 & 0.000 & 0.010 & 0.010 & 0.000 & 0.000 & 0.000 & 0.000 & 0.000 & 0.000 & 0.000 & 0.000 & 0.010 \\
\hline PMCaO & 0.000 & 0.000 & 0.000 & 0.000 & 0.000 & 0.000 & 0.000 & 0.000 & 0.000 & 0.000 & 0.000 & 0.000 & 0.000 & 0.000 \\
\hline PMZnO & 0.000 & 0.000 & 0.000 & 0.000 & 0.000 & 0.000 & 0.000 & 0.000 & 0.000 & 0.000 & 0.000 & 0.000 & 0.000 & 0.000 \\
\hline PMCr2O3 & 0.000 & 0.000 & 0.000 & 0.000 & 0.000 & 0.000 & 0.000 & 0.000 & 0.000 & 0.000 & 0.000 & 0.000 & 0.000 & 0.000 \\
\hline PMFe2O3 & 0.020 & 0.010 & 0.010 & 0.010 & 0.020 & 0.010 & 0.010 & 0.020 & 0.020 & 0.010 & 0.020 & 0.010 & 0.020 & 0.020 \\
\hline \begin{tabular}{|l|} 
PMFeO \\
\end{tabular} & 0.630 & 0.640 & 0.640 & 0.640 & 0.630 & 0.650 & 0.640 & 0.640 & 0.630 & 0.620 & 0.620 & 0.620 & 0.610 & 0.610 \\
\hline SOMA & 1.30 & 1.31 & 1.31 & 1.31 & 1.30 & 1.31 & 1.29 & 1.30 & 1.30 & 1.29 & 1.30 & 1.29 & 1.28 & 1.30 \\
\hline
\end{tabular}




\begin{tabular}{|c|c|c|c|c|c|c|c|c|c|c|c|c|c|}
\hline \multicolumn{11}{|c|}{ Anexo 5: Tabela 8 - Química Mineral de Arsenopiritas } & \multicolumn{3}{|c|}{$\%$ atm reclaculados a $100 \%$} \\
\hline Amostra & Análise & $\mathrm{C}$ & $\mathrm{M}$ & B & As & Fe & S & $\%$ atm & Mina & Obs, & As & $\mathrm{Fe}$ & $S$ \\
\hline QSB-002 & $i$ & $x$ & & & 27,841 & 32,800 & 39,249 & 99,9 & Sbento & Remobil & 27,87 & 32,84 & 39,29 \\
\hline $\mathrm{QSB}-002$ & 2 & & & $\mathrm{x}$ & 29,464 & 33,108 & 37,376 & 99,9 & Sbento & Remobil & 29,48 & 33,13 & 37,40 \\
\hline GSB-002 & 3 & $x$ & & & 29,664 & 33,116 & 37,087 & 99,9 & Sbento & Remobil & 29,70 & 33,16 & 37,14 \\
\hline QSB-002 & 4 & & & $x$ & 28,757 & 32,850 & 37,872 & 99,5 & Sbento & Remobil & 28,91 & 33,02 & 38,07 \\
\hline QSB-002 & 9 & $x$ & & & 30,873 & 33,188 & 35,855 & 99,9 & Sbento & Remobil & 30,90 & 33,22 & 35,89 \\
\hline GSB-002 & 10 & & & $x$ & 27,963 & 33,332 & 38,609 & 99,9 & Sbento & Remobil & 27,99 & 33,36 & 38,65 \\
\hline GSB-005 & 13 & $x$ & & & 29,119 & 32,779 & 38,054 & 100,0 & Sbento & Bandado & 29,13 & 32,79 & 38,07 \\
\hline GSB-005 & 14 & & & $x$ & 30,222 & 32,909 & 36,819 & 100,0 & Sbento & Bandado & 30,24 & 32,93 & 36,84 \\
\hline GSB.005 & 17 & $x$ & & & 30,025 & 32,936 & 36,973 & 99,9 & Sbento & Bandado & 30,04 & 32,96 & 37,00 \\
\hline GSB-005 & 18 & & & $x$ & 30,041 & 32,466 & 37,470 & 100,0 & Sbento & Bandado & 30,05 & 32,47 & 37,48 \\
\hline asB-005 & 21 & $x$ & & & 28,863 & 32,698 & 38,425 & 100,0 & Sbento & Bandado & 28,87 & 32,70 & 38,43 \\
\hline GSB-005 & 22 & & & $x$ & 30,926 & 32,595 & 36,454 & 100,0 & Sbento & Bandado & 30,93 & 32,60 & 36,46 \\
\hline QSB.005 & 25 & $x$ & & & 28,891 & 33,112 & 37,976 & 100,0 & Sbento & Gandado & 28,90 & 33,12 & 37,98 \\
\hline GSB-005 & 26 & & & $x$ & 29,604 & 32,927 & 37,383 & 99,9 & Sbento & Bandado & 29,63 & 32,96 & 37,42 \\
\hline QSB-003 & 38 & $x$ & & & 30,055 & 32,971 & 36,875 & 99,9 & Sbento & Remob. Rico & 30,08 & 33,00 & 36,91 \\
\hline GSB-003 & 39 & & & $x$ & 29,024 & 32,834 & 38,034 & 99,9 & Sbento & Remob. Rico & 29,06 & 32,87 & 38,08 \\
\hline GSB-003 & 40 & $x$ & & & 28,917 & 32,899 & 38,048 & 99,9 & Sbento & Remob. Rico & 28,96 & 32,94 & 38,10 \\
\hline GSB-003 & 41 & & & $x$ & 28,905 & 33,022 & 37,985 & 99,9 & Sbento & Remob. Rico & 28,93 & 33,05 & 38,02 \\
\hline GSB-003 & 42 & $x$ & & & 29,543 & 32,711 & 37,670 & 99,9 & Sbento & Remob. Fico & 29,57 & 32,74 & 37,70 \\
\hline ASB-003 & 43 & & & $x$ & 28,379 & 33,038 & 38,493 & 99,9 & Sbento & Remob. Rico & 28,40 & 33,07 & 38,53 \\
\hline GSB-003 & 44 & $x$ & & & 28,409 & 32,493 & 38,974 & 99,9 & Sbento & Remob. Rico & 28,44 & 32,53 & 39,02 \\
\hline GSB-003 & 45 & & & $x$ & 29,266 & 32,619 & 38,030 & 99,9 & Sbento & Femob. Rico & 29,29 & 32,65 & 38,06 \\
\hline GSB-004 & 46 & $x$ & & & 29,595 & 32,988 & 37,279 & 99,9 & Sbento & Band. Pobre & 29,64 & 33,03 & 37,33 \\
\hline QSB-004 & 47 & & & $x$ & 29,888 & 32,786 & 37,224 & 99,9 & Sbento & Band, Pobre & 29,92 & 32,82 & 37,26 \\
\hline GSB-004 & 50 & $x$ & & & 29,558 & 32,840 & 37,404 & 99,8 & Sbento & Band. Pobre & 29,62 & 32,91 & 37,48 \\
\hline GSB-004 & 51 & & & $x$ & 31,495 & 32,919 & 35,468 & 99,9 & Sbento & Band. Pobre & 31,53 & 32,96 & 35,51 \\
\hline QSB-004 & 54 & $x$ & & & 30,129 & 32,738 & 37,040 & 99,9 & Sbento & Band. Pobre & 30,16 & 32,77 & 37,07 \\
\hline GSB-004 & 55 & & & $x$ & 31,510 & 32,672 & 35,724 & 99,9 & Sbento & Band. Pobre & 31,54 & 32,70 & 35,76 \\
\hline GSB-004 & 56 & $x$ & & & 30,733 & 32,443 & 36,732 & 99,9 & Sbento & Band. Pobre & 30,76 & 32,47 & 36,77 \\
\hline GSB-004 & 57 & & & $x$ & 29,235 & 32,878 & 37,799 & 99,9 & Sbento & Band. Pobre & 29,26 & 32,91 & 37,83 \\
\hline GSB-004 & 58 & $x$ & & & 30,493 & 33,126 & 36,254 & 99,9 & Sbento & Band, Pobre & 30,53 & 33,17 & 36,30 \\
\hline asB-004 & 59 & & & $x$ & 30,436 & 32,955 & 36,476 & 99,9 & Sbento & Band. Pobre & 30,48 & 33,00 & 36,52 \\
\hline $\mathrm{GP}_{-14}$ & 76 & $x$ & & & 30,210 & 32,980 & 36,719 & 99,9 & Pari & FW-Anf fino & 30,24 & 33,01 & 36,75 \\
\hline$G P-14$ & 77 & & $x$ & & 33,627 & 32,775 & 33,534 & 99,9 & Pari & FW-Anf fino & 33,65 & 32,80 & 33,56 \\
\hline GP-14 & 78 & & & $x$ & 31,788 & 32,886 & 35,256 & 99,9 & Pari & FW-Anf fino & 31,81 & 32,91 & 35,28 \\
\hline GP-21A & 114 & $x$ & & & 31,570 & 32,638 & 35,702 & 99,9 & Pari & $N=10$, rico & 31,60 & 32,67 & 35,73 \\
\hline GP. $21 \mathrm{~A}$ & 115 & & & $x$ & 32,959 & 32,693 & 34,196 & 99,8 & Pari & $\mathrm{N}-10$, rico & 33,01 & 32,74 & 34,25 \\
\hline GP-21A & 119 & $x$ & & & 32,314 & 32,718 & 34,846 & 99,9 & Pari & $\mathrm{N}-10$, rico & 32,35 & 32,76 & 34,89 \\
\hline GP. $21 \mathrm{~A}$ & 120 & & & $x$ & 33,008 & 32,690 & 34,153 & 99,9 & Pari & $N-10$, rico & 33,06 & 32,74 & 34,20 \\
\hline $\mathrm{GP}-21 \mathrm{~A}$ & 121 & $x$ & & & 31,992 & 32,893 & 35,038 & 99,9 & Pari & $\mathrm{N}-10$, rico & 32,02 & 32,92 & 35,07 \\
\hline $\mathrm{GP}-21 \mathrm{~A}$ & 122 & & & $x$ & 31,924 & 32,791 & 35,184 & 99,9 & Pari & $\mathrm{N}-10$, rico & 31,96 & 32,82 & 35,22 \\
\hline QP-21A & 125 & $x$ & & & 33,447 & 32,975 & 33,440 & 99,9 & Pari & $\mathrm{N}-10$, rico & 33,49 & 33,02 & 33,49 \\
\hline $\mathrm{QP}-21 \mathrm{~A}$ & 126 & & & $x$ & 33,107 & 32,885 & 33,805 & 99,8 & Pari & $\mathrm{N}-10$, rico & 33,17 & 32,95 & 33,87 \\
\hline GP.21A & 129 & $x$ & & & 32,437 & 33,083 & 34,353 & 99,9 & Pari & $\mathrm{N}-10$, rico & 32,48 & 33,13 & 34,40 \\
\hline $\mathrm{GP}-21 \mathrm{~A}$ & 130 & & & $x$ & 33,938 & 32,872 & 33,003 & 99,8 & Pari & $\mathrm{N}-10$, rico & 34,00 & 32,93 & 33,06 \\
\hline GP-21A & 137 & $x$ & & & 31,769 & 33,067 & 35,111 & 99,9 & Pari & $\mathrm{N}-10$, rico & 31,79 & 33,08 & 35,13 \\
\hline $\mathrm{GP}-21 \mathrm{~A}$ & 138 & & $x$ & & 32,654 & 33,243 & 34,020 & 99,9 & Pari & $N-10$, rico & 32,68 & 33,27 & 34,05 \\
\hline GP-21A & 139 & & & $x$ & 32,183 & 33,106 & 34,582 & 99,9 & Pati & $N-10$, rico & 32,22 & 33,15 & 34,63 \\
\hline GP-21A & 140 & $x$ & & & 33,680 & 32,738 & 33,424 & 99,8 & Pari & $\mathrm{N}-10$, rico & 33,73 & 32,79 & 33,48 \\
\hline QP.21A & 141 & & & $x$ & 33,414 & 32,628 & 33,839 & 99,9 & Pari & $\mathrm{N}-10$, rico & 33,45 & 32,67 & 33,88 \\
\hline GP-21A & 142 & $x$ & & & 31,807 & 32,772 & 35,329 & 99,9 & Pari & $\mathrm{N}-10$, rico & 31,84 & 32,80 & 35,36 \\
\hline QP-21A & 143 & & & $x$ & 33,193 & 32,772 & 33,912 & 99,9 & Pari & $\mathrm{N}-10$, rico & 33,23 & 32,81 & 33,95 \\
\hline GP-2IA & 146 & $x$ & & & 31,945 & 33,099 & 34,783 & 99,8 & Pari & $\mathrm{N}-10$, rico & 32,00 & 33,16 & 34,84 \\
\hline QP-21A & 147 & & & $x$ & 31,424 & 32,891 & 35,620 & 99,9 & Pari & N-10, rico & 31,44 & 32,91 & 35,64 \\
\hline GP-21A & 148 & $\mathrm{x}$ & & & 33,707 & 33,062 & 33,058 & 99,8 & Pari & $\mathrm{N}-10$, rico & 33,77 & 33,12 & 33,12 \\
\hline GP-21A & 149 & & & $x$ & 32,186 & 32,912 & 34,762 & 99,9 & Pari & $\mathrm{N}-10$, rico & 32,23 & 32,96 & 34,81 \\
\hline $\mathrm{QP}-21 \mathrm{~A}$ & 152 & $x$ & & & 32,335 & 33,133 & 34,439 & 99,9 & Pari & $\mathrm{N}-10$, rico & 32,37 & 33,16 & 34,47 \\
\hline $\mathrm{QP}-21 \mathrm{~A}$ & 153 & & $x$ & & 32,586 & 32,849 & 34,376 & 99,8 & Pari & $\mathrm{N}-10$, rico & 32,65 & 32,91 & 34,44 \\
\hline GP-21A & 154 & & & $\mathrm{x}$ & 33,295 & 32,853 & 33,756 & 99,9 & Pant & $\mathrm{N}-10$, rico & 33,33 & 32,88 & 33,79 \\
\hline GP-21B & 155 & $x$ & & & 33,374 & 32,668 & 33,802 & 99,8 & Pari & $N-10$, rico & 33,43 & 32,72 & 33,85 \\
\hline$Q P-21 B$ & 156 & & & $x$ & 33,646 & 32,734 & 33,327 & 99,7 & Pari & $\mathrm{N}-10$, rico & 33,74 & 32,83 & 33,42 \\
\hline $\mathrm{GP}-2 \mathrm{BB}$ & 161 & $x$ & & & 32,275 & 32,887 & 33,366 & 98,5 & Pari & $\mathrm{N}-10$, rico & 32,76 & 33,38 & 33,86 \\
\hline QP-21B & 162 & & $x$ & & 31,303 & 32,993 & 35,576 & 99,9 & Pari & $\mathrm{N}-10$, rico & 31,34 & 33,04 & 35,62 \\
\hline $\mathrm{GP}-21 \mathrm{~B}$ & 163 & & & $x$ & 33,364 & 33,028 & 33,496 & 99,9 & Pari & N-10, rico & 33,40 & 33,07 & 33,53 \\
\hline
\end{tabular}




\begin{tabular}{|c|c|c|c|c|c|c|c|c|c|}
\hline \multicolumn{10}{|c|}{ Anexo 5: Tabela 9 - Química Mineral de Piritas } \\
\hline & & & & & & & \multicolumn{2}{|c|}{$\%$ atm recalc. $100 \%$} & \\
\hline Amostra & Análise & $\mathrm{C}$ & $\bar{B}$ & $\mathrm{Fe}$ & $\bar{S}$ & Soma & $\mathrm{Fe}$ & $s$ & $\mathrm{Fe} / \mathrm{S}$ \\
\hline GSB-02 & 7 & $\bar{x}$ & & 32,876 & 67,032 & 99,908 & 32,91 & 67,09 & 2,0 \\
\hline GSB-02 & 8 & & $x$ & 32,936 & 66,896 & 99,832 & 32,99 & 67,01 & 2,0 \\
\hline GSB-06 & 27 & $x$ & & 32,882 & 67,061 & 99,943 & 32,90 & 67,10 & 2,0 \\
\hline GSB-06 & 28 & & $x$ & 32,799 & 67,124 & 99,923 & 32,82 & 67,18 & 2,0 \\
\hline GSB-06 & 29 & $x$ & & 32,738 & 67,085 & 99,823 & 32,80 & 67,20 & 2,0 \\
\hline GSB-06 & 30 & & $x$ & 32,854 & 66,994 & 99,848 & 32,90 & 67,10 & 2,0 \\
\hline GSB-06 & 31 & $x$ & & 33,606 & 65,853 & 99,459 & 33,79 & $66,2\}$ & 2,0 \\
\hline GSB-06 & 32 & & $x$ & 33,182 & 66,705 & 99,887 & 33,22 & 66,78 & 2,0 \\
\hline GSB-06 & 35 & $x$ & & 33,191 & 66,729 & 99,920 & 33,22 & 66,78 & 2,0 \\
\hline GP19A & 96 & $x$ & & 33,204 & 66,637 & 99,841 & 33,26 & 66,74 & 2,0 \\
\hline GP19A & 97 & & $x$ & 33,086 & 66,770 & 99,856 & 33,13 & 66,87 & 2,0 \\
\hline GP19A & 100 & $x$ & & 33,397 & 66,335 & 99,732 & 33,49 & 66,51 & 2,0 \\
\hline GP19A & 101 & & $x$ & 33,237 & 66,516 & 99,753 & 33,32 & 66,68 & 2,0 \\
\hline
\end{tabular}




\begin{tabular}{|c|c|c|c|c|c|c|c|c|c|c|c|}
\hline \multicolumn{8}{|c|}{$\begin{array}{c}\text { Anexo 5: Tabela } 10 \text { - Quím } \\
\text { C-Centro; B-Borda do grāo }\end{array}$} & \multicolumn{2}{|c|}{$\%$ at rec. $100 \%$} & \multirow[b]{2}{*}{$\mathrm{Fe} / \mathrm{S}$} & \\
\hline Amostra & Análise & $c$ & $B$ & $\mathrm{Fe}$ & $S$ & Soma & Observ. & $\mathrm{Fe}$ & $\mathrm{S}$ & & $x$ \\
\hline GSB-02 & 5 & $x$ & & 46,518 & 53,388 & 99,9 & Sbento, remob. & 46,56 & 53,44 & 0,871 & 0,129 \\
\hline GSB-02 & 6 & & $x$ & 45,985 & 53,850 & 99,8 & Sbento, remob. & 46,06 & 53,94 & 0,854 & 0,146 \\
\hline GSB-02 & 11 & $x$ & & 46,68 & 53,242 & 99,9 & Sbento, remob. & 46,72 & 53,28 & 0,877 & 0,123 \\
\hline GSB-02 & 12 & & $x$ & 46,566 & 53,372 & 99,9 & Sbento, zemob. & 46,59 & 53,41 & 0,872 & 0,128 \\
\hline QSB-05 & 15 & $x$ & & 45,916 & 53,986 & 99,9 & Bandado Sulf. & 45,96 & 54,04 & 0,851 & 0,149 \\
\hline GSB.05 & 16 & & $x$ & 45,792 & 54,142 & 99,9 & Banciado Sulf. & 45,82 & 54,18 & 0,846 & 0,154 \\
\hline GSB-05 & 19 & $x$ & & 46,622 & 53,318 & 99,9 & Bandado Sulf. & 46,65 & $53_{4} 35$ & 0,874 & 0,126 \\
\hline GSB-05 & 20 & & $x$ & 46,169 & 53,774 & 99,9 & Bandado Sulf. & 46,20 & 53,80 & 0,859 & 0,141 \\
\hline GSB-05 & 23 & $x$ & & 46,185 & 53,712 & 99,9 & Bandado Sulf. & 46,23 & 53,77 & 0,860 & 0,140 \\
\hline GSB-05 & 24 & & $x$ & 45,760 & 54,178 & 99,9 & Bandado Sulf. & 45,79 & 54,21 & 0,845 & 0,155 \\
\hline GSB-04 & 48 & $x$ & & 46,506 & 53,384 & 99,9 & bandado mag. & 46,56 & 53,44 & 0,871 & 0,129 \\
\hline QSB-04 & 49 & $x$ & & 46,707 & 53,220 & 99,9 & bandado mag. & 46,74 & 53,26 & 0,878 & 0,122 \\
\hline QSB-04 & 52 & $x$ & & 46,388 & 53,511 & 99,9 & bandado mag. & 46,43 & 53,57 & 0,867 & 0,133 \\
\hline GSB-04 & 53 & & $x$ & 46,607 & 53,303 & 99,9 & bandado mag. & 46,65 & 53,35 & 0,874 & 0,126 \\
\hline$Q P-01$ & 60 & $x$ & & 46,549 & 53,172 & 99,7 & Sulf. Mac. & 46,68 & 53,32 & 0,875 & 0,125 \\
\hline QP.01 & 61 & & $x$ & 46,041 & 53,655 & 99,7 & Sulf. Mac. & 46,18 & 53,82 & 0,858 & 0,142 \\
\hline GP.01 & 62 & $x$ & & 44,729 & 55,020 & 99,7 & Sult. Mac. & 44,84 & 55,16 & 0,813 & 0,187 \\
\hline QP-01 & 63 & & $x$ & 45,306 & 54,465 & 99,8 & Sulf. Mac. & 45,41 & 54,59 & 0,832 & 0,168 \\
\hline QP-01 & 64 & $x$ & & 46,349 & 53,377 & 99,7 & Sulf. Mac. & 46,48 & 53,52 & 0,868 & 0,132 \\
\hline GP-01 & 65 & & $x$ & 46,060 & 53,633 & 99,7 & Sulf. Mac. & 46,20 & 53,80 & 0,859 & 0,141 \\
\hline QP-01 & 66 & $x$ & & 45,706 & 53,953 & 99,7 & Sulf. Mac. & 45,86 & 54,14 & 0,847 & 0,153 \\
\hline GP-01 & 67 & & $x$ & 44,867 & 54,664 & 99,5 & Sulf. Mac. & 45,08 & 54,92 & 0,821 & 0,179 \\
\hline GP-01 & 68 & $x$ & & 46,113 & 53,607 & 99,7 & Sulf. Mac. & 46,24 & 53,76 & 0,860 & 0,140 \\
\hline GP.01 & 69 & & $x$ & 46,707 & 52,966 & 99,7 & Sulf. Mac. & 46,86 & 53,14 & 0,882 & 0,118 \\
\hline $14 \mathrm{~B}$ & 70 & $x$ & & 46,105 & 53,753 & 99,8 & minério $\mathrm{N}-10$ & 46,17 & 53,83 & 0,858 & 0,142 \\
\hline $14 B$ & 71 & & $x$ & 46,193 & 53,648 & 99,8 & minério N-30 & 46,27 & 53,73 & 0,861 & 0,139 \\
\hline $14 \mathrm{~B}$ & 72 & $\mathrm{x}$ & & 46,193 & 53,692 & 99,9 & minério N"10 & 46,25 & 53,75 & 0,860 & 0,140 \\
\hline 14B & 73 & & $x$ & 46,354 & 53,538 & 99,9 & minério $\mathrm{N}-10$ & 46,40 & 53,60 & 0,866 & 0,134 \\
\hline $14 \mathrm{~B}$ & 74 & $x$ & & 45,974 & 53,923 & 99,9 & minerio $N-10$ & 46,02 & 53,98 & 0,853 & 0,147 \\
\hline $14 \mathrm{~B}$ & 75 & & $x$ & 45,767 & 54,13 & 99,9 & minério N-10 & 45,81 & 54,19 & 0,846 & 0,154 \\
\hline $14 B$ & 79 & $x$ & & 46,186 & 53,696 & 99,9 & minério N-10 & 46,24 & 53,76 & 0,860 & 0,140 \\
\hline $14 \mathrm{~B}$ & 80 & & $x$ & 46,349 & 53,508 & 99,9 & minério N-10 & 46,42 & 53,58 & 0,866 & 0,134 \\
\hline $14 \mathrm{~B}$ & 81 & $x$ & & 45,895 & 53,949 & 99,8 & minério $\mathrm{N}-10$ & 45,97 & 54,03 & 0,851 & 0,149 \\
\hline $14 \mathrm{~B}$ & 82 & & $x$ & 45,491 & 54,389 & 99,8 & minério $\mathrm{N}-10$ & 45,51 & 54,49 & 0,835 & 0,165 \\
\hline GN-26 & 85 & $x$ & & 45,644 & 54,034 & 99,7 & Anf. FW NDO & 45,79 & 54,21 & 0,845 & 0,155 \\
\hline QN-26 & 86 & $x$ & & 45,747 & 53,975 & 99,7 & Anf. FW NoO & 45,87 & 54,13 & 0,848 & 0,152 \\
\hline GN-26 & 87 & & $\mathrm{x}$ & 45,759 & 53,94 & 99.7 & Anf. FW NOO & 45,90 & 54,10 & 0,848 & 0,152 \\
\hline GP-19a & 88 & $x$ & & 45,945 & 53,894 & 99,8 & minério $\mathrm{N}-10$ & 46,02 & 53,98 & 0,853 & 0,147 \\
\hline GP-19a & 89 & & $x$ & 45,932 & 53,881 & 99,8 & minério N-10 & 46,02 & 53,98 & 0,852 & 0,148 \\
\hline QP-19a & 90 & $x$ & & 46,146 & 53,714 & 99,9 & minerio $\mathrm{N}-10$ & 46,21 & 53,79 & 0,859 & 0,141 \\
\hline$G P-19 a$ & 91 & & $x$ & 45,875 & 53,922 & 99,8 & minério N-10 & 45,97 & 54,03 & 0,851 & 0,149 \\
\hline GP.19a & 92 & $x$ & & 45,484 & 54,342 & 99,8 & minério $\mathrm{N}-10$ & 45,56 & 54,44 & 0,837 & 0,163 \\
\hline GP-19a & 93 & & $x$ & 45,545 & 54,249 & 99,8 & minério N-10 & 45,64 & 54,36 & 0,840 & 0,160 \\
\hline GP-19a & 94 & $\mathrm{x}$ & & 45,770 & 54,108 & 99,9 & minerio $\mathrm{N}-10$ & 45,83 & 54,17 & 0,846 & 0,154 \\
\hline GP-19a & 95 & & $\mathrm{x}$ & 45,694 & 54,099 & 99,8 & minério $N-10$ & 45,79 & 54,21 & 0,845 & 0,155 \\
\hline GP-19a & 98 & $x$ & & 46,095 & 53,784 & 99,9 & minério $N-10$ & 46,15 & 53,85 & 0,857 & 0,143 \\
\hline QP-19a & 99 & & $x$ & 45,978 & 53,867 & 99,8 & minério $N-10$ & 46,05 & 53,95 & 0,854 & 0,146 \\
\hline Q-8 & 102 & $x$ & & 46,541 & 53,313 & 99,9 & minerio N-10 & 46,61 & 53,39 & 0,873 & 0,127 \\
\hline Q.8 & 103 & & $\mathrm{x}$ & 46,078 & 53,891 & 100,0 & minério $\mathrm{N}-10$ & 46,09 & 53,91 & 0,855 & 0,145 \\
\hline G.8 & 112 & $x$ & & 46,400 & 53,469 & 99,9 & minério $N-10$ & 46,46 & 53,54 & 0,868 & 0,132 \\
\hline $\mathrm{Q}-8$ & 113 & & $x$ & 45,921 & 53,962 & 99,9 & minério $N-10$ & 45,97 & 54,03 & 0,851 & 0,149 \\
\hline $\mathrm{Gm} 8$ & 116 & $x$ & & 46,635 & 53,253 & 99,9 & minério $\mathrm{N}-10$ & 46,69 & 53,31 & 0,876 & 0,124 \\
\hline $\mathrm{G}-8$ & 117 & & $x$ & 45,934 & 53,927 & 99,9 & minério N-10 & 46,00 & 54,00 & 0,852 & 0,148 \\
\hline G-8 & 123 & $x$ & & 46,872 & 52,996 & 99,9 & minério $N-10$ & 46,93 & 53,07 & 0,884 & 0,116 \\
\hline Q.8 & 124 & & $x$ & 46,094 & 53,855 & 99,9 & minerio N-10 & 46,12 & 53,88 & 0,856 & 0,144 \\
\hline G.8 & 133 & $x$ & & 46,441 & 53,471 & 99,9 & minério $\mathrm{N}-10$ & 46,48 & 53,52 & 0,869 & 0,131 \\
\hline$Q-8$ & 134 & & $x$ & 45,894 & 53,987 & 99,9 & minério $\mathrm{N}-10$ & 45,95 & 54,05 & 0,850 & 0,150 \\
\hline $\mathrm{G}-8$ & 135 & $x$ & & 46,679 & 53,179 & 99,9 & minério $\mathrm{N}-10$ & 46,75 & 53,25 & 0,878 & 0,122 \\
\hline$Q .8$ & 136 & & $x$ & 46,337 & 53,567 & 99,9 & minério N-10 & 46,38 & 53,62 & 0,865 & 0,135 \\
\hline Q.8 & 144 & $x$ & & 46,747 & 53,104 & 99,9 & minério $N-10$ & 46,82 & 53,18 & 0,880 & 0,120 \\
\hline Q-8 & 145 & & $x$ & 46,047 & 53,802 & 99,8 & minério $N-10$ & 46,12 & 53,88 & 0,856 & 0,144 \\
\hline$G-8$ & 150 & $x$ & & 44,927 & 54,929 & 99,9 & minério N-10 & 44,99 & 55,01 & 0,818 & 0,182 \\
\hline $\mathrm{Q}-8$ & 158 & & $x$ & 45,699 & 54,122 & 99,8 & minério N-10 & 45,78 & 54,22 & 0,844 & 0,156 \\
\hline
\end{tabular}




\begin{tabular}{|c|c|c|c|c|c|c|c|c|c|c|}
\hline \multicolumn{11}{|c|}{$\begin{array}{l}\text { Anexo 5: Tabela } 11 \text { - Química Mineral de Calcopiritas } \\
\text { C-Centro; B-Borda dos grãos }\end{array}$} \\
\hline Amostra & Análise & $\frac{0}{c}$ & $\frac{\mathrm{aus}}{\mathrm{B}}$ & & & & & \multicolumn{3}{|c|}{ \%atm recalc. $100 \%$} \\
\hline GP-26 & 83 & $x$ & & $\mathrm{Cu}$ & $\mathrm{Fe}$ & S & Soma & $\mathrm{Cu}$ & $\mathrm{Fe}$ & S \\
\hline GP-26 & 84 & & $x$ & 24,581 & 24,865 & 50,454 & 99,9 & 24,61 & 24,89 & 50,50 \\
\hline GP-21A & 118 & $x$ & & 24,698 & 24,508 & 50,678 & 99,9 & 24,73 & 24,54 & 50,74 \\
\hline GP-21A & 127 & $x$ & & 25,022 & 24,307 & 50,606 & 99,9 & 25,04 & 24,32 & 50,64 \\
\hline GP-21A & 128 & & $x$ & 25,027 & 24,832 & 50,005 & 99,9 & 25,06 & 24,87 & 50,07 \\
\hline GP-21A & 131 & $x$ & & 24,858 & 24,959 & 50,061 & 99,9 & 24,89 & 24,99 & 50,12 \\
\hline GP-21A & 132 & & $x$ & $\begin{array}{r}25,192 \\
24808\end{array}$ & 24,354 & 50,406 & 100,0 & 25,20 & 24,37 & 50,43 \\
\hline GP-21B & 159 & $x$ & & $\frac{24,898}{25,082}$ & 24,937 & 24,898 & 74,7 & 33,32 & 33,37 & 33,32 \\
\hline GP-21B & 160 & & $x$ & $\frac{25,082}{24,986}$ & 24,515 & 50,323 & 99,9 & 25,10 & 24,53 & 50,36 \\
\hline & & & & 24,980 & 24,63 & 50,311 & 99,9 & 25,00 & 24,65 & 50,35 \\
\hline
\end{tabular}


Anexo 5: Tabela 12 - Química Mineral de Esfaleritas

C-Centro; B-Borda de grãos

\begin{tabular}{|c|c|c|c|c|c|c|c|c|c|c|c|}
\hline Amostra & Análise & $C$ & $B$ & $\mathrm{Zn}$ & $\mathrm{Fe}$ & $S$ & soma \%at & soma $w t \%$ & $\mathrm{Zn}$ & $\mathrm{Fe}$ & $\bar{S}$ \\
\hline GP-21a & 104 & $x$ & & 41,517 & 7,971 & 50,258 & 99,746 & 97,199 & 55,302 & 9,070 & 32,827 \\
\hline GP-21a & 105 & & $x$ & 40,864 & 7,938 & 50,554 & 99,356 & 96,086 & 54,207 & 8,994 & 32,885 \\
\hline GP-21a & 106 & $x$ & & 40,811 & 8,303 & 50,766 & 99,880 & 96,910 & 54,329 & 9,442 & 33,139 \\
\hline GP-21a & 107 & & $x$ & 40,931 & 8,283 & 50,643 & 99,857 & 97,292 & 54,672 & 9,450 & 33,170 \\
\hline GP-21a & 108 & $x$ & & 41,755 & 7,965 & 50,109 & 99,829 & 97,482 & 55,659 & 9,069 & 32,754 \\
\hline GP-21a & 109 & & $x$ & 40,657 & 8,208 & 50,986 & 99,851 & 96,001 & 53,710 & 9,262 & 33,029 \\
\hline GP-21a & 110 & $x$ & & 40,974 & 8,447 & 50,391 & 99,812 & 97,190 & 54,627 & 9,620 & 32,943 \\
\hline GP-21a & 111 & & $x$ & 40,749 & 8,258 & 50,842 & 99,849 & 97,125 & 54,414 & 9,420 & 33,291 \\
\hline
\end{tabular}

\begin{tabular}{|c|c|c|}
\hline & \multicolumn{2}{|c|}{$\%$ moles FeS } \\
\hline $\mathrm{Zn}$ & $\mathrm{Fe}$ & $\mathrm{S}$ \\
\hline 82,6 & 15,9 & 100 \\
\hline 80,8 & 15,7 & 100 \\
\hline 80,4 & 16,4 & 100 \\
\hline 80,8 & 16,4 & 100 \\
\hline 83,3 & 15,9 & 100 \\
\hline 79,7 & 16,1 & 100 \\
\hline 81,3 & 16,8 & 100 \\
\hline 80,1 & 16,2 & 100 \\
\hline
\end{tabular}


Anexo 6: Pranchas 16, 17 e 18 de Fotomicrografias de Minérios (Luz Refletida) 


\section{Prancha 16}
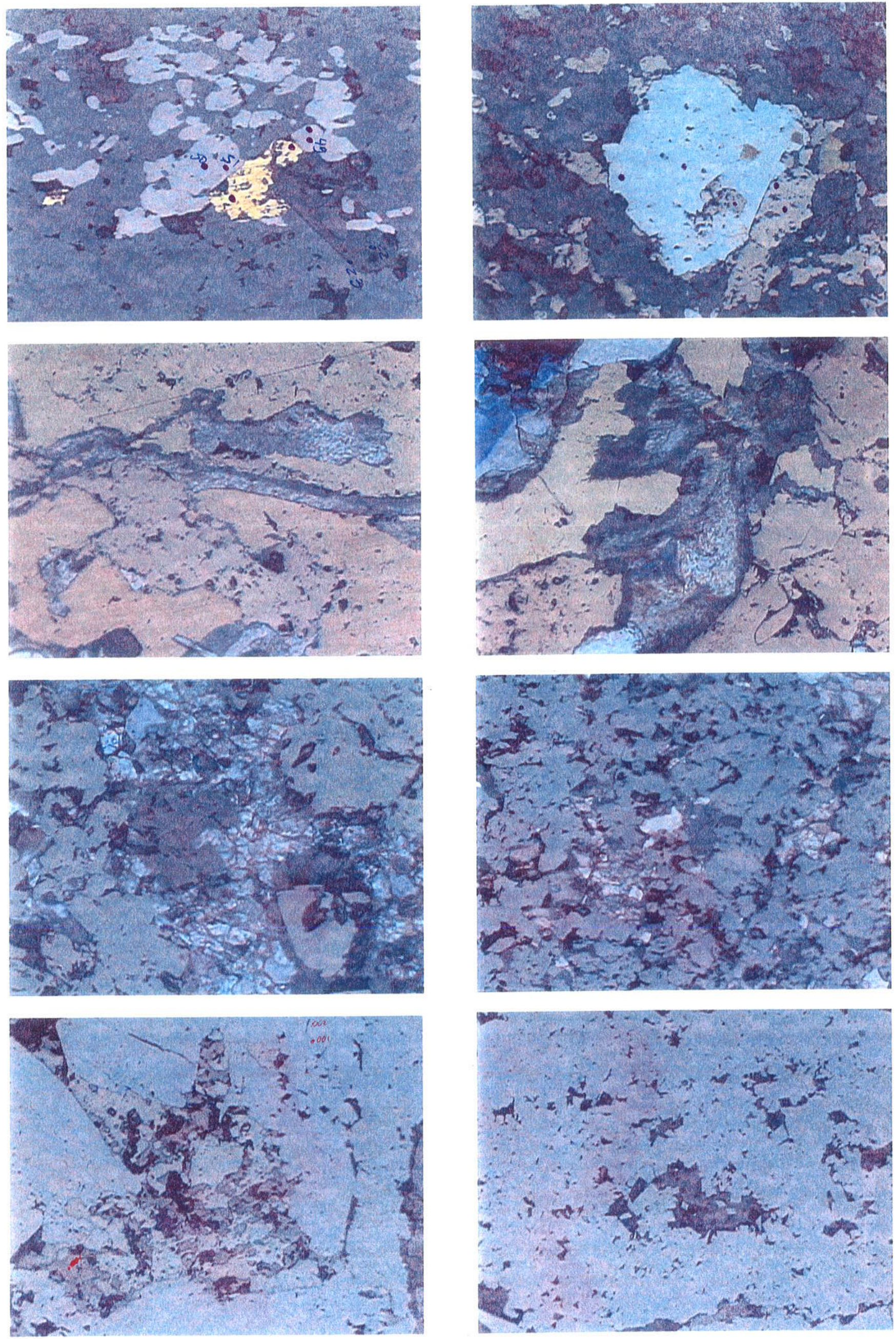


\section{Prancha 16}

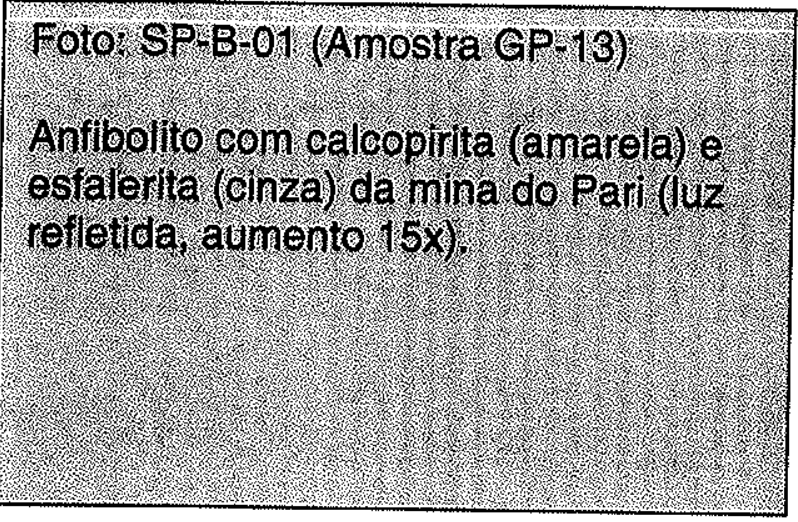

\section{Foto: SP-C-01 (Amostra GP-19A)}

Pirta (amarelo latáo) tardia remobilizada em fraturas juntamente com pirrotitas, mina do Pari (luz refletida, aumento $20 x$ )

\section{Foto: SPCC.03 (Amostra GSB.01)}

Minerio remobilizado da mina São Bento, onde observa-se massa sulfetada cinza em meio a ganga transparente incolor (luz refletida e. transmittida simultaneas, aumento 20x).

\section{Foto: SP.C.05 (Amostra GSB-02)}

Minério remobilizado da mina são Bento, onde observa-se massa sulfetada rica em arsenopirita (branca) e restos intersticiaís de pirrotita (castanha) e pirita (amarela) (luz refietida, aumento $20 x$ )

\section{Foto: SP-B-27 (Amostra GP-14B)}

Arsenopirita (branca) com inclusoes de pirrotita (castanha), mina do Pari (luz refletida, aumento $20 \mathrm{x}$ ).

Foto: SP-C-02 (Amostra GP-19B)

Pirta (amarelo latäo) tardia remibilizada em fraturas juntamente com pirrotitas, mina do Pari fluz refietida, aumento $20 x$ ).

Foto: SP.C-04 (Amostra GSB-01)

Minério remoboiliza do da mina Săo Bento, onde observa-se massa sulfetada cinza em meio a ganga. transparente incolor (luz refletida $e$ transmitida simultaneas, aumento $20 x$.

Foto. SP.C-06 (Amostra GSB-03)

Minério remobilizado da mina Sáo Bento, onde observa-se massa suffetada rica em arsenopirita (branca) e restos intersticiais de magnetita e. esfalerita de cor cinza (luz refletica. aumente 20x). 


\section{Prancha 17}
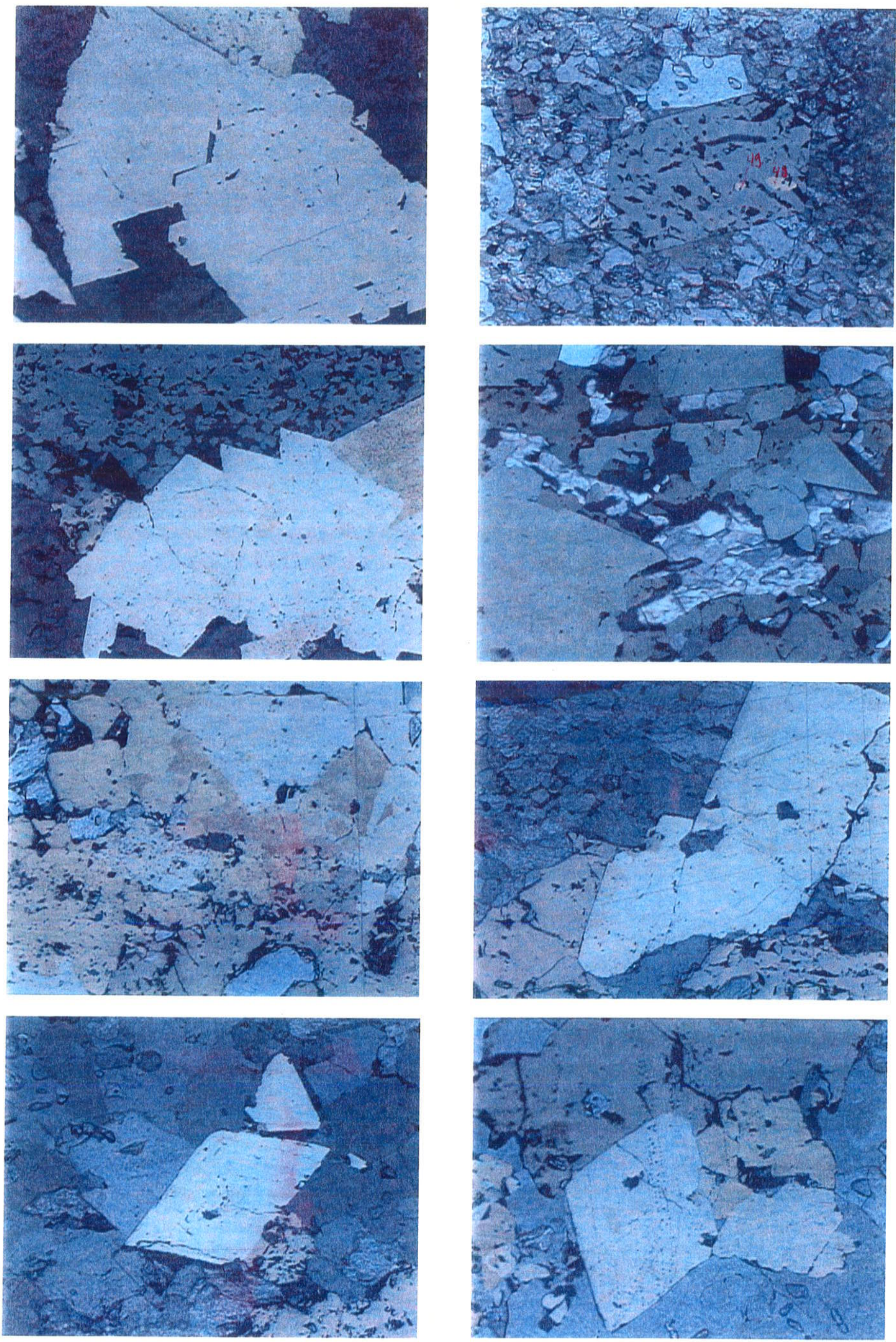


\section{Prancha 17}

Foto: SP-C-07 (Amostra GSB-03)

Minério remobilizado da mina São Bento, com cristais euhedrais de arsenopirita (branca) e restos intersticiais de pirrotita e ganga (luz refletida, aumento $20 \mathrm{x}$ ).

\section{Foto: SP-C-09 (Amostra GSB-04)}

Minério bandado da mina São Bento, porção sulfetada, com cristais euhedrais de arsenopirita (branca) (luz refletida, aumento $20 x$ ).

\section{Foto: SP-C-11 (Amostra GSB-05)}

Minério bandado da mina São Bento, porção sulfetada, com cristais euhedrais de arsenopirita (branca) pirrotita e pirita (amarela) (luz refletida e transmitida, aumento 20x).

\section{Foto: SP-C-13 (Amostra GSB-05)}

Cristais de arsenopirita euhedrica (branca) e pirrotita (castanha), mina São Bento (luz refletida e transmitida, aumento 20x).
Foto: SP-C-08 (Amostra GSB-04)

Minério bandado da mina São Bento, porção magnetítica, com cristais euhedrais de magnetita (cinza) englobando restos intersticiais de pirrotita e pirita (luz refletida e transmitida simultaneas, aumento 20x).

Foto: SP-C-10 (Amostra GSB-04)

Minério bandado da mina São Bento, porção sulfetada, com cristais euhedrais de arsenopirita (branca) englobando restos intersticiais de pirrotita e esfalerita (cinza) (luz refletida e transmitida simultaneas, aumento 20x).

Foto: SP-C-12 (Amostra GSB-05)

Minério bandado da mina São Bento, porção sulfetada, com cristais euhedrais de arsenopirita (branca) e pirrotita (castanha) (luz refletida e transmitida, aumento 20x).

Foto: SP-C-14 (Amostra GSB-06)

Cristais de arsenopirita euhedrica (branca), pirrotita (castanha) e pirita amarela, mina São Bento (luz refletida, aumento 20x). 


\section{Prancha 18}
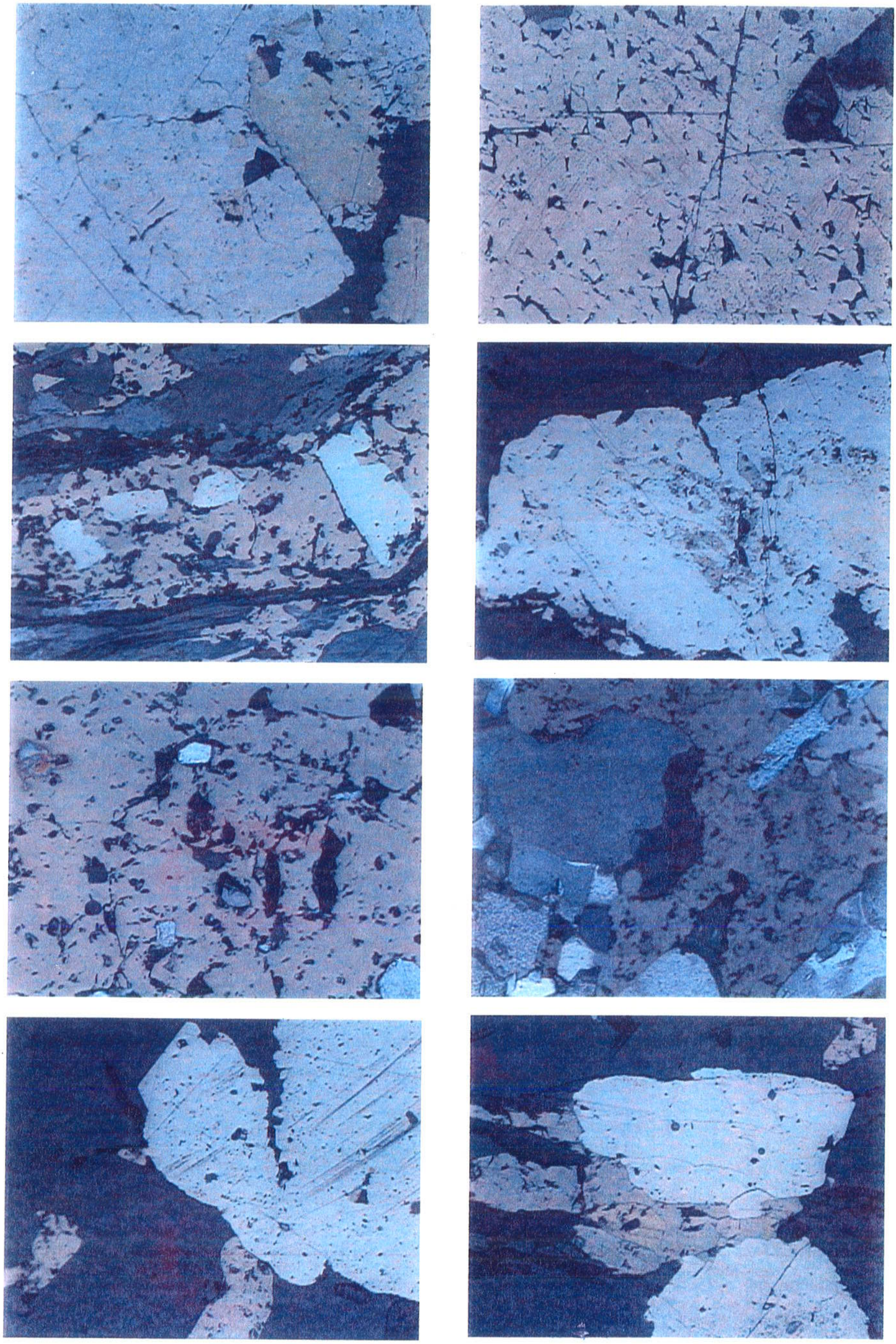


\section{Prancha 18}

Foto: SP-C-15 (Amostra GSB-06)

Detalhe de arsenoprita (branca) englobando parcialmente pirrotita (castanha) e magnetita (cinza), mina Sáo Bento (luz refletida, aumento 20x).

Foto: SP-C-17 (Amostra GP-14C)

BMicroboudin de sulfeto (arsenopirita e pirrotita) envolto por ganga silicática cisalhada, mina do Pari (luz refletida, aumento 20x).

\section{Foto: SP-C-19 (Amostra GP-19C)}

Detalhe de cristal de pirrotita com restos de ganga e esfalerita, mina do Pari (luz refletida, aumento $20 x$ ).

Foto: SP-C-21 (Amostra GP-07A)

Arsenopirita xenomórfica em contato com pirrotita, mina do Pari (luz refletida, aumento $20 x$ ).
Foto: SP-C-16 (Amostra GP-01)

Detalhe de cristal de pirrotita com restos de ganga e magnetita, mina do Pari (luz refletida, aumento $20 x$ ).

Foto: SP.C. 18 (Amostra GP-14C)

Porfiroblasto de arsenopirita rica em inclusões de pirrotita e esfalerita, mina do Pari (luz refletida, aumento $15 \mathrm{x}$ ).

Foto: SP-C-20 (Amostra GP-07A)

Contato lobular entre pirrotita $e$ magnetita, mina do Pari (luz refletida, aumento $25 \mathrm{x}$ ).

Foto: SP-C-22 (Amostra GP-07A)

Arsenopirita xenomórfica em contato com pirrotita, que contem uma inclusão de calcopirita, mina do Pari (luz refletida, aumento $20 \mathrm{x}$ ). 
Anexo 7: Gráficos Normalizados de ETR (Elementos Terras Raras)

Pág. 01 - Normalização : Condrito $C 1$

Pág. 02 - Normalização : N-MORB

Pág. 03 - Normalização : E-MORB

Pág. 04 - Normalização : Barberton peridotitic komatiite

Pág. 05 - Normalização : Toleiíto arqueano seg. Kuhno

Pág. 06 - Normalização : Basaltos recentes do East Pacific Rise

Pág. 07 - Normalização : OBS (ocean bottom sediments) of the East Pacific Rise vents

Pág. 08 - Normalização : Pillow lava do East Pacific Rise

Pág. 09 - Normalização : Vent fluids do East Pacific Rise

Pág. 10 - Normalização : Água do mar

Pág. 11 - Normalização : NASC 

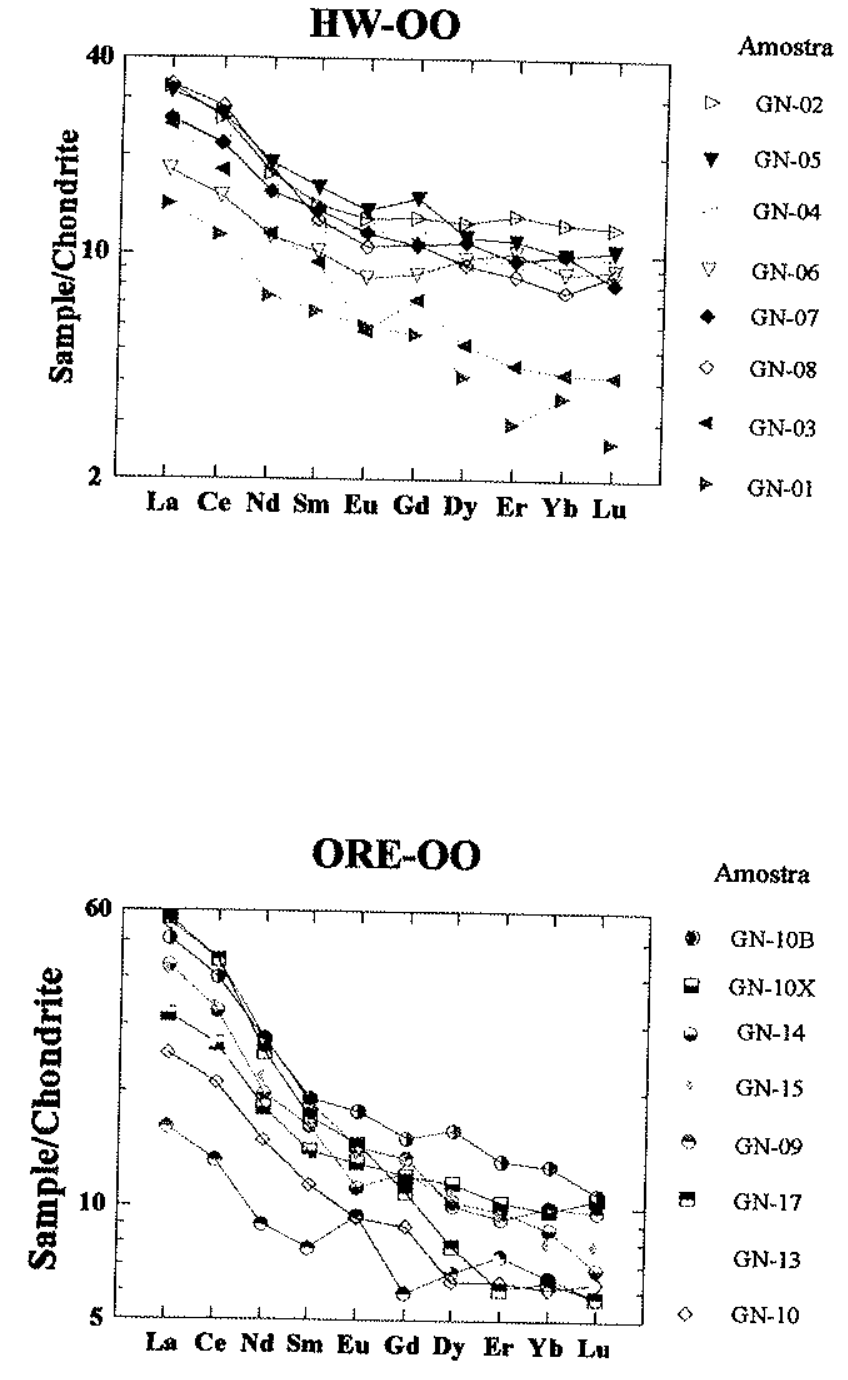

FW-OO

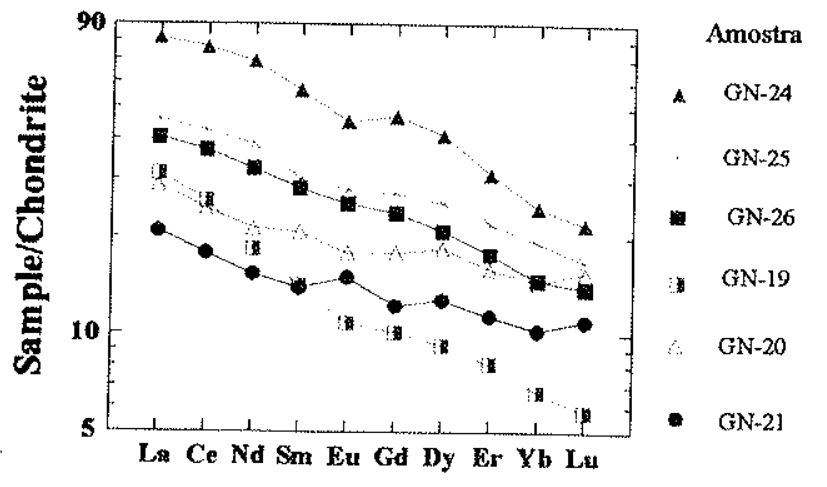

HW-10

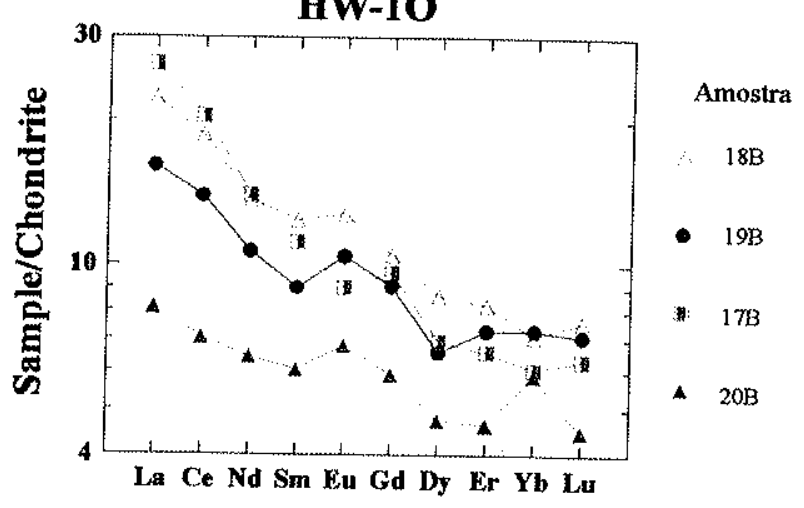

ORE-10

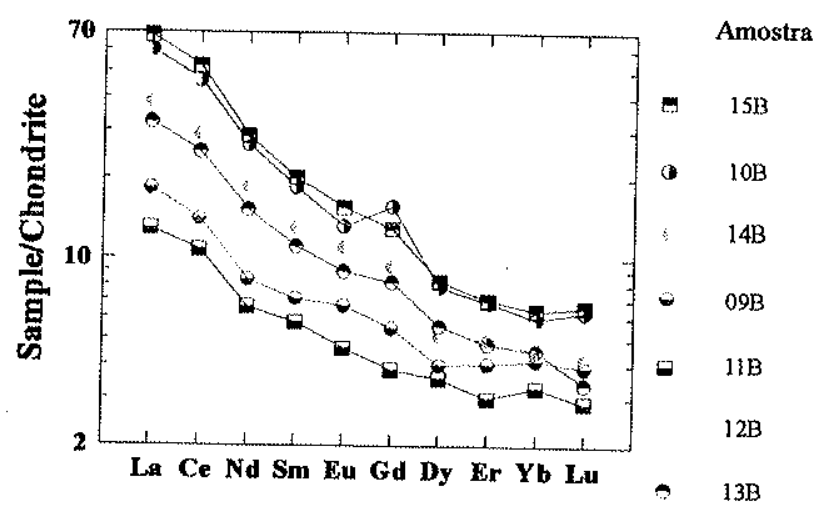

FW-10

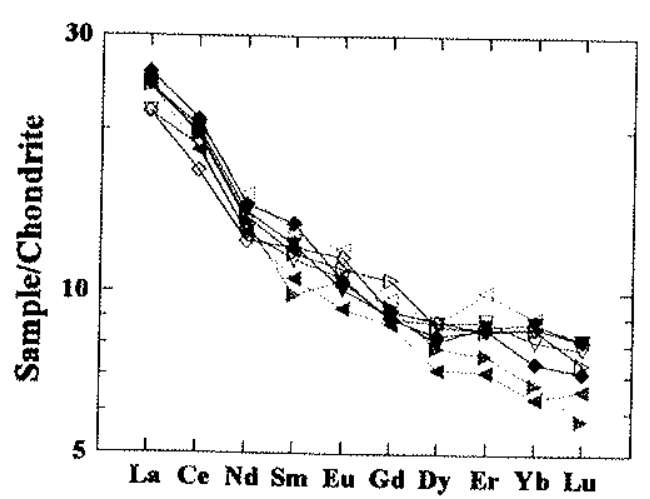

Amostra

$\therefore \quad 048$

\% OSB

․ $06 \mathrm{~B}$

$D \quad 02 \mathrm{~B}$

- 03B

- $01 \mathrm{~B}$

- $07 \mathrm{~B}$

c 08B 


\section{HW-OO}
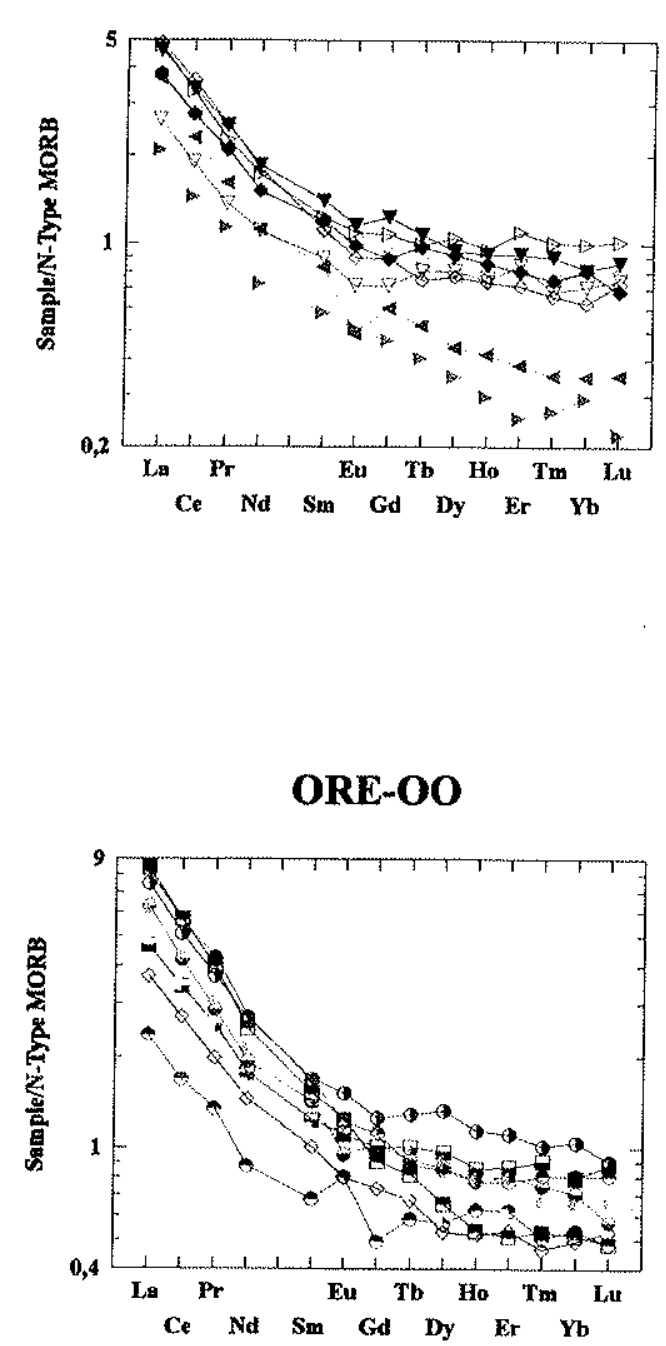

Amostra

- GN-1OB

- GN-10X

- GN-14

GN-15

- GN-09

- GN-17

GN-13

GN-10

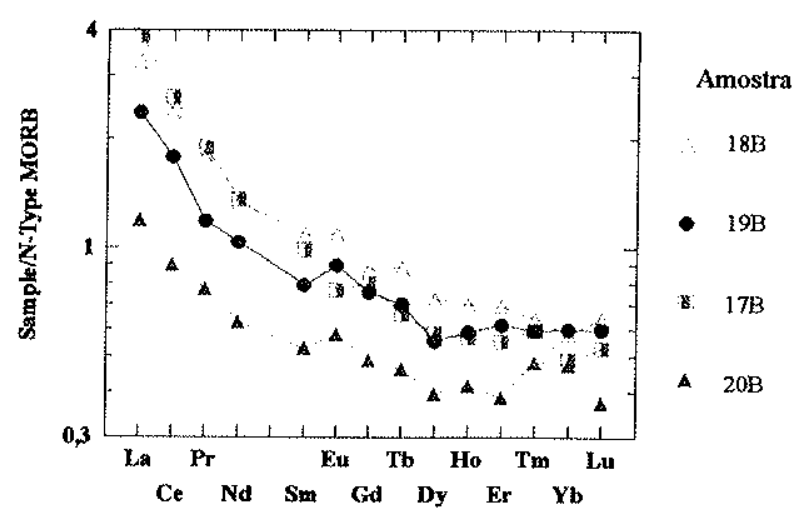

ORE-10

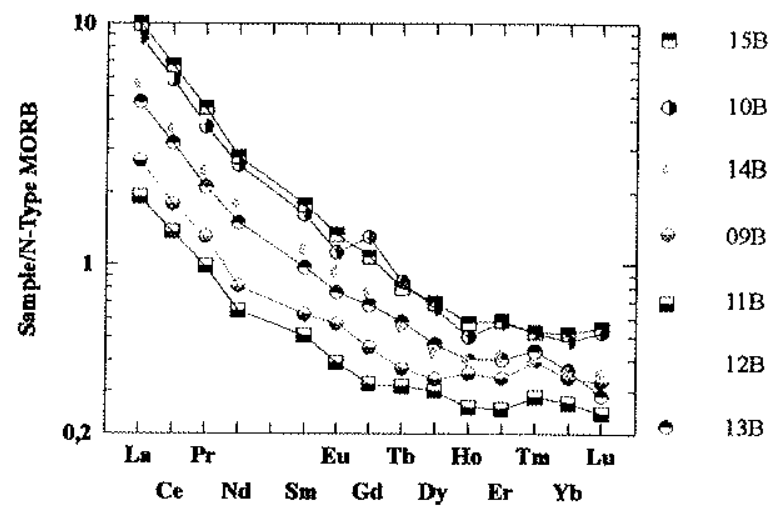

Amosira

$15 B$

91 $3 \mathrm{~B}$
FW-OO

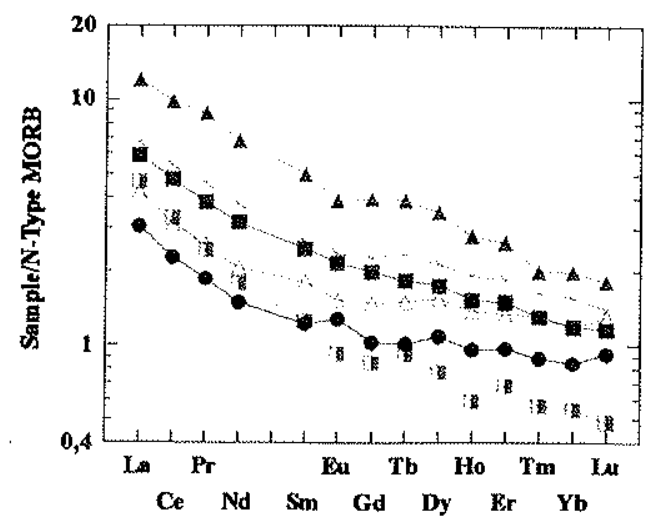

Amostra

- GN-24 GN-2S

- GN-26

- $\quad$ N -19

GN-20

- GN-2l
FW-10

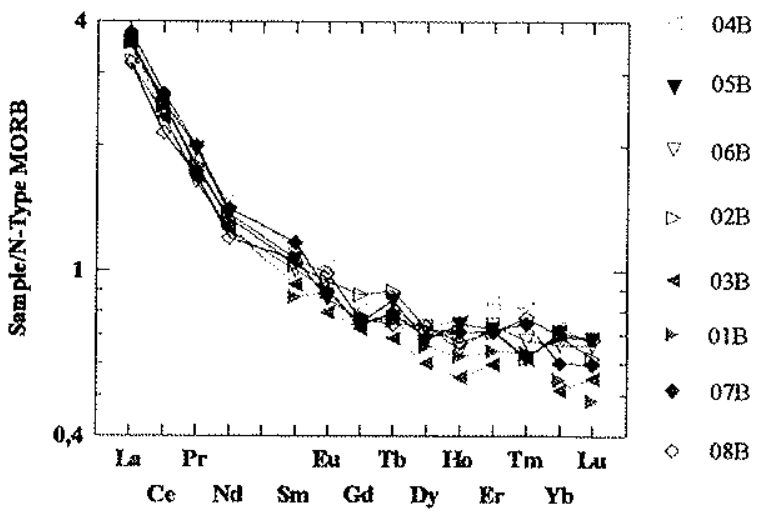


HW-OO

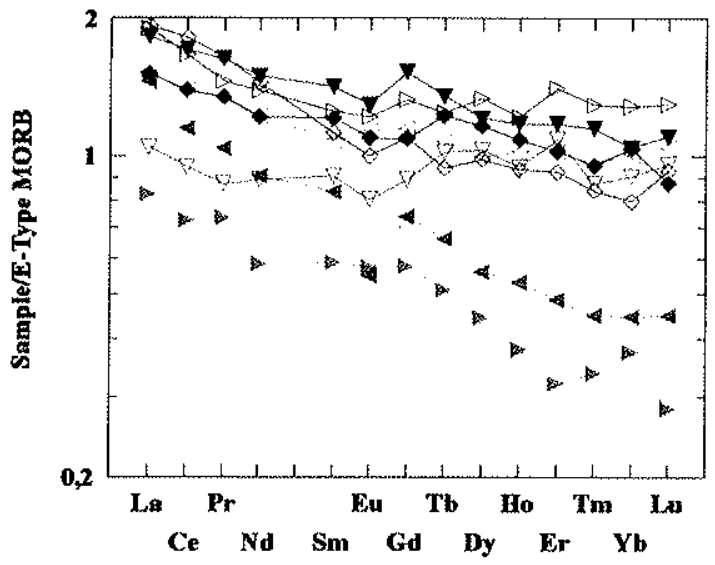

\section{ORE-OO}

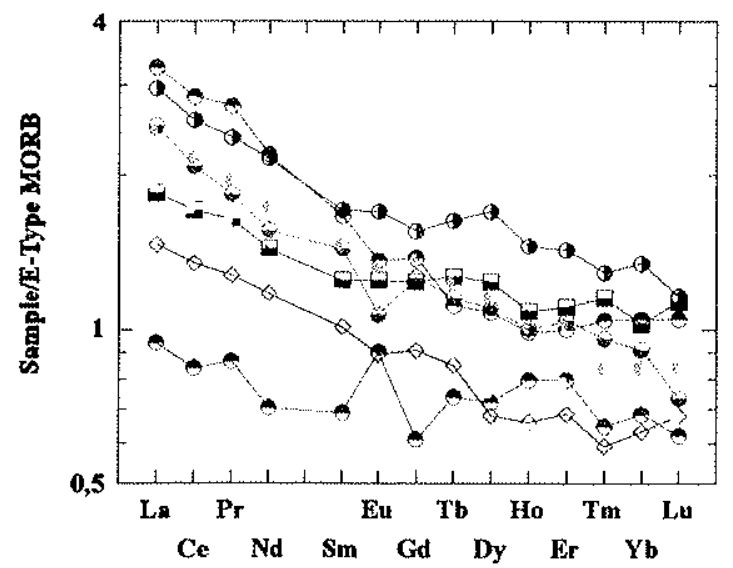

FW-OO

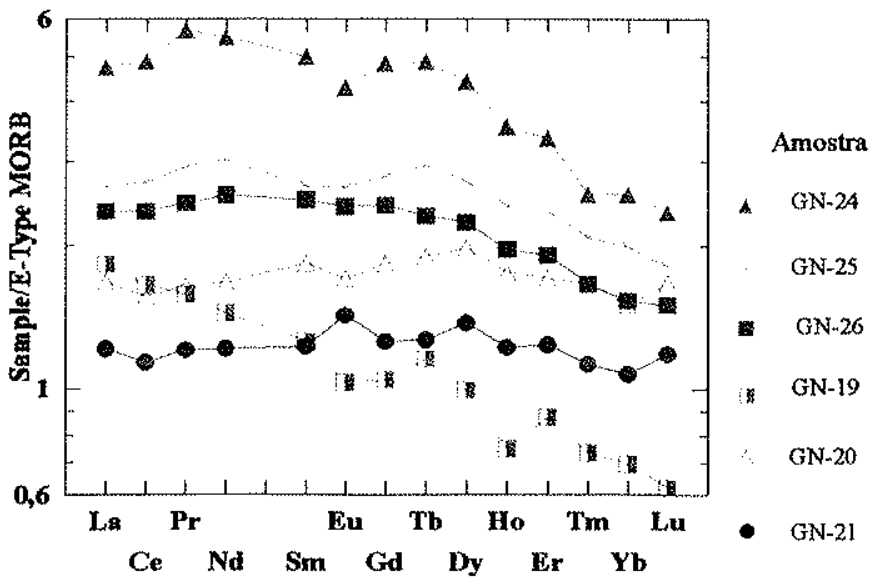

HW-10
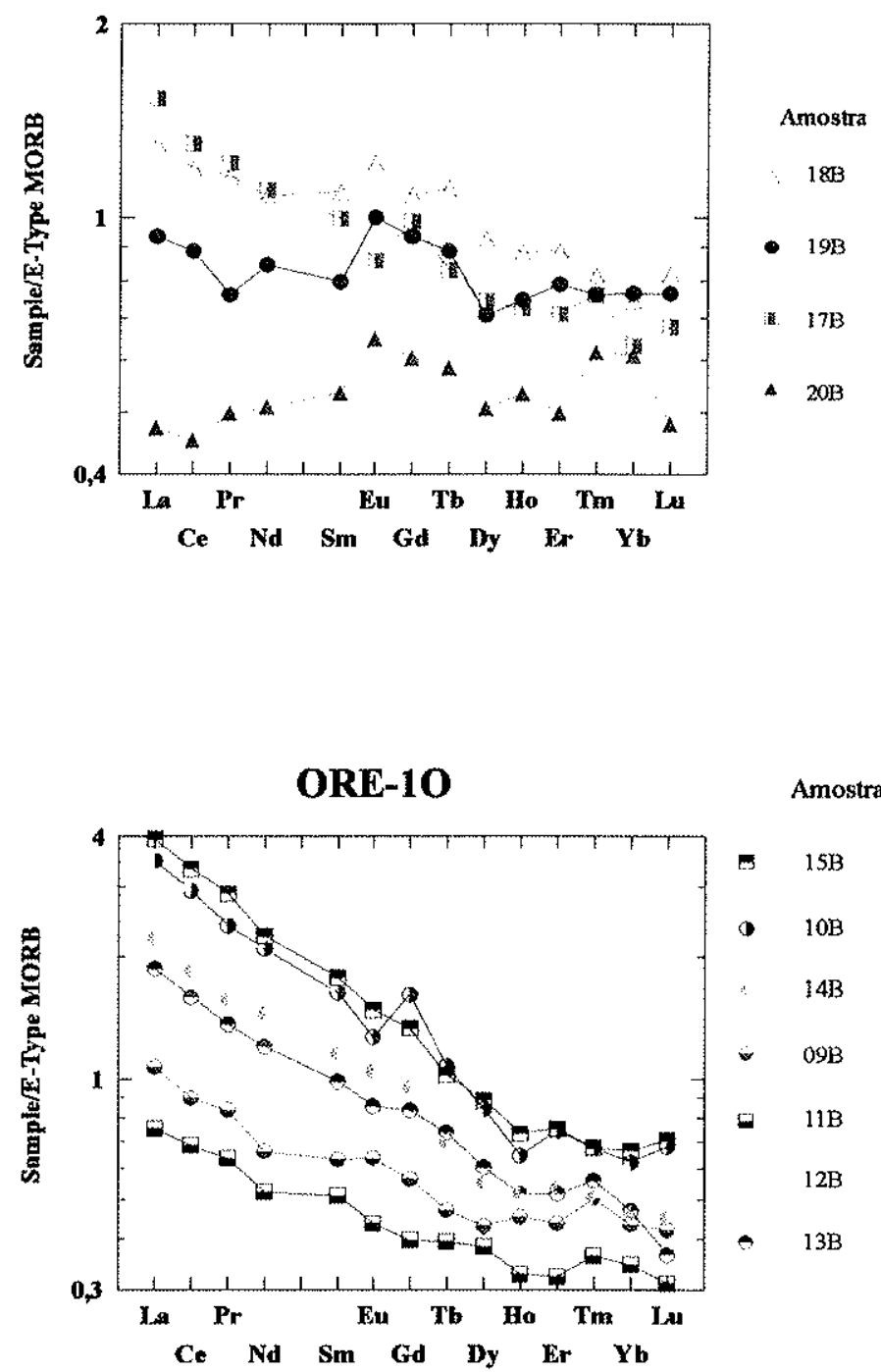

FW-10

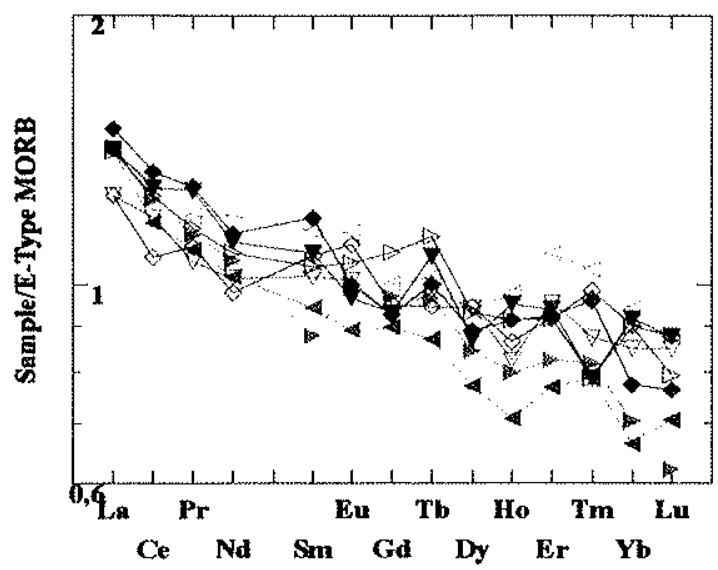

Amostra

$04 \mathrm{~B}$

v $05 \mathrm{~B}$

O6B

b. $02 \mathrm{~B}$

$4 \quad 03 B$

- 013

- ote

$\diamond \quad 08 \mathrm{~B}$ 
HW-OO

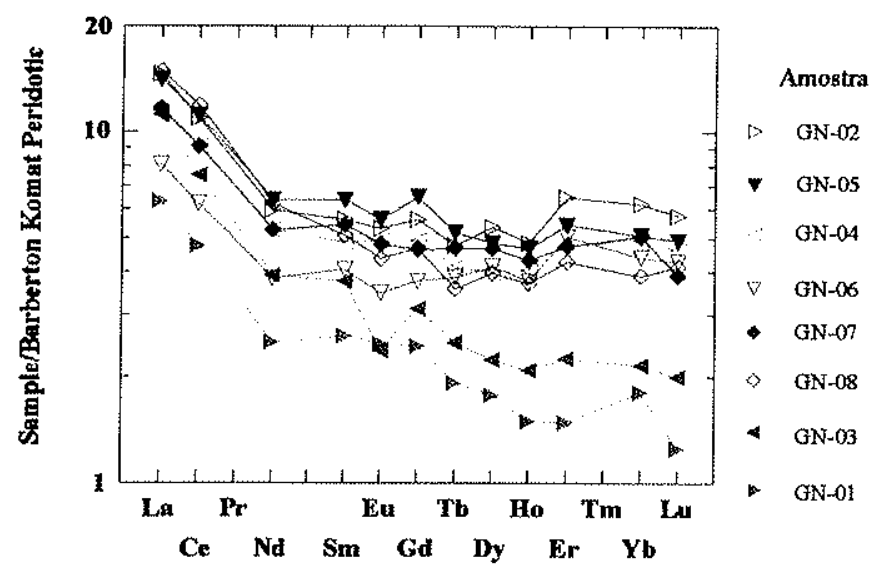

\section{ORE-OO}

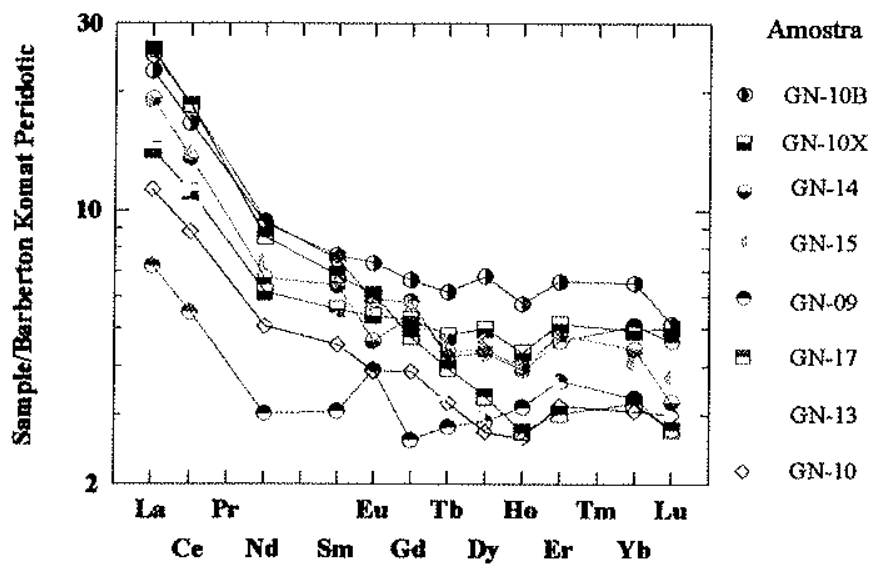

FW-OO

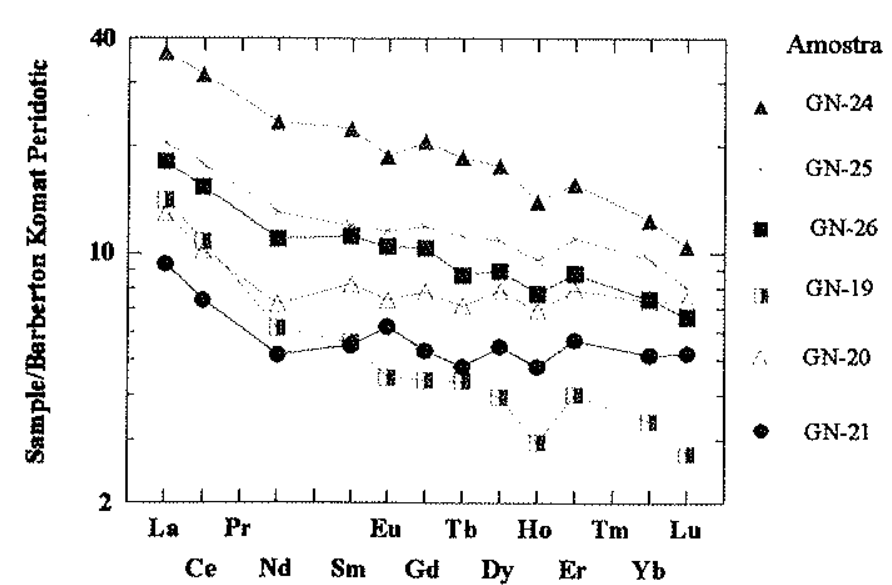

HW-10

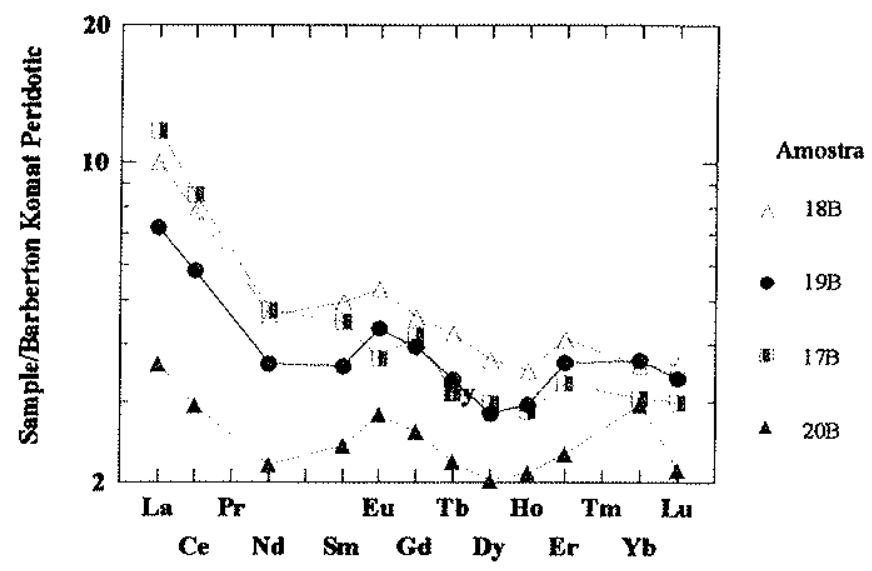

ORE-10

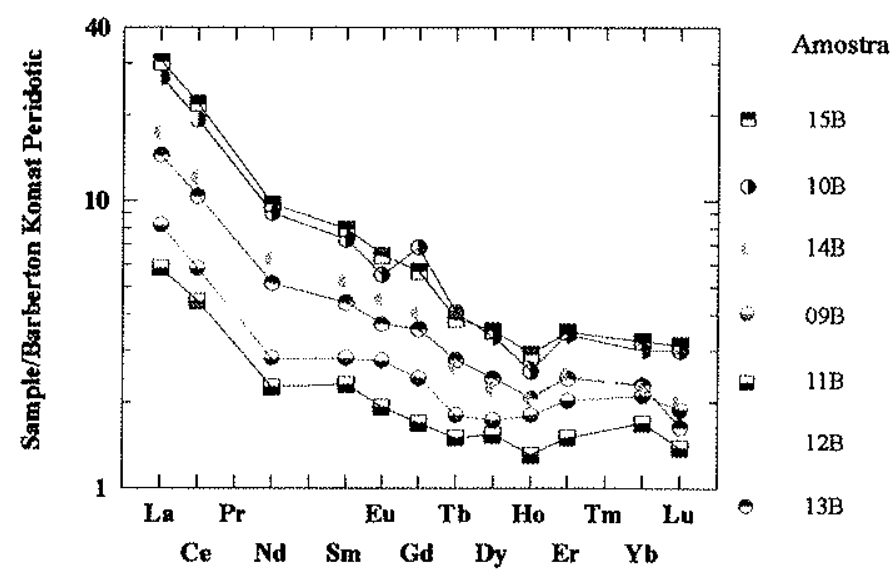

FW-10

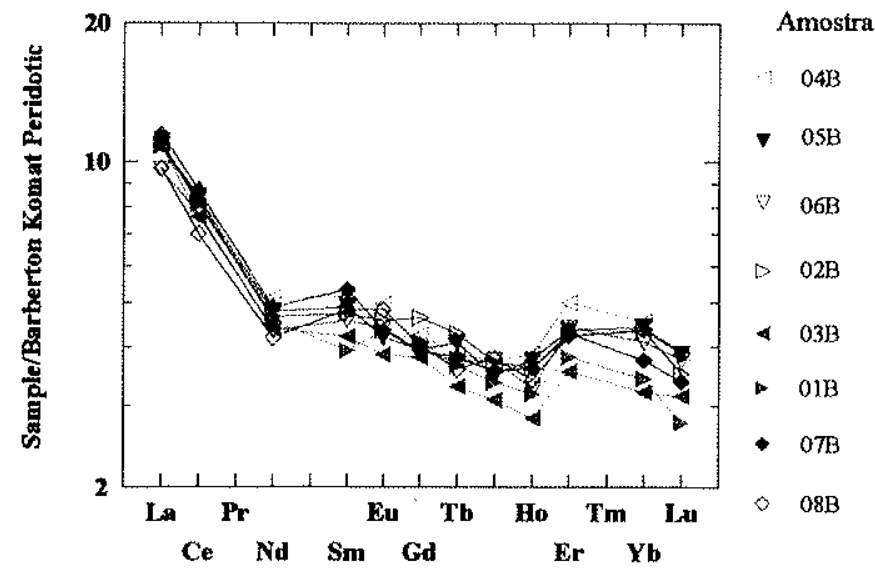


HW-OO

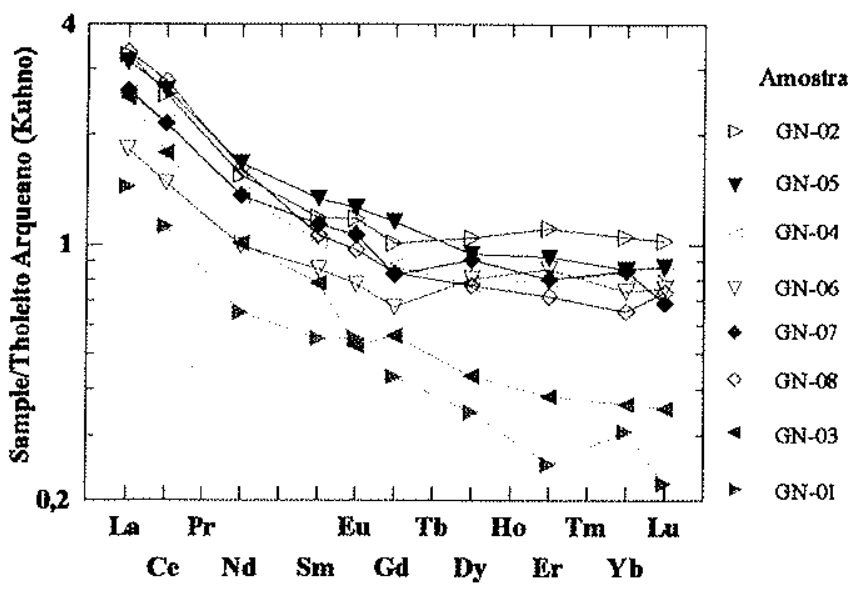

ORE-OO

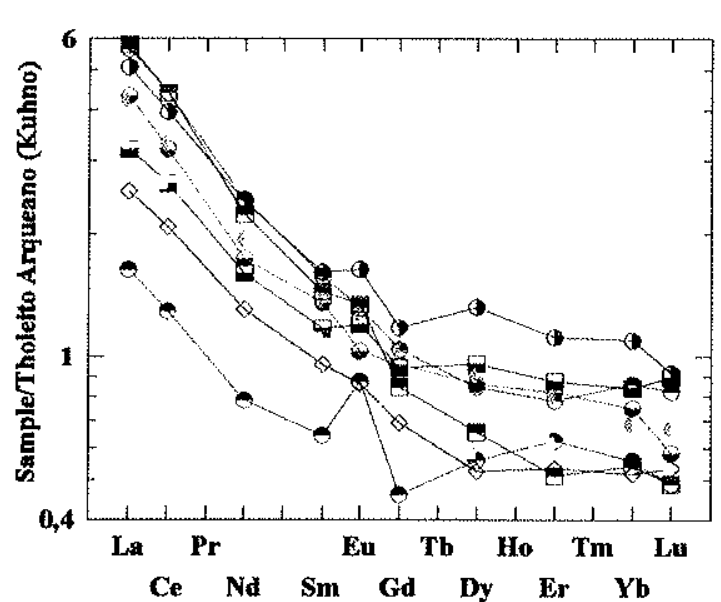

FW-OO

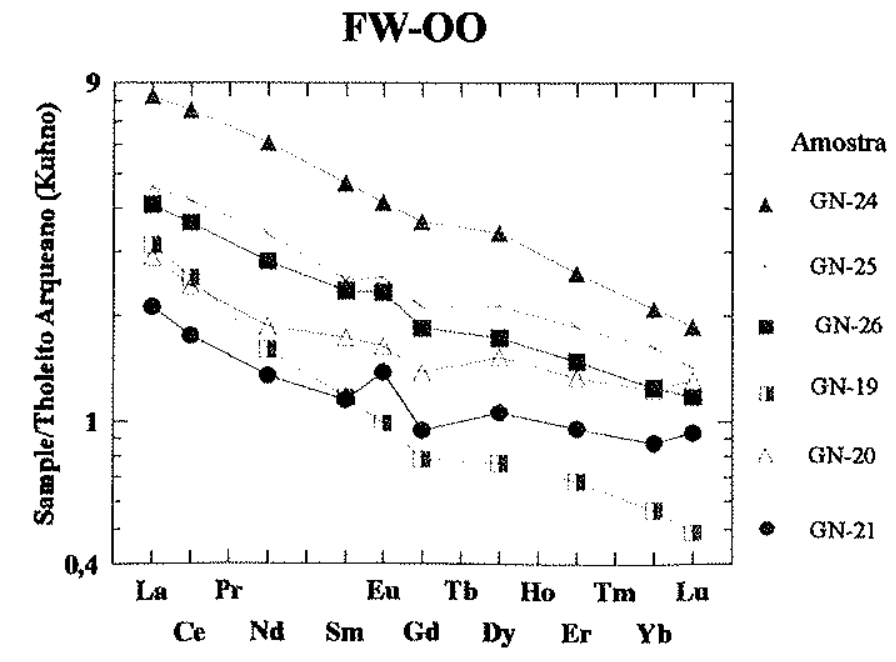

HW-10

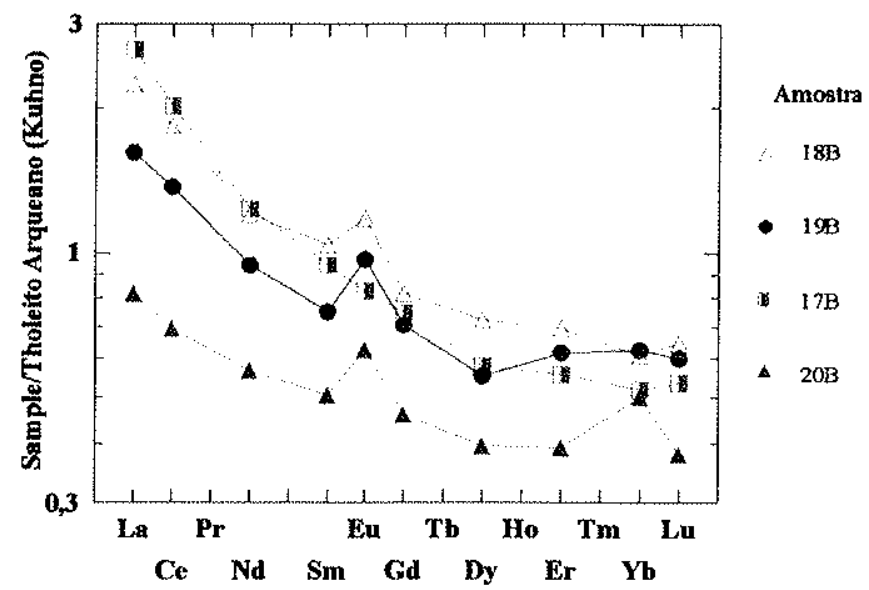

ORE-10

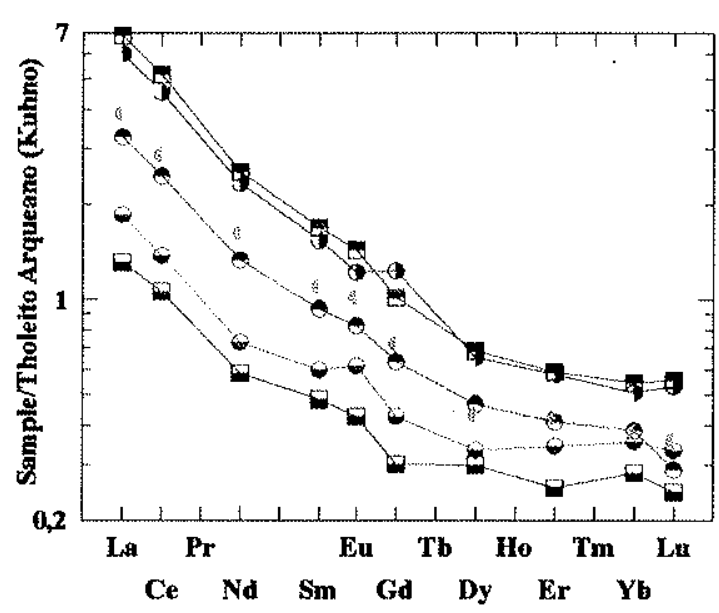

Amostra

9 153

- $10 \mathrm{~B}$

$14 B$

\% 093

$=\quad$ I1B

$12 B$

- $13 \mathrm{~B}$

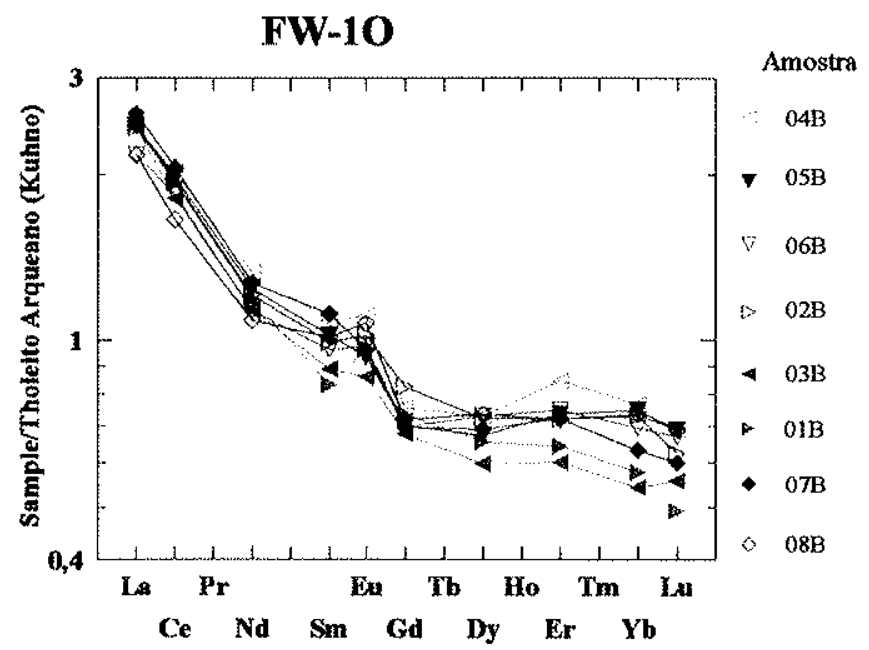


HW-OO

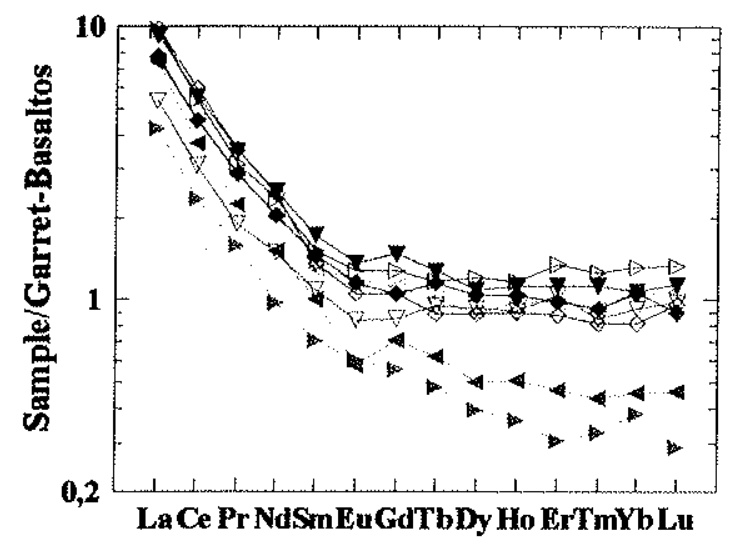

ORE-OO

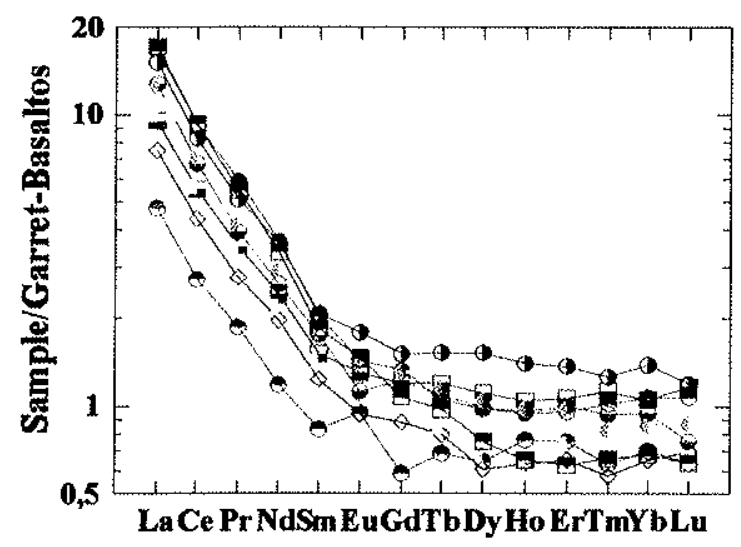

FW-OO

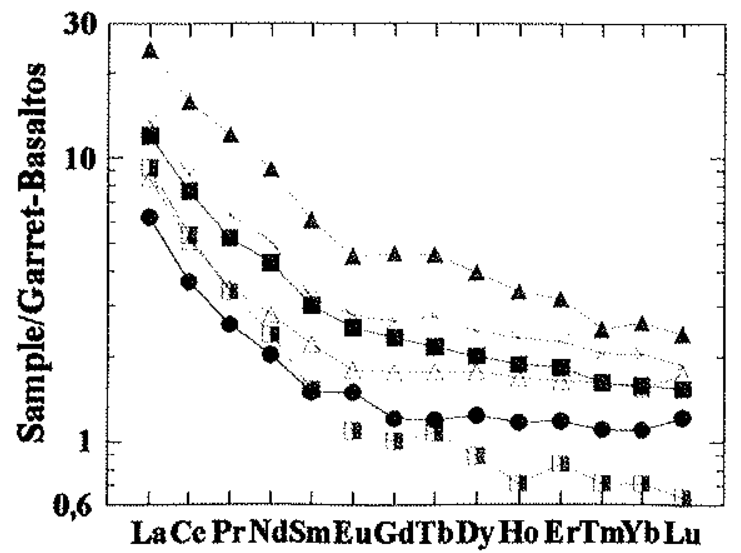

HW-10

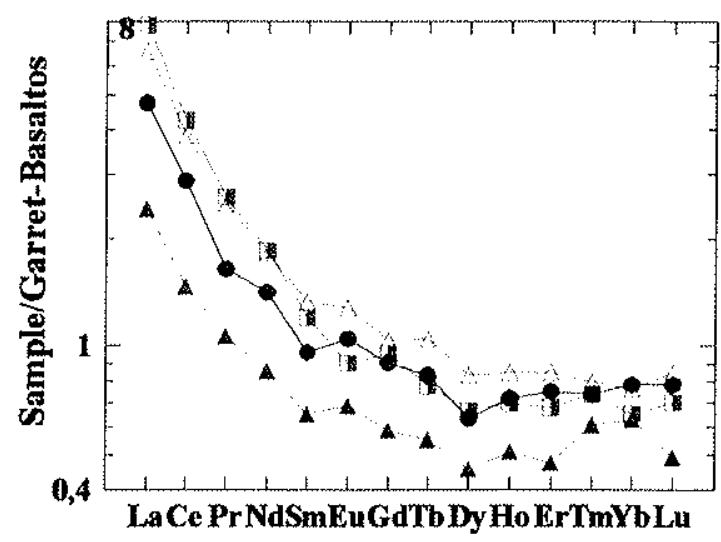

ORE-10

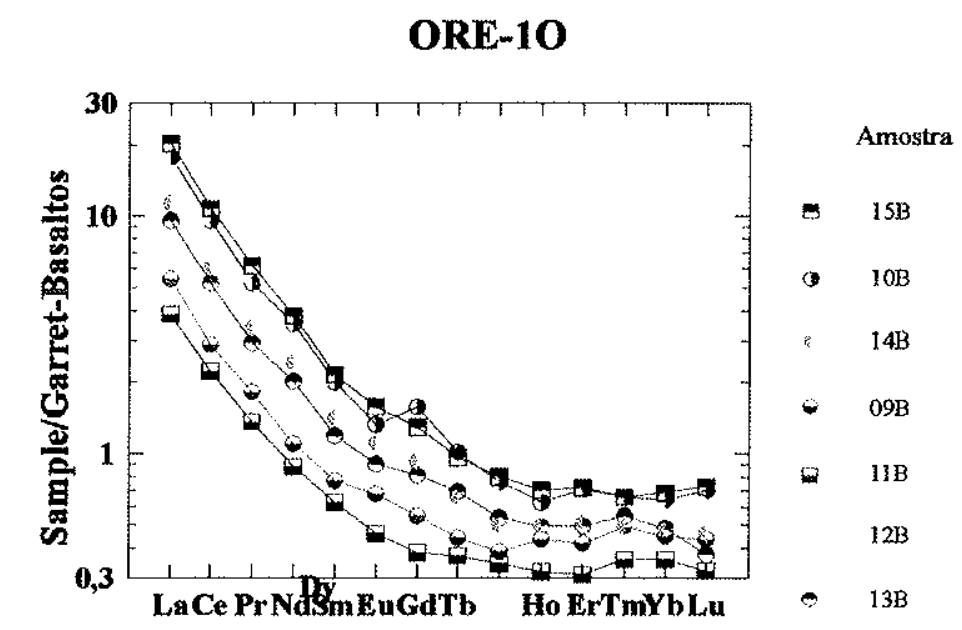

- GN-10B

- GN-10X

¿ GN-14

* GN-15

- GN-09

GN-17

GN-13

GN-10

FW-10
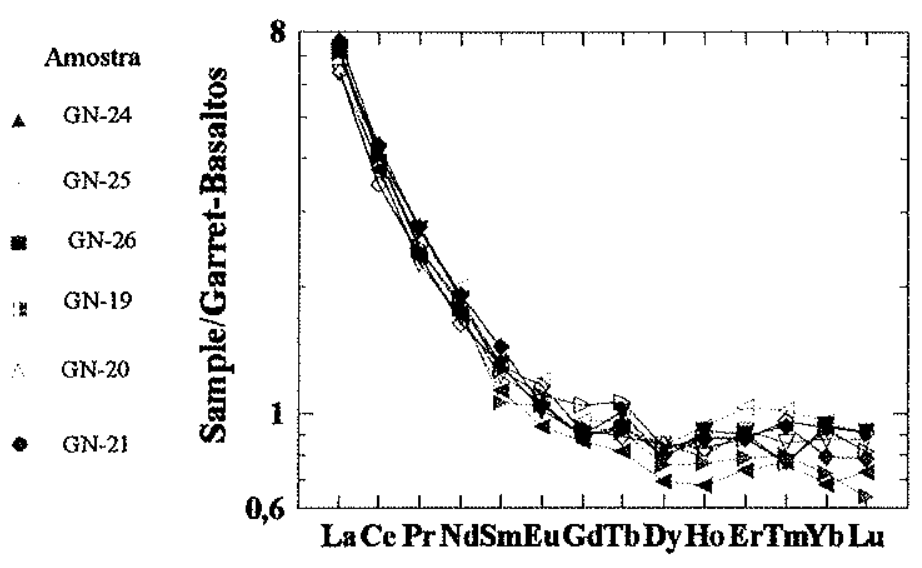

Amostra

04B

> $05 \mathrm{~B}$

ए $06 \mathrm{~B}$

$D \quad 02 B$

- 03B

- 01B

- $07 \mathrm{~B}$ 
HW-OO

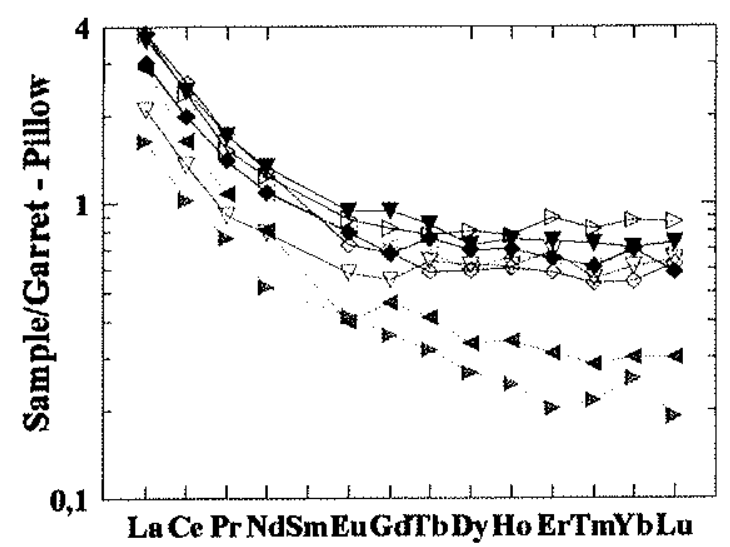

ORE-

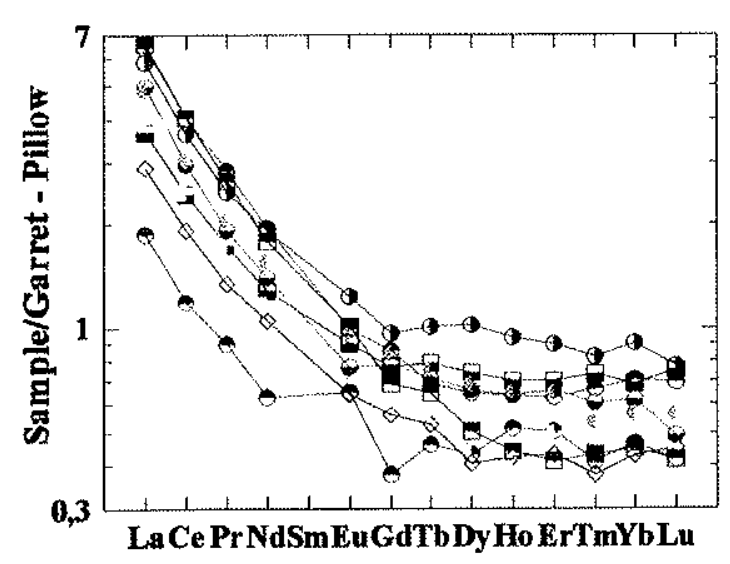

FW-OO

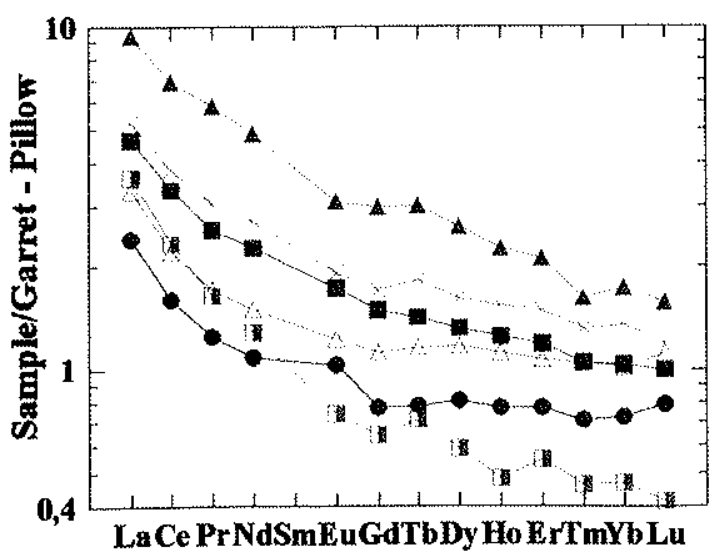

HW-10

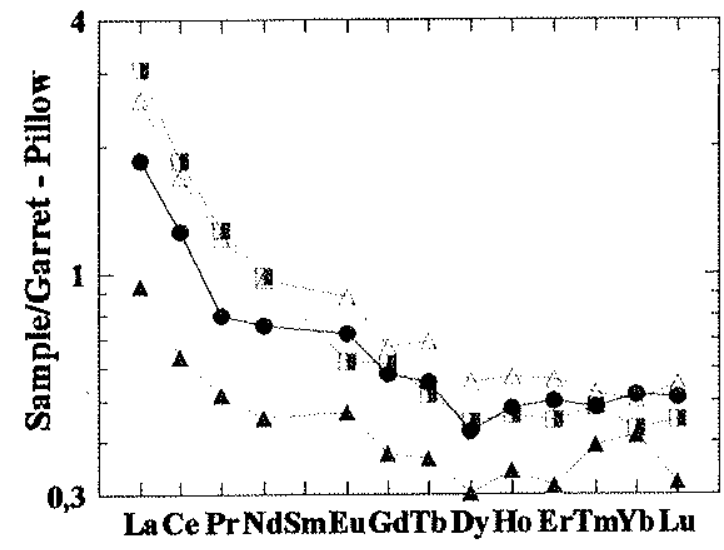

Amostra

$18 \mathrm{~B}$

- $19 \mathrm{~B}$

*) $17 \mathrm{~B}$

A $20 \mathrm{~B}$

\section{ORE-10}

Amostra

- GN-10B

ㄷ. GN-10X

- GN-14

GN-15

- GN-09

- GN-17

GN-13

GN-10

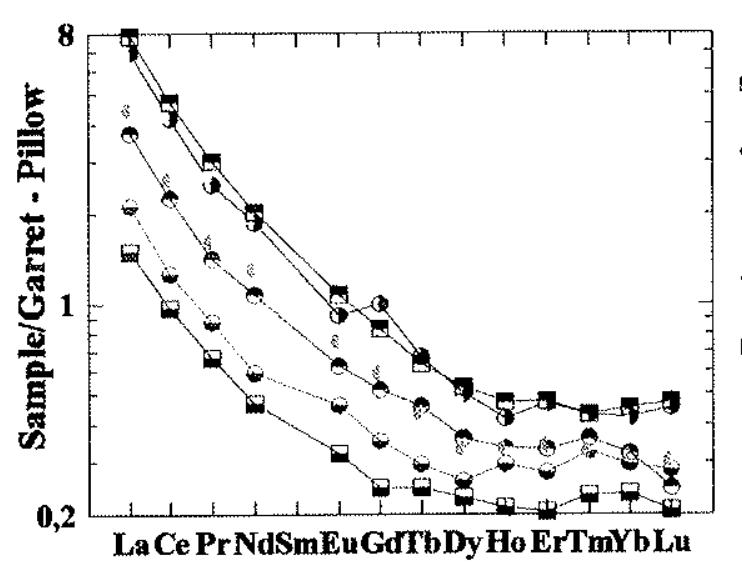

Amostra

= $15 \mathrm{~B}$

- $10 \mathrm{~B}$

$14 \mathrm{~B}$

$-0913$

(1) $11 \mathrm{~B}$

$12 \mathrm{~B}$

13B

FW-10

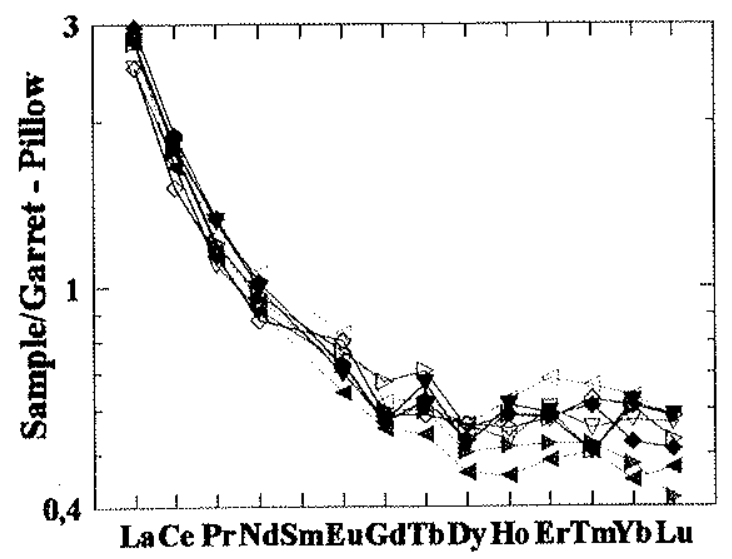

Amostra

04B

\% OSB

v $06 \mathrm{~B}$

$>\quad 02 \mathrm{~B}$

$4 \quad 03 \mathrm{~B}$

- 013

- $07 \mathrm{~B}$

6. $08 \mathrm{~B}$ 
HW-OO

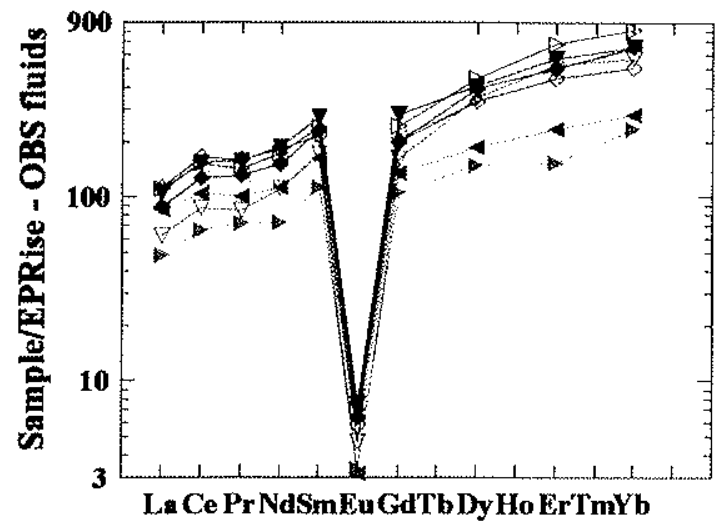

ORE-OO

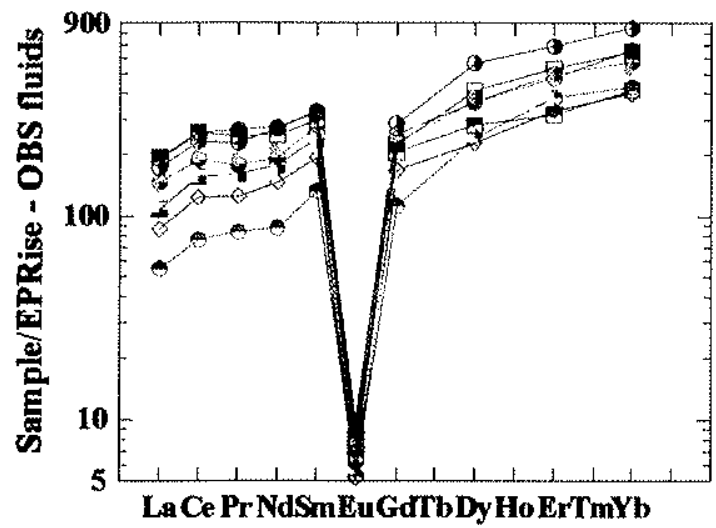

FW-OO

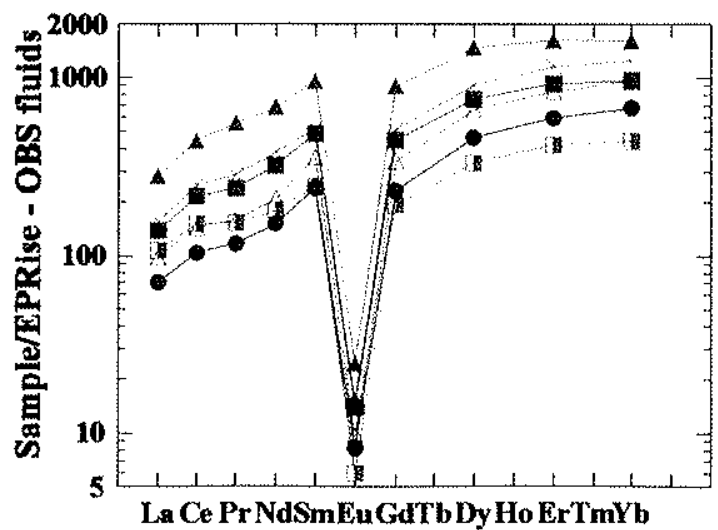

HW-10

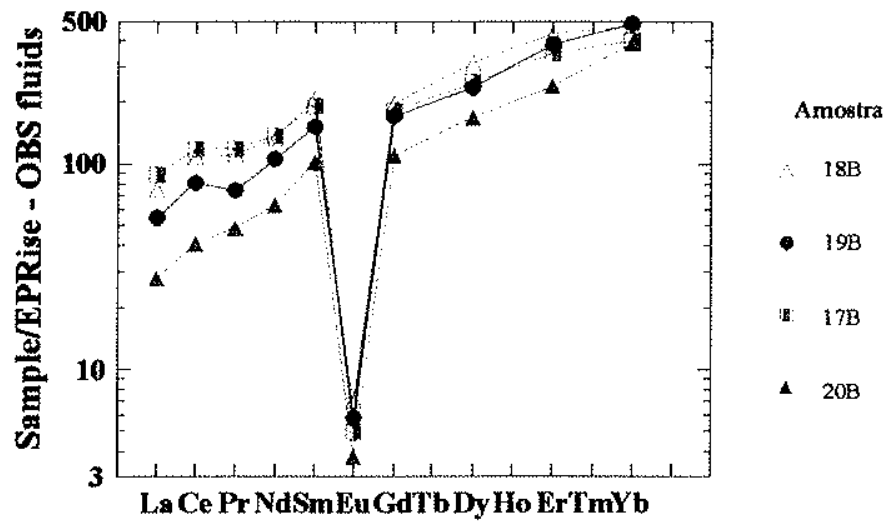

ORE-10

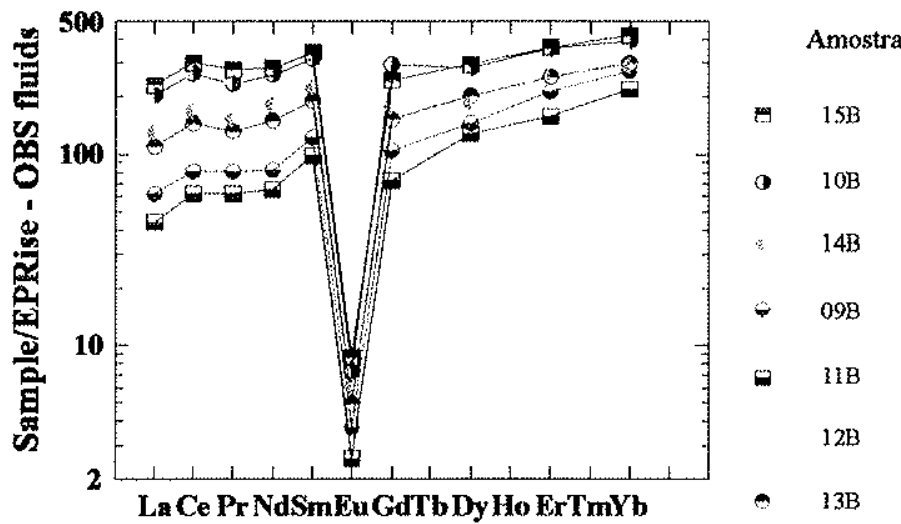

FW-10

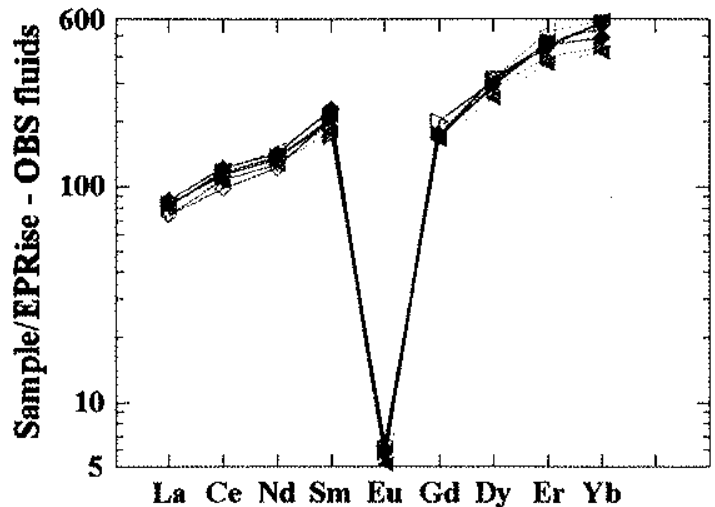

Amostra

$04 \mathrm{~B}$

$\checkmark \quad$ osB

$\checkmark 06 \mathrm{~B}$

$>\quad 02 \mathrm{~B}$

$\varangle \quad 03 B$

- $01 \mathrm{~B}$

- $07 \mathrm{~T}$

- 08B 
HW-OO

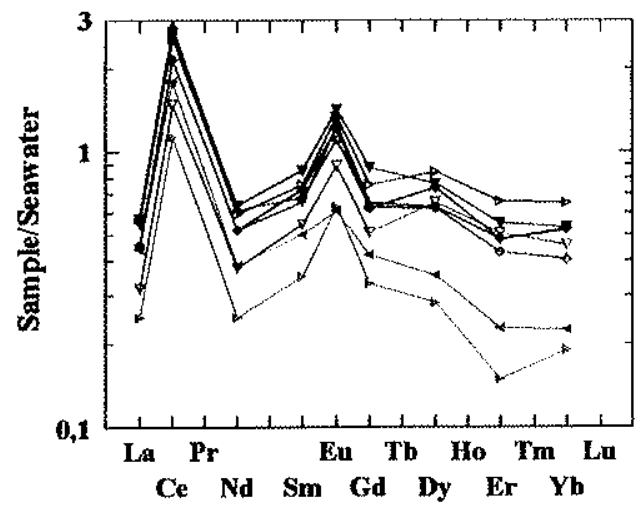

ORE-OO

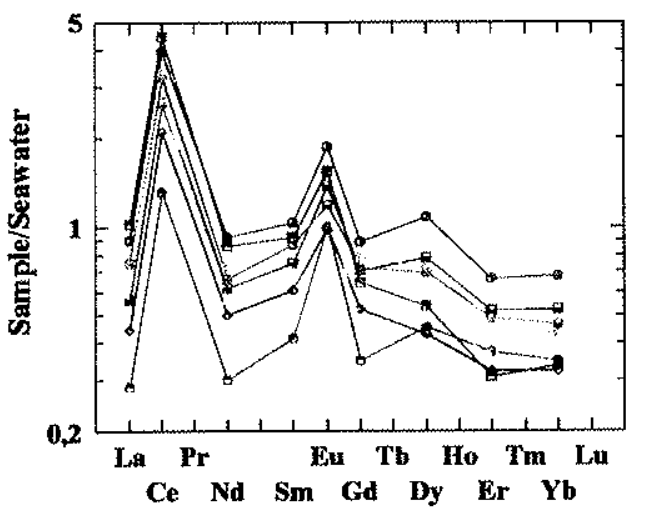

FW-OO

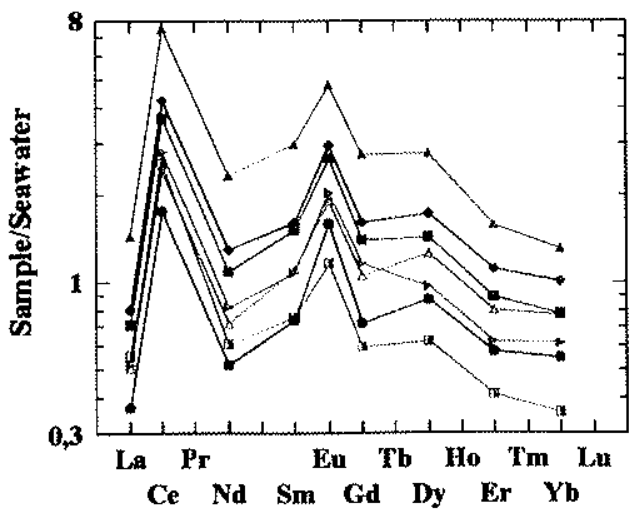

HW-10

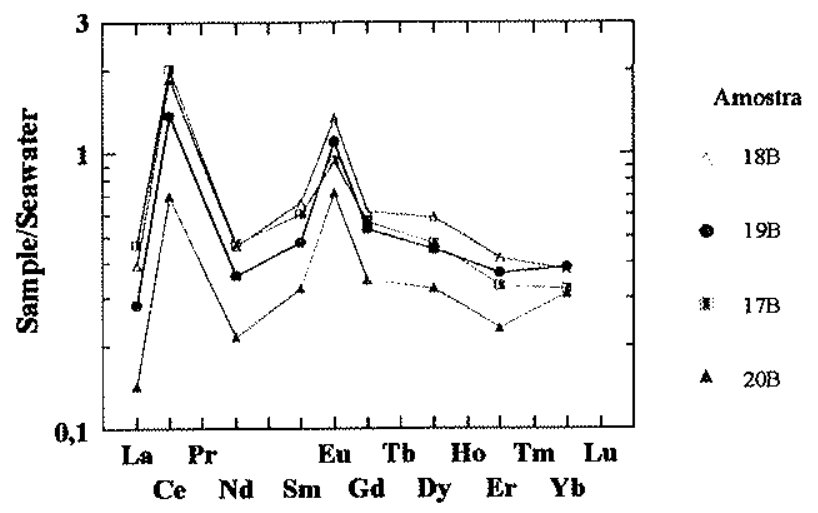

ORE-10

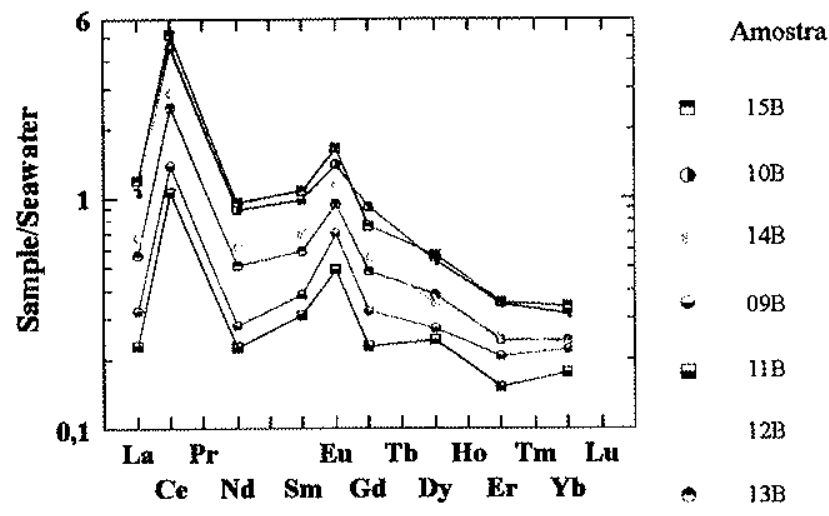

FW-10

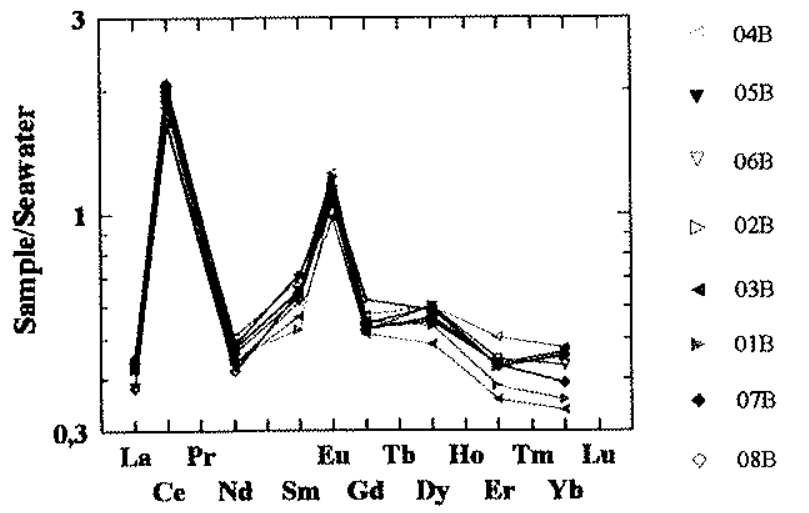




\section{HW-OO}

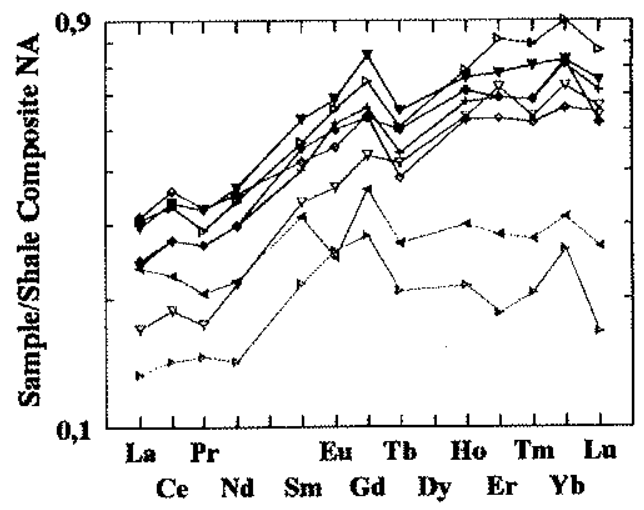

\section{ORE-OO}

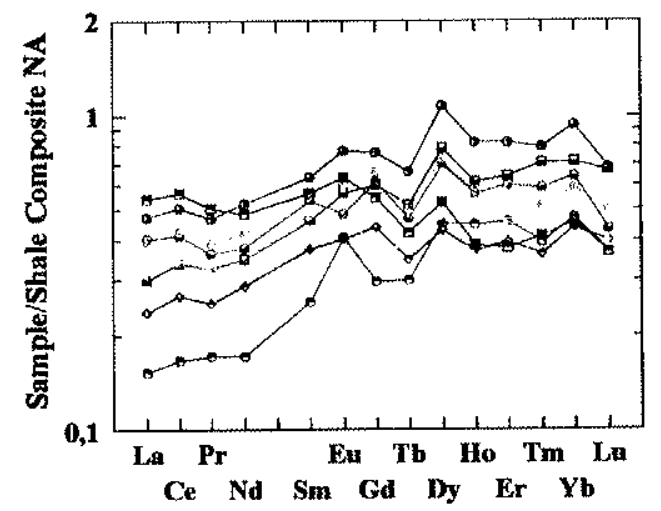

FW-OO

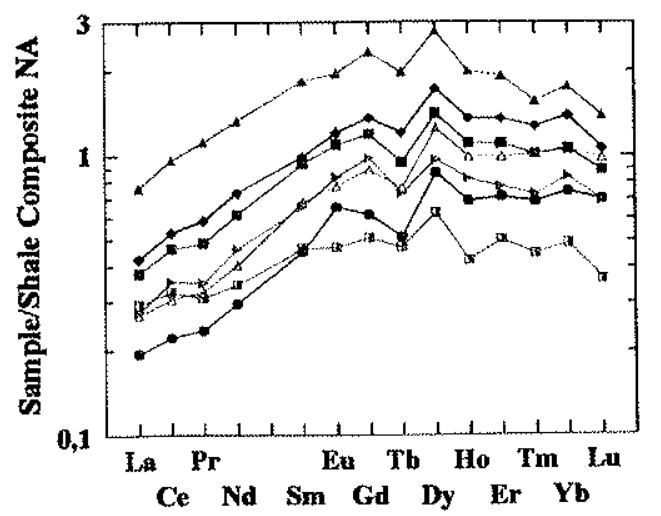

Amostra

GN-2A

GN-25

- GN-26

GN-19

GN-20

- GN-21

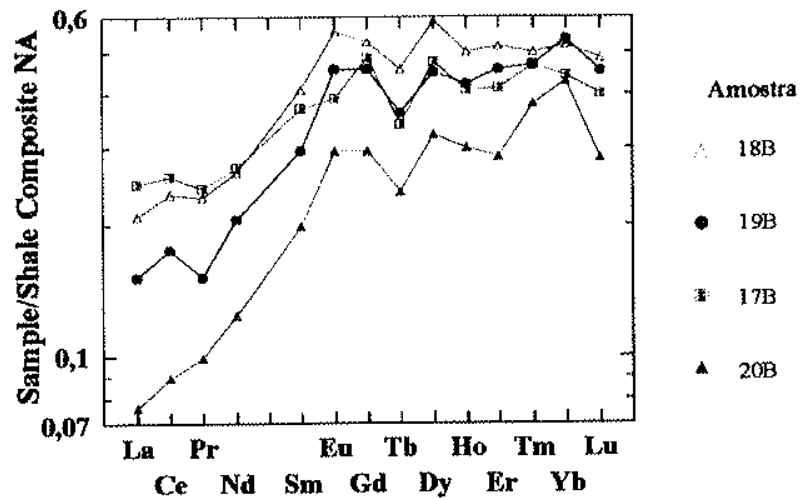

ORE-10

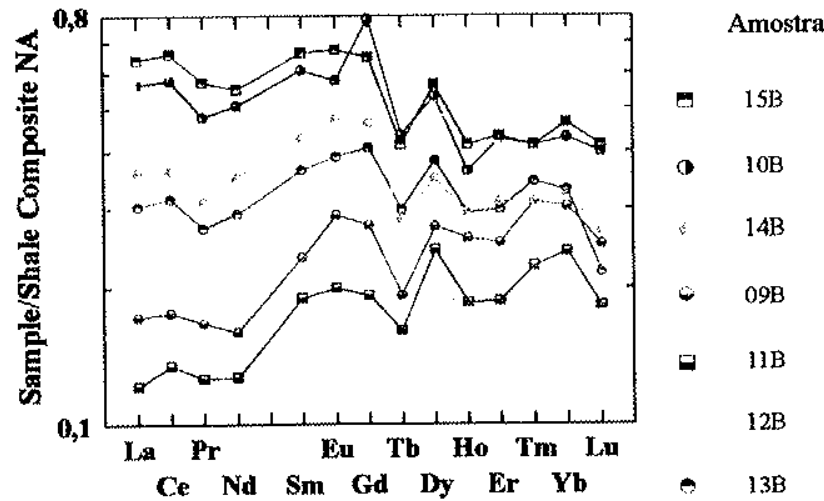

FW-10

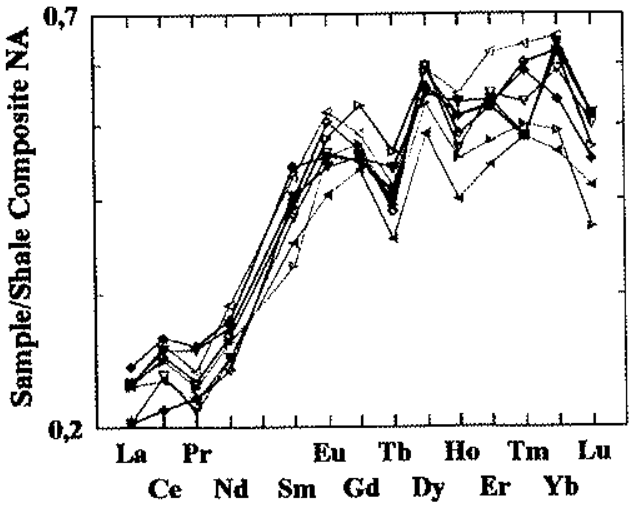

Amostra

04B

- 05B

06B

$>02 B$

$+\quad 03 \mathrm{~B}$

- 01B

- $\quad 07 \mathrm{~B}$

○ 08B 
Anexo 8: Coeficientes de Correlação e Dados Estatísticos Básicos Litogeoquímicos 
Anexo 8: Tabela 1 - Coeficientes de correlação geoquimicos de todas as amostras da Mina do Pari

\begin{tabular}{|c|c|c|c|c|c|c|c|c|c|c|c|c|c|c|c|c|c|c|c|c|c|}
\hline$n=52$ & $\mathrm{SiO2}$ & TiO2 & Al2O3 & $\mathrm{Fe} 2 \mathrm{O} 3 \mathrm{~T}$ & Mno & MgO & $\mathrm{CaO}$ & $\mathrm{Na2O}$ & $\mathrm{K} 2 \mathrm{O}$ & P205 & LOI & $\mathrm{Ba}$ & $\mathbf{R b}$ & $\mathrm{sr}$ & $\bar{Y}$ & $\overline{Z r}$ & $\mathrm{Nb}$ & Th & $\mathrm{Pb}$ & $\mathrm{Ga}$ & $\mathrm{Zn}$ \\
\hline $\mathrm{Nd}$ & 0.10 & 0.16 & 0.08 & -0.02 & -0.24 & -0.02 & -0.21 & 0.13 & 0.14 & -0.03 & -0.17 & 0.13 & 0.14 & 0.16 & 0.28 & 0.41 & 0.39 & 0.12 & 0.21 & 0.20 & 0.30 \\
\hline $\mathrm{Ce}$ & -0.16 & -0.20 & -0.11 & 0.38 & -0.30 & -0.25 & -0.50 & -0.18 & 0.52 & -0.08 & 0.11 & 0.24 & 0.51 & -0.03 & -0.12 & 0.00 & 0.06 & 0.36 & 0.56 & -0.07 & 0.32 \\
\hline La & 0.10 & -0.28 & -0.52 & 0.45 & -0.24 & -0.44 & -0.41 & -0.42 & 0.13 & -0.10 & 0.05 & 0.11 & 0.18 & -0.22 & -0.12 & -0.06 & 0.02 & 0.42 & -0.06 & 0.01 & 0.49 \\
\hline $\mathrm{Ag}$ & -0.27 & 0.34 & 0.04 & 0.00 & 0.29 & -0.07 & 0.42 & 0.09 & -0.37 & 0.30 & 0.04 & -0.30 & -0.39 & 0.06 & 0.18 & 0.13 & -0.09 & -0.16 & -0.06 & 0.36 & -0.18 \\
\hline $\mathrm{Au}$ & -0.48 & -0.27 & -0.54 & 0.67 & 0.12 & -0.34 & -0.35 & -0.40 & -0.03 & -0.09 & 0.65 & -0.04 & 0.00 & -0.35 & -0.23 & -0.23 & -0.21 & 0.32 & -0.09 & -0.17 & 0.12 \\
\hline As & -0.51 & -0.24 & -0.51 & 0.65 & 0.13 & -0.31 & -0.33 & -0.37 & -0.04 & -0.07 & 0.66 & -0.05 & -0.01 & -0.31 & -0.19 & -0.21 & -0.20 & 0.29 & -0.09 & -0.16 & 0.11 \\
\hline $\mathbf{s}$ & -0.37 & -0.43 & -0.73 & 0.83 & -0.07 & -0.59 & -0.52 & -0.57 & 0.10 & -0.15 & 0.61 & 0.05 & 0.14 & -0.41 & -0.30 & -0.24 & -0.23 & 0.51 & -0.10 & -0.15 & 0.41 \\
\hline U & -0.18 & -0.33 & -0.49 & 0.50 & -0.07 & -0.34 & -0.42 & -0.43 & 0.26 & -0.22 & 0.52 & 0.35 & 0.29 & -0.18 & -0.16 & -0.01 & -0.16 & 0.60 & 0.16 & -0.01 & 0.22 \\
\hline Co & -0.31 & 0.16 & 0.10 & -0.07 & 0.28 & 0.13 & 0.31 & 0.21 & -0.36 & 0.12 & 0.22 & -0.15 & -0.37 & 0.16 & 0.03 & -0.07 & -0.22 & -0.06 & -0.15 & 0.03 & -0.30 \\
\hline $\mathrm{Cr}$ & 0.27 & -0.31 & -0.06 & -0.28 & -0.01 & 0.78 & -0.28 & -0.18 & 0.22 & -0.23 & 0.01 & 0.09 & 0.25 & -0.14 & -0.06 & .0 .26 & 0.06 & -0.10 & 0.21 & -0.35 & 0.02 \\
\hline v & -0.14 & 0.93 & 0.46 & -0.03 & 0.42 & 0.05 & 0.23 & 0.15 & -0.38 & 0.45 & -0.57 & -0.36 & -0.45 & -0.02 & 0.07 & 0.48 & 0.44 & -0.13 & -0.33 & -0.01 & -0.21 \\
\hline $\mathrm{Ni}$ & 0.25 & -0.20 & -0.18 & .0 .05 & -0.10 & 0.53 & -0.41 & -0.30 & 0.14 & 0.05 & -0.04 & 0.02 & 0.17 & -0.18 & -0.25 & -0.31 & 0.15 & 0.08 & 0.16 & -0.46 & 0.23 \\
\hline $\mathrm{Cu}$ & -0.27 & -0.21 & -0.61 & 0.68 & -0.05 & -0.59 & -0.29 & -0.45 & -0.07 & -0.12 & 0.27 & -0.12 & -0.05 & -0.33 & -0.25 & -0.10 & -0.13 & 0.48 & -0.12 & -0.10 & 0.35 \\
\hline $\mathrm{Zn}$ & 0.02 & -0.25 & -0.07 & 0.32 & -0.43 & .0 .42 & -0.55 & -0.05 & 0.37 & -0.13 & 0.26 & 0.44 & 0.39 & 0.19 & -0.24 & 0.14 & 0.20 & 0.41 & 0.12 & 0.16 & \\
\hline Ga & -0.19 & 0.17 & 0.29 & -0.17 & -0.03 & -0.33 & 0.36 & 0.45 & 0.04 & -0.02 & 0.21 & 0.31 & 0.04 & 0.50 & 0.43 & 0.44 & -0.04 & -0.05 & 0.02 & & \\
\hline $\mathrm{Pb}$ & 0.05 & -0.21 & 0.21 & -0.17 & -0.36 & 0.05 & -0.16 & 0.26 & 0.57 & -0.15 & 0.05 & 0.35 & 0.54 & 0.42 & 0.07 & 0.04 & -0.01 & 0.16 & & & \\
\hline Th & -0.21 & -0.13 & -0.24 & 0.56 & 0.00 & -0.46 & -0.45 & -0.32 & 0.15 & -0.17 & 0.19 & 0.17 & 0.17 & -0.14 & -0.12 & 0.16 & -0.12 & & & & \\
\hline $\mathrm{Nb}$ & 0.08 & 0.46 & 0.33 & -0.01 & -0.05 & 0.16 & -0.31 & 0.14 & 0.11 & 0.20 & -0.41 & 0.12 & 0.09 & 0.06 & -0.07 & 0.46 & & & & & \\
\hline $\mathrm{Zr}$ & -0.18 & 0.63 & 0.51 & -0.02 & 0.14 & -0.22 & 0.03 & 0.38 & 0.08 & -0.04 & -0.22 & 0.30 & 0.04 & 0.38 & 0.20 & & & & & & \\
\hline $\mathbf{Y}$ & 0.03 & 0.11 & 0.18 & -0.33 & 0.06 & 0.14 & 0.31 & 0.36 & 0.00 & 0.06 & -0.06 & 0.04 & 0.00 & 0.24 & & & & & & & \\
\hline Sr & 0.16 & 0.14 & 0.60 & -0.59 & -0.47 & -0.09 & 0.32 & 0.82 & 0.24 & -0.04 & 0.00 & 0.43 & 0.22 & & & & & & & & \\
\hline $\mathbf{R} \mathbf{b}$ & 0.17 & -0.40 & 0.03 & 0.00 & -0.40 & -0.06 & -0.60 & 0.02 & 0.99 & -0.23 & 0.30 & 0.83 & & & & & & & & & \\
\hline $\mathrm{Ba}$ & 0.14 & -0.23 & 0.13 & .0 .05 & -0.35 & -0.19 & -0.44 & 0.16 & 0.82 & -0.18 & 0.35 & & & & & & & & & & \\
\hline LOI & -0.39 & -0.51 & -0.43 & 0.35 & -0.10 & -0.30 & -0.20 & -0.18 & 0.25 & -0.23 & & & & & & & & & & & \\
\hline P2O5 & -0.14 & 0.51 & 0.11 & 0.05 & 0.21 & -0.05 & 0.17 & 0.01 & -0.19 & & & & & & & & & & & & \\
\hline K2O & 0.13 & -0.33 & 0.10 & -0.01 & -0.38 & -0.06 & -0.57 & 0.06 & & & & & & & & & & & & & \\
\hline $\mathrm{Na} 2 \mathrm{O}$ & 0.18 & 0.26 & 0.76 & -0.70 & -0.33 & 0.08 & 0.41 & & & & & & & & & & & & & & \\
\hline $\mathrm{CaO}$ & -0.14 & 0.32 & 0.31 & -0.50 & 0.24 & 0.14 & & & & & & & & & & & & & & & \\
\hline $\mathrm{MgO}$ & 0.26 & -0.01 & 0.20 & -0.56 & 0.15 & & & & & & & & & & & & & & & & \\
\hline Mno & -0.53 & 0.43 & -0.01 & 0.29 & & & & & & & & & & & & & & & & & \\
\hline $\mathrm{Fe} 2 \mathrm{O} T \mathrm{~T}$ & -0.58 & -0.06 & -0.56 & & & & & & & & & & & & & & & & & & \\
\hline $\mathrm{Al} 2 \mathrm{O} 3$ & 0.02 & 0.51 & & & & & & & & & & & & & & & & & & & \\
\hline TiO2 & -0.24 & & & & & & & & & & & & & & & & & & & & \\
\hline
\end{tabular}


Anexo 8: Tabela 1 - Coeficientes de correlação geoquimicos de todas as amostras da Mina do Pari (cont.)

\begin{tabular}{|c|c|c|c|c|c|c|c|c|c|c|c|c|}
\hline$\overline{\mathrm{Cu}}$ & $\overline{N i}$ & $\bar{V}$ & $\overline{\mathrm{Cr}}$ & $\overline{C o}$ & $\bar{U}$ & $\bar{s}$ & $\overline{\mathrm{As}}$ & $\overline{\mathrm{Au}}$ & $\overline{\mathrm{Ag}}$ & $\overline{L a}$ & $\mathrm{Ce}$ & $\mathrm{Nd}$ \\
\hline 0.10 & 0.08 & 0.07 & 0.09 & -0.42 & -0.08 & -0.05 & -0.19 & -0.22 & 0.11 & 0.48 & 0.31 & \\
\hline 0.24 & 0.14 & -0.21 & 0.04 & -0.40 & 0.22 & 0.39 & 0.20 & 0.18 & -0.14 & 0.43 & & \\
\hline 0.57 & 0.08 & -0.27 & -0.10 & -0.51 & 0.22 & 0.51 & 0.07 & 0.08 & -0.07 & & & \\
\hline-0.03 & -0.16 & 0.25 & -0.19 & 0.01 & -0.09 & -0.14 & -0.04 & -0.05 & & & & \\
\hline 0.39 & -0.03 & -0.26 & -0.15 & 0.32 & 0.48 & 0.75 & 0.98 & & & & & \\
\hline 0.35 & -0.01 & -0.23 & -0.13 & 0.36 & 0.45 & 0.74 & & & & & & \\
\hline 0.80 & -0.01 & -0.40 & -0.22 & -0.05 & 0.57 & & & & & & & \\
\hline 0.39 & 0.03 & -0.38 & -0.03 & -0.02 & & & & & & & & \\
\hline-0.15 & 0.02 & 0.12 & 0.02 & & & & & & & & & \\
\hline-0.31 & 0.83 & -0.23 & & & & & & & & & & \\
\hline-0.19 & -0.10 & & & & & & & & & & & \\
\hline-0.06 & & & & & & & & & & & & \\
\hline & & & & & & & & & & & & \\
\hline & & & & & & & & & & & & \\
\hline & & & & & & & & & & & & \\
\hline & & & & & & & & & & & & \\
\hline & & & & & & & & & & & & \\
\hline & & & & & & & & & & & & \\
\hline & & & & & & & & & & & & \\
\hline & & & & & & & & & & & & \\
\hline & & & & & & & & & & & & \\
\hline & & & & & & & & & & & & \\
\hline & & & & & & & & & & & & \\
\hline & & & & & & & & & & & & \\
\hline & & & & & & & & & & & & \\
\hline & & & & & & & & & & & & \\
\hline & & & & & & & & & & & & \\
\hline & & & & & & & & & & & & \\
\hline & & & & & & & & & & & & \\
\hline & & & & & & & & & & & & \\
\hline
\end{tabular}


ANEXO 8: Tabela 2 - Estatística básica de todas as amostras da Mina do Parí

\begin{tabular}{|c|c|c|c|c|c|c|}
\hline & SiO2 & TiO2 & $\mathrm{Al} 2 \mathrm{O3}$ & $\mathrm{Fe} 2 \mathrm{O} 3 \mathrm{~T}$ & MnO & $\mathrm{MgO}$ \\
\hline Minimum & 33,43 & 0,03 & 4,09 & 6,23 & 0,03 & 2,45 \\
\hline Maximum & 60,12 & 2,7 & 18,75 & 39,7 & 0,36 & 12,34 \\
\hline Mean & 50,05 & 0,87 & 12,55 & 15,34 & 0,2 & 6 \\
\hline St.Deviation & 4,86 & 0,67 & 3,03 & 6,97 & 0,06 & 2,55 \\
\hline Variance & 23,67 & 0,45 & 9,18 & 48,62 & 0 & 6,5 \\
\hline \multirow[t]{2}{*}{ Number Of Cases } & 52 & 52 & 52 & 52 & 52 & 52 \\
\hline & $\mathrm{CaO}$ & $\mathrm{Na2O}$ & $\mathrm{K2O}$ & P2O5 & LOI & \\
\hline Minimum & 1,26 & 0,03 & 0,11 & 0 & 0,16 & \\
\hline Maximum & 17,33 & 3,73 & 3,85 & 2,53 & 14,9 & \\
\hline Mean & 7,74 & 1,71 & 1,04 & 0,17 & 3,28 & \\
\hline St.Deviation & 3,52 & 0,96 & 0,85 & 0,34 & 2,63 & \\
\hline Variance & 12,42 & 0,91 & 0,72 & 0,12 & 6,93 & \\
\hline \multirow[t]{2}{*}{ Number Of Cases } & 52 & 52 & 52 & 52 & 52 & \\
\hline & $P_{2}$ & & & & & \\
\hline Minimum & $\frac{\mathrm{Ba}}{0}$ & $\mathrm{Cu}$ & $\mathrm{Ni}$ & v & $\mathrm{Cr}$ & Co \\
\hline Maximum & $\frac{0}{772}$ & $\frac{4}{0710}$ & 64 & 44 & 12 & 0 \\
\hline Mean & $\frac{1 / 2}{233.42}$ & 874,8 & 685 & 447 & 1237 & 130 \\
\hline St.Deviation & $\frac{233,42}{199,71}$ & 141,1 & 243,5 & 183 & 372 & 41,4 \\
\hline Variance & $\frac{199,11}{3988476}$ & 184,1 & 167 & 93 & 334 & 24,3 \\
\hline \multirow{3}{*}{ Number Of Cases } & 39884,76 & 33883,9 & 27881,9 & 8633 & 111374 & 590,6 \\
\hline & 52 & 52 & 52 & 32 & 52 & 52 \\
\hline & $\mathbf{U}$ & $\mathbf{R b}$ & $\mathbf{S r}$ & $\mathbf{Y}$ & $\mathbf{S}$ & As \\
\hline Minimum & 0 & 0 & 0 & 4 & 10 & 50 \\
\hline Maximum & 18 & 144 & 407 & 87 & 116000 & 113500 \\
\hline Mean & 5,01 & 37 & 161 & 25 & 15282 & 4735,58 \\
\hline St.Deviation & 3,85 & 35 & 102 & 13 & 25193 & 16340,52 \\
\hline Variance & 14,81 & 1229 & 10471 & 167 & $6,35 E+08$ & $2,67 E+08$ \\
\hline \multirow[t]{2}{*}{ Number Of Cases } & 52 & 52 & 52 & 52 & 52 & 52 \\
\hline & $\mathrm{Au}$ & $\mathrm{Ag}$ & Zn & $\mathbf{P b}$ & Ga & Nd \\
\hline Minimum & 0 & 0 & 79,9 & 0 & 10 & 0 \\
\hline Maximum & 56,84 & 121,88 & 2737,3 & 122 & 47 & 65 \\
\hline Mean & 2,58 & 14,05 & 445,4 & 17,6 & 23,3 & 27,22 \\
\hline St.Deviation & 8,28 & 21,41 & 593,3 & 16,6 & 7,4 & 15,27 \\
\hline Variance & 68,59 & 458,25 & 351996,8 & 275,1 & 55,1 & 233,19 \\
\hline \multirow[t]{2}{*}{ Number Of Cases } & 52 & 52 & 52 & 52 & 52 & 52 \\
\hline & & h & Th & & $\mathrm{Ca}$ & \\
\hline Minimum & 25 & $\frac{10}{2}$ & 0 & $\frac{L a}{0}$ & $\frac{0}{0}$ & \\
\hline Maximum & 258 & 16 & 16 & 85 & 720 & \\
\hline Mean & 83 & 8,5 & 5,4 & 19,23 & 68,18 & \\
\hline St.Deviation & 40 & 3,2 & 4,7 & 18,32 & 135,89 & \\
\hline Variance & 1576 & 10,1 & 22,3 & 335,77 & 18466,64 & \\
\hline Number Of Cases & 52 & 52 & 52 & 52 & 52 & \\
\hline
\end{tabular}


Anexo 8: Tabela 3 - Coeficientes de correlação geoquimicos dos minérios de ouro da Mina do Pari

\begin{tabular}{|c|c|c|c|c|c|c|c|c|c|c|c|c|c|c|c|c|c|c|c|c|}
\hline$n=17$ & SiO2 & TiO2 & $\bar{A} 1203$ & $\mathrm{Fe} 2 \mathrm{O} 3 \mathrm{~T}$ & MnO & $\mathrm{MgO}$ & $\mathrm{CaO}$ & $\mathrm{Na2O}$ & $\mathrm{K} 2 \mathrm{O}$ & P205 & LOI & $\overline{\mathrm{Ba}}$ & $\mathrm{Rb}$ & $\overline{\mathrm{Sr}}$ & $\bar{Y}$ & $\overline{Z r}$ & $\mathrm{Nb}$ & Th & $\overline{\mathrm{Pb}}$ & $\overline{G a}$ \\
\hline Nd & 0.21 & 0.51 & 0.46 & -0.44 & -0.45 & 0.19 & 0.12 & 0.54 & 0.00 & 0.39 & -0.47 & -0.17 & 0.00 & 0.41 & 0.80 & 0.34 & 0.61 & -0.18 & 0.10 & $\overline{0.16}$ \\
\hline $\mathrm{Ce}$ & -0.14 & -0.03 & 0.12 & 0.10 & -0.28 & -0.03 & -0.32 & 0.08 & 0.53 & -0.04 & -0.18 & 0.04 & 0.52 & 0.16 & 0.28 & -0.03 & -0.03 & 0.17 & 0.61 & -0.08 \\
\hline $\mathrm{La}$ & 0.34 & 0.01 & -0.12 & -0.12 & -0.29 & -0.31 & -0.01 & 0.04 & -0.10 & 0.14 & -0.36 & -0.02 & .0 .03 & 0.12 & 0.60 & 0.12 & 0.16 & -0.10 & -0.28 & 0.32 \\
\hline $\mathrm{Ag}$ & -0.40 & 0.00 & -0.15 & 0.27 & 0.20 & 0.12 & 0.33 & -0.07 & -0.56 & 0.19 & 0.42 & -0.46 & -0.59 & -0.21 & -0.18 & -0.31 & -0.11 & -0.09 & -0.20 & -0.18 \\
\hline Au & -0.60 & -0.56 & -0.68 & 0.78 & 0.30 & -0.34 & -0.14 & -0.43 & -0.37 & -0.13 & 0.80 & -0.31 & -0.36 & -0.38 & -0.37 & -0.59 & -0.56 & 0.19 & -0.19 & -0.28 \\
\hline As & -0.63 & -0.53 & -0.67 & 0.79 & 0.29 & -0.36 & -0.16 & .0 .41 & .0 .35 & -0.11 & 0.82 & $-0,30$ & -0.34 & -0.33 & -0.29 & -0.56 & -0.55 & 0.19 & -0.17 & -0.25 \\
\hline s & -0.51 & -0.75 & -0.81 & 0.83 & 0.13 & -0.63 & -0.29 & -0.49 & -0.29 & -0.14 & 0.83 & -0.22 & -0.24 & -0.35 & .0 .24 & -0.48 & -0.59 & 0.07 & -0.33 & 0.11 \\
\hline U & -0.22 & -0.68 & -0.47 & 0.49 & 0.16 & -0.40 & -0.42 & -0.43 & 0.04 & -0.66 & 0.68 & 0.32 & 0.06 & -0.19 & -0.67 & -0.21 & -0.60 & 0.52 & 0.03 & -0.15 \\
\hline Co & -0.53 & -0.25 & -0.30 & 0.49 & 0.25 & -0.23 & -0.02 & -0.14 & -0.34 & .0 .30 & 0.75 & 0.07 & .0 .35 & 0.04 & $\frac{-0.01}{-0.50}$ & $\frac{-0.21}{-0.11}$ & -0.26 & 0.40 & .0 .05 & -0.03 \\
\hline $\mathrm{Cr}$ & 0.12 & 0.63 & 0.76 & -0.59 & 0.00 & 0.74 & -0.01 & 0.52 & 0.48 & -0.05 & -0.41 & 0.33 & 0.42 & 0.42 & 0.20 & 0.46 & 0.68 & -0.12 & 0.51 & 0.01 \\
\hline v & 0.25 & 0.81 & 0.64 & -0.60 & .0 .06 & 0.49 & 0.32 & 0.55 & 0.02 & 0.63 & .0 .60 & -0.22 & -0.01 & 0.21 & 0.62 & 0.34 & 0.65 & -0.43 & -0.05 & 0.18 \\
\hline $\mathrm{Ni}$ & 0.19 & 0.40 & 0.57 & -0.54 & -0.47 & 0.24 & -0.22 & 0.81 & 0.42 & -0.10 & .0 .14 & 0.43 & 0.37 & 0.78 & 0.03 & 0.52 & 0.64 & -0.02 & 0.52 & 0.18 \\
\hline $\mathrm{Cu}$ & -0.27 & -0.50 & -0.48 & 0.46 & -0.16 & -0.58 & -0.16 & -0.11 & -0.27 & 0.08 & 0.58 & -0.24 & -0.25 & -0.09 & -0.12 & -0.22 & -0.26 & -0.07 & -0.32 & 0.06 \\
\hline $\mathrm{Zn}$ & 0.21 & 0.39 & 0.40 & -0.37 & -0.49 & -0.34 & .0 .04 & 0.69 & 0.08 & 0.10 & -0.05 & 0.39 & 0.09 & 0.75 & 0.05 & 0.75 & 0.45 & 0.03 & 0.01 & 0.68 \\
\hline Ga & 0.07 & 0.27 & 0.28 & -0.13 & -0.11 & -0.23 & -0.16 & 0.23 & 0.16 & -0.27 & .0 .04 & 0.59 & 0.18 & 0.34 & 0.11 & 0.69 & 0.30 & 0.08 & -0.26 & \\
\hline $\mathrm{Pb}$ & 0.03 & 0.28 & 0.52 & -0.29 & -0.27 & 0.20 & -0.18 & 0.44 & 0.65 & 0.04 & -0.27 & 0.22 & 0.60 & 0.51 & -0.11 & 0.18 & 0.12 & 0.35 & & \\
\hline Th & -0.28 & -0.10 & 0.07 & 0.27 & 0.02 & -0.31 & -0.09 & -0.09 & 0.10 & -0.38 & 0.21 & 0.29 & 0.10 & 0.17 & -0.37 & 0.16 & -0.29 & & & \\
\hline $\mathrm{Nb}$ & 0.24 & 0.70 & 0.73 & -0.66 & -0.27 & 0.51 & 0.10 & 0.72 & 0.19 & 0.16 & -0.49 & 0.21 & 0.17 & 0.57 & 0.48 & 0.66 & & & & \\
\hline $\mathrm{Zr}$ & 0.18 & 0.54 & 0.71 & -0.46 & -0.25 & 0.01 & -0.16 & 0.59 & 0.40 & -0.29 & -0.25 & 0.74 & 0.40 & 0.73 & 0.08 & & & & & \\
\hline$Y$ & 0.08 & 0.43 & 0.27 & -0.25 & -0.08 & 0.40 & 0.05 & 0.18 & 0.02 & 0.41 & -0.43 & .0 .30 & 0.03 & -0.03 & & & & & & \\
\hline Sr & 0.35 & 0.41 & 0.58 & -0.59 & -0.64 & -0.14 & -0.10 & 0.87 & 0.32 & 0.01 & -0.22 & 0.50 & 0.31 & & & & & & & \\
\hline $\mathbf{R b}$ & 0.16 & 0.10 & 0.40 & -0.18 & -0.04 & 0.02 & .0 .72 & 0.22 & 0.99 & -0.35 & -0.22 & 0.65 & & & & & & & & \\
\hline $\mathrm{Ba}$ & 0.20 & 0.04 & 0.33 & -0.18 & -0.06 & -0.23 & -0.57 & 0.21 & 0.62 & -0.73 & 0.02 & & & & & & & & & \\
\hline LOI & -0.59 & -0.61 & -0.59 & 0.76 & 0.24 & -0.48 & -0.37 & -0.37 & -0.24 & -0.39 & & & & & & & & & & \\
\hline P2O5 & 0.11 & 0.42 & 0.13 & -0.31 & -0.14 & 0.27 & 0.61 & 0.31 & -0.31 & & & & & & & & & & & \\
\hline $\mathrm{K} 20$ & 0.12 & 0.17 & 0.47 & -0.22 & -0.03 & 0.10 & -0.67 & 0.26 & & & & & & & & & & & & \\
\hline $\mathrm{Na} 2 \mathrm{O}$ & 0.37 & 0.62 & 0.71 & -0.75 & -0.63 & 0.17 & 0.04 & & & & & & & & & & & & & \\
\hline $\mathrm{CaO}$ & -0.01 & 0.40 & 0.11 & -0.22 & 0.03 & 0.35 & & & & & & & & & & & & & & \\
\hline $\mathrm{MgO}$ & -0.08 & 0.64 & 0.56 & -0.38 & 0.26 & & & & & & & & & & & & & & & \\
\hline Mno & -0.55 & 0.02 & -0.16 & 0.52 & & & & & & & & & & & & & & & & \\
\hline $\mathrm{Fe} 2 \mathrm{O} 3 \mathrm{~T}$ & -0.78 & -0.59 & -0.67 & & & & & & & & & & & & & & & & & \\
\hline $\mathrm{Al} 2 \mathrm{O} 3$ & 0.15 & 0.88 & & & & & & & & & & & & & & & & & & \\
\hline TiO2 & 0.04 & & & & & & & & & & & & & & & & & & & \\
\hline
\end{tabular}


Anexo 8: Tabela 3 - Coeficientes de correlação geoquimicos dos minérios de ouro da Mina do Pari (cont.)

\begin{tabular}{|c|c|c|c|c|c|c|c|c|c|c|c|c|c|}
\hline $\mathrm{Zn}$ & $\mathrm{Cu}$ & $\mathbf{N i}$ & V & $\mathrm{Cr}$ & Co & $\mathrm{U}$ & s & As & $\mathrm{Au}$ & $\mathrm{Ag}$ & $\mathrm{La}$ & $\mathrm{Ce}$ & $\mathrm{Nd}$ \\
\hline 0.37 & 0.00 & 0.29 & 0.63 & 0.23 & -0.41 & -0.73 & -0.33 & -0.38 & -0.46 & -0.11 & 0.60 & 0.32 & \\
\hline-0.13 & 0.07 & 0.19 & -0.19 & 0.11 & -0.28 & -0.09 & 0.09 & 0.00 & -0.06 & -0.33 & 0.29 & & \\
\hline 0.26 & 0.07 & -0.14 & 0.20 & -0.31 & -0.42 & -0.43 & 0.02 & -0.20 & -0.27 & -0.45 & & & \\
\hline-0.13 & 0.37 & -0.14 & 0.00 & -0.13 & 0.53 & 0.01 & 0.26 & 0.49 & 0.56 & & & & \\
\hline-0.30 & 0.45 & -0.22 & -0.56 & -0.50 & 0.74 & 0.50 & 0.79 & 0.98 & & & & & \\
\hline-0.26 & 0.45 & -0.18 & -0.55 & -0.47 & 0.76 & 0.48 & 0.83 & & & & & & \\
\hline-0.14 & 0.77 & -0.34 & -0.60 & -0.67 & 0.48 & 0.45 & & & & & & & \\
\hline-0.30 & 0.12 & -0.10 & -0.84 & -0.20 & 0.56 & & & & & & & & \\
\hline-0.02 & 0.18 & 0.16 & -0.52 & -0.08 & & & & & & & & & \\
\hline 0.00 & $=0.55$ & 0.71 & 0.32 & & & & & & & & & & \\
\hline 0.40 & -10.24 & 0.15 & & & & & & & & & & & \\
\hline 0.42 & -0.23 & & & & & & & & & & & & \\
\hline \multicolumn{14}{|l|}{0.15} \\
\hline & & & & & & & & & & & & & \\
\hline & & & & & & & & & & & & & \\
\hline & & & & & & & & & & & & & \\
\hline & & & & & & & & & & & & & \\
\hline & & & & & & & & & & & & & \\
\hline & & & & & & & & & & & & & \\
\hline & & & & & & & & & & & & & \\
\hline & & & & & & & & & & & & & \\
\hline & & & & & & & & & & & & & \\
\hline & & & & & & & & & & & & & \\
\hline & & & & & & & & & & & & & \\
\hline & & & & & & & & & & & & & \\
\hline & & & & & & & & & & & & & \\
\hline & & & & & & & & & & & & & \\
\hline & & & & & & & & & & & & & \\
\hline & & & & & & & & & & & & & \\
\hline
\end{tabular}


ANEXO 8: Tabela 4 - Estatística básica das amostras de minério

\begin{tabular}{|c|c|c|c|c|c|c|}
\hline & SiO2 & TiO2 & Al2O3 & $\mathrm{Fe2O3T}$ & Mno & $\mathrm{MgO}$ \\
\hline Minimum & 33,43 & 0,03 & 4,41 & 11,12 & 0,03 & 2,45 \\
\hline Maximum & 59,07 & 0,87 & 16,67 & 39,7 & 0,36 & 9,58 \\
\hline Mean & 49,1 & 0,5 & 11,22 & 21,52 & 0,18 & 4,31 \\
\hline St.Deviation & 6,8 & 0,22 & 3,39 & 7 & 0,08 & 1,84 \\
\hline Variance & 46,29 & 0,05 & 11,46 & 48,93 & 0,01 & 3,38 \\
\hline \multirow[t]{2}{*}{ Number Of Cases } & 17 & 17 & 17 & 17 & 17 & 17 \\
\hline & $\mathrm{CaO}$ & $\mathrm{Na2O}$ & $\mathrm{K2O}$ & P205 & LOI & \\
\hline Minimum & 1,26 & 0,03 & 0,33 & 0 & 1,79 & \\
\hline Maximum & 8,25 & 3,3 & 3,85 & 0,15 & 14,9 & \\
\hline Mean & 4,13 & 1,15 & 1,56 & 0,08 & 4,75 & \\
\hline St.Deviation & 2,14 & 0,93 & 0,9 & 0,04 & 3,16 & \\
\hline Variance & 4,59 & 0,87 & 0,81 & 0 & 10 & \\
\hline \multirow[t]{2}{*}{ Number Of Cases } & 17 & 17 & 17 & 17 & 17 & \\
\hline & $\mathrm{Ba}$ & $\mathbf{R b}$ & $\overline{\mathbf{S r}}$ & $\bar{Y}$ & $\mathrm{Zr}$ & $\mathrm{Nb}$ \\
\hline Minimum & 82 & 10 & 0 & 9 & 33 & 4 \\
\hline Maximum & 772 & 144 & 407 & 27 & 137 & 14 \\
\hline Mean & 333,41 & 60 & 127 & 18 & 80 & 8,8 \\
\hline St.Deviation & 222,57 & 35 & 128 & 5 & 25 & 2,6 \\
\hline Variance & 49539,01 & 1242 & 16351 & 26 & 644 & 6,7 \\
\hline \multirow[t]{2}{*}{ Number Of Cases } & 17 & 17 & 17 & 17 & 17 & 17 \\
\hline & Th & $\mathrm{Pb}$ & $\mathbf{G a}$ & $\mathrm{Zn}$ & $\mathrm{Cu}$ & $\mathrm{Ni}$ \\
\hline Minimum & 2 & 4 & 14 & 207,8 & 8 & 147,9 \\
\hline Maximum & 16 & 122 & 34 & 2737,3 & 617 & 511,5 \\
\hline Mean & 9,1 & 21,2 & 22,4 & 1056,2 & 251,9 & 273,1 \\
\hline St.Deviation & 3,7 & 26,6 & 6,8 & 723,5 & 150 & 117,8 \\
\hline Variance & 13,6 & 705,9 & 45,9 & 523431,1 & 22489,4 & 13876,4 \\
\hline \multirow[t]{2}{*}{ Number Of Cases } & 17 & 17 & 17 & 17 & 17 & 17 \\
\hline & $\mathbf{V}$ & $\mathrm{Cr}$ & Co & $\mathbf{U}$ & s & As \\
\hline Minimum & 78 & 141 & 0 & 2 & 400 & 100 \\
\hline Maximum & 184 & 836 & 130 & 18 & 116000 & 113500 \\
\hline Mean & 138 & 367 & 27,8 & 7,65 & 38488 & 13535,29 \\
\hline St.Deviation & 34 & 180 & 31,6 & 4,26 & 29046 & 26993,17 \\
\hline Variance & 1130 & 32576 & 995,7 & 18,12 & $8,44 \mathrm{E}+08$ & $7,29 E+08$ \\
\hline \multirow[t]{2}{*}{ Number Of Cases } & 17 & 17 & 17 & 17 & 17 & 17 \\
\hline & $\overline{A u}$ & $\mathrm{Ag}$ & La & $\mathrm{Ce}$ & Nd & \\
\hline Minimum & 0,06 & 2 & 0 & 19 & 0 & \\
\hline Maximum & 56,84 & 16 & 85 & 720 & 57 & \\
\hline Mean & 7,52 & 6,94 & 32,29 & 172,29 & 30,53 & \\
\hline St.Deviation & 13,4 & 3,94 & 20,9 & 203,27 & 18,75 & \\
\hline Variance & 179,44 & 15,54 & 436,85 & 41318,97 & 351,39 & \\
\hline Number Of Cases & 17 & 17 & 17 & 17 & 17 & \\
\hline
\end{tabular}


Anexo 8: Tabela 5 - Coeficientes de correlação geoquimicos das rochas encaixantes da Mina do Pari

\begin{tabular}{|c|c|c|c|c|c|c|c|c|c|c|c|c|c|c|c|c|c|c|c|c|}
\hline$\frac{n=35}{N d}$ & $\mathrm{SiO2}$ & $\mathrm{THO}^{2}$ & $\mathrm{~A} 12 \mathrm{O} 3$ & $\mathrm{Fe2O3T}$ & $\mathrm{MnO}$ & $\mathrm{MgO}$ & $\mathrm{CaO}$ & $\mathrm{Na2O}$ & $\mathrm{K} 2 \mathrm{O}$ & P2O5 & LOI & $\mathrm{Ba}$ & $\mathbf{R b}$ & $\mathrm{Sr}$ & $\bar{Y}$ & $\overline{\mathrm{Zr}}$ & $\mathrm{Nb}$ & Th & $\overline{\mathrm{Pb}}$ & Ga \\
\hline $\begin{array}{l}\mathrm{Nd} \\
\mathrm{Ce}\end{array}$ & $\begin{array}{l}0.01 \\
0.07\end{array}$ & $\begin{array}{l}0.25 \\
0.26\end{array}$ & $\frac{-0.15}{-0.03}$ & $\frac{0.16}{-0.02}$ & 0.09 & 0.00 & -0.30 & -0.03 & 0.15 & -0.03 & -0.03 & 0.30 & 0.14 & 0.00 & 0.32 & 0.51 & 0.30 & 0.17 & 0.44 & 0.27 \\
\hline La & 0.00 & -0.15 & $\begin{array}{c}-0.03 \\
-0.75\end{array}$ & $\frac{-0.02}{0.58}$ & $\frac{0.04}{0.07}$ & $\begin{array}{l}0.21 \\
-0.27\end{array}$ & -0.33 & -0.02 & 0.30 & 0.18 & 0.01 & 0.45 & 0.30 & 0.05 & 0.22 & 0.44 & 0.38 & -0.05 & 0.29 & 0.12 \\
\hline $\mathrm{Ag}$ & -0.46 & 0.28 & -0.04 & 0.24 & $\frac{0.01}{0.40}$ & $\begin{array}{c}-0.27 \\
-0.25\end{array}$ & 0.12 & -0.53 & -0.11 & -0.03 & 0.02 & -0.13 & -0.10 & -0.40 & -0.07 & -0.12 & -0.13 & 0.40 & 0.09 & -0.09 \\
\hline $\mathrm{Au}$ & 0.00 & -0.28 & -0.55 & 0.46 & -0.01 & $\begin{array}{l}\frac{-0.25}{0.33} \\
-0.33\end{array}$ & 0.41 & 0.00 & -0.36 & 0.27 & 0.17 & -0.28 & -0.38 & 0.03 & 0.12 & 0.14 & -0.08 & -0.05 & -0.02 & 0.42 \\
\hline As & -0.04 & 0.16 & -0.24 & 0.29 & 0.50 & $\frac{-0.33}{0.31}$ & 0.02 & -0.39 & -0.21 & -0.09 & -0.05 & -0.25 & -0.19 & -0.36 & -0.12 & -0.26 & -0.18 & 0.15 & 0.01 & -0.10 \\
\hline s & -0.11 & -0.24 & -0.70 & 0.58 & 0.07 & -0.39 & $\frac{-0.12}{0.06}$ & -0.56 & -0.33 & 0.32 & -0.28 & -0.44 & -0.32 & -0.53 & -0.30 & -0.28 & -0.04 & 0.02 & -0.67 & -0.56 \\
\hline U & -0.03 & -0.12 & -0.35 & 0.09 & -0.10 & -0.03 & 0.06 & -0.44 & -0.25 & -0.07 & -0.02 & -0.31 & -0.23 & -0.36 & -0.12 & -0.26 & -0.29 & 0.45 & -0.06 & -0.17 \\
\hline Co & -0.17 & 0.07 & 0.29 & -0.09 & 0.15 & 0.03 & $\frac{0.04}{0.09}$ & -0.20 & 0.10 & -0.17 & 0.13 & 0.13 & 0.13 & 0.04 & 0.17 & 0.11 & -0.05 & 0.44 & 0.27 & 0.16 \\
\hline $\mathrm{Cr}$ & 0.42 & -0.41 & -0.30 & -0.34 & -0.03 & 0.92 & 0.09 & 0.27 & -0.12 & 0.12 & 0.01 & -0.11 & -0.13 & 0.11 & -0.04 & -0.11 & -0.21 & 0.08 & -0.26 & 0.00 \\
\hline v & -0.41 & 0.93 & 0.41 & 0.51 & 0.66 & -0.21 & $\frac{-0.49}{-0.08}$ & -0.38 & 0.22 & -0.25 & 0.17 & 0.05 & 0.27 & -0.35 & .0 .09 & -0.35 & -0.04 & -0.12 & 0.18 & -0.43 \\
\hline $\mathrm{Ni}$ & 0.38 & -0.23 & -0.43 & -0.02 & 0.13 & 0.77 & $\frac{-0.08}{-0.53}$ & -0.07 & -0.38 & 0.42 & -0.61 & -0.33 & -0.46 & -0.21 & .0 .09 & 0.51 & 0.49 & 0.16 & -0.71 & -0.08 \\
\hline $\mathrm{Cu}$ & -0.24 & 0.00 & -0.62 & 0.71 & 0.23 & -0.47 & $\frac{-0.53}{0.08}$ & -0.63 & -0.01 & 0.09 & -0.09 & -0.20 & 0.04 & -0.60 & -0.25 & -0.44 & 0.03 & 0.01 & -0.13 & -0.62 \\
\hline $\mathrm{Zn}$ & 0.08 & -0.17 & -0.23 & 0.11 & -0.06 & 0.19 & $\frac{0.08}{-0.32}$ & -0.44 & -0.34 & -0.06 & -0.15 & -0.36 & -0.34 & -0.37 & .0 .14 & 0.06 & -0.15 & 0.46 & -0.18 & -0.12 \\
\hline $\mathbf{G a}$ & -0.45 & 0.14 & 0.28 & -0.17 & -0.01 & -0.48 & $\frac{-0.32}{0.63}$ & -0.26 & 0.39 & -0.07 & 0.02 & 0.24 & 0.39 & -0.10 & 0.06 & -0.07 & 0.08 & -0.09 & 0.21 & -0.09 \\
\hline $\mathrm{Pb}$ & 0.19 & -0.52 & -0.11 & -0.52 & -0.56 & 0.16 & 0.04 & 0.56 & 0.05 & -0.03 & 0.49 & 0.26 & 0.05 & 0.62 & 0.49 & 0.38 & -0.13 & -0.02 & 0.44 & \\
\hline Th & -0.09 & 0.15 & -0.17 & 0.39 & 0.29 & -0.27 & -0.07 & $\frac{0.34}{-0.14}$ & 0.55 & -0.31 & 0.58 & 0.58 & 0.57 & 0.47 & 0.40 & -0.03 & -0.19 & -0.23 & & \\
\hline Nb & 0.02 & 0.54 & 0.23 & 0.24 & 0.12 & 0.14 & -0.51 & $\begin{array}{r}-0.14 \\
-0.02\end{array}$ & -0.23 & -0.08 & -0.21 & -0.21 & -0.23 & -0.14 & 0.17 & 0.24 & -0.17 & & & \\
\hline $\mathrm{Zr}$ & -0.42 & 0.69 & 0.50 & 0.20 & 0.36 & -0.33 & 0.03 & $\frac{-0.02}{0.36}$ & 0.05 & 0.23 & -0.52 & 0.05 & 0.02 & -0.18 & -0.11 & 0.42 & & & & \\
\hline $\mathbf{Y}$ & -0.06 & -0.06 & 0.05 & -0.17 & -0.02 & -0.07 & 0.10 & $\frac{0.36}{0.30}$ & 0.02 & -0.04 & -0.25 & 0.24 & -0.03 & 0.30 & 0.21 & & & & & \\
\hline $\mathrm{Sr}$ & -0.17 & -0.02 & 0.57 & -0.57 & -0.44 & -0.29 & 0.43 & $\frac{0.30}{0.80}$ & $\frac{0.24}{0.45}$ & $\begin{array}{c}-0.01 \\
-013\end{array}$ & 0.24 & 0.32 & 0.24 & 0.26 & & & & & & \\
\hline $\mathbf{R b}$ & 0.38 & -0.37 & 0.06 & -0.58 & -0.70 & 0.27 & -0.32 & 0.28 & 0.99 & $\frac{-0.13}{-0.20}$ & & 0.62 & 0.43 & & & & & & & \\
\hline $\mathrm{Ba}$ & 0.20 & -0.16 & 0.23 & -0.55 & -0.59 & 0.06 & -0.16 & 0.45 & 0.92 & $\begin{array}{r}-0.20 \\
-0.13\end{array}$ & 0.46 & 0.92 & & & & & & & & \\
\hline LOI & -0.06 & -0.49 & -0.13 & -0.55 & -0.37 & 0.03 & 0.44 & 0.24 & 0.41 & $\frac{-0.13}{-0.23}$ & 0.47 & & & & & & & & & \\
\hline P2O5 & -0.28 & 0.49 & 0.07 & 0.33 & 0.31 & -0.18 & 0.05 & -0.10 & -0.16 & & & & & & & & & & & \\
\hline $\mathrm{K} 2 \mathrm{O}$ & 0.32 & -0.29 & 0.12 & -0.54 & -0.67 & 0.22 & -0.32 & 0.31 & & & & & & & & & & & & \\
\hline $\mathrm{Na2O}$ & -0.09 & 0.06 & 0.75 & -0.55 & -0.36 & -0.26 & 0.26 & & & & & & & & & & & & & \\
\hline $\mathrm{CaO}$ & -0.64 & 0.02 & 0.14 & -0.03 & 0.18 & -0.52 & & & & & & & & & & & & & & \\
\hline MgO & 0.47 & -0.35 & -0.15 & -0.43 & -0.10 & & & & & & & & & & & & & & & \\
\hline Mno & -0.64 & 0.63 & -0.01 & 0.67 & & & & & & & & & & & & & & & & \\
\hline Fe2O3T & -0.47 & 0.52 & -0.34 & & & & & & & & & & & & & & & & & \\
\hline $\mathrm{Al} 2 \mathrm{O} 3$ & -0.23 & 0.43 & & & & & & & & & & & & & & & & & & \\
\hline $\mathrm{TiO}_{2}$ & -0.55 & & & & & & & & & & & & & & & & & & & \\
\hline
\end{tabular}


Anexo 8: Tabela 5 - Coeficientes de correlação geoquimicos das rochas encaixantes da Mina do Pari (cont.)

\begin{tabular}{|c|c|c|c|c|c|c|c|c|c|c|c|c|c|}
\hline $\mathrm{Zn}$ & $\mathrm{Cu}$ & Ni & $\bar{V}$ & $\overline{\mathrm{Cr}}$ & $\mathrm{Co}_{0}$ & $\bar{U}$ & $\overline{\mathbf{S}}$ & $\overline{\mathbf{A S}}$ & $\overline{\mathrm{Au}}$ & $\overline{\mathrm{Ag}}$ & $\mathrm{La}$ & $\mathrm{Ce}$ & Nd \\
\hline 0.18 & 0.07 & -0.03 & 0.06 & 0.06 & -0.40 & 0.35 & -0.01 & -0.34 & 0.10 & 0.22 & 0.34 & 0.78 & \\
\hline 0.20 & .0 .24 & 0.11 & 0.08 & 0.19 & -0.30 & 0.11 & -0.28 & -0.07 & -0.05 & 0.13 & 0.09 & & \\
\hline 0.26 & 0.74 & 0.10 & -0.23 & -0.06 & -0.36 & 0.42 & 0.77 & -0.07 & 0.61 & 0.14 & & & \\
\hline-0.03 & 0.07 & -0.14 & 0.20 & -0.20 & -0.22 & 0.04 & -0.02 & 0.07 & 0.02 & & & & \\
\hline 0.31 & 0,59 & -0.07 & -0.30 & -0.14 & -0.17 & 0.06 & 0.71 & 0.03 & & & & & \\
\hline 0.13 & 0.05 & 0.59 & 0.32 & 0.35 & 0.19 & -0.32 & 0.05 & & & & & & \\
\hline 0.06 & 0.95 & -0.02 & -0.27 & -0.21 & -0.07 & 0.30 & & & & & & & \\
\hline-0.04 & 0.31 & -0.02 & -0.19 & 0.03 & -0.24 & & & & & & & & \\
\hline-0.19 & -0.09 & 0.04 & 0.13 & 0.06 & & & & & & & & & \\
\hline 0.34 & -0.31 & 0.86 & -0.29 & & & & & & & & & & \\
\hline-0.19 & -0.04 & -0.08 & & & & & & & & & & & \\
\hline 0.29 & -0.10 & & & & & & & & & & & & \\
\hline-0.02 & & & & & & & & & & & & & \\
\hline & & & & & & & & & & & & & \\
\hline & & & & & & & & & & & & & \\
\hline & & & & & & & & & & & & & \\
\hline & & & & & & & & & & & & & \\
\hline & & & & & & & & & & & & & \\
\hline & & & & & & & & & & & & & \\
\hline & & & & & & & & & & & & & \\
\hline & & & & & & & & & & & & & \\
\hline & & & & & & & & & & & & & \\
\hline & & & & & & & & & & & & & \\
\hline & & & & & & & & & & & & & \\
\hline & & & & & & & & & & & & & \\
\hline & & & & & & & & & & & & & \\
\hline & & & & & & & & & & & & & \\
\hline & & & & & & & & & & & & & \\
\hline & & & & & & & & & & & & & \\
\hline & & & & & & & & & & & & & \\
\hline & & & & & & & & & & & & & \\
\hline & & & & & & & & & & & & & \\
\hline & & & & & & & & & & & & & \\
\hline
\end{tabular}


ANEXO 8: Tabela 6 - Estatística básica das amostras das encaixantes

\begin{tabular}{|c|c|c|c|c|c|c|}
\hline & SiO2 & TiO2 & $\mathrm{Al2O3}$ & Fe203T & MnO & $\mathrm{MgO}$ \\
\hline Minimum & 43,45 & 0,07 & 4,09 & 6,23 & 0,14 & 3,47 \\
\hline Maximum & 60,12 & 2,7 & 18,75 & 22,54 & 0,3 & 12,34 \\
\hline Mean & 50,51 & 1,06 & 13,2 & 12,34 & 0,21 & 6,83 \\
\hline St.Deviation & 3,61 & 0,74 & 2,65 & 4,64 & 0,04 & 2,46 \\
\hline Variance & 13,05 & 0,55 & 7,04 & 21,56 & 0 & 6,03 \\
\hline \multirow[t]{2}{*}{ Number of Cases } & 35 & 35 & 35 & 35 & 35 & 35 \\
\hline & $\mathrm{CaO}$ & $\mathrm{Na2O}$ & $\mathrm{K2O}$ & P205 & LOI & \\
\hline Minimum & 3,4 & 0,39 & 0,11 & 0,06 & 0,16 & \\
\hline Maximum & 17,33 & 3,73 & 2,88 & 2,53 & 8,22 & \\
\hline Mean & 9,49 & 1,97 & 0,79 & 0,21 & 2,57 & \\
\hline St.Deviation & 2,6 & 0,86 & 0,7 & 0,41 & 2,02 & \\
\hline Variance & 6,79 & 0,74 & 0,49 & 0,17 & 4,08 & \\
\hline \multirow[t]{3}{*}{ Number Of Cases } & 35 & 35 & 35 & 35 & 35 & \\
\hline & & & & & & \\
\hline & $\mathrm{Ba}$ & $\mathbf{R b}$ & $\mathrm{Sr}$ & $\mathbf{Y}$ & $\mathbf{Z r}$ & $\mathrm{Nb}$ \\
\hline Minimum & 0 & 0 & 28 & 4 & 25 & 2 \\
\hline Maximum & 581 & 114 & 324 & 87 & 258 & 16 \\
\hline Mean & 184,86 & 26 & 178 & 28 & 84 & 8,3 \\
\hline St.Deviation & 170,55 & 30 & 85 & 14 & 45 & 3,5 \\
\hline Variance & 29087,77 & 881 & 7165 & 209 & 2055 & 11,9 \\
\hline \multirow[t]{2}{*}{ Number Of Cases } & 35 & 35 & 35 & 35 & 35 & 35 \\
\hline & Th & $\overline{\mathbf{P b}}$ & $\mathbf{G a}$ & $\mathrm{Zn}$ & $\mathrm{Cu}$ & $\overline{\mathrm{Ni}}$ \\
\hline Minimum & 0 & 0 & 10 & 79,9 & 4 & 64 \\
\hline \begin{tabular}{|l} 
Maximum \\
\end{tabular} & 15 & 29 & 47 & 399,9 & 874,8 & 685 \\
\hline Mean & 3,6 & 15,8 & 23,7 & 148,8 & 87,3 & 229,1 \\
\hline St.Deviation & 4,1 & 8,4 & 7,8 & 67,5 & 176,4 & 186,1 \\
\hline Variance & 16,7 & 70,7 & 60,4 & 4556,8 & 31132,2 & 34639,7 \\
\hline \multirow[t]{3}{*}{ Number Of Cases } & 35 & 35 & 35 & 35 & 35 & 35 \\
\hline & & & & & & \\
\hline & $\mathbf{v}$ & $\mathrm{Cr}$ & Co & $\mathbf{U}$ & $\mathbf{S}$ & As \\
\hline Minimum & 44 & 12 & 26 & 0 & 10 & 50 \\
\hline Maximum & 447 & 1237 & 85 & 10 & 63900 & 1500 \\
\hline Mean & 205 & 374 & 48 & 3,73 & 4010 & 461,43 \\
\hline St.Deviation & 104 & 390 & 16,7 & 2,92 & 12449 & 332,57 \\
\hline \begin{tabular}{|l} 
Variance \\
\end{tabular} & 10912 & 151716 & 280,4 & 8,53 & $1,55 \mathrm{E}+08$ & 110600,8 \\
\hline \multirow[t]{3}{*}{ Number Of Cases } & 35 & 35 & 35 & 35 & 35 & 35 \\
\hline & & & & & & \\
\hline & $\mathbf{A u}$ & $\mathrm{Ag}$ & La & $\mathrm{Ce}$ & Nd & \\
\hline Minimum & 0 & 0 & 0 & 0 & 0 & \\
\hline Maximum & 2,8 & 121,88 & 58 & 64 & 65 & \\
\hline Mean & 0,18 & 17,5 & 12,88 & 17,6 & 25,62 & \\
\hline St.Deviation & 0,59 & 25,35 & 13,09 & 14,23 & 13,28 & \\
\hline Variance & 0,35 & 642,51 & 171,27 & 202,57 & 176,32 & \\
\hline Number Of Cases & 35 & 35 & 35 & 35 & 35 & \\
\hline
\end{tabular}


Anexo 8: Tabela 7 - Cálculo das Composiçőes Médias das rochas utilizadas no Balanço de Massa

\begin{tabular}{|c|c|c|c|c|c|c|c|}
\hline & Médias L & $\operatorname{apa}(F W)$ & Médias C & apa (HW) & Media AnfGr(FW) & Médias Anf. HW & \\
\hline Coluna & 1 & 2 & 3 & 4 & 5 & 6 & \\
\hline Amostra & xistos-00 & xistos -10 & Xistos-00 & xistos-10 & AnfGr & Anf Finos & \\
\hline $\mathrm{SiO} 2$ & 50,550 & 51,710 & 52,593 & 55,583 & 48,408 & 49,427 & $\mathrm{SiO} 2$ \\
\hline $\mathrm{TiO} 2$ & 0,970 & 0,718 & 0,533 & 0,613 & 1,965 & 1,057 & $\mathrm{TiO} 2$ \\
\hline $\mathrm{Al} 2 \mathrm{O3}$ & 12,957 & 14,228 & 13,270 & 10,623 & 15,700 & 14,740 & $\mathrm{Al} 2 \mathrm{O3}$ \\
\hline Fe2O3tot, & 11,073 & 7,738 & 11,960 & 10,590 & 16,343 & 11,900 & Fe2O3tot, \\
\hline $\mathrm{MnO}$ & 0,213 & 0,163 & 0,193 & 0,203 & 0,245 & 0,213 & $\mathrm{MnO}$ \\
\hline $\mathrm{MgO}$ & 9,587 & 6,033 & 6,755 & 11,163 & 5,180 & 6,183 & $\mathrm{MgO}$ \\
\hline $\mathrm{CaO}$ & 7,900 & 9,688 & 9,038 & 5,903 & 9,268 & 11,983 & $\mathrm{CaO}$ \\
\hline $\mathrm{Na2O}$ & 1,610 & 2,735 & 2,120 & 0,965 & 1,988 & 1,820 & $\mathrm{Na2O}$ \\
\hline $\mathrm{K} 2 \mathrm{O}$ & 0,607 & 1,828 & 0,703 & 1,105 & 0,305 & 0,187 & $\mathrm{~K} 2 \mathrm{O}$ \\
\hline $\mathrm{P} 205$ & 0,110 & 0,113 & 0,110 & 0,083 & 0,178 & 0,167 & P205 \\
\hline $\mathrm{PF}$ & 3,490 & 4,665 & 1,265 & 1,910 & 0,083 & 1,637 & PF \\
\hline $\mathrm{Cr}$ & 0,088 & 0,028 & 0,025 & 0,108 & 0,009 & 168,667 & $\mathrm{Cr}$ \\
\hline $\mathrm{Ni}$ & 0,041 & 0,011 & 0,012 & 0,062 & 0,010 & 120,333 & $\mathrm{Ni}$ \\
\hline $\mathrm{Co}$ & 0,005 & 0,006 & 0,004 & 0,004 & 0,006 & 47,333 & Co \\
\hline V & 0,019 & 0,013 & 0,015 & 0,017 & 0,038 & 237,000 & V \\
\hline $\mathrm{Cu}$ & 0,002 & 0,000 & 0,003 & 0,001 & 0,018 & 65,000 & $\mathrm{Cu}$ \\
\hline $\mathrm{Pb}$ & 0,008 & 0,013 & 0,011 & 0,009 & 0,000 & 5,667 & $\mathrm{~Pb}$ \\
\hline $\mathrm{Zn}$ & 0,016 & 0,018 & 0,017 & 0,021 & 0,013 & 77,667 & $\mathrm{Zn}$ \\
\hline$S$ & 0,030 & 0,003 & 0,350 & 0,021 & 0,022 & 40,000 & $\mathrm{~s}$ \\
\hline $\mathrm{Rb}$ & 0,002 & 0,007 & 0,002 & 0,004 & 0,000 & 3,000 & $\mathrm{Rb}$ \\
\hline $\mathrm{Ba}$ & 0,016 & 0,048 & 0,014 & 0,019 & 0,004 & 54,000 & $\mathrm{Ba}$ \\
\hline $\mathrm{Sr}$ & 0,015 & 0,030 & 0,015 & 0,010 & 0,016 & 165,000 & $\mathrm{Sr}$ \\
\hline $\mathrm{Ga}$ & 0,002 & 0,003 & 0,002 & 0,001 & 0,002 & 18,333 & $\mathrm{Ga}$ \\
\hline $\mathrm{Nb}$ & 0,001 & 0,001 & 0,001 & 0,001 & 0,001 & 7,667 & $\mathrm{Nb}$ \\
\hline $\mathrm{Zr}$ & 0,007 & 0,009 & 0,008 & 0,006 & 0,010 & 81,667 & $\mathrm{Zr}$ \\
\hline$Y$ & 0,002 & 0,003 & 0,003 & 0,003 & 0,002 & 9,000 & $Y$ \\
\hline Th & 0,000 & 0,000 & 0,000 & 0,000 & 0,001 & 1,667 & Th \\
\hline $\mathrm{U}$ & 0,001 & 0,000 & 0,000 & 0,000 & 0,000 & 3,667 & U \\
\hline $\mathrm{La}$ & 0,001 & 0,001 & 0,001 & 0,002 & 0,001 & 1,000 & La \\
\hline $\mathrm{Ce}$ & 0,003 & 0,002 & 0,002 & 0,003 & 0,000 & 2,000 & $\mathrm{Ce}$ \\
\hline $\mathrm{Nd}$ & 0,003 & 0,003 & 0,003 & 0,003 & 0,001 & 6,667 & Nd \\
\hline $\mathrm{Au}$ & 0,000 & 0,000 & 0,000 & 0,000 & 0,000 & 0,000 & $\mathrm{Au}$ \\
\hline $\mathrm{Ag}$ & 0,002 & 0,000 & 0,001 & 0,000 & 0,000 & 0,000 & $\mathrm{Ag}$ \\
\hline As & 0,040 & 0,020 & 0,040 & 0,080 & 0,000 & 0,000 & As \\
\hline \multicolumn{3}{|c|}{ Amostras utilizadas: } & & & & & \\
\hline \begin{tabular}{|l|} 
Coluna 1: \\
Coluna 2:
\end{tabular} & \multicolumn{2}{|c|}{$G N-19,20,21$} & & & & & \\
\hline \begin{tabular}{l|} 
Coluna 2: \\
Coluna 3:
\end{tabular} & $1 \mathrm{~B}, 2 \mathrm{~B}, 3 \mathrm{~B}, 4 \mathrm{~B}$ & $\mathrm{GN}-03,04,05,06$ & & & & & \\
\hline Coluna 4: & \multicolumn{2}{|c|}{$17 \mathrm{~B}, 18 \mathrm{~B}, 19 \mathrm{~B}, 20 \mathrm{~B}$} & & & & & \\
\hline Coluna 5: & \multicolumn{2}{|c|}{ GN-22, GN-23, G-1 } & & & & & \\
\hline Coluna 6 : & \multicolumn{2}{|c|}{ GN-01, T. $41, T-42$} & & & & & \\
\hline
\end{tabular}


Anexo 8: Tabela 8 - Perdas e ganhos do balanço de Massa $(b=$ inclin. da reta $y=b x)$

\begin{tabular}{|c|c|c|c|c|}
\hline Roc. Alterada & Xisto $\mathrm{HW}-00$ & Xisto HW-10 & AnfG-FW-00 & AnfG FW-10 \\
\hline Roc. Original & Anfibolito & Anfibolito & Anf. Granat. & Anf. Granat. \\
\hline b & 0,8982 & 0,7199 & 1,2163 & 1,1563 \\
\hline $\mathrm{SiO} 2$ & 9,12655 & 27,78197 & $-6,84703$ & $-3,68727$ \\
\hline $\mathrm{TiO} 2$ & $-0,46381$ & $-0,20585$ & $-1,16750$ & $-1,34449$ \\
\hline $\mathrm{A} / 2 \mathrm{O} 3$ & 0,03399 & 0,01552 & $-5,04747$ & $-3,39567$ \\
\hline Fe2O3tot, & 1,41552 & 2,81038 & $-7,23839$ & $-9,65090$ \\
\hline $\mathrm{MnO}$ & 0,00098 & 0,06796 & $-0,06960$ & $-0,10447$ \\
\hline $\mathrm{MgO}$ & 1,33726 & 9,32229 & 2,70183 & 0,03707 \\
\hline $\mathrm{CaO}$ & $-1,92154$ & $-3,78428$ & $-2,77239$ & $-0,88948$ \\
\hline $\mathrm{Na2O}$ & 0,54028 & $-0,47954$ & $-0,66381$ & 0,37780 \\
\hline $\mathrm{K} 2 \mathrm{O}$ & 0,59545 & 1,34827 & 0,19378 & 1,27547 \\
\hline P205 & $-0,04420$ & $-0,05207$ & $-0,08706$ & $-0,08021$ \\
\hline $\mathrm{PF}$ & $-0,22829$ & 1,01648 & 2,78686 & 3,95192 \\
\hline $\mathrm{Cr}$ & 0,01052 & 0,13364 & 0,06357 & 0,01568 \\
\hline $\mathrm{Ni}$ & 0,00109 & 0,07380 & 0,02398 & $-0,00081$ \\
\hline $\mathrm{Co}$ & $-0,00053$ & 0,00072 & $-0,00173$ & $-0,00104$ \\
\hline $\mathrm{V}$ & $\sim 0,00678$ & 0,00012 & $-0,02215$ & $-0,02607$ \\
\hline $\mathrm{Cu}$ & $-0,00266$ & $-0,00490$ & $-0,01638$ & $-0,01732$ \\
\hline $\mathrm{Pb}$ & 0,01223 & 0,01234 & 0,00659 & 0,01081 \\
\hline $\mathrm{Zn}$ & 0,01087 & 0,02208 & 0,00023 & 0,00302 \\
\hline$s$ & 0,38567 & 0,02482 & 0,00266 & $-0,01919$ \\
\hline $\mathrm{Rb}$ & 0,00209 & 0,00574 & 0,00173 & 0,00596 \\
\hline $\mathrm{Ba}$ & 0,01035 & 0,02089 & 0,00896 & 0,03721 \\
\hline $\mathrm{Sr}$ & $-0,00016$ & $-0,00261$ & $-0,00340$ & 0,01004 \\
\hline $\mathrm{Ga}$ & 0,00076 & 0,00011 & $-0,00019$ & 0,00044 \\
\hline $\mathrm{Nb}$ & 0,00012 & 0,00045 & $-0,00012$ & $-0,00039$ \\
\hline $\mathrm{Zr}$ & 0,00099 & $-0,00018$ & $-0,00425$ & $-0,00257$ \\
\hline$Y$ & 0,00191 & 0,00261 & $-0,00005$ & 0,00098 \\
\hline Th & $-0,00003$ & 0,00042 & $-0,00041$ & $-0,00050$ \\
\hline $\mathrm{U}$ & $-0,00003$ & 0,00015 & 0,00037 & 0,00020 \\
\hline La & 0,00110 & 0,00198 & 0,00029 & 0,00005 \\
\hline $\mathrm{Ce}$ & 0,00150 & 0,00369 & 0,00176 & 0,00126 \\
\hline Nd & 0,00248 & 0,00347 & 0,00147 & 0,00090 \\
\hline $\mathrm{Au}$ & 0,00008 & 0,00000 & 0,00001 & 0,00000 \\
\hline $\mathrm{Ag}$ & 0,00128 & 0,00042 & 0,00181 & 0,00017 \\
\hline As & 0,04453 & 0,11113 & 0,03289 & 0,01730 \\
\hline Soma & 10,870 & 38,252 & $-18,113$ & $-13,47407$ \\
\hline
\end{tabular}


Anexo 9: Geotermômetros Granada-Anfibólio e Granada-Biotita 


\begin{tabular}{|c|c|c|c|c|c|c|c|c|c|c|c|}
\hline \multicolumn{6}{|c|}{ Anexo 9: Tabela 1 - Geotermómetros Granada-Anfibólio } & \multicolumn{2}{|c|}{ Temperaturas $\left({ }^{\circ} \mathrm{C}\right)$} & \multicolumn{2}{|c|}{ Diferença } & \multicolumn{2}{|c|}{ Médias } \\
\hline Amostra & Descriçåo & & & & & & & G.8P. & P. et al. & Graham \& Powell (1984) & Perchuk et al. 1985 \\
\hline & & Granada & Aiffibolio & c & $b$ & Graham \& Powell (1984 & Perchuk et al. 1985 & $\mathrm{~B}-\mathrm{C}$ & B-C & Médias & Médias \\
\hline$\frac{G P-10}{G P-10}$ & \begin{tabular}{|l|} 
Anfibolito Grosso HW BR-57 \\
Anfibolito Grosso HW BR-57
\end{tabular} & $\frac{227}{228}$ & 194 & $x$ & & 534.36 & 465.47 & & & & \\
\hline$\frac{G P-10}{G P-10}$ & & $\frac{228}{227}$ & 195 & & $x$ & $\frac{573.35}{5.37 .96}$ & 523.11 & 38.99 & 57.64 & & \\
\hline GP-10 & $\begin{array}{l}\text { Anfibolito Grosso HW BR-57 } \\
\end{array}$ & $\frac{227}{228}$ & 192 & $\mathrm{x}$ & & 527.96 & 459.49 & & & & \\
\hline GP-10 & Anfibolito Grosso HW BR-57 & $\frac{228}{227}$ & $\frac{192}{195}$ & $\bar{x}$ & $x$ & $\frac{563.77}{536.50}$ & 513.90 & 35.81 & 54.41 & & \\
\hline GP-10 & & sd & sd & & $x$ & $\begin{array}{c}536.50 \\
\text { sd }\end{array}$ & $\begin{array}{c}467.46 \\
\text { sd }\end{array}$ & & & & \\
\hline$\frac{G P-10}{G P-10}$ & $\begin{array}{l}\text { Anfibolito Grosso HW BR-57 } \\
\text { Anfibolito Grosso HW BR-57 }\end{array}$ & $\frac{227}{228}$ & 196 & $x$ & & 529.48 & 460.91 & & & Centro & Centro \\
\hline GP-10 & $\begin{array}{l}\text { Anfibolito Grosso HW BR-57 } \\
\text { Anfibolito Grosso HW BR-57 }\end{array}$ & $\frac{228}{229}$ & 197 & & $x$ & 573.03 & 522.80 & 43.55 & 61.89 & 538.33 & 472.92 \\
\hline GP-10 & $\begin{array}{l}\text { Anfibolito Grosso HW BR-57 } \\
\text { Anfibolito Grosso HW BR-57 } \\
\end{array}$ & $\frac{229}{230}$ & 196 & $\mathrm{x}$ & & 559.45 & 505.87 & & & & \\
\hline $\mathrm{GN}-08$ & Bi-Hb-Xisto HW $(\mathrm{N}-00)$ & 69 & $\frac{197}{87}$ & $x$ & $x$ & $\frac{581.03}{537.25}$ & $\frac{526.53}{499.73}$ & 21.58 & 20.66 & 564.42 & $\begin{array}{l}\text { Bordas } \\
513.44\end{array}$ \\
\hline $\mathrm{GN}-08$ & Bi-Hb-Xisto HW $(\mathrm{N}-00)$ & 70 & $\frac{87}{88}$ & $x$ & $x$ & 548.20 & 511.20 & 10.95 & 11.47 & & \\
\hline $\mathrm{GP}-10$ & Bi-Hb-Xisto HW $(\mathrm{N}-00)$ & 225 & 200 & $\mathrm{x}$ & & 550.42 & 469.50 & & & $\mathrm{~B}-\mathrm{C}$ & $\mathrm{B-C}$ \\
\hline$\frac{G P-10}{G P-10}$ & Bi-Hb-Xisto HW (N-00) & 226 & 201 & & $x$ & 574.33 & 521.53 & 23.91 & 52.03 & 26.09 & \\
\hline GP-10 & Bi-Hb-Xisto HW $(\mathrm{N}-\mathrm{O} 0)$ & 225 & 198 & $x$ & & 546.25 & 465.66 & & & & \\
\hline GP-10 & Bi-Hb-Xisto HW $(\mathrm{N}-00)$ & 226 & 199 & & $x$ & 564.86 & 512.46 & 18.61 & 46.80 & & \\
\hline$\frac{G P-10}{G P-10}$ & Bi-Hb-Xisto $H W(N-O 0)$ & 225 & 202 & $x$ & & 554.29 & 473.07 & & & & \\
\hline GP-10 & Bi-Hb-Xisto HW (N-00) & 226 & 203 & & $x$ & 562.94 & 481.03 & 8.65 & 7.96 & & \\
\hline$\frac{G N-08}{G N-08}$ & Bi-Hb-Xisto HW (N-00) & 71 & 85 & $x$ & & $\begin{array}{l}507.37 \\
538.30\end{array}$ & $\begin{array}{l}462.08 \\
508.41\end{array}$ & 30.93 & 46.33 & & \\
\hline$\frac{G P-05}{G P-05}$ & \begin{tabular}{|l|} 
Anfibolito Granatffero FW distante \\
Anfibolito Granatifero FW distante
\end{tabular} & $\frac{65}{66}$ & $\frac{83}{84}$ & & $\bar{x}$ & 514.09 & 536.68 & -17.90 & -21.17 & & \\
\hline GP-05 & Anfibolito Granat fero FW distante & 61 & 79 & $x$ & & 547.08 & 567.08 & & & $\begin{array}{ll}\text { Centro } \\
\end{array}$ & $\begin{array}{l}\text { Centro } \\
555.11\end{array}$ \\
\hline GP-05 & Anfibolito Granatffero FW distante & 62 & 80 & & $x$ & 519.64 & $\frac{540.81}{553233}$ & -27.44 & -26.27 & & \\
\hline GP-05 & Anfibolito Granatffero FW distante & 61 & 81 & $x$ & & $\begin{array}{l}538.86 \\
494.99\end{array}$ & $\begin{array}{l}559.33 \\
514.95\end{array}$ & .43 .87 & -44.38 & & \\
\hline GP-05 & Anfibolito Granatifero FW distante & 62 & 82 & & $x$ & $\frac{494.99}{541.45}$ & $\frac{514.90}{560.04}$ & -93.81 & -44.00 & Bordas & Bordas \\
\hline$\frac{G P-05}{G P-05}$ & \begin{tabular}{|l} 
Anfibolito Granatifero FW distante \\
Anfibolito Granatfiero FW distante
\end{tabular} & $\frac{66}{59}$ & $\frac{84}{75}$ & $\frac{x}{x}$ & $x$ & 543.58 & 565.95 & & & & \\
\hline$\frac{\text { GP-05 }}{\text { GP-05 }}$ & \begin{tabular}{|l} 
Anfibolito Granatifero FW distante \\
Anfibolito Granatifero FW distante
\end{tabular} & $\frac{59}{60}$ & $\frac{10}{76}$ & & $x$ & 533.25 & 560.07 & -10.33 & -5.88 & & \\
\hline GP-05 & Anfibolito Granatifero FW distante & 59 & 77 & $x$ & & 542.37 & 564.68 & & & $\mathrm{~B}-\mathrm{C}$ & $B-C$ \\
\hline GP-05 & Anfibolito Granatifero FW distante & 60 & 78 & & $\bar{x}$ & 524.51 & 550.83 & -17.86 & -13.85 & & \\
\hline GP-05 & Anfibolito Granatifero FW distante & 57 & 77 & $x$ & & 549.99 & 564.67 & & & & \\
\hline GP-05 & Anfibolito Granatifero FW distante & 58 & 78 & & $x$ & 517.23 & 522.80 & -32.76 & -41.87 & & \\
\hline GP-04 & Anfibolito Granatifero FW distante & 73 & 89 & $x$ & & 507.21 & 491.74 & & & & \\
\hline GP-04 & Anfibolito Granatifero FW distante & 74 & 90 & & $x$ & 523.15 & 518.71 & 15.94 & 26.97 & & \\
\hline$\overline{G P}-05$ & Anfibolito Granatifero FW distante & 63 & 81 & $x$ & & 531.19 & 555.60 & & & & \\
\hline GP-05 & Anfibolito Granatifero FW distante & 64 & 82 & & $x$ & 508.02 & 533.30 & -23.17 & -22.30 & & \\
\hline GP-05 & Anfibolito Granatifero FW distante & 63 & 79 & $x$ & & $\begin{array}{l}539.29 \\
533.68\end{array}$ & $\begin{array}{l}564.14 \\
560.40\end{array}$ & -5.61 & -3.74 & & \\
\hline GP-05 & Anfibolito Granatifero FW distante & 64 & 80 & & $x$ & 533.68 & $\frac{560.40}{457.63}$ & -5.61 & -3.14 & & \\
\hline $14 \mathrm{~B}$ & Minério Central N-10 & 221 & 208 & $\mathrm{x}$ & $\bar{Y}$ & $\begin{array}{l}482.88 \\
501.73\end{array}$ & $\begin{array}{l}457.63 \\
472.37\end{array}$ & 18.85 & 14.74 & & \\
\hline $14 \mathrm{~B}$ & $\frac{\text { Minério Central N-10 }}{\text { Mińrio Central N-10 }}$ & $\frac{222}{110}$ & $\frac{209}{208}$ & $x$ & $x$ & $\frac{501.73}{484.83}$ & 462.27 & & & Centro & Centro \\
\hline$\frac{14 B}{14 B}$ & & $\frac{219}{220}$ & $\frac{208}{209}$ & $x$ & $x$ & $\begin{array}{l}404.00 \\
505.33 \\
\end{array}$ & 493.09 & 20.50 & 30.82 & 496.65 & 466.64 \\
\hline$\frac{14 \mathrm{~B}}{14 \mathrm{~B}}$ & $\begin{array}{l}\text { Minério Central } N-10 \\
\text { Minério Central } N-10 \\
\end{array}$ & 221 & 210 & $x$ & & 503.69 & 478.17 & & & & \\
\hline $14 \mathrm{~B}$ & Minério Central $\mathrm{N}-10$ & 222 & 211 & & $\mathrm{x}$ & 485.51 & 456.45 & -18.18 & -21.72 & & \\
\hline $14 \mathrm{~B}$ & Minério Central N-10 & 219 & 210 & $x$ & & 505.82 & 483.08 & & & Bordas & Bordas \\
\hline $14 \mathrm{~B}$ & Minério Central N-10 & 220 & 211 & & $x$ & 488.97 & 476.65 & -16.85 & -6.43 & 511.78 & 489.04 \\
\hline 148 & Minério Central $\mathrm{N}-10$ & 216 & 214 & $x$ & & 480.14 & 438.88 & & & & \\
\hline 14B & Minério Central $\mathrm{N}-10$ & 218 & 215 & & $x$ & 560.99 & 534.08 & 80.85 & 95.20 & $\mathrm{~B}-\mathrm{C}$ & $\mathrm{B}-\mathrm{C}$ \\
\hline $14 \mathrm{~B}$ & Minério Central $\mathrm{N}-10$ & 216 & 212 & $x$ & & 522.55 & 479.81 & & & 15.12 & 22.40 \\
\hline $14 \mathrm{~B}$ & Minério Central N-10 & 218 & 213 & & $x$ & 528.12 & 501.58 & 5.57 & 21.77 & & \\
\hline GP-15 & BIF tipco Algoma (FW Pari) & 117 & 125 & $x$ & & 543.94 & 504.66 & & & Centro & Centro \\
\hline GP-15 & BIF tipco Algoma (FW Pari) & 118 & 126 & & $x$ & 536.52 & 501.69 & -7.42 & -2.97 & 544.79 & 501.92 \\
\hline GP-15 & BIF tipco Algoma (FW Pari) & 117 & 123 & $x$ & & 555.70 & 516.10 & & & & \\
\hline GP-15 & BIF tipco Algoma (FW Pari) & 118 & 124 & & $x$ & 546.87 & 511.81 & -8.83 & -4.29 & Bordas & Bordas \\
\hline GP-15 & BIF tipco Algoma (FW Pari) & 119 & 125 & $\mathrm{x}$ & & 534.07 & 487.98 & & & 546.39 & 505.29 \\
\hline GP-15 & BIF tipco Algoma (FW Pari) & 120 & 126 & & $x$ & 545.86 & 498.81 & 11.79 & 10.83 & & \\
\hline GP-15 & BIF tipco Algoma (FW Pari) & 119 & 123 & $\bar{x}$ & & 545.43 & 498.93 & & & $\mathrm{~B}-\mathrm{C}$ & $\mathrm{B}-\mathrm{C}$ \\
\hline GP-15 & BIF tipco Algoma (FW Pari) & 120 & 124 & & $x$ & 556.29 & 508.86 & 10.86 & 9.93 & 1.60 & 3.38 \\
\hline
\end{tabular}




\begin{tabular}{|c|c|c|c|c|c|c|c|c|c|c|c|}
\hline \multicolumn{6}{|c|}{ Anexo 9: Tabela 2 - Geotermômetros Granada-Biotita } & \multicolumn{2}{|c|}{ Temperaturas $\left({ }^{\circ} \mathrm{C}\right)$} & \multirow{2}{*}{\multicolumn{2}{|c|}{$\frac{\text { Diferença }}{\text { T(B-C) }}$}} & \multicolumn{2}{|c|}{ Médias } \\
\hline Amostra & Descriçăo & \multicolumn{2}{|c|}{ Pontos } & \multicolumn{2}{|c|}{ Posigäo } & \multirow[t]{2}{*}{ Thompson, 1976} & \multirow[t]{2}{*}{ Goldman\&Albee, $77-1$} & & & \multirow{2}{*}{$\begin{array}{c}\text { Thompson, } 1976 \\
\text { Médias }\end{array}$} & \multirow{2}{*}{$\begin{array}{c}\text { Goldman\&Albee, } 77-1 \\
\text { Médias }\end{array}$} \\
\hline GP-10 & Anfibolito Grosso HW BR-57 & 223 & 243 & $\frac{x^{2}}{x}$ & Borda & & & & & & \\
\hline GP-10 & Anfibolito Grosso HW BR-57 & 224 & 244 & & $\bar{x}$ & 506,2 & 487,1 & 34,9 & 24,1 & & \\
\hline GP-10 & Anfibolito Grosso HW 8R-57 & 223 & 245 & $x$ & & 471,7 & 463,3 & & & & \\
\hline GP-10 & Anfibolito Grosso HW BR-57 & 224 & 246 & & $x$ & 499,6 & 482,5 & 27,8 & 19,2 & Centro & Centro \\
\hline GN-08 & Bi-Hb-Xisto HW (N-D) & 69 & 93 & \multirow[t]{2}{*}{$x$} & \multirow[b]{2}{*}{$x$} & 505,0 & 486,2 & & & 469,03 & 461,44 \\
\hline GN-08 & Bi-Hb-Xisto HW (N-OO) & 70 & 94 & & & 521,3 & 497,5 & 16,3 & 11,3 & & \\
\hline GP-10 & Anfibolito Grosso HW BR-57 & 225 & 241 & \multirow[t]{2}{*}{$x$} & \multirow[b]{2}{*}{$x$} & 460,5 & 455,6 & & & & \\
\hline GP-10 & Anfibolito Grosso HW BR-57 & 226 & 242 & & & 515,2 & 493,3 & 54,7 & 37,8 & Borda & Borda \\
\hline GP-10 & Anfibolito Grosso HW BR-57 & 225 & 239 & \multirow[t]{2}{*}{$\bar{x}$} & \multirow[b]{2}{*}{$x$} & 467,3 & 460,3 & & & 510,70 & 490,20 \\
\hline GP-10 & Anfibolito Grosso HW BR-57 & 226 & 240 & & & 525,4 & 500,4 & 58,0 & 40,1 & & \\
\hline GP-10 & Anfibolito Grosso HW BR-57 & 227 & 235 & \multirow[t]{2}{*}{$x$} & \multirow[b]{2}{*}{$x$} & 437,7 & 439,9 & & & & \\
\hline GP-10 & Anfibolito Grosso HW BR-57 & 228 & 236 & & & 502,3 & 484,4 & 64,6 & 44,5 & $\overline{B-C}$ & $\overline{B-C}$ \\
\hline GP-10 & Anfibolito Grosso HW BR-57 & 227 & 233 & \multirow[t]{2}{*}{$\bar{x}$} & \multirow[b]{2}{*}{$x$} & 442,5 & 443,2 & & & 41,67 & 28,76 \\
\hline$G P-10$ & Anfibolito Grosso HW BR-57 & 228 & 234 & & & 503,2 & 485,0 & 60,7 & 41,8 & & \\
\hline GP-10 & Anfibolito Grosso HW BR-57 & 229 & 231 & \multirow[t]{2}{*}{$\bar{x}$} & \multirow[b]{2}{*}{$x$} & 496,2 & 480,2 & & & & \\
\hline GP-10 & Anfibolito Grosso HW BR-57 & 230 & 232 & & & 512,5 & 491,4 & 16,3 & 11,3 & & \\
\hline GP-05 & Anfibolito Granatifero FW distante & 59 & 99 & $x$ & & 549,0 & 516,8 & & & Centro & Centro \\
\hline GP-05 & Anfibolito Granatifero FW distante & 60 & 100 & & $x$ & 527,2 & 501,6 & 21.8 & 15.2 & 528,66 & 502,68 \\
\hline \multirow{2}{*}{$\begin{array}{l}\text { GP-04 } \\
\text { GP-04 }\end{array}$} & \multirow{2}{*}{$\begin{array}{l}\text { Anfibolito Granatifero FW dist. } \\
\text { Anfibolito Granatifero FW dist. }\end{array}$} & 73 & 91 & $\bar{x}$ & & 502,0 & 484,2 & & & Borda & Borda \\
\hline & & 74 & 92 & & $x$ & 527,7 & 502,0 & 25,7 & 17,8 & 523,05 & 498,76 \\
\hline \multirow{3}{*}{$\begin{array}{l}\text { GP-05 } \\
\text { GP-05 }\end{array}$} & Anfibolito Granatifero FW distante & 65 & 97 & $x$ & & 535,0 & 507,1 & & & $\mathrm{~B}-\mathrm{C}$ & $8-C$ \\
\hline & Anfibolito Granatifero FW distante & 66 & 98 & & $x$ & 514,3 & 492,7 & 20.7 & 14.4 & $-5,62$ & $-3,92$ \\
\hline & & & & & & & & & & $\begin{array}{l}\text { Centro } \\
400,86\end{array}$ & $\begin{array}{l}\text { Centro } \\
414.64\end{array}$ \\
\hline \multirow{4}{*}{$\begin{array}{l}15 \mathrm{~B}-1 \\
15 \mathrm{~B}-1 \\
15 \mathrm{~B}-2 \\
15 \mathrm{~B}-2\end{array}$} & \multirow{4}{*}{\begin{tabular}{|l|} 
Minério Central N-10 \\
Minério Central N-10 \\
Minério Central N-10 \\
Minério Central N-10 \\
\end{tabular}} & 113 & 166 & $x$ & & 366,9 & 391,3 & & & $\begin{array}{l}400,80 \\
\text { Borda }\end{array}$ & $\begin{array}{l}414,64 \\
\text { Borda }\end{array}$ \\
\hline & & 115 & 167 & & $x$ & 450,7 & 448,8 & 83,8 & 57,5 & 493,12 & 478,13 \\
\hline & & 265 & 267 & $x$ & & 434,9 & 437,9 & & & $B-0$ & B-1 \\
\hline & & 266 & 268 & & $x$ & 535,6 & 507,5 & 100,7 & 69,5 & 92,25 & 63,49 \\
\hline
\end{tabular}


